$$
\begin{aligned}
& \omega
\end{aligned}
$$

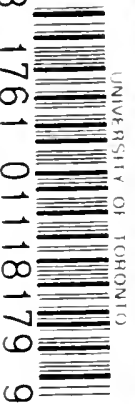







\title{
LITURGY AND RITUAL OF THE CELTIC CHURCH
}

\author{
$W A R R E N$
}




\section{Fondon}

\section{HENRY FROWDE}

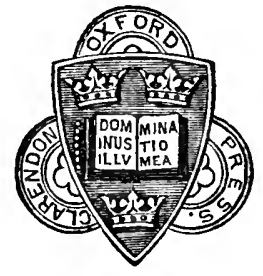

OXFORD UNIVERSITY PRESS WAREHOUSE

7 PATERNOSTER ROW 


\section{THE}

\section{LITURGY AND RITUAL}

OF THE

\section{CELTIC CHURCH}

BY

F. E. WARREN, B.D.

FELLOW OF ST. JOHN'S COLLEGE, OXFORD

\section{Oxfard}

AT THE CLARENDON PRESS

M DCCC LXXXI

[All rights reserved] 
Qualis fuerit apud Britones et Hibernos sacrificandi ritus non plane compertum est. Modum tamen illum a Romano divisum exstitisse intelligitur ex Bernardo in libro de vita Malachiae cc. iii, viii, ubi Malachias barbaras consuetudines Romanis mutasse, et canonicum divinae laudis officium in illas ecclesias invexisse memoratur.

Mabillon, De Lit. Gall. lib. i. cap. ii. §14.

Hactenus lyturgia Scottica typis vulgata non habetur; et Britannise virorum dcctorum esset, fragmenta ritus Scottici, circumquaque dispersa, colligere et illustrare.

C. Purton Cooper's (intended) Report on Foedera, Appendix A, $p .94$.

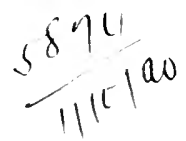




\section{CONTENTS.}

Authorities cited

PAGE

xiii

\section{CHAPTER I.}

5 1. Extent and Duration of the Celtic Church . . . . I

$\$ 2$ 2. Its Monastic and Missionary Character . . . . . 12

3. Its Orthodoxy . . . . . . . . . . 26

8. Its Independence of Rome . . . . . . . 29

6 5. Eastern Connection . . . . . . . . . $4^{6}$

6. Gallican Connection . . . . . . • • • 57

6. Spanish Connectiou . . . . . . . . . 62

8. Points of Difference between Celtic and Roman Churches . 63

CHAPTER II.

1. Material, Structure, and Arrangement of Churches . . $8 \mathfrak{j}$

2. Titles of the Liturgy . . . . . . . . 94

8. Multiplicity of Collects . . . . . . . . . 96

8 4. The Lord's Prayer . • . . . . . . . 98

5. Lections . . . . . . . . . • . 98

§. Sermon . . . . . . . . . . . . 99

5 7. Proper Prefaces . . . . . . . . . . 99

8. Benediction . . . . . . . . . . 100

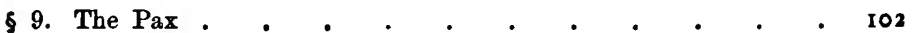

810. Prayer for the Dead . . . . . . . . 102

$\$ 11$. Consecration Prayer. . . . . . . . 108

\$ 12. Communion Anthems . . . . . . . . I10

5 13. Benedicite . . . . . . . . . . III

5 14. Position of the Priest . . . . . . . . II I

15. Vestments . . . . . . . . . . 112

16. Use of Colours . . . . . . . . . . 132

§ 17. Choral Service . . . . . . . . . 125

$\S 18$. Incense . . . . . . . . . . . 127

§19. Joint Consecration . . . . . . . . . 128

$\S 20$. Oblations and Offertory . . . . . . . . 130 
$\S 21$. Unleavened Bread . . . . . . . . . . I 131

§ 22. Mixed Chalice . . . . . . . . . $\quad .133$

$\S 23$. Communion in both kinds . . . . . . . . . $\quad$ I34

$\S 24$. Communion of Infants . . . . . . . . 136

\$25. Women to be Veiled . . . . . . . . 136

$\S 26$. Reservation . . . . . . . . . . 138

$\S 27$. Eulogiae . . . . . . . . . . . 139

$\S 28$. Frequency of Celebration . . . . . . . 140

$\S 29$. Hours of Celebration . . . . . . . . $\mathbf{I}_{42}^{2}$

§ 30. Duplicating . . . . . . . . . . 143

$\S 31$. Paten and Chalice . . . . . . . . . . 143

$\S 32$. Fan, Knife . . . . . . . . . . . . $\quad . \quad 144$

§3. Sign of the Cross . . . . . . . . . . 145

§ 34. Fasting . . . . . . . . . . . 146

$\S 35$. Confession . . . . . . . . . . . $\quad$. 147

CHAPTER III.

§ 1. No traces of a Vernacular Liturgy . . . . . . . $\quad$ I55

§ 2. Cornish Fragment. Missa S. Germani . . . . . 159

§ 3. Welsh Fragments. Missa de S. David . . . . . 16I

§ 4. " Missa de S. Teila . . . . . 162

§5. Scottish Fragment. Book of Deer . . . . . . $16_{3}$

§ 6. Irish Fragments. Book of Dimma . . . . . . 167

§. " Book of Mulling . . . . . 171

§ 8. " Book of Armagh . . . . . 173

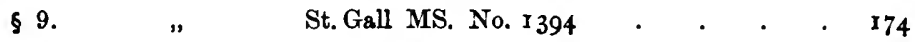

§ 10. $\quad$ St. Gall MS. No. I395 • . . . $\quad$ I 79

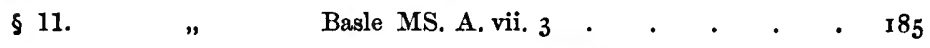

§ 12. " Antiphonary of Bangor . . . . 187

$\S 13 . \quad$ " Book of Hymns . . . . . . . 194

§ 14. " $\quad$ Stowe Missal . • • • . 198

§ 15. " $\quad$ Drummond, Corpus, and Rosslyn Missals . 269

§ 16. " Paris MS. 2333 A. Colbert • . . 271

§ 17. Missale Vesontionense . . . . . . . 272

Index of Collects and other Liturgical Formulae . . . 275

Index of Passages of Scripture $\quad$ - . $\quad$. $\quad . \quad$. 282

General Index . . $. \quad . \quad . \quad . \quad . \quad . \quad{ }^{283}$ 


\section{PREF A CE.}

THe following pages contain an account of the Liturgy and Ritual of the Celtic Church in these islands, so far as their character can be ascertained from the limited sources of information open to us. They relate to a subject about which, until recently, very little was known. The great continental Liturgiologists of the seventeenth and eighteenth centuries were either silent about it, or dismissed it as offering no data for information and no materials for investigation. Mabillon wrote: 'Qualis fuerit apud Britonos et Hibernos sacrificandi ritus, non plane compertum est. Modum tamen illum a Romano diversum exstitisse intelligitur ex Bernardo in libro de vita Malachiae, capitibus iii et viii, ubi Malachias barbaras consuetudines Romanis mutasse, et canonicum divinae laudis officium in illas ecclesias invexisse memoratur.'-De Liturgia Gallicana, lib. i.c. ii. § 14. Gerbert wrote: 'In dubio est qui et qualis antiquitus ea in orbis plaga fuerit ordo operis Dei.'-Lit. Aleman. i. 76.

In more recent times Dr. Lingard has disclaimed all possibility of any knowledge of the subject: 'Whether the sacrificial service of the Scottish missionaries varied from that of the Romans we have no means of judging.'-AngloSaxon Church, edit. 1858, vol. i. p. 271.

Sir W. Palmer in his Origines Liturgicae (i. 176-189) devoted one short chapter to the Liturgy of the Celtic Church, which consisted largely of guesses and of the repetition at secondhand of statements which he was unable to verify, but which, were he to write now, he would either 
abandon or modify. Within the last few years extensive additions have been made to the scanty materials available to Sir W. Palmer in 1839 , in some instances by the discovery, in other instances by the publication for the first time, of various ancient Irish and Scottish liturgical fragments; by the printing of certain important Celtic manuscripts; by the collection in palæographical and archæological volumes of the representations in Celtic illuminated MSS.; by the examination of architectural remains, and of stonework inscriptions and designs.

The sources from which the information contained in the present volume has been drawn are chiefly the following:

(a) Scattered notices in the works of contemporary writers; viz. fifth century, Fastidius, Patricius, Secundinus; sixth century, Columba, Fiacc, Gildas ; seventh century, Cuminius Albus, Adamnanus, Columbanus. Bachiarius and Sedulius are omitted from this list, in consequence of the uncertainty attaching to their date and nationality. Non-Celtic authors, e.g. Alcuin, Bede, Bernard of Clairvaux, Jonas, Walafrid Strabo, \&c., have been frequently referred to.

(b) Scattered notices in Celtic MSS., viz. Catalogus Sanctorum Hiberniae, Leabhar Breac, Sinodus Hibernensis, Senchus Mor, \&c.

(c) Fragments of the ancient Celtic Liturgy surviving in the Stowe (ninth century), Drummond (eleventh century), and Corpus (twelfth century) Irish Missals; in the Books of Mulling (seventh century), Dimma (seventh century), Deer (ninth century), Armagh (ninth century); in Irish MSS. on the Continent, Nos. 1394 and I 395 (ninth century) at St. Gall, and the Antiphonarium Benchorense (eighth century) at Milan, and in a few other MSS. enumerated in Chapter iii.

(d) Illuminations in Celtic manuscripts, which have lately become accessible to the untravelled student in the magnifi- 


\section{Preface.}

cent volumes of Professor Westwood, Mr. Gilbert, and the late Dr. Todd.

(e) Architectural remains of churches, sepulchral inscriptions, sculptured crosses, carved or engraved book-covers, caskets, pastoral staves, bells, chalices, spoons, and other ecclesiastical relics.

In drawing information from such various quarters the author can hardly hope to have escaped all errors of detail, and not to have hazarded some conjectures which will be criticised, and to have drawn some conclusions which will be disputed.

A certain elemcnt of incompleteness is still inevitable in the treatment of this subject from the state of a part of the material from which our knowledge is derived. Some important Irish manuscripts, as the Stowe Missal, \&c., have never been published ; others, as the Leabhar Breac, \&c., have been published in facsimile, without note or comment, and need the editorial explanations of some one who is at once an antiquarian, an ecclesiastical historian, and a palæographer, in order to assign their date and value to the historical, ecclesiastical, and liturgical tracts of which they are composed ${ }^{1}$. There is a vast amount of unsifted and undated, or erroneously dated, material preserved in various collections, especially in the Bollandists' edition of the Acta Sanctorum. Much of it might be useful for illustration in matters of detail, even where it could in no sense be relied upon as historical. But until some discriminating hagiologist shall have undertaken the laborious task of visiting the various European libraries, and critically examining the original MSS. from which such Lives are drawn, and publishing the

1 Since this sentence was written one of the most important of these documents, the Félire of Oengus, has been edited by Mr. Whitley Stokes, with a translation and complete apparatus criticus. Transactions of R. I. A., June, 1880. 
result of such investigations, they must be regarded as more likely to mislead than to inform. Occasional reference has been made to a very few of these biographies, viz. those of Cogitosus, Ultan, St. Evin, \&c., which have been passed and repassed through the crucible of modern criticism, and the evidential value of which it has therefore been possible approximately to ascertain. The general importance of this hagiologic literature has been discussed by the late Sir Thomas Duffus Hardy, in his Preface to the Rerum Britannicarum medii aevi Scriptores (pp. 18-20), a work which includes a dated catalogue of all the MS. material accessible in Great Britain; and, so far as Ireland and Scotland are concerned, by Mr. Skene (Celtic Scotland, ii. cap. $x$, and Chronicles of the Picts and Scots, Preface). Its value for liturgical illustration is diminished by the fact that it all belongs to a period subsequent to the conformity of the Celtic Church to the Church of Rome. This appears plainly on the face of such unhistorical passages as the following in Ultan's Life of St. Bridget. The author thus describes her dream and consequent action: 'In urbe Romana juxta corpora Petri et Pauli audivi missas; et nimis desidero ut ad me istius ordo et universa regula feratur a Roma. Tunc misit Brigida viros sapientes et detulerunt inde missas et regulam.'-Cap. 9r. The introduction of the Roman Liturgy into the Irish Church is antedated in this passage by many centuries. Its historical value is equal to that of the next chapter, which describes St. Bridget hanging her clothes to dry on a sunbeam.

A part of Chapter ii has previously appeared in the form of an article in the Church Quarterly Review (vol. x. p. 50), and a part of Chapter iii in letters to the Editor of the Academy.

Latin authorities have been frequently quoted in extenso. 


\section{Preface.}

Gaelic authorities have merely been referred to. Iong passages in the ancient dialects of Ireland, Scotland, and Wales would have added considerably to the bulk of the volume, and would have been unintelligible to the majority of readers.

The retention of an original orthography will explain the occasional occurrence of such forms as 'sinodus,' 'imnus,' ' oremen,' \&c., for 'synodus,' 'hymnus,' 'crimen,' \&c. The retention of a popular nomenclature will account for such forms as Charlemagne, Iona, \&c., instead of Karl the Great, $\mathrm{Hi}$, \&c.

It would not be possible to compile such a volume as the present one without being largely beholden to the labours of other writers. The source of information has been generally indicated in foot-notes, but in case of accidental omission the author begs once for all to express his indebtedness to such recently deceased writers as Dr. Todd, Mr. Haddan, and Bishop Forbes, and to such living writers as Professor Stubbs, Mr. Skene, and Dr. Reeves, from whose edition of Adamnan's Life of St. Columba, as from a rich quarry, a knowledge of many facts recorded in this volume has been obtained. It is doubtful whether in the anuals of literature so much important information has ever before been so lavishly accumulated and so skilfully arranged within a few hundred pages, or whether any other editorial task bas ever been more thoroughly executed.

The author also begs to express his thanks to the Earl of Ashburnham for his kind permission to inspect and copy out the liturgical portion of the MS. volume known as the Stowe Missal, and to Professor Rhŷs, Mr. Whitley Stokes, Professor Westwood, and Mr. Henry Bradshaw for their kindly-afforded assistance in linguistic and palæographical questions respectively. 



\section{AUTHORITIES CITED.}

[This list is not exhaustive. It only includes certain well-known works, to which frequent reference has been made, in the case of which it seemed desirable to specify once for all the edition made use of; and certain less-known works, to which occasional reference has been made, and to which it seemed desirable to append the date of their composition, and of the earliest MS. authority.]

\section{Adamnani Canones: sec Canones.}

Adamnani Vita S. Columbae. The Latin text, taken from an early eighthcentury MS. at Schaffhausen, was published with copious notes by Dr. Reeves at Dublin, 1857. Adamnan was the ninth presbyter-abbot of Iona, A.D. 679-704. Rolls Series, Descriptive Catalogue, vol. i. pt. i. p. I67. Antiphonarium Benchorense. A seventh-century MS. originally belonging to the monastery of Bangor, county Down. It is proved from internal evidence to have been written A.D. 680-691, during the life-time of Abbot Cronan. It is now preserved in the Ambrosian Library at Milan. It has been printed in Muratori's Anecdota Bibliothecae Ambrosianae, vol. iv. pp. I 2 II 59 ; Migne, Patrol. Curs. Lat. lxxii. $5^{82}$; Ulster Journal of Archaeology, I853, pp. I68-I 79 .

Archaeologia : London, from 1770.

Archaeologia Cambrensis: London, from I846.

Archaeologia Scotica : Edinburgh, from 1792.

$\mathbf{B}=$ British Martyrology : London, $\mathrm{i} 76 \mathrm{r}$.

Bedae Historia Ecclesiastica : edited by G. H. Moberly, Oxford, r869. Rolls

Series, Descriptive Catalogue, vol. i. pt. i. p. 433.

Bernardi de Vita Malachiae Liber: fol. Paris, I586. Rolls Series, Descriptive Catalogue, vol. ii. p. $23^{6}$.

Betham, Sir W., Irish Antiquarian Researches : Dublin, 1827 .

Black Book of Caermarthen : a twelfth-century Welsh MS. (A.D. I I 54-I I 89), published in Skene's (W. F.) Four Ancient Books of Wales, Edinburgh, I 868.

Blight, J. T., Ancient Crosses and other Antiquities in the East of Cornwall : London, $185^{8}$.

Book of Armagh : in Trinity College, Dublin, written by Ferdomnach A.D. 807. The evidence for this date, together with a description of the contents of this MS., is given in the Nat. MSS. of Ireland, part i. p. xiv.

Book of Deer: see p. 163 .

Book of Dimma : see p. 167 . $^{\circ}$

Book of Hymns : see Liber Hymnorum.

Book of Mulling : see p. I7I.

Book of Obits : a ffteenth-century MS. in Trinity College, Dublin, published by Irish Arch. Soc. Dublin, 1844. 
Borlase, W. C., The Age of the Saints (Cornish): Truro, 1878.

Bright, W., Early English Church History : Oxford, 1878 .

Canones Adamnani: MS. Codex Paris, 3182 ; saec. xi; printed in Wasserschleben, Bussordnung. der Abendländ. Kirche, p. 120.

Canones S. Patricii : Irish Canons, (I) Sinodi episcoporum, Patricii Auxilii, Isernini, (2) two single Canons attributed to St. Patrick, (3) Canones secundae S. Patricii sinodi, all eroneously so attributed, and to be referred in their present form to a date A.D. 716-807. Printed in H. and S. vol. ii. pt. ii. p. $3^{28}$.

Canones Wallici belonging to the period A.D. 550-650; MS. Cod. Paris. S. Germani, I2 I, saec. viii. Printed in H. and S. i. I27.

Catalogus Sanctorum Hiberniae : traditionally believed to have been composed by Tirechan c. 650 , and certainly not later than the middle of the eighth century. Printed by Archbp. Ussher, De Brit. Eccles. Prim. cap. xvii, from two MSS. of which he does not give the date. H. and S. vol. ii. pt. ii. p. 292.

Codex MS. Vetustissimus. A document containing information about the British Liturgy, assigned by Spelman to the ninth century on palaeographical grounds, but proved on internal evidence to have been written in the eighth century. Printed in H. and S. i. ${ }_{3} 8$.

Cogitosi Vita S. Brigidae : printed in Colgan, Trias. Thaum. pp. 518-26. The date of this work is discussed in the Transactions of the Royal Irish Acad. vol. xx. pp. 195-205. The earliest MS. authority for it belongs to the middle of the ninth century. Cogitosus has been identified with the father of Muirchu Macumactheni (ob. A.D. 699); therefore the work must originally have been written c. A.D. 650, unless Mr. Skene is right in his conjecture, that the work has been fathered on Cogitosus, and erroneously assigned to the seventh century (Celtic Scotland, ii. 296); a conjecture supported by internal evidence, see p. 90. Rolls Series, Descriptive Catalogue, i. ro6.

Colgan, J., Acta Sanctorum veteris et majoris Scotiae seu Hiberniae : Lovanii, 1645 .

Colgan, J., Triadis Thaumaturgae Acta : Lovanii, 1647.

Columbae : Regula, vide Rule ; Hymnus, 'Altus Prosator' in Liber Hymnorum, p. 20r ; Leabhar Breac, 237, col. 1.

Columbani Opera : quoted from Fleming's Collectan. Sacra, printed by him 'ex antiquis monasterii Bobiensis monumentis.'

Cooper, C. Purton: Appendix A, B, C, D, E to intended Report on Foedera, in three vols. printed 1837 , published, but not publicly circulated, by the Record Office, 1869 .

Corpus Missal = Missale Vetus Hibernicum, q. v.

Culdees : see Rule of.

Cuminii De mensura Poenitentiarum, or Poenitentiale. It is doubtful how far this work retains its original Scottish form. Wasserschleben considers that it has so far lost it as to rank it among Frankish rather than Celtic Penitentials. Haddan and Stubbs (Introd. p. xii) incline to consider it the work of a Bishop Cummian at Bobbio, A.D. 7 rI-744. It may however be regarded as founded upon an earlier Celtic work. References are made to Fleming's Collectan. Sacra, p. 197, by whom it was printed from a St. Gall MS., No. 550. 


\section{Authorities Cited.}

Cuminii Albi (or Cummenei, or Cumeani), Vita S. Columbae : written by Cummene Ailbhe, son of Ernan, seventh presbyter-abbot of Iona, A. D. 657-669. The reference, unless otherwise specified, is to Pinkerton's edit. Rolls Series, Descriptive Catalogue, i. 166.

Cumming, J. G., Runic and other Monumental Remains in the Isle of Man : London, I 857 .

D. = Martyrology of Donegal, q. v.

Descriptive Catalogue of the Materials relating to the History of Great Britain and Ireland, by T. Duffus Hardy : Rolls Series, London, 1862.

Döllinger, J. von, Geschichte der christlichen Kirche : Landshut, I833.

Dunraven, Lord, Irish Architectural Antiquities : edited by Margaret Stokes, London, 1878 .

Evin, St., Vita S. Patricii : a ninth, tenth, or eleventh century compilation (Skene's Celtic Scotland, ii. 442 ; Chron. of Picts and Scots, Pref. xxix), known as the Tripartite Life of St. Patrick, attributed to his disciple St. Evin in the sixth century, by whom it was supposed to have been written partly in Irish and partly in Latin. Translated in Colgan, Trias Thaum. pp. 1 17-169, from three Irish MSS. which cannot now be with certainty identified. Rolls Series, Descriptive Catalogue, i. 65.

F. = Félire of Oengus, q.v.

Fastidii De Vita Christiana Liber unus: addressed by Fastidius, Bishop of London in the fifth century, to a widow named Fatalis. This book bears internal marks of genuineness, and is no doubt the work alluded to by Gennadius of Marseilles writing at the end of the fifth century. "Fastidius Britanniarum Episcopus scripsit ad Fatalem (quendam) de Vita Christiana librum unum, et alium de viduitate servanda, sana et Deo digna doctrina.' Gennadius (c. 458), De Viris Illustr. in Hieron. Opp. v. 39. Bened. It has been printed by Migne, Patrol. Curs. Lat. vol. 1. p. 385; Galland. Bib. Vet. Pat. ix. $4^{81}$.

Félire of Oengus: a metrical account of the festivals of the Church, attributed to Oengus the Culdee in the beginning of the ninth century, but certainly written after A.D. $9^{82}$, preserved in the Leabhar Breac, and in six other MSS. of which an account is given by Mr. Whitley Stokes (pp. 2-6). It is described in E. O'Curry's Lectures on MS. Materials of Ancient Irish History (pp. $3^{64-7 I}$ ), and has recently been published by Mr. Whitley Stokes with translation and glossary in the Transactions of the Royal Irish Academy, Irish MS. Ser. vol. i. part I, June, I880. Arabic numerals refer to pages in the Leabhar Breac, Roman numerals to pages in Mr. W. Stokes' edition.

Fiacc, St., Bishop of Slebhte (c. 4I8-495), Gaelic Hymn of : perhaps composed as early as the end of the sixth century. The earliest extant MS. copy is in the Liber Hymnorum, q. v. Printed in H. and S. ii. 2. Mr. Skene considers this hymn a composition of the ninth century (Celtic Scotland, ii. 435). Rolls Series, Descriptive Catalogue, i. 62.

Fleming, Patricii, Collectanea Sacra : Louvain, 1667.

Forbes, A. P., Kalendar of Scottish Saints : Edinburgh, 1872.

Gilbert, J. T., Facsimiles of National MSS. of Ireland, in four parts : Ordnance Survey Office, Southampton, I 874 .

Gildas: British historian (De Excidio Britanniae), sixth century A.D. His genuine works are, Epistola (c. A.D. 547-550); Fragmenta ex Epistola 
altera (c. A.D. 565-570); Prefatio de Penitentia (ante A.D. 570), MS. Cod. Paris. 3182, saec. xi. Unless otherwise specified, reference has been made to J. Stevenson's edit., London, 1838. Rolls Series, Descriptive Catalogue, i. I 32.

Greith, C. J., Geschichte der altirischen Kirche : Breisgau, I867.

Haddan, A. W., Remains of: edited by A. P. Forbes, Bishop of Brechin, Oxford, 1876 .

H. and S. = Haddan, A. W., and Stubbs, W., Councils and Ecclesiastical Documents of Great Britain and Ireland : Oxford, 1869.

Hardy, T. Duffus : see Descriptive Catalogue.

Hibernensis Sinodus : see Wasserschleben.

Howel Dda, Welsh laws of, A. D. 928. Earliest MS. authority twelfth and thirteenth century. Printed in H. and S. i. $211-285$.

Hübner, Amilius, Inscriptiones Britanniae Christianae: Berolini, MDccclxxvI. Jonae Vita S. Columbani. Jonas, a native of Susa in Piedmont, wrote (c. A.D. 624) by order of Attala and Eustace, successors of Columbanus, the former at Bobbio, the latter at Luxeuil. Several MSS. of this Life exist on the continent, none of them probably earlier than a ninth-century copy which was sold in London at M. Liber's sale, March 9, I858 (Catal. No. 269, p. 63). It is printed in Fleming's Collectanea, ii. 214-243. Rolls Series, Descriptive Catalogue, i. 2 I 2.

Irish Archaeological and Celtic Society, Publications of the : Dublin University Press, from 1855 . Volumes from $1840-1855$ were published by two separate 'Archaeological and 'Celtic' Societies which amalgamated in the latter year. Keller, F., Bilder und Schriftzïge in den irischen Manuscripten, in Mittheilungen des antiquarischen Gesellschaft in $Z$ urich, vol. vii. p. 6r.

Leabhar Breac, or Lebar Brecc: The Speckled Book, otherwise called Leabbar Mor Duna, The Great Book of Dun Doighre; a large fol. vellum volume in the Royal Irish Academy, Dublin, containing a collection of pieces in Irish and Latin, compiled from ancient sources about the end of the fourteenth century. Published in facsimile from the original MS., Dublin, 1876 .

Liber Davidis: MS. Cod. Paris. 3182, saec. xi; printed in H. and S. i. 118.

Liber Hymnorum, or 'Book of Hymns,' a MS. Irish collection of hymns and collects. See page I94. A second MS. copy belongs to S. Isidore's College at Rome.

Liber Kilkenniensis : a fourteenth-century MS. containing lives of Irish Saints; Marsh's Library, Dublin. It is described at length by Dr. Reeves in the Proceedings of the Royal Irish Academy, Second Series, vol. i.

Liber Landavensis: a tenth-century MS. containing lives of Welsh Saints, \&c. (see Rees' Preface), written during the episcopate of Bishop Urban, I 107-34; published by L. J. Rees, Llandovery, I 840 .

Mart. = Martene, Edm., De Antiquis Ecclesiae Ritibus : Bassani, Mncclxxxvirr. Martyrology of Christ Church, Dublin : a fifteenth-century MS. in Trinity College, Dublin, published, together with the Book of Obits, by the Irish Archaeological Society, Dublin, 1844 .

Martyrology of Donegal: compiled in the Franciscan Convent of Donegal by Michael O'Clery, and finished on April 19, 1630; published by Irish Archaeological and Celtic Society, Dublin, 1863.

Martyrology of Oengus $=$ Felire of Oengus, q. $\mathbf{v}$. 
Martyrology of Tallaght. Traditionally said to have been compiled at the end of the ninth century by St. Maelruain and St. Oengus, but certainly as late as the tenth century; imperfectly edited by M. Kelly, Dublin, I857, from an early seventeenth-century MS. copy in the Burgundian Library at Brussels.

Missale de Arbuthnott (fifteenth century, Scottish) : edited by A. P. Forbes: Burntisland, $186_{4}$.

Missale Drummondense (Irish MS., eleventh century). See p. 269.

Missale Gallicanum : Pitsligo Press edition; Burntisland, 1855.

Missale Gothicum : Pitsligo Press edition ; Burntisland, I855.

Missale Mozarabicum : Migne, Patrol. Curs. Lat., vol. Ixxxv.

Missale Richenovense (Gallican): Burntisland, I855.

Missale Romanum: Mechliniae, 1870.

Missale Rosslynianum : Irish MS., fourteenth century. See p. 269.

Missale Sarisburiense: Burntisland, I861.

Missale Stowense. See p. 198 .

Missale Vesontionense : Pitsligo edition; Burntisland, 1855, and in Mabillon's Museum Italicum, tom. i. p. 273. See p. 272.

Missale Vetus Hibernicum (twelfth century): Pickering, London, I879.

Montalembert, Comte de, Les moines d'Occident: Paris, $1860-77$; Authorised translation, Edinburgh, I 86I-77.

O'Conor, C., Bibliotbeca MS. Stowensis: Buckinghamiae, MD.ccoxvilu. Dr. O'Conor's liturgical remarks and criticisms are often erroneous and misleading (see p. 198), and his palaeographical descriptions must be received with caution.

O'Conor, C., Rerum Hibern. Scriptores Veteres, tom. iv: Buckinghamiae, MDCCCXIV.

O'Neill, H., Sculptured Crosses of ancient Ireland : London, I857.

Ozanam, A. F., La Civilisation Chrétienne chez les Francs: Paris, I849.

Patricii Opera: : all composed befure A.D. 493, i.e. (1) Confessio, in Book of Armagh; (2) Epistola ad Corotici subditos, in Cotton MS. Nero E. i. (eleventh century); (3) Canticum Scotticum, in the Liber Hymnorum; printed in $H$. and S. vol. ii. pt. ii. pp. 296-323.

Petrie, G., Christian Inscriptions in the Irish Language : edited by M. Stokes, Dublin, $1870-78$.

Petrie, G., The Ecclesiastical Architecture of Ireland anterior to the AngloNorman Invasion; vol. xx. of the Transactions of the Royal Irish Acad.

Pinkerton, J., Vitae Antiq. SS. Scotiae: London, 1789.

Poenitentiale Columbani : printed in Fleming's Collectan. Sac. p. 94, from a sixth-century MS. at Bobbio; also by Wasserschleben, Bussordnungen, p. 353, who ranks it among Frankish Penitentials, and proves that it has been erroneously attributed to St. Columbanus, p. I 2.

Poenitentiale Cuminii : vide Cuminii.

Poenitentiale Gildae: ante A. D. 570. MS. Cod. Paris. 3182, saec. xi=Prefatio Gildae de penitentia : vide Gildas.

Poenitentiale Vinniani : MS. Cod. Vindob. Theol. $725,8^{\circ}$. saec. ix, printed in

Wasserschleben, Bussordnung. der abendländ. Kirche, p. 108.

Proceedings of Royal Irish Academy : Dublin, from 1836.

Proceedings of the Society of Antiquaries of London: from I843.

Proceedings of the Society of Antiquaries of Scotland : from 1856 .

R. = Missale Romanum, q. v. 
Reeves, W., Ecclesiastical Antiquities of Down, Connor, and Dromore : Dublin, 1847 .

Reeves, W., Life of Columba : see Adamnan.

Regula: see Rule.

Report on Foedera: see Cooper, C. P.

Rituale Romanum (Rit. Rom.): Mechliniae, Mdccchxx.

Rule of St. Columba : from a seventeenth-century MS. in the Burgundian Library at Brussels; itself a transcription by Michael O'Clery, one of the Four Masters, from earlier MS. records. It is probably the compilation of a later Columban monk. Printed in Gaelic, with a translation, by $\mathrm{H}$. and S. ii. pt. i. p. 119.

Rule of St. Columbanus : Regula Sancti Columbani, descripta ex MS. Codice Monasterii Bobiensis, et collata cum aliis exemplaribus MSS. Bib. Oxenhusani in Suevia et SS. Afrae et Uldarici urbis Augustinae. Printed in Fleming's Collectanea, pp. 4, 19.

Rule of the Culdees (Riagail na Celedne o Maelruain cecinit), in the Leabhar Breac, q. v. It is an Irish tract drawn up in its present form in the twelfth or thirteenth century, but regarded by Dr. Reeves to be an amplified and modernised form of the Rule drawn up by St. Maelruain, founder, abbot, and bishop of the Church of Tamlacht (Tallaght), near Dublin, at the close of the eighth century. The pages referred to are those of Dr. Reeves' edition, Dublin, I864.

S. = Missale Sarisburiense, q. v.

Sacramentarium Ga.licanum = Missale Vesontionense, q. v.

Sacramentarium Leonianum, Gelasianum, Gregorianum. All paginal references are to Muratorii Liturgia Romana Vetus : Venetiis, MDccxlvir.

Schoell, C. G., De ecclesiasticis Britonum Scotorumque fontibus : Berlin, $185 \mathrm{I}$. Secundini Hymnus in laudem S. Patricii : Hymn of St. Sechnall, composed before A.D. $44^{8}$; written in the Antiphon. Benchor., q.v. Printed in H. and S. vol. ii. pt. ii. p. $3^{24}$.

Senchus Mor: a collection of Irish laws drawn up A.J.438-44I, between the sixth and ninth years after St. Patrick's arrival in Ireland, representing the modifications which the ancient Pagan laws underwent on the conversion of Ireland to Christianity; printed at Dublin, 1865. Four MS. copies exist, the earliest of which was written in the fourteenth century (Pref. vol. i. pp. xxxi-xxxiv), and a few MS. fragments (Pref. vol. iii. p. lxv).

Sinodus Aquilonalis Britanniae: MS. Cod. Paris. $3^{182}$, saec. xi ; printed in H. and S. i. I I 7 .

Sinodus Hibernensis : see Wasserschleben.

Sinodus Luci Victoriae, A.D. 569: MS. Cod. Paris. 3182, saec. xi ; printed in H. and S. i. I 16.

Skene, W. F., Celtic Scotland, two vols. : Edinb. I 876 .

Stowe Missal, see p. 198.

Stuart, J., Sculptured Stones of Scotland, in vol. xxvi of the publications of the Spalding Club.

T. = Martyrology of Tallaght, q. v.

Todd, J. H., Descriptive Remarks on Illuminations in certain ancient Irish MSS. : London, I869.

Todd, J. H., Life of St. Patrick : Dublin, I864.

Transactions of Royal Irish Academy: 4to., Dublin, from ${ }_{7} 787$. 
Transactions of Society of Antiquaries of Scotland : Edinb., from I $79^{2}$.

Ulster Journal of Archaeology: Belfast, 1853-62.

Ultani Vita S. Brigidae: a tenth-century MS. in the monastery of St. Magnus at Ratisbon, of a work by Ultan Bishop of Ardbraccan (ob. A.D. 656-7); printed in Colgan's Trias. Thaum. pp. 542-5.

Ussher, Archbishop, Brit. Eccles. Antiquitates : Dublin, 1739.

Ussher, Archbishop, Opera Omnia : Dublin, 1847.

V. = Biblia Sacra Vulgatae Editionis : Angustae Taurinorum, 1875.

Walafridus Strabo, Vita S. Galli: quoted from Goldasti, Aleman. Rerum Script. aliquot vetusti, Francof. 1606. There is a ninth-century MS. in the Library at Bern.

Wasserschleben, F. W. H., Die Bussordnungen der abendländischen Kirche: Halle, 1851 .

Wasserschleben, F. W. H., Irische Kanonensammlung: Giessen, 1874. A collection of Irish canons of the end of the seventh or beginning of the eighth centuries. The grounds for assigning this date, and the age of various MS. copies collated in different European libraries, are discussed in the Preface. The MSS. vary from the eighth to the eleventh centuries. A tenth-century MS. copy exists in the Bodleian Library (Hatton MSS. No. 42, fol. I-65), and a ninth or tenth century MS. in C. C. C., Camb., No. 279, both uncollated by Wasserschleben, but mentioned in the Introduction, pp. xvi, xxi.

Wattenbach, Dr., Die Kongregation der schötten Klöster in Deutschland. Translated, with notes, by Dr. Reeves in Ulster Journal of Archaeology, vii. $227,295$.

Westwood, J. O., Lapidarium Walliae : Oxford, 1876-9.

Westwood, J. O., Miniatures and Ornaments of Anglo-Saxon and Irish MSS.: London, I 868.

Westwood, J. O., Pala eographia Sacra Pictoria: London, I843.

Wilson, D., Archaeology and pre-historic Annals of Scotland : Edinburgh, 1851 . 



\section{CHA P T E R I.}

\section{INTROWUCTION.}

§ 1. Extent and Duration of the Celtic Church. - $\S 2$. Its Monastic and Missionary Character. $-\S 3$. Its Orthodoxy. - $\$ 4$. Its Independence of Roine. - $\S 5$. Eastern connection. $-\S 6$. Gallican connection. 7. Spanish connection. $-\$ 8$. Points of difference between Celtic and Roman Churches. 



\section{CHAPTER I.}

INTRODUCTION.

IT would be alien to the purpose with which this volume is written, and impossible within the limits which it is intended to assume, to present to the reader a complete history of the 'Celtic Church;' but it is necessary to define at the outset what is meant by that term, and it will be advantageous to add to this definition a notice of such of its more important features and general characteristics as have an $a$ priori bearing on the probable genus of its Liturgy and Ritual, which will then be described with as much detail as the nature of the subject-matter and the amount of evidence at our disposal render possible.

$\S 1$. Extent and Duration of the Celtic Church.-By the term 'Celtic Church' is meant the Church which existed in Great Britain and Ireland (with certain continental offshoots) before the mission of St. Augustine, and to a varying extent after that event, until by absorption or submission the various parts of it were at different dates incorporated with the Church of the Anglo-Saxons 1 .

Central England.-The Celtic Church in Central England became extinct at the close of the fifth century, its members being then either exterminated in war, or retiring to the

1 The Scoti and Britones are often mentioned together, as in the letter of the first Anglo-Saxon Bishops preserved by Bede (H. F. lib. ii. c. 4); in the Penitential of Theodore, cap. ix. $\S$ 1. See p. 9. n. 2, p. 28. n. 6. 
remoter parts of the country for shelter from the attacks of heathen invaders from Jutland, Sleswick, and Holstein. In those more distant quarters the ancient national Church maintained a separate existence and a corporate continuity long after the conversion of the Anglo-Saxons which was begun by the Roman mission under the leadership of St. Augustine.

Wales.-The Britons of North Wales did not conform to the usages of the Anglo-Saxon Church till A.D. 768, those of South Wales not till A.D. 777. The supremacy of the See of Canterbury was not fully established here till the twelfth century.

Southern England.-The British Church in Somerset and Devon, or to speak more exactly the British population dwelling within the territory conquered by the West-Saxons, conformed at the beginning of the eighth century, through the influence of Aldhelm, who became Abbot of Malmesbury A.D. 67I, Bishop of Sherborne A.D. $705^{1}$.

In Cornwall the Bishops of the British Church were not subject to the See of Canterbury before the time of King Athelstan (925-940), the submission of Bishop Kenstec to Archbishop Ceolnoth (833-7c) being the only exception. On the conquest of Cornwall by the Saxons the British Bishop Conan submitted to Archbishop Wulfhelm, and was recognised by King Athelstan, who formally nominated him to the Cornish See of Bodmin A.D. $93^{6}$.

Northumberland.-The Celtic Church, established in Northumberland by King Oswald A.D. 634-5, after having flourished thirty years under the Scottish bishops Aidan, Finan, and Colman, successively, conformed to the Roman practice at the Synod of Whitby A.D. $66_{4}$; when Colman, who had throughout unsuccessfully opposed the change, 'perceiving that his doctrine was rejected and his sect despised, took with him such as were willing to follow him, and would not comply with the Catholic Easter and coronal tonsure,-for there was much 


\section{\$.] Extent and Duration of the Celtic Church. 5}

controversy about that also,-and went back into Scotia, to consult with his people what was to be done in this case.'

Strathclyde.-The Britons of Strathclyde conformed A.D. 688, the year after the death of St. Cuthbert, on the occasion of a visit among them of Adamnan, Abbot of Iona, who himself had been persuaded about this time to adopt the new policy. Sedulius, the first British Bishop of Strathclyde who conformed to Roman usage, is mentioned as present at a council held at Rome under Gregory II, A.D. $721^{2}$.

Scotland.-Adamnan attempted to force the Scottish Church to conform to Roman usage at the close of the seventh century, after his return from his second mission to King Aldfrith in Northumbria A.D. 688, but unsuccessfully. His action is thus recorded by Bede:-

'Adamnan, priest and abbot of the monks who were in the isle of Hii, was sent ambassador by his nation to Aldfrith, King of the Angles, where, having made some stay, he observed the canonical rites of the Church, and was earnestly admonished by many who were more learned than himself, not to presume to live contrary to the universal custom of the Church in relation to either the observance of Easter or any other decrees whatsoever, considering the small number of his followers seatcd at so distant a corner of the world. In consequence of this he changed his mind, and readily preferred those things which he had seen and heard in the Cliurches of the Angles to the customs which he and his people had hitherto followed. For he was a good and wise man and remarkably learned in the knowledge of the Scriptures. Accordingly returning home he endeavoured to bring his own people that were in $\mathrm{Hii}$, or that were subject to that monastery, into the way of truth, which he himself had learned and embraced with all his heart, but in this he could not prevail ${ }^{3}$.'

\footnotetext{
1 Bede, H. E. iii. 25.

2 'Sedulius, episcopus Britanniae, de genere Scottorum, huic constituto a nobis promulgato subscripsi.' $H$. and $S$. ii. 7 , with note.

3 Bede, H. E. v. 15.
} 
After the death of Adamnan, A.D. 704, there were two parties in this controversy, which was eventually settled in favour of the Roman rule by a decree of Nectan, King of the Picts, A.D. 7 10. ' Not long after which,' says Bede, 'those monks also of the Scottish nation who lived in the isle of Hii, with the other monasteries that were subject to them, were, by the procurement of our Lord, brought to the canonical observance of Easter and the right mode of tonsure. For in the year after the incarnation of our Lord A.D. 716 , the father and priest Ecgberct, beloved of God, and worthy to be named with all honour, coming to them from Ireland was very honourably and joyfully received by them . . . and by his pious and frequent exhortations he converted them from the inveterate tradition of their ancestors. He taught them to perform the principal solemnity after the Catholic and Apostolic manner. The monks of $\mathrm{Hii}$ by the instruction of Ecgberct adopted the Catholic rites, under Abbot Dunchad (A.D. 710-7I7), about eighty years after they had sent Bishop Aidan to preach to the nation of the Angles'.'

But the acceptance of the Paschal rule at $\mathrm{Hii}$ in 716 did not settle the practice of that Church finally, for we are informed that the Easter-tide of Ecgberct's death (A.D. 729) was the first Easter celebrated according to the Roman calculation ${ }^{2}$. A schism had taken place at Iona A.D. 704, and rival abbots existed till A.D. 772, when on the death of the Abbot Suibhne the conformity of the whole monastery of Iona to the Roman Church may be considered to have been established ${ }^{3}$. But this remark does not apply to the whole of Scotland. Customs and ritual peculiar to the ancient Church of the country existed long after the

\footnotetext{
1 Bede, H. E. v. 22.

2 Ib. 'Cum eo die (i.e. viii. Kal. Maii) Pascha celebraretur, quo nunquam prius in eis locis celebrari solebat.' In 716 the Columban monks were banished from the territories of Nectan, king of the Picts, in consequence of their refusal to comply with a royal edict commanding the adoption of the Roman Paschal cycle and coronal tonsure. Annals of Ulster.

s Skene, W. F., Celtic Scotland, ii. 288.
} 
eighth century. When St. Margaret, a Saxon Princess, married King Malcolm III, A.D. I069, she promoted a religious reformation, which is said to have included the abolition of the following four Scottish customs:-

I. The commencement of Lent on the first Monday in Lent instead of on Ash Wednesday. This is the custom at Milan to the present day. It may perhaps be traced in the Sarum direction to cover up all crosses, \&c. on the first Monday in Lent.

2. The non-reception of the Holy Eucharist on Easter Day. It is difficult to understand this statement, because Easter Day in the early Scottish Church was 'the festival of joy',' and the Easter Communion was especially singled out for mention ${ }^{2}$. In the early Irish Church it was enjoined on all the faithful by one of the canons attributed to St. Patrick ${ }^{3}$. A King of Leinster is said to have paid a visit to St. Bridget, in order to listen to preaching and celebration on Easter Day 4 .

3. Labour on the Lord's Day.

4. Strange customs in the Mass.

St. Margaret's biographer tells us that 'in some places among the Scots there were persons who, contrary to the custom of the whole Church, had been accustomed to celebrate Masses by some barbarous rite, which the Queen, kindled with God's zeal, so laboured to destroy and bring to nothing, that thenceforth there appeared no one in the whole race of the Scots who dared to do such a thing ${ }^{5}$.'

1 'Laetitiae festivitas.' Adamnan, Vit. S. Columbae, iii. 23.

2 'Ut in Paschali solemnitate ad altarium accedas, et Eucharistiam sumas. ... Et post peractam Paschae sollennitatem in qua jussus ad altare accessit.' Ibid. ii. 39 .

3 'Maxime antem in nocte Paschae, in qua qui non communicat, fidelis non est.' Can. S. Patricii, Secundae Sinodi, xxii.

- Leabhar Breac, fol. 64 a.

s ' Praeterea in aliquibus locis Scottorum quidam fuerunt, qui contra totius Ecclesiae consuetudinem, nescio quo ritu barbaro, missas celebrare consueverant ; quod regins, zelo Dei accensa, ita destruere atque annihilare studuit, ut deinceps qui tale quid praesumeret, nemo in tota Scottorum gente appareret.' Theoderic, Vit. S. Margaret. cc. 8 sq.; H. and S. ii. i. $15^{8}$. 
In the absence of any direct statement as to what these liturgical peculiarities were, we are left to conjecture either that they were connected with the celebration of Mass in the vernacular instead of in the Latin language ${ }^{1}$, or, with more probability $^{2}$, that up to the eleventh century the Ephesine and the Roman Liturgies were used contemporaneously in Scotland, somewhat in the same way that in France a transition period can be traced through such service books as the 'Sacramentariun Gallicanum,' in which Ephesine and Petrine forms present themselves alternately. The above charges also indicate that the final extinction of the old Celtic Church in Scotland was partly owing to internal decay, as well as to the line of policy adopted by Queen Margaret and Malcolm Canmore, which was the same as that adopted in the next century by the Anglo-Norman kings towards Ireland. Neither a national Church nor a religious movement can be easily extinguished by royal authority, uuless there are other and co-operating influences at work. St. Margaret was not immediately successful in her attempts at suppression. Fifty years later, in the reign of King David, we learn that the Culdees 'in a corner of their church which was very small used to celebrate their own office after their own fashion ${ }^{3}$ '. It is the last spark in the expiring embers of the controversy and the struggle for supremacy between two elements in the ecclesiastical history of Scotland; the old national Celtic element represented by

1 This is Mr. Skene's view, who lays stress on the words 'barbaro ritu.' His words are: 'It is not explained in what this peculiarity existed, but it was something done after a barbarous manner, so that it is impossible to tell how it (Mass) was celebrated, and it was entirely suppressed. This is hardly applicable to the mere introduction of some peculiar forms or ceremonies, and the most probable explanation of these expressions is that in the remote and mountainous districts the service was performed in the native langliage and not in Latin, as was the custom of the universal Church.' Celtic Scotland, ii. 349 .

2 This is Bishop Forbes' view. Missale de Arbuthnot, Preface, lv.

3 ' Keledei enim in angulo quodam ecclesire, quae modica nimis erat, suum officium more suo celebrabant.' Chron, Picts and Scots, p. r9o, edited by W. F. Skene; Edinb. 1867 . 


\section{\$I.] Extent and Duration of the Celtic Church. 9}

the independence of the Scottish episcopate and the retention of the ancient Missal; and the Anglicising element, patronised by the royal authority of Malcolm Canmore and Queen Margaret, subjecting the Scottish episcopate to the supremacy of York, and introducing the Anglicanised (Roman) Missal. It is possible but not certain that this was the Use of Sarum. St. Osmund published that Use in A.D. 1085. St. Margaret died in A.D. 1093. There was therefore time for her to bave seen, approved, and initiated the circulation of the Sarum Missal; but considering the slowness of communication in those days, and the time necessarily occupied in the transcription of copies, it is more probable that she introduced the Anglican rite in the form in which it existed before it was arranged by St. Osmund. This probability is increased by the fact that the Sarum Use was not introduced into the Cathedral and See of Glasgow till the time of Bishop Herbert (A.D. I $147-64$.)

Ireland.-The Celtic Church in the South of Ireland conformed to Rome on the Paschal controversy, and probably in other respects as well, during the pontificate of Honorius (A.D. 626-638). The letter of that Pope, urging such conformity, has been preserved by Bede ${ }^{1}$, and the letter of Cummian, Abbot of Durrow, written A.D. 634 to Segine, fifth Abbot of Iona, announcing the determination of Southern Ireland to conform to Roman usage, is still extant ${ }^{2}$. The Church in Northern Ireland was induced to take a similar step, at the instance of Adamnan, at the Synod of Tara, A.D. $692^{3}$.

But in the case of Ireland, as in Scotland, complete conformity to Roman usage was not secured for many centuries

3 Bede, H. E. ii. 19.

2 Migne, Bib. Pat. Lat. 1xxxvii. p. 969. In this letter Cummian parodies the independent position of the Celtic Church by representing its members as saying, 'Roma errat; Hierosolyma errat; Alexandria errat; Antiochia errat; soli tantum Scoti et Britones rectum sapiunt.'

${ }^{3}$ An account of this synod is given in Reeves' edition of Adamnan's Life of Columba, Appendix to Preface, p. 1 . 
afterwards. The last vestiges of the old national rite, and of liturgical and ritual independence, were not swept away till the time of St. Malachy, the great Romaniser - the Wilfridof the Irish Church. Born A.D. 1075, he became Bishop of Armagh (II34-II48), and in that capacity visited Pope Innocent II, demanded the pallium, which had not hithertobeen worn by Irish bishops, and was invested with legatine authority over the Irish Church. His biographer St. Bernard expressly states that 'Roman laws and ecclesiastical customs were introduced by him into his native country ${ }^{1}$ ' And again, ' $\mathrm{He}$ established in all Churches the Apostolical constitutions, and the decrees of the holy fathers, and especially the customs of the boly Roman Church².' Gillebert, the papal legate, Bishop of Limerick (1 106-I I39), implies that there had been more than one Liturgical Use in Ireland previously to that date. He said in the Prologue of a book 'De Usu Ecclesiastico,' addressed to the whole clergy of Ireland :-

'At the request and also at the command of many of you, most dearly beloved, I have endeavoured to set down in writing the canonical custom of saying the hours, and performing the office of the whole ecclesiastical order, not presumptuously, but desiring to serve your most godly command, in order that those diverse and schismatical orders, with which nearly all Ireland has been deluded, may give place to one Catholic and Roman Office ${ }^{3}$.'

At a Synod held at Kells $\mathbf{A}$. D. I I 52, under the papal legate

1 'Fiunt de medio barbaricae leges, Romanae introducuntur. Recipiuntur ubique ecclesiasticae consuetudines, contrariae rejiciuntur.' Bernard, Vit. S. Malachiae, cap. 8 . $\$$ I 7 .

2 'A postolicas sanctiones, ac decreta sanctorum Patrum, praecipueque consuetudines sanctae Romanae ecclesiae in cunctis ecclesiis statuebat.' Ibid. cap. 3. $\$ 7$.

3 'Rogatu necnon et praecepto multorum ex vobis, carissimi, canonicalem consuetudinem in dicendis horis, et peragendo totius ecclesiastici ordinis officio, scribere conatus sum; non praesumptivo sed vestrae cupiens piissimae servire jussioni ; ut diversi et schismatici illi ordines, quibus Hibernia poene tota delusa est, uni Catholico et Romano cedant officio.' Gilleberti, Lunicensis Episc., De Usu Ecclesiastico. MS. in Camb. Univ. Lib., Ff. i. 27. Art. I6. 
Jobannes Paparo, further steps were taken to enforce conformity to Roman usage ${ }^{1}$.

In the year 1172, at the Synod of Cashel, presided over by Christianus, Bishop of Lismore and papal legate, the Anglican Use, that is to say the Sarum modification of the Roman Missal, was ordered to be introduced into every Church in Ireland, by the following canon:-

'From this time forward let all the divine offices of the Holy Church be performed in all parts of the (Irish) Church, according to the Use of the Church of England ${ }^{2}$.'

The above-quoted passages, while implying a previous diversity of liturgical usage and a discrepancy between that of Ireland and that of Rome, unfortunately afford no direct information as to what the nature of the early Celtie Liturgy was. It will be the endeavour of the following pages to throw some light on this at present unsolved and perhaps, to a certain extent, insoluble question.

Continent.-The Celtic Churches on the Continent, founded by the missionary enterprise of the native Church of these islands chiefly during the fifth, sixth, and seventh centuries, included parts of modern France, Belgium, Prussia, Austria, Italy, Switzerland, and Spain. Iceland and the Faroe Islands also were colonised by Celtic missions.

The cessation of Celtic usage in the greater part of this Continental Church is closely connected with the life and efforts of the Anglo-Saxon apostle of Germany, St. Boniface (A.D. 680-755). In Spanish Gallicia Celtic usage as to Easter, \&c. was abrogated by the Fourth Council of Toledo, A.D. 633, can. 4I. In Brittany British customs prevailed

1 Mansi, Concil. xxi. 768; xxii. I ror ; Gams, Series Episc. p. 207.

2 Omnia divina ad instar sacrosanctae ecclesiae, juxta quod Anglicana observat ecclesia, in omnibus partibus ecclesiae [Hibernicae] amodo tractentur,' - with a reason appended which can never have proceeded from genuine Irish sentiment.

'Dignum etenim et justissimum est ut sicut dominum et regem ex Anglia sortita est divinitus Hibernia, sic etiam exinde vivendi formam accipiant meliorem.' Wilkins, Concil. i. 473. 
till A.D. 8I7, when they were abolished under Louis le Débonnaire, and at the same time the Rule of St. Benedict was everywhere substituted for that of St. Columbanus'.

Among the peculiar features and distinguishing characteristics of this wide-spread Celtic Church, the following are deserving of especial mention :-

$\S 2$. Its Monastic and Missionary Character.-Monasticism was during the best known period of Celtic Church History a more conspicuous feature and prevailing element of the Celtic Church than of any other portion of the Western Church at any other time. Not only was it a feature, as it is in other Churches East and West, which comprise a regular and a secular clergy side by side, but the first Church in these islands seems to have been at one time so far entirely monastic in its character that its hierarchy consisted of regular clergy almost exclusively, a secular priesthood being, if not unknown, at most an inconsiderable minority ${ }^{2}$. As it overflowed its own territorial limits, and invaded the continent of Europe, it was rendered for a time doubtful whether the monastic ideal of later Christendom would spring from a Celtic or an Italian quarter, whether it would be represented in the Rules of St. Columbanus and St. Columba, or of St. Benedict. For its exclusively monastic constitution was closely bound up with its missionary character, and was at once the cause of its temporary triumph and of its ultimate decay.

Success in missionary enterprise can only be achieved, and has only been achieved, on any large scale, from the time of the Apostles downwards, by men who have so far caught the ascetic spirit as to surrender this world and its ties to the exclusive and absorbing task of the evangelisation of mankind. But a Church which attempts to frame almost its

1 H. \& S. ii. i. 7 I, 79, 80.

2 Bede said of the Celtic Church at Lindisfarne (7th cent.): 'Omnes presbyteri, diaconi, cantores, lectores, ceterique gradus ecclesiastici monachi monachican per omnia cum ipso episcopo, regulam servant.' Vit. S. Cuth. c. xvi. 
whole constitution on a monastic basis, which provides no outlet for the zeal and earnestness which, while shrinking from the total self-surrender and separation from the world involved in the monastic life, will fill the avocations of a secular priesthood, may achieve a brilliant but shortlived success, but aims at too high an ideal for permanent success. This fact, added to the intolerable severity of the Columban Rule (p. 17), seems to be the key to the rise and fall of the Celtic Church.

There are however passages which prove that a married priesthood was not unknown in various parts, and at various periods in the history of the Celtic Church. St. Patrick (fifth century) says that he was the son of a deacon and the grandson of a priest 1. An early Irish canon alludes to priests' wives :-

'Quicunque clericus ab hostiario usque ad sacerdotem sine tunica visus fuerit . . . et uxor ejus si non velato capite ambulaverit pariter a laicis contemnentur et ab ecclesia separentur'.'

The words of Gildas (A.D. 547) may imply a married priesthood in Britain in the sixth century, and have been quoted in that sense by Archbishop Ussher ${ }^{3}$. They form part of the ' increpatio in sacerdotes' with which the 'Epistola i. Gildae' concludes :-

'[Paulus dicit] " unius uxoris virum." Quid ita apud nos quoque contemnitur quasi non audiretur et idem dicere et "virum uxorum." . . Sed videamus et sequentia. "Domum" inquit "suam bene regentem, filios habentem subditos, cum omni castitate." Ergo imperfecta est patrum castitas, si eidem non et filiorum accumuletur. Sed quid erit ubi nec pater, nec filius mali genitoris exemplo pravatus, conspicitur castus? Si quis autem domui suae praeesse nescit, quomodo Ecclesiae Dei diligentiam adhibebit?'

1 Confessio, c. r.

Canones Patricii, Aux. Isern. \& 6. See Book of Armagh, fol. r8.

Op. iv. p. 294 . 
Notices of married bishops, priests, and deacons, and of various attempts to enforce clerical celibacy in the tenth century, and of the opposition encountered, prove that a married clergy existed in Wales till the eleventh or twelfth century ${ }^{1}$. There are also allusions to married priests in the Celtic Church in Brittany ${ }^{2}$. These facts have led a modern Roman Catholic author to make the unhistorical assertion that 'l'Eglise Romaine tolera quelque temps chez les Brétons et les Irlandais l'ordination des hommes mariés, comme elle la tolere encore chez les catholiques des rites orientaux ${ }^{3}$ ' Why did he not add 'comme elle la tolera autrefois chez les catholiques de Rome'? There are allusions to married episcopi, presbyteri, and diaconi in the inscriptions in the Catacombs ${ }^{4}$. But the existence of married priests in the Celtic Church was due to independence of, not to toleration by, the Roman See.

Some idea of the monastic character and extent of the Celtic Church may be gained from a bare enumeration of a few of its more famous houses.

In England (including Northumbria): Lindisfarne, Lastingham, Ripon, Whitby, St. Bees, Malmesbury, Glastonbury, Burgh Castle, Mailros (old Melrose), Coldingham, \&c.

In Wales: Hentland-on-the-Wye, Caerworgern, Caerleon, Bangor-Deiniol (or Mawr), Bangor-Garmon, Llandabarnfawr, Llancarvan, Bangor-Iscoed, Clynnog-Fawr, Llan-Iltut, Llanelwy, afterwards St. Asaph, Caergybi, Enlli, Tygwyn-ar Daf, Docwinni.

In Ireland: Durrow, Clonard, Kildare, Clonmacnois,

1 Haddan, A. W., Remains, p. 209 ; H. and S. i. pp. I 55, 285.

2 Courson, A., Histoire des Peuples Brétons, ii. 163.

3 Ozanam, La Civilization Chretienne, p. 100 ; Paris, 1849.

- De Rossi, Inscriptiones Christianae, sub ann. 404, 405. Among them there are records of Stephen, son of a priest Melon; Boeckh, Corpus Inscriptt. Graec. vol. iv. fasc. 2. no. 9289 ; Philip, a son of a priest Alypius; Ibid. no. 9579, \&c. Inscriptions to the memory of Roman priests and deacons whose wives were buried with them have been found up to the close of the fourth century; Northcote, J.S., Epitaphs of the Catacombs, p. I 17 . 


\section{\$2.] Its Monastic and Missionary Character. 15}

Aghaboe, Kells, Bangor, Birr, Tirrdaglas, Glaisnaoidhen, Inismacsaint, Clonfert, Dromore, Moville, \&c. One of the successors of St. Patrick, Luan by name, is asserted by St. Bernard to have founded alone a hundred monasteries ${ }^{1}$. The smaller islands round Ireland swarmed with them. Ten monasteries were founded by St. Enda alone on one of the Aran isles off the coast of Galway ${ }^{2}$.

In Scotland numerous monasteries were founded by St. Columba and his monks among the Picts and Scots, the names of fifty-three of which, in addition to his own central monastery at Iona, have been preserved, at Soroby, Dunkeld, Incheolm ${ }^{3}, \&$ c. Many of the Scottish monasteries were placed on islands, which, perhaps on account of their superior safety, had a great fascination for the Celtic monk ${ }^{4}$.

In France: Remiremont, Lure, Besançon, Romain-Moutier, Bezieres, Brezille, Cusance, St. Ursanne, Jouarre, Reuil, Rebais, Faremoutier, St. Maur-les-Fosses, Lagny, Moutierla-Celle, Hautvilliers, Moutier-en-Der, St. Salaberga, Fontenelles, Jumièges, St. Saens, Luxeuil (A.D. 599), Anegray, Fontaines, Peronne, Toul, Amboise, Beaulieu, Strasbourg, in addition to other countless and nameless 'Hospitalia Scotorum,' alluded to in the Capitularies of Charles the Bald, A.D. $846^{5}$.

The above mentioned were Irish foundations. Brittany had been colonised by British Christians at a much earlier date. The single Welsh monastery of Llan-Iltut numbered among its disciples SS. Malo, Samson, Teilo, Magloire, Brieuc, Frugdual, Corentin, Gildas, \&c., all of whom are reported to have passed over into Brittany, in consequence of the persecution of the Saxons, and there to have founded

1 Vita S. Malachiae, c. vi.

Skene, W. F., Celtic Scotland, ii. 62. For an extended list see Historians of Scotland, vol. vi. p. xlix; Edinb. 1874 .

' Reeves' edit. of Adamnan's Life of St. Columba, p. 289.

- Lindisfarne off the coast of Northumbria, St. Michael's Mount in Brittany, and in Cornwall, will at once occur to the reader's mind.

- Pertz, Mon. Germ. Hist. Legum, tom. i. 390. 
towns, or built monasteries, or established bishoprics, which in many instances still bear their names'.

In the Netherlands: Namur, Liege, Gueldres, Hautmont, Soignes, \&c.

In Germany and Switzerland : Hohenaug, Erfurt, Freyburg, Ettenheimmünster, Schuttern, Nüremberg, Würtzburg, Memmingen, Mentz, Cologne, Regensburg, Constance, St. Gall, Mont St. Victor, Reichenau, Bregenz, Rheinau, Seckingen.

In Italy: Bobbio (A.D. 6r2), Taranto, Lucca, Faenza, Fiesole.

This list might be largely extended. It does not include many monasteries which, Celtic in their origin, passed subsequently into foreign hands, as was the case with Great St. Martin's at Cologne, where, as elsewhere, when the first fervour of its Celtic inmates dwindled away, their places were filled up by the inhabitants of the country in which the monastery was situated ${ }^{2}$. St. Bernard compared the missionary inundation of foreign countries by the Irish to a flood ${ }^{3}$. A list of 122 monasteries founded by Irishmen in England, Scotland, and on the Continent was collected by Colgan in a lost work, of which the Index has been preserved and is printed in the Proceedings of the Royal Irish Academy, vol. vi. p. 106.

They were of various sizes. Those planted on the barren

1 The travelling tendencies of the members of the British Church are thus attested by Gildas: 'Transnavigare maria terrasque spatiosas transmeare non tam piget [Britannos sacerdotes] quam delectat.' Ep. H. and S. ii. i. 70 .

2 Notice of its Irish origin is preserved in a fragment of an eleventh-century chronicle from a palimpsest vellum leaf printed in Pertz, Monum. Germ. Hist. tom. ii. p. 214. It begins thus :-

'Scoti multo tempore illud incoluerunt, donec a primo fervore tepescentes ex hoc, sicut etiam ex aliis quibusdam monasteriis expulsi sunt, et alii Germani sunt substituti,' \&c.

A good deal of detail about the later Celtic monasteries on the Continent will be found in the Chronicle of Marianus Scotus, whose Irish name was Maelbrighte, but who, like most of his countrymen, assumed an equivalent and more pronounceable Latin name. He died in seclusion at Mentz A.D. 1082; Pertz, Monum. Germ. Hist. v. 481 .

3 'In exteras regiones, quasi inundatione facta, illa se sanctorum examina effuderunt.' Vita S. Mal. c. 6. 


\section{\$2.] Its Monastic and Missionary Character.}

islands off the coasts of Great Britain and Ireland must have been small. Others were very large. The Irish monastery of St. Finnian of Clonard, and that of St. Comgall at Bangor, were said to contain three thousand inmates. The Welsh monastery of Bangor-Iscoed contained, according to Bede, two thousand one hundred monks, of whom twelve hundred were slaughtered under the Northumbrian King \&thelfrith ${ }^{1}$. St. Patrick asserted that the number of Irish men and women who embraced the monastic life in his own time was incalculable ${ }^{2}$.

The structure of the monasteries was of a simple and inexpensive character. Like the early Celtic churches (ch. iii) they were built at first of earth, and wattles, or wood. It was not till the end of the eighth century that stone buildings began in Scotland and Ireland to be substituted for wooden ones, as a protection against the ravages of the Danes.

The Rule of the Western monks, as laid down in the writings of St. Columbanus, was very severe, far more so than the Rule of St. Benedict. Its principles were absolute and unreserved obedience, constant and severe labour, daily self-denial and fasting; and the least deviation from the Rule was visited with corporal punishment or a severe form of fast, the precise number of blows and of days or hours of fasting being minutely prescribed ${ }^{3}$.

1 Bede, H. E. ii. 2.

2 'Et filii Scotorum et filiae Regulorum monachi fiebant et virgines Christi quos enumerare nequeo.' Patricii, ad Corot. ep. vi. Further details are given in Reeves' edit. of Adamnan, p. 336.

${ }^{3}$ Ussher, iv. 305 ; Montalembert, Monks of the West, ii. 447. The Rule itself is printed in Fleming, Collectanea Sacra, p. 4. It is frequently alluded to along with other Irish Rules in the Lives of the Saints, passages from which have been collected by Dr. Reeves in his edit. of Archbishop Colton's Visitation of Derry, p. 109. It was mentioned by Wilfrid in his controversy with St. Colman: 'De patre autem vestro Columba et sequacibus ejus, quorum sanctitatem vos imitari, et regulam ac praecepta caelestibus signis confirmata sequi perhibetis, possem respondere.' Bede, H. E. iii. 25 .

In describing the success of St. Aidan's mission to Northumberland, Bede speaks of the erection of churches and monasteries where imbuebautur prae- 
The chief occupation of all the monks, and the only occupation of the more aged, apart from the services of the Church, consisted of reading and writing. It was said of the Irish monastery of Lughmagh under Bishop Mochta, that

'Threescore psalm-singing seniors

Were his household, royal the number,

Without tillage, reaping, or kiln-drying,

Without work except reading '.'

The office of Scribe (Scribhnidh or Scriblıneoir) was of such honour and importance in an Irish monastery, that the.penalty for shedding his blood was as great as that for killing a bishop or abbot ${ }^{2}$. Sometimes in Scotland, in the seventh to tenth centuries, a scribe was elected to be an abbot or a bishop, and the head of a diocese or monastery thought that it added to the dignity of his position to be able to append the title of 'scriba' to his name. Baithene, the second Abbot of Iona, was an accomplished scribe, and was selected by Columba before his death to finish the Psalter left incomplete by himself ${ }^{3}$. The eighteenth and thirtieth Abbots of Iona, in 797

ceptoribus Scottis parvuli Anglorum, una cum majoribus studiis et observatione disciplinae regularis.' Hist. Ec. iii. 3.

The Irish Rule at Bangor in the seventh century is described in the Antiphon. Benchor. p. 156 :-

\footnotetext{
- Benchuir bona regula

Recta atque divina,

Stricta, sancta, sedula,' etc.
}

Ozanam attributes the eventual failure of Columban rule on the Continent to its Eastern severity ; La Civilization Chretienne, p. $14^{\circ}$.

1 Nartyrology of Donegal, p. 2 I6; Félire of Oengus, p. cxxxii.

2 'Sanguis Episcopi vel excelsi Principis [= Abbot] vel Scribae qui ad terram effunditur, si collirio indiguerit, eum qui effuderit, sapientes crucifigi judicant, vel vii ancillas reddant.' 8th cent. Canon of a Sinodus Hibernensis ; Wasserschleben, Bussordnungen, p. I 4 O. The latter alternative (=vii ancillarum pretium) is St. Patrick's modification of what would be demanded under the older national law of retaliation. See also Sinodus Hibernensis, cap. 29; ib. p. 138. Again: 'Patricius dicit omnis qui ausus fuerit ea quae sunt regis vel episcopi vel scribae furari aut aliquod in eos committere, parvi pendens dispicere, vii ancillarum pretium reddat, aut vii annis peniteat cum episcopo vel scriba.' Sin. Hibern. iii. c. 8 , ib. p. 141 ; iv. c. 6, ib. p. $14^{2}$.

${ }^{3}$ ddamnan, Vit. S. Col. i. 23, iii. 23. 


\section{\$2.] Its Monastic and Missionary Character.}

and 978, and the Bishop of the Isles of Alba in 96I, are also recorded to have been scribes ${ }^{1}$.

St. Patrick is said to have first taught his converts letters in a passage which is interpreted as attributing to him the introduction of a written alphabet. If so, it was probably the Irish or Latin-Irish alphabet supplanting the earlier Ogham characters ${ }^{2}$; and the books of Durrow, Kells, Dimma, Mulling, \&c. survive to show what apt scholars the Irish were, and to what a marvellous pitch of perfection calligraphy reached within a few centuries after St. Patrick's death ${ }^{3}$. The art of writing was transferred from Ireland to Scotland by St. Columba and his followers. It may have flourished at an earlier date in Southern Pictland at the time of St. Ninian's mission, as doubtless it flourished in the early British Church in England, but invading waves of beathenism had swept that earlier Christian civilisation away, and all traces of its sacred and liturgical writings are irrecoverably lost. But in connection with Iona there are many references to books. St. Columba himself wrote a volume containing hymns for the various services of the week ${ }^{4}$. He possessed a volume containing the Prayers and Ceremonial for the Consecration and Coronation of Kings, which, perhaps on account of its beautiful binding, was called the 'book of glass' and considered to be of celestial origin ${ }^{5}$. His last occupation on earth was the writing of a Psalter, and he was engaged in transcribing the thirty-fourth Psalm for it on the evening before his death ${ }^{6}$. Baithene wrote a Psalter so correctly that a single omission of the vowel ' $i$ ' was the only

I Annals of the Four Masters. For further information see Skene's Celtic Scotland, ii. pp. 423, 444.

2 Skene's Celtic Scotland, ii. 449.

sacsimiles of National MSS. in Ireland, edited by J. T. Gilbert.

- 'Hymnorum Liber Septimaniorum;' Adamnan, Vit. S. Col. ii. 9. The total number of books written by St. Columba was, according to tradition, three hundred; Leabhar Breac, p. 32 b. The same number of books was said to bave been written by Dagaeus (ob. 586 ); Acta SS. Aug. iii. $\mathbf{6}_{\mathbf{5}} 6$.

5 'Vitreum ordinationis regum librum ;' Adamnan, Vit. S. Col. iii. 5 .

Ib. iii. 23. 
mistake which St. Columba could find throughout it ${ }^{1}$. There are many other allusions to books and writing, as in the case of the awkward monk who dropped the book which he was reading into a vessel full of water $^{2}$, and of the impetuous guest who in his anxiety to greet St. Columba managed to spill that saint's ink-horn ${ }^{3}$.

Sometimes the monks wrote on wax tablets, ceracula, pugillaria, tabulae, with a hard pointed instrument, graphium, or stimulus. 'Cum in agro ipse sederet allato angelus Domini ceraculo eum litterarum docuit elementa ${ }^{4}$.'

Adamnan narrates in his work 'De Locis Sanctis' how Bishop Arnulf 'primo in tabulas describenti fideli et indubitabili narratione dictavit quae nunc in membranis brevi textu scribuntur ${ }^{5}$ '?

In the Codex Sangallensis, 242, entitled 'De pugillaribus id est parvis tabulis,' there is a gloss written over v. 3, Sicut videtur in tabulis Scotorum. The parchment skins ('membranae'), the use of which superseded the 'ceracula,' were either bound together in the form of a volume ${ }^{6}$, or assumed the shape of a long scroll ${ }^{7}$. The word commonly in use for writing was caraxare, charaxare, craxare, crassare, or xraxare. The Irish monk Arbedoc, who wrote the MS. Cod. Lat. Paris. I2021, begins by invoking the Divine blessing thus: 'Mihi xraxanti literas missereatur trinitas.' Adamnan closes his work 'De Locis Sanctis' by a request that the reader would offer a prayer 'pro me misello peccatore eorundem craxatore.' The same Abbot closes his Vita S. Columbae with this adjuration, 'Obsecro eos quicumque volu-

1 Adamnan, Vit. S. Col. i. 23.

2 Ib. i. 24 .

s Ib. i. 25. Many other phrases and allusions to the art of writing have been colleoted together by Dr. Reeves in the additional notes to his edit. of Adamnan's Life of Columba, p. 359.

- Vita S. Mochtei, Acta SS. Aug. tom. iii. die xix. 743 .

${ }^{5}$ In Prologo Auctoris, Migne, Bib. Pat. Lat. Ixxxviii. 78 r.

6 Westwood, Facsimiles, Plates $x$, xxii, xxiii, xxvi.

Ib. Pl. i, xv, xvi. 
erint hos describere libellos, immo potius adjuro per Christum judicem saeculorum, ut postquam diligenter descripserint, conferant et emendent cum omni diligentia ad exemplar unde caraxerunt et hanc quoque adjurationem loc in loco subscribant ${ }^{1}$.' Specimens of the early Scottish style of writing survive in an eighth-century MS. Life of Columba by Adamnan, Codex A at Schaffhausen, and in the Book of Deer written by a native scribe of Alba in the ninth century. These two MSS. are specially mentioned because the facsimiles of the originals which accompany the careful editions of the books by Dr. Reeves and Mr. Stuart place samples of early Scottish calligraphy within the reach of every modern reader. Their ornamentation and initial letters, though less elaborate than those of the Book of Kells and other early Irish MSS., confirm the statements so often made in the Lives of the Saints, that the arts of designing, drawing, and illuminating were extensively practised in these early times ${ }^{2}$. Other monks were skilful workers in leather, metal, and wood. St. Patrick himself was said to have been accompanied by workers in bronze and artificers of sacred vessels ${ }^{3}$. It was recorded of St. Dega, an Irish monk and bishop (d. 586 ), that he spent his nights in transcribing MSS., his days in reading them, and in carving in copper and iron ${ }^{4}$. Among the articles of most frequent construction were costly reliquaries for enshrining the remains of saints, metal cases of embossed

1 Caraxare seems to be a Latinised form of $\chi a \rho a ́ r t e \iota v$, and to point to the earlier form of writing by engraving letters on wax tablets.

2 The passages referred to are collected by Professor Westrood in his Palaeographia Sacra, Gospels of Meiel Brith Mac Durnan, p. 7. The epithet 'pictorium' in the passage quoted there from Adamnan, Vit. S. Col. iii. ro, is an erroneous reading for 'pistorium.'

3 'Tres fabri aerarii vasorumque sacrorum fabricatores.' Colgan, Trias. Thaum. p. 167 a.

- 'Idem Daygeus episcopus abbatibus aliisque Hiberniae sanctis, campanas, cymbala, baculos, cruces, scrinia, capsas, pyxides, calices, discos, altariola, chrysmalia, liborumque coopertoria; quaedam horum nuda, quaedam vero alia auro atque argento, gemmisque pretiosis circumtecta, pro amore Dei et sanctorum honore, sine ullo terreno pretio, ingeniose ac mirabiliter composuit.' Acta SS. Aug. tom. iii. p. 659 a. Montalembert, Monks of the West, iii. $8 \mathrm{~g}$. 
bronze or silver (cumhdachs) for enclosing copies of the Gospels or other MSS., and leathern cases (polaires) for carrying about portable missals and other service books ${ }^{1}$.

Education was also carried on by these early monks. Their monasteries were seminaries for the training of the native youth $^{2}$, and were frequented by adult foreigners, who flocked to Ireland from all parts of Great Britain, France, and the Continent generally for purposes of study ${ }^{3}$. Among the distinguished persons who thus visited Irish or Scottish monasteries were Egbert and Chad ${ }^{4}$, the French Agilbert, who snceeded Birinus as second Bishop of Dorchester A.D. $65^{\circ}{ }^{5}$, Aldfrith, who succeeded his brother Ecgfrith as King of Northumbria A.D. $685^{6}$, Willibrord, the Anglo-Saxon missionary to Frisia A.D. $690^{7}$, \&c.

While the seniors were exclusively engaged in the sedentary occupations of reading, writing, and teaching, the younger monks also laboured in the various departments of husbandry, at least so far as to provide for the wants of their own monasteries. When St. Columba visited the monastery of Clonmacnois the monks at work in the fields flocked together to receive him ${ }^{8}$. St. Cuthbert and St. Furseus worked with their own hands ${ }^{9}$. St. Gall went fishing while his monks

1 Further account of these various articles is giren in J. O. Westwood's Facsimiles, \&c., pp. 80, 149, 150.

2 W. Skene, Celtic Scotland, ii. 75.

3 'Erant ibidem eo tempore (A.D. 664) multi nobilium simul et mediocrinm de gente Anglorum, qui tempore Finani et Colmani episcoporum, relicta insula patria, vel divinae lectionis, vel continentioris vitae gratia, illo secesserant. Et quidam quidem mox se monasticae conversationi fideliter mancipaverunt; alii magis circumeundo per cellas magistrorum lectioni operam dare gaudebant; quos omues Scotti libentissime suscipientes victum eis quotidianum sine pretio, libros quoque ad legendum, et magisterium gratuitum praebere curabant.' Bede, H. E. iii. 27.

+ Bede, H. E. iv. 3 .

5 'Natione quidem Gallus sed tunc legendarum gratia Scripturarum in Hibernia non parvo tempore demoratus.' Ib. iii. 7 .

- Vit. S. Cuthberti auct. anon., quoted in Skene's Celtic Scotland, ii. 422.

7 'Et quia in Hibernia scholasticarn eruditionem viguisse audivit Hiberniam secessit,' \&c. Alcuin, Vit. Willibrordi, lib. i. cap. 4.

Adr mnan, Vit. S. Col. i. 3.

$\checkmark$ Bede, Vit. S. Cuthberti, cap. 19 ; H. E. iii. 19. 


\section{\$2.] Its Monastic and Missionary Character. 23}

were, some of them, working in the garden, and others were dressing the orchard ${ }^{1}$.

One short fragment of an ancient Celtic Pontifical survives in the Public Library, Zurich, in an Irish handwriting of the tenth century. The first page is quite illegible, having been made the outside cover of a book. Page 2 contains these words :-

\section{[De Virgine Investienda.]}

'(a) Permaneat ad prudentibus qui ... virginibus vigilantia . . . adferte copuletur ... per.

(b) Oremus, fratres carissimi, misericordiam ut euntum bonum tribuere dignetur huic puellae N. quae Deo votum candidam vestem perferre cum integritate coronae in resurrectione vitae aeternae quam facturus est; orantibus nobis, praestet Deus.

(c) Conserva, Domine, istius devotae pudorem castitatis dilectionem continentiae in factis, in dictis, in cogitationibus; Per te, Christe Jesu, qui.

(d) Accipe, puella, pallium candidum quod perferas ante tribunal Domini.'

This fragment is interesting as showing that the office for the reception of a nun into a Celtic monastery included, in addition to the ceremony of crowning, the formal presentation of a white dress, which is not part of the 'Ordo de Consecratione Virginum' in the present Roman Pontifical. Nor are $(a)(b)(c)(d)$ found elsewhere, although a formula resembling $(d)$ accompanies the presentation of the veil, in a tenth-century order for the 'Consecratio Sacrae Virginis' printed in Gerbert, Liturg. Aleman. ii. 96: 'Accipe velum sacrum, puella, quod praeferas sine macula ante tribunal Domini nostri Jesu Christi.'

And again in the tenth-century copy of the Pontifical of

1 'Alii hortum laboraverunt, alii arbores pomiferas excoluerunt, B. vero Gallus texebat retia,' \&c. Wal. Strabo, Vit. S. Galli, cap. 6. 
Egbert, Archbishop of York, at the presentation of the 'pallium' in the 'Consecratio Viduae :'-

\section{'Post haec imponis viduae pallium et dicis.}

'Accipe viduae pallium quod perferas sine macula ante tribunal Domini nostri Jesu Christi ${ }^{1}$.'

The monastic was closely connected with the missionary character of the Celtic Church. The list of monasteries given on pp. 14-16 proves how widespread was the area once covered by its evangelistic agency and monastic development; but such development was not the work of one century, nor due to the energy of a single portion of the Celtic Church.

It began by the colonisation of Brittany from the British Church in the fifth century ${ }^{2}$.

A British colony was established in Spanish Gallicia in the sixth century, where a Celtic See was occupied by a bishop named Madoc, c. A.D. $570^{3}$.

In the same century the Irish Church began to exhibit its missionary power. The Christianising of the whole of the north and north-west of Scotland and its adjacent islands was due to St. Columba, chief among the missionary Irish. He was Abbot of Iona, and patron saint of Mull, Tiree, Islay, Oronsay, and Lewis. Maccaldus, a native of Down, became Bishop of Man in the fifth century; St. Donnan of Egg; St. Maelrubha of Skye; St. Moluoc of Lismore, and Raasay; St. Brendan of Seil; St. Molaise of Arran; SS. Catan and Blaan of Bute. St. Columba's successors at Iona converted in a similar way the whole of the Anglo-Saxon population north of the Humber. St. Aidan, the Apostle of the Northumbrians (A.D. 634), whose diocese extended from the Humber to the Frith of Forth, was an Irishman

1 Pontif. Ecgb. (Surtees Soc.), p. I 14 .

2 See p. 15.

$s$ The evidence on these points will be found in H.\& S., Councils, vol.i. There was a mission on the part of the British Church to Ireland to restore the faith c. A.D. 550, conducted by SS. David, Gildas, and Cadoc; ib. p. II 5 . 
and a monk of Iona; so were his successors Finan and Colman, the latter of whom resigned his see after the Synod of Whitby A.D. 664, and retired to his native country rather than accept its anti-Scottish decisions ${ }^{1}$. Diuma, the first bishop of the Mercians, and his successor Ceollach, were both of them Irishmen, the former certainly and the latter probably having been brought up at Iona. Other distinguished Irish saints in England were St. Fursa, who planted Christianity at Burghcastle in Suffolk; Mailduf (Meildulfus), the founder of Malmesbury; St. Bega, the foundress of St. Bees in Cumberland; St. Moninna (Modwenna), the patron saint of Burton-on-Trent; St. Ciaran, or Piran, whose name occurs frequently in the dedications of Cornish churches ${ }^{2}$.

But Irish missionary zeal sought a vent beyond the confines of Great Britain. Early in the sixtl century (A.D. 5I I) the Irish St. Fridolin appeared at Poitiers, Strasbourg, and Seckingen near Basle, as the pioneer of future missionary hosts. Late in the sixth and early in the seventh centuries St. Columbanus and St. Gall, with their companions, traversed Gaul, Italy, and Switzerland, founding their chief monasteries at Luxeuil, Bobbio, and St. Gall. Soon afterwards St. Kilian, with his companions the priest Totman and the deacon Colman, penetrated to Würzburg, where he was martyred A.D. 687 ; and the later names of Fiacrius, Chillenus, Furseus, Ultanus, Foillanus, \&c., celebrated at Lagny near Paris, at Meaux, Peronne, \&c., indicate the Irish nationality of many who laboured successfully in propagating the Christian faith

1 Bede, H. E. iii. $25,26$.

2 Even for St. Cuthbert an Irish origin has been claimed. Bede introduces him to the reader of his $\mathbf{H}$. E. without mentioning his birth-place or nationality (iv. 28), but recognises him as a native of Britain in his poetical life of St. Cuthbert; Smith's Bede, p. 269. The authority for his Irish origin is a Libellus de Ortu S. Cuthberti written in the twelfth century, but the earliest extant copy of which belongs to the fourteenth century. It has been published by the Surtees Soc. vol. viii. St. Cuthbert's Irish name is said to have been Mullucc. 
in France, Belgium, and other parts of central Europe. Less known Irish missions also carried Christianity to the Faroe Isles c. A.D. 725, and to Iceland A.D. 795 ${ }^{1}$. Thus between the fifth and eighth centuries the Celtic Church extended, with intermissions, North and South from Iceland to Spain, East and West from the Atlantic to the Danube, from Westernmost Ireland to the Italian Bobbio A.D. 6I2, and the German Salzburg A.D. 696.

Even beyond these limits Irishmen were afterwards and occasionally elected bishops, as Cataldus at Taranto and his brother Donatus at Lupiae in the eighth century, and another Donatus at Fiesole a century and a half later.

It will have been noticed that all the great leaders in this Celtic wave of missionary enterprise were of Irish origin, viz. St. Columba, the Apostle of the Picts and Scots; St. Aidan, the Apostle of Northumbria; St. Columbanus, the Apostle of the Burgundians of the Vosges district of Alsace; St. Gall, the Apostle of North-east Switzerland and Alemannia; St. Kilian, the Apostle of Thuringia ; and Virgilius, the Apostle of Carinthia.

§3. Orthodoxy of the Celtic Church.-There are no substantial grounds for impugning the orthodoxy of the Celtic Church. On the contrary, there is unimpeachable evidence the other way. But expressions have been sometimes used with reference to it which would lead to a different conclusion. Pope Gregory probably knew very little about the faith of the British Church when he claimed the right of subjecting to the jurisdiction of Augustine 'not only the bishops whom he should ordain, but also all the priests in Britain, that they might learn the rule of believing rightly and living well from his life and teaching ${ }^{2}$.'

1 Recorded by Dicuilus (an Irish monk A.D. 825), De Mensura Orbis, pp. 29, 3o. His work exists in a tenth-century MS. at Paris (Bibl. Imp. no. 4806), printed by A. C. A. Walckener at Paris, 1807 .

${ }^{2}$ Bede, H. E. i. 29. 
Certainly Britain, like the rest of Christendom, may have been partially tainted with Arianism in the fourth century, when certain British bishops at Ariminum A.D. 359 were deceived or terrified into signing a semi-Arian creed; and with Pelagianism in the fifth century, which was the canse of the joint visit of Germanus Bishop of Auxerre and Lupus Bishop of Troyes A.D. 429, and of another visit of Germanus with Severus Bishop of Treves, A.D. 447. But the Gallican bishops are recorded to have been eminently successful in their mission, and to have returned across the Channel leaving the Catholic faith firmly established in these islands ${ }^{1}$. The real difficulty here is to understand how the rationalism of Pelagius can have had even a passing attraction for the naturally superstitious and mystic Celt, not how Germanus succeeded in stamping it out. There is nothing in these admitted facts to justify us in inferring from the abovequoted words of St. Gregory that the Celtic Church was destitute of any 'forma recte credendi ${ }^{2}$;' or in acquiescing in the language of an Anglo-Saxon Synod (A.D. 705), which took steps for 'the destruction of the malignant and too flourishing heresy of the Britons ${ }^{3}$.'

On the other hand, a catena of evidence can be produced to disprove the charge of heresy and in support of the orthodoxy of the first Church of the British Isles. Hilary of Poitiers (A.D 358) congratulates the bishops of the British

1 Authority for this and other statements of a historical character with reference to this period are accumulated in H. and S., rol. i. p. 10. Arianism is referred to by name and Pelagianism by inference in Gildas, Hist. $§ 12$.

2 "Tua vero fraternitas . . . omnes Brittaniae sacerdotes habeat ... subjectos, quatenus ex lingua et vita tuae sanctitatis, et recte credendi et bene vivendi formam percipiant, atque officium suum fide ac moribus exsequentes, ad cuelestia, cum Dominus voluerit, regna pertingant.' Bede, H. E.i. 29.

3 "Quo maligna quae tunc supra modum pullulabat haeresis Britonum destrueretur.' H. and S. iii. 268. The visit of Victricius Bishop of Rouen, A.D. 396, was for the purpose of settling some British dispute, not, as has been groundlessly surmised, for the purpose of quelling Arianism. The Epistle of Gildas proves the moral depravity of the British priesthood in the sixth century, but is silent as to any charge of heresy. 
provinces on 'their having continued uncontaminated and uninjured by any contact with the detestable heresy' (of Arianism). Athanasius (A.D. 363) states that the British Churches had signified by letter to him their adbesion to the Nicene faith ${ }^{2}$. St. Chrysostom (A.D. 386-398) said that 'even the British Isles have felt the power of the word, for there too churches and altars have been erected. There too, as on the shores of the Euxine or in the South, men may be heard discussing points in Scripture, with differing voices but not with differing belief, with varying tongues but not with varying faith ${ }^{3}$ '. St. Jerome (c. A.D. 400) asserted that 'Britain in common with Rome, Gaul, Africa, Pcrsia, the East, and India, adores one Christ, observes one rule of faith 4.' Venantius Fortunatus (c. A.D. 580) testified to British orthodoxy in the sixth century ${ }^{5}$, and Wilfrid in the seventh century. The testimony of the latter, whose hostility to the Celtic Church was notorious, is as honourable to himself, as it is placed beyond all suspicion of inaccuracy or exaggeration. Present at Rome A.D. 680 at a council of a hundred and twenty-five bishops, held in anticipation of the Ecumenical Council of Constantinople in the same year against the Monothelites, Wilfrid asserted that the true Catholic faith was held by the Irish, Scottish, and British, as well as by the Anglo-Saxon Church ${ }^{6}$. It had therefore been no vain boast of Columbanus to Pope Boniface (A.D. 612) that his Church was not schismatical or heretical, but that it held the whole Catholic faith?

1 Hilar. Pictav. De Synodis, Prolog. et $\$ 2$.

2 Athanas. Ep. ad Jov. Imp. 2.

${ }^{3}$ Chrys. Quod Christus sit Deus, 12 ; In Princip. Act. 3. I.

4 Hieron. Ep. ad Evangel. c. I.

. 'Currit ad extremas fidei pia fabula gentes

Ex trans Oceanum terra Britanna fovet.' Ad Justin. Jun. Imp.

- 'Pro omni Aquiloui parte Britanniae et Hiberniae, insulisque quae ab Anglorum et Britonum necnon Scotorum et Pictorum gentibus colebantur, verain et catholicanı fidem confessus est, et cum subscriptione sua corroboravit.' Eddiue, Vit. Wilfrid. c. li.

3 - Nihil extra Evangelicam et Apostolicam doctrinam recipientes; nullus 
Had it been otherwise, could British bishops have been present certainly at the Council of Arles A.D. 3I4, perhaps at Nice A.D. 325 , probably at Sardica A.D. $347^{1}$ ? Could the conferences have taken place at Augustine's Oak A.D. 603 , and at Whitby A.D. 664, without at all events far more serious questions having been raised than the form of the tonsure or the calculation of Easter ${ }^{2}$ ? Would Wini Bishop of Winchester have associated two British bishops with himself in the consecration of St. Chad A.D. $664^{3}$ ?

Both direct testimony and indirect inference lead us to conclude with reference to the whole Celtic Church what Montalembert allows with regard to primitive Ireland, that it was 'profoundly and unchangeably Catholic in doctrine, but separated from Rome in various points of discipline and liturgy ${ }^{4}$.'

\$ 4. Independence of Rome.-Another noteworthy feature of the Celtic Church was its independence of the Roman Church in its origin, mission, and jurisdiction.

Before the sixth century Roman claims were not opposed, partly because such claims were not yet in existence in the form which they assumed after St. Augustine's mission, partly because, so far as they may have existed potentially, there was an entire unconsciousness of them on the part of the Christian Church in these islands.

The contrary view has notwithstanding been entertained, and rests on the testimony of early and generally trustworthy witnesses on the Roman side, or on later native

haereticus, nullus Judaeus, nullus schismaticus fuit, sed fides Catholica sicut a vobis primum, sanctorum scilicet Apostolorum successoribus tradita est, inconcussa tenetur.' Epist iv. ad Bonifacium; Fleming, Collectan. 139.

1 H. \& S. i. pp. 7-8.

2 For other minor points of difference raised by Augustine see Bede, H. E. ii. 2.

3 Bede, H. E. iii. 28. The validity of this consecration was afterwards disputed by Archbishop Theodore, on grounds which are discussed at length in W. Bright's Early Eng. Ch. Hist. pp. $213,226-7$.

4 Monks of the West, iii. 79. 
writers, who however do not profess to be independent or original authorities on this subject.

Bede attributes the conversion of England to the agency of Pope Eleutherus (A.D. I $7 \mathrm{I}-190$ ), during the joint reigns of Aurelius and Verus $(16 r-9)$, in the time of the British prince Lucius ${ }^{1}$.

This story is now known to have originated in Rome in the fifth or sixth century, 300 years or more after the date assigned to that event. In the eighth century Bede introduced it into England, where by the ninth century it had grown into the conversion of the whole of Britain, while the full-fledged fiction, connecting it specially with Wales and Glastonbury, and entering into further details, grew up between the ninth and twelfth centuries ${ }^{2}$.

Prosper of Aquitaine (A.D. 402-463), who went to Rome on a mission to Pope Cælestine, A. D. 43r, and was afterwards secretary to Pope Leo the Great, writing c. 455, asserts with regard to the conversion of Ireland that 'Palladius was consecrated by Pope Cælestine (422-432), and sent to the Scots believing in Christ, as their first bishop ${ }^{3}$.' This is the original source of a statement which reappears in substance, though not in this exact form, in many later documents, and with considerable additional detail. It would be difficult to find any other sentence penned by any ecclesiastical historian which has caused so much confusion, or which has been so variously interpreted. In the first place, who were the Scots to whom Prosper refers? We know beyond a doubt that they were the inhabitants of Ireland, but this necessary limitation of the meaning of the term

1 Bede, H. E. i. 4.

2 This conclusion with further and interesting details will be found in H. and S. i. pp. 25-26. The historical anachronism involved in Bede's account is pointed out by G. H. Moberly, edit. of Bede, p. I 4 n. Oxf. I 869 .

3 'Ad Scotos in Christum credentes ordinatur a Papa Coelestino Palladius, et primus episcopus mittitur.' Prosper, Chron. Consular. ad ann. 429. In another place Prosper says, 'Et ordinato Scotis episcopo, dum Romanam insulam studet servare Catholicam, fecit etiam barbaram Christianam.' Contra Collat. xxi. 
before the tenth century has only recently become generally accepted and understood, and it is probable that the later legends connecting Palladius with Scotland, as found in the Aberdeen Breviary, in the Leabhar Breac, and in the Scotichronicon of John of Fordun (14th cent.), have originated in a misinterpretation of Prosper's language. Secondly, who was Palladius? Was he, as Prosper intimates rather than asserts, a Roman, or, as is stated in the Book of Armagh, an archdeacon of the Church of Rome ${ }^{1}$ ? or was he, as Dr. Todd concludes, a Gaul ${ }^{2}$, and is to be identified with a certain Gallican bishop, commemorated under the name of Patricius, at Clermont, in the Roman martyrology on March 16 ? or was he an Irishman? and as the annotations of Tirechan on the Life of St. Patrick state that 'Palladius was also called Patricks,' has there been some confusion between St. Palladius and St. Patrick, and can statements which were meant to apply to the one have become transferred to the other? Thirdly, what is the force of 'primus'? Is it to be interpreted chronologically, and accepted as a disproof of numerous later legends, which allude to the existence of Christianity and of Christian bishops in Ireland before A.D. $43^{I}$ ? or are we to infer that there was previously a presbyterian form of Christianity in that country? or is 'primus' to be taken in the sense of precedence, and is it the primacy of Ireland which was conferred at this early date by a Bishop of Rome upon Palladius ${ }^{4}$ ? There is no contemporaneous evidence for the Roman mission of St. Patrick, for the earliest authority for which see p. 37 .

The first introduction of Christianity into Scotland was due to the labours of Ninian among the Southern Picts

1 Fol. 2 a.

2 Todd, J. H., Life of St. Patrick, p. 279.

3 Book of Armagh, fol. 16 a, quoted in H. \& S. ii. pt. ii. p. 290.

- We have preferred to enumerate the difficulties of this passage, rather than to suggest their solution. The question is discussed at much length by Dr. Todd, Life of St. Patrick, pp. 270-309, and the available evidence is summarised in H. \& S. ii. pt. ii. pp. 290-291. 
(c. A. D. 40I), who, 'according to Bede,' had been regularly instructed in the faith and the mysteries of the truth at Rome $^{1}$; and who, according to Ailred ${ }^{2}$, had been consecrated a bishop by Pope Siricius.

These statements appear again and again in the later annals and lives of the saints, acquiring a more circumstantial character the further they are removed from the period of which they profess to give an account. Their truth has been generally taken for granted by modern writers ${ }^{3}$, until the careful research of Messrs. Haddan and Stubbs has given the death-blow to the story of King Lucius and Pope Eleutherus ${ }^{4}$, and it may be suspected, although the difficulty of proving the negative has not been fully overcome, that the stories of the consecration of Palladius by Pope Cælestine and of Ninian by Pope Siricius are equally without foundation. For while Prosper and Bede must be accepted as generally impartial and trustworthy historians, no one can read the works of the former without noticing that his chief object was to magnify the importance of the Papacy ${ }^{5}$; and,

1 Bede, H. E. iii. 4 .

2 Ailred, Vita S. Niniani, cap. 2. Ailred wrote in the twelfth century.

${ }^{3}$ Mr. Skene, who certainly cannot be suspected of any Roman bias, says, chiefly on the strength of the above authorities, that the early British Church ' regarded the Patriarch of Rome as the Head of the Western Church, and the source of ecclesiastical authority and mission.' Celtic Scotland, ii. p. 6. The reader will find facts on pp. 35-40 which disprove such a statement as far as the later Celtic Church-and therefore inferentially as far as the earlier Celtic Church-is concerned.

4 Councils, \&c. i. 25.

5 I. p. I 7 n. As an instance of Prosper's Roman bias compare his statement that Germanus of Auxerre (and Lupus) were sent by Pope Cælestine to Britain to combat Pelagianism A.D. 429, with the statement of Constantius a presbyter of Lyons (A.D. 473-492) that they were sent by a Gallican synod.

Prosper says, 'Ad actionem Palladii diaconi Papa Caelestinus Germanum Autesiodorensem episcopum vice sua mittit, et deburbatis haereticis Britannos ad Catholicam fidem dirigit.' Chron. [after A.D. 455].

Constantius says, 'Eodem tempore ex Britanniis directa legatio Gallicanis episcopis runciavit Pelagianam perversitatem in locis suis late fopulos occnpasse, et quanprimum fidei Catholicae debere succurri. Ob quam causam synodus numerosa collecta est; omniumque judicio duo praeclara religionis lumina universorum precibus ambiuntur, Germanus et Lupus, apostolici sacer- 
on the other hand, Bede, who was removed by more than a century from the events recorded in the first Book of his Ecclesiastical History, was actuated by an intense dislike of the independent Celtic Church, which has been stigmatised by a modern Roman Catholic writer in the following words :-

'This (i. e. the feeling and attitude of the British Church) is called by Bede, in language too like that which Muscovite writers of our own day employ in respect to the Poles, "a domestic and immoral hatred:" "Britones maxima ex parte domestico sibi odio gentem Anglorum et totius Ecclesiae Catholicae statum Pascha, minus recte moribusque improbis pugnant." There is no just reason for imputing to the British Christians a lower rate of morals than those of the Saxon converts; but our venerable historian, blinded by his passions and prejudices, goes still further, and yields, as so many have done after him, to the hateful temptation of identifying the work of God with a human conquest. "Tamen et divina sibi et humana prorsus resistente virtute, in neutro cupitum possunt obtinere propositum; quippe qui quamvis ex parte sui sint juris, nonnulla tamen ex parte Anglorum sunt servitio mancipati." (H. E. v. 23.) He says elsewhere (v. I8) that St. Aldhelm wrote "librum egregium adversus errorem Britonum, quo vel Pascha non suo tempore celebrant, vel alia perplura ecclesiasticae castitati et paci contraria gerunt." In all Aldhelm's writings that have been preserved to us there is not the least allusion to the irregular morals of the Celtic clergy '?

So Bede uses such epithets as 'nefanda' and 'perfida' of

dote qui,' \&c. De Vita Germani, i. I9. This is also Bede's account, H. E. i. 7 .

For further evidence of the pro-papal tendency of Prosper, read his Praeteritorum Sedis Apostolicae Episcoporum auctoritates, Praef. cap. vii, viii ; Liber contra Collatorem, cap. v, xxi, xliii ; Carmen de Ingratis, pt. i. ll. 40, 78,184 .

1 Montalembert, Monks of the West, v. 25. It has been suggested that 'castitas' in the above passage may mean 'purity of eccleaiastical discipline' rather than 'purity of morals.' Bede elsewhere describes Acca, Bishop of Hexham, as 'in catholicae fidei confessione castissimus' (H. E.v. 2I). 
the British nation when he records their defeat by Æthelfrith at the battle of Chester A.D. 613, and the massacre of the monks of Bangor, in accordance with the prophecy of St. Augustine'. The clue to such language is the fact that Bede wrote under the influence of two motives, independent in their origin but conducing to the same result. Firstly, there was a national hatred of the British Church and nation. This was no doubt largely due to a feeling of resentment at the absence of British evangelistic enterprise in Anglo-Saxon heathendom, of which Bede complains once and again ${ }^{2}$. But we have seen that the British Church was not destitute of missionary power ${ }^{3}$; and more allowance must be made in the instance before us than Bede is inclined to make for the difficulties of the case. It is easier for the conquerors to preach to the conquered, than vice versa ${ }^{4}$. Mission work must have been very difficult while the state of feeling between the two nationalities was as embittered as it was still in the eleventh century, when any Welshman found armed east of Offa's Dyke was legally punishable by mutilation ${ }^{5}$. A second motive for Bede's violence may have been a desire to aggrandise Rome at the expense of the rest of Christendom, and to represent her as the mother of all Western Churches; a desire which began to exhibit itself as early as the fifth century in the writings of Prosper, and which

1 H. E. ii. 2.

2 'Qui, inter alia inenarrabilium scelera, quae historicus eorum Gildus flebili sermone describit, et hoc addebant, ut nunquam genti Saxonum sive Anglorum, secum Brittaniam incolenti verbum fidei praedicando committerent.' H. E. i. 22.

Compare the threat and prophecy with which St. Augustine wound up the conference with British bishops at 'Augustinæs ac:' 'Quibus vir Domini Augustinus fertur minitans praedixisse, quia si pacem cum fratribus accipere nollent, bellum ab hostibus forent accepturi; et si nationi Anglorum noluissent viam vitae praedicare, per horum manus ultionem essent mortis passuri. Quod ita per omnia, ut praedixerat divino agente judicio patratum est.' Tb. ii. 2. The state of hostility between the two Churches is further illustrated at p. $4^{2}$.

3 p. I5.

- Eddius speaks of the "loca sancta in diversis regionibus, quae Clerus Britonum, aciem gladii hostilis manu gentis nostrae fugiens, deseruit.' Vit. S. Wilfr. c. xvii.

${ }^{5}$ Iohannes Sarisbur. Polycraticus, vi. 6. 
became intensified instead of diminished in each succeeding century.

The following facts tend to prove a non-Roman origin of the Celtic Church.

(a) Incidental allusions in ancient documents to the existence of a primitive Christian Church in these islands differing from the Anglo-Roman or Scoto-Roman Church of later days.

Giraldus Cambrensis in his description of Ireland (A. D. I 185) narrates how ' in North Munster there is a lake containing two islands; in the greater island there is a church of the ancient monastic rule ('ecclesia antiquae religionis'), and in the lesser a chapel wherein a few monks, called Culdees, devoutly serve God '.' In South Munster the same traveller visited the church of St. Michael ('ecclesiam antiquae nimis et authenticae religionis ${ }^{2}$ '). This ancient monastic rule may have been that not only of SS. Patrick, Columba, \&c., but also of (1) Mansuetus, first Bishop of Toul in France (fourth century); (2) Sedulius, the Christian poet (fifth century); (3) Caelestius, the Pelagian (third and fourth centuries); (4) Eliphius and Eucharius, martyrs in France (fourth century). All these were Irishmen, and though much obscurity hangs over the history and date of (2) and (4), they may all have been trained under the pre-Roman ' antiqua et authentica religio Hiberniae ${ }^{3}$.'

There are also allusions to an 'ecclesia primitiva' in Scotland in the Aberdeen Breviary ${ }^{4}$, the strange Masses of which were finally abolished by Queen Margaret ${ }^{5}$.

The independence of the ancient Cornish Church is attested by a passage in the Leofric Missal, an eleventh-century MS. in the Bodleian Library, which describes low Eadulf, the

1 Top. Hib. ii. cap. 4, Master of Rolls Ser., v. p. 82.

2 Ib. ii. 3o, p. 118 .

s For further evidence for the existence of Christianity in Ireland before St. Patrick, see R. Brash, Eccles. Architecture of Ireland, p. I10; H. and S. vol. ii. p. 291.

- See Index.

5 p. 7 . 
first Anglo-Saxon Bishop of Crediton (A.D. 909-34), acquired three properties in Cornwall that he might more frequently visit the erroneous and unruly Church in that county ${ }^{1}$.

Its divergence from the Roman Church early in the eighth century had been complained of by Aldhelm Abbot of Malmesbury A.D. $705^{2}$.

(b) The absence of any allusion to a Roman mission or jurisdiction in the few surviving genuine writings of Celtic saints, Gildas ${ }^{3}$, Fastidius, Aileran, Patrick, Sechnall, Fiacc, Columbanus, Columba, Cuminius, Adamnan.

(c) The presence in such writings of passages which are inconsistent with any recognition of Roman mission or anthority. St. Patrick in his Confession and his 'Epistola ad Corotici subditos' is not only silent as to any commission

1 'Ut inde singulis annis visitaret gentem Cornubiensem ad exprimendos eorum errores, nam antea in quantum potuerant veritati resistebant, et non decretis apostolicis oboediebant.' (MS. no. 579. fol. 2 b.)

2 'Auditum namque et diversis rumoribus compertum nobis est, quod sacerdotes vestri a Catholicae fidei regula, secundum Scripturae preceptum minime concordent.' Aldhelm, Ep. ad Gerunt. Reg. Damnoniae; H. \& S. i. 6;2.

3 An obscure sentence of Gildas quoted by Dr. Lingard (A.S. Church, i. 335, 345) does not mention and does not seem to refer to Rome. The following passage occurs in Gildas' description of the British priesthood: 'Praecepta Christi spernentes, et suas libidines votis omnibns implere curantes, sedem Petri Apostoli immundis pedibus usurpantes, sed merito cupiditatis in Judae traditoris pestilentem cathedram decidentes.' Epistola, in H. and S., Councils, i. 74. Bishop Forbes sees in this passage an allusion to British pilgrimages to Rome (Historians of Scotland, v. p. 263); but surely the allusion to the two Apostles is purely metaphorical, though British pilgrimages to Rome, and to Jerusalem also, were probable enough, and common enough according to the Lives of the Saints : e.g. Ailred, writing a life of St. Ninian in the twelfth century, attributes these sentiments to him: - In terra mea quaesiri quem diligit anima mea et non inreni. Surgam et circuibo mare et aridam ... Transiensque Britannicum mare, et per Gallicanas Alpes ingressus Italiam, prospero itinere ad urbem nsque perrenit.' Pinkerton, J., Vit. SS. Scot. p. 4. The contemporary evidence of Theodoret, \&c. about British pilgrimages is quoted in H. and S., Councils, \&c. i. I3. Gildas interpreted St. Matt. xvi. I8, 19 as a divine commission given to every priest: "Vero sacerdoti dicitur, "Tu es Petrus et super hanc petram aedificabo Ecclesiam meam;" vos quidem assimilamini viro stulto qui aedificavit domum suam super arenam . . . itemque omni sancto sacerdoti promittitur; "Et quaecunque solveris super terram erunt soluta et in coelis, et quaecunque ligaveris," \&c. Sed quomodo vos aliquid solvetis ut sit solutum et in coelis, ob scelera adempti, et immanium peccatorum funibus compediti,' \&c. Epistola, sub finem. 
from a Bishop of Rome, but describes himself in general terms as a bishop in Ireland, deriving his commission directly from God Himself. 'The latter letter opens thus: 'Patricius peccator indoctus, Hiberione constitutus episcopus, a Deo accepi id quod sum.'

In other passages he attributes his Irish apostleship to an inward call, which he regarded as a divine command, and to a vision of a man (or an angel) in the night beckoning him over to Ireland ${ }^{1}$. The earliest written records of St. Patrick, the Hymn attributed to St. Fiacc Bishop of Sletty, near Carlow, a convert and disciple of St. Patrick-the Hymn of St. Sechnall (S. Secundinus), another contemporary of St. Patrick, whose sister's son he is said to have been,the ancient Life of St. Patrick, written by Muirchu Maccumachtheni at the dictation of Aedh Bishop of Sletty, (d. 698), and preserved in the Book of Armagh, all alike are silent as to any Roman mission of St. Patrick ${ }^{2}$.

The language of a later Irish saint-Columbanus-representing the attitude of that portion of the Celtic Church to Rome at the end of the sixth and the beginning of the

1 The passages are too long to quote. They will be found in English in Todd's Life of St. Patrick, pp. 377-379.

2 According to St. Sechnall, St. Patrick :

'A postolatum a Deo sortibus est.'

This is the more remarkable as St. Peter is mentioned in the previous line without any allusion to a mission to St. Patrick from his successor in the See of Rome. And again :

- Dominus eum elegit ut doceret barbaros,

Quem Deus misit, ut Paulum ad gentes, apostolum.'

St. Fiacc's Hymn mentions the admonition of an angel (stanza 7); Liber Hymnorum, pp. 287-304; H. and S. vol. ii. pt. ii. p. 339 n. The earliest Irish authority for St. Patrick's Roman mission are the annotations of Tirechan in the Book of Armagh, and the Scholia (ninth century or later) to St. Fiacc's Hymn.

The unhistorical character of Tirechan's Life of St. Patrick is demonstrated in Skene's Celtic Scotland, ii. 425. Bede does not mention St. Patrick. The 'Vita S. Patricii' sometimes printed among his works was written by the Irish Probus, ob. 859. Adamnan makes only one, and that quite an incidental, allusion to him: 'Nam quidam proselytus Brito, homo sanctus, sancti Patricii episcopi discipulus, Maucteus nomine,' \&c. Vit. S. Colum. Praef. ii. p. 6. 
seventh century, is quite inconsistent with any theory of its Roman origin, and must sound strange in the ears of a modern Ultramontane. The position assumed by Columbanus, writing on the Continent to the Pope, substantially amounted to this: an acknowledgment of the Bishop of Rome as a true bishop of the Church of Christ, and of the need of courteous language in addressing the occupant of so distinguished a See, with, throughout, an implied assertion of exemption from his jurisdiction, and a claim to be allowed to criticise freely, and from the independent standpoint of an equal, the character and conduct of any Roman pontiff.

The language which he used to Boniface IV is not that of a subordinate, but is couched in terms the freedom of which may have been resented then, but would certainly be resented now. He laments over the infamy attaching itself to the Chair of St. Peter in consequence of disputes at Rome ${ }^{1}$. He exhorts the Pope to be more on the watch ${ }^{2}$, and to cleanse his See from error, because it would be a lamentable thing if the Catholic faith was not held in the Apostolic See ${ }^{3}$. He says that many persons entertain doubts as to the purity of the faith of the Roman bishop ${ }^{4}$. He allows a high post of honour to the See of Rome, but seeond to that of Jerusalem, the place of our Lord's resurrection ${ }^{5}$. He upbraids the Roman Church

1 'Dolor enim potius me quam elatio compellit vobis indicare, humillima, ut decet, suggestione, quod nomen Dei per vos contendentes utrinque blasphematur inter gentes; doleo enim, fateor, de infamia catbedrae Sancti Petri.' iv. Epist. ad Bonif.; Fleming, Collectan. I39. He apparently alludes here to some dispute among the Italian bishops, for he says afterwards, "Agnoscite vos invicem, ut sit gaudium in coelo et in terra pro pace et conjunctione vestra ;' and in another place, 'Unum itaque omnes dicite, et unum sentite, ut utrique unum sitis toti Christiani,' \&c.

2 'Vigila, itaque quaeso, Papa, vigila, et iterum dico, vigila, quia forte non bene vigilavit Vigilius $(537-555)$ quem caput scandali isti clamant qui nobis culpam injiciunt. Vigila primo pro fide,' \&c. Ib. p. 140.

3 'Ut mundes cathedram Petri ab omni errore (a later MS. hand has attempted to substitute (horrore') si qui est, ut aiunt, intromissus, si non puritas agnoscatur ab omnibus. Dolenduru enim ac deflendum est, si in sede Apostolica fides Catholica non tenetur.' Ib. p. I4I.

- 'Rogo vos, quia multi dubitant de fidei vestrae puritate.' Epist. v. ad Bonifac. § I 4 .

5 -Propter Christi geminos apostolos, vos prope coelestes estis, et Roma 
for proudly claiming a greater authority and power in divine things than was possessed by other Churches merely because of a certain fact recorded in the Gospels, and denied by no one, that our Lord entrusted the keys of the kingdom of heaven to St. Peter, and points out that the prerogative of the keys stands upon a different basis, and must be wielded on other grounds ${ }^{1}$.

Writers from a Roman standpoint have resorted to curious devices to escape the necessary inference from such passages. Dr. von Döllinger collects the courteous expressions contained in the Epistles of Columbanus, and deduces from them the conclusion that the Celtic saints 'recognised in the Roman Bishop the Head of the Church, and were in unbroken communion with him, and through him with the Church universal!' He sees in St. Columbanus' claim to Catholicity in a passage previously quoted ' 'a clear proof of the Roman mission of St. Patrick ${ }^{3}$ !'

Ozanam's explanation of Columbanus' language is still more amazing. It is due 'to the disordered eloquence of the seventh eentury. This period was one of those in which thought, ceasing to be the mistress of language, betrays itself

orbis terrarum caput et ecclesiarum, salva loci Dominicae resurrectionis singulari praerogativa.' Ep. iv. p. I43.

1 He warns the Bishop of Rome, 'Ut non perdatis vestram dignitatem per aliquam perversitatem. Tamdiu enim potestas apud vos erit, quamdiu rectá ratio permanserit; ille enim certus regni coelorum clavicularius est qui dignis per veram scientiam aperit et indignis claudit. Alioquin si contraria fecerit nec aperire nec claudere poterit. Cum haec igitur vera sint, et sine ulla contradictione ab omnibus vere sapientibus recepta sint, licet omnibus notum est, et nemo qui nesciat qualiter salvator noster Sancto Petro regni coelorum contulit claves, et vos per hoc forte superciliosum nescio quid prae ceteris vobis majoris auctoritatis ac in divinis rebus potestatis indicatis; noveritis, minorem fore potestatem vestram apud Dominum si vel cogitatis hoc in cordibus vestris. Quia unitas fidei in toto orbe unitatem facit potestatis et praerogativae, ita ut libertas veritati ubique ab omnibus detur, et aditus erroris ab omnibus similiter abnegetur.' Ep. v. § го.

${ }^{2}$ p. 28. n. 7 .

3 But Dr. Döllinger wrote thus as far back as 1833 ; Geschichte der christlichen Kirche, Periode ii. Seite 185. Landshut. Other writers who adduce Columbanus as a witness in favour of Roman supremacy are Dr. Moran, Essays on Early Irish Church, p. 99, and Mr. C. F. B. Allnatt, Cathedra Petri, 2nd edit. pp. $69,80$. 
either by an excess or defect of expression, whereby a writer says less than he means, or more than he means, seldom what he means to say'.'

The whole subsequent history of the Celtic Church, both in these islands and on the continent, exhibits occasional proofs of its independence of, and hostility to, the claims of Rome.

In A.D. 60I Gregory entirely ignored the existence of the Celtic bishops, as bishops, in his answer to Augustine's sixth question whether consecration by a single bishop is valid. 'Yes,' he replied, 'in the English Church, while you are the only bishop, you can only consecrate in the absence of other bishops. But when bishops shall come over from Gaul they will assist you as witnesses at the ordination of a bishop ${ }^{2}$.' In answer to his seventh question Gregory committed all the bishops of Britain to his supervision and control ${ }^{3}$, a position of subordination which they repudiated, not surely through any misapprehension of the nature and grounds of St. Augustine's claims, but because they ignored the theory of papal supremacy.

In 4.D. 604 Augustine was succeeded in the See of Canterbury by one of his companions, Laurentius by name. 'Archbishop Laurence,' Bede tells us, ' not only attended to the charge of the new Church that was gathered from the English people, but also regarded with pastoral solicitude the old natives of Britain, and likewise the people of the Scots who inhabit the island of Ireland adjacent to Britain. For observing that the practice and profession of the Scots in their own country, and also those of the Britons in Britain itself, were less in accordance with Church order in many things, particularly because they used not to celebrate the solemnity of Easter at the proper time ... he in conjunction with his fellow-bishops wrote them a letter of exhortation, beseeching and entreating them to keep the bond of peace and

1 La Civilization Chrétienne, chap. iv. p. I 3.

Gregorii Magni Op., Migne; Bib. Pat. Lat. Ixxvii. p. 1191.

2 Bede, H. E. i. 27. 
Catholic observance with that Church of Christ which is extended all over the world;' of which letter these were the opening words: "To our lords and most dear brethren the bishops or abbots throughout all Scotia, Laurentius, Mellitus, bishops, the servants of the servants of God. When the Apostolic See, according to her practice in all the world, directed us to preach to the pagan nations in these western parts, and so it came to pass that we entered into this island which is called Britain, before we were acquainted with it, believing that they walked in the ways of the Universal Church, we felt a very high respect for the Britons as well as the Scots, from our great regard to their sanctity; but when we came to know the Britons we supposed the Scots must be superior to them. However, we have learned from Bishop Daganus coming into this island, and from Abbot Columbanus coming into Gaul, that the Scots differ not at all from the Britons in their habits; for Bishop Daganus, when he came to us, not only would not take food with us, but would not even eat in the same lodging where we were eating.'

Daganus was the Celtic bishop of Inverdaoile in Wexford. The Saxon Archbishop's letter cannot have had all the desired effect, for writing 127 years later (A.D. 731) Bede implies that the state of separation and the feelings of enmity between the two Churches remained at least unchanged ${ }^{2}$. In fact they became gradually intensified. The Roman attitude towards the Celtic Church, both British and Irish, in the latter part of the seventh century was one of unmitigated hostility.

Late in $4 . D .664$ St. Wilfrid went to France for consecration to his Northumbrian See, refusing to be consecrated at home by bishops out of communion with the See of Rome ${ }^{3}$. The

I Bede, H. E. ii. 4 .

2 'Sed quantum haec agendo profecerit, adhuc praesentis tempora declarant.' Ib.

3 'Sed perstitit ille negare, ne ab episcopis Scotis, vel ab iis quos Scoti ordinaverant consecrationem susciperet, quorum communionem sedes aspernaretur catholica.' Guliel. Malm. de Gestis Pontif. lib. iii; Migne, Bib. Pat. Lat. clxxix, I555. The speech of Wilfrid on this occasion has been preserved by Eddius, his earliest and most trustworthy biographer: 'Omnibus modis 
whole of England, except Kent, East Anglia, Wessex, and Sussex, was at this time in communion with the Scoto-Celtic Church. Of the excepted parts, Sussex was still heathen. Wessex was under a Bishop Wini, in Gallican orders, and in communion with the British bishops. Kent and East Anglia alone remained in complete communion with Rome and Canterbury.

In A.D. 667 Pope Vitalian wrote to Oswy, saying that he would look out for a fit person to fill the Archiepiscopal See of Canterbury, a person who would eradicate the tares from the whole of the island, alluding under this expression to the clergy of the Celtic Church ${ }^{1}$.

We learn from the Penitential of Archbishop Theodore (A.D. 668-690) that the validity of its Orders was denied, if not entirely, at least so far as to need a fresh imposition of hands by a Catholic bishop; the consecration of its churches was not recognised; its members were refused communion, without first making a formal submission; and doubts were thrown out even as to the validity of their baptism ${ }^{2}$. And the Areh-

nobis necessarium est cousiderare, quomodo cum electione vestra sine accusatione Catholicorum virorum, ad gradum episcopalem cum dei adjutorio venire valeam ; sunt enim hic in Britannia multi Episcopi, quorum nullum meum est accusare, quamvis veraciter sciam, quod aut quartadecimani sunt ut Britones, ut Scoti, aut ab illis sunt ordinati quos nec Apostolica sedes in communionem recipit, neque eos qui schismaticis consentiunt. Et ideo in multa humilitate a vobis posco, ut me mittatis cum vestro praesidio trans mare ad Galliarum regionem, ubi Catholici Episcopi multi habentur, ut sine controversia Apostolicae sedis, licet indignus, gradum Episcopalem merear accipere.' Vit. S. Wilf. cap. xii. Eddius, like Bede, betrays a strong anti-Celtic bias, speaking of the 'schismatici Britanniae et Hiberniae' (ib. c. v.), and of 'peccatum ordinandi a Quartadecimanis in sedem alterius' (ib. c. xv).

1 ' Ut ipse et viva voce et per divina oracula omnem inimici zizaniana ex omni vestra insula cum divino nutu eradicet.' Bede,H.E. iii. 29. The meaning of the passage is obvious from the context.

2 ' 1 . Qui ordinati sunt a Scottorum vel Britonum episcopis, qui in Pascha vel tonsura catholici non sunt, adunati ecclesiae non sunt, sed iterum a catholico episcopo manus impositione confirmentur.

' 2. Similiter et aecclesiae quae ab ipsis episcopis ordinantur, aqua exorcizata aspergantur et aliqua collectione confirmentur.

'3. Licentiam quoque non habemus eis poscentibus crismam vel Eucharistiam dare, nisi ante confessi fuerint velle nobiscum esse in unitate ecclesiae. Et qui ex horum similiter gente vel quicunque de baptismo suo dubitaverit, baptizetur.' Poenitentiale Theodori, ii. 9. 
bishop gave a practical proof that he meant what he said, by objecting to the regularity of Chad's consecration as Bishop of York (A.D. 665-6) because two of his consecrators, assistants of Wini of Winchester, had been British bishops, probably summoned from Cornwall for the purpose; and on Chad's transference to Mercia Theodore 'completed his consecration afresh in the Catholic manner',' A.D. 669.

In A.D. 687 the dying words of St. Cuthbert, himself a convert to Roman usage, with reference to that Celtic Church in which he had spent some thirty years of his life, exhibit much bitterness. 'Keep peace,' he said, 'one with another, and heavenly charity; and when necessity demands of you to hold counsel as to your state, take great care that you be of one mind in your conclusions; and, moreover, maintain mutual concord with other servants of Christ, and despise not the household of the faith who come to you seeking hospitality, but be careful to receive such persons, to entertain them, and to send them away with friendly kindness; and do not think you are better than other followers of the same faith and conversation; but with those that err from the unity of Catholic peace either by not celebrating Easter at the proper time, or by living perversely, have no communion ${ }^{2}$.'

On the other hand, the members of the British Church reciprocated by in their turn regarding the Christianity of the Anglo-Saxons a thing of nought, and refusing to hold any intercourse with them. In the year A.D. 705, Aldhelm Abbot of Malmesbury, instructed by a West Saxon Synod, wrote a letter to Geruntius (Geraint) King of Damnonia (Devonshire and Cornwall), in which he complained that 'beyond the mouth of the Severn, the priests of Cambria, proud of the purity of their morals ${ }^{3}$, have such a horror of

\footnotetext{
1 Bede, H. E. iv. 2.
}

2 Bede, Vit. S. Cud. xxxvii-xxxix. The date of St. Cuthbert's birth is unknown, but he entered the monastery of Melrose A.D. $65 \mathrm{I}$, conformed to Roman usage after the Synod of Whitby A.D. 664, and died A.D. 687.

3 This fact, admitted by Aldhelm, unless his words are sarcastic, contrasts curiously with the accusations of Gildas, A.D. 547 ; Epist. in H. and S. i. 74. 
communication with us, that they refuse to pray with us in the churches, or to seat themselves at the same table: more than this, what is left from our meals is thrown to dogs and swine, the dishes and bottles we have used have to be rubbed with sand or purified by fire, before they will condescend to touch them. The Britons give us neither the salutation nor the kiss of peace; and if one of us went to live in their country, the natives would hold no communication with him till after he had been made to endure a penance of forty days.'

Aldhelm then proceeds to assume that these British Christians, with their bishops, are outside the pale of the Catholic Church, and to assert in language, which has often been heard in more modern times, that it is impossible to be a Catholic and yet not in visible union with the See of St. Peter.

'We entreat you on our knees, in view of our future and common country in heaven, and of the angels our future fellow-countrymen, do not persevere in your arrogant contempt of the decrees of St. Peter and the traditions of the Roman Church, by a proud and tyrannical attachment to the decrees of your ancestors. Whatever may be the perfection of faith and good works, they are unprofitable ont of the Catholic Church. . . To sum up everything in one word, it is vain for any man to take credit to himself for belonging to the Catholic faith, so long as he rejects the doctrine and rule of St. Peter. For the foundation of the Church and the consolidation of the faith, placed first in Christ and secondly in St. Peter, will not waver before the assaults of any tempest. It was on St. Peter that the Truth Himself conferred the privilege of the Cburch, saying, Thou art Peter, and upon this rock will I build my Church '.'

In A.D. 8I6, the Council of Celchyth, under Wulfred Archbishop of Canterbury and Kenulf King of Mercia, passed a

1 H. and S. iii. 268-273. 
resolution questioning the ordination of certain Irish clergy and the efficacy of Sacraments administered by them ${ }^{1}$.

The same state of antagonism between the Roman Church and the Celtic communities existed on the Continent. The Anglo-Saxon Winfrid, $\Delta . D .680-755$, better known as Boniface Archbishop of Mentz, and styled 'The Apostle of Germany,' regarded the Irish and British missionaries with whom he came in contact in Germany as little or nothing else than heretics. He induced Pope Gregory III (A.D. 73 I74I) to write a letter exhorting the bishops of Bavaria and Alemannia to reject the 'teaching and the ritual of the Gentiles,' and 'of those Britons who came there,' as well as of 'other false priests and heretics ${ }^{2}$ '. He delated two of them, Virgilius the Apostle of Carinthia, who had been known in Ireland as Ferghal Abbot of Aghabo, and Sidonius, to Pope Zachary A.D. 746, for incorrectly administering baptism, and though the Pope acquitted them on this score, Boniface secured their condemnation in the following year on a question of the existence and character of the antipodes. A third Irishman was charged with holding heretical views of baptism, and a fourth, named Clement, was condemned for heterodoxy A.D. 742, and afterwards imprisoned by Carloman.

The above facts present to our view a vast Celtic communion existing in Great Britain and Ireland, and sending its missions among the Teutonic tribes on the Continent, and to distant islands like Iceland; Catholic in doctrine and practice, and yet with its claims to Catholicity ignored or impugned by the Church of Rome; with a long roll of saints, every name of note on which is either that of one like

1 - Ut nullus permittatur de genere Scottorum in alicujus diocesi sacram sibi ministeria usurpare, neque ei consentire liceat ex sacro ordine aliquot attingere, vel $a b$ eis accipere in baptismo, aut in celebratione missarum, $v \in l$ etiam Eucharistiam populo praebere, quia incertum est nobis, unde, en (an) ab aliquo ordinentur,' \&c. Cap. $\nabla$; H. and S. iii. $5^{81}$.

2 'Gentilitatis ritum, et doctrinam, vel venientium Brittonum, vel falsorum sacerdotum et haereticorum, aut undecunque sint, renuentes ac prohibentes adjiciatis,' \&c. Greg. III. Epist. ad Episcopos Bajoariae et Alemanniae; ib. i. p. 203. 
St. Columbanus taking a line wholly independent of Rome, or, like Bishop Colman at the Synod of Whitby, directly in collision with her; having its own Liturgy, its own translation of the Bible, its own mode of chanting, its own monastic rule, its own cycle for the calculation of Easter; and presenting both internal and external evidence of a complete autonomy ${ }^{1}$.

§5. Eastern Origin.-It is hardly possible to pass over in silence the theory of the Eastern origin of the Celtic Church which was once much in vogue, but which is now generally abandoned as untenable. This theory has, for obvious and polemical reasons, been maintained by all Protestant, and by some Anglican writers, while it has been as uniformly repudiated by writers of the Church of Rome ${ }^{2}$. Neander writes: "The peculiarity of the British Church is evidence against its origin from Rome, for in many ritual matters it departed from the usage of the Roman Church, and agreed much more nearly with the Church of Asia Minor ${ }^{3}$.'

On the other hand, Messrs. Haddan and Stubbs speak of - the groundlessness of the so often alleged Orientalism of the early British Church,-Oriental in no other sense than that its Christianity originated like all Christianity in Asia, and found its way to Britain through (most probably) Lyons, and not through the then equally Greek Church of Rome, but without imprinting one single trace upon the British Church itself of any one thing in a peculiar sense Greek or

1 The foregoing is for the most part a picture of the early Celtic Church only. The influence of Rome began to predominate in Ireland in the seventh century, and appeals to Rome are recognised in the Book of Armagh. It did not fully establish itself till the twelfth century (see p. 10). All the arguments brought forward by Bishop Greith (Altirischen Kirche, p. 453) to prove the recognition of the papal supremacy by the early Church of Ireland, and the authorities by which he supports them, refer not to the Church of SS.Columba and Columbanus, much less of SS. Patrick and Bridget, but to the Irish Church after conformity to the Roman Church had commenced to set in (for dates see p. 9).

${ }^{2}$ Sir James Dalrymple, Collections, Epist. Dedicat. p. 2 ; Pref. p. xliv ; George Buchanan, Hist. in Rege Aidano; David Buchanan, Pref. to Knox, Hist. edit. Lond. fol. p. 15I ; Spottiswoode, Vindication of Collections, p. 30; Thomas Innes, Civ. and Eccles. Hist. of Scotland, p. I I, Aberdeen $18_{53}$.

${ }^{3}$ Gen. Ch. Hist. i. I 17. 
Oriental 1'. Elsewhere Mr. Haddan speaks of 'the common but utterly groundless idea of a specially Greek origin of the British Church 2.'

After such decided expressions of opinion from persons so qualified to form them, it is yet hoped that it may not be considered as labour thrown away to accumulate and lay before the reader the various converging facts which, though they do not establish a specially Oriental origin of the Celtic Church, yet go far to save such a theory from the charge of being 'utterly groundless,' and explain how it grew up. This theory is of course quite distinct from the ethnological question as to the origin of Celtic nations, and from the philological question as to the relation of the Celtic language to the Indo-Germanic family. Its discussion is complicated by the fact that the date of the evidence offered is sometimes difficult to ascertain. Such similarities as that of British weapons found in barrows, in form and alloy, to those found in the plains of Phœnicia, and of cromlechs and pillars in Ireland to stone monuments in Palestine ${ }^{3}$, have reference to an original connection long anterior to the introduction of Christianity, and are chronologically irrelevant to the subject in hand. The similarity in these and other points between Cornwall, Ireland and the East, is almost certainly due to the fact that in the earliest historical times the great traders and navigators were the Phœnicians, who brought their commerce to these shores, and may have influenced the manners and customs of their inhabitants in their architecture, arts, and manners. With regard to the carved symbol of the Greek cross which is frequently found, but not in a majority of cases, on the ancient sculptured stones of Christian Scotland ${ }^{4}$, while in Cornwall and Brittany the same form of the cross preponderates ${ }^{5}$, and with regard to other supposed signs of

\footnotetext{
1 Councils and Eccles. Doc. i. p. xix.

2 Remains, p. 2 ro.

3 Ulster Journ. Arch. i. 226.

4 Stuart, J., Sculptured Stones of Scotland, ii. p. 1xxxvi.

5 Blight, J. T., Ancient Crosses of the West of Cornwall, Lond. 1856; Archaeol. Cambrensis for 1857 , p. 370 .
} 
an Eastern origin said to be exhibited by the British Christian architectural remains in Cornwall ${ }^{1}$, their use may be traced in all early Continental Western art, and is only due to the original connection of all Western Christianity with the East ${ }^{2}$.

Architectural Evidence.-Mr. Fergusson makes the following remarks on the general Eastern character of early Christian Irish architecture :- 'Ireland possesses what may properly be called a Celtic style of architecture, which is as interesting in itself as any of the minor local styles in any part of the world, and, so far as at present known, is quite peculiar to the island. None of the buildings of this style are large, though the ornaments of many of them are of great beauty and elegance. Their interest lies in their singularly local character and in their age, which probably extends from the fifth or sixth century to the time of the English conquest in I 76 . They consist chiefly of churches and round towers ${ }^{3}$... No Irish church of this period, now remaining, is perhaps even 60 feet in length, and generally they are very much smaller, the most common dimensions being from 20 to 40 feet $^{4}$. Increase of magnificence was sought more by extending the number than by augmenting the size. The favourite number for a complete ecclesiastical establishment was seven, as in Greece, this number being identical with that of the seven Apocalyptic Churches of Asia. Thus, there are seven at Glendalough, seven at Cashel, and the same sacred number is found

1 Journal of Brit. Archaeol. Assoc. vol. xxiii. pp. 22 I-230.

2 The Labarum has been found on sepulchral stones, as on the Frampton stone in Dorset, \&c., and on an oval tin ornament, fourth century; Hübner, Am., Inscript. Britan. p. 12, Nos. 31, 198, 21 7, 218, 219, 220, 228. For the Greek cross in early Italian art, see J. H. Parker's photographs, No. 442, in Early Irish Art, Kilkenny Archaeol. Soc. 1854, p. 297.

3 The date of the existing round towers is much later.

4 Some of the oratories in fact are much smaller. St. Mollagga's oratory, Co. Cork, measures 10 ft. $\times 7$ ft. 2 in. ; St. Declan's at Ardmore, 13 ft. 8 in. $\times$ $8 \mathrm{ft} .4$ in.; St. Molua's, Killaloe, 1o ft. 6 in. $\times 6$ ft. 4 in.; St. Columb's, at Kells, 16 ft. $I$ in. $\times 13 \mathrm{ft}$; St. Kevin's, at Glendalough, $22 \mathrm{ft} .7$ in. $\times 14 \mathrm{ft}$. I 3 in., exclusive of the walls. R. Brash, Eccles. Architect. of Ireland, p. 8. The dimensions of churches are stated ib. p. 12 I. 
at several other places, and generally two or three, at least, are found grouped together.

'No church is known to have existed in Ireland before the Norman Conquest that can be called a basilica, none of them being divided into aisles either by stone or wooden pillars, or possessing an apse, and no circular church has yet been found; nothing in short that would lead us to believe that Ireland obtained her architecture direct from Rome; while everything, on the contrary, tends to confirm the belief of an intimate connection with the farther East, and that her early Christianity and religious forms were derived from Greece by some of the more southerly commercial routes which at that period seem to have abutted on Ireland.

'Both in Greece and Ireland the smallness of the churches is remarkable. They never were, in fact, basilicas for the assembly of large congregations of worshippers, but oratories, where the priest could celebrate the divine mysteries for the benefit of the laity. It is not only at Mount Athos, and other places in Europe, but also in Asia Minor, that we find the method of grouping a large number of small churches together, seven being the favourite number and one often attained ${ }^{\text {'.' }}$

A little further on Mr. Fergusson alludes to the still older class of antiquities - 'the circular domical dwellings found in the west of the island, constructed of loose stones in horizontal layers, approaching one another till they meet at the apex like the old so-called treasuries of the Greeks, or the domes of the Jains in India ${ }^{2}$ '. Some words of Tertullian with reference to the Eastern sect of the Marcionites have been somewhat fancifully quoted as fitly describing these early Irish beehive-shaped buildings: ' Habent apes favos, habent et ecclesias Marcionitae,' \&c.

Similar Christian architectural remains have been found

1 Fergusson, J., Illustrated Handbook of Architecture, London, 1855 , vol.
ii. p. 915. 
in Cornwall (A.D. $25^{\circ}-45^{\circ}$ ), and are described by Mr. Borlase in his 'Age of the Saints '.'

In his Preface to the Sculptured Stones of Scotland Mr. Stuart quotes Dr. Wise's assertion that there is a striking similarity between the stone monuments of the East and those of Britain ${ }^{2}$, and Mr. Chalmers' assertion that there are figures on some of the stones in Scotland identical with those on Gnostic gems ${ }^{3}$.

These and such like facts, without amounting to proof, are suggestive of Eastern origin or influence, more probably the latter. On the other hand, the explanation which has already been given ${ }^{4}$ of the existence of Greek crosses in Cornwall may be extended to all the other points of architectural similarity between the early Christian remains of Great Britain and Ireland and those of the East ${ }^{5}$.

Palaeographical Evidence.-The palaeographical evidence is at first sight strongly in favour of an Eastern connection, though the tendency of recent writers and of fuller investigation has been to modify the extent of the connection, or even to deny it altogether.

The distinctive style of ornamentation adopted or invented by native artists consisted of intricate designs formed-

I. By the use of dots, generally in different coloured inks.

2. By simple lines, straight or curved.

3. By the step-like angulated pattern.

4. By the Chinese-like $\mathrm{z}$ pattern.

5. By interlaced ribbons.

6. By interlaced zoomorphic patterns.

7. By various spiral patterns, which are by far the most characteristic of the whole.

8. By the formation of gigantic initial letters, sometimes occupying a whole page, which are filled up with geometrical

${ }^{3}$ p. 30. 2 p.iv. $\quad 3$ p. xiv. p. $4^{8}$

5 Haddan, Remains, p. 238 . For an account and explanation of the mixture of Buddhist and Christian symbols on Scottish stones, see Proceedings of Royal Irish Acad. vii. 118. 
designs of interlaced work, convoluted serpentine figures, spiral ornaments, grotesque birds, insects, quadrupeds, \&c. ${ }^{1}$

What is the origin of this style of Celtic art?

A Roman origin is impossible, because not a single Italian MS. nor a single piece of Italian sculpture can be produced older than the ninth century having a close resemblance to those of this country. The illuminations in the Book of Kells find no exact parallel in Italy. They resemble Assyrian or Egyptian rather than Italian work.

A Scandinavian origin, suggested by the existence of Runic inscriptions on stones found in various places, especially in the Isle of Man, is impossible, because all such stones are several centuries more recent than the oldest Celtic MSS., the writers of which had no intercourse with the inhabitants of Denmark or Norway.

An Eastern origin is suggested by the similarity of much of the Celtic ornamentation to that found in early Syriac, Egyptian, Ethiopic, \&c. MSS., by a resemblance in the delineation of birds and animals to Egyptian fresco painting, in the manner of drawing the wings, in the conventional representations of eagles, lions, calves, \&c., in the swathed mummy-like figures of $\mathrm{Christ}^{2}$. The theory of such an origin is facilitated by the early commercial intercourse which is known to have existed between this country and the East, and by the frequent expeditions recorded to have been made by early Christian pilgrims of the Celtic Church to the Holy Land, and by the immigration of foreign ecclesiastics ${ }^{3}$. On the other hand, it is rendered doubtful by the fact that work resembling Byzantine work, and some features of Oriental ornamentation, are to be found in very early MSS. not only in the East, but also throughout Western Christendom ${ }^{4}$.

1 See the monogram of the Book of Kells, Gilbert, J. T., Nat. MSS. of Ireland, i. pl. vii ; Westwood, J. O., Facsimiles, \&c., p. iv.

2 Westwood, J. O., Facsimiles, \&c., plates xxvi, xxviii. 'S See p. 56.

- 'Professor Westwood said in his Palaeographia Sacra (1845, not paged): 
A peculiarity of Greek writing, sometimes adopted by Celtic scribes, as in the Scottish Book of Deer; the Welsh ninthcentury Ovid preserved in the Bodleian Library (Auct. F. iv. 32); the Irish Stowe Missal (ff. I 8, 20-24); consists in the written letters depending from the line above them, instead of resting on the line beneath.

Another feature suggestive of Oriental influence is the introduction of the serpent as a common form of ornamentation in the elaborate illuminations of interlaced work which adorn the early Irish MSS. It is also prominent among Christian emblems on the rudely carved stone crosses, most of which are earlier than the ninth century, and some of which are coeval with the introduction of Christianity into these islands ${ }^{1}$. This serpentine ornamentation reaches a climax on the case of St. Patrick's Bell (eleventh century), ' one side of which is beautified with stones with ornaments of fine gold representing serpents, curiously and elegantly intertwined in most intricate folds, and in varions knots, like the complicated involutions in the collar of the Order of the Knights of St. Patrick. On one of the ends below the knob and ring by which it is suspended there are eight serpents so singularly infolded and intermingled with one

'The collection of many of these MSS. has also furnished additional though unlooked-for evidence that the ancient Church in these islands was independent of Rome, and that it corresponded, on the contrary, with the Eastern Churches. .... These apparently trifling circumstances (ornamental details) seem to me to prove, more forcibly than the most laborious arguments, the connexion between the early Christians in these islands and those of the East, so strongly insisted on by various writers.' It is fair to add that in 1868 the Professor seems so far to have modified his opinion of the Eastern origin of the style of illumination as to speak of it as probable rather than as capable of positive proof; Facsimiles, \&c., Introd. p. 5 .

1 For specimens, see Wilson's Archaeology of Scotland, p. 503; Stuart's Sculptured Stones of Scotland, vol. i. plates lxii, lxiv, lexvii ; vol. ii. plate xxv ; O'Neil's Sculptured Crosses of Ancient Ireland, plate xxxv; Petrie's Irish Inscriptions, part v. p. xxxvii. For the prominence of the serpent in the ancient worship of Africa, Asia, Egypt, Greece, see Dennis, G., Cities and Cemeteries of Etruria, vol. i. p. 169, note 1. edit. 1878; Fergusson, J., Tree and Serpent Worship, London, 1873, Introd. Essay. 
another, that it requires minute attention and singular discrimination to trace each separately and to distinguish it from its fellows. Their eyes are skilfully formed of blue glass. Above the cross are four of the same kind, and in each of the four compartments into which it is divided there are two golden serpents in relief. Below the knob of su :pension, on the opposite end or side, are six other serpents, with blue eyes, but differently intertwined. On the top is a strange representation of two of these creatures with two legs ${ }^{1}$.'

The serpent continued to make its appearance in the Ritual of the Anglo-Saxons, according to a traditional use possibly perpetuated from their Celtic predecessors. On Maundy Thursday, after Nones, a procession went down to the church door, bearing with it a staff which ended at the top in the shape of a serpent. There, fire, struck from a flint, was first hallowed, and then used for lighting a candle which came out of the serpent's mouth. From this all other candles were lighted; and the same ceremonial was repeated on Good Friday and Easter Eve ${ }^{2}$.

The serpent appears in the Mozarabic Liturgy, which contains the following rubric amid the ceremonial of Easter Eve : 'Hic exeat Subdiaconus cum cruce hoc ordine. Ceroferarii cum cereis pergant coram cruce; et cereus paschalis coram cereis, et serpens coram cereo,' \&c. ${ }^{3}$ There is no evidence as to early Gallican usage on this point, but the serpent-rod was in use at Rouen as late as the commencement of the eighteenth century ${ }^{4}$, and in England up to the sixteenth century ${ }^{5}$.

Another custom common to Ireland and the East, though

1 Reeves, Description of St. Patrick's Bell, Belfast, 1850, p. 6, plates iv, v.

2 Rayneri, Apostolatus Benedictinorum in Anglia, Appendix, p. 87. 'Dunstani Concordia praescribens ritus in Coena Domini servandos ait; Hora congrua agatur nona, qua cantata .... fratres pergant ad ostium ecclesiae ferentes hastam cum imagine serpentis ibique ... . candela quae in ore serpentis infixa est accendatur.' Zaccaria, F. A., Onomasticon, ii. 149 .

${ }^{3}$ Migne, Pat. Lat. lxxxv. 461, 470.

4 De Moleon, Voyages Liturgiques, p. 304.

5 Sarum Processional, edit. 1502, fol. 70. For the serpentine formation of the pastoral staff of Eastern bishops, see Goar, Euchol. pp. I I5, 314. 
not exclusively confined to Ireland among Western nations, was that of providing their more precious sacred books with leather satchels called 'polaires,' furnished with straps for slinging round the shoulder, and ornamented in a kind of basso-relievo produced by stamping the leather. Woodcuts of the polaire of the Book of Armagh and of the shrine of St. Maidoc are given in Mr. Petrie's Round Towers, pp.329,322 ; Archæologia, vol. xliii. plate xiv. There are before the writer at this moment the leather satchel of the Irish Missal belonging to C. C. C. Library, Oxford, and the leather satchel of an Æthiopic MS. of about the same date belonging to St. John's College, Oxford. They resemble each other so closely in texture and design that they might be thought to have come from the same workshop.

An independent origin is claimed for the Celtic style of ornamentation by some modern writers; as by Mr. French, who thinks that it is an imitation of the interlaced wickerwork of gigantic animals within which the natives in a preChristian period immolated their victims ${ }^{1}$. The anonymous writer of a recent article on this subject gives it as his view that 'English interlacings and Irish spirals are not traditional or taught ornament, but the special fancies of a race;' and again, speaking of the miniatures in the Book of Kells the same writer says that 'they are constructed not without power or beauty, but with the quaintness which marks the work of an isolated Church, which owed Rome nothing, and to which Greece or Syria had taught nothing but the faith 2.'

Liturgical Evidence.-The monastic rule of the Celtic Church has been often ascribed to an Eastern origin ${ }^{3}$. Its canons, so far as they can be judged from the extant remains of the

1 Origin and Meaning of the early Interlaced Ornamentation found on ancient Sculptured Stones of Scotland ; 1858, Manchester.

2 Church Quarterly, vol. v. p. 457. Mr. R. Brash also claims an independent origin for Irish art; Eccles. Architecture of Ireland, p. 29.

3 e.g. in the Vita S. Guingaloëi in a passage quoted in H. and S. ii. i. 79; Will. of Malmesbury, quoted in O'Conor, Rerum Hibern. Script. vol. ii. p. 166. 
Rules of St. Columba, Columbanus, Adamnan, \&c., are not identical with any other Eastern or Western code. They are found on comparison rather to resemble the former than the latter in the greater severity of their regulations ${ }^{2}$, which probably caused them to give way eventually before the milder Rule of St. Benedict, and in the appearance in the Rule of St. Columbanus of such Eastern words as paximacium, paracaraximus, Archimandrita, Nonnus ${ }^{2}$.

The scattered traces of Oriental influence in the remains of the Celtic Litury and Ritual may be summed up as consisting of the following points:-

(a) The episcopal benediction immediately preceding the communion of the people, and sometimes bestowed in the Eastern fashion ${ }^{3}$.

(b) The veiling of women at the reception of the Eucharist4.

(c) The use of unleavened bread ${ }^{5}$.

(d) The custom of fasting on Wednesdays and Fridays" is spoken of by Archbishop Ussher as 'agreeable to the custom of the Grecian rather than of the Roman Church ?', But there does not seem to be sufficient authority for drawing such a distinction.

(e) Several of the points of Celtic Ritual, specified on p. $6 \mathrm{r}$ as Gallican, are Oriental in their origin.

Historical Evidence.-Mention may be made, in con-

1 The penalty of beating, which is reserved in the Benedictine Code for a few extreme cases, was assigned in the Penitential of St. Columbanus to the most trivial offences, the number of blows to be inflicted varying from six to two hundred. Montalembert, Monks of the West, ii. 448.

${ }^{2}$ Of these words, Nonnus, though said to be an Egyptian word, appears also in the Reg. S. Bened., and Archimandrita, in a different sense, is used by later Western writers.

${ }^{3}$ Ch. ii. $\$ 8$.

4 Ch. ii. $\S 25$.

$5 \mathrm{Ch}$. ii. $\S 25$. Very early Western authority can be found for most of these ritual Orientalisms, in the representations in the Catacombs, or in early Italian mosaics. All that they prove is therefore the Oriental origin of the Celtic Church in common with the rest of Western Christianity.

' Ch. ii. $\$ 34$.

T Op. vol. iv. p. 305. The question is treated at length in Smith, Dict. of Chr. Antiq.; Bingham, Antiq. book xxi. ch. 3. The fast on Wednesday and Friday is ordered in the Eastern Rule of St. Antony, cap. $x v$; in the Western Rule of St. Caesarius of Arles, c. xxii. 
nection with the above facts, of the constant allusions to the East, and especially to Jerusalem, in the legeudary lives of the saints; e.g. in the legend connecting Scotland with St. Andrew as its patron saint, and describing the arrival of Regulus, a monkish pilgrim from the city of Constantinople, bringing the bones of the Apostle from the East. The oldest document containing this legend is of the twelfth century, and is printed in the Chronicles of the Picts and Scots ${ }^{1}$. So in the legendary lives of St. Bonifacius ${ }^{2}$, St. Servanus ${ }^{3}$, and of others enumerated in Haddan and Stubbs' Councils, \&c. ${ }^{4}$, in the legendary consecration at Jerusalem, in the sixth century, of St. David first Bishop of St. David's, St. Teilo second Bishop of Llandaff, St. Patern Bishop of Llandabarn. Sometimes Eastern pilgrims visited Ireland. Seven Egyptian monks, buried at Disert Ulidh, are invoked in the Félire of Oengus ${ }^{5}$.

Celtic saints sometimes referred to Eastern authority in selfdefence, in their controversies with Rome. St. Columbanus, soon after the arrival of his mission in Gaul A.D. 590, protected himself from the charge of schism, and defended the Celtic mode of determining the fall of Easter, by referring to the authority of Anatolius Bishop of Laodicea, A.D. 270. He accused the continental Church of innovation; its computation having been altered by Sulpicius Severus A.D. 410, by Victorius of Aquitaine 450, by Dionysius Exiguus 525; and he finally declared to Pope Boniface his readiness to abide by the second canon of the Second Council of Constantinople, 'Let not bishops go out of their dioceses to churches out of their bounds, nor bring confusion on the Churches,' \&c.

At the Synod of Whitby, while St. Wilfrid urged the acceptance of the Roman calculation of the fall of Easter on the authority of St. Peter, Bp. Colman defended the Celtic cycle on the authority of St. John. 'Then Colman said, The Easter which I keep I received from my elders who sent

i p. 138.

2 Skene, IV. F., Celtic Scotland, ii. 229.

Ib. ii. $255 . \quad$ i. 35 ; ii. pt. i. $86,{ }^{5}$ Colgan, Acta SS. Hib. p. 539. 
me bishop hither; all our forefathers, men beloved of God, are known to have kept it after the same manner; and that the same may not seem to any contemptible or worthy to be rejected, it is the same which St. John the Evangelist, the disciple beloved of our Lord, with all the Churches over which he presided, is recorded to have observed '.'

British clergy are recorded to have visited Constantinople during the patriarehate of Methodius (842-847) for the sake of obtaining information about the Paschal cycle ${ }^{2}$.

The above facts go far to explain and justify the opinion that there must have been originally some connection between the Celtic and Oriental Churches. But this connection need not have been direct. The most proballe hypothesis is that Christianity reached the British isles through Gaul, and that whatever traces of Eastern influence may be found in the earliest Liturgy and Ritual of Great Britain and Ireland are not due to a direct introduction of Christianity from the East, but to the Eastern character and origin of that Church through which Christianity first reached these shores.

$\S 6$. Gallican Connection.-There is strong circumstantial evidence in favour of the immediately Gallican origin of the British Church, and for fixing the date of its foundation between A. D. I76 and 208. In the former year Irenaens, enumerating the Christian Churches then in existence, made no allusion to any Church in Britain ${ }^{3}$. In the latter year Tertullian wrote a passage which contains the first historical allusion to the existence of Christianity in these islands ${ }^{4}$. The dispersion

${ }^{1}$ Bede, H. E. iii. 25. The author does not wish to be considered as endorsing the historical accuracy of Colman's assertions, but merely to call attention to the fact that the Celtic party themselves, however erroneously, claimed an Eastern origin of and sought Eastern authority for their Paschal cycle. Its non-Eastern origin is proved by Messrs. Haddan and Stubbs, Councils, \&c. i. I57.

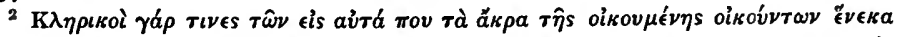

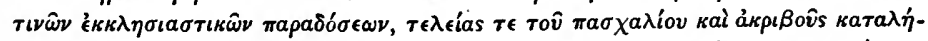

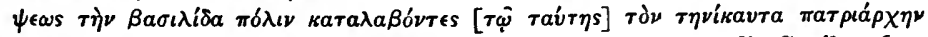
' $\pi \rho \circ \sigma \epsilon \lambda \eta \lambda \hat{v} \theta a \sigma$. Vit. Anon. Chrysost., Op. tom. viii. p. 321.5; edit. Savile, I6r 2.

$s$ Haer. i. 1o.

¿... Galliarum diversae nationes, et Britannorum inaccessa Romanis 
of the Gallican Church in the fierce persecution which raged in Gallica Celtica-the district round Lyons and VienneA.D. 177 probably brought Christian refugees across the Channel, and in accordance with a law of growth often exemplified in the early history of Christianity, the blood of Gallican martyrs became the seed of the British Church ${ }^{1}$. This early Gallican Church was a colony from Asia Minor. Pothinus the first Bishop of Lyons had come directly from that country, bringing with him Irenaeus the disciple of Polycarp, the disciple of St. John. The names of its bishops and nartyrs were Greek. The writings of its saints and some of its earliest extant inscriptions are in the same language. The account of its sufferings under Marcus Aurelius was sent by the Christians of Lyons and Vienne by letter to their brethren in Asia and Phrygia ${ }^{2}$. Any features of Oriental ritual in the British Church may be accounted for and traced, as has been already suggested ${ }^{3}$, through this intermediate Gallican channel.

Other proofs are forthcoming of the intercourse which existed at a subsequent date between these islands and France. Passages indicating an intercourse of the British and Gallican Churches during the first six centuries are found in the writings of the anonymous author of a tract De Septem Ordinibus Ecclesiae, Arnobius junior, St. Patrick, and Venantius Fortunatus ${ }^{4}$. During the fourth and fifth centuries there was a constant emigration of British Christians into Armorica, and legendary lives exist of many saints who migrated from Wales or Cornwall into Brittany A.D. 450-600 ${ }^{5}$. The presence of

loca Christo vero subdita .... in quibus omnibus locis Christi nomen qui jam venit regnat....utpote in quibus omnibus locis populus nominis Christi inhabitet .... Christi autem regnum et nomen ubique porrigitur, ubique creditur, ab omnibus gentibus supra enumeratis colitur,' \&c. Adv. Jud. vii.

${ }^{1}$ Mr. Pryce would place this mission to Britain before A.D. 177; Ancient British Church, pp. 60, 61. But in that case we should expect to find some allusion to it in the writings of Irenaeus. $\quad{ }^{2}$ Eus. Hist. Eccl. lib. v. c. 1.

${ }^{3}$ p. 57. "Quoted at length in H. and S. i. 13.

5 Enumerated in H. and S. ii. App. B, and in the Journal of the British Archaeol. Assoc. vol. iv. p. 235 . 
British bishops at various Gallican Councils is attested by their signatures, as at Tours A.D. 461 , at Vannes 465 , at Orleans 5I I, at Paris 555. Mansuetus the first Bishop of Toul was an Irishman ${ }^{1}$; Mansuetus was also the name of the first known Breton bishop; St. Beatus Bishop of Lausanne, and Apostle of Switzerland (fourth century), was likewise Irish. There was also constant commercial intercourse between the two countries. Diodorus Siculus states that tin was exported from Britain to Gaul, and transported through Gaul to the mouths of the Rhone and to Narbonne ${ }^{2}$. Strabo speaks generally of the exchange of commerce between Britain and Gaul ${ }^{3}$. When St. Columbanus was at Nantes, and the authorities there wished to send him back to Ireland, an Irish merchant-ship was found lying in the harbour ready for the purpose ${ }^{4}$. Gallic traders are reported to have visited Clonmacnois in the days of St. Kieran, A.D. $548-9^{5}$. Gallic sailors with their ship came to Iona or its immediate neighbourhood in the sixth century ${ }^{6}$.

The intimate connection between Wales and Brittany can be traced up to the eleventh century, when Rhys ap Tewdwr, the representative of the royal line of South Wales, took refuge there, returning thence to his throne in 1077 with the unanimous consent of the people?

There are traces of the presence or influence of many Gallican bishops in England; St. Martin of Tours ${ }^{8}$ (371-97), Hilary of Poictiers ${ }^{9}$ (350-67), Victricius of Rouen ${ }^{10}$ (c. 407),

1 Martene and Durand, Thes. Nov. iii. 991.

2 Hist. lib. v. 22, $3^{8}$.

3 Books ii, iv.

- Jonas, Vit. S. Columbani, c. 22.

3 Vit. S. Kierani, c. 3 I.

- Vit. S. Columbae, i. 28. These 'Gallici nautae de Galliarum provinciis adventantes' touched at 'Caput Regionis,' probably ' Cantyre.'

7 Skene, W.F., Four Ancient Books of Wales, i. 20.

s Later legends made St. Columba go to Tours, and carry away with him St. Martin's Book of the Gospels, in reward for showing the inhabitants where the saint lay buried. St. Martin was also reported to be the great-uncle of St. Patrick, and the ritual of Tours thus came, it was supposed, to be imported into Ireland; Colgan, Trias Thaum.; Bede, H. E. i. 26, iii. 4.

- There is a Hymnus S. Hilarii in the Liber Hymnorum and in the Antiphon. Benchor. H. and S. i. 9.

10 Victr. Lib. de Laude Sanctorum; Gallandus, viii. 228. 
Germanus of Auxerre ${ }^{1}\left(429\right.$ and 447), Lupus of Troyes ${ }^{2}$ (429), Severus of Treves ${ }^{3}$ (447), Gregory of Tours ${ }^{4}$ (573-95), and of Arculfus ${ }^{5}$, who was entertained by Adamnan at Iona A.D. 686 .

We may also note the dedication of Celtic churches to Gallican saints; as in the case of the very ancient churches at Canterbury and Whitheru to St. Martin; the many churches in Cornwall and Wales dedicated to St. Germanus; two churches in Glamorganshire dedicated to St. Lupus ${ }^{6}$.

The missions, derived according to some accounts from Gallican sources, of St. Keby into Wales in connection with St. Hilary; of St. Ninian to Scotland, and of St. Patrick into Ireland, in connection with St. Martin.

The employment by the British Church of the Paschal Cycle of Gaul as drawn up by Sulpicius Severus, the disciple of St. Martin, c. 410 . The Irish Church followed the still earlier cycle of Auatolius?.

The use of the Gallican Psalter ${ }^{8}$.

1 Bede, H.E. i. I 7, 2 1, See the Cornish Missa S. Germani, ch. iii ; Martyrol. Bedae, Kal. Aug.

${ }^{2}$ Bede, H. E. i. I7; Martyrol. Bedae, iv. Kal. Aug. ${ }^{3}$ Bede, H. E. i. 2 I.

( Greg. Tur. de Mirae S. Martini, iv. 46.

5 Bede, H. E. v. I 5 .

6 Under the name of St. Bleiddian. Rees, R., Welsh Saints, p. I26.

7 Aldhelm, Ep. ad Geruntium; H. and S. i. I3. See p. 64.

${ }^{8}$ Asserted by Archbishop Ussher on the authority of Sedulius, Works, iv. p. 248. The Roman Psalter is the first revision of the old Latin text made by Jerome c. A.D. $\mathbf{3}^{8} 3$, at the request of Pope Damasus. It was retained in use in Italy till the pontificate of Pius V (A.D. I 566), who introduced the Gallican Psalter generally, though the Roman Psalter was still allowed to be used in three Italian churches, 'in una Romae Vaticana ecclesia et extra urbem in Mediolanensi, et in ecclesia S. Marci Venetiis.' The Gallican Psalter is the second revision made by Jerome A.D. $3^{87-39}$. In it he attempted to represent as far as possible, by the help of the Greek versions, the real reading of the Hebrew. It obtained its name from the fact that it was introduced from Rome in the public services of France by St. Gregory of Tours (573-595), and was only accepted south of the Alps at a much later date.

The abore account is taken from Smith's Dict. of the Bible, vol. iii. p. I698. It is the inverse of the account of the two versions given by Bede, so far as Pope Damasus is concerned, who died A.D. $3^{84}$.

'Sciendum est translationes esse duas apud Latinos in usu atque honore, Romanam, scilicet et Gallicam. Romana est qua utuntur Romani et plerique 
The approximation to Gallican usage in certain features of the Liturgy and ritual; e.g. lections ${ }^{1}$, proper prefaces ${ }^{2}$, position of the benediction ${ }^{3}$, the 'deprecatio' for the departed 4 , the Hymnus trium puerorum ${ }^{5}$, the use of ecclesiastical colours $^{6}$, of Eulogiae ${ }^{7}$, of bracelets, crowns, \&c. ${ }^{8}$

The observance of Rogation Days ${ }^{9}$.

The commemoration of S. Eugenia by name in the Canon of the Drummond Missal, as in the Gallican Missale Vesontionense (p. 207), where her name is added in the Commemoratio pro defunctis in the Canon, and where she is commemorated on Dec. 25 instead of S. Anastasia. Her name also appears on Dec. 25 in the Liber S. Trinitatis, a fourteenthcentury Irish Martyrology ${ }^{10}$; and also with that of St. Anastasia in the Sacramentary of Leo ${ }^{11}$.

Whole passages, in addition to many isolated phrases, from the Gallican Liturgy appear in the Stowe Missal ${ }^{12}$, and in the liturgical fragments in the Books of Deer, Dimma, and Mulling ${ }^{13}$.

The second and often-quoted question of St. Augustine to Gregory I, together with the papal answer, imply either the identity of the British and Gallican Liturgies, or that St. Augustine found the Gallican Rite in use in Britain; probably in the church of St. Martin at Canterbury, where Liudhard Bishop of Senlis, who had accompanied Queen Bertha from the court of Charibert at Paris, on her mar-

Itali, quae de Graeco in Latinum a Symmacho et Aquila sumpta est secunduin lxx interpretes Ptolonaei regis. Gallica est qua precipue Galli utuntur. Haec autem praecipue sumpta est rogatu Damasi Papae a beato Hieronymo de Hebraeo ad sententiam.' Praefatio ad Psalmos, tom. viii. col. 423, fol. Basiliae, $15^{6} 3$.

Until a complete collation shall have been made of the Celtic text of the Oll Testament it is impossible to verify or refute the inference drawn by Ussher from the doubtful authority of Sedulius. The materials for such a collation are indicated in H. and S., i. pp. $170-19^{8}$. They seem to prove the existence of a special Celtic revision of the text of the Vetus Latina.
1 Ch. ii. $\$ 5$.
2 Ib. $\$ 7$.
3 Ib. $\S 8$.
- Ib. § 10.
s Ib. $\$ 13$.
Ib. $\S 16$.
7 Ib. $\S 27$.
8 lb. $\$ 15$.
- Ib. $\$ 34$.
10 Irish Archaeol. Soc. vi. I9r.
11 viii. Kal. Jan.

${ }^{12} \mathrm{Cb}$. iii. § I4.

${ }^{13}$ Ib. $\S \S 5,6,7$. 
riage with Ethelbert of Kent, would naturally have been using it.

St. Augustine asked: 'Whereas the faith is one and the same, why are there different customs in different Churches, and why is one form of Mass observed in the holy Roman Church, and another in the Gallican Church?'

To which St. Gregory replied: 'You know, my brother, the custom of the Roman Church, in which you remember you were bred up. But it pleases me that if you have found anything either in the Roman, or the Gallican, or any other Church, which may be more acceptable to Almighty God, you carefully make choice of the same, and sedulously teach the Church of the English, which as yet is new in the faith, whatsoever sou can gather from the several Churches. For things are not to be loved for the sake of places, but places for the sake of good things. Choose, therefore, from every Church those things which are pious, religious, and upright, and when you have, as it were, made them up into one body, let the minds of the English people be accustomed thereto '.'

§7. Spanish Connection.-There are traces of a connection between the Celtic and Spanish Churches in the following facts :-

In A.D. 380 certain Priscillianist bishops were banished from Spain to the Seilly Islands ${ }^{2}$.

The existence of a British See of Bretona in Gallicia in N.W. Spain is alluded to in the Council of Lugo (Lucus Augusti), A.D. $5^{6} 9$.

The Second Council of Braga, A.D. 572, is subscribed to by Mailoc, a British bishop, suffragan of Martin Archbishop of Braga.

1 Bede, H. E. i. 27. The above facts, while they certainly do not establish the identity of the Gallican and British Liturgies, disprove the assertion of Lingard that this theory is 'without even the semblance of a proof;' AngloSaxon Church, i. $3^{8} 5$.

${ }^{2}$ Sulpicius Severus, Hist. Sac. ii. 51 . 
There are traces of the prevalence in Spain of the British mode of calculating Easter c. A.v. $59^{1}$.

The Fourth Council of Toledo, A.D. 633, can. 4I, abolished a particular-probably the British-form of tonsure, said to have prevailed in Gallicia, and to have caused an undesirable want of uniformity in Spain. It was subscribed by Metopius, a British bishop.

The signature of an 'Episcopus Britonensis,' sometimes with a Gothic sometimes with a Celtic name, is found appended to the Councils of Toledo VII, A. D. 646; Toledo VIII, A.D. 653; Braga IV, A. D. 675; Toledo XIII, A.D. 683; Toledo XVI, A. D. 693. Traces of the existence of this British See of Britona or Britonia (Sedes Britoniensis) are found in lists as late as A.D. $115^{6}$; but the See had become merged in or united with that of Montenedo or Oviedo A.D. 830 .

Passages which are found likewise in the Mozarabic Liturgy are incorporated in Celtic liturgical fragments in the Books of Deer, Dimma, Mulling, and in the Stowe Missal ${ }^{2}$.

$\S 8$. Points of Difference between the Roman and Celtic CHURCH. - A consideration of the chief points of difference between the Roman and Celtic Churches will rather incline readers to agree with the old British historian ${ }^{3}$, and with St. Augustine of Canterbury ${ }^{4}$, that the British were in many respects hostile to Roman customs, than with the more accomplished modern author who says that no traces can be discovered of any permanent divergence between them in doctrine or practice ${ }^{5}$.

The chief points of divergence were these :-

I. The Calculation of Easter.-There was a difference be-

1 Greg. Tur. v. 17, x. 23.

${ }^{2}$ Ch. iii. $\$ \S 5,6,7,14$. Most of the above facts are given more at length in H. and S., ii. pt. i. 99 .

3 - Britanni toti mundo contrarii, moribus Romanis inimici, non solum in missa, sed in tonsura etiam.' Gildre Epist. ii.

- St. Augustine said to the British bishops at the synod of Bangor, 'Quia in multis quidem nostrae consuetudini, immo universalis Ecclesiae contraria geritis.' Bede, H. E. ii. 2.

skene, W. F., Celtic Scotland, ii. 6. 
tween the Roman and Celtic Churches in determining the date of Easter, which, though intrinsically of an unessential nature, became the crucial point of controversy in the seventh century, being prominently insisted on by St. Augustine at the Bangor conference with the seven British bishops ${ }^{1}$. Some points in connection with it have been already alluded to ${ }^{2}$. The real state of the controversy and the important facts to be remembered are these,-that before the Council of Nice the practice of the British harmonised with that of the Roman Church, the most ancient Roman table for Easter agreeing with that of the British Church; but that owing to its isolation from the rest of Western Christendom, the Celtic Church had never adopted the various alterations and improvements which, on astronomical and not on theological grounds, had been from time to time accepted by the Continental Church ${ }^{3}$.

2. Baptism.--One of the conditions of union offered by St. Augustine to the British bishops was that of their consenting to administer baptism according to the custom of the Roman Church ${ }^{4}$. Bede does not inform his readers in what the difference between the two baptismal rites consisted, but it probably lay in one or more of the following points :-

(a) Single immersion.-The practice of immersion, as against affusion, is proved by the large size of still surviving fonts, such as the font of sixth-century workmanship found at St. Brecan's Bed ${ }^{5}$, and another of twelfth-century workmanship at Cashel, in the chapel of Cormac King of South Munster (1123-38) $)^{6}$. Single immersion was the custom ' in tota diocesi Macloviensi' in Brittany up to $4 . D .1620$ ?

\footnotetext{
1 Bede, H. E. ii. 2. Appendix D, with a lucid summary of the whole controversy. the Cuuncil of Clovesho, H. and S. iii. 367 .

5 Lord Dunraven, Notes on Irish Architecture, p. 90.

- Brash, R., Eccles. Architecture of Ireland, p. 95.

7 Mart. lib. i. cap. i. art. xv. $\S 8$.
}

2 p. 56 .

3 The various authorities for this statement are given in H. and S. i. 152,

4 Bede, H. E. ii. 2. A difference is also implied in the thirteenth canon of 


\section{§8.] Difference between Roman and Celtic Church. 65}

It prevailed in the sixth century in Spain, where Gregory I advised its retention under the peculiar circumstances in which the Spanish Church stood at that time with regard to Arianism ', and where a British bishopric existed at that date $^{2}$. It is left optional in the three extant 'Ordines Baptismi' of the ancient Gallican Church ${ }^{3}$, while a rubric directing trine immersion is contained in the earliest Ordines Romani ${ }^{4}$. Trine immersion, with the alternative of aspersion, is ordered in the earliest extant Irish Baptismal Office, in the composition of which however Roman influence is strongly marked ${ }^{5}$.

(b) The omission of unction.-Lanfranc complained to Tirlagh, chief king of the Irish A. D. 1074, that the Irish baptized their infants without any $\operatorname{chrism}^{6}$; and St. Bernard asserted in the twelfth century that they omitted confirmation ${ }^{7}$. This almost incredible accusation of the disuse of confirmation is possibly based on the fact that unction was sometimes omitted in that rite as administered in the Celtic Church. Alcuin sent a present of some oil to a lector named Colcu in Ireland in the eighth century, and requested him to distribute it among the bishops because oil was scarce ${ }^{8}$, a fact which suggests that the occasional omission of unction may have been due to the difficulty of obtaining the necessary material. But if St. Bernard's exaggerated accusations were true of the Irish in the twelfth century they do not apply to an earlier date. St.Patrick, writing to the subjects of Coroticus C.A.D. 497, alludes to chrism, along with the sign of the cross and the white chrisom, as all connected with the baptismal rite ${ }^{9}$. The

1 Ep. i. 43.

2 p. 62.

3 Missale Gothicum, p. 97 ; Gallicanum, p. I9I ; Vesontionense, p. 270.

4 Mart. lib. i. cap. i. art. xviii. ord. iv, v. ${ }^{5}$ Stowe Missal, ch. iii. § 14.

- Ep. ad Tirdelvac, Op. p. 320, ed. Ben.

7 'Usum saluberrimum confessionis, sacramentum confirmationis, contractum conjugiorum (quae omnia aut ignorabant aut negligebant) Malachias de novo instituit.' Bernard in Vita Malachiae, cap. iii.

8 'Misi charitati tuae aliquid de oleo quod vix modo in Britannia invenitur, ut dispensares per loca necessaria episcoporum ad utilitatem hominum vel honorem Dei.' Ep. xviii. in Ussher's Works, iv. 467.

- 'Postera die qua crismati neophyti in veste candida, dum fides flagrabat in fronte ipsorum.' Ep. ad Corot. subditos, sect. 2. The danghters of King 
earliest extant Irish Baptismal Office-in the volume known as the Stowe Missal ${ }^{1}$-enjoins three separate acts of unction:-

(i) At an early point in the service between the interrogations of the candidate: 'Deinde tanges pectus dorsum de oleo et crismate.'

(ii) Shortly before the act of Baptism: 'Incipit oleari oleo et crismate in pectus et item scabulas antequam baptizaretur.'

(iii) Immediately after Baptism: 'Postquam baptizaretur oleatur cresmate in cerebrum in fronte.' The personal formula following, with the vernacular rubric introducing it, is peculiar to the Stowe Missal2 ${ }^{2}$.

Of these three rites, (i) is unrepresented in the present Roman Ordines Baptismi; (ii) is directed to be performed with the oil of the catechumens only; (iii) is performed somewhat differently: 'perungat verticem Electi in modum crucis' (Ordo Bapt. Adult.), 'ungit infantem in summitate capitis,' \&c. (Ordo Bapt, Parvulor.)

(c) The 'Pedilavium, or ceremonial washing of the feet after baptism ${ }^{3}$.

In connection with the subject it may be mentioned that one of the earliest Anglo-Saxon decrees, under Augustine, provided for the invocation of each Person of the Holy Trinity in Baptism. Pope Zachary writing to Boniface of Mentz A.D. 748 told him that the following canon on Baptism had been passed in England A.D. 597-603: 'Dinoscitur ut quicunque sine invocatione Trinitatis lotus fuisset, quod sacramentum regenerationis non haberet... Hoc quoque observasse in supradicta synodo sacerdotes, ut qui vel unam

Leoghaire were clothed in white garments after their baptism by St. Patrick. Book of Armagh, fol. I 2 a.

1 Ch. iii. § I 4 .

${ }^{2}$ It has been fancifully suggested that certain ancient bronze spoons may have been used for pouring the oil of chrism over the head of the newly baptized person. (Archaeol. Cambr. vol. ii. Fourth Ser. p. I6.) In the anonymous Life of St. Bridget this passage occurs: 'Magus dormiens vidit duos clericos vestibus albis indutos effundere oleum super caput puellae, ordinem baptismi complentes consueto more.' Acta SS. ed. Bolland., Feb., tom. i. p. I19; Leabhar Breac, fol. $62 \mathrm{~b}$.

S Sce note to the passage in the Stowe Ordo Baptismi, ch. iii. $\$$ I4. 


\section{\$8.] Difference between Roman and Celtic Church. 67}

Personam de Trinitate in baptismo non nominaret, illud baptismum esse non posset, quod pro certo verum est quia qui Unum ex sancta Trinitate confessus non fuerit perfectus Christianus esse non potest ${ }^{1}$.'

In describing the proceedings of the Synod of Cashel A.D. 1172 Benedict of Peterborough mentions the following curious facts : 'In illo autem concilio statuerunt, et auctoritate summi pontificis praeceperunt, pueros in ecclesia baptizari, In nomine Patris, et Filii, et Spiritus Sancti, et hoc a sacerdotibus fieri praeceperunt. Mos enim prius erat per diversa loca Hiberniae, quod statim cum puer nasceretur, pater ipsius vel quilibet alius eum ter mergeret in aqua. Et si divitis filius esset, ter mergeret in lacte ${ }^{2}$ ' Archbishop Theodore's doubts of the validity of British Baptism have been noticed ${ }^{3}$. If there was any reason for supposing that the abuses in Ireland in the twelfth century had any counterpart in England in the seventh century, they would have been justifiable. It is curious that the formula of Baptism is omitted in the Office preserved in the Stowe Missal 4 .

3. The Tonsure.-The Roman tonsure was formed by the top of the head being shaved close, and a circle or crown of hair left to grow around it. The Eastern tonsure, styled St. Paul's, was total. The Celtic tonsure consisted in shaving all the hair in front of a line drawn over the top of the head from ear to ear. The Roman party traced their form of tonsure to St. Peter, and attributed that of their opponents to Simon Magus. Abbot Ceolfrid discussed the subject at length in his letter to Nectan King of the Picts A.D. $710^{5}$.

1 Inter Epp. S. Bonifac. lxxxii, edit. Würdtwein, p. 235, quoted in H. and S. iii. 51. An Irish priest named Sampson was accused by the same pope of erroneous teaching about Baptism ; Ep. xvii. ad Bonifac. ; Ussher, iv. 463.

2 Rolls Ser. 1867 , vol. i. p. 28, ed. W. Stubbs. The only allusion to Baptism in the eight canons of this Council which are extant is in the first, which orders its administration to take place in the font at church, implying that the laxer custom of baptizing in private houses was creeping in or had become prevalent. (Mansi, Concil. tom. xxii. p. I34; Girald. Cambr. Expugn. Hibern. lib. i. cap. 35 ; Master of Rolls' Ser. vol. v. p. 282.)

'p. 42 . 2 Ch. iii. \$ 4 .

sede, H. E. v. 21. 
Although not brought forward by St. Augustine, this question of the tonsure (together with that of Easter) formed the subject of the most frequent and violent controversy in Britain during the seventh century. There are traces of the same controversy in France, where a Saxon colony at Bayeux had copied the Celtic tonsure from the Bretons before A.D. $59^{1}$; and in Spain, where a tonsure like the Celtic was condemned by the fourth Council of Toledo ${ }^{2}$.

\section{The Ordinal.}

(a) The Consecration of Bishops by a single Bishop. In the Life of St. Kentigern it is related that he was consecrated to the episcopate by a single bishop who had been summoned from Ireland for that purpose, according to the custom of the Britons and Scots ${ }^{3}$. A similar fact is recorded in the legendary lives of the Welsh SS. David, Dubricius, Teilo, \&c. ${ }^{4}$ There is a curious legend of the consecration of St. Columba by Bishop Etchain, who conferred on him priest's instead of bishop's orders by mistake ${ }^{5}$. Was this the flaw which caused Archbishop Theodore to suspect the imperfection of Celtic Orders ${ }^{6}$, and think it necessary to confirm the consecration of Chad to the see of York? That consecration had been performed by Wini Bishop of Winchester, assisted by two British bishops, A.D. $665^{7}$, but such assistance may have been regarded as valueless ${ }^{8}$. In Ire-

1 Greg. Tur. Hist. Franc. x. 9.

2 Conc. Tolet. IV. A.D. 633. can. xli; Mansi, Concil. x. p. 630. Further details are given by Bede, H. E. iv. 1 ; Gildas, Epist. ii ; Aldhelm, Epist. ad Geruntium, in H. and S. iii. 268; Mabillon, Ann. Bened. i. 528; Act. SS. Ord. Ben, saec. ii. pp. I I9-20.

3 'Rex et clerus regionis Cambrensis (in Glasguo) ... a accito de Hibernia uno Episcopo, more Britonum et Scottorum, in Episcopum ipsum consecrari fecerunt.' Vita S. Kentegerni, auctore Jocelino, c. xii.

- Acta SS. Mart. i. 44, \&c.

5 Félire of Oengus, at the end of March.

6 'Qui ordinati sunt a Scottorum vel Britonum episcopis ... adunati aecclesiae non sunt, sed iterum a catbolico episcopo manus impositione confirmentur.' Theodore's Penitential, book ii. sect. ix.

${ }^{7}$ Bede, H. E. iii. 28.

${ }^{8}$ Ib. iv. 2. Theodore's reason is not obvious. Consecration by a single bishop has always been recognised as valid, though irregular. Bingham, Antiq. book ii. cap. xi. sect. 5 ; Bright, W., Early Eng. Ch. Hist. pp. 227-8. 


\section{\$8.] Difference between Roman and Celtic Church. 69}

land the custom of single consecration still obtained in the eleventh century, and was complained of by St. Anselm writing to the Irish king Tirlagh, A.D. I074, and by Lanfranc writing to King Muriardach, A.D. $110^{1}$. It is strange that such a custom should have prevailed in the British Church, as three of its bishops had been present and had subscribed to the canons of the Council of Arles, A.D. 314, which ordered that at least three, and if possible seven, bishops should take part in every episcopal consecration ${ }^{2}$.

(b) The Lections of Scripture used in the British Ordinal differed from those in use in other Western Ordinals. Their variations are exhibited in the following table:-

\begin{tabular}{|c|c|c|}
\hline $\begin{array}{l}\text { Brimish ORdivaL. } \\
\text { (From Gildas.) }\end{array}$ & $\begin{array}{c}\text { GaLLican ORDinal. } \\
\text { (From Lectionarium Lux- } \\
\text { oviense.) }\end{array}$ & $\begin{array}{l}\text { Roman Ordinal. } \\
\text { (From Div. Hieron. Comes } \\
\text { Pamelii Liturg. ii. 6o.) }\end{array}$ \\
\hline $\begin{array}{c}\text { At O,dination. } \\
\text { I Pet. i. 3, I3, I4, } 22 \text {; ii. } \\
\text { I, 9. } \\
\text { Acts i. I5, 16. } \\
\text { 'Secunda Lectio Pauli.' } \\
\text { I Tim. iii. I \&c. } \\
\text { Matt. xvi. 16-1 } 8 .\end{array}$ & $\begin{array}{l}\text { Ordination of Deacons. } \\
\text { Ezek. xliv. 15, 16. } \\
\text { Tim. iii. 8-13. } \\
\text { Luke ix. 57-62. } \\
\text { Of Priests. } \\
\text { Tit. i. 1-6. } \\
\text { Luke xii. 42-44. } \\
\text { Of Bishops. } \\
\text { Mal. i. 6-11. } \\
\text { I Cor. ix. 7-12. } \\
\text { Luke xx. 45-xxi. } 4 \text {. }\end{array}$ & 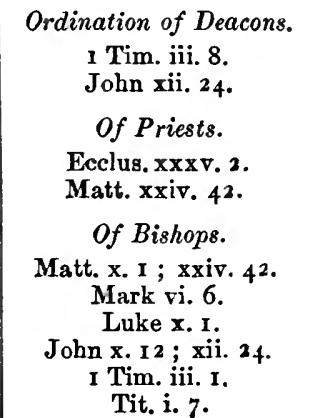 \\
\hline
\end{tabular}

St. Gregory, in his celebrated answers to St. Augustine, distinctly recognised the validity of consecration by single bishops in case of necessity, and authorised and commissioned him to consecrate single-handed. "Truly in the Church of the English, in which as yet you are found the only bishop, you cannot ordain a bishop otherwise than without other bishops.' Bede, H. E. i. 27. Respons. vi.

1 St. Anselm said, 'Episcopi quoque qui debent esse forma et exemplum aliis canonicae religionis, inordinate, sicut audimus, aut a solis episcopis, aut in locis, ubi non debent, consecrantur.' Ussher, Vet. Epist. Hibern. Sylloge, Ep. $\times \times x \nabla$; also in Ep. xxxvi. Lanfranc complained 'Quod episcopi ab uno episcopo consecrantur.' Ib. Ep. xxvii.

2 ' Ut sine tribus episcopis nullus episcopus ordinetur. De his qui usurpant sibi quod soli debeant episcopos ordinare, placuit ut nullus hoc sibi praesumat nisi assumptis secum septem aliis episcopis : si tamen non potuerit septem infra tres non audeat ordinare.' Mansi, Conc. tom. ii. p. 474. can. xx. 
(c) The anointing of the hands of deacons and priests at ordination. This custom, together with the above use of lections, is vouched for by the contemporaneous authority of Gildas: 'Recurrere tandem aliquando usque ad lectiones illas, quae ad hoc non solum ut recitentur, sed etiam adstipulentur benedictioni, qua initiantur sacerdotum vel ministrorum manus,' \&c. ${ }^{1}$

The earliest extant formula for such unction is found in the Pontifical of the Anglo-Saxon Egbert Archbishop of York $\left(73^{2-766)}\right.$, and runs as follows ${ }^{2}:-$

\section{'AD ORDINANDOS PRESBITEROS.}

\section{(1) Consecratio Manus.}

(2) Benedic, Domine, et sanctifica has manus sacerdotis tui Ill. ad consecrandas hostias quae pro delictis atque neglegentiis populi offeruntur, et ad cetera benedicenda quae ad usus populi necessaria sunt; et praesta, quaesumus, ut quaecunque benedixerint benedicentur, et quaecunque sacrauerint sacrentur, Saluator mundi, qui uiuis et regnas.

(3) Faciens crucem sanctam de chrismate in manibus eius (uel eorum) et dicis:

(4) Consecrentur manus istae, quaesumus, Domine, et sanctificentur; per istam sanctam unctionem et nostram inuocationem, adque diuinam benedictionem, ut quodquod benedixerint sit benedictum, et quodquod sanctificauerint sit sanctificatum. Per.

(5) Consecratio capitis oleo.

(6) Unguatur et consecretur caput tuum coelesti benedic-

1 Gildae Epist. If this interpretation of the passage is correct, Jocelin (twelfth century) must be wrong in stating that unction of the head only formed part of the British rite. 'Mos inolevit in Britannia in consecratione pontificum tam modo capita eorum sacri crismatis infusione perungere, cum invocatione Sancti Spiritus, et benedictione et manus impositione; quem ritum dicebant disipientes se suscepisse divinae legis institutionem, et Apostolorum traditionem.' Vit. S. Kent. c. xi, ap. Pinkerton, Vit. Antiq. p. 223.

${ }^{2}$ Printed by the Surtees Society, vol. xxvii. p. 24, from a tenth-century MS. in the Imperial Library at Paris. 
tione in ordine sacerdotali, in nomine Patris, et Filii, et Spiritus Sancti. Amen.

Pax tibi.

Presp. Et cum Spiritu tuo.'

In the ordination of deacons in the same Pontifical ${ }^{1}$ there is the following rubric and collect:-

(7) 'Consecratio manuum Diaconi de oleo sancto et chrisma.

(8) Consecrentur manus, iste, quaesumus Domine, et sanctificentur per istam unctionem, ut quaecunque benedixerint benedicta sint, et quaecunque sanctificauerint sanctificata sint.'

(1) and (4) are found in the Gregorian Sacramentary ${ }^{2}$; not in the Gelasian; and in three ninth-century Gallican Sacramentaries ${ }^{3}$.

The rubric and formula for the unction of the hands in the consecration of priests, in the present Roman Pontifical, are as follows:-

'Pontifex cum oleo catechumenorum inungit unicuique ambas manus, simul junctas, in modum crucis, producendo cum pollice suo dextero in dictum oleum intincto duas lineas, videlicet, a pollice dexterae manus usque ad indicem sinistrae, et a pollice sinistrae usque ad indicem dexterae, ungendo mox totaliter palmas, dicens, dum quemlibet inungit:

Consecrare et sanctificare digneris, Domine, manus istas per istam unctionem et nostram benedictionem. $R$. Amen.

Pontifex producit manu dextera signum crucis super manus illius, quem ordinat, el prosequitur:

Ut quaecunque benedixerint benedicantur, et quaecunque consecrauerint consecrentur et sanctificentur in nomine Domini nostri Jesu Christi. Amen ${ }^{4}$ '

${ }^{1}$ Ib. p. 21, ${ }^{2}$ Muratori, Lit. Rom. Vet. ii. 414, from a tenth-century MS.

3 Mart. i. viii. xi. ordo iv. vol. ii. p. $4^{\text {r. }}$.

- There is a passage in a letter from Pope Nicolas I (858-867) to Rodulph Archbishop of Bourges, asserting that the anointing of the hands was not then in use in the Roman Church in the ordination either of priests or deacons : 'Sciscitaris utrum solis presbyteris an et diaconibus debeant cum ordinantur manus chrismatis liquore perungi ; quod in sancta hac Romana, cui Deo auctore 
The anointing of the hands at the ordination of deacons $[(7)$ and (8)] is not found in any form of the Roman Ordinal, ancient or modern, nor in any Gallican Ordinal ${ }^{1}$. It is found in the Anglo-Saxon Ordinals of St. Dunstan ${ }^{2}$, of Egbert ${ }^{3}$, of $\mathrm{Bec}^{4}$; and is asserted by Martene to have been a peculiarity of the Anglo-Saxon Church ${ }^{5}$. With the passage of Gildas in view ${ }^{6}$, it seems a safe inference that it was imported into the Anglo-Saxon Ordinal from the more aucient forms of the British Church.

A similar inference has been drawn with reference to the following points, but with less certainty, as there is no passage of Gildas, or other Celtic author, which can be produced to throw light on the earlier British practice.

(d) The Prayer at the giving of the stole to deacons at Ordination :-

'In nomine sanctae Trinitatis et unicae divinitatis accipe stolam quam tibi Dominus per humilitatis nostrae famulatum, seu per manus nostras, accipiendam praeparavit; per quam scias sarcinam Domini Dei tui cervicibus tuis impositam, et ad humilitatem atque ministrationem te esse connexum, et per quam te cognoscant fratres tui ministrum Dei esse ordinatum, ut qui in diaconatus ministerio es constitutus, leuitice benedictionis ordine clarescas, et spiritali conuersatione praefulgens gratia sanctificationis eluceas; sed et in Christo Jesu firmus et stabilis perseveres, quatenus hoc quod per hanc stolam significatur in die districti iudicii ante tribunal Domini siue macula representare ualeas; ipso auxiliante cui est honor et gloria in saecula saeculorum. Amen.'

deservimus, ecclesia, neutris agitur.' Martene expresses his astonishment at this passage. Certainly Amalarius (ob. 837), writing some years previously, had asserted the custom in the case of the ordination of priests: 'Hunc morem tenent episcopi nostri ; manus presbyterorum ungunt de oleo.' De Div. Off. lib. ii. c. I 3. Rodulph and Amalarius were familiar with Gallican, and perhaps also with Anglo-Saxon Ritual.

1 But (8) is found in the ordering of priests in an early Poitiers Pontifical, Cod. Pictav. saec. vii. in Bibl. Vatican.
2 Mart. i. viii. xi. ordo iii.
Ib. ordo ii.
- Ib. ordo xi.
Ib. i. viii. ix. § 9 .
6 p. 70. 
This prayer is found in the Winchester Pontifical ${ }^{1}$, and in the English Pontificals of Egbert ${ }^{2}$ and St. Dunstan at Paris ${ }^{3}$, and in that of Jumièges ${ }^{4}$, but not in any other Western ordinals.

(e) Rite of delivering the book of the Gospels to Deacons at Ordination.

This rite, shich is now in general use in the Roman Church, is not found in any of the Ordines Romani in the Western Pontificals prior to A.D. I000, except in the abovementioned Pontificals of the Anglo-Saxon Church. The words with which it is there accompanied are these:-

'Postea tradat ei episcopus sanctum euangelium, dicens:

Accipe illnd uolumen Euangelii. Lege, et intellige, et aliis trade, et tu opere adimple ${ }^{5}$ '

It is not mentioned by the early ritualists St. Isidore, Amalarius, or Alcuin. It must therefore have been imported from England into France ${ }^{6}$, and through France into the rest of Western Christendom, - and from what other source is the Anglo-Saxon Church likely to have obtained it except from the ancient Celtic Church which preceded it?

$(f)$ Rite of investing priests with a stole at ordination.

This rite is not mentioned in the Gelasian or Gregorian Sacramentaries, nor in any of the carlier Western Rituals collected by Martene, who conjectures that its absence is due to the fact that the stole had already been given to the deacon at ordination ${ }^{7}$. But the rite does appear in the Office for the Ordination of Priests in the English Pontificals before

1 Harl. MSS. 561. saec. xiv; Maskell, Mon. Rit. iii. 198.

2 Mart. ii. p. 35 .

3 Ib. p. 39.

4 Rouen MSS. 362. saec. $x$; Mart. ii. p. 37 .

${ }^{5} \mathrm{Ib} . \mathrm{p} .39$. The present Roman formula is very different: 'Postremo Pontifex accipit et tradit omnibus librum Evangeliorum quem manu dextera tangunt, dicens; Accipe potestatem legendi Evangelium in Ecclesia Dei tam pro vivis quam pro defunctis. In nomine Domini. Amen.'

6 ' Cum ergo solemnis fuerit in Anglia evangelii traditio, reperiaturque in omnibus quos inde videremus Libris Ritualibus, ab ea ecclesia hunc ritum initium traxisse facile colligitur.' Mart. i. viii. ix. $\S 8$.

7 Mart. i. viii. ix. § 13 . 
mentioned, whence it probably spread, like the Delivery of the Gospels, into the rest of Western Christendom. The Pontifical of Egbert contains the following directions :-

' Presbyter cum ordinatur, circumdentur humeri eius cum stola ab episcopo ${ }^{1}$.

Quando datur stola Presbytero.

$\mathrm{Stola}(\mathrm{m})$ iustitiae cireumdet Dominus cervicem tuam et ab omni corruptione peccati purificet Dominus mentem tuam ${ }^{2}$.'

The same reason exists as in $(c)$ for supposing a Celtic origin for this rite.

5. Peculiar mode of consecrating Churches and Monasteries.

(a) Celtic Churches as a rule, to which those of St. Martin and of the 'Quatuor Coronati ${ }^{3}$ ' at Canterbury and that of St. Martin at Whithern must be considered exceptions, were not named after departed saints, but after their living founders. On one occasion Archbishop Theodore supplied an Anglo-Roman dedication to the wooden cathedral which had been built some fourteen years previously at Lindisfarne by the Celtic Bishop Finan. Bede narrates how (A.D. 65I) 'Aidan, the Bishop, having departed this life, Finan, who was ordained and sent by the Scots, succeeded him in the bishopric, and built a cathedral church in the isle of Lindisfarne; nevertheless after the manner of the Scots, he made it not of stone, but of hewn oak, and covered it with reeds; and the same was afterwards dedicated in honour of St. Peter the Apostle by the most reverend Archbishop Theodore.' The dedications of Celtic churches may be divided into two classes, those to native saints before the existence of the Anglo-Saxon

1 The Roman Ordinal has the following: 'Pontifex sedet accepta mitra et reflectit orarium, sine stolam, ab humero sinistro cujuslibet, capiens partem quae retro pendet, et imponens super dexterum humerum, aptat eam ante pectus in modum crucis singulis dicens.

'Accipe jugum Domini ; jugum enim ejus suave est et onus ejus leve.'

2 Surtees Soc. vol. xxvii. p. 2 I.

3 Bede, H. E. i. 26 ; ii. 7 .

- Bede, H. E. iii. 25. We are indebted to this Celtic custom of dedicating churches to their living founders or consecrators for the preservation of many saints' names, especially in Cornwall. 


\section{\$8.] Difference between Roman and Celtic Church. 75}

Church, those to saints in the Anglo-Saxon or Roman Calendar imposed at a later date ${ }^{1}$. Sometimes the earlier dedication lingered on in use by the Celtic population, side by side with the later one, as in the case of 'St. Elider and St. James,' 'St. Beuno and St. Michael,' 'St. Dogmael and St. Thomas' \&c. in Wales ; 'St. Mawnanus and St. Stephen,' 'St. Manacus and St. Dunstan,' 'St. Meran and St. Thomas a Becket' in Cornwall.

(b) The consecration of a church or monastery was preceded by a long fast. Bishop Cedd of the East Saxons (653-664) told Ethelwald, King of Deira, that 'it was the custom of those from whom he had learned a rule of regular discipline that they should first consecrate with prayer and fasting those places which had been newly obtained for founding a monastery or church.' Accordingly he fasted 'for the whole forty days of Lent,' and the exercise of fasting and prayer being completed he built-a monastery, which is now called Lastingham, and established it with religious customs, according to the practice of Lindisfarne, where he had been educated ${ }^{2}$.

\section{The Liturgy and the Ritual of the Mass.}

The surviving fragments of the Celtic Liturgy have been put together in ch. iii, and the information which can be gleaned about its ritual is contained in ch. ii. It will therefore be sufficient to group together here certain passages which supply historical evidence of the existence of a Liturgy, other than the Roman, in these islands.

In England and Wales.-The use of a Liturgy here, certainly different from the Roman, and either identical with or very like the Gallican Liturgy, is an inference from the second of the questions put by Augustine to Gregory I, and from that

1 Borlase, Age of the Saints, pp. 74-76. Mr. R. Rees has detected a third and intermediate list of Celtic dedications to St. Michael, ranging from the seventh to the tenth century. Welsh Saints, p. 65 .

2 Bede, H. E. iii. 23. The detail with which Bede records the above facts implies that he thought this mode of consecration unusual and deserving of special mention. 
Pope's reply ${ }^{1}$. It is strengthened by the language in which Augustine addressed the British bishops at the Synod of Bangor: 'In many respects you act in a manner contrary to our customs, and indeed to those of the Universal Church; and yet if you will obey me in these three things; to celebrate Easter at the proper time; to perform the office of baptism, in which we are born again to God, according to the custom of the Holy Roman and Apostolic Church; and to join us in preaching the word of God to the English people (Anglorum genti), we will tolerate all your other customs, though contrary to our ovon.' The last clause almost certainly includes a difference of Liturgy, which however Augustine had previously received instructions from Gregory not to elevate into a casus belli.

Gildas c. A.D. 570 had asserted a difference between the British and Roman Liturgies in these words: 'The Britons are at variance with the whole world, and are opposed to Roman customs, not only in the Mass, but also in their tonsure ${ }^{3}$.'

The Council of Clovesho, A.D. 747, can. xiii, ordered the general adoption of Roman Sacramental usages throughout the English dioceses: 'Tertio decimo definitur decreto: Ut uno eodemque modo Dominicae dispensationis in carne sacrosanctae festivitates, in omnibus ad cas rite competentibus rebus, id est, in Baptismi officio, in Missarum celebratione, in cantilenae modo celebrantur, juxta exemplar videlicet quod scriptum de Romana habemus Ecclesia. Itemque ut per gyrum totius anni natalitia sanctorum uno edemque die, juxta martyrologium ejusdem Romanae Ecclesiae, cum sua sibi convenienti psalmodio seu cantilena venerentur'.'

This passage proves that in A.D. 747 the Roman Liturgy was only in partial, not in universal use in England. Possibly

\footnotetext{
${ }^{1}$ Bede, H. E. i. 27 ; Krazer, P. A., De Lit. p. 89, ed. 1787 .

2 Bede, H. E. ii. 2.

3 'Britones toti mundo contrarii, moribus Romanis inimici non solum in missa sed in tonsura etiam.' Gildas, Epist. ii ; H. and S. i. I I 2.

- H. and S. iii. p. $3^{67}$.
} 


\section{\$8.] Difference between Roman and Celtic Church. 77}

the Gregorian Canon had been introduced in some places without the whole service baving been assimilated to the Roman type, as is concluded, from an examination of the old Gallican Liturgies, to have been the case in France ${ }^{1}$.

The Irish Catalogue of the Saints, A.D. 750, asserts that a British Liturgy, different from St. Patrick's, had been introduced into Ireland, in the latter half of the sixth century, by St. David, St. Cadoc, and Gildas ${ }^{2}$.

At the close of the eighth century the Scottish Liturgy was said to be still in daily use in the church of York, and Alcuin writing from France (790-800) urged Archbishop Eanbald to abolish it, just as Charles the Great, in 789, had ordered the Roman rite to be substituted everywhere in France for the old Gallican Liturgy ${ }^{3}$.

In Ireland.-The following account of the origin of the Scottish (=Irish) Liturgy, and of the British (after A. D. 429) assumed to be the same, tracing it through Germanus and Lupus to St. Mark and distinguishing it from the Gallican, was drawn up by some foreign Scoto-Irish monk probably in the eighth century:-

'Cursus Romanus ${ }^{4}$.-Beatus Trosimus, Episcopus Arelatensis, et Sanctus Photinus, martir et Episcopus Lugdunensis, discipulus S. Petri, sicut et refert Josephus, et Eusebius Caesariensis Episcopus, cursum Romanum in Galeis tradiderunt.

1 Missale Francorum, p. 692, edit. Muratori ; Mabillon de Lit. Gall. p. 46.

${ }^{2}$ p. 81 .

3 '(Presbyteri) non despiciant Romanos discere ordines.' Ep. 56. 'Nuncquid non habes Romano more ordinatos libellos sacratorios abundanter? Habes quoque et veteris consuetudinis sufficienter sacramentaria majora ... Aliquid voluissem tuam auctoritatem incepisse Romani ordinis in clero tuo, ut exempla a te sumantur, et ecclesiastica officia venerabiliter et laudabiliter vobiscum agantur.' Ep. lxv. Ad Simeonem [= Eanbaldum.]

4 Transcribed from H. and S. i. $13^{8}$. The conjectural emendations of Spelman (Concil. i. 167) have been incorporated in the text, so far as is necessary to make it grammatical, and where possible intelligible. The evidence of this confusing document, so far as it is worth anything, asserts the original Irish Liturgy used by St. Patrick to have been neither Roman, nor Gallican, but Alexandrian. In this respect it is au isolated statement, unsupported by any other evidence. 
Cursus Gallorum.-Inde postea relatione beati Photini martyris, cum quadraginta et octo martiribus retrusi in ergastulum, relatione ad beatum Clementem IV loci successorem beati Petri Apostoli deportaverunt, et beatum Irenaeum Episcopum beatus Clemens ordinavit. Hoc in libro sancti ipsius Irenaei, Episcopi et martiris, reperies. Edoctus a beato Polycarpo Smyrnaeorum Episcopo et martyre, qui fuit discipulus Johannis Apostoli, sicut refert Historiographus Josephus, et Irenaeus Episcopus, in suo libro.

Johannes Evangelista primum cursum Gallorum decantavit; inde postea beatus Polycarpus discipulus Sancti Johannis; inde postea Irenaeus qui fuit Episcopus Lugdunensis Gallei, tertius ipse, ipsum cursum decantaverunt in Galleis. Inde per diversorum prudentium virorum, et modulationibus, series Scripturarum Novi ac Veteris Testamenti diversorum prudentium virorum paginis, non de propriis sed de sacris Scripturis, reciproca, antiphonas, et responsus seu sonus, et alleluyas composuerunt; et per universum mundum peragravit, atque per universum orbem terrarum Ecclesiae ordo cursus Gallorum diffusus est. Quem beatus Hieronimus presbiter, et Germanus et Lupus Episcopi, Pelagianam haeresim (non sicut multi opinantur et Gallicanus quidam clericus Britto modulatione deditus, quod ipsum edidisset, quod non fecit) quod beatus Hieronimus presbiter, Germanus et Lupus, Pelagianam haeresim vel Gallianam (quae nomen ipsius titulatur) ex Britannis et Scotiis provinciis expulerunt.

Cursus Scottorum.-Unde et alium cursum, qui dicitur praesenti tempore Scottorum, quae sit opinione, jactatur. Sed beatus Marcus Evangelista, sicut refert Josephus et Eusebius in libro quarto, totum Aegyptum vel Italiam taliter praedicaverunt sicut unam Ecclesiam, ut omnis sanctus, vel Gloria in Excelsis Deo, vel Oratione Dominica, et Amen, universi tam viri quam foeminae decantarent. Tanta fuit sua praedicatio unita, et postea Evangelium ex ore Petri Apostoli edidit.

Beatus Hieronimus affirmat, ipsum cursum, qui dicitur praesenti tempore Scottorum, beatus Marcus decantavit, et post 
ipsum Gregorius Nanzianzenus, quem Hieronimus suum magistrum esse affirmat. Et beatus Basilius, frater ipsius sancti Gregorii, Antonius, Paulus, Macarius, vel Johannes et Malchus, secundum ordinem Patrum decantaverunt.

Inde postea beatissimus Cassianus, qui Linerensi monasterio beatum Honorium habuit comparem. Et post ipsum beatus Honoratus primus abba, et sanctus Caesarius Episcopus qui fuit in Arelata, et beatus Porcarius abbas, qui in ipso monasterio fuit, ipsum cursum decantaverunt, qui beatum Lupum et beatum Germanum monachos in eorum monasterio habuerunt. Et ipsi sub normam reguli ipsum cursum ibidem decantaverunt, et postea in Episcopatus cathedra summi honoris, pro reverentia sanctitatis eorum, sunt adepti. Et postea in Britannis vel Scotiis praedicaverunt, quae Vita Germani Episcopi Autisiodorensis, et Vita beati Lupi adfirmant. Qui beatum Patricium spiritaliter litteras sacras docuerunt atque innutrierunt, et ipsum Episcopum pro eorum praedicatione Archiepiscopum in Scotiis et Britanniis posuerunt; qui vixit annos cLIIr, et ipsum cursum ibidem decantavit.

Et post ipsum beatus Wandilochus senex, et beatus Gomogillus, qui habuerunt in eorum monasterio monachos circiter tria millia.

Inde beatus Wandilochus in praedicationis ministerium a beato Gomogillo missus est, et beatus Columbanus, partibus Galliarum; destinati sunt Luxogilum monasterium, et ibidem ipsum cursum decantaverunt.

Et inde postea percrebuit forma sanctitatis eorum per universum orbem terrarum, et multa coenobia ex eorum doctrina, tam virorum quam puellarum, sunt congregata.

Et postea inde sumpsit exordium sub beato Columbano, quod ante beatus Marcus Evangelista decantavit. Et si nos non creditis, inquirite in Vita beati Columbani et beati Eustacii abbatis; plenius invenietis, et dicta beati Athleti abbatis Edbovensis.

Cursus alius Orientalis.-Est alius cursus Orientalis a sancto 
Cromacio, et Eliodoro, et beato Paulino, seu Athanasio Episcopo editus, qui in Gallorum consuetudine non habetur; quem sanctus Macarius decantavit, hoc est, per duodenas, hoc est, unaquaeque ora.

Cursus S. Ambrosii.-Est et alius cursus, quem refert beatus Augustinus Episcopus, quem beatus Ambrosius papa propter haereticorum ordinem dissimilem composuit, qui in Italia antea decantabatur.

Cursus S. Benedicti._Est et alius cursus beati Benedicti, qui ipsum singulariter pauco discordante a cursu Romano; in sua regula repperies scriptum. Sed tamen beatus Gregorius, urbis Romae pontifex, quasi privilegium monachis, ipsum sua auctoritate in Vita S. Benedicti in libro Dialogorum affirmavit; ubi dixit, "Non aliter sanctus vir docere poterat, nisi sicut ipse beatus Benedictus vixit.",

Another document, drawn up about the middle of the eighth century, is entitled 'Catalogus Sanctorum Hiberniae secundum diversa tempora.' It is believed to be the work of Tirechan, the author of the Annotations on the Life of St. Patrick in the Book of Armagh. It gives the following information, which is generally accepted as historical :-

'A. D. 440 (?)-534. The first order of Catholic saints was in the time of Patricius; and then they were all bishops, famous and holy, and full of the Holy Ghost; $35^{\circ}$ in number, founders of churches. They had one head, Christ; and one chief, Patricius ; they observed one mass, one celebration, one tonsure from ear to ear. They celebrated one Easter, on the fourteenth moon after the vernal equinox; and what was excommunicated by one Church, all excommunicated. They rejected not the services and society of women ${ }^{1}$; because founded on the Rock of Christ, they feared not the blast of temptation. This order of saints continued for four reigns. All these bishops were sprung from the Romans, and Franks, and Britons, and Scots.

\footnotetext{
1 According to another MS., "They excluded from the churches neither laymen nor women.'
} 


\section{\$ 8.] Difference between Roman and Celtic Church. 8 I}

'A. D. 534-572. The second order was of Catholic presbyters. For in this order there were few bishops, and many presbyters, in number 300 . They had one head, our Lord. They celebrated different masses, and had different rules; one Easter, on the fourteenth moon after the equinox; one tonsure, from ear to ear; they refused the services of women, separating them from the monasteries. This order has hitherto lasted for four reigns. They received a mass from Bishop David, and Gillas and Docus, the Britons.

'A.D. 572-666. The third order of saints was of this sort:-They were holy presbyters and a few bishops; 100 in number; who dwelt in desert places, and lived on herbs and water, and the alms; they shunned private property; they had different rules and masses, and different tonsures, for some had the coronal, and others the hair [behind]; and a different Paschal festival. For some celebrated the Resurrection on the fourteenth moon or on the sixteenth, with hard intentions. These lived during four reigns, and continued to that great mortality ${ }^{1}$ [A.D. 666].'

In Scotland. - There are no historical documents extant about the character of the ancient Scottish Liturgy. The existence of such a Liturgy is proved by the character of the solitary fragment in the Book of Deer ${ }^{2}$; by the frequent Liturgical and Ritual allusions in the works of Adamnan and other writers of the Celtic Church in Scotland; by the account of the steps taken by Queen Margaret to get it abolished in the eleventh century ${ }^{3}$. St. Serf is said in the Aberdeen Breviary to have lived 'sub forma et ritu primitivae Ecclesiae 4' When Palladius arrived in Scotland he is said to lave found persons 'habentes fidei doctores et sacramentorum ministros presbiteros et monachos, prima-

1 The original document is printed in H. and S. ii.pt. ii. 292, where it is attributed to an anonymous author, c. $\Delta . D .750$. It ncludes the names of many kings, bishops, and presbyters, by the aid of which the date of the periods referred to is ascertained, varying slightly from the dates in the above text, which are taken with the translation from Skene's Celtic Scotland, ii. I2.

2 Ch. iii. $\$ 5$.

'p.7

1 Brev. Aberd. July i, fol. xp. 
tivae ecclesiae solum modo sequentes ritum et consuetudinem '.' At Culross he found St. Serf ' virum devotum, mansuetum, et pium quem, ejus exigentibus meritis, catholicum juxta Romanae Ecclesiae morem rite ordinavit episcopum, et in eadem fide divinitus informavit,' \&c. ${ }^{2}$ Passing on through Scotland, 'ecclesias consecravit, vestimentis sacerdotalibus modum imposuit, et ab eisdem horas canonicas dicendas, prout ecclesia instituebat Romana, sollenniter jussit ${ }^{3}$.' The use of the old Scottish Liturgy at York has been already alluded to ${ }^{4}$.

1 Brev, Aberd. July vi, fol. xxiv.

2 Ib. fol. xxv. Lect. $\nabla$.

3 Ib. Lect.vi. It is doubtful whether Palladius ever visited Scotland (Skene, W. F., Celtic Scotland, ii. 27), but documents like the Aberdeen Breviary, even where historically valueless, preserve allusions or indications of otherwise unknown or forgotten circumstances. This is true generally of the 'Acta Sanctorum,' and of some of the Lections in the present Roman Breviary.

${ }^{4}$ p. 77 . 


\section{CHAPTER II.}

CELTIC RITUAL.

§ 1. Material, Structure, and Arrangement of Churches. $-\S 2$. Titles of the Liturgy. - $\$$ 3. Multiplicity of Collects. - $\$$ 4. The Lord's Prayer. § 5. Lections. - §6. Sermon. - § 7. Proper Prefaces, - § 8. Benediction. - 9. The Pax. - $\S 10$. Prayer for the Dead. - $\$ 11$. Consecration Prayer. - § 12. Communion Anthems. - $\$ 13$. Benedicite. $-\S 14$. Position of the Priest. - $\$ 15$. Vestments. $-\$ 16$. Use of Colours. $-\$ 17$. Choral Service. - \$18. Incense. $-\$ 19$. Joint Consecration. - $\$ 20$. Oblations and Offertory. - $\S 21$. Unleavened Bread. — $\$ 22$. Mixed Chalice. - $\$ 23$. Communion in both kinds. - $\$ 24$. Communion of Infants. \$25. Women to be Veiled. $-\S 26$. Reservation. $-\S 27$. Eulogiae. $-\S 28$. Frequency of Celebration. - $\$ 29$. Hour of Celebration. - $\$ 30$. Duplicating. - \$ 31. Paten and Chalice. - §32. Fan, Knife. - §33. Sign of the Cross. $-\S 34$. Fasting. $-\S 35$. Confession. 



\section{CHAPTER II.}

\section{CELTIC RITUAL.}

IT is proposed in this chapter to lay before the reader such information as can be gathered both directly and incidentally about the structure and decoration of Celtic churches, the dress and ornaments of the clergy, and the ritual of the service performed by them. The sources from which such information is forthcoming have been generally summed up in the Preface, and will be more particularly specified in foot-notes.

$\S$ 1. Churches. Of Earth. - Celtic churches were occasionally and at a very early date constructed of earth. In Tirechan's Annotations on the Life of St. Patrick it is stated, that 'when Patrick went to the place which is called Foirrgea of the sons of Awley, to divide it among the sons of Awley, he built there a quadrangular church of earth, because wood was not near at hand'.'

of Wood.-Where however wood could be obtained it was generally employed, so much so, that the custom of the Irish to use wood for building obtained for it in the middle ages the title of 'mos Scottorum,' 'opus Scoticum,' ' the Scottish style.'

The church of St. Derbhfraich, near Clogher, in Tyrone (fifth century), was a wooden structure ${ }^{2}$. So was that of St. Ciaran of Saighir, in the same century ${ }^{3}$.

In the sixth century St. Monenna 'founded a monastery, which was made of smooth planks according to the fashion

\footnotetext{
${ }^{2}$ Félire of Oengus, April 4, pp. 458, lxxiii. ${ }^{3}$ Colgan, Acta SS. p. $45^{8}$.
} 
of the Scottish nation, who were not accustomed to erect stone walls or to get them erected '.' St. Columba's church at Derry was built of timber and wattling ${ }^{2}$.

In the seventh century St. Kevin (Coemgen) built his oratory of rods of wood ${ }^{3}$; St. Gobban, a famous builder, constructed a wooden church for St. Mulling ${ }^{4}$. It is told of St. Mochaoi, abbot of Nendrum, that on one occasion he went with sevenscore young men to cut wattles to make his church $^{5}$.

In the ninth century the Annals of Ulster record a hurricane which occurred on the festival of St. Martin, and which prostrated a great many trees in the woods, and carried the churches (DiURThEachs) from their places ${ }^{6}$.

In the twelfth century the custom of building churches of wood was still continued in Ireland, as appears from St. Bernard's notice of a church built by Malachy Archbishop of Armagh?

The same custom prevailed in other portions of the Celtic Church. In Scotland St. Ninian's church among the Southern Picts, at the end of the fourth or beginning of the fifth century obtained its name of Candida Casa from the very unusual circumstance that it was built of stone, the use of which material for building purposes was not customary at that date $^{8}$.

1 'Ecclesia in monasterio sanctae Monennae cum supradicta abbatissa construitur tabulis dedolatis, juxta morem Scotticarum gentium, eo quod macerias Scotti non solent facere nec factas habere.' Conchubran's Life of St. Monenna, a twelfth.century compilation, quoted from Cod. Cotton. Cleop. A. 2 by Dr. Reeves in his edition of Adamnan, p. 178 . note e.

${ }^{2}$ Leabhar Breac, p. $3^{2}$ a. $\quad 3$ Bolland, Acta SS. June i. p. 316.

4 - Quidam famosissimus in omni arte lignorum et lapidum erat in Hibernia nomine Gobbanus, cujus artis fama usque in finem saeculi erit in ea.' Colgan, Acta SS. p. 619.

5 Martyrology of Donegal, p. I77.

6 Annals of Ulster, 4.D. 89I.

7 'Porro oratorium intra paucos dies consummatum est de lignis quidem levigatis, sed apte firmiterque contextum, opus Scoticum pulchrum satis.' $S$. Bernardi, Vita S. Malachiae, c. vi. § 14.

8 'Eo quod ibi ecclesiam de lapide, insolito Brittonibus more fecerit.' Bede, H. E. iii. 4 . 
St. Adamnan implies that the first buildings at Iona, including the church, were of wood 1 .

Early in the eighth century, Nectan king of the Picts sent into England for builders in stone, after that Benedict Biscop had introduced there the Roman custom of employing this more durable material ${ }^{2}$.

In the Northumbrian Church, Finan, who had been a ponk at Iona, and who succeeded Aidan as bishop of Linorifarne A.D. 65 I, 'built a church fit for an episcopal see, not o stone, but altogether of sawn wood covered with reeds after the Scotic fashion ${ }^{3}$.'

In England, the buildings at Glastonbury, as they existed in the British Church, before the Anglo-Saxon refoundation of that monastery in the seventh century, were, according to tradition, of wood ${ }^{4}$.

In Wales, when St. Kentigern founded his monastery of St. Asaph, in the sixth century, he built the church of dressed wood, 'after the manner of the Britons, since they were not yet either accustomed or able to build with stone ${ }^{5}$.' St. Gwynllyw, at the close of the same century, is recorded to have built a cemetery chapel of $\operatorname{wood}^{e}$.

On the Continent, when the great Celtic missionary St. Columbanus received from the king of the Lombards a site for his church and monastery at Bobbio A.D. 615, he was said to

1 Adamnan, Vit. S. Columbae, i. 35 ; ii. $41-46$.

2 'Architectos sibi mitti petiit, qui juxta morem Romanorum ecclesiam de lapide in gente ipsius facerent.' Bede, Hist. Eccles. v. 2 I. Biscop had brought from Gaul ' caementarios qui lapideam sibi ecclesiam juxta Romanorum morem facerent.' Ib. Vit. SS. Abb. Mon. in Wiramutha, in Migne, Bib. Pat. Lat. xciv. 7 I5.

3 'Fecit ecclesiam episcopali sedi congruam, quam tamen more Scottorum non de lapide sed dé robore secto totam composuit, atque harundine texit.' Bede, Hist. Eccles. iii. 25.

4 Dugdale's Monasticon, vol. i. p. 1.

5 'More Britonum, quum de lapide nondum construere poterant, nec usum habebant.' Pinkerton, Vitae SS. Scotiae, Vita Kentegerni, p. 248.

- 'Signavit cimiterium, et in medio tabulis et virgis fundavit templum.' Rees, W. J., Lives of Cambro-British Saints, Vita S. Gundleii, p. ${ }^{8} 8$. 
have been supernaturally assisted in procuring the wood necessary for that purpose ${ }^{1}$.

Of Stone.-Stone buildings, though not the general rule, were by no means unknown throughout this period. The remains of rude oratories of uncemented stone still survive in Ireland, either like the oratory of Gallerus, of a date antecedent to the mission of St. Patrick, or like that of Crumtherim, coeval with him, or, as in the case of the church of St. Kienan (Cianan, Kenan), built by his disciples ${ }^{2}$. Stone began to be universally adopted in Ireland for building purposes after the first irruption of the Danes, A. D. 794, and the consequent transfer of the monastic establishment of Iona to Kells, A.D. 8r4.

In Seotland, it has been noticed that St. Ninian's church at Candida Casa, c. A.D. 400, was a stone structure. There are remains of a stone chapel of St. Medan, an Irish virgin and a disciple of St. Ninian, at Kirkmaiden on the Bay of Luce in Wigtonshire, similar to remains found in Cornwall and Brittany. There are also in the same neighbourbood stones, sepulchral slabs, \&c., with representations of crosses, animals of interlaced work of Hiberno-British character, like the single stones found in Ireland, and described in detail by Mr. Petrie ${ }^{3}$.

The remains of British churches in England and Wales

1 Jonae Vit. S. Columbani, in Mabillon, Acta SS. Ord. Ben. tom. ii ; Vita S. Columbani Abbatis, pp. 28, 40. It must not be inferred that the use of wooden buildings was confined to the Celtic race. Such work in France was known as 'opus Gallicum,' in contradiction to stone-work, 'opus Romanense.' It is described in Italia Monumenta Historiae Patriae, vol. i, Edict. Reg. Langobard. App. xi. p. 245. In Anglo-Saxon times King Edwin (616-633) built a wooden church at Tynemouth; there was a 'monasteriolum ligneum' in the same town, rebuilt by St. Oswald in stone. The wooden cathedral at Chester-le-Street remained till A.D. 1042. Lelandi Collect. vol. iv. p. 43. The first church of St. Peter at York, A.D. 627, was 'de ligno.' Bede, H. E. ii. 14. There is a wooden church, of the eleventh century, at Greensted in Essex now.

2 Petrie, G., Round Towers, p. 132; Colgan, Trias Thaum. pp. 163, 217. Lime cement has been used in the building ascribed to St. Kienan.

3 Transactions of Royal Irish Academy, xx. 123; Stuart, J., Sculptured Stones of Scotland, vol. ii. passim. 
enumerated and described at length by Messrs. Haddan and Stubbs exhibit Romano-British stone or brickwork ${ }^{1}$.

- An examination of these ruins points to the small dimensions of these primitive churches, and this inference is corroborated by early testimony. Sixty feet was the length of the Great Church of St. Patrick at Teltown in Meath ${ }^{2}$; one hundred feet that of the first cathedral at Armagh, c. A.D. $445^{3}$. But larger churches soon rose. The Annals of Ulster record the burning of two hundred and sixty persons in a wooden church A.D. 849. The following is the description of St. Bridget's church at Kildare, in her life by Cogitosus :-

'The church in which repose the bodies of both, that is, Bishop Conlaeth, and this Virgin Saint Bridget, on the right and left of the decorated altar, deposited in ornaments adorned with various embellishments of gold and silver and gems and precious stone, with crowns of gold and silver depending from above. For the number of the faithful of both sexes increasing, the church occupied a spacious area, and was elevated to a menacing height, and was adorned with painted pictures, having within three oratories large and separated by partitions of planks under one roof of the greater house, wherein one partition-decorated and painted with figures, and covered with linen hangings - extended along the breadth in the eastern part of the chureh, from the one to the other partywall of the church : which partition has at its extremity two doors; and through the one door, placed in the right side, the chief bishop enters the sanctuary, accompanied by his regular school, and those who are deputed to the sacred ministry of offering sacred and dominical sacrifices; through the other door, placed in the left part of the above-mentioned partition, and lying transversely, none enter but the abless with her virgins and faithful widows, when going to participate

I H. and S. i. 37 .

2 Book of Armagh, fol. 10 a, b, quoted in Trans. of Royal Irish Acad. xx. 16I.

3 St. Evin's Life of St. Patrick, ap. Colgan, Trias Thaum. p. I64. Most of the churches were still smaller; p. $4^{8}$. n. 4 . 
in the banquet of the body and blood of Jesus Christ. But another partition, dividing the pavement of the house into two equal parts, extends from the eastern (western?) side to the transverse partition Jying across the breadth. Moreover the church has in it many windows, and one ornamented doorway on the right side, through which the priests and the faithful of the male sex enter the church, and another doorway on the left side, through which the congregation of virgins and faithful women are accustomed to enter. And thus in one very great temple, a multitude of people, in different order and ranks, and sex and situation, separated by partitions, in different order but with one mind worship Almighty God"'

The remains of Bishop Conlaeth referred to in this extract were disinterred and enshrined A.D. 799. Cogitosus describes the windows as 'numerous' and the walls as 'covered with mural paintings.' 'This points to a date at least as late as the eighth century, for Bede assigns the first introduction of glass and painting into England A.D. 676 to Benedict Biscop, and he had to bring glaziers from Gaul ${ }^{2}$; unless Dr. O'Conor ${ }^{3}$ is right in seeing in Cogitosus' work only a proof of the early and more advanced state of art in Ireland, or unless Mr. Petrie is right in laying stress on the fact that there is no mention of glass in these windows, which may have been only apertures ${ }^{4}$.

The ornamentation of the church need not cause surprise, for there are extant elaborately-worked gold, silver, and bronze utensils and ornaments recently discovered in Ireland, and undoubtedly belonging to a still earlier date. See the description of silver flagons and cups with interlaced and triangular ornamentation found near Coleraine A.D. I854,

1 Cogitosus, Vita S. Brigidae, ap. Canisii Op. i. 423.

2 Vit. SS. Abb. Monasterii in Wiramutha, in Migne, Bib. Pat. xciv. 7 I 7.

3 Rerum Hibern. Scriptores, ii. 109.

- But Mr. Petrie, on other grounds, assigns this description to the ninth century; Trans. of Royal Irish Acad. xx. pp. 199-206. It is erroneously placed among works of the sixth century in Migne's Patrol. vol. Ixxii. 
and assigned to a date $400-600$ B.c. in the Ulster Journal of Archæology, vol. ii. p. 182.

The surviving architectural remains are a proof of the number of Celtic churches which must at one time have existed. As far as England alone is concerned, there is the direct testimony of the British historian Gildas, who speaks of the multitude of churches destroyed in England during the Diocletian persecution ${ }^{1}$ (A.D. 305-313), and again during the invasions of the heathen Saxons in the sixth century ${ }^{2}$. Further details of Irish churches and oratories will be found in Dr. Petrie's Ecclesiastical Architecture of Ireland, p. I86, and of Scottish churches in the Proceedings of the Society of Antiquaries of Scotland, ii. 5 I 7 .

Certain main features deserve to be further dwelt upon.

Screens. - There appears to have been in early Celtic churches a substantial screen with doors in it, separating the chancel from the nave. This is implied in Cogitosus' description of St. Bridget's church (p. 89), and is stated in a fiftcenth-century Gaelic MS. Life of St. Columba preserved in the Advocates' Library at Edinburgh, and translated in Mr. Skene's Celtic Scotland, vol. ii. p. 500.

Altars.-British churches at the beginning of the fourth century had more than one altar. This is inferred from the expressions of Gildas, 'inter altaria' (p. 72), 'inter ipsa sacrosancta altaria' (p. 37). The altar was called 'coelestis sacrificii sedes' (p. 37). It stood at the east end of the church ${ }^{3}$. It was sometimes made of wood, as in the case of the altar in the church of St. Bridget" ${ }^{4}$; sometimes of stone. Gildas

1 Specifying their possession of ' altars' and 'towers;' sect. 6.

2 Sect. 13. Their sites were claimed afterwards by the Anglo-Saxon Church : ' Stans itaque sanctus Wilfridus episcopus ante altare, conversus ad populum, coram regibus enumerans regiones quas ante reges ... illi dederunt, lucide enunciavit; necnon et ea loca sancta in diversis regionibus, quae clerus Britonum aciem gladii hostilis manu gentis nostrae fugiens deseruit.' Eddius, Vit. S. Wilfridi, xvii ; H. and S. i. 124 .

${ }^{3}$ Ancient Scholiast on Fiacc's Hymn ; Todd's Life of St. Patrick, p. 4 II ; unless the church stood N. and S., as was the case at Derry, Saul, and Armagh; Historians of Scotland, vol. vi. p. 1, Edinb. 1874; Leabhar Breac, fol. 26 a.

4 Canisii Op.i.p. 4I7. When St. Bridget received the veil at the hands 
alludes to the stone altars of British churches'. A stone altar is mentioned as having been discovered by St. Patrick in a cave, a possible proof of the existence of Christians in Ireland before the arrival of that saint ${ }^{2}$; and stone altars of the Celtic period have been found on the island of Ardoilan, six miles from the coast of Orney, on the site of the antique monastery of St. Fechin ${ }^{3}$; in the oratory of St. Molaise at Inismurray ${ }^{4}$; at Temple Molaga, with two stone candlesticks close to it $^{4}$; in the oratory of St. Piran at Perranzabuloe in Cornwall $^{5}$; and in that of St. Michael at Penkivel in the same county ${ }^{6}$.

Vestry.-There was frequently an outside vestry attached to the church, 'exedra' or 'exedriola ${ }^{7}$,' where the sacred vessels were kept, and which served for the other purposes of a sacristy.

Bells.-Each church had its bell, 'clocea' or 'campana,' used for summoning the congregation together for the divine offices ${ }^{8}$. The bells of St. Columba and St. Ninian, the former being possibly the very bell alluded to by St. Adamnan, are still in existence in the collection made by the late Mr. John Bell of Dungannon. Pictures of them, with minute description and measurements, are given in Stuart's Sculptured Stones of Scotland ${ }^{9}$, Wilson's Archæology of Scotland ${ }^{10}$, Arehæologia Scotica ${ }^{11}$. A similar bell was found six hundred years ago in the ruins of Bangor Abbey, of which there is a woodcut in the Ulster Journal of Archæology ${ }^{12}$. There is a handbell in

of the British St. Mel (Moel or Mael) Bishop of Ardagh, bowing her head she touched with her hands one of the wooden pillars of the altar, which ever afterwards remained green and sound.

1 'Inter altaria jurejurando demorantes, et haec eadem ac si lutulenta paulo post saxa despicientes.' H. and S. i. 49.

${ }^{2}$ St. Evin's Life of St. Patrick, ap. Colgan, Trias Thaum. p. I34; Todd's Life of St. Patrick, p. 222 ; see Leabhar Breac, fol. 26 a.

3 Transactions of Royal Irish Academy, sx. 42 I-3.

- Dunraven, Lord, Notes on Irish Architecture, pp. 47, 62.

5 Transactions of Exeter Dioc. Arch. Soc. vol. ii. p. 95. 'Ib. vol. iv. p. 91.

7 Adamnan, Vit. S. Columbae, iii. 19; Id. de Locis Sanctis, i. 8.

8 'Cloccam pulsa, cujus sonitu fratres incitati ad ecclesiam ocius currunt.' Vit. S. Columbae, i. 8 ; iii. 23 ; Cummian, Vit. S. Columbae, p. $4^{1}$.

ii. p. liii.

${ }^{10}$ p. $65^{2}$.

11 iv. IIg.

12 i. 179. 
the hands of a very ancient sculptured figure of an ecclesiastic '. A 'campanarius' is mentioned in the list of various persons who formed the household of St. Patrick, who is also said to have given fifty bells to the chürches of Connaught ${ }^{2}$. St. Fillan's bell, with its possibly phallic ornamentation, and with an account of the superstitious usages with which till lately it has been connected, is described in the Proceedings of the Society of Antiquaries of Scotland ${ }^{3}$. Small quadrangular hand-bells of great age, very similar in construction to the Irish type of workmanship, have been found in Wales : an account of one dug up on the site of the oratory of St. Cenan, and of another formerly preserved in the church of Llangwynodd, is given in the Archæologia Cambrensis ${ }^{4}$. Various ancient Irish bells still exist, of which the earliest is perhaps that of St. Patrick. A description of it has been published by Dr. Reeves ${ }^{5}$.

A short account of the ancient bells of other Celtic saints is given by Professor Westwood ${ }^{6}$. St. Mogue's bell and three others are figured in the Proceedings of the Society of Antiquaries of London?, where Mr. Franks describes them as presumably 'hand-bells used by the early missionaries and eremitical bishops of the British Church to summon their followers to prayer.' They were kept either in the vestry, or in those round towers both of Scotland and Ireland which were so long a puzzle to antiquaries, but which are believed by some persons to have been belfries, as well perhaps as repositories for relics, books, and other valuables ${ }^{8}$.

Strange miracles sometimes attested the sanctity of these

1 Transactions of Royal Irish Academy, xx. 248.

St. Evin's Life of St. Patrick, p. 143 .

3 viii. $265-76$.

- Fourth Series, ii. 2;4.

5 In a folio volume with five plates, $185^{\circ}$.

- Facsimiles of the Miniatures, \&c., p. $\mathbf{5}^{2}$.

T Second Series, iii. 150.

- Adamnan, Vita S. Columbae, iii. 15 ; Stuart, Sculptured Stones of Scotland, notice of plate i. p. I ; Petrie, Ecclesiastical Architecture of Ireland, p. I 20. This theory of the use of the round towers is combated by Mr. Brash in Ulster Journ. Archæol. viii. 280-91. And Miss Stokes, as Editor of Lord Dunraven's Ecclesiastical Antiquities of Ireland, assigns to the earliest of them a date not earlier than the close of the ninth century. 
bells, as in the case of the construction of a 'ferrea campana et quadrata suae ecclesiae pernecessaria' by St. Molocus', and of the bell which followed St. Ternan day by day all the way from Rome to Scotland ${ }^{2}$. They were also used, as well as pastoral staves, in the administration of oaths ${ }^{3}$.

Churchyards.-In close proximity to the British church, then as now, was the churchyard, in the midst of which was planted the emblematic evergreen yew-tree. Many of the trees now standing date from the British period. The yewtree at Aldworth, Berks, was examined A.D. I84I, and then concluded to be $\mathrm{I} 377$ years old; i.e. it must have been planted c. A.D. 464, shortly after the preaching of St. Germanus against the Pelagian heresy. Crowhurst yew in Surrey is said to be 1450 years, and the yews at Fountains Abbey are of great antiquity 4 . Giraldus Cambrensis noticed the abundance and age of yews in Ireland, especially in churchyards and cemeteries $^{5}$.

\section{Liturgy and Ritual of the Celtic Church.}

We now pass on from the church itself and its surroundings to some account of the service which took place within its walls.

$\S 2$. Titles of the Liturgy.-The Altar Service itself was entitled Communio ${ }^{6}$, Communio altaris ${ }^{7}$, Comna ${ }^{8}$, Conviaticum $^{9}$, Eucharistia ${ }^{10}$, Hostia ${ }^{11}$, Oblatio ${ }^{12}$, Oiffrenn ${ }^{13}$,

1 Brev. A berdon. June 25, fol. vi.

${ }^{2}$ Ib. June I 2, fol. cvi.

3 Kilkenny Archæol. Soc. 1852, p. 5I ; Girald. Cambrens. Top. Hib. iii. 33.

4 Rock, D., Church of our Fathers, ii. 320 ; Loudon, Arboretum, iv. 2073. The precision with which these calculations have been made is ridiculous, but the author is assured by the Professor of Botany in Oxford that there is nothing abstractly impossible in the existence of certain trees, such as the yew, more than a thousand years old.

- Maxime vero in coemeteriis antiquis, locisque sacris, sanctorum virorum manibus olim plantatas.' Top. Hib. Dist. iii. c. Io.

- Poenitentiale Uinniani, $\S \S 34,3^{6}$; Hibernensis, lib. ii. c. 16.

- Poenitentiale Uinniani,, \$ 14 .

${ }^{8}$ [= Communion], Senchus Mor, iii. 32, 39; Comann, Leabhar Breac, fol. $29 \mathrm{~b}$; F. cxxxiv, cxciv.

9 Hibernensis, ii. 16.

${ }_{10}$ Ib. iii. 8 ; Prefat. Gildae de Peniten.; Book of Dimma.

11 Hibernensis, ii 2 I. 12 Ib. iii. 6; Reg. Columbani, cap. iv.

1s (= Offering, modern Irish Aifrion), Senchus Mor, i. I26; ii. 344; F. Ixxv, cxciv. 
Sacorfaicc ${ }^{1}$, Sacrificium ${ }^{2}$, Sacrificale mysterium ${ }^{3}$, Viaticum ${ }^{4}$.

The word 'sacrificium' was used equally for that which was offered to God, and for that which was given to and received by the communicant. St. Gall told his scholar Magnoaldus, ' My master Columbanus is accustomed to offer unto the Lord the sacrifice of salvation in brazen vessels ${ }^{5}$.' The twelfth canon of the synod of St. Patrick runs thus: 'He who deserveth not to receive the sacrifice in his life, how can it benefit him after his death ${ }^{6}$ ?' St. Patrick said to the newlybaptized virgin daughters of Laoghaire, 'Ye cannot see the face of Christ except ye taste of death, and except ye receive the sacrifice. And they answered, Give us the sacrifice, that we may behold the Son, our Spouse. And they received the Eucharist of God and they slept in death '.' The two words 'communion and sacrifice' are frequently used together in one phrase in the Leabhar Breac ${ }^{8}$.

To celebrate the Holy Eucharist was expressed by Offerre ${ }^{9}$, Sacra offere ${ }^{10}$, Offerre sacrificium ${ }^{11}$, Christi corpus conficere ${ }^{12}$, Eucharistiae celebrare mysteria ${ }^{13}$, Sacra Eucharistiae mysteria

1 Book of Deer; Sacarbaic, Leabhar Breac, fol. 29 b; F. ccxxxviii.

2 Reg. S. Columbani, c. xii ; Gildae, Prefat. de Peniten. $\$ \$ 6,7,8$; Hibernensis, xli. 4 .

3 Cuminius, Vit. S. Col. p. 29.

- Hibernensis, ii. 16.

5 'Preceptor meus beatus Columbanus in vasis aeneis Domino solet sacrificum offerre salutis.' Walafrid Strabo, Vita S. Galli, i. I9.

- 'Qui in vita suâ non merebitur sacrificium accipere, quomodo post mortem illi potest adjuvare?' Canons attributed to St. Patrick, xii, H. and S. ii. pt. ii. p. 335 .

7 Book of Armagh, fol. I 2 a.

8 'Rofaid Patraic aspirut iarsin 7 rogab comaind 7 sacarbaic dolaim tassaig escuip' = 'Thereafter Patrick sent forth his spirit and he received communion and sacrifice from Bishop Tassach's hand.' Leabhar Breac, fol. $29 \mathrm{~b}$; also on fol. 65 a, 66 a. Sacorfaicc in umed for the reserved sacrament given to the sick in a rubric in the Book of Deer (ch. iii. $\S 5$ ); and Sacrificium is used in the same way in a rubric in a tenth century German Rituale printed by Gerbert, Lit. Aleman. ii. I 29.

- Gildas, Pref. de Penit. xxiv ; Hibernensis, lib. xviii. c. 6.

10 Gildas, ib. xxiii.

11 Liber Davidis, can. xii ; Patricii Confessio, xiv.

12 Adamnan, Vita S. Columbae, i. 44.

13 Ib. ïi. I 2. 
conficere $^{1}$, Sacra oblationis mysteria ministrare ${ }^{2}$, Missarum peragere sollemnia ${ }^{3}$, Sacra Eucharistiae consecrare mysteria 4 , Missarum sollemnia celebrare ${ }^{5}$, Sacram oblationem con secrare $^{6}$, Sacrosancta ministeria perficere ${ }^{7}$, Frangere panem ${ }^{8}$, Sacra celebrare mysteria ${ }^{9}$, Sacrosancta mysteria perficere ${ }^{10}$, Immolare hostiam ${ }^{11}$, Offerre sacrificium ${ }^{12}$, Altario jungi ${ }^{13}$.

\$ 3. Multiplicity of Collects.-A peculiar feature of the Celtic Liturgy, at least in its Irish form, was a multiplicity of collects. A synod was held at Matiscon (Macon) in Gaul A.D. 623, to consider the charges brought by a certain monk Agrestius against the Rule of St. Columban.

Mabillon gives a full account of the controversy, and mentions, after several trivial objections brought by Agrestius, the following more important one, that the Irish differed from the ritual and rule of other Churches, and celebrated the Holy Eucharist with great variation and multiplication of collects and prayers ${ }^{14}$.

Eustasius, the disciple and successor of Columbanus in the monastery of Luxovium (Luxeuil), admitted the charge, but pleaded in defence the general acceptableness of all prayer before God.

It is impossible to decide with certainty to what Agrestius referred in his charge. Benedict XIV interpreted it of the substitution of several collects for the one collect which ordinarily precedes the Epistle in the Roman Missal, and which is thus referred to in one of the opening rubries in the Gregorian Sacramentary: 'Postmodum dicitur oratio, deinde sequitur Apostolus ${ }^{15}$ '. Commenting on this rubric Benedict XIV

\footnotetext{
${ }^{3}$ Adamnan, Vita S. Columbae, i. 40.

5 Ib.

Ib.

$7 \mathrm{Ib}$.

Columbae, c. 12.

$10 \mathrm{Ib}$.

Hymns, p. I 7 .

${ }^{2}$ Ib. ${ }^{3}$ Ib. Ib. iii. I7.

${ }^{8}$ Ib. i. 44 . Cuminius, Vita S.

is [ = to be admitted to communion], Poenitentiale Uinniani, §§ I 5, 35.

14 'In summs quod a caeterorum ritu ac norma desciscerent, et sacra missarum sollemnia orationum et collectarum multiplici varietate celebrarent.' Annals of the Bened. Order, i. 320.

15 Migne, Bibl. Pat. Lat. lxxviii. 25; on which Menard remarks, 'In hoc sancti Eligii codice ut in Codicibus Rodradi et Ratoldi, atque in Editis, et in
} 
says, 'Una tantum olim in hac Missae parte Collecta seu Oratio dicebatur, ut ostendit Menardus in notis ad Sacramentarium S. Gregorii. Sanctum quondam Columbanum accusavit Agrestinus (Agrestius?) quod contra Ecclesiae morem plures in Missa Orationes recitaret, quem egregie defendit Eustasius,' \&c. ${ }^{1}$

But why should not the charge of Agrestius have referred to the existence of other, and to the Roman worshipper unknown collects, which are found in the Gallican and Mozarabic Liturgies, and to which Alex. Lesleus, writing a Latin Preface to his edition of the latter Liturgy, refers thus: "Tum sacerdos, in utraque Liturgia (i.e. Gallicana et Mozarabica) populum salutat, et ad altare accedens, septem illas solemnes orationes, quibus liturgiae Gallicana, GothoHispana, et Mozarabica praecipue constant, et ab aliis quibuscunque distinguuntur, devote recitabat,' i.e. (i) Praefatio Missae, (ii) alia oratio, (iii) post nomina, (iv) ad pacem, (v) Contestatio aut Immolatio Missae aut Illatio, (vi) post mysterium aut post pridie, (vii) Dominica oratio cui brevis oratio praemittitur, ante orationem Dominicam Gallis dicta, et subsequitur alia, quae iisdem post orationem Dominicam nominatur '2'?

Dr. O'Conor commenting on this point says, 'This multiplicity of prayers is expressly mentioned by Columbanus himself in his Rule, c. $7^{3}$ ', But on reference to that Rule it is found that St. Columbanus is not speaking of the Liturgy at all, but of petitions in the form of versicles inserted in the Day-hours of the Divine Office ${ }^{4}$.

Ordine Romano, unica habetur oratio seu collecta in prima parte missae ante Evangelium, raro duae,' \&c. Ib. p. 268. n. 10.

1 De Sacrosancto Missae Sacrificio, lib. ii. cap. 5. sect. 3 ; Benedicti XIV, Op. edit. 1777 , tom. viii. p. 33 .

2 Migne, Bibl. Pat. Lat. lxxxv. p. 25.

Bibl. MS. Stowensis, vol. i. appendix i. p. 43.

- His words are, 'Sed quia orationem canonicarum noscendus est modus, in quo omnes simul orantes horis conveniant statutis, quibusque absolutis unusquisque in cubiculo suo orare debet; per diurnas terni psalmi horas, pro operum interpositione statuti sunt a senioribus nostris cum versiculorum augmento intervenientium, pro peccatis primum nostris, deinde pro omni populo 
§ 4. The Lond's Prayer.-The Lord's Prayer formed an essential part of the Celtic as of every other known Liturgy except the Clementine. Heavy penalties were specially enjoined at Iona by the abbot Cuminius in the case of any mistake in its recitation ${ }^{1}$.

It was not introduced with the unvarying formula of the Roman Missal in its earliest as well as latest editions, 'Praeceptis salutaribus moniti, et divina institutione formati audemus dicere,' nor was it followed by the Roman embolismus, 'Libera nos, quaesumus, Domine ab omnibus malis,' \&c. The varying forms substituted for these in the fragments of the Books of Deer, Dimma, and Mulling, and in the Stowe Missal ${ }^{2}$, are one of the strongest proofs of an Ephesine rather than a Petrine origin of the Celtic Liturgy.

The names of local saints were sometimes introduced into the embolismus, as that of St. Patrick in the embolismus in the ancient Irish fragment at St. Gall, MS. No. $1394^{3}$, and in that of the Stowe Missal ${ }^{4}$.

\$5. Lections.-Lections are mentioned as forming part of the Liturgy. The following is among the directions of the abbot Cuminius: 'Sacrificium non est accipiendum de manu sacerdotis, qui orationes et lectiones secundum ritum implere non potest ${ }^{5}$.'

This may imply that in addition to the Epistle and Gospel there was a third lection from the Old Testament-the lectio prophetica-preceding them, as in the Mozarabic and Gallican Liturgies, of which Lesleus says in his Preface, 'In utraque Liturgia tres leguntur Scripturae lectiones una e Veteri, duae e novo Testamento ${ }^{6}$.'

Christiano, deinde pro sacerdotibus et reliquis Deo consecratis sacrae plebis gradibus, postremo pro eleemosynas facientibus, postea pro pace regum, novissime pro inimicis.' Migne, Bibl. Pat. Lat. lxxx. p. 2 I 2.

1 'Si titubaverit sacerdos super orationem Dominicam, quae dicitur periculosa, si una vice quinquaginta plagas secunda centum, tertia superponat.' Cuminii Abbatis, de Mensura Poenitentiarum, c. xiii, ap. Flening, Collect. Sacra, p. 209.

${ }^{2} \mathrm{Ch}$. iii. $\S \S 5,6,7,14$.

3 Ib. $\$ 9$.

I Ib. § 14 .

5 De Mensura Poenitentiarum, c. xiv, ap. Fleming, Collect. Sacr. p. 2 Ic.

- Migne, Bibl. Pat. Lat. 1xxxv. 25. 
The order of the Gallican Service is thus described by Germanus Bishop of Paris: 'Sequebatur lectio ex prophetis et ex apostolo. Nam praeter Evangelii lectionem, duas, unam ex veteri, alteram ex Novo Testamento, lectiones cantabant, quem ritum videre est apud Gregorium Turonensem (Lib. i. de Mirac. S. Martini, cap. 5) ubi haec labet; "Factum est ut illa Dominica, prophetica lectione jam lecta, ante altarium staret, qui lectionem beati Pauli proferret." In sanctorum festivitatibus, sive martyrum, sive confessorum, acta eorum etiam publice legebantur, ut, auditis eorum virtutibus, populi ad similia perpetranda accenderentur. Ita Gregorius 'Iuroncnsis ${ }^{1}$ lectam fuisse S. Polycarpi passionem narrat ${ }^{2}$.'

It appears, from a passage in Adamnan's Life of St. Columba, as if an additional lection from the Gospels preceded the Liturgy itself: ' $\mathrm{Hi}$ uno eodenque consensu elegerunt ut sanctus Columba coram ipsis in ecclesia sacra Eucharistiae consecraret mysteria. Qui eorum obsecundans jussioni, simul cum eis, die Dominica ex more, post Evangelii lectionem, ecclesiam ingreditur, ibidemque dum missarum sollemnia celebrarentur,' \&c. ${ }^{3}$

$\S 6$. Sermon.-The sermon, when there was one, came next in order after the Gospel, as on the occasion of the Eucharist which followed the elevation of Johannes Diaconus to the rank of bishop, when St. Gall preached the consecration sermon after the Gospel had been read 4 .

$\S 7$. Proper Prefaces. - The use of a Proper Preface for the Festival of St. Patrick 'sollemnitas dormitationis ejus' is alluded to in Tirechan's Annotations, but no trace of its wording has survived ${ }^{5}$. In the Book of Armagh it

1 Lib. i. de Glor. Martyrum, cap. 86.

2 Germani Paris. Expos. Brev. Antiq. Lit. Gall. 6th cent. ${ }^{3}$ Lib. iii. c. I7.

- 'Praemissis ergo ex more divinae libationis initiis, post lectionem Evangelii rogavere venerabilem Gallum ut multitudini quae aderat verbi officio sacrae instructionis pabula ministraret.' Walafrid Strabo, Vit. S. Galli, i. 25. The sermon was preached in the vernacular tongue. A list of some extant sermons will be found on p. 157 .

5 Todd, Life of St. Patrick, p. 430. 
is ordered that on that Festival 'offertorium ejus proprium immolari.' This probably means that commemoration of St. Patrick should be made in the Liturgy in a Proper Preface, for which the Gallican name was 'Immolatio Missae 1.'

A portion of the Proper Preface for the Feast of the Circumcision survives in a ninth-century MS. fragment of four pages of an ancient Irish Liturgy, No. I 394, in the library of St. Gall ${ }^{2}$. Other Celtic Prefaces have been preserved in the Stowe Missal ${ }^{3}$.

\$ 8. Benediction.-The benediction was given with the right hand ${ }^{4}$ and in the Eastern manner; that is to say, the first, second, and fourth fingers were extended, while the third was closed down upon the extremity of the thumb over the palm of the hand. This may be seen in the representation of our Lord in glory in an Irish ninth-century MS. of the Four Gospels at St. Gall ${ }^{5}$; of St. Matthew surmounted by an angel, both of them extending the right hand in the Eastern attitude of blessing, in the Golden Gospels of Stockholm, of composite sixth-century Celtic and eighth or ninth-century Anglo-Saxon work ${ }^{6}$.

There are also traces of the use of the Roman mode of benediction. The thumb, fore and middle fingers are extended, and the third and fourth fingers are bent in the case of a figure sculptured in the attitude of blessing on an Iona cross ${ }^{7}$, and on a tenth-century cross at Oransay $^{8}$.

With regard to the position in the Liturgy of the episcopal benediction, Dr. Döllinger ${ }^{9}$ concludes that it was given after

I The expression 'immolare hymnum ' occurs in the 'Hymnum S. Comgilli' in the Antiphon. Benchor. p. $\mathbf{4}_{42}$.

2 Ch. iii. $\$ 9$.

3 Ch. iii. $\$ 14$.

- 'Diormitius tum sanctam sublevat ad benedicendum Sancti monachornm chorum dexteram manum.' Adamnan, Vit. S. Columbae, iii. 23.

- Westwood, J. O., Facsimiles of Anglo-Saxon and Irish MSS., plate xxvii.

- Ib. plate i. For early and mediaeval Italian representations of this mode of benediction, see J. H. Parker's Photographs, No. 3569 .

7 Stuart, J., Sculptured Stones of Scotland, vol. ii. plate lrii.

- Ib. plate lxiii.

- Geschichte der christlichen Kirche, vol. i. part ii. p. I83. 
the consecration and fraction, and before the immission of the consecrated particle into the chalice. This is an inference from the language in which the celebration of the Eucharist by Bishop Cronan at Iona is described by Adamnan .

The episcopal benediction occupied a similar position in the ancient Gallican and Mozarabic Liturgies ${ }^{2}$. The same position was assigned to it in the Liturgy of the Anglo-Saxon Church $^{3}$, and was perpetuated in the Sarum Use up to the first vernacular Prayer Book of $1549^{4}$, as it was also in France at Paris, Arles, Lyons, Rouen, Clermont, Angers, Tours, \&c. ${ }^{5}$ Dr. Rock argues thus for the Gallican origin of this liturgical peculiarity :-

'That such episcopal blessings formed a part of the old liturgy followed by the Gauls long before Pope St. Gregory and St. Austin's days we learn from the fact that St. Caesarius of Arles, who lived almost a whole century before those apostles of our Anglo-Saxon fathers, speaks of this rite as a thing practised everywhere about him. Knowing then as we do from the formal and public visit made to the Church in this island by SS. Germanus and Lupus how the British and

1 Lib. i. cap. 44.

2 Haminond, C. E., Lit. E. and W. p. xxviii. It can be traced in the old Gallican Liturgies, p. $5_{56}$, in the Mozarabic Liturgy, p. 563. For the Eastern custom see Syriac Liturgy of St. James, Renaudot, Liturg. Or. Coll. ii. p. 24 .

${ }^{3}$ Lingard, Anglo-Saxon Church, i. 295, edit. 1845.

- Sarum Missal, p. 622.

5 De Moleon, Voyages Liturgiques, pp. 59, 76, \&c.

- 'Ideo qui vult missas ad integrum cum lucro animae suae celebrare, usquequo oratio dominica dicatur, et benedictio populo detur, humiliato corpore et compuncto corde se debet in ecclesia continere' (S. Caesarii Arelat. Hom. xii. ed. Binio; Bib. Pat. viii. p. 832, edit. 1677 .) ' Unius aut duarum horarum spatium patientiam habeamus, donec in illa spiritali mensâ animarum cibus apponitur, et sacramenta spiritalia consecrantur, Et quia praemissa oratione dominica vobis non ab homine sed per hominem datur, grato et pio animo, humiliato corpore et corde compuncto, rorem divinae benedictionis accipite.' (Ejusdem Hom. viii. ed. Gallandio, Vet. Pat. Bib.xi. I 2.) A few years afterwards it was enacted, A.D. $53^{8}$, in the third council of Orleans: 'De missis nullus laicorum antea discedat quam dominica dicatur oratio, et si episcopus praesens fuerit, ejus benedictio expectetur.' (Concil. Aurelian. III, can. xxix ; Mansi, Concil. tom. ix. p. 19.) 
Gallic Churches were knit together, not only by the feelings of religious friendship, but by the oneness of true belief, we are warranted in thinking that a ceremonial then in common use throughout a neighbouring country with which this land kept up such an intimate connection in matters of faith, must have been common, too, here; so that our bishops among the Britons, like their bretbren beyond the sea in Gaul, used to bestow their episcopal blessing at this part of the holy sacrifice ${ }^{\text {'.' }}$

§9. The PAx.-The kiss of peace was given after the prayer of consecration, and immediately before the communion of the people, the priest saying these words as he gave the pax: ' Pax et caritas Domini, et communicatio sanctorum omnium sit semper vobiscum.' To which the people replied : 'Et cum spiritu tuo ${ }^{2}$.'

The following form is found in the Antiphonarium Benchorense: 'Ad pacem celebrandam. Injuste egimus. Redemisti nos Domine Deus veritatis in tuo sancto sanguine, nunc adjuva nos in omnibus Jesu Christe, qui regnas. Pax multa diligentibus; pax tua Domine, rex coelestis, permaneat semper in visceribus nostris ut non timeamus a timore noctis Qui regnas ${ }^{3}$ ' Exclusion from communion and from the liss of peace was the punishment for certain offences in the Welsh Church, A.D. $570^{4}$.

$\S 10$. Prayer for the Dead.-To pray for the dead was a recognised custom in the ancient Celtic, as in every other portion of the primitive Church.

Traces of it are found in the earliest inscriptions on sepulchral or memorial stones. The following words are inscribed in Hiberno-Saxon characters on a stone cross at Gwnnws in

1 Church of our Fathers, vol. iii. pt. 2. p. 40.

${ }^{2}$ St. Gall MS. No. 1394, ch. iii. §9; Stowe Missal, ib. § 14. This is the Roman, not the Gallican position of the Pax. There is no evidence as to the earlier Celtic usage.

3 Muratori, Anecdota Bibl. Ambros. iv. 145. The latter of these two forms may be a collect from the night-hours, not a portion of the Liturgy.

- Gildae Praefatio de Penitentia, § I. 
Cardiganshire: 'Quicunque explicaverit hoc nomen det benedixionem pro anima Hiroidil filius Carotinn'.' And on a stone in the ruins of Caldey Priory, Pembrokeshire, in letters assigned by Professor Westwood to a date soon after the departure of the Romans from these islands in the fifth century: ' $\mathrm{Et}$ singno erucis in illam fingsi; rogo omnibus ammulantibus ibi [ut] exorent pro anima Catuoconi ${ }^{2}$.'

Ancient inscriptions on gravestones at Iona in Scotland, and Lismore, \&c. in Ireland, contain requests for prayers for the departed, facsimiles of which may be seen in the Ulster Journal of Archaeology ${ }^{3}$, Lord Dunraven's Notes on Irish Architecture ${ }^{4}$, Amilius Hübner's Inscriptiones Britanniae Christianae ${ }^{5}$. Others in vernacular Irish, centuries vi-x, are given in Petrie's (G.) Christian Inscriptions in the Irish Language ${ }^{6}$. In one instance a bilingual inscription (Irish and Latin) has been found on a stone at Inismurray: 'Ordo Moredach hu chomochain hic dormit?'.

The writers of manuscripts in old days would end their volumes by requesting the prayers of their hereafter readers. On the fly-leaf of the book of Durrow, or Gospel of St. Columba, a sixth-century MS. in the Library of Trinity College, Dublin, there is this entry: 'Rogo beatitudinem tuam, sancte preshyter Patrice, ut quicunque hune libellum manu tenuerit meminerit Columbae scriptoris, qui hoc scripsi ipsemet evangelium per xii dierum spatium, gratia Domini nostri.' A little below in a contemporary hand: 'Ora pro me frater mi; Dominus tecum sit ${ }^{8}$.'

The colophon at the end of the Book of MacRegol (end of eighth or beginning of ninth century) is: 'Quicunque

1 Archaeologia Cambrensis, Fourth Series, vol, v. p. 245.

2 Ib. vol. i. p. I39; Westwood, J. O., Lapidarium Walliae, pt. iii. p. I07.

s Vol. i. pp. 85-6.

${ }^{5}$ pp. 33, 75, \&c.

${ }^{4}$ pp. $4^{8,} 5^{8}, 88,89$.

6 Parts i-vi.

7 Ib. Very similar prayers abound in the sepulchral inscriptions in the Catacombs. See Boeckh, Corpus Inscriptionum, vol. iv. Facs. ii. Nos. 9644, 9650 , et passim.

Westwood, J. O., Facsimiles, \&c., p. 23. 
legeret et intelligeret istam narrationem orat pro Mac Reguil scriptori ${ }^{1}$ '

Adamnan ends his tract De Locis Sanctis (seventh century) with these words: 'Obsecro itaque eos quicunque breves legerint libellos ut pro eodem sancto sacerdote Arculfo divinam precentur clementiam, qui haec de sanctis experimenta locis eorum frequentator libentissime nobis dictavit. Quae et ego quamlibet inter laboriosas et prope insustentabiles tota die undique conglobatas ecclesiasticas sollicitudines constitutus, sibi quamvis sermone describens declaravi. Horum ergo lectorem admone experimentorum, ut pro me misello peccatore, eorundem craxatore, Christum judicem saeculorum exorare non neglegat ${ }^{2}$ '

The colophon at the end of Adamnan's Vita S. Col. (Codex A, an early eighth-century MS.) is :-

'Quicunque hos virtutum libellos Columbae legerit pro me Dorbbeneo

Dominum deprecetur, ut vitam post mortem aeternam possideam ${ }^{3}$ '

That at the end of St. John's Gospel (seventh century) in the Stowe Missal runs thus: 'Deo gratias. Amen. Finit. Amen. Rogo quicunque hune librum legeris ut memineris

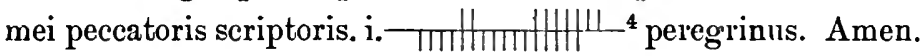
Sanus sit qui scripsit et cui scriptum est. Amen.'

It was part of the constant duty of the Irish Culdees in the eighth century to offer intercessions, in the shape of litanies, on behalf of the living and the dead ${ }^{5}$. The old Irish civil law recognised the fact that tithes, first-fruits, and alms were due from the people to the Cluurch, the Church in return being bound to provide for the people, offering or communion, baptism, and preaching, and burial and requiem or hymn of souls ${ }^{6}$. The old Irish ecclesiastical law enumerated benefit to the souls of the departed among the three chief objects for which the Eucharistic offering was made ${ }^{7}$. In one of the

1 O'Conor, Rer. Hibern. SS. Lib. Nuncupat. i. 230.

2 Mabillon, Acta SS. Ord. Bened. saec. iii. pt. ii. p. 472, Venet. 1734.

3 Reeves' edit. p. 242. $\quad$ =Sonid if read forward, Dinos if read backward.

5 Rule of the Culdees, p. 95, \&c.

${ }^{6}$ Senchus Mor, ii. 344 ; iii. 33, 39.

' 'Nunc ecclesia multis modis offert Domino; primo, pro se ipsa; secundo, 
canons of the Synod of St. Patrick the question is asked how the Sacrifice could be expected to benefit a person after his death, who had not received it during his lifetime ${ }^{1}$. The monks at Iona were enjoined to display 'fervour in singing the office for the dead as if every dead person was a particular friend of theirs ${ }^{2}$ ' The Eucharist was celebrated on the day of the funeral, and on the third or seventh day afterwards ${ }^{3}$. When St. Gall was informed of the death of St. Columbanus he forthwith gave orders for preparations to be made to enable him to offer the sacrifice of salvation for the repose of the departed saint 4 . A like kind office was performed on behalf of St. Gall by a surviving episcopal friend ${ }^{5}$.

The commemoration of the departed, being one aspect and object of the Eucharist, naturally occupied a recognised position in the Liturgy.

Diptychs containing the names of the deceased were brought by the deacon to the celebrant, and their contents were announced by him during the offertory, after the first oblation of the unconsecrated elements and before the Canon. A special penance was assigned to the deacon who forgot this part of his duty ${ }^{6}$. This recitation of names was followed

pro commemoratione Jesu Christi qui dicit; hoc facite in meam memoriam; tertio, pro animabus defunctorum.' Sinodus Hibernensis, lib. ii. cap. 9 .

1 'Qui enim in vita sua sacrificum non merebitur accipere, quomodo post mortem illi poterit adjuvare.' Syn. S. Patricii, cap. xii.

2 Regula S. Columbae, sect. I 3.

3 Cuminius de Mens. Poenitent. cap. xiv.

4 'Post hujus vigilias noctis cognovi per visionem Dominum et patrem meum Columbanum de hujus vitae angustiis hodie ad Paradisi gaudia commigrasse. Pro ejus itaque requie sacrificium salutis debet immolari, et signo pulsato oratorium ingressi prostraverunt se in orationem, et coeperunt missas agere, et precibus insistere, pro commemoratione B. Columbani.' Walafrid Strabo, Vita B. Galli, i. cap. xxvi. St. Columba acted in the same way when he heard of the death of Columbanus of Leinster; Adamnan, Vita S. Col. iii. 12.

5 'Intraverunt ergo ecclesias et episcopus pro carissimo salutares hostias immolavit amico.' Wal. Strabo, Vita B. Galli, i. cap. $\mathrm{xxx}$.

- 'Diaconus obliviscens oblationem adferre donec auferatur linteamen, quando recitantur nomina pausantium, similiter poeniteat.' Cuminius, De Mens. Penitent. c. xiii. For the use of the word 'pausantium' see Stowe Missal, ch. iii. § I 4, where the Irish form of collect in use after the reading of the diptychs is preserved. 
by an anthem in an authorised form of words called the 'deprecatio.' It contained an enumeration of the names of those departed saints for whose repose the prayers of the congregation were requested, and of those by whose intercessions such prayers would be assisted. We know that this collect at Iona ended with the name of St. Martin, and that on one occasion St. Columba, celebrating on the day following his reception of the news of the death of Bishop Columbanus, suddenly turned to the cantors, and bade them add that bishop's name to the deprecatio. The words of Adamnan in narrating this incident are these: 'Sed forte dum inter talia cum modulatione officia, illa consueta decanteretur deprecatio in qua sancti Martini commemoratur nomen, subito sanctus ad cantores ejusdem onomatis ad locum pervenientes, Hodie, ait, pro sancto Columbano episcopo decantare debetis. Tunc omnes qui inerant fratres intellexere quod Columbanus, episcopus Lagenensis (=Leinster), carus Columbae amicus, ad Dominum emigrarerit'?

This passage affords a presumption in favour of the identity of the Celtic and Gallican Liturgies. In the latter Liturgy; the priest after presenting the oblations on the altar, and praying for the illapse of the Holy Ghost, recited from the diptychs the names of saints both quick and dead, in whose memory and for whom the offering was made. The liturgical formula in use for this purpose in the Church of Arles in the time of St. Aurelian (545-553) has been preserved, and in spite of its length is here subjoined in full, as being probably identical with the form of words which constituted the deprecatio in the Celtic Liturgy in use at Iona. The words suggesting such identity are printed in italics. 'Simulque precantes oramus etiam, Domine, pro animabus famulorum tuorum Patrum atque institutorum quondam nostrorum, Aureliani, Petri, Florentini, Redempti, Constantini, Himiteri, Hilarini, Januarini, Reparati, Childeberti, Ultrog othae, vel om-

\footnotetext{
1 Adamnan, Vit. S. Columbae, iii. 12.
} 
nium fratrum nostrorum, quos de hoc loco ad te vocare dignatus es. Cunctorumque etiam hujus loci memores fidelium, pariterque parentum nostrorum atque servientium hujus loci, et pro animabus omnium fidelium famulorum tuorum, vel famularum, ac peregrinorum in pace ecclesiae defunctorum, ut eis tu, Domine Deus noster, peccatorum tribuas veniam et requiem largiaris aeternam; meritis et intercessionibus sanctorum tuorum, Mariae genitricis Domini nostri Jesu Christi, Joannis Baptistae et praecursoris Domini nostri Jesu Christi, Stephani, Petri, Pauli, Joannis, Jacobi, Andreae, Philippi, Thomae, Bartholomaei, Matthaei, Jacobi, Simonis, Judae, Matthiae, Genesii, Symphoriani, Baudilii, Victoris, Hilarii, episcopi et confessoris, Martini episcopi et confessoris, Caesarii episcopi, haec propitius praestare et exaudire digneris, qui vivis et regnas in unitate Spiritus sancti Deus in saecula saeculorum. Amen 1.'

The first group of names in this 'deprecatio ${ }^{2}$ ' (this title being suggested by the word 'precantes') consists of fathers and founders of the Church of Arles; the second group consists of fifteen saints of Holy Scripture, followed by certain leading Gallican saints, the last of whom is Caesarius Bishop of Arles, died A.D. 542. His name, which appears here on account of a local relation, would probably have been omitted at Iona, and so the name of St. Martin, who was held in special veneration in these islands, would be the last on the list, until on the occasion referred to by Adamnan St. Columba ordered the name of Columbanus to be added to it ${ }^{3}$. Two specimens of the 'deprecatio' or 'Collectio post nomina' of the ancient Irish Liturgy have survived in the Stowe Missal 4 .

This position of the commemoration of the living and the

1 Mabillon, de Liturg. Gallic. lib. i. cap. v. sect. 12 ; Migne, Bib. Pat. Lat. lxviii. 395 .

2 For another liturgical use of the word 'deprecatio', see Stowe Missal, ch. iii. § 14 .

3 Transcribed nearly verbatim from Dr. Reeves' note in his edit. of Adamnan, p. 211 . For an example of a Deprecatio pro vivis, sce Stowe Missal, ch. iii. 
dead survives in the Anglican Liturgy, while in the Roman it occupies a different place, being within and a portion of the Canon itself.

There are no instances recorded of the modern practice of praying to departed saints, although there was a strong and devout belief in the efficacy of their prayers for those left on earth. St. Columba's power of prevailing with God by intercession was recognised as continuing to be exercised after his death ${ }^{1}$. Several instances of it are recorded by Adamnan ${ }^{2}$, among them the exemption of the Picts and Scots from a pestilence which devastated the rest of Great Britain and Ireland. Adamnan's belief is expressed in these words: 'Now to what other person can this favour granted them by God be attributed unless to St. Columba, whose monasteries lie within the territories of both these people, and have been regarded by both with the greatest respect up to the present time? But what I am now to say cannot I think be heard without a sigh, that there are very many stupid people in both countries, who in their ignorance that they owe their exemption from the plague to the prayers of the saint, ungratefully and wickedly abuse the patience and the goodness of God 3.' In a very early collect for St. Patrick's Day preserved in the Corpus Missal ${ }^{4}$ God is directly besought to receive St Patrick's intercessions on behalf of His people. Staus \$11. Prayer of Consecration.-The original Celtic formula ; Ondo of consecration does not survive, but there are allusions to it Gal- which imply that, like the rest of the service, it was pronounced

${ }^{1}$ Adamnan, Vit. S. Col. i. I.

${ }^{2}$ Tb. ii. $44,45,4^{6}$.

$s$ 'Cui alii itaque haec tribuitur gratia a Deo collata, nisi sancto Columbae cujus monasteria, intra utrorumque populorum terminos fundata, ab utrisque ad praesens tempus valde sunt honorificata. Sed hoc quod nunc dicturi sumus, ut arbitramur non sine gemitu audiendum est, quia sunt plerique in utrisque populis valde stolidi, qui se sanctorum orationibus a morbis defensos nescientes, ingrati Dei patientia male abutuntur.' Ib. ii. $4^{6}$. It is easy to understand how this belief produced in the course of time the habit of invocation of saints, as found in the later Litanies in the Stowe Missal (ch. iii. § 14), St. Gall MS. 1395 (ib. $\S 10$ ), and in the later lives of the saints passim.

- Ch. iii. § I5. Similar forms of Collect abound in the Leon. and Gelas. Sacramentaries. 
in an audible voice 1 . The breaking of the bread formed so integral a portion of its ritual that 'frangere panem' is used as an equivalent term for 'missarum sollemnia celebrare ${ }^{2}$ ' The use of the words of institution and consecration is sometimes indicated in Celtic MSS., as in surviving Gallican fragments, by the opening words, 'Qui pridie 3.' In both cases the Prayer of Consecration seems to have been brief, the introductory clauses up to this point varying with each festival.

If this inference is admitted, we are able to reconstruct the Canon of the Celtic Church, as used on saints' days, in the following form:-

'Verc sanctus, vere benedictus, vere mirabilis in sanctis suis, Deus noster Jesus Christus ipse dabit virtutem, et fortitudinem plebi suae; benedictus Deus, quem benedicimus in Apostolis, et in omnibus sanctis suis, qui placuerunt ei ab initio saeculi, per eundem Dominum nostrum Jesum Christum,

Qui pridie quam pateretur, in sanctis manibus suis accepit panem, respexit in coelum ad te, sancte Pater, omnipotens aeterne Deus, gratias agens, benedixit, fregit, fractumque apostolis suis et discipulis suis tradidit dicens;

Accipite et edite ex hoc omnes; hoc est enim corpus meum, quod pro multis confringetur.

Similiter etiam calicem postquam coenatum est, pridie quam pateretur, accepit, respexit in caelum ad te, sancte Pater, omnipotens aeterne Deus, gratias agens, benedixit, apostolis suis et discipulis suis tradidit dicens;

Accipite et bibite ex hoc omnes; hic est enim sanguis meus ${ }^{4}$ '

I 'Quendam audiens presbyterum sacra eucharistiae mysteria conficientem.' Adamnan, Vit. S. Columbae, i. 40.

2 Ib. i. 44. A reference to this passage will show the untenability of Dr. Reeves' suggestion that the expression 'frange panem' may be an allusion to the distribution of the consecrated bread to the communicants, and not to the fraction in the act of consecration.

3 Stowe Missal, ch. iii. § I4.

The first part of this Prayer of Consecration is taken from the Stowe 
The absence of the full text of the Consecration Prayer as used in the earliest Liturgies of the Churches of Britain and Gaul has been sometimes accounted for by a theory, supported rather by conjecture than by evidence, that it was supplanted by the Roman Canon before the 'disciplina arcani' had been altogether abandoned, so that though the rest of the service was written, the Canon was recited by the priest from memory, only its opening words 'Qui pridie' being sometimes indicated in writing.

The presence of the Roman Canon in the Stowe Missal ${ }^{1}$ proves that it was introduced into at least partial use in Ireland late in the eighth century, the numerous passages interpolated into it being probably survivals of the earlier and now lost Celtic rite.

\$12. Comunnion Antheys.-In the ancient Irish Church a hymn was sung after the prayer of consecration, during the communion of the clergy and before that of the people. In the Preface to the Leabhar Breac, a composition assigned to the seventh or eighth century, there is a legend which speaks of a choir of angels being heard in the church of St. Sechnall chanting the hymn 'Sancti Venite,' \&c., which hymn, the writer adds, has been sung in the Irish Church while the people were communicating ${ }^{2}$. No trace of such a hymn has been hitherto found in any mediaeval Breviaries or Antiphonaries, but it is preserved in the Antiphonarium Benchorense, where it is entitled Hymnum quando communicarent sacerdotes ${ }^{3}$.

During the communion of the people anthems were sung, slightly varying forms of which liave been preserved in the St. Gall MS. No. I $394^{4}$, the Antiphonary of Bangor ${ }^{5}$, and the Stowe Missal ${ }^{6}$.

They occupied a position corresponding to that of the

Missal, ch. iii. § 14. Compare the Collectio post Sanctus for Christmas Eve in the Missale Gothicum, p. 33. The second part is taken from the Gallican work known under the title of Ambros. de Sacramentis, lib. iv. cap. v.
1 Ch. iii. § 14 .
Liber Hymnorum, p. 44.
${ }^{3}$ Cb. iii. § I 2.
- Ib. $\$ 9$.
5 Ib. $\$ 12$.
- Ib. \$ 14 . 
anthem called 'Transitorium' in the Ambrosian, the 'Trecanum' in the Gallican, the anthem 'Gustate et videte' \&c. in the Mozarabic, and the 'Communio' in the Roman rite.

\$ 13. The Benedicite.-The 'Song of the Three Children' appears in various forms and occupies a prominent position in the Antiphonary of Bangor ${ }^{1}$, from which fact we infer that this canticle with its antiphons formed a constituent part of the Celtic, as it did of the Gallican ${ }^{2}$ and Mozarabic Liturgies $^{3}$, where it was sung before the Gospel (Gall.), or before the Epistle (Moz.), on all Sundays and saints' days.

We pass on from the service itself to some account of its ritual accessories.

\$14. Position of the Priest.-The position of the celebrant was before the altar ('ante altare'), that is to say, facing the altar and with his back to the congregation. This we infer from the expression 'de vertice' in Cuminius' description of the four brothers watching St. Columba celebrate at Iona, and seeing a strange light streaming down upon his head". Gildas speaking of the degenerate character of the British

1 Chap. iii. § 12.

2 'Lectionibus pronuntiatis chorus hymnum trium puerorum decantabat, et quidem ut reor per modum responsorii, quem sane hymnum a Gregorio Turonensi (Hist. Franc. lib. viii. cap. 3) psalmum responsorium dici conjicio.' Germani Parisiens. Expos. brevis Antiq. Lit. Gall. sect. vii.

${ }^{3}$ One of the liturgical irregularities which had grown up in Spain in the sixth century was a tendency to omit this canticle. 'Hymnum quoque trium puerorum in quo universa coeli terraeque creatura Dominum collaudat, et quem Ecclesia catholica per totum orbem diffusa celebrat, quidam Eacerdotes in missa Dominicorum dierum et in solemnitatibus martyrum canere negligunt; proinde hoc sanctum consilium instituit ut per omnes ecclesias Hispaniae vel Galliae in omnium missarum sollemnitate idem in pulpito decantetur; comnunionem amissuri, qui et antiquam hujus hymni consuetudinem nostramque definitionem excesserint.'

The fourteenth canon of the Fourth Council of Toledo, A.D. 633, was in these words:- Diebus Dominicis atque in martyrum sollemnitatibus ante epistolam cautatur canticum trium puerorum.'

4 'Sed illi post Evangelii recitationem viderunt quendam igneum globum tt valde luminosum de vertice sancti Culumbae ante altare stantis et sacram oblationem consecrantis tamdiu ardere, et ad instar alicujus columnae sursum ascendere donec eadem perficerentur sacrosancta mysteria.' Cuminius, Vit. S. Col. cap. xii. 
priesthood describes them as 'seldom sacrificing and never with clean bearts standing at the altar'.'

Extended hands.-Gildas also makes mention of extended hands as part of the ritual of the Mass, speaking of British priests as 'extending their hands over the holy sacrifice ${ }^{2}$ ' an expression which may find a counterpart in the rubric which in the Sarum Missal immediately follows the consecration of the chalice, 'Deinde sacerdos elevet brachia sua in modum crucis ;' in the 'extensis manibus' of the Roman rite; and in various rubrical directions in the Anglican and Eastern Liturgies ${ }^{3}$. It is also the ordinary attitude of prayer in early Italian art 4 .

$\S 15$. VestMENTs.-Special vestments were in use at the altar. It is recorded among the instances of the generosity of St. Bridget that 'she gave away to the poor the transmarine and foreign vestments of Bishop Condlaedh, of glorious light, which he was accustomed to use when offering the holy mysteries at the altars, on the festivals of our Lord and the vigils of the Apostles ${ }^{5}$.' Adamnan relates how on one occasion the vestments and books of St. Columba were placed on the altar ${ }^{6}$.

Among the episcopal or sacerdotal vestments and ornaments alluded to in these passages as being in use in these early times we have proof of the existence of the following:-

The Chasuble.-This vestment in its primitive full circular shape $^{7}$, with embroidered orphreys, is represented on figures

1 'Raro sacrificantes, et nunquam puro corde inter altaria stantes.' Gildse Epist. § 66. Compare a similar phrase, 'Et quum altari adsistitur semper ad Patrem dirigatur oratio,' Con. Carth. III, can. xxiv. A.D. 397 .

2 Manus sacrosanctis Christi sacrificiis extensuri.' Epist. §67.

s Hammond, C. E., edit. pp. 2 II, $24^{2}$.

4 Parker, J. H., Photographs, Nos. 479, 1710,1806 , \&c.

5 -Vestimenta transmarina et peregrina Episcopi Conlaith, decorati luminis, quibus in solempnitatibus Domini et vigiliis Apostolorum, sacra in altaribus offerens nysteria utebatur, pauperibus largita est.' Cogitosus, Vita S. Brigid. cap. 29.

- Beati viri vestimenta et libros, inito consilio, super al tare, cum psalmis et jejunatione, et ejus nominis invocatione posuimus.' Lib. ii. cap. 45.

7 'Cum scriptorum pleriqne casulam a casa dictam scribunt, quod totum 
in the reliquary of St. Maedoc ${ }^{1}$ (eighth-century, Irish), on Evangelists depicted in the Book of Deer ${ }^{2}$ (ninth-century, Scottish), and on figures of priests sculptured on the very ancient Kirriermuir stones in Scotland. Two of these priests hold books, the third has no book, but a $\Delta$-shaped ornament on the lower front part of his dress just above the feet ${ }^{3}$. Several of these figures will be seen to have in front of them a rectangular ornament which may be taken for a book borne in the band, but which is possibly the rationale.

Rationale.-The rationale is an ancient but little known ornament of the Celtic bishops, which according to Dr. Rock is never found in Anglo-Saxon times, but which re-appeared among the episcopal ornaments in Anglo-Norman days, and dropped entirely out of use in the fourteenth century. It was fashioned in all shapes, at one time round, at another a trefoil or a quatrefoil, but more generally an oblong square. It was made of gold or silver, studded with precious stones, and it was worn in imitation of the rational of the Aaronic priesthood, from which it took its name ${ }^{4}$. Another example of it

hominem ut casa tegat, respexerunt ad veterem casularum formam, quae totum revera sacerdotem a collo ad pedes ambibat, atque adeo brachia ipsa et manus tegebat, ita ut si iis ad sacra facienda, aut ad alios usus vellent uti, necesse haberent casulam ad utrumque latus erigere, aut fibula cohibere.' Du Cange, sub voc.

1 Archaeologia, xliii. I 40.

2 Westwood, J. O., Facsimiles, \&c., plate li.

${ }^{3}$ Stuart, J., Sculptured Stones of Scotland, vol. i. plate xliii. Alcuin asserts that the pallium has taken the place of the rationale in the case of archbishops; Lib. de Div. Offic. p. $6_{4}$ A, edit. Hittorp.

- The following Oratio ad induendum rationale occurs in the 'Missa Illyrici :' 'Da nobis Domine veritatem tuam firmiter retinere, et doctrinam veritatis plebi tuae digne aperire.' Mart. i. p. I77. Du Cange says of the rationale, 'Vestis episcoporum novae legis vel ornamentum, sed cujusmodi fuerit hactenus incertum manet.' Garland, a thirteenth-century writer, is more explicit: 'Hoc est ornamentum episcopale et dicitur alio modo logion quod debet reponi in pectore episcopi ad modum laminae aureae in quo cernuntur duodecim lapides, et in illis xii. nomina prophetarum, et scripta erant in illa lamina aurea ita duo nomina, "justicia et judicium." ' Caius Coll. MS. 385 ; quoted by Dr. Rock, Church of our Fathers, i. 369. See Honorius Augustod. Gemma Animae' in Migne's Bibl. Pat. Lat. clxxii. p. 608; Gerbertus, Vet. Liturg. Aleman. i. 26r; Bock, Fr., Geschichte der Liturgischen Gewänder des Mittel- 
may be seen on a figure of St. Gall in the Golden Psalter ${ }^{1}$. It corresponds to the Greek Peristethion, an oblong plate of jewelled gold or silver worn over the chasuble by patriarchs and metropolitans in the Eastern Church.

$A l b$. - The figures above referred to on the shrine of St. Maedoc are vested in albs with embroidered borders (apparels) under their chasubles ${ }^{2}$. So also are those on the Soiscel Molaise ${ }^{3}$.

Maniple.-The maniple appears to have been worn not on the wrist, but over, and depending from the forefinger of the left hand, as on the figure of St. Jerome in the Golden Psalter at St. Gall 4. The same mode of wearing it prevailed in the Anglo-Saxon Church, as may be seen by the vested figure worked on St. Cuthbert's stole at Durham, and proved by the inscription on it to have been embroidered by Queen Elfleda, wife of King Edward the Elder, 905-906; and at Rome up to the eleventh century, as in the fresco of St. Clement ${ }^{5}$.

Ring.-There was a ring in the tomb of Ebregesilus Bishop of Meaux, a monk of the Columban school, when it was opened in the seventh century ${ }^{6}$. There is still earlier evidence of the use of the episcopal ring in Gaul, which is a presumption in favour of its use among contemporaneous British bishops. Clovis I, writing to the Gallican bishops A.D. 510 , promised to pay every attention to their letters provided that they sealed them with the seals of their pastoral rings ${ }^{7}$. Avitus, Bishop of Vienne, writing to Apollinaris

alters. vol. i. p. 375. Taf. vi, where it is part of the dress of a thirteenth-century Italian bishop.

1 Unless this is a book which is so often represented in the hands of saints, held where the rationale would appear, if worn. Westwood, J. O., Unpublished Facsimiles.

${ }^{2}$ Archaeologia, xliii. plate xviii.

3 Ib. plate $x x$.

- Westwood, J. O., Unpublished Facsimiles. See Rahn, J. F., description of this Psalter, Taf. vii ; St. Gallen, 1878.

s Marriott, W. B., Vestiarium Christianum, plate xliii.

- Mabillon, Annal. Bened. i. 456.

7 Noureau Traité de Diplom. iv. 318. 
Bishop of Valence, requested that his monogram might be engraved on his ring ${ }^{1}$.

Pectoral Cross.-The pectoral cross of St. Aidan, a monk of Iona and first Bishop of Lindisfarne (635-652), was preserved among the relics at Durbam in the fourteenth century ${ }^{2}$. There is evidence in the writings of St. Gregory of Tours that pectoral crosses were worn by Gallican bishops in the sixth century ${ }^{3}$.

Pastoral Staff.-There is varied evidence for the early use of the pastoral staff as an ornament and emblem of authority borne by bishops. Its Celtic name was cambutta, cambota, or more rarely cambo ${ }^{4}$. St. Patrick's staff is alluded to in a seventh-century Irish prophecy, preserved by the Scholiast on Fiacc's Hymn ${ }^{5}$, and later authority asserts that it was made of gold, and adorned with precious stones ${ }^{6}$. His disciples St. Dagaeus and St. Asic were traditionally famous for their skill in gilding and bejewelling pastoral staffs and other ecclesiastical ornaments ${ }^{7}$. St. Columba is said to have made many crosses, book-satchels (polaires), and pastoral staffs $^{8}$. When he and St. Kentigern met they exchanged staffs, and St. Kentigern's staff, as given to him by St. Columba, covered with gold and jewels, was still preserved

1 Epist. 78.

2 Raine, J., St. Cuthbert, p. 9. The ring and the pectoral cross were also worn by bishops in the Anglo-Saxon Church. Id. pp. 216-17.

3 'Hujus beatae Virginis reliquias . . super me in aurea cruce positas exhibebam. Tunc extractam a pectore crucem elevo,' etc. De Gloria Martyrum, lib. i. cap. I I. St. Gregory of Tours evidently wore a gold pectoral cross within the folds of his garment on his breast, which also served as a reliquary.

4 Walafrid Strabo, Vit. S. Galli, i. 26 ; Fleming, Collectan. p. 243. In Durandus (Rat. vi. 24) the word has become modified into sambuca. According to Du Cange it is an Armoric word. It is used in a rubric in the Gregorian Sacramentary ; Migne, Bibl. Pat. Lat. 1xxviii. p. I53.

s Todd, J. H., St. Patrick, p. 4I I.

- 'Porro Nigellus videns sibi imminere fugam tulit secum insignia quaedam aedis illius, textum scilicet Evangeliorum, qui fuit beati Patricii, baculumque auro tectum, gemmis pretiosissimis adornatum,' \&c. S. Bernardi de Vita Malachiae, c. 8.

7 Acta SS. in Vita Dagaei.

8 Ancient Irish Life of St. Columba in the Leabhar Breac, translated in Skene's Celtic Scotland, vol. ii. App. p. $4^{88}$. 
at Ripon in the beginning of the fifteenth century ${ }^{1}$. In the tenth century it was held in great veneration, and was carried as a standard in going to battle under the name of 'Cathbhuaidh ${ }^{2}$ ' (= Battle Victory).

In its original shape the episcopal staff was short, rounded at the top, truncated at the bottom, and made of wood. A specimen may be seen in the hands of one of the figures engraved on the ancient Irish shrine of St. Maedoc of Ferns ${ }^{3}$; and in the hand of an ecclesiastic, vested in an embroidered chasuble, engraved on the Soiscel Molaise, a small box of tenthcentury work at the latest, which once contained a now lost copy of the Gospels written in the sixth century by St. Molaise of Devenish. It is fair to add that it rather resembles an aspersory than a pastoral staff ${ }^{4}$, in which case it might be appealed to as evidence for the early use of holy water, and the small circular vessel, like a pome, held by another figure, might be a holy-water stoup ${ }^{5}$, but the smallness of the vessel and the largeness of the staff seem fatal to this explanation. It is not unlike the baton of a ruler of a choir. St. Padarn, who arrived in Wales from Armorica A.D. 576 and became first bishop of Llandabarn, had a choral cap and staff presented to him by the people in recognition of his musical talent ${ }^{6}$. But on the whole it may be with most probability inferred that it is an early form of a Celtic bishop's pastoral staff, which in the ninth or tenth century began to assume its more modern and now usual form. Other

1 'Ac nunc cambo, quem beatus Kentigernus a beato Columba receperat in ecclesia Sancti Wilfridi de Ripoun, aureis crustulis inclusus, ac margaritarum diversitate circumstellatus cum magna reverentia adhuc servatur.' Fordun, Scotichronicon, iii. 30 .

Irish Annals, quoted in Reeves' edit. of Adamnan's Life of Columba, p. 333. Compare the anxiety of the detected thief to swear to bis innocence over the staff of St. Serf; Brev. Aberdon., July 2, lect. viii. fol. I6 a.

s St. Maedoc was born $\Delta . D$. 555, but the shrine is at least a century later. Archaeologia, xliii. 140.

4 Archaeologia, xliii. plate 20.

${ }^{5} \mathrm{Ib}$. plate 18 . There is a reference to the miraculous power (not the liturgical use) of holy water, blessed by St. Columba, in Adamnan, Vit. S. Col. ii. 4, 5, 6, 17 ; and by St. Bridget, in her Life by Ultan, cap. 45 .

- Liber Landavensis, ch. iii. sect. I. 
specimens of the primitive cambutta, in its transition size and shape, may be seen in the hands of $S$. Matthew and St. Luke, as depieted in the MS. Gospels of Meiel Brith Mac Durnan, c. A.D. $85^{\circ}$, and in the case of a figure carved on the cumhdach, or metal-work cover, of the Stowe Missal 2. The Bachal-more of St. Moloch, in the possession of the Duke of Argyll, and figured in the Origines Parochiales (ii. 163), is a black-thorn bludgeon, with traces of a metal covering, measuring only 2 feet 10 inches in length. Several of the bronze cambuttas preserved in the museum of the Irish Academy are little longer.

Bracelets.-It has been suggested that bracelets or cuffs formed part of the sacerdotal costume of a British priest. In the absence of documentary or other reliable evidence this is merely an inference from the custom of the early Gallican priesthood to wear metal bracelets or cuffs of silk or other handsome texture ${ }^{3}$.

'If,' says Dr. Rock, 'the ritual observances of our Britons were like those of their nearest neighbour, Gaul, -and there is every reason for thinking so,-then do we, far off as we are from their times, catch a glimpse of another among the sacred appurtenances of a priest in the British era of our Church history; and beholding him vested for the holy sacrifice of

1 Westwood, J. O., Facsiniles, \&c. plate xxii; Stuart, Sculptured Stones of Scotland, vol. ii. p. lxxviii.

2 Westwood, J. O., Facsimiles, \&c. plate li. fig. 9. Further descriptions and details are given in Stuart, Sculptured Stones of Scotland, ii. p.lv; O'Neil, H., Fine Arts and Civilization of Ireland, 1863 , plates $\tau_{2}$, 10 ; figures of Kilklispeen and Monasterboice Crosses, Ulster Journal of Archaeology, ix. 51 ; in an account of the Shrine of St. Manchan in Kilkenny Archaeol. Soc. 1874, p. I 47; Proceedings of the Soc. of Antiq. of Scotland, vol. ii. pp. I 4, I 25. An account of Welsh. Relic8, including the staff of St. Cyric, the bell of St. David, \&c., is given in the Welsh itinerary of Giraldus Cambrensis, edit. Lond. 1806, pp. 6, 7, 13, 14.

3 The evidence for the Gallican custom in the niddle of the sixth century is explicit: 'Manualia vero, id est manicas induere sacerdotibus mos est instar armillarum, quas regum vel sacerdotum brachia constringebantur. Ideo ex quolibet pretioso vellere, non metalli duritia extant, vel ut onnes communiter sacerdotes, etiam minoris dignitatis in saeculo facilius inveniant.' Germani

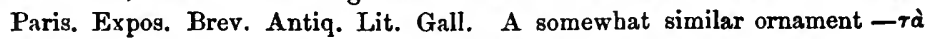
'inıนavısía -is worn by the Greek clergy. Marriott, W, B., Vest. Christ. p. 169. 
the Mass, we shall perceive that along with the fine full chasuble he wore a kind of apparel on the sleeves of his alb. Cuffs of this sort are still found in use among the Greeks, who call them '̇ $\pi \iota \mu a v \iota \kappa a^{1}{ }^{1}$ ' \&c.

Bracelets have frequently been found in ancient tumuli, and in other places and positions. A gold bracelet found in a loch in Galloway, and consisting of two very artificially intertwining circles, has been assigued to a late Celtic period ${ }^{2}$. Celtic circular ornaments of gold have been found in Peeblesshire ${ }^{3}$; bracelets, armlets, earrings, bead and jet ornaments have been discovered in British burial-places ${ }^{4}$, and in Ireland ${ }^{5}$. But there is nothing in the shape of proof, it is mere conjecture to assign to these bracelets, as has been sometimes done, any ecclesiastical connection. Such a connection, in any case, would more probably be with Druidism than with Christianity. The Druid priests of Great Britain may have resembled those of Gaul, who, Strabo informs us, wore golden bracelets, and coloured vesture variegated with gold ${ }^{6}$. But the tendency of recent investigation has been to assign to all such relics a distant prehistoric date, perhaps as far back as the neolithic period of mankind 7 .

Comb.-The ritual use of the comb, now long since obsolete, but as it was employed in Anglo-Saxon times before High Mass ${ }^{8}$, was probably derived from the Celtic Church. The

${ }^{1}$ Church of our Fathers, i. 438 .

${ }^{2}$ Stuart, J., Sculptured Stones of Scotland, ii p. ix.

3 Archaeol. Scot. iv. 217.

- Archaeol. Cambreusis, xiv. $220 . \quad 5$ Ulster Journal of Archaeol. ix. 28, \&c.

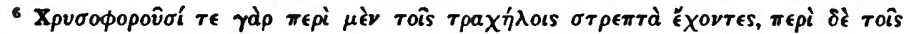

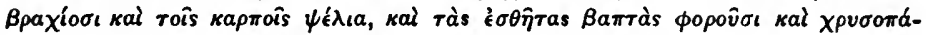

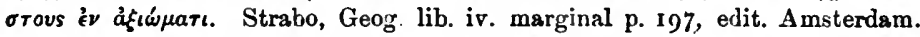
1707. Diodorus Siculus mentions bracelets and brooches among the personal ornaments of the Celts; lib. v. p. 35 r, edit. 1745.

7 Greenwell and Rolleston, British Barrows. In an article in the Edinburgh Review for April, 1878, it is concluded that most of these ornaments belong either to the iron age, or to the third and last, the Maeringian, period of the bronze age.

8 The Anglo-Saxon ritual was as follows:-If a bishop pontificated, the deacon and sub-deacon combed his hair as soon as his saudals had been put on his feet, while seated on his episcopal chair within the chancel; if a priest 
comb of St. Kentigern was one of the relics kept in Glasgow Cathedral ${ }^{1}$. That of St. Cuthbert was buried with him ${ }^{2}$. Representations of a comb, sometimes accompanied with scissors, are frequently found in the early sculptured stones of Scotland, where its appearance las been variously interpreted as a trace of the Eastern custom of designating the sex of a person by a single-toothed or double-toothed comb or as a sign of his trade, or dignity, or as having some ecclesiastical significance. These and other theories are discussed at length and with much ingenuity by Mr. Stuart ${ }^{3}$. The Christian character of the device is just possible, but is incapable of proof, and is more nearly disproved by the probable date of the stones themselves. The profession of a Christian priest is usually indicated by other symbols, such as a book in the hand, a chalice and paten, or a consecrated host as in the Nigg stone 4

Crowns.-The Celtic bishops wore crowns instead of mitres. St. Sampson, a Welshman, generally but incorrectly described as Archbishop of York, and subsequently of Dol in Brittany ${ }^{5}$, c. A.D. 557 , is said to have dreamed that he saw 'three eminent bishops adorned with golden crowns standing before him ${ }^{6}$.'

celebrated, the same office of the comb was perfurmed for him seated in the sedilia. More curious was the ritual at Viviers in France, A.D. ${ }_{3} 360$, where the ceremony of combing was performed several times during Mass: 'Sacra celebraturus sedet dum in choro Kyrie, Gloria, et Credo decantantur ; unde quoties assurgebat, ipsi capillos pectebat diaconus, amoto ejus capello seu almucio, licet id officii jam in secretario antequam ad altare procederet, sollicite ei praestitisset.' Du Cange, in verbo Sedes Majestatis.

1 Regist. Glasg. vol. ii. p. 330, Edinb. 1843 .

2 Reginald de Adm. S. Cuthberti Virtut. p. 89.

${ }^{3}$ Stuart, J., Sculptured Stones of Scotland, vol. ii. p. 5, \&c. The comb as found on sepulchral tablets in the Roman Catacombs is a mark of the woolcombing trade of the deceased. Withrow, W. H., The Catacombs of Rome, p. 231 .

Ib. vol. i. plate xxviii ; vol. ii. plate lvii.

- For the facts in the life of St. Sampson and of other Celtic saints, see H. and S. i. Appendix C. p. 142 .

- Sanctus Samson adınirabilem vidit visum. Quadam nocte circumseptari se a delicatis ac densissimis candidatorum turbis cernit, et tres episcopos egregios diadematibus aureis in capite ornatos, atque holcsericis ac pulcherrimis amictos vestibus in faciem sibi adsistere,' \&c. Vita S. Samsonis ab 
There is a representation of an Irisl bishop thus crowned on a sculptured bas-relief of great antiquity, part of a ruined chapel in the valley of Glindalough ${ }^{1}$. The use of this crown in a modified form ${ }^{2}$ conti:ued in Anglo-Saxon times until the tenth century, when rep:"esentations of the mitre, properly so called, begin to be founc; which originally resembled a flat cap, and did not assume its present cloven and horned shape till after the Conquest ${ }^{3}$.

Sometimes crowns were suspended over shrines, as in the case of the early Irish church of $\mathrm{St}$. Bridget described by Cogitosus ${ }^{4}$, where there was a richly decorated altar with gold and silver crowns hanging over it. This was an Eastern custom. According to $\mathrm{Du}$ Cange, the custom of hanging crowns over the altar in the church of St. Sophia dated from the time of Constantine the Great ${ }^{5}$. It was also a Gallican custom. Crowns were suspended over the tomb of St. Martin at Tours $^{6}$, a tomb to which the early Irish made frequent pilgrimages ${ }^{7}$.

Discs or Brooches. - Two figures carved on an old stone at Invergowrie ${ }^{8}$ have on their necks ornaments which

auctore anonymo subaequali apud Mabillon, Acta Sanct. tom.i. p. 176. sect. 43 . The crown or mitre of an Eastern priest is alluded to in the rubrics of the Armenian Liturgy; Hammond, C. E., Lit. E. and W. p. 168.

1 Woodcut in Transactions of Royal Irish Academy, vol. xx. pp. 248, 265.

2 There is a figure of an ecclesiastic wearing a circlet of gold set with precious stones in the Benedictional of St. Fthelwold; edited by J. Gage, London, 1832, plate $\mathbf{1 8 x}$. Can this crown represent the petalum of St. John the

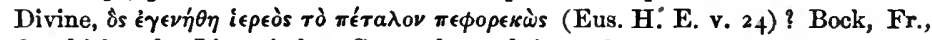
Geschichte der Liturgischen Gewänder, vol. i. p. 387 .

s See the flat mitres on the bishops in the twelfth-century set of chessmen, made of the tusk of the walrus, and found in the isle of Lewis ; Archaeol. xxiv. plate xlvii.

p. 89.

s Du Cange, Constantinopolis Christiana, 1. iii. 43 ; Histor. Byzantina, part ii. p. 37 .

${ }^{6}$ S. Greg. Tur. de Mirac. S. Mart. lib. i. cap. 2.

7 O'Conor, Bib. MS. Stow. vol, i. appendix i. p. 23. There are traces of the same custom in Italy. Leo III, 7I9-8I6, gave a crown to the monastery of St. Pancras, near the Lateran (Mis. Lateran. p. xxvi). See Smith's Dictionary of Christian Antiq. for an account of the three crowns preserved in the treasury of the cathedral of Monza.

${ }^{8}$ Stuart, J., Sculptured Stones of Scotland, vol. i. plate lxxxvii. 
look like dises of metal, fastened to the dress by laces passed through small holes perforated in the dises. They are possibly insignia of either lay rank or sacred dignity, or else large brooches which are often represented as fastening up the dress at the shoulder in the case of ecclesiastics on the early Irish crosses ${ }^{1}$. The Brehon laws assign the brooch as one of the distinctive emblems of royalty; ' brooches of gold having crystal inserted in them with the sons of the King of Erin, and of the king of a province, and brooches of silver with the sons of a king of a territory,' \&c. ${ }^{2}$ The following account gives a quasi-supernatural sanction for the brooch becoming part of a saint's dress: 'Then Diarmoyt, the son of Cearbuyll King of Ireland, who ruled in the city of Themoria in the country of Midhi, saw in a dream two angels take the royal necklace from off his neck and give it to a man unknown to himself. On the next day St. Brendan came to that king. And when he beheld him, he said to his friends, "This is the man to whom I saw my necklace given." Then the wise men said to the king, "Hitherto the rule of Ireland has been in the hands of kings; hereafter thy kingdom will be divided among Ireland's saints ${ }^{3} . "$,

We may take the fact that the brooch, which was originally part of the regal insignia, became a part also of ecclesiastical dress, as a sign of the great honour which was paid in early times to the saints in Ireland ${ }^{4}$.

${ }^{1}$ O'Neill, Irish Crosses, plates xiv, xxii, xxiv.

${ }^{2}$ Senchus Mor, vol. ii. p. 147.

3 'Tunc Diarmoyt, flius Cearbuyll rex Hyberniae (A.D. 544-64), qui regnabat in urbe Themoria in regione Midhi sompnium uidit, id est, duos angelos torquem regiam de collo eius tollentes et dantes homini sibi ignoto. Crastino iam die peruenit sanctus Brendanus ad regem illum. Cumque uidesset eum rex, dixit amicis suis : hic est uir ille cui uidi torquem meam dari. Tunc sapientes dixerunt regi: Regnum Hyberniae usque nunc erat regibus, amodo diuidetur inter sanctos Hyberniae regnum tuum.' Vita S. Brendani, cap. xxiv, Liber Kilkenniensis.

A serpentine bird-headed silver brooch resembling in its design some of the initial letters in early Irish MSS. is figured in the Proceedings of the Kilkenny Archaeol. Soc. vol. for 1872, p. 74 .

4 Westwood, J.O., Facsimiles, \&c., p. 30, plate x, etc. 
Sandals.-Sandals are represented on the feet of St. Matthew and St. John in the Book of Kells, and in the case of many other figures in early Celtic MSS. They were worn at Iona, and were called 'calceus,' or 'calceamentum,' or 'fico,' all words frequently employed in the Lives of Celtic saints'. Curiously-shaped slippers are to be seen on the feet of four ecclesiastics on a sculptured stone at St. Vigean's, to whom the Roman tonsure on their heads compels the assiguation of a date subsequent to A.D. $710^{2}$.

Caracalla. - The ordinary outer dress of a British priest was a long hair cassock called a 'caracalla.' This was worn by the priest Amphibalus ${ }^{3}$, and assumed by St. Alban in exchange for his own clothes in order to facilitate the escape of the former". The ordinary outer cloak of a monk at Iona was called 'amphibalus ${ }^{5}$ ' or 'cuculla ${ }^{6}$ ', worn over a white under-dress, ' tunica candida' or 'pallium?'.'

$\S 16$. UsE of Colours. - It has been asserted that the assigning of special colours to certain seasons for sacerdotal vestments or altar coverings does not belong to the first eight centuries of Christianity ${ }^{8}$. This is true as far as any

I Adamnan, Vit. S. Colum. ii. 13 ; iii. 12 ; Du Cange, sub voc.

2 Stuart, J., Sculptured Stones of Scotland, vol. i. plate lxx; vol. ii. p. 8.

${ }^{3}$ For the possible origin of the name Amphibalus, which is not mentioned by Bede, see G. H. Moberly, edit. of Bede's H. E. p. 18. n. 7.

4 'Qui cum ad tugurium martyris pervenissent mox se sanctus Albanus pro hospite ac magistro suo, ipsius habitu, id est caracalla qua vestiebatur indutus, militibus exhibuit, atque ad judicem vinctus perductus est.' Bede, H. E. i. 7. But the caracalla was not an exclusively sacerdotal dress. Du Cange, Facciolati, sub roc

S Adamnan, Vit. S. Col. i. 3; ii. 6. Also in Britain: 'sub sancti abbatis amphibalo ;' Gildae Ep., H. and S. i. 49. 'Aınphibalus' was also, at least in Gaul, the Latin for a chasuble. Germani Paris. Epist. ii. in Martene et Durand. Thesaur. Anecd. tom. v. col. 99. Sulpicius Severus represents St. Martin as celebrating the Eucharist in an 'amphibalum ;' Dial. ii. $\$$ r. p. 545, Lugdun. Batav. 1647.

5 Adamnan, Vit. S. Col. ii. 24.

7 Ib. ii. 44 .

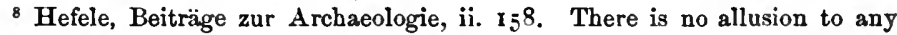
systematic sequence of colours in the earlier Ordines Romani, or in the writings of the earlier ritualists. The first reference to the regular Roman sequence of four colours is found in the works of Innocent III (119S-1216), De Myst. Missae, lib. i. cap. lxv, black being there substituted for violet. 
elaborate cycle of colours is concerned, such as is prescribed in mediaeval Missals and Rituals, but allusion to the ecclesiastical use in the Celtic Church of at least two colours has been preserved to us.

Purple.-Gildas refers to the custom of covering the altars in British churches with purple palls ${ }^{1}$. The three choirs of saints which appeared to St. Brendan were clad 'in vestibus candidissimis jacinctinis purpureis' (Navigatio S. Brendani, eleventh century MS. Nat. Lib. Paris, No. 3784). St.

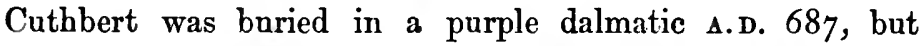
this fact illustrates early Anglo-Saxon rather than Celtic usage $^{2}$. In the legend of St. Mulling, as preserved in the Book of Leinster, an Irish MS. of the earlier half of the twelfth century, Christ is represented as appearing to that saint, in a vision vouchsafed to him in church, in a purple garment ${ }^{3}$. Purple is very largely introduced into the earliest extant specimens of Celtic illumination, as in the Book of Kells, and into the later Irish MSS. at St. Gall ${ }^{4}$. A passage in Bede's works alluding to the ease with which a red or purple dye could be obtained from shells on the Irish coasts, at once explains and renders probable the preponderating ecclesiastical use of this colour ${ }^{5}$. We have evidence of the use of purple altar-cloths-pallae-in the early Gallican Church. St. Germanus of Paris, c. A.D. 550, explains the use of this colour by referring to the mention of purple in

1 'Sub sancti abbatis amphibalo latera regiorum tenerrima puerorum inter ipsa, ut dixi, sacrosancta altaria, nefando ense hastaque pro dentibus laceravit, ita ut sacrificii coelestis sedem purpurea ac si coagulati cruoris pallia attingerent.' Gildae Epist. p. 37.

2 'Christianorum more pontificum post haec tunica et dalmatica indutus est, quarum utrarumque genus ex pretioso purpurae colore et textili varietate satis venustum et permirabile est.' Reg. Dunelm. p. 87, Surtees Soc. 1835, and Bolland, Acta SS. Mart. xx. tom. iii. p. 140.

3 Reeves, W., British Culdees, p. 77. F. civ.

- Facsimiles of National MSS. of Ireland, plate viii, \&c.

5 'Sunt et cochleae satis superque abandantes quibus tinctura coccinei coloris conficitur, cujus ruber pulcherrimus nullo unquam solis ardore, nulla valet pluviarum injuria pallescere. Sed quo vetustior est, solet esse venustior ;' quoted in Ulster Journal of Archaeology, viii. 22I, and in Keller's Bilder und Schriftzuige, p. 70 . 
the Levitical account of the tabernacle'. St. Gregory of Tours, in the same century, mentions the defence of the Abbess of St. Radegund against the charge of cutting up one of these purple altar-coverings for a dress for her niece ${ }^{2}$. And the use of these purple altar-palls was perpetuated, like other British and Gallican customs, in the Anglo-Saxon Church $^{3}$.

White.-The second colour, of the ecclesiastical use of which there is distinct mention, is white. It was the festal colour at Iona. Adamnan describes how white vestments were worn by St. Columba and his attendants on the occasion of the celebration in memory of Columbanus, as if it was a holy day ${ }^{4}$.

The same saint when dying before the altar at Iona was clothed in a white dress ${ }^{5}$. White is the only colour referred to in the early Irish Canons, which order that the deacon at the time of oblation should be clad in a white vestment ${ }^{6}$; whereas in a mediaeval Irish tract on the origin and meaning of colours in the mass-vestments, as many as seven colours are named, yellow, blue, white, green, red, black, purple? ${ }^{7}$ In this employment of white the custom

1 - Siricum (vid. Du Cange) autem ornatur aut auro vel gemmis quia Dominus Moysae in tabernaculo fieri velamina jussit ex auro jacintho et purpura coccoque bis tincto et bysso retorta.' Germani Paris. Expos. Brev. Antiq. Lit. Gall.

2 'De reliquo vero quantum opportunum fuit ad ornatum altaris pallam condigne condiderit, et de illa inscissura quae pallae superfuit, purpuram nepti suae in tunica posuerit.' Gregorii Tur. Hist. lib. x. c. 16.

3 'Altaria purpura et serico induta' are mentioned in Vita S. Wilfridi, c. $x \times i$, ap. Mabillon, Acta Sanct. tom. v. A purple altar-cloth is depicted in the Benedictional of St. Ethelwold; Archaeologia, vol. xxiv. p. 116. Five purple altar-coverings were among the gifts of Bishop Leofric to Exeter Cathedral ; Codex Dip. Anglo-Sax. iv. 275, \&c.

- Et his dictis fratres obsequuntur, et juxta Sancti jussionem, eadem ociantur die, praeparatisque sacris ad ecclesiam ministeriis, quasi die solenni albati cum sancto pergunt.' Adamnan, Vit. S. Columbae, c. I2.

5 ' Candida tunica qua in hora exitus indutus erat.' Cuminii Vit. S. Columbae, c. 26 .

6 'Diaconus tempore oblationis alba utatur veste.' Hibernensig, lib.iii. cap. 6.

7 Buide, gorm, gel, uāie, dond, d̄g, dub, corcair. Leabhar Breac, fol. I08 a. For information about the mediaeval use of colours, the reader is referred to C. C. Rolfe, The Ancieut Use of Liturgical Colours, Oxford, I879. 
of the Celtic agreed with that of the early Gallican Church. In the fifth and sixth centuries white was recognised there as the festal, and especially as the Paschal colour. St. Remigius Bishop of Rheims, in his will A.D. 499, bequeathed to his successor his white Easter vestment ${ }^{1}$. Similar allusions are found in the case of St. Caesarius of Arles ${ }^{2}$, and of St. Gregory of Tours ${ }^{3}$. St. Germanus of Paris c. $55^{\circ}$ mentions the appearance of angels clad in white at the sepulchre as the symbolical reason for the selection of white as the liturgical colour at Eastertide 4 .

The predominant employment of white and red in the Sarum Use may be a survival of the early British preference for those colours.

Is it only a coincidence that the Rule of St. Columba recognised but two classes of martyrdom, 'red martyrdom' (= death), 'white martyrdom ${ }^{5}$ ' (= self-mortification)?

$\S 17$. Choral Service.-The services of the Celtic Church, both at the altar and in the choir, were choral. Gildas, referring to Britain, speaks of ' ecclesiastical melodies,' and the musical voices of the young sweetly singing the praises of God ${ }^{6}$. The word 'decantare' is used of the introduction of the Liturgy into Ireland in the fifth century ${ }^{7}$, and of its performance at Iona in the sixth century ${ }^{8}$. Adamnan states

1 'Futuro episcopo successori meo amphibalum album paschalem relinquo.' Migne, Bibl. Pat. Lat. lxv. 97 I.

2 'Casulamque quam processoriam habebat albamque Paschalem eí dedit.' Greg. Tur. Op. p. I187, note 1 .

3 'Diacono quidam casulam tribuit . . cappa cujus ita dilatata erat atque consuta, ut solet in illis candidis fieri quae per paschalia festa sacerdotum humeris imponuntur.' Greg. Tur. Op. 1188.

- 'Albis autem vestibus in Pascha induetur secundum quod angelus ad monumentum albis vestibus cerneretur.' Germani Paris. Expos. Brev. Antiq. Lit. Gall.

${ }^{5}$ H. and S. ii. pt. i. r 20. The fragment of an Irish sermon in the Codex Cameracensis adds a third, or 'green' martyrdom. The original Gaelic with a Latin translation is given in Zeuss. Grammat. Celtic. p. 1007.

- 'Ecclesiasticae melodiae'- 'Dei laudes canora Christi tyrorum voce suaviter modulante.' Epist. p. 44.

1 Cotton MS. c. 800, de Officiorum Ecclesiasticorum Origine.

8 Adamnan, Vit. S. Columbar, iii. I2. 
that the voice of St. Columba was so powerful that when he was chaunting he could be heard sometimes balf a mile, sometimes even a mile off,-a statement not necessarily involving either miracle or exaggeration,-in the still air of an autumn day on one of the western islands of Scotland ${ }^{1}$. In Ireland music was an art early cultivated, and intimately connected with divine worship. Harpers are represented on the most ancient sculptured stones of Ireland, and pipers are introduced as decorations of initial letters in sacred manuscripts of the eighth and ninth centuries ${ }^{2}$. In the Félire of Oengus a good man is compared to 'an altar whereon wine is shed, round which is sung a multitude of melodies ${ }^{3}$ ' Irish Annals speak of the destruction of church organs A.D. 814 4 There is nothing improbable in such an entry, as organs are known to have been in general use in Western Europe before that date ${ }^{5}$. The more interesting question is, What was the style and character of the music in the Celtic Church? To this enquiry, unfortunately, no answer can be given beyond the negative one, that it was not the Roman chaunt in its

I 'Sed et hoc silere non debemus quod ab expertis quibusdam de voce beati psalmodiae viri indubitanter traditum est. Quae scilicet vox venerabilis viri in ecclesia cum fratribus decantantis aliquando per quatuor stadia hoc est $D$. passos, aliquando vero per octo, hoc est M. passus incomparabili elevata modo audiebatur.' Adamnan. Vit. S. Colum. i. 37. The distance has grown to 1500 paces in an old Gaelic poem preserved in the Leabhar Breac, fol. $3 \mathrm{I} b$.

2 Zurich. Antiq. Gesellschaft, vii. 65.

${ }^{3}$ p. cri. June 17 .

1 'Direptio organorum ecclesiae Clooncrene.' Annales Ultonienses, ann. DCCCXIV.

5 There are drawings of two organs in the Utrecht Psalter (sixth or ninth century) in the illustrations to $\mathrm{Pss}$. cl, cli. There is a still earlier representation of an organ on one of the catacomb stones in the monastery of San Paolo fuori le Mura at Rome. St. Augustine says that organs with bellows were used in his day; Comment in Ps. lxi. These organs must have been curious and cumbrous structures if they resembled that which Alfeah Bishop of Winchester (934-51) caused to be constructed in his monastery, which required seventy men to blow it.

'Bisseni supra sociantur in ordine folles, Inferiusque jacent quattuor atque decem.

Flatibus alternis spiracula maxima reddunt, Quos agitant validi septuaginta viri.'

Wolstanus in Prologo ad Vitam Metricam S. Swithuni, Leland. Collect. i. I52. 
Gregorian, nor probably in any other form. Bede asserts that the Roman style of singing was first introduced into England generally by Benedict Biscop, Abbot of Wearmouth, A.D. 678 , and into the monasteries founded by Scottish missionaries in the North of England by St. Wilfrid, who died c. $\Delta . D .709^{1}$.

Dr. O'Conor discusses the question with much ingenuity and research in his 'Rerum Hibernicarum Scriptores'.' He endorses to a certain extent the conclusion of Mabillon, that the choral service of the British Church which was not 'juxta morem Romanum' was therefore 'juxta morem Orientalem.' The Eastern course having been introduced into the monasteries of Lerins and Marseilles (as described by Cassian $^{3}$ ), and having been learned there or elsewhere in Gaul by Germanus and Lupus (and Patrick), was by them introduced into Great Britain and Ireland in the fifth century, and was transferred thence to Scotland by Irish missionaries in the sixth century ${ }^{4}$. The subject is hardly sufficiently relevant to the Liturgy to be discussed here at further length.

\$ 18. Incense.-We have been unable to discover any passage referring to the use of incense in the Celtic Church ${ }^{5}$. Thuribles or incense-cups have often been found in British burial-places, as at Lancaster Moor ${ }^{6}$, at Brixworth ${ }^{7}$, \&c. The perforation of these cups near the upper rim implies that they were to be swung, and the occurrence of ornamentation on the under surface, which is not found in cinerary and other urns,

1 Hist. Eccl. iv. 18.

2 Vol. iv. pp. 153-160.

3 Lib. ii. Instit. an. 420.

- The words of Mabillon are: 'Alterum (ecclesiasticum cursum) voco Alexandrinum auctore Marco Evangelista, qui cursus in monasteriis Lerinensi et Massiliensi Cassiani receptus sii ; atque inde per sanctos Germanum Autisiodorensem et Lupum Tricassinum antistites in Scotiam, et per Caesarium in Arelatensem ecclesiam inductus; quem demum Columbanus in Luxovium admiserit.' De Cursu Gallicano, p. $3^{81}$.

s A single allusion to it in Aileran's Interpretat. Moralis (Migne, Bibl. Pat. Lat. 1xxx. 338) is plainly metaphorical.

- Brit. Archaeol. Journal, xxi. 16r.

7 Ib. xix. 21. 
proves that they were intended to be suspended above the level of the eye. The symbol of the cross has been found on some of these cups, as on those discovered at Bryn Seiont, Carnarvonshire, and at other places ${ }^{1}$. The date of such relics is undetermined. The mark of the cross used generally to be referred to as an evidence of their connection with Christianity, and was often relied upon by antiquarians as a proof of a post-Christian date, as in the case of bronze spoons found at Llanfair in Wales, and of inscribed stones, \&c. elsewhere ${ }^{2}$. But it has been found as an emblem on vases, ornaments and relics, both in the British islands and in continental pilewrought villages, and lacustrine dwellings and cemeteries, many centuries anterior to the Christian $\mathrm{era}^{3}$; and the most recent and experienced archaeologists are decided in their view that these incense urns have no connection with Christianity". The psalm 'Dirigatur,' \&c. which accompanies the act of censing in the modern Roman Missal is indicated for use in the Stowe Missal, but there are no rubrical directions there for the use of incense ${ }^{5}$. It may be added that no trace exists of the use of incense in the early Gallican Church. It is not mentioned in any rubric of the surviving Missals, nor is there any allusion to it in the somewhat full 'Expositio Missae' of Germanus Parisiensis (sixth century.)

§ 19. Joint Consecration.-A very singular custom existed at Iona of two or more priests being ordinarily united in the Eucharistic prayer and act of consecration; to consecrate singly being the prerogative of bishops, or of individual priests specially selected and empowered to consecrate on account of their sanctity or eminence.

Adamnan records how 'on one occasion a stranger from the

1 Archaeol. Cambrensis, Third Series, vol. xiv. p. 25, figs, 18, 19; p. 260, figs. 23, 24 .

${ }^{2}$ Ib. Third Series, vol. viii. p. 219 ; vol. for 1856 , p. 49.

3 Gabriel de Montillet, La signe de la Croix avant le Christianisme, Paris, 1866.

- Greenwell and Rolleston, British Barrows, p. 76, \&c.

Sh. iii. 5 I4. Fol. $18 \mathrm{a}$ in the later handwriting. 
province of Munster, who concealed through humility the fact that he was a bishop, was invited, on the next Sunday, by Columba to join with him in consecrating the body of Christ, that as two priests they might break the bread of the Lord together. Columba, on going to the altar, discovered his rank, and addressed him thus: "Christ bless thee, brother; consecrate alone as a bishop; now we know that thou art of episcopal rank. Why hast thou endeavoured to disguise thyself so long, and to prevent our giving thee the honour due to thee ${ }^{1}$ ?",

On another occasion four illustrious visitors from Ireland paid a special mark of respect to $S$. Columba by requesting him to offer the Eucharist in their presence ${ }^{2}$.

This custom of joint celebrants in the case of priests, and of a single celebrant in the case of a bishop, is peculiar to the Celtic rite, no similar practice existing in any other country or at any other time. There was something exactly opposed to it in the once general but now nearly obsolete rule of the Western Church, that when a bishop celebrated the priests present should unite with him in the words and acts of consecration ${ }^{3}$. This direction still survives in the Roman service for the 'Ordering of Presbyters,' when the newly-ordained priests join with the bishop in repeating the words of the Canon ${ }^{4}$. The same custom

1 'Alio in tempore, quidam de Muminensium provincia proselytus ad sanctum venit, qui se, in quantum potuit, occultabat humiliter ut nullus sciret quod esset episcopus; sed tamen Sanctum hoc non potuit latere. Nam alia die Dominica a Sancto jussus Christi corpus ex more conficere, Sanctum advocat, ut simu] quasi duo presbyteri Dominicum panem frangerent. Sanctus proinde ad altarium accedens, repente intuitus faciem ejus, sic eum compellat, Benedicat te Christus, frater, hunc solus, episcopali ritu, frange panem; nunc scimus quod sis episcopus. Quare hucusque te occultare conatus es, ut tibi a nobis debita non redderetur veneratio?' Adamnan, Vita S. Columbae, i. 44.

2 "Hi uno eodemque consensu elegerunt ut sanctus Columba coram ipsis in ecclesia sacra Eucharistiae consecraret mysteria.' Ib. iii. 17.

3 'Ut in confectione immolationis Christi adsint presbyteri et simul cum pontifice verbis et manu conficiant.' Martene, de Antiq. Eccles. Rit. i. 3. 8 ; Conf. Amalarius, lib. i. cap. 12.

1 The rubric in the Pontifical (De Ordinatione Presbyteri) directs the celebrating bishop to speak 'aliquantulum alte, ita ut ordinati sacerdotes 
existed at Chartres, on Maundy Thursday, as late as the fifteenth century ${ }^{1}$.

$\S 20$. Oblations and Offertory.-The oblations of bread and wine for the Eucharistic service, and offerings of money, ornaments or other precious gifts, were made, in accordance with the general custom of the Gallican and Mozarabic Liturgies, just before the recitation from the diptychs of the names of departed saints ${ }^{2}$. St. Angustine seems to have found this custom in existence in England, for one of his first questions to St. Gregory was as to the proportion in which such alms and offerings were to be distributed ${ }^{3}$.

Early Irish canons, attributed to St. Patrick, lay down that the offerings of the wicked and the excommunicate are not to be accepted ${ }^{4}$. St. Patrick mentions in his Confession how the devoted and warm-bearted Irish women among his disciples made offerings at his altar of ornameuts and personal presents, and how he offended them by always returning them afterwards, lest the unbelieving should have appearance of ground for scandal against him ${ }^{5}$. When St. Columba was making 'the offering of Christ's Body and Blood' in the presence of Comgall and Cainnech, at their special request, 'then it was

possint secum omnia dicere, et presertim verba consecrationis, quae dici debent exlem momento per ordinatos quo dicuntur per pontificem.'

2. Le Jeudi-saint six Archidiacres Prêtres celebrent la grand' Messe conjointement avec l'Ereque ... l'Ereque est au milieu de l'A utel; il a trois Prêtres a sa droite, et trois a sa gauche, sur la meme ligne. Ils chantent tous sept unanimement, et pratiquent ensemble toutes les cérémonies de la Messe.' De Moleon, Voyages Liturgiques, p. 231.

${ }^{3}$ See p. 105. n. 6.

4 'Prima interrogatio beati Angustini episcopi Cantuariorum ecclesiae. De episcopis, qualiter cum suis clericis conversentur, vel de his quae fidelium oblationibus accedunt altaris; quantae debent fieri portiones, et qualiter episcopns agere in ecclesia debeat.' Bede, H. E. i. 27, Interrogatio i.

5 'Contentus tegmento et alimento tuo cetera dona iniquorum reproba.' $S$. Patric. Synodus, c. 2. 'Quicunque Christianus excommunicatus fuerit, nec ejus eleemosyna recipiatur.' Synodus Episcoporum Patricii, \&c. xii.

- The passage is corrupt, but the meaning is obvious. 'Nam etsi imperitus sum in omnibus, tamen conatus sum quispiam servare me etian et fratribus Christianis, et virginibus Christi, et mulieribus religiosis, quae mihi ultronea munuscula donabant, et super altare reddebant, ex ornamentis suis, et iterum reddebam illis,' \&c. Patricii Confessio, c. xxi. 
that Cainnech beheld a pillar of fire over Colombcille's head while at the offertory ${ }^{1}$.

In the Mozarabic and Gallican Liturgies an anthem or hymn was sung during the offertory called 'Sacrificium' or 'Sonum 2.' Such may be this short anthem in the Antiphonary of Bangor, which resembles an offertory sentence of the Anglican Liturgy rather than the offertorium of the Roman Missal.

'Pro eleemosynariis. - Dispersit, dedit pauperibus, iustitia ejus manet in saeculum saeculi, cornu ejus exaltabitur in gloriâ.

Eleemosynas facientibus in hoc mundo retribue, Domine, in regno tuo sancto.'

An account is preserved in the Leabhar Breac of the ritual accompanying the oblation of the elements which is probably a genuine survival of the ancient Celtic Liturgy. First three drops of water were placed in the chalice, the priest saying, 'Peto [or Quaeso] te, pater, deprecor te, filii, obsecro te, spiritus sancte;' then three drops of wine, with the accompanying formula, 'Mittet pater, indulgeat filius, misseretur spiritus sanctus ${ }^{3}$;' or, ' Remittet pater, indulget filius, misseretur spiritus sanctus'.'

§ 21. Unleavened Bread.-Dr. Döllinger enumerates the use of unleavened bread in the Eucharist among the peculiarities of the British Church, and as one of the points on which it differed from the rest of Western Christendom: 'Dass der Gebrauch der Azyma eine Eigenthumlichkeit der Briten gewesen sey, schliesse ich aus einer Stelle der capitula selecta canonum Hibern bei D’Achery, Spicileg. i. 505: Gildas ait: Britones toto mundo contrarii, moribus Romanis inimici non solum in missa, sed etiam in tonsura cum Judaeis umbrae futurorum servientes. Gerade so drückt sich Nisetas contra

1 Leabhar Breac, p. $3^{2}$ b. The word used here is idpairt, to which no technical meaning is affixed. The usual word for the Eucharistic offering itself was oiffrenn $=$ 'the mass.'

${ }^{2}$ Leslei, Praefatio in Liturg. Moz. sect. 76 ; Germani Paris. Expos. Brev. Ant. Lit. Gall., De Sono.

3 Fol. 251 a.

- Stowe Mis. fol. $6_{4}$ b.

K 2 
Latinos, Bibl. PP. Max. xviii. 405. aus; Qui azymorum adhuc participant, sub umbra legis sunt, et Hebraeorum mensam comedunt ${ }^{1}$ '

This ingenious inference is supported, as far as the later continental Celtic Church is concerned, by a statement of Walafrid Strabo that it was the custom of St. Gall to use unleavened bread ${ }^{2}$. The design at the foot of the monogram of the Book of Kells may be taken to prove that circular wafer bread, stamped with a $\times$, was in use in Ireland in the sixth century. The consecrated wafer bread is there drawn between animals which seem to hesitate to destroy or devour it $^{3}$. The host in a circular form, with a chalice or portable altar underneath it, is represented between two kneeling figures on the Nigg stone in Ross-shire ${ }^{4}$. In mediaeval Celtic literature there are plentiful allusions to wafer bread.

' I asked the secular priests,

To their bishops and their judges,

What is the best thing of the soul?

The Paternoster, and consecrated wafers, and a holy Creed ${ }^{5}$ '

Dr. Döllinger is not quite right in inferring that in their use of unleavened bread the British Church differed from the rest of Western Christendom,-' wahrend man sich damals in der Römischen Kirche und im übrigen Occident noch des gesäuerten Brodes bediente,'-and Bingham is quite wrong: in asserting that it is 'a matter beyond all dispute that the Church for a thousand years used no other but common or

${ }^{3}$ Geschichte der christlichen Kirche, p. 21 \%, Landshut, 1833.

2 'Dum de hujusmodi colloquium rebus haberent, superveniens Ioannes Diaconus secundum consuetudinem obtulit ei panes azymos et lagunculam vini.' Wal. Strabo, Vita S. Galli, i. I7.

${ }^{3}$ Dr. Todd suggests that these animals are bearers with their young; Illumination of Ancient Irish MSS. plate i; Descriptive remarks, p. Io. An uncrossed wafer is depicted on another page of the same MS. See S. Ferguson's Cromlech of Howth, App. p. 21. For a similar representation of the wafer in a thirteenth-century Italian fresco, see J. H. Parker's Photographs, No. 123.

* Stuart, J., Sculptured Stones of Scotland, vol. i. plate xxviii.

b Black Book of Caermarthen, xxvii. plate ii. (twelfth century). 
leavened bread in the Eucharist'? Unleavened bread was not only used in the early Celtic Church, but also in the African Church in St. Cyprian's time ${ }^{2}$, in the Spanish Church in the ninth century ${ }^{3}$, in the Anglo-Saxon Church under Archbishop Theodore ${ }^{4}$, and in Alcuin's time ${ }^{5}$.

$\S 22$. Mrxed Chalice.-The universal custom of the primitive Church to mix water with the wine for consecration in the Eucharistic cup ${ }^{6}$ obtained in the Celtic Church also. This may be inferred from Adamnan's account of St. Columba in his youth, in Ireland (Scotia), acting on one occasion as deacon and fetching water for the celebration of the Eucharist?

On one occasion, when St. Finden of Movilla was celebrating, water only, and not wine, had been provided. St. Columba, who was present, removed the difficulty by turning the water into wine ${ }^{8}$.

The cross engraved on bronze spoons found at Llanfair in Wales has been held to be a proof of their connection with Christian usage ${ }^{9}$; and it has been suggested that they were Eucharistic spoons used for the administration of the consecrated wine. This is merely conjecture, faintly supported by the fact that a bronze chalice was used by St. Columbanus in the sixth century, and that another bronze chalice of eighthcentury Irish workmanship is still preserved in the convent of Kremsmünster on the Rhine. But if these bronze spoons had any liturgical use at all, they were more probably

1 Antiq. xv, ii. 5.

2 Ep. 63. 3.

3 Martene, de Antiq. Eccles. Rit. i. iii. vii. 26.

4 Thorpe, B., Anc. Laws, fol. ed. $88_{40}$, p. 304.

5 Alcuini Ep. lxxv, Ad Fratres, Lugdun. t. i. p. 107.

- Martenc, de Eccles. Antiq. Rit. iii. vii. 30.

7 'Ad fontem sumpto pergit urceo, ut ad sacrae Eucharistiae ministeria aquam, quasi diaconus, fontanam hauriret.' Vita S. Columbae, ii. I. Or was this water required for the 'lavabo,' the symbolical washing of the priest's hands, a practice asserted by St. Augustine of Hippo to have prevailed universally in the primitive Church? 'Nam utique et altare portarent, et vasa ejus, et aquam in manus funderent sacerdoti sicut videmus per omnes ecclesias.' Quaest. V. et N. Test. Ior.

${ }^{8}$ Leabhar Breac, f. $3^{\text {I }}$ b.

- Archaeol. Cambrens. Third Series, vol. viii. p. 2 19. For the question of the date to be assigned to the use of a cross, see p. 128 . 
employed for conveying a little water into the chalice of wine before consecration, in accordance with a custom which prevailed almost universally in the early Church ${ }^{1}$. Such might have been the usc of the small bronze spoon found under St. Martin's Cross at Iona, and now in the possession of the Duke of Argyll ${ }^{2}$, and of a diminutive gold spoon found in the river Bann, and figured in the Ulster Journal of Archaeology ${ }^{3}$. An account of ancient bronze spoons found at Weston is given in the Proceedings of the Society of Antiquaries for Scotland 4. Notwithstanding the sacred character which has been conjecturally assigned to their ornamentation, it is probable that all these spoons were put to ordinary culinary, rather than to any ecclesiastical use.

$\S 23$. Coumunion in вотн кinds.-We might infer the fact of communion in both kinds from such words as these of Columbanus: 'If thou art thirsty, drink the Fount of life; if thou art hungry, eat the Bread of life. Blessed are they who hunger for this Bread, and thirst for this Fount, for ever eating and drinking, they still desire to eat and drink ${ }^{5}$.' They form a metaphor the full force of which would have been lost in a Church where communion in one kind only was the rule. But more direct proof is obtainable. In the Rule of Columbanus a special penalty is assigned to any who iujure the chalice with their teeth ${ }^{6}$. In St. Sechnall's Hymn in praise of St. Patrick that saint is described as one ' who draws heavenly wine in heavenly cups, and gives drink to the people of God from a spiritual chalice?' The

1 Bona, Rer. Lit. lib. ii. c. ix. § iii ; Leabhar Breac, f. 25 I a.

2 A woodcut representation is given in Ulster Journal of Archaeol. i. 80.

3 Vol. i. p. 81 .

4 Vol. viii. p. 363 . plate viii.

5 - Si sitis, bibe fontem vitae; si esuris ede panem vitae. Beati qui esuriunt hune panem, et sitiunt hunc fontem; semper enim edentes et bibentes, adbuc edere et bihere desiderant.' S. Columbani, Instructio xiv. de fonte vivo Christo Jesu adeundo et potando.

- 'Similiter qui pertaderit dentibus calicem salutaris, sex percussionibus.' S. Columbani, Regula Coenobialis, cap. iv.

7 "Qui celeste aurit vinum in vasis celestibus,

Propinansque Dei plebem spirituali poculo.'

Liber Hymnorum, p. 19. 
Communion Hymn of the early Irish Church ${ }^{1}$ is full of allusions to the reception of the chalice. So are the formulae of Administration and of the Communio preserved at the close of the Antiphonary of Bangor ${ }^{2}$.

In the later lives of the saints such expressions as these abound: 'After the girl had received the Body of Clirist and His blood she died without anxiety;' and 'The old man pointed out to them the land of which they were in search, i.e. the Land of Promise, and having received the Body of Christ and His blood he went to heaven ${ }^{3}$ '' Reference has been already made to the possible connection of certain ancient spoons with the administration of the Eucharist ${ }^{4}$. In the church at Kildare there was ' a special door through which St. Bridget and her virgins passed, that they might enjoy the banquet of the Body and Blood of Jesus Christ ${ }^{5}$.' The act of communion was called 'going to the chalice' in the Rule of the Irish Culdees ${ }^{6}$. St. Cuthbert, who cannot be supposed in his later days to have deserted on such a point as this the Celtic traditions of his youth 7 , was entreated by an officer of the court of Egfrid King of Northumberland to send a priest to visit his wife before her death, and to administer to her 'the Sacrament of the Body and Blood of Christ ${ }^{8}$;'

1 Chap. iii. $\$ 12$.

${ }^{2}$ Chap. iii. $\$ 12$. Some of these passages appear also in the Books of Deer (ib. § 5), Dimma (ib. § 6), and Mulling (ib. §7); St. Gall. MS. 1394 (ib. § 9); the Stowe Canon (ib. $\S J_{4}$ ); to which notes are appended indicating the source of all, and the Mozarabic connection of some, of the antiphons.

3 Irish Life of St. Brendan, quoted in Todd's Life of St. Patrick, p. $460, n$. Although the separate mention of the Body and Blood of Christ indicates the double administration, the absence of such two-fold mention does not necessarily disprove it. In Jonas' Life of St. Columbanus, that saint is described as giving the viaticum to another person named Columbanus in these words, 'Corpus Christi abeunti de hoc vita viaticum praebet.' Fleming, Collectan. p. 228.

${ }^{4}$ p. I33.

5 'Per alterum ostium abbatissa cum suis prellis et viduis fidelibus tantum intrant, ut convivio corporis et sanguinis fruantur Jesu Christi.' Cogitosus, Vita S. Brigidae ; Canisii Op. i. 423.

'Reeves' edit. p. 86.

7 Communion in both kinds was also the practice of the Anglo-Saxon Church.

8 'Mittas presbyterum qui illam, priusquam moriatur, visitet, eique Dominici corporis et sanguinis sacramenta ministret.' Bede, de Vit. Cuthbert. pros. cap. I 5 . 
and himself, immediately before his own death, received the Blessed Sacrament in both kinds from the hands of Herefrid Abbot of Lindisfarne ${ }^{\mathbf{1}}$.

The cup was administered by the deacon. There are extant certain canonical regulations of the Welsh Church c. A.D. 589, where among the penances attached to greater crimes are a refusal of permission to a priest to celebrate or to a deacon to hold the chalice ${ }^{2}$. The chalice from which St. Bridget was communicated was administered by 'unus de pueris Episcopi ${ }^{3}$.'

\$24. Communion of Infants.- There are traces of the once universal custom of administering the Eucharist to children after baptism in the Stowe Missal, where a formula of communion and several collects of thanksgiving after eucharistic reception are placed at the close of a Baptismal Office, the language of which implies that it was intended to be used in the case of infants as well as of adults. In a later Irish Ordo Baptismi (twefth century) it is directed that the newlybaptized infant shall be confirmed if a bishop be present ${ }^{5}$. There may also be some significance in the appointment of St. Matt. xix. I4 (Sinite parvulos, \&c.) as an Antiphon ad Communionem in the Stowe Missal ${ }^{6}$ and in the St. Gall MS. I $394^{7}$.

§25. WoMen to be veiled at the Reception of the Sacrament, and not to approach the Altar.-Among the regula-

1 'Exitum suum Dominici corporis et sanguinis communione munivit.' Ib. cap. 39. The following language of Jonas is still more explicit: 'Quaedam ex illis cum jam corpus Domini accepisset ac sanguinem libasset.' Vita Burgundofarae, \& vi, ap. Mab. Acta SS. ii. 443. It could hardly, like previous quotations, be used, with theological exactness, of communion in one kind.

2 'Hinc autem presbitero offerre sacrificium, vel diacono tenere calicem non licet; aut in sublimiorem gradum ascendere.' Twelfth-century MS. Paris. No. 3182, H. and S. i. IIg. 'Diaconus, praesente presbytero, eucharistiam populo si necessitas cogat, eroget.' Syn. Hibernens. lib. iii. c. 8.

3 Ultani, Vita S. Brig. cap. 94. The story is told rather differently in the Leabhar Breac, fol. $6_{5}$ b.

4 Ch. iii. \$ 14 .

- Hic vestitur infans, et si episcopus fuerit statin confirmare eum chrismate oportet.' Corpus Missal, p. 203. Similar directions are found in the Service Books of the Anglo-Saxon Church.

- Ch. iii. § I4.

7 Ib. $\$ 9$. 
tions laid down in the Penitential of Cuminius is one that 'women shall receive the Holy Communion under a dark veil;' and St. Basil is referred to as an authority for this undoubtedly Eastern custom ${ }^{1}$. There was a similar order for women to approach the altar with their heads veiled in the Apostolic Constitutions, in a passage relied upon by Bunsen ${ }^{2}$ as a proof of

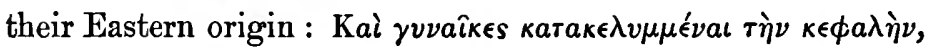

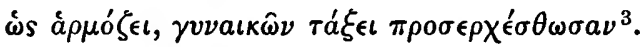

This was also a custom of the early Gallican Church, where a head-covering (dominicale) was ordered to be worn by women at the time of communion, by the 42 nd canon of the Council of Auxerre ${ }^{4}$.

In later times we hear of a church in North Munster into which no woman, or any animal of the feminine gender, ever entered but it immediately died ${ }^{5}$. There was another church where Irish women were prohibited from going near the altar, or taking the chalice in their hands: 'Nulla femina ad altare Domini aceedat, nec calicem Domini tanget ${ }^{6}$.' The latter part of this direction proves it to be of considerable antiquity. It occurs in a 'Sermo sinodalis parrotianis prespeteris,' but must surely apply only to some particular monastic altars. Yet injunctions of a similar character were not confined to Ireland. The Gallican Constitutions of Theodulf Bishop of Orleans (A.D. 802-II) ordered 'ut feminae ad altare non

1 'Mulieres possunt sub nigro velamine accipere sacrificium; Basilius hoc judicavit.' Cuminii de Mensura Poenitentiarum, cap. xiv. 'The same direction occurs in the Penitential of Theodore, vii. 3.

2 Reliquiae Liturgicae, iii. 248.

3 Book ii. ch. 57.

- 'Ut unaquaeque mulier quando communicat dominicale suum habeat, quod si qua non habuerit, usque ad alium diem Dominicum non communicet.' Conc. Autissiodor. can. 42. There was formerly some uncertainty about the interpretation of the word 'dominicale;' Gavant, Thes. Rit. i. 269; Scudamore, W. E., Notit. Euchar. edit. 1876, p. 723. n. 5. Women are represented as veiled in early and mediaeval Italian sacred art; J. H. Parker's Photographs, Nos. 479, I7 I0.

${ }_{5}^{5}$ Giraldus Cambrensis, Top. Hib. ii. c. 4. A.D. I185; Master of the Rolls' Ser. vol. v. p. 8o. No woman might enter the church or mill of St. Fechin at Fore; ib. ii. 52. p. I34.

6 Leabhar Breac, f. 248. col. I. 
accedant ${ }^{1}$ ' Women were not allowed to enter the chancel of Durham Cathedral within a line of blue marble which ran across the nave ${ }^{2}$. In a collection of tenth-century AngloSaxon laws the Gallican rule of Theodulf was incorporated and expanded thus: 'Eac we beodad pæt pæm tidum pe mæsse-preost mæssan singe pæt nan wif ne zenealæce pam weofode, ac standen on hyra stedum, and pe mæsse preost pær æt hiom onfó pære ofrunge pe hiz Gode ofrian wyllath ${ }^{3}$.'

$\S 26$. RESERVATION.-The consecrated elements were reserved for the use of the sick or absent, to whom they were afterwards conveyed. A person going to procure Communion for the sick was exempt from liability to arrest and from the law of distress ${ }^{4}$. Special warnings were directed against the loss of the reserved Sacrament from a boat or a bridge or while on horseback ${ }^{5}$. It was carried in a vessel called a ' chrismal,' or in a satchel suspended from the neck ${ }^{6}$; and various penalties were assigned by St. Columbanus for dropping it accidentally, or for leaving it behind through negligence ${ }^{7}$. It is not always clear whether these directions contemplate the Eucharist being conveyed to the sick, or worn as an amulet about the person, but in the absence of proof of the existence of the latter custom we may conclude that they are connected with administration to the sick $^{8}$. The reserved Eu-

1 Pertz, Leges, i. 107, 17 I.

2 Irish Life of St Cuthbert, Surtees Soc. Biog. Misc. pp. 63-87.

3 Anglice, 'We also command that when the priest sings mass, no women draw near the altar, but stand in their places, and let the mass priest there receive from them the offerings which they are ready to make to God.' A great deal of information as to the mediaeval custom on this head is collected by Canon Simmons (Lay Folks' Mass Book, pp. 233-236), from which it appears that such injunctions had reference generally to the approach to the altar for offering alms (or for vesting the altar, B. Thorpe, Ancient Laws, folio edit. 1840, pp. 303,375 ), not for the purpose of communicating.

4 Senchus Mor, i. 267.

5 Cuminii de Mensura Poenitentiarum, cap. xiii.

- 'Perula, quam, more patriae, presbyter itinerans sub indumento a collo suspensam deferebat.' Girald. Cambrens. Top. Hib. dist. ii. c. 19.

7 Regula Coen. xv. For the number of blows inflicted on these occasions, see Migne, Pat. Lat. Curs. lxxx. 218.

B Both customs existed in Anglo-Saxon days. Rock, D., Church of our Fathers, i. 134. 
charist was at a very early date placed on a person's breast when he was buried, as in the case of St. Cuthbert, whose body was found 'oblatis super sanctum corpus positis'.' May we infer from the use of the plural number here that the reservation took place in both kinds, just as Dr. Rock infers from the employment of the singular number in another case that in Anglo-Saxon days the reservation was of one kind only ${ }^{2}$ ? The decolorisation of the reserved Sacrament alluded to as a test of its corruption in the Regula St. Columbani, cap. xv, possibly points to the twofold but conjoint reservation of both elements ${ }^{3}$. The Eastern custom of simultaneous administration of both reserved elements is implied in the cases of sick or death-bed Communion previously referred to ${ }^{4}$, and in the Celtic remains of services for the Communion of the Sick in the Books of Deer, Dimma, Mulling, and Stowe ${ }^{5}$.

$\S 27$. EulogiaE.-It was a primitive Eastern custom to bless a loaf of bread at the conclusion of the Liturgy, which was then cut up into small pieces with a knife specially consecrated for that purpose, and distributed to the congregation, who came forward and received it at the priest's hands ; there is ample evidence for the existence of such a custom universally prevailing in the primitive and mediaeval Church, where it was variously known by the names of Eulogiae, Panis Benedictus, and Pain Béni ${ }^{6}$.

There are proofs of its use in the Celtic Church. Adamnan states that at St. Kenneth's monastery at Aghaboe in Ireland there was a table in the refectory on which the Eulogiae were cut up for distribution. The passage is curious, as showing that in Ireland in the sixth century it was customary to partake of the Eulogiae, not in connexion with the Eucharist in

1 Raine, J., St. Cuthbert, p. 34 ; Lingard, Anglo-Saxon Church, ii. p. 44, edit. 1858 .

2 'Oblationis particula,' Bede, H. E. iv. $1_{4}$; Rock, Church of our Fathers, i. 133 .

p. 135 .

3 Fleming, Collectanea Sacra, 24.

5 Chap. iii. $\$ \$ 5,6,7,14$.

- For authorities, see Rock, Church of our Fathers, i. 133 . 
the oratory, but at the afternoon meal in the refectory ${ }^{1}$. The same practice existed at Iona in Scotland ${ }^{2}$, and, as has been inferred from a passage in the old hymn attributed to St. Columba, under the same conditions of time and place as at Aghaboe $^{3}$. At Lindisfarne, in St. Cuthbert's time, it was distributed at the third hour, after Mass ${ }^{4}$.

In the continental monasteries of St. Columbanus it was distributed on Sundays and holy days after Mass. It is recorded of the saintly and humble Ermenfried, who presided over the Columban monastery of Cusance $(625-670)$, that he always kissed the hands of the poorest persons before distribution ${ }^{5}$. Its unworthy reception was forbidden by special enactment ${ }^{6}$.

$\S 28$. Frequency of Celebration.-There does not appear to have been a daily Eucharist in the Celtic Church, but only on Sundays, saints' days, and days specially appointed by the head of the monastery.

By the old law of distress in Ireland a stay of two days was granted in the case of church furniture, and the requisites of the Mass, though it be not celebrated every day ${ }^{7}$.

On Sundays. - When four distinguished Irish saints visited St. Columba at Iona and requested that he would celebrate

1 'Et cum forte post nonam coepisset horam in refectorio eulogiam frangere, ocius deserit inensulam,' \&c. Vit. S. Columbae, ii. I 2.

2 'Die crastina, his quae necessaria sunt citius praeparatis, Silnanus accepto de manu Sancti pane benedicto, in pace enagavit.' Ib. ii. 4.

s Skene, Celtic Scotland, ii. 99 ; Liber Hymnorum, part ii. 22.

4 'Facto jam signo diei borae tertiae et oratione consummata mensam statim apposuit, quia enim panis casu aliquo non erat in diversorio, tantum micas pro benedicto pane congregatas super nensam constituit.' S. Cutbberti Vita Anon., quoted by Rock, Church of our Fathers, i. 138. ' Repente unus eorum intulit, quia secum haberet panem quem sibi nuper vir Domini Cuthbertus benedictionis gratia dedisset.' Bede, Vit. S. Cuthberti, c. ix.

5 'Dicebant etiam de beato viro, quod, humilitatis causa, cum Dominicis vel festivis sanctorum diebus post expletionem Missarum, ut mos est ecclesiasticus eulogias populis daret, si vidisset aliquem operatorem aut pauperrimum crepatis manibus, non ante eulogias dabat quan benignissimus Pater conversa vice manus ipsas oscularetur; et tune demum eulogias dabat.' Egilbertus, Vita S. Ermenfredi, ap. Bolland. t. vii. Sept. p. I 20.

' 'Eulogias immundus accipiens xii. percussionibus.' Reg. Columb. c. iv.

7 Senchus Mor, vol. i. p. I 26. 
in their presence he complied with their request, as usual on Sunday'. The same saint is described as celebrating on the last Sunday (June 2, 597) before his death, which took place on the Saturday following ${ }^{2}$. Cuminius in his Penitential defends and explains these Sunday celebrations by a reference to the custom of the Greeks ${ }^{3}$. In the eighth century in Ireland there was a seven years' probation for admission into the society of the Culdees. In the first year the novice was not allowed to communicate at all, only to be present at the sacrifice. In the second year his communions began, and gradually increased in number, till they mounted to communion every Sunday in the seventh year ${ }^{4}$.

On Saints' Days. - We read of St. Columba at Iona giving special orders for the celebration of the Eucharist in commemoration of St. Brendan ${ }^{5}$ and of Columbanus, and it is noted that the latter order was carried out in detail, as if it had been a regular and recognised holy-day ${ }^{6}$. Passengers - on their way to Iona pray that they may reach the island in time to celebrate the Eucharist on the day dedicated to St. Columba and St. Baithene, on whose joint festival (June 9) the wished-for Eucharist is offered ${ }^{7}$. In Ireland, in the sixth century, we read of celebration on a holy-day in the church of St. Finnian at Movilla, county Down ${ }^{8}$. In St. Bridget's

1 'Die dominica ex more.' Adamnan, Vit. S. Columbae, iii. I7 ; Cuminius, Vita, \&c. cap. 12.

${ }^{2}$ Adamnan, Vit. S. Col. iii. 23. On this occasion his face was illumined with a glow of light which he described as caused by his vision of an angel who had been sent 'to demand a deposit dear to God,' and whose appearance was vouchsafed to Columba 'dum missarum sollemnia, ex more, Dominica celebrarentur die.'

3 'Graeci omni Dominica communicant, clerici et laici; et qui in tribus Dominicis non communicaverint, excommunicentur sicut canones habent.' Cuminius, De Mensura Poenitentiarum, cap. xiv.

Rule of the Culdees, p. 87.

5 "Vir venerandus mane primo suum advocat saepe memoratum ministra. torem Diormitium nomine, eique praecipit, inquiens, Sacra celeriter Eucharistiae ministeria praeparentur. Hodie enim natalis beati Brendani dies' ( $\approx$ dies obitus). Adamnan, Vit. S. Col. iii. I r.

- 'Quasi die solenni.' Ib. iii. I2. See the whole chapter.

T' Ot in tua celebremus ecclesia tui natalis missarum sollemnia.' Ib. ii. 45 .

8 'Quadam solenni die.' Ib. ii. I. 
church at Kildare, early in the sixth century, there was a celebration on Sundays and on the vigils of the feasts of Apostles ${ }^{1}$. In the mother church of every Irish monastery in the eighth century there was an offering upon every altar on Sundays and solemnities ${ }^{2}$.

St. Gall ordered a special celebration in commemoration of St. Columbanus on receiving intelligence of his death ${ }^{3}$, and no doubt from that day forward the festival of St. Columbanus was added to the Kalendar of St. Gall.

$\S 29$. Hodrs of Celebration.-Mass was always celebrated at an early, generally at a very early, hour of the day. The Mass of St. Columbanus was celebrated by St. Columba at Iona ' in the morning 4,' by St. Gall in Switzerland 'at daybreak ${ }^{5}$ ' That of St. Brendan at Iona was ' in the very early morning ${ }^{6}$.' The solemn Mass of St. Baithene was sung at the later hour of noon ${ }^{7}$. An early hour was ordered in the continental Irish monasteries under a heavy penalty ${ }^{8}$.

In all these passages, as usually in the language of the seventh century, the word 'Missa' means the Liturgy proper, and such phrases as 'Missarum sullennia' and 'sacra Eucharistiae ministeria' are used as synonymous expressions, but the word Missa is also used occasionally to denote any sacred office. The last service at which St. Columba was present is called the 'vespertinalis Dominicae noctis Missa 9.' This service was evidently not an evening communion, but 'Vigiliae nocturnae' or 'nocturns.' The word 'Missale' or 'Missal' was also used to denote not only the text of the Mass itself,

1 ' In solemnitatibus Domini et vigiliis Apostolorum.' Cogitosus, Vit. S. Brig. cap. 29.

2 Rule of Culdees, p. 94 .

S Walafrid Strabo, Vit. S. Galli, tom. i. part ii. c. 27.

\& 'Mane.' Adamnan, Vit. S. Columbae, iii. 12.

- 'Primo diluculo.' Walafrid Strabo, Vita S. Galli, cap. xxvi.

- 'Mane primo.' Adamnan, Vita S. Columbae, iii. I I. ${ }^{7}$ Ib. ii. 45.

8 'Obliviscens oblationem facere usque dum itur ad officium centum percussionibus.' Reg. Columban. cap. iv.

- Adamnan, Vit. S. Col. iii. 23. So in the Regula Caesarii Arel. cap. xxi, the word 'Missa' is used as equivalent to 'Lectio.' Migne, Bibl. Pat. Lat. lxvii. p. 1162 . 
but also other Office Books. The book which in the Irish life of St. Columba is called the Book of the Grospels, but which is no longer extant, is called by Colgan in his Latin translation 'Missarum Liber.'

$\S 30$. Duplicating.-Priests were allowed at Iona, in the seventh century, to celebrate twice, and by implication, as a general rule, not more than twice on the same day ${ }^{1}$.

\$31. Paten and Chalice.-The paten (called 'discus' or patena $^{2}$, 'patinus ${ }^{3}$ ') and chalice (called 'Calix Domini ${ }^{4}$,' 'vas ${ }^{5}$,' ' laguncula ${ }^{6}$,' 'coilech 7 ', 'cailech ${ }^{8}$ ') were probably originally made of glass. A stone altar with four glass chalices upon it is mentioned by later writers as having been discovered by St. Patrick in a cave, and as evidence of the existence of Christianity in Ireland before the arrival of that saint ${ }^{9}$. The cups and patens brought by that saint on his arrival from beyond the sea were possibly of the same material ${ }^{10}$, for there is testimony as to the early use of glass chalices in Gaul ${ }^{11}$. Bronze chalices were used at a little later period, in the Irish continental monasteries. St. Gall refused to use silver vessels for the altar, saying that St. Columbanus was accustomed to offer the sacrifice in vessels of bronze, in memory of the fact that his Saviour was fastened to the cross with brazen nails ${ }^{12}$.

A golden chalice, a relic of Iona, perhaps coeval with St. Columba himself, once existed, but has in recent times been

1 Cuminii De Mensura Poenitentiarum, cap. xiv.

2 St. Evin, Vita S. Patricii, ii. 54. 3 Book of Armagh, fol. 8, 1 I.

- Adamnan, De Locis Sanctis, i. 8. B Wal. Strabo, Vit. S. Galli, i. I7.

6 Ib.i. 19. $\quad 7$ = chalice. Leabhar Breac, fol. 31 b. ${ }^{8}$ F. cri.

- St. Evin, Vita S. Patricii, ii. 35. The story is copied in other and still later biographies. Glass as well as wooden chalices were forbidden by later Irish authority: 'Nullus presumat missam cantare in ligneo vel in vitreo calice.' Leabhar Breac, p. 248 . col. i.

${ }^{10}$ Scholiast on St. Fiacc's Hymn, seventh century. The original Irish, with a translation, is given in Dr Todd's Life of St. Patrick, p. $4^{11}$.

1 St. Hilary of Arles possessed 'patenae et calices vitrei.' Honorati, Vita S. Hilarii, ap. Bolland. Acta SS. ad v. Maii, tom. ii. p. 28.

12 ' Praeceptor meus B. Columbanus in vasis aeneis Domino solet sacrificium offerre salutis.' Walafrid Strabo, Vit. S. Galli, i. I9. 
unfortunately lost '. A similar fate has attended the relics of St. Kieran (sixth century). When his grave was opened A.D. I79I his relics comprised beads strung on brass wire, a crozier, a hollow brass ball which opened, resembling the ball (possibly a pome) in the hands of one of the figures on the Breac Moedog (Archaeol. xliii. pl. r8), and a paten and chalice ${ }^{2}$.

$\S 32 . F_{\Delta N}$.- The only evidence for the use of this wellknown Eastern accessory of liturgical worship is derived from illuminations in ancient books. There is a 'flabellum' or fan represented in the right hand of St. Matthew in a Hiberno-Saxon MS. of the Gospels (eighth century) at Treves ${ }^{3}$, also in the hands of the angels in the monogram of the Book of Kells (sixth century, Irish), where they seem to be constructed of thin plates of metal surrounded by little bells like those used by the Maronites ${ }^{4}$.

Plentiful evidence of the early use of the flabellum in Western Christendom is adduced by Gerbert ${ }^{5}$, and especially as to Gaul in Smith's Dictionary of Christian Antiquities ${ }^{6}$. In a thirteenth-century illumination in a French MS., a facsimile of which is given in Bastard's Peintures et Ornements ${ }^{7}$, a priest vested in an ample chasuble is represented in the act of consecration at Mass. Behind him stands the deacon in a dalmatic, waving a flabellum composed of peacocks feathers.

Knife.-A knife is depicted in the left hand of St. Matthew in the Treves Gospels ${ }^{8}$, and in the right hand of the righthand figure in the monogram of the Garland of Horwth ${ }^{9}$. It

1 The circumstances attending its loss are recorded in Wilson's Archaeology of Scotland, pp. 668-9.

There are early and frequent allusions to golden chalices in Gaul ; Greg. Tur. De Glor. Confess. clxiii ; Hist. Franc. lib. iii. cap. 10 ; lib. vii. cap. 24. For information as to other countries, see Scudamore, Notit. Eucharist., second edit. p. $55^{8}$.

3 Westwood, J. O., Facsimiles, \&c., plate xx.

4 Ib. plate liii. No. 7 ; Todd, J. H., Descriptive Remarks, \&c.

S Liturg. Aleman. i. 228.

'Sub voc. Flabellum.

7 Tom. iii.

8 Westwood, J. O., Facsimiles, \&c., plate xx.

- Todd, J. H., Descriptive Remarks, \&c., plate iii. 
is impossible without further evidence to decide for what purpose this knife was employed, although its character as a sacred symbol is evident. It may have been used as the holy spear $(\lambda o ́ \gamma \times \eta)$ is used in the Eastern Church, for the ceremonial piercing of the Amnos and severing the host into portions during the Liturgy $^{1}$, or as the knife specially set apart in the Anglo-Saxon Church for the purpose of cutting up the Eulogiae ${ }^{2}$.

$\S 33$. Sign of the Cross. Frequent mention is made of the use of the sign of the cross for various purposes by the Scottish monks at Iona and by Irish monks under St. Columbanus. It was the sign ordinarily attending the sacerdotal act of benediction. We may infer therefore that it was employed in every Celtic act of consecration, although there is no direct evidence extant to that effect. There are directions for its use once over the chalice in St. Gall MS. $1394^{3}$; once in the Rite of Unction in the Book of Dimma ${ }^{3}$, and in the Stowe $\mathrm{Missal}^{4}$; once in the Ordo Baptismi, and five times in the Gelasian Canon in the latter volume ${ }^{4}$. Instances of its use at Iona have been collected by Dr. Reeves in his edition of Adamnan ${ }^{5}$. It was made over the pail before milking ${ }^{6}$, over tools before using them ${ }^{7}$, over a spoon ${ }^{8}$, over a lantern ${ }^{9}$. It was considered effectual to banish evil spirits ${ }^{10}$, to restrain a river monster ${ }^{11}$, to stop a wild boar ${ }^{12}$, to unlock a door ${ }^{13}$, to endow a pebble with healing virtue ${ }^{14}$, or bread ${ }^{15}$, or water ${ }^{16}$, or salt ${ }^{17}$. It deprived a spear ${ }^{18}$ or a dagger ${ }^{19}$ of its power of hurting, etc. etc. In the first eight of these instances the sign of the cross is mentioned, in the latter seven it is implied in the word 'benedixit.' It was made 'extensa,' or ' elevata manus,' or 'manus protensione.' There are numerous allusions to its use in all the later lives of the saints.

1 There is slight evidence in favour of the use of a knife in the early Gallican Liturgy in the account of the vision recorded by Germanus Paris. in the Expos. Missae, Mart. i. p. 168. col. 2.

3 Ch. iii. $\S \S 6,9$.

7 Ib. ii. 29.

${ }^{10}$ Adamnan, ii. 17.

$4 \mathrm{Ib}$ \$ I4.

2 Rock, D., Church of our Fathers, i. 36 .

14 Ib. ii. 33 .

8 Reg. Columban. cap.i.

18 Ib. ii. 25.

11 Ib. ii. $27 . \quad 12$ Ib. ii. 26.

15 Ib. ii. 4.

16 Ib. ii. 5 .

6 Ib. ii. 16.

- Ib. cap. ii.

13 Ib. ii. 35 .

19 Ib. ii 29.

17 Ib. ii. 6. 
\$34. FASTING.-There is no direct evidence of the practice of fasting reception of the Communion, but we may infer it from the early hour at which the Eucharist was celebrated ${ }^{1}$, and from the prominent position assigned to fasting generally in the regulations of the Celtic Church.

Wednesday and Friday were observed as fast-days at Iona, but a dispensation was granted by the abbot in the case of the reception of strangers ${ }^{2}$, \&c. ; also at Lindisfarne, where the Celtic custom of fasting till three o'clock (except in Eastertide) had been introduced by St. Aidan from Iona ${ }^{3}$. The Rule of St. Columbanus prescribed the same custom for the Irish continental monasteries ${ }^{4}$. In the Rule of the Irish Culdees (eighth century) skimmed milk was allowed on St. Patrick's Day even if it fell on a Wednesday or Friday ${ }^{5}$. The noneating of flesh on Wednesdays and Fridays was one of the customary laws by which the soul-friend (anmeara) bound the Irish people ${ }^{6}$.

Lent (dies quadragesimales) was observed at Iona as a season of preparation for Easter ${ }^{7}$. The severity of the Lenten Rule may be gathered from the statement of Bishop Cedd that the strict rule which he observed had been learned by him in the Columban monastery in which he had been brought up ${ }^{8}$.

The three Rogation Days, before the Feast of the Ascen-

1 p. I42.

2 Adamnan, Vit. S. Col. i. 26.

3 'Per totum annum, excepta remissione quinquagesimae paschalis, quarta et soxta sabbati jejunium ad nonam usque horam protelare.' Bede, H. E. iii. 5 .

- Si quis ante horam nonam quarta sextaque feria manducat, nisi infirmus, duos dies in pane et aqua.' Cap. xiii. p. 23.

${ }^{5}$ p. 84 . In the Black Book of Caermarthen (Welsh, twelfth century) this charge is brought against an irreligious person : "Thou respectedst not Friday, of thy great humility,' \&c.; v. 30.

6 Senchus Mor, iii. I5.

7 Adamnan, Vit. S. Col. ii. 39 .

8 'Diebus cunctis, excepta Dominica, jejunium ad vesperam usque juxta morem protelans, ne tunc quidem nisi panis permodicum, et unum ovum gallinaceum cum parvo lacte aqua mixto percipiebat. Dicebat enim hanc esse consuetudinem eorum, a quibus normam disciplinae regularis didicerat.' Bede, H. E. iii. 23 The rule of St. Benedict was the same as to the hours of food both on Wednesdays and Fridays and in Lent, and it appears to have been still more strict as to quality (cc. $39,4^{1}, 49$ ). 
sion, were observed, with fasting up to the ninth hour, and their observation was perpetuated in the Anglo-Saxon Church by the I6th canon of the Council of Clovesho (A.D. 747), which expressly refers to their observation not as a custom derived from Rome, but as a traditional custom of the country: 'Sexto decimo condixerunt capitulo: Ut Laetaniae, id est rogationes, a clero omnique populo his diebus cum magna reverentia agantur, id est, die septimo kalendarum Maiarum, juxta ritum Romanae Ecclesiae, quae et Letania major apud eam vocatur. Et item quoque, secundum morem priorum nostrorum, tres dies ante Ascensionem Domini in caelos cum jejunio usque ad horam nonam et Missarum celebratione venerantur ${ }^{1}$,' \&c.

The wording of this canon is noteworthy. The observance of the Rogation Days was a Gallican custom, unknown at that date in the Roman Church, into which it was first introduced by Leo III (795-8I6); and their recognition in the British Church, and their perpetuation from that source in the Anglo-Saxon Church, if we may see an allusion to that Church in the words 'priores nostri,' is a link in the proof of the early connection between the British and Gallican Churches.

The connection of a special fast with the Celtic rite of the consecration of churches has been already pointed out ${ }^{2}$.

$\S 35$. Confession.-There is plentiful evidence of the practice of confession in the Celtic Church, but there is no trace of its connection with or of its use as a preparation for the celebration or reception of the Eucharist. Gildas uses the general expressions 'poenitentiae medicamen' and ' ut peccata sua delerentur humilitate confessionis ${ }^{3}$.' The ordinary Irish title for a confessor was 'anmcara' or 'soul's friend,' and every person seems to have attached some priest to himself in that capacity.

1 H. and S. iii. 368 .

${ }^{2}$ p. 75.

s Epist., H. and S. i. 78,8 o. 
St. Donnan of Eig requested St. Columba to act as his anmcara. 'This Donnan went to Columcille to make him his soul's friend; upon which Columcille said to him, "I shall not be soul's friend to a company of red martyrdom; for thou shalt come to red martyrdom, and thy people with thee." And it was so fulfilled'.' St. Columba is said to have been 'anmcara' to Aidan King of Dalriada A.D. $574^{2}$.

Adamnan acted, as anincara to Finnsnechta, who became monarch of Ireland A.D. $675^{3}$. Minute regulations about confession are laid down in the Irish Rule of the Culdees (pp. 88-9o). In some of the later entries in the Annals of Ulster the office of chief confessor is named". There are various regulations on the subject of penance and confession in the Welsh laws of Howel ${ }^{5}$. In the Black Book of Caermarthen an irreligious Welshman is taunted with the question, "What gavest thou of thy wealth before private confession ${ }^{6}$ ?'

Three points are worthy of note with regard to the practice of confession in the Celtic Church.

(a) It was public rather than private.

We read how a certain Irishman (de Scotia), named Feachnaus, touched with remorse for some crime committed by him, came to Iona, and falling at St. Columba's feet, lamenting bitterly, 'confessed his sins before all that were there present.' Whereupon St. Columba, weeping together with him, absolved him in these words: ' Rise up, my son, and be comforted; thy sins which thou hast committed are forgiven, because, as it is written, a contrite and a humble heart God doth not despise?.'

1 Félire of Oengus, p. 86 . line 3 ; also p. cxxix and passim.

2 MS. H. 2. 16. Trin. Coll., Dublin, p. 858 , quoted in Reeres' Adamnan, p. lxxvi.

3 MS. quoted in Reeves' Adamnan, p. xliii.

$1 \mathrm{As}$ in the case of Oengus O'Donnellan, primh anmcara, wrongly translated by O'Conor 'primus anachoreta' of the Columban monks; anno MCIX.

5 H. and S. i. pp. 2I I-283.

6 V. 21 .

7 ' Feachnaus, cum fletu et lamento, ante pedes ejus [sc. Columbae] ingeniculans flexis genibus amarissime ingemuit, et coram omnibus qui ibidem inerant 
On another occasion, when St. Columba was visiting the little monastery of Trevet, co. Meath, a priest who had been chosen by the brethren to celebrate the Eucharist on account of his supposed superior sanctity, was consciencestricken by some words uttered by St. Columba, and 'was compelled to confess his sin in the presence of them all 1'.'

An old Irish canon speaks of confession of sins in the presence of priest and people ${ }^{2}$.

(b) It was optional rather than compulsory.

In early Irish law there is frequent mention of the anmeara, and of confession to him being profitable (not necessary), and of his power to impose penances, such as a pilgrimage after a murder ${ }^{3}$.

The direction on the subject in the Penitential of Cuminius ran in these words: "Confessio autem Deo soli ut agatur, si necesse est, licebit ${ }^{4}$ ' It was perhaps owing to its optional character that the practice of confession seems to have dropped into disuse in the later Irish Church. Alcuin writing to certain brethren in Ireland (eighth century) urged the practice of confession very strongly on men and women, secular and religious, young and old ${ }^{5}$. In another letter he complained

peccantias confitetur suas. Sanctus tum, cum eo pariter illacrymatus, ad eum ait, Surge fili, et consolare; dimissa sunt tua quae commisisti pecamina; quia sicut scriptum est, Cor contritum et humiliatum Deus non spernit.' Adamnan Vit. S. Col. i. 3 o.

1 "Presbyter ille " de quo haec dicebantur verba coram omnibus peccantiam compulsus est suam confiteri." Ib. i. 40.

2 'Post confessionem peccatorum coram sacerdote et plebe.' Sin. Hibern. ii. c. 4 .

3 Senchus Mor, iii. 39, 73 .

4 The same direction appears in the Anglo-Saxon Penitential of Theodore (668-69o): 'Confessio autem Deo soli agatur licebit si necesse est. Et hoc necessarium in quibusdam codicibus non est;' cap. xii. sect. 7 . The meaning of these directions depends upon the interpretation which is placed upon the conditional clause. Is the necessity alluded to 'objective' as maintained by Roman writers, kuch as would be caused by a stroke of paralysis, or by the impossibility of access to a priest? or is it 'subjective,' of the existence of which each person is judge according to his own spiritual needs? Lingard, A. S. Church, i. 304.

- Alcuini Epist. ccxxv. ad fratres qui in Hibernia insula per diversa loca Deo deservire videntur. 
that ' it is reported that none of the laity are willing to make their confession to the priests, whom we believe together with the holy Apostles to have received the power of binding and loosing from God in Clirist '.'

St. Bernard asserted that the custom of going to confession had died out in Ireland in the twelfth century, and that its restoration was one among the reforms of St. Malachi ${ }^{2}$.

(c) It was not the custom to pronounce absolution until after the penance assigned had been fulfilled.

An early Irish canon assigned a year of penitence as the punishment for certain crimes. When the year was accomplished the penitent might come with witnesses and receive absolution from the priest $^{3}$. Bede records how an Irish youth named Adamnanus made confession to a priest, and on hearing the penance imposed complained of it, not on account of its severity, but because he wished more quickly to receive absolution. The penance had been imposed for an indefinite time, and absolution was deferred until the priest should see him again. No second interview ever took place, in consequence of the sudden death of the priest in his native country (Ireland), whither a sudden emergency had caused him to return, and Adamnanus continued to comply with the conditions of the penance for the rest of his natural life 4 .

This regulation, although it led to a practical inconvenience in the case of Adamnanus, is more in accordance with the discipline of the primitive Church than the modern

1 'Dicitur vero neminem ex laicis suam velle confessionem sacerdotibus dare, quos a Deo Christo cum sanctis Apostolis ligandi solvendique potestatem accepisse credimus.' Epist. cxii. ad fratres in provincia Scotorum [al. Gothorum].

2 - Usum saluberrimum confessionis, sacramentum confirmationis, contractum conjugiorum (quae omnia aut ignorabant aut negligebant) Malachias de novo instituit.' S. Bernard in Vita Malachiae, cap. iii.ad finem; see also cap. viii. $\S$ I 7 .

3 'Christianus qui occiderit, aut fornicationem fecerit, aut more gentilium ad aruspicem juraverit, per singula cremina annum poenitentiae agat; impleto cum testibus veniat anno poenitentiae, et postea resolvetur a sacerdote.' Sinodus Patricii, Auxilii, Isernini, cap. xiv.

4 This story is told at some length in Bede, H. E. iv. 25. 
practice of making the absolution precede the performance of the penance ${ }^{1}$.

The following portion of an Irish Penitential survives among the MSS. at St. Gall ${ }^{2}$ :-

'Capitula quaedam ad emendationem vitae.

\section{Incipit ordo ad Poenitentiam dandam.}

Credis in Patrem et Filium et Spiritum Sanctum? $R$. Credo.

Credis quod istae tres personae, quo modo diximus, Pater et Filius et Spiritus Sanctus, tres sunt, et unus Deus est? $R$. Credo.

Credis quod in ista ipsa carne in qua nunc es habes resurgere in die iudicii et recipere siue [bonum] siue malum quod egisti? $[R$. Credo.]

Uis dimittere illis quicunque in te peccauerint, Domino dicente, Si non remiseritis hominibus peccata eis, nec Pater uester coelestis dimittet uobis peccata uestra? (R. Dimitto.)

Et require diligenter si sit incestuosus ${ }^{3}$; si non unlt ipsa

1 Bingham, Antiq. book xix. c. 2. For the present Roman rule and practice, see Schouppe, F. X., Elementa Theol. Dog. vol. ii. tract xiv. c. ii.

2 F. F. iii. 15.

3 The presence of this question as a typical question to be put to an Irish penitent corroborates the dark picture drawn by St. Bernard of the morals of the Irish; p. 150. n. 2. Statements about the prevalence of incest in Ireland in the eleventh century are also made by Lanfranc Archbishop of Canterbury, in letters addressed to Gothric King of Dublin (Ep. xxvi ; Ussher's Works, iv. 490), to Terdelvacus King of Ireland (Ep. xxvii ; ib. 493); by Anselm, in letters to Muriardachus King of Ireland (Ep. xxxv; ib. p. $5^{21}$ : Ep. xxxvi ; ib. p. 523); by Giraldus Cambrensis, writing A.D. 1 I 85 ; Topograph. Hibern. distinct. iii. cap. 19. The first canon of the Synod of Cashel, A.D. I I 72, is directed against the same irregularity (Mansi, Concil. vol. xxii. p. 134). But the early Irish ecclesiastical law of marriage was strict; Canones S. Patricii, ii Synod. xxv-xxviii. Compare the decision of Columba in a matrimonial dispute in the island of Rechrea, off the coast of Antrim; Adamnan, Vit. S. Col. ii. 4I. It is also noteworthy that the same question is directed to be put to the penitent in a tenthcentury German Office published by Gerbert (vol. ii. p. 25, ex Cod. MS. Bibl. Caes. Vindob. Theol. No. 685), and in an almost identical French Ordo Penitentiae printed in Martene, de Antiq. Eccl. Rit. lib. i. cap. vi. art. vii. ordo vi, ex MS. Gellonensi, saec. ix aut $x$, in diocesi Lodevensi. Possibly therefore the question was a necessity of the times rather than indicative of any special 
incesta dimittere, non potes ei dare poenitentiam; et si unlt ipsa incesta dimittere, fac eum confiteri omnia peccata sua, et ad ultimum dicere,

Multa sunt peccata mea in factis, in uerbis, in cogitationibus.

Tunc da illi poenitentiam, et dic istas orationes super eum,

\section{Oremus.}

Preueniat hunc famulum tuum ill. Domine misericordia tua, et omnes iniquitates eius celeri indulgentia deleat. Per ${ }^{1}$.

\section{Oremus.}

Exaudi, Domine, preces nostras, et confitentium tibi parce peccatis, et quos conscientiae reatus accusat, indulgentia tuae pietatis absoluat ${ }^{2}$.

Et caeteras si tempus habueris sic in sacramentario continentur. Si tibi non uacat istae sufficiant.

Et si homo ingeniosus est, da ei consilium ut ueniat tempore statuto ad te aut ad alium sacerdotem in Coena Domini, et reconciliaretur sic in Sacramentario continetur. Quicquid manens in corpore consecutus non fuerit (hoc est reconciliatio) exutus carne consequi non poterit. Si uero minus intelligens fuerit, quod ipse non intelligit, in uno statu reconciliare potes eum, ita dicendo,

\section{Oremus.}

Presta, quesumus, Domine, dignum poenitentiae fructum huic famulo, ut Ecclesiae tuae sanctae, a cuius integritate deuiarat peccando, admissorum ueniam consequendo reddatur innocuus $^{3}$. Per.

Si infirmus est homo, statim reconciliare eum deles.

degradation in the morality of Ireland. It should also be remembered that marriages with persons occupying positions of spiritual affinity as well as with rear kindred fell ander the designation of incest. (Hook, W. F., Archbishops of Canterbury, i. 372. § 7.) The charge of 'incest' was frequently brought against the Anglo-Saxons in the ninth century. (Lingard, A. S. Church, ii. 220.)

1 Sacr. Gelas. p. 504; Greg. p. 209 ; Sarum Mirsal, p. 132.

Ib.

s This collect occurs in the Orjo Excommunicandi, \&c. in the Pontif. Rom. 


\section{CHAPTER III.}

\section{RELIQUiAE CELTICAE LITURGICAE :}

Together with certain Missae and Collects, which, though not portions of the original Celtic Liturgy, were used in the later Celtic Church, or are associated with the names of Celtic Saints, or refer to incidents in their lives, or have relics of the ancient Liturgy interwoven in their structure or contents.

$\S 1$. No traces of a vernacular Liturgy. - $\$ 2$. Cornish Fragment. Missa S. Germani. - §3. Welsh Fragments. Missa de S. David.—§ 4. Missa de S. Teilao. §5. Scottish Fragment. Book of Deer. - $\$$. Irish Fragments. Book of Dimma. - $\$ 7$. Book of Mulling. - $\$ 8$. Book of Armagh. - § 9. St. Gall. MS. No. 1394. - § 10. St. Gall. MS. No. I395. - 11 . Basle MS. A. vii. 3. - 12 . Antiphonary of Bangor. $-\S 13$. Book of Hymns. - § 14. Stowe Missal. - $\$ 15$. Drummond, Corpus, and Rosslyn Missals. — $\$ 16$. Paris MS. 2333 A. Colbert. - $\$ 17$. Missale Vesontionense.

Throughout the documents printed in this chapter the original orthography and accentuation have been retained. The punctuation has been modernised and capital letters have been introduced after full stops. Words or letters within square brackets [] are not in the MS. text. Those within round brackets () have been added by a later hand. Rubrics have been printed in italics, Titles in small capitals. Contractions and abbreviations have been expanded.

$\S \S 2,3,4 b, 5,6,7,8,13,1_{4}, 1_{5}, 16$ have been printed from the original MSS ; $\S \S 9$, Io from facsimiles of the original MSS. ; $\S_{4} a$, II, I 2 from collations with the original MSS., kindly supplied by P. B. Davies-Cooke, Esq., Dr. L. Sieber, and the Very Rev. W. Reeves, D.D. 



\section{CHAPTER III.}

Reriquiae celticae liturgicae.

\section{§1. No traces of a Vernacular Liturgy.}

THERE is no trace of a vernacular Liturgy having been in use in any portion of the Celtic Church; but in the absence of any liturgical remains of an earlier date than the seventh century, only negative evidence can be produced on this point. The undoubtedly Celtic liturgical fragments of a later date which have survived are in the Latin language, relieved by an occasional vernacular rubric, as in the case of the St. Gall MSS., the Stowe Missal, and the Books of Deer, Dimma, and Mulling1. But there is not only an absence of direct proof, but also of any indirect evidence which points to a vernacular Liturgy having once existed, if we except a possible interpretation of the 'ritus barbarus,' abolished in Scotland by Queen Margaret ${ }^{2}$.

As far as the earliest British Church is concerned many facts suggest a partially Latin origin. The most important British bishoprics belonged to the capitals of Roman provincesYork, London, and possibly Caerleon. The earliest Christian martyrs in Britain bore Roman, or at least not Celtic namesAlbanus, Julius, Aaron. The earliest antiquarian remains of British Christianity are connected with Roman stations, as at Canterbury, Dover, Lyminge, Richborough, \&c. Ptolemy, writing in the earlier part of the second century (c. A.D. I20), enumerates under their Latin titles fifty-six cities then

2 Theoderic. Vita S. Margaret. c. 8, quoted on p. 7. n. 5 . 
existing in Britain ${ }^{1}$; Marcianus in the third century reckons fifty-nine ${ }^{2}$. Other names of towns have been collected from the pages of Asser, Nennius, Henry of Huntingdon, and the Saxon Chronicle ${ }^{3}$. The walls by which some of these places are still surrounded, the ruins of theatres, villas, baths, and other public and private buildings, the vases, coins, inscriptions discovered from time to time, prove that they once contained a flourishing Roman population. Possibly, therefore, the earliest Christian Church in these islands consisted of converts to Christianity among its Roman invaders and of such natives as were brought into immediate connection with them ${ }^{4}$. Gradually, as the Roman power dwindled away, the Church spread over the population of these islands; but in quite early days Latin, and not any form of Gaelic, may have been, if not the vernacular language, at least a language understood by all the members of the Christian Church in Britain. Tacitus informs us that the Roman language was adopted by the leading inhabitants of Britain under the 'policy' of Agricola ${ }^{5}$. Most of the writings of the British, Scottish, and Irish authors of the first six centuries ${ }^{6}$, all the extant Psalters and Books of the Gospels, and the fer liturgical fragments which have been preserved, are written in the Latin language by scribes who not only understood what they wrote, but were so far masters of the language in which they were writing as to have compiled a special British and Irish revision of the old Latin text of the Bible for use in their orwn Church ${ }^{7}$. The ecclesiastical use of the ancient

1 Geogr. lib. ii. cap. 2.

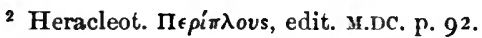

s Their Celtic names, and where possible the Roman equivalents, are given by Thomas Gale (Hist. Brit. Script. p. 135) and W. Gunn (Edit. of Nennius, p. 97 .

4 The remains of Celtic churches, crosses, \&c. in Cornwall are to be referred to this period.

5 Tacitus, Vit. Agric. c. 2 I.

${ }^{6}$ p. $3^{6}$.

7 Including the Domnach-Airgid MS., written in the fifth century and believed to have belonged to St. Patrick, now in the Royal Irish Academy at Dublin; an ancient version of the Gospels, fifth to seventh century, in Trinity College, Duhlin; the Psalter styled Cathach, and the volume of the Gospels known as the Book of Durrow (Vulg.), both written by St.Columba in the six th century. 


\section{§..] No traces of a Vernacular Liturgy. I 57}

Celtic tongue, if this theory is correct, commenced when the Churoh began to include among its members and to receive into its priesthood persons who were ignorant of Latin; but even then it was confined to the rubrics, and to sermons or addresses. A large fragment of a sermon on self-denial and compassion in the old Irish language from the Codex Camaracensis (eighth century) is printed in Zeuss, Grammatica Celtica ${ }^{1}$. Vernacular sermons are in existence for the Feast of All Saints ${ }^{2}$, on the Beatitudes ${ }^{3}$, Judgment and Resurrection ${ }^{4}$.

The above is virtually Mr. Haddan's theory of the Latin character of the earliest Church in Britain. A counter theory of its non-Latin and purely Celtic character has been more recently advanced by Mr. Brewer, and supported by the following considerations:-(1) Christianity was not as yet (second and part of third centuries) tolerated by Roman law, and those who under Roman law had just been

Facsimiles of some of their pages are given in The National MSS. of Ireland, part i. plates i-vi; Dublin, 1874. The evidence for a special Seoto-Britannic version is collected in H. and S. i. I 7o- 198 .

Bede says that, through the study of the sacred Scriptures, Latin had become ' a common language for the Angles, Britons, Picts, and Irish ;' Hist. Eccl. lib. i. cap. I. There are traces of the use of Greek. Greek words are introduced into the Hymnus Sancti Comgilli, and in the Antiphon. Benchor. (ch. iii. §II). Occasional Graecisms occur in Adamnan's Life of Columba, and in the writings of other early Irish saints. Examples of Hiberno-Greek characters are given in Keller's Bilder, \&c., plates xii, xiii. In the Book of Armagh Greek characters occur frequently, e.g. in the Gospel of St. Matthew, where the Latin text of the Lord's Prayer is written in Greek letters. The same is also found in Codex A, an èghth-century Irish MS. Vita S. Columbae, by Adamnan, of which a facsimile is given in Reeve's edit. plate 3. The colophon at the end of the Second Book is likewise in Greek. Ib. Preface, p. xiv; see pp. 158,354. There is a story extant of St. Brendan finding a Missal written in Greek characters in the Welsh monastery of St. Gildas: ' Et habebat Sanctus Gylldas missalem librum scriptum Graecis litteris, et possitus est ille liber super altare. Et custos templi ex iussione saneti Gilldae dixit sancto Brendano ; vir Dei, praecipit tibi sanctus senex noster ut offeras corpus Christi ; ecce altare hic et librum Graecis litteris scriptum et canta in eo sicut abbas noster. Aperiensque sanctus Brendanus librum ait: Demonstra michi Domine ihesu istas litteras ignotas sicut aperuisti ostia clausa ante nos. Profecto possibilia sunt omnia credenti. Ilico iam litteras grecas sciuit sanctus Brendanus sicuti Latinas quas didicit ab infancia.' Vita S. Brendani, cap. $x v$, in the Liber Kilkenniensis.

1 p. 1004 . 2 Leabhar Breac, fol. 187 a.

3 In Bodl. MS. Laud 6ro, twelfth century.

* In the Leabhar na h-Uidre, eleventh century. 
trampled upon would hardly seek Romans for the materials of a Church. (2) Tertullian's words imply that Christians were numerous where the Roman arms had not reached: 'Britannorum inaccessa Romanis loca Christo vero subdita?.' (3) The founders of the British Church had come from Celtic districts of Gaul ; in many instances they themselves probably were Celts, or mixed Celts, and therefore mostly attracted to the Celtic blood of Britain. (4) The subsequent history, which must have sprung from these beginnings, is the history of a Celtic Church, the Roman architecture of existing remains proving no more than that when Britons built churches they built as those great builders the Romans taught them ${ }^{2}$.

It may be concluded that both elements, the Latin and the Celtic, coexisted in the British Church of the third and fourth centuries, but exactly how far this composite character affected its Liturgy there is no documentary evidence, and it is a chimera to expect that there ever will be such evidence forthcoming to show.

The Roman Canon of the Mass seems certainly, but not universally, to have been introduced into the Irish portion of the Celtic Church in the course of the ninth century. This is proved by its presence in the earliest extant Irish Missal, where it is largely intermingled with fragments of an earlier pre-Roman Use ${ }^{3}$. There are signs of local friendly intercourse beginning to grow up between the Irish and Anglo-Saxon Churches about this time, and of the spread of Anglo-Saxon influence in the former Church. Among such signs are the introduction of the names of the second, third, and fourth archbishops of Canterbury among the Irish saints commemorated in the Canon of the Mass ${ }^{4}$, although the appeal of one of them (Laurence) to the Irish bishops to conform to Roman usage in the seventh century had been ineffectual $^{5}$. We may also notice the reference to Roman authority in early Irish canons (late seventh and eighth centuries),

1 H. \& S. i. 3 .

3 Stowe Missal, \$ 14 . See $\$ 8$.

${ }^{2}$ Quarterly Review, No. 294. p. 519.

${ }^{4}$ p. 239.

${ }^{5}$ p. 40. 
where such expressions abound as 'Synodus Romana' or 'Romani dicunt,' ' Regula Canonica dicit Romana,' 'Disputatio Romana,' 'Institutio Romana.' Extracts from Greek, African, and even native early Irish conciliar decrees are sometimes erroneously quoted under the above headings. But the earliest extant MS. copies of these canons vary between the ninth and eleventh centuries, when the desire of assimilation to Rome, the habit of referring to Roman authority, and the spread of Roman influence had become strong and more wide-spread.

\section{§ 2. Cornish Fraguent-Missa S. Germani.}

The following fragment of an ancient Cornish Liturgy was written in the ninth century on fol. 1 of a MS. in the Bodleian Library, No. 572. It was composed after the Cornish Church had fallen under Anglo-Saxon influence, and has no claim to be considered as a genuine Celtic Missa either in form or substance.

\section{Missa Propria Germani Episcopi.}

Fol. 1. Deus ${ }^{I}$, qui famulantibus tibi mentis et corporis subsidia misericorditer largiris, presta quesumus ut bi qui pro amore supernę patriae ardenter cęlestia premia per fidem et spem caritatemque adipisci cupiunt, intercedente beato archimandrita $^{2}$ confessore tuo germano ${ }^{3}$, ab omnibus iniquitatibus liberentur per dominum.

$$
\text { et item alia. }
$$

Propitiare, domine deus, omni populo christiano ex diversis partibus linguarum conuenienti in unum, ut hi qui locum

1 The first thirteen words of this collect occur in Sacram. Gregor. p. 230.

2 Archimandrita is often used, as in the text, for 'Prelate' in mediaeval non-Liturgical writings; Alcuin, Ep. 72, \&c. (see Du Cange, Gloss.) There is a Vita de S. Theodoro Archimandrita, Surins, tom. ii. p. 727.

${ }^{3}$ A Gallican Missa S. Germani records in its Proper Preface how 'hic tuus devotissimus Germanus episcopus Tartarum eorum [ = Auturicorum] restigiis subsecutus, per totas Gallias, inectalia [ = in Italia] Roma, in Brettania annis triginta corpore adflictus Janius [ = jejuniis] jugiter in tuo nomine praedicavit, haereses abstulit, adduxit populum ad plenan et integram fidem,' \&c. Missale Gallicanum, p. 153 . 
preclarum atque notum ubique lannaledensem ${ }^{\mathbf{1}}$ ubi reliquię germani episcopi conduntur, quanto ardensius tanto cicius uisitare cupiunt ab omnibus infirmitatibus anime et corporis fideliter liberentur. Per.

\section{Secreta.}

Concede nobis, omnipotens et misericors deus, ut haec $\mathrm{n}$ [obis sit] salutifera oblatio, et intercedente beato germano confessorae tuo atque episcopo, a nostris reatibus liberet, et a cunctis tueatur aduersitatibus. Per dominum ${ }^{2}$.

\section{[Praefatio.]}

$\mathrm{U}[\mathrm{ere}] \mathrm{D}[\mathrm{ignum}]$ eterne deus. Et te laudare mirabilem dominum in sanctis tuis, quos ante constitutionem mundi in aeternam tibi gloriam preparasti, ut per eos huic mundo ueritatis tue lumen ostenderes, de quorum collegio iste germanus episcopus, a sancto gregorio romane urbis apostolico ad nos missus ${ }^{3}$, lucerna et columna cornubiae et preco veritatis efulsit, qui in lannaledensis aeclesiae tuae prato sicut rosae et lilia floruit, et tenebras infidelitatis quae obcecabant corda et sensus nostros detersit. Propterea suppliciter atque lacrimabiliter deprecamur totis uiribus claementiam tuam, ut licet meritis non exsigentibus misereri tamen nostri semper digneris, quia priscis temporibus legimus te irasci magis quam misereri, propter uesaniam dementiamque imp[ii] et crudelis regis guortherni ${ }^{4}$.

1 The date and character of this fragment are indicated by this preservation of the old British but otherwise unknown name of Llanaledh for St. Germans. There was a monasterium Lanaletense [ $=$ of Alet] in Brittany, to which the Pontificale Gemmeticense (tenth century) once belonged; Archaeologia, xxv. 247.

${ }^{2}$ Compare the Secret 'Concede nobis,' \&c. in Sacr. Gelas. pp. 692, 714; Gregor. p. $\mathbf{1}^{2} \mathbf{2}$.

s The ecclesiastical infuence of the neighbouring Saxons so far prevailed when this Missa was composed as to induce its compilers by a violent anachronism to attribute the mission of St. Germanus to Gregory the Great.

- Note this mention of Vortigern and his enormities. The contest between him and St. Germanus is thus described by a ninth-century historian : 'Et super haec omnia mala adjiciens, Guorthigernus accessit filiam suam propriam in uxorem sibi quae peperit ei flium, Hoc autem cum compertum esset a $S$. Germano, venit corripere regem cum omni clero Britonum. Et dum conventa esset magnn synodus clericorum ac laicorum in uno consilio, ipse rex praemonuit filiam suam, ut exiret ad conventum, et ut daret filium suum in sinu Germani, diceretque quod ipse erat pater ejus. Ac ipsa fecit sicut edocts erat. S. Germanus eum benigne accepit; et dicere coepit : Pater tibi ero; nec te permittam, 
Idcirco petemus, obsecramus, deprecamur in his ultimis diebus indulgentiam pietatis tuę, ut per te neniam peccatorum nostrorum mereamur accipere, et post finem huius seculi, te interpellante, cum deo et sanctis eius immaculati conregnare possimus. Et ideo

\section{Postcommunio.}

Sumptis, domine, sacramentis in honore sancti confessoris tui germani episcopi, cuius uenerandam hodię celebramus festiuitatem, nos claementer exaudi tuam misericordiam obsecrantes; ut ab hac ${ }^{1 * * *}$

\section{§ 3. Welsh Fragments. Missa de S. David.}

These so-called Welsh fragments have no real claim to be called Celtic. The oldest, the 'Missa de S. David,' is based upon the Lectiones taken from Ricemarch's Life, and can hardly have been compiled before the Welsh Church had become Normanised or Anglicised.

The following Missa is written by the original scribe in MS. Cott. Vesp. A. xiv, a MS. of the latter part of the twelfth century, after the conclusion of the Life of St. David by Ricemarch. Fol. 69 b.

\section{Missa de Eodem.}

[Oratio.]

Deus, qui beatum confessorem tuum Dauid atque pontificem, angelo nuntiante, Patricio prophetante, triginta annos antequam nasceretur predixisti; quesumus, ut cuius memoriam recolimus, eius intercessione ad eterna gaudia perueniamus, per secula seculorum ${ }^{2}$. Per.

nisi mihi novacula cum fornice pectineque detur, et ad patrem tuum carnalem tibi dare liceat. Mox ut audivit puer, obedivit verbo senioris sancti, et ad avum suum patremque suum carnalem Guorthigernum perrexit, et dixit illi: Pater meus es tu, caput meum tonde, et comam capitis mei pecte. Ille autem siluit, et puero respondere noluit ; sed surrexit iratusque est vehementer, et ut a facie S. Germani fugeret quaerebat : et maledictus est, et damnatus a B. Germano et omni consilio Britonum.' Nennius, Hist. Britonum, cap. xxxix.

1 The fragment breaks off here abruptly at the end of the last line on the verso of fol. $\mathrm{I}$.

2 This collect is written with slight verbal variations in Add. MSS. 5810, 


\section{SeCReTA.}

Hostias laudis et preces deuotionis, quas tibi in honore beati confessoris tui Dauid atque pontificis, omnipotens deus, deferimus, placatus intende; et quod nostrum non optinet meritum, tua clementia et illius pro nobis frequens intercessio efficiat. Per.

\section{Postcommonio.}

Repleti, domine, participatione sacramenti, quesumus, ut sancti Dauid confessoris tui atque pontificis meritis, cuius gloriosam celebramus festiuitatem, ineffabilis misericordie tue patro(ci)nia sentiamus. Per.

\section{\$ 4 a. Welsh Fragments. Oratio de S. Thelyao.}

This collect is written in a fourteenth-century hand on the fly-leaf at the end of the Liber Landavensis, now in the possession of P. B. Davies-Cooke, Esq. of Owston in Yorkshire.

Omnipotens sempiterne deus, qui de beato corpore sancti thelyai confessoris tui atque pontificis tria corpora consecrasti, et per illud miraculum pacem et concordiam inter inimicos reformasti; concede propitius per eius suffragia pietatis tue ueniam consequamur, per dominum nostrum. amen ${ }^{\mathbf{l}}$.

\$ 4 b. Welsh Fragments. Missa de S. Teilao.

This Missa is written in a fifteenth-century hand upon a vacant space at the end of a MS. Sarum Missal in the Cambridge University Library, MS. Add. 451, which belonged formerly to the Hungerford family, who owned property on the marches of Wales.

\section{[Missa] de Sancto Teilao.}

Omnipotens sempiterne deus, virtutum omnium fons et origo, qui per beatum theilaum gloriosissimum confessorem tuum atque pontificem ingentis vipere seuisiam in mare demersisti ; da, quesumus, vt antiqui hostis nequicia superata, diuini a moris igne succensi, pie peticionis consequamur effectum.

fol. 198 a, Brit. Mus., and is printed in the Camden Soc. 1880 , New Ser. xxvi. p. $3^{6}$. It is the collect of the Sarum Breviary, March $\mathbf{~}$.

1 The miracles of St. Teilo commemorated in this collect and in the following collect and Postcommunion will be found in the Liber Landar. pp. 104, 110. 


\section{Secreta.}

Beati theliai confessoris tui atque pontificis supplicacione, munus oblatum, domine, quesumus fiat nobis imperpetuum salutare, per christum dominum.

\section{Postcommunio.}

Quesumus, omnipotens deus, vt meritis reparati sanctissimi confessoris tui atque pontificis theilai, pro quo tue gentis belligere munitiua tria funera mirifice prodidisti, triplici seueritate hostium superata, mereamur indiuidue trinitatis percipere uisionem, per dominum.

\section{§ 5. Scottish Fragment. Book of Deer.}

Dr. Lingard writing in 1844 asserted that we had no means of judging whether the sacrificial service of the Scottish missionaries varied from that of the Roman Church ${ }^{1}$. But since that date a single liturgical fragment has been discovered, belonging to the Celtic period of the Scottish Church, which, though brief, exhibits sufficiently distinctive marks to enable us to answer the question which Dr. Lingard considered insoluble. It is a portion of the Service for the Communion of the Sick written before the year II 30 on a vacant space in the Book of Deer (ff. 28 b, 29a), an early Evangeliarium in the Cambridge University Library ${ }^{2}$. This MS. was published by the Spalding Club, I 869, under the editorship of Dr. J. Stuart. A good account of it is given in the preface to that work. There is a close coincidence between many expressions in the short Eucharistic Office which it contains and those of the Mozarabic and Gallican Missals, and there is a marked deviation from certain invariable features of the Roman Liturgy. Therefore this fragment, short as it is, affords evidence that the Scoto-Pictish Liturgy of the Columban Church in Scotland belonged to the 'Ephesine' and not to the 'Petrine' family of Liturgies. The reasons for this conclusion are given in detail in the following notes. 


\section{BOOK OF DEER.}

\section{ITEM ORATIO ANTE DOMINICAM ORATIONEM.}

Crętor naturarum omnium ${ }^{1}$ deus et parens uniuersarum in celo et interra originum, hás trementis populi tui relegiosas preces exillo inaccessibileis lucis trono tuo ${ }^{2}$ suscipe, et interhiruphín et zaraphin indefessas circumstantium laudes exaudi spei nonambigue precationes ${ }^{3}$.

Pater noster quies usque in finem.

Libera nós, domine, a malo, domine christe ihesu, custodi nos semper inomni opere bona, fons et auctor omnium bonorum deus euacua nos uitiis, et reple nos uirtutibus bonis. per te christe ihesu ${ }^{4}$.

\section{Hisund dubar sacorfaice dau ${ }^{5}$.}

Corpus cum sangine domini nostri ihesu christi sanitas sit tibi in uitam perpetua et salutem ${ }^{6}$.

1 This phrase occurs in the Mozarabic service for the Nativity of St. John the Baptist, of whom it is said, 'Qui nobis naturarum om nium creatorem necdum natus ostendit.' Mis. Moz. 332 c.

${ }^{2}$ Compare the petition, 'Respice nos de excelso throno gloriae tuae.' Mis. Moz. 3 I 2 c.

s The Roman Liturgy, in all its forms, has a fixed introduction, 'Praeceptis salutaribus moniti,' \&ce, and conclusion, 'Libera nos, quaesumus, ab omnibus malis,' \&c.; which never vary. The very fact of there being even a fixed introduction is enough to show a connection in remote times with what is called the Ephesine family. In the Ephesine family, on the other hand, the introduction and embolismus vary with every service. The fact alone would be sufficient to establish a generic difference between the Petrine Liturgy and the Celtic Services preserved here in the Scottish Book of Deer, and in the Irish Books of Dimma, p. 169, Mulling, p. 172, Stowe Missal, § 14, St. Gall MS. I 394, p. I 77 .

4 This embolismus resembles in its wording very closely the forms preserved in the Gallican Liturgies: 'Libera nos a malo, omnipotens Deus, et custodi in bono. Evacua nos vitiis et reple virtutibus,' pp. 33, I44; 'Libera nos, omnipotens Deus, a malis, et constitue nos in bonis ; evacua nos a vitiis et reple virtutibus tuis,' p. 147 ; 'Libera nos a malo, evacua nos vitiis et reple nos virtutibus,' p. I9. 'The last passage is taken from the Mis. Richenovense, the most pure and ancient specimen yet discovered of the Ephesine Liturgy, without any trace of its having been interpolated with Roman collects.

5 Anglice, 'Here give the sacrifice to him.' Mark the use of 'sacrificium " for 'sacramentum.' There is a similar use of it in the Leofric Mis. fol. 324 a ; in a rubric in a ninth-century Pontifical of Prudentius of Troyes, 'Hinc detur sacrificium infirmo ita dicendo, Corpus et sanguis,' \&c. Mart. i. p. 304 ; soe Ch. ii. § 2.

${ }^{6}$ Book of Dimma,p. I 70 ; Book of Mulling, p. I 73; Antiphon. Benchor. p. 192; 
Reffecti christi corpore et sanguine tibi semper dicamus domine. alleluia, alleluia ${ }^{1}$.

Quia satiauit animam inanem, et animam essurientem satiauit bonis ${ }^{2}$. alleluia, alleluia.

Et sacrificent sacrificium laudis et usque exultatione ${ }^{3}$. alleluia, alleluia.

Calicem salutaris accipiam, et nomen domini inuocabo ${ }^{4}$. alleluia, alleluia.

Reffecti christi corpore. alleluia, alleluia ${ }^{1}$.

Laudate dominum omnes gentes ${ }^{5}$. alleluia, alleluia.

Gloria.

Reffecti christi ${ }^{1}$. alleluia, alleluia.

et nunc. Et semper.

Reffecti ${ }^{1}$.

Sacrificate sacrificium iustitiae et sperate indomino ${ }^{6}$.

Deus ${ }^{7}$, tibi gratias agimus per quem, misteria sancta celebrauimus et ate sanctitatis dona deposcimus, miserere nobis, domine, saluator mundi. Qui regnas insecula seculorum, amen.

Finit.

Stowe Missal, p. 224. Both consecrated elements seem to have been administered at once. For evidence as to the prevalence of this custom of intinction in the West between the seventh and twelfth centuries, see Scudamore, W. E., Notit. Eucharist. second edit. p. 705. Compare the formula of joint administration in the Syriac Lit. of St. James, and in the Armenian Lit. (Hammond, C. E., Lit. E. and W. pp. 8I, I65).

1 This formula of thanksgiving, coupled with a thanksgiving collect, as in the Book of Dimma, p. I 7 I, Book of Mulling, p. I 73, Stowe Missal, p. 224, Antiphon. Benchor. p. 192, is a mark of Ephesine origin: 'Refecti Christi corpore et sanguine te laudamus, Domine, Alleluia, alleluia, alleluia.' Mis. Moz. $45^{2}$ A. The Gloria Patri forms part of the Mozar. Ant. ad Accedentes, pp. 343,377 .

2 Ps. cri. 9; Stowe Missal, p. 224 .

3 Ps. cvi. 22 ; Book of Mulling, p. 173.

4 Ps. exv. 13; Book of Dimma, p. I70; Book of Mulling, p. I73; Stowe Missal, p. 225.

5 Ps. cxvi; Book of Dimma,p. 171 ; Book of Mulling, p. I 73; Stowe Missal,p. 225.

${ }^{6}$ Ps. iv. I6; Book of Dimma, p. I7I ; Book of Mulling, p. I73; Stowe Missal. p. 225.

7 This collect, occurring also in the Books of Dimma (p. I7 I), Mulling (p. I 73), and Stowe Missal (p. 225), appears twice in a nearly similar form in the Missale Gothicum: 'Deus, gratias tibi agimus per quem mysteria sancta celebramus; a te quoque sanctitatis et misericordiae dona deposcimus. Per.' pp. 144, 150. It is not found in any of the Roman Sacramentaries. 
The same MS. contains at the close of the volume, and in the bandwriting of the original scribe, the Apostles' Creed, which runs as follows:-

Fol. 85. a. Credo indeum patrem omni potentem, creatorem cẹli et terre. Et inhesum christum filium eius, unicum dominum nostrum, qui conceptus est de spiritu sancto, natus ex maria uirgine, passus sub pontio pylato, crucifixus etsepultus. Discendit ad inferna. Tertia die resurrexit amortuis, ascendit in celum, sedit addexteram dei patris omni potentis, inde uenturus est iudicare niuos et mortuos. Credo et inspiritum sanctum, sanctamque aeclisiam catholicam, sanctorum communionem, remissionem peccatorum, carnis resurrectionis, nitam eternam. amen ${ }^{1}$.

Immediately below this Creed the scribe has written a rhyming couplet in his own language.

No other MS. liturgical remains known to exist in Scotland are connected with the Scoto-Celtic Church.

(I) The Arbuthnott Missal [Liber Ecclesiae beati Terrenani de Arbuthnott] is a Sarum Missal with certain Scottish additions and modifications, written in 1491 by an ecclesiastic named Sybbald, Vicar of Arbuthnot. It was printed at the Pitsligo Press, 1864, under the editorship of the late Bishop of Brechin (A. P. Forbes), and bis brother the Rev. G. H. Forbes.

(2) The Celtic Kalendar printed by Bishop Forbes (Kalendar of Scottish Saints, pp. 79-92) is a late and unimportant document. The Antiquae Litaniae published in the same work (Appendix to Preface, No. iii. pp. lvi-lxv; H. \& S. ii. i. 278) belong in their present form to the sixteenth century, though they may contain portions of a genuine earlier Culdee document.

(3) The Drummond and Rosslyn Missals will be referred to hereafter in connection with the Irish Church ${ }^{2}$.

1 Other early forms of the Creed are giren in Antiphon. Benchor. p. 189; Stowe Missal, p. 23 I.

${ }^{2} \S 15$. 


\section{§ 6. Irish Fragments. Book of Dimma.}

The following 'Missa de Infirmis' is written between the Gospels of St. Luke and St. John on ff. 52-54 of the 'Book of Dimma,' a Book of the Gospels, preserved in the Library of Trinity College, Dublin ${ }^{1}$. The writer having been identified with one Dimma, who lived in the middle of the seventh century, the MS. has on that account been attributed to that date.

The remarks in the Notes appended to the 'Missa de Infirmis' in the Scottish 'Book of Deer ',' proving its Ephesine character, apply equally to the Missae which have survived in the ancient Irish Books of Dimma and Mulling, and in the Stowe Missal. Additional indications of the same connection are noted below.

\section{Extract from the Book of Dimma.}

Oremus, fratres ${ }^{3}$, dominum deum nostrum pro fratre nostro .n. quem duri adpresens malum langoris adulcerat, ut eum domini pietas caelestibus dignetur curare medicínís; qui dedit animam det etsalutem, perdominum nostrum.

Deum ${ }^{4}$ uiuum omnipotentem, cui omnia opera restaurare [et] confirmare facillimum est, fratres carissimi ${ }^{3}$, profratre nostro infirmo supliciter oremus, quo creatura manum sentiat creatoris aut inreparando aut inrecipiendo; inlomine suo pius pater opus suum recreare dignetur, perdominum nostrum.

Domine ${ }^{5}$, sancte pater, uniuersitatis auctor ${ }^{6}$, omnipotens aeternae deus, cui cuncta uiuunt, qui uiuificas mortuos et uocas

A. $4 \cdot 23$.

${ }^{2}$ p. 164.

3 These addresses to the people, or 'biddings,' called 'Prefaces' in the Gallican Liturgies, are a distinct mark of Ephesine origin. The Roman Liturgy, which consists almost exclusively of collects addressed to God, nevertheless retains still in the Good Friday service a remnant of the Ephesine character, which was no doubt eschewed by the Italian, as much as it was cultivated by the Gallican branches of the Church. See Stowe Missal, p. 22I (note 2), where these two addresses occur again verbatim, together with some of the following collects and lections. This address also occurs in a tenth-century German Ritual, Gerbert, Lit. Al. ii. 33.
4 Stowe Missal, p. 22 I.
$5 \mathrm{Ib}$.
6. 271, n. 1 . 
ea quae non sunt, tanquam ea quae sunt, tuum solitum opus, qui es artifex, pie exerce in hoc plasmate ${ }^{1}$ tuo, perdominum.

Deum $^{2}$ in cuius manu tam alitus uiuentis quam uita morientis, fratres dilectissimi ${ }^{3}$, deprecemur, ut corporis huius infirmitatem sanet et animae salutem prestet; ut quod per meritum non meretur, misericordiae gratia consequatur, orantibus nobis, perdominum.

Deus $^{4}$, qui non uís mortem peccatoris, sed ut conuertatur et uiuat $^{5}$, huic adte excorde conuerso peccata dimite, et perennis uitae tribu[e] gratiam, perdominum.

Deus $^{6}$, qui facturam tuam pio semper do[mi]nares afectu, inclina aurem tuam suplicantibus nobis tibi; ad famulum tuum .n. aduersitate ualitudinis corporis laborantem placitus respice; uisita eum insalutare tuo, et caelestis gratiae ad medicamentum, per dominum.

\section{LECTIO APOSTOLI AD CORINTHEOS.}

Sí in hacuita tantum in christo sperantes sumus misserabiliores sumus omnibus hominibus. Nunc hautem christus resurrexit a mortuis, primitiae dormientium : quoniam quidem per hominem mors, et per hominem resurectio mortuorum ; et sicut in adam omnes moriuntur, ita ${ }^{7}$ in christo omnes uiuificabuntur ${ }^{8}$.

1 The word 'plasma' is not found in the Roman, but is frequently used in the Mozarabic and Gallican Liturgies; as in the exorcismus in the Ordo Baptismi in Sacram. Gall., Mab. edit. p. 324 ; Mis. Mozar. p. $3 \mathrm{~J} 4$; also in a collect in Anglo-Saxon Missal of Leofric (Surtees Soc. lxi. p. 348). It also occurs in this same collect in the Stowe Missal, p. 220. It is interesting to find it in the hymn assigned for the first Vespers, 'In natali unius Apostoli,' in the Sarum Breviary, 'Salva, Redemptor, plasma tuum nobile' (line 5), of which Daniel says, 'Videtur carnien Galliae et Angliae fuisse proprium.' Thes. Hymnol. i. 273.

2 Stowe Missal, p. 221.

${ }^{3}$ See p. 167 , note 3 .

4 Stowe Missal, p. 222, q.v.

5 ' Rex gloriae qui non vis mortem peccatoris, sed ut convertatur et vivat,' Miss. Goth. p. 93 .

6 Stowe Missal, p. 222 ; Corpus Mis. p. 207; Gerbert, Lit. Aleman. ii. 29, 37. This collect occurs almost verbatim in an old Ritual of St. Benedict of Fleury, given in Martene de Rit. Antiq. iii. p. 377, and very nearly in its present form in the Breviarium Gothicum; Migne's edit. p. 974. Sac. Gelas. p. 735, Gregor. p. 2 II.

$7 \mathrm{~V} .+$ et.

8 I Cor. xv, 19-22. For this lection the Stowe Missal (p. 222) substitutes Matt. xxiv. 29-3I. 
In illo die accesserunt ad eum saducei qui dicunt non esse resurrectionem, et interrogauerunt eum. Respondens hautem ihesus ait illis; erratis nescientes scripturas neque uirtutem dei. In resurrectione enim neque nubent neque nubentur, sed erunt sicut angueli ${ }^{1}$ in caelo. De resurrectione bautem mortuorum non legistis quod dictum est a deo, dicente uobis; Ego sum deus abraam ${ }^{2}$, deus isac, ${ }^{3}$ deus iacob? non ${ }^{4}$ deus mortuorum sed uiuentium ${ }^{5}$. Audientes turbae admirabautur ${ }^{6}$ in doctrinam ${ }^{7}$ eius $^{8}$.

Diuino magisterio edocti, et diuina institutione formati, audemus dicire ${ }^{9}$.

Credo in deum patrem omnipotentem;

Credo et in ihesum christum filium ejus;

Credo et in spiritum sanctum;

Credo uitam post mortem;

Credo me resurgere.

Ungo te deoleo sanctificato in nomine trinitatis, ut salueris in saecula saeculorum ${ }^{10}$.

Concede nobis famulis tuis ut orantes cum fiducia dicire mereamur ${ }^{11}$ Pater noster.

Infirmus canit si potest; si non, persona eius canit sacerdos. Agnosce, domine, uerba quae precipisti; ignosce presumpsioni quam imperasti ; ignorantia est nobis, non agno-

1 V. + Dei.

$5 \mathrm{~V} .+$ et.

2 V. Abraham + et. $6 \mathrm{~V}$. mirabantur. s $\nabla .+$ et.

8 Matt. xxii. 23-33. This passage also forms one of the lections in the Stowe Missal, p. 222.

9 'Divino magisterio edocti et divina institutione formati audemus dicere. Pater.' Miss. Gall. p. 74. Nowhere, except here, has this or any sinilar Preface been found to introduce the Creed. Compare Stowe Missal, p. 242. n. $x_{5}$ o. The Credos are written continuously in the original MS.

10 Book of Mulling, p. x72 ; Stowe Missal, p. 223.

11 Stowe Missal, p. 223. This is an old Gallican preface to the Pater Noster. 'Concede, Domine, famulis tuis; ut orantes cum fiducia dicamus, sicut.' Mis. Gall. p. 144. Very similar forms of preface will be found in Mis. Gall. pp. 46, 60,66 ; Mis. Moz. $\S 18$. line $12 ; \S 66$, ad finem; $\S 74$. line $65 ; \S 243,3$; $\S 249,3 \mathrm{r} ; \S 333,63 ; \S 447,42 ; \S 263, x 8 ; \S 28 \mathrm{r}, 37 ; \S 330,6 ; \S 464,75$. It occura verbatim together with the following embolismus (Libera, \&c.) in a Constantinopolitan Pontifical ; Mart. ordo xxi. vol. i. p. 333 . 
scere meritum; contumacie non seruare preceptum, quo iubemur dicere ${ }^{1}$ Pater noster.

Libera nos, domine, ab omni malo, et custodia nos semper in omni bono, christe ihesu, auctor omnium bonorum, qui regnas in saecula ${ }^{2}$.

Páx et caritás domini nostri ihesu christi sit semper nobiscum ${ }^{3}$.

Hic pax datur ei, et dicis.

Pax et commonicatio sanctorum tuorum, christe ihesu, sit semper nobiscum ${ }^{3}$.

Respondit, Amén.

Dás ei euchari[s]tiam dicens,

Corpus et sanguis domini nostri ihesu christi filii dei uiui conseruat animam tuam in uitam perpetuam ${ }^{5}$.

Post adsumptum ait,

Agimus deo patri omnipotenti gratias quod terr[en]ae nos originis atque naturae, sacramenti sui dono in celestem uiuificauerit demotationem ${ }^{6}$.

\section{Item oratio.}

Ostende $^{7}$ nobis, domine, missericordiam.

Conuerte $^{8}$ nos deus salutum nostrarum, et firmare presta salutem nostrorum; qui regnas in saecula saeculorum.

Alleluia. Calicem salutaris usque inuocabo ${ }^{9}$.

1 'Agnosce, Domine, verba quae praecepisti; ignosce praesumptioni quam imperâsti; ignorantia est nobis non agnoscere meritum; contumacia non servare praeceptum, quo jubemur dicere, Pater noster.' Mis. Gall. pp. I 50, 153.

2 Book of Deer, p. 164. n. 4 .

${ }^{3}$ For similar forms of words to be used at the bestowal of the Pax, see Stowe Missal, pp. 224, 242 ; St. Gall. MS. 1394, p. 177.

* This is the Roman position of the Pax, which is placed before the Canon in the Ephesine Liturgy ; but as the Canon would not be repeated at all in the case of communicating a person from the reserved gifts, no argument can be based upon this circumstance; but the same position is assigned to the $\mathrm{Pax}$ in the St. Gall. MS. No. 1394 (p. 1 77), and in the Stowe Missal (p. 242), neither of which is a private Office 'ad communicandum infirmum.'

${ }_{5}^{5}$ Book of Deer, p. 164. n. $6 . \quad{ }^{6}$ Ib. p. $16_{5}$; Stowe Missal, p. 243.

7 Ps. Ixxxiv. 8; Stowe Missal, pp. $220,232$.

8 Adapted from Ps. lxxxiv. 5 ; Stowe Missal, p. 24.

Ps. cxv. 13; Book of Deer, p. 165; Book of Mulling, p. I 73; Stowe Missal, p. 225. 
Alleluia. Fortitudo mea usque in salutem'.

Alleluia. Refecti christi corpore et sanguine, tibi semper dicamus ${ }^{2}$.

Alleluia. Laudate dominum omnes gentes ${ }^{3}$ usque in finem. Alleluia. Sacrificate sacrificium iustitiae usque in domino ${ }^{4}$.

$$
\text { Tunc signas et dicis }{ }^{5} \text {, }
$$

Pax tecum. Benedicat tibi dominus, et custodiat té, conseruat uultum tuum ad té, ut det tibi pacem ${ }^{6}$.

\section{Respondit.}

Deus, tibi gratias agimus per quem ministeria sancta celebramus, et ate dona sanctitatis deposcimus, qui regnas in saecula ${ }^{7}$.

\section{\& 7. Irish Fragments. Book of Mulling.}

The following 'Missa de Infirmis' is written in a ninthcentury hand at the end of St. Matthew's Gospel in the Book of Mulling, containing the entry 'nomen seriptoris Mulling,' and therefore ascribed to Mulling Bishop of Ferns, who died A.D. 697. It is now in the Library of Trinity College, Dublin.

\section{Oratio communis pro infirmo incipit.}

Oremus, fratres carissimi ${ }^{8}$, pro spiritu cari nostri .n. qui secundum carnem egritudinem patitur, ut dominus ei reuelationem dolorum presentet, uitam concedat, tutellam salutis remunerationem bonorum operum impertiat, per dominum.

Prefatio ${ }^{9}$ communis incipit.

Oremus, fratres carissimi ${ }^{8}$, pro fratre nostro .n. qui in-

1 Ps. cxvii. 14 ; Stowe Missal, p. 225.

${ }^{2}$ See p. 165. n. I.

3 Ps. cxvi ; Book ofDeer, p. I65 ; Book of Mulling, p. 173 ; Stowe Missal, p. 25.

- Ps.iv. I6 ; Book of Deer, p. 165 ; Book of Mulling, p. 173 ; Stowe Missal, p. 25.

5 The sign of the cross is also directed to be made at the conclusion of the Office for Unction in the Stowe Missal, p. 225.

6 This blessing is given in an amplified form in Stowe Missal, p. 225; Book of Mulling, p. I 72 .

7 Book of Deer, p. 165. n. 7 .

${ }^{8}$ Book of Dimma, p. I67. note 3 .

- This use of the word 'Praefatio' for a short exhortation to the people is peculiar to and common in the old Gallican Liturgies. 
commodo carnis et egretudine uexatur, ut domini pietas per angelnm medicinę celestis uisitare et corroborare dignetur, per dominum.

[pate]r omnipotens, et conserua famulum tuum hunc .n. quem [sancti]ficasti et redemisti pre[tio] magno sancti sanguinis tui, in secula seculorum.

Benedictio super aquaM.

Oremus et postulemus de domini missericordia, ut celesti spiritu hunc fontem benedicere et sanctificare dignetur, per dominum.

\section{Benedictio hominis.}

Benedicat ${ }^{1}$ tibi dominus et custodiat te ; illuminet $^{2}$ domi- $^{-}$ nus faciem suam super ${ }^{3}$ te ${ }^{4}$ et misseriatur tui, conuertatque ${ }^{5}$ dominus uultum suum adte, et det tibi pacem et ${ }^{3}$ sanitatem $^{3}$. Misserere n. d. a.

Tum unges eum oleo.

Unguo $^{6}$ te deoleo sanctificationis in nomine dei patris, et filii, et spiritus sancti, ut saluus eris in nomine sanctę trinitatis.

\section{Simul canit.}

Credo in deum patrem.

Tum dicitur ei ut dimittat omnia.

Collectio orationis dominicae.

Creator naturarum omnium ${ }^{7}$, deus, et pariens uniuersarum in celo et interra originum has trinitatis populi tui relegiosas preces ex illo inaccesse lucis throno tuo suscipe, et inter hiruphin et saraph[in i]n-deffessas circu[m] st[an]tium laudes exaudi spei non ambi[gue] precationes.

$\mathbf{P}[$ ater $]$ noster.

Collectio nunc sequitur.

Libera nos a malo, domine christe ihesu, et custodies nos in

1 Num. vi. 24-26; Book of Dimma, p. 171 .

s V.om.

\&. tibi.

6 Book of Dimma, p. 169.
${ }^{2}$ V. ostendet.

5 V. om. que.

${ }^{7}$ Book of Deer, p. 164 . 
omni opere bono, auctor omnium bonorum, manens et regnans in saecula saeculorum ${ }^{1}$, amen.

Tum reficitur corpore et sanguine ${ }^{2}$.

Corpus cum sanguine domini nostri ihesu christi sanitas sit tibi in uitam ęternam.

Oratio post sumptam euchari[s]tiam.

Custodi intra nos, domine, glorię tuę munus, ut aduersus omnia presentis saeculi mala euchari[s]tiae quam percipimus uiribus muniamur ${ }^{3}$; per dominum.

Alleluia.

Et sacrificent sacrificium laudis usque annuntiant opera eius in exultatione ${ }^{4}$, alleluia.

Calicem salutaris accipiam et nomen domini inuocabo ${ }^{5}$.

Reffecti christi corpore et sanguine, tibi semper, domine, dicamus, alleluia ${ }^{6}$.

Laudate dominum omnes?

Glo[ria patri].

Sacrificate sacrificium iustitię et sperate in domino ${ }^{8}$.

Deus ${ }^{9}$, tibi gratias agimus, per quem misteria sancta celebrauimus, et ate sanctitatis dona deposcimus, per dominum nostrum ihesum christum filium taum, cui gloria in saecula saeculorum.

§ 8. Irish Fragments. Book of Armagh.

The following extracts are from the Book of Armagh, a New Testament with Latin and Irish additions, written in A.D. 807 by Ferdomnach, a scribe of that city, now in the Library of Trinity College, Dublin.

${ }^{1}$ Book of Deer, p. 164 .

3 'Custodi intra nos, Domine, gloriae tuae munus, ut contra omnia praesentis saeculi macula eucharistiae viribus quam accepimus muniamur.' Mis. Goth. p. $\mathbf{1 4}_{4} 6$.

4 Ps. cvi. 22 ; Book of Deer, p. 165.

5 Ps.cxv. 13 ; Book of Deer, p. 165; Book of Dimma, p. 1 70; Stowe Missal, p. 25.

- Book of Deer, p. 165 .

7 Ps. exvi; Book of Deer, p. 165; Book of Dimma, p. I 7 I ; Stowe Missal, p. 225.

${ }^{8}$ Ps.iv. 16 ; Book of Deer, p. $16_{5}$; Book of Dimma, p. 17 ; Stowe Missal, p. 25.

Book of Deer, p. 165; Book of Dimma, p. 171. 
Hanc igitur oblationem seruitutis nostrae sed et cunctae familiae tuae quesumus domine ut placatus accipias + diesque nostros in tua pace disponas atque ab aeterna dampnatione nos eripi et in electorum tuorum iubeas grege numerari, per christum dominum nostrum.

Lib. Armacan. fol. 19 a.

These lines, containing a portion of the Roman Canon, with the words 'diesque nostros,' \&c. said to have been inserted by St. Gregory, are interesting as proving that the Roman Canon in its Gregorian form was known in Armagh early in the ninth century.

The following collect is written at the end of St. Matthew's Gospel. Though intended for private rather than liturgical use, it may be added here for the sake of comparison with the Anglican Collect for St. Mattherw's Day :-

Deus, inmensae clementiae atque ineffabilis pietatis, submissa uoce rogare presumo, ut quomodo ex puplicano matteum preclarum apostolum fecisti, ita per missericordiam tuam arcessere me digneris adperfectam in hoc saeculo uiam, atque anguelicis hierusalem caelestis choris collocare, ut perpetuo solio infinitae laetitiae ymnidicis archanguelorum laudibus conlaudare te merear, per unigenitum filium tuum, qui tecum uiuit in unitate spiritus sancti, per omnia saecula saeculorum. Amen.

Lib. Armacan, fol. $5^{2}$ b.

§ 9. Irish Fragments. St. Gall MS. I394.

At St. Gall there is the following fragment of an Irish Sacramentary, supposed to be written in the ninth century, and now forming one of a collection of fragments marked MS. 1394. A facsimile of the original was sent from St. Gall to Mr. C. Purton Cooper, and was printed by him ${ }^{1}$ :-

1 Appendix A to (intended) Report on Rymer's Foedera, p. 95. There is mention made of a 'Missalis' among the 'Libri Scottice scripti' in a ninth- 
petimus omnipotens deus nost[er ... $]^{1}$

placatus accipere $\mathrm{p}$ [er Dominum]

Deus qui unigenito tuo not[am (=vam)] creaturam nos tibi esse fecisti respice in [opera misericordiae] tuae et ab omnibus nós maçllis vetustatis emunda] ut per auxilium gratiae tuae [in illius invenianur] forma in qua tecum [est nostra substantia. per] ${ }^{2}$

IN tuis tibi domine gratias ...

primordis quibus sub ... hodie fructus offerimu[s] ...

Uere dignum et iustum es[t. Qui ut nos a servitute] gravi legis eximeret le[galis circumcisionis] natur purgationis in qua [et observationis antiquae] probatur existeret, et hum[anam in se naturam vetus-] tate expoliens ut inuocanti [praeteriti sacramentorum con] sumator misteri idemque be [=le-gislator et custos precipie $]$ ns et obediens diues in su[o pauper in nostro par tur-] torum aut do̊s pullůs co[lumbarum sacrificio vix] subffecit coeli terraeq[ue possessori grandaevi $\mathrm{Sy}-$ ] meonis inualidis gastati [= gestatur manibus a quo mundi] rector et domini predicator $[=\mathrm{d} \overline{\mathrm{n}} \mathrm{s}$ predicatur accedit etiam testificantis ora-]

century catalogue of MSS. in the monastery of st. Gall. This Missal has been lost, but it is possible that this fragment is a portion of it (Keller, F., Bilder und Schriftziuge, p. 6I). In Haenel's Catalogus Librorum MSS. Monasterii B.V.M. Rhenoviensis (p. 734) there is this entry: 'Missale antiquissimum Saec. viii. Hoc Missale ab aliquo Scoto scriptum S. Fintanus noster, ex Scotia oriundus, forsan vel ipsemet scripsit, vel scriptum secum in monasterium nostrum Rhenoviense attulit' (Pertz, Archiv der Gesellschaft für ältere deutsche Geschichtkunde, vii. I82). No trace of this Missal can be found, and the notice is now believed to be due to some mistake on the part of the compiler of the Catalogue (Keller, ut supr., p. 94). Professor Westwood has searched for such a volume in vain at Rheinau, Zurich, Carlsiuhe, \&c.

1 Letters and words in brackets have been supplied conjecturally. The original rubrics are written continuously with, and in the same handwriting as, the rest of the text. Contracted and abbreviated words have been written at length. $A l$, all, alle are the various abbreviations used for alleluia here and in other Irish fragments.

${ }^{2}$ This collect occurs in Gerbert, Liturg. Aleman. i. I4, for the Festival of the Circumcision, Kl. Jan. in octava Domini. Sacram. Gelas. p. 500. 
culum uiduae quoniam dicebat $[=$ decebat ut ab utroque adnunciaretur sexu utriusque salvator] et ideo cum angelis [et arch $] \mathrm{an}\left[\right.$ gelis $^{1}{ }^{1} \ldots$

Participes a diabulici(o) co[nvivio jubes abstinere] aeterne deus qui tuae mens[ae]. ${ }^{2}$ da quaesumus plebi tuae ut gu[stu mortiferae pro] sanitatis abiecto puris [mentibus ad epulas] aeternae salutis accedant $[\text { per. }]^{3}$

ut salutare tuum no[va coelorum luce] [Concede nobis] omnipotens deus et misericors ${ }^{2}$ mirabili quod ad salutem [mundi hodierna] uirtute processit nostris sem[per innovandis] cordibus innovatur. per dominum ${ }^{4}$.

[Coelesti lumine quaesumus Domine] semper et ubique nos $\mathrm{p}$ [raeveni ut mysterium] [cuju]s nos participes esse uo[luisti et puro cernamus] intuitu et digno particip [= percipiamus effectu per] dominum nostrum ${ }^{5}$

... enus ad [altare] . . me per christum dominum [nostrum ... nen ... sce] nos stella christi ante dominum

deum de . . . editum deum nostrum . . . ut [a]perti[s thesauris . . laetus suscipe . . in illa] [munera mistica... dispensat $\left.{ }^{6}\right] \ldots$

P ... [mun]demus ${ }^{7}$ conscientias nost $[\mathrm{r}]$ as ab omni labe uitiorum ut nihil sit in [nobis subdolum vel] superbum, sed in

1 Gerbert, Liturg. Aleman. i. 14 ; Mis. Ambros. in Pamel. Liturg. i. $3^{1} 2$.

2 This line and the previous line ought to be transposed.

s Sacr. Leon. p. 301 ; Gelas. p. 50I. The references in this collect are to the 'Missa de prohibendo ab Idolis' formerly appointed for Jan. $r$.

'Sacr. Gregor. pp. I1, 17. Read 'festivitate' for 'virtute,' 'oriatur' for 'innovatur.'

${ }^{5}$ This collect occurs in the Benedictio Thymiamatis in Sabbato Sancto, Sarum Missal, p. 336. Sacr. Gelas. p. $5 \circ 3$; Gregor. p. 78.

- Report on Foedera, App. A, plate xxviii.

7 Ib. plate xxix. 
humilitatis studium et $c[a]$ ritatis pen [sum et] sanguinem dominici corporis fraternitas uincta copuletur ... dicere :-

Diuino magisterio edocti et diuina institutione formati audiemus dicere ${ }^{1}$, Pater nost[er] Lib[era] nos, domine, ab omni malo praeterito prae[scnti] et futuro, et intercedentibus pro nobis be[atis a]postolis tuis petro et paulo et patricio [episcopo] da propitius pacem tuam in diebus nostris [ut op] missericordiae tuae adiuti et a peccatis $\mathrm{s}$ [empe]r simus liberi et ab omni perturbatione securi ... per dominum ${ }^{2}$.

[Sacerdos] tenens sancta in manibus signat calicem cruce, et hic pax datur ${ }^{3}$ et dicit sacerdos.

$\mathrm{P}[\mathrm{a}] \mathrm{x}$ et caritas domini et commonicatio sanctorum omni $[\mathrm{u}] \mathrm{m}$ sit semper uobiscum 4 . populus respondit. .

Et cu[m spiritu] tuo

etmittit sacerdos sancta in calicem, et dat sibi populas $p[a]$ cem, [atque commo]nicant, et iuxta commonionem canitur . .

Pacem meam do uobis, [meam pa]cem relinquo uobis ${ }^{5}$. alleluia. Dominus reget $\mathrm{me}^{6}$

Qui manducat corp[us meum et bi]bit meum sanguinem. alleluia.

ipse in me manet et ego in illo? alleluia.

[Hic est] panis uiuus qui de coelo discendit ${ }^{8}$. alleluia. Qui manducat [ex eo viuet in et] ernum ${ }^{9}$. alleluia.

1 Book of Deer, p. 164 ; Stowe Missal, p. $24^{2}$.

2 This embolismus after, as well as the introduction to, the Pater Noster show strong traces of Latin influence. They approximate to without being identical with the Roman form. The same wording occurs in the Stowe Missal, p. $24^{2}$. Compare Book of Deer, p. 164. n. 4.

3 For this position of the Pax see Book of Dimma, p. I70. n. 3 .

- Book of Dimma, p. 170.

5 St. John xiv. 27. The whole of this anthem [pacem-meus alleluia] occurs in an extended form in the Stowe Missal, q. v. p. 242. Many of its expressions imply (perhaps simultaneous) communion in both kinds.

6 Pв. xxii. I. Stowe Missal, p. 242.

7 St. John vi. 57. Stowe Missal, p. 242.

B St. John vi. 59. Stowe Missal, p. 243 ; Antiphon. Benchor. p. 192.

- St. John vi. I 5. Stowe Missal, p. 243. 
Ad te, Domine, leuaui ${ }^{1}$.

Uenite, comedite panem me[um et bibite ui]num quem $\operatorname{misc}$ [ui] uobis ${ }^{2}$.

Iudica me, domine, quoniam ego ${ }^{3}$.

Comedite amici ${ }^{4}$.

rngeiorn ${ }^{5}$.

Et nolite eos prohibere, alleluia, talium enim est regnum coelorum ${ }^{6}$. alleluia.

Et uiolenti rapiunt illud ${ }^{7}$. alleluia.

Penitentiam agite, alleluia, adprop[inq]uauit enim regnum coelorum $^{8}$. alleluia.

Hoc sacrum corpus domini et saluator[is] sanguinem, alleluia, sumite uobis in uitam

perennem ${ }^{9}$. alleluia.

In labis meis meditabor [hymnum]. alleluia. Cum docueris me ego iustitias respondebo ${ }^{10}$. alleluia.

Uenite bene[di]cti patris mei, possedete regnum, alleluia, quod uobis paratum est

ab origine $[\mathrm{m}]$ undi ${ }^{11}$. alleluia.

Ubi ego fuero illic erit et minister $\mathrm{m}\left[\mathrm{eus}^{12}\right]$. alleluia.

\section{In Natale DOMINI ${ }^{13}$.}

Nos oportet celebrare, alleluia, magni regis in natale, alleluia. Christum mundi salu[ator]em, alleluia. sacrosancto sanguine, alleluia.

\section{IN AEPIPHANIA.}

Babtiz[atus est dominus] ap[er]ti sunt coeli, alleluia. et uidit spiritum descendentem super se, alleluia ${ }^{14}$.

1 Ps. xxiv. I. Stowe Missal, p. 243.

2 Prov. ix. 5. Ib.

${ }^{3}$ Ps. vii. 9. Ib.

4 Cant. v. I. Ib.

5 These eight letters are rudely written as if by a scribe testing his pen. A facsimile of this page is contained in Appendix A to (intended) Report on Rymer's Foedera, plate xxx.

7 Matt. xi. I 2. Ib.

6 Matt. xix. I4. Stowe Missal, p. 243.

9 Stowe Missal, p. 243 ; Antiphon. Benchor. p. r92.

${ }_{10}$ Ps. cxviii. I7I. Stowe Missal, p. 243 ; Antiphon. Benchor. p. 192.

11 Matt. xxv. 34. Stowe Missal. p. $243 .{ }^{12}$ Ioan. xii. 26. Ib. p. 243.

${ }_{13}$ For the festivals for which there is special commemoration in the Stowe 
IN DIE PASCHE.

Saeculi saluator dominus hodie resurrexit, et in dextera dei pat[ris] uirtute consedit, alleluia.

$$
\text { IN PENTI[coste]. }
$$

Effundam de spiritu meo, alleluia, super omnem [car]nem, alleluia, et quidam in seruos meos et in ancellas [m] eas ${ }^{1}$, alleluia.

$$
\text { POST[COMMUNio]. }
$$

Quos caelesti, domine, dono satiasti praesta ut a nostris mundemur occultis et ab hostium liberemur insidis, per dominum nostrum ihesum ${ }^{2}$.

Gratias tibi agimus, domine, sancte pater, omnipo[t]ens aeterne deus, qui nos corporis et sanguinis christi filii tui commo[ni]one satiasti, tuamque misericordiam humiliter postulamur, ut hóc tuum domine sacramentum non sit nob[is] reatus ad poenam sed intercessio salutaris ad [uen]iam sit ${ }^{3} .$.

\section{§ 10.-Irish Fragments. St. Gall MS. I395.}

The following Litany occurs in MS. I 395 at St. Gall. It is on a single leaf in an Irish handwriting of the eighth or ninth century. A facsimile of the original MS. is given in the (intended) Report on Rymer's Foedera 4 .

Peccauimus, domine, peccauimus par*.

Parce peccatis nostrís et salua nos. qui gubernasti nóe super undas dilui exaudi nos, et ionam de abiso uerbo reuocasti libera nos. Qui petro mergenti manum porrex(is)ti auxiliare, christe, filíi dei, fecisti mirabilia, domine, cum patribus nostris, et nostrís propitiare temporibus, emitte manum

1 Compare Acts ii. I 7, 18.

2 This post-com. which is not part of the Canon in the Roman and Sarum Missals, occurs in the Stowe Canon (p. 243), and in the Sarum Domin. vi. post Trin. (p. 478) and the Missa contra paganos (p. 824*), in both of which places a different post-com. is provided in the Roman Missal. Sacr. Gel. p. 687 ; Greg. p. 167 .

${ }_{3}$ The fragment breaks off here abruptly at the bottom of fol. ii. verso. The rest of the collect may be supplied from the Stowe Missal, p. 243.

- Appendix A, plates xxiii, xxiv. 
tuam de alto, libera nos, christe audi nos, christe audi nos, christe audi nos ${ }^{1}$.

Sancta maria, ora pro [nobis] sancte petre, ora pro [nobis] sancte paule, ora pro [nobis] sancte andria, ora pro [nobis] sancte iacobe, ora pro [nobis] sancte iohannis, ora pro [nobis] sancte pilippe, ora pro [nobis] sancte bartholomei, o[ra] pro [nobis] sancte thomas, ora pro [nobis] sancte mathái, ora pro [nobis] sancte simón, ora [pro nobis] sancte iacobe, ora [pro nobis] sancte thathe, [ora pro nobis] sancte madiane ${ }^{2}$, [ora pro nobis] sancte marce, [ora pro nobis] sancte lucas, [ora pro nobis] sancte stefane, [ora pro nobis].

The following fragment of an 'Officium Defunctorum' is written on a single leaf of a small Irish Missal of the eighth or ninth century, formerly the property of the monastery of St. Gall ${ }^{3}$, but now lost. It is bound up in MS. 1395. A facsimile page is given in the (intended) Report on Rymer's Foedera 4

Te decet, domine, [hymnus] deus in sion, et reddetur uotum in hirusalem, exaudi orationem meam, ad te omnis caro ueniet ${ }^{5}$.

${ }^{6}$ In ${ }^{7}$ illis diebus dixit ihesus addiscipulos suos; lazarus amicus noster infirmabatur et manifeste mortuus est ${ }^{7}$; et gaudeo

1 This anthem occurs at the commencement of the Stowe Canon, p. 226. It seems to be a peculiarity of the Celtic Liturgy, taking the place of the Kyrie in the Roman rite.

- Madianus occupies this position in the lists of saints in the Stowe Missal, pp. 226, 240. It is the Hiberno-Latin form of Matthias; p. 262. n. 91.

\footnotetext{
p. 175 .

- Appendix A, plate xxxi.

5 Ps. Lxv. 2, 3.
}

- St. John xi. 14-44. The whole passage is printed in H. and S. vol. i. p. 197, with much additional and valuable information as to the affinities of the text in this and other frigments of the Holy Scriptures as used in the Celtic Church.

7-7 An adaptation of $\nabla v$. II and I4. Variations from $V$, are marked in the following notes. 
propter uos, ut credatis, quoniam non eram ibi, sed eamus ad eum. Dixit autem ${ }^{1}$ thomas, qui dicitur didimus, ${ }^{2}$ cum discipulis suis ${ }^{2}$, eamus et nos ${ }^{3}$ moriamur cum illo ${ }^{4}$. Uenil ${ }^{5}$ ihesus et inuerit eum ${ }^{6} \mathrm{iam}$ quartum $\operatorname{diem}^{6}$ in monumento habentem. Erat autem bethania iuxta hirusolimam quassi stadiis quindecim. Multi antem $\mathbf{a}^{7}$ iudaeis uenerunt ${ }^{8} \ldots$ [ob]uiam ${ }^{9}$ uenit ei $^{9}$. Maria autem domi sedebat. Dixit ergo martha ad ihesum, domine, si fuises ${ }^{10}$, ${ }^{11}$ non fuiset mortuus frater meus ${ }^{11}$. Sed ${ }^{12}$ nunc scio quoniam ${ }^{13}$ quaecumque petieris ${ }^{14}$ a domino ${ }^{15}$ dabit tibi dominus ${ }^{16}$. Ait ${ }^{17}$ ei ${ }^{18}$ ihesus; resurget frater tuus. Dicit ei martha, scio quia resurget in resurrectione in novissimo die. Dixit ${ }^{19}$ ihesus, ego sum resurrectio et uita; qui credit in me, etsi ${ }^{20}$ mortuus fuerit, uiuet; et ${ }^{21}$ qui uiuit et credit in me non morietur ${ }^{22}$. Credis hoc? Dixit ${ }^{23} \mathrm{ei}^{24}$, utique, domine, ego credidi quoniam $^{25}$ tu es christus, filius dei ${ }^{26}$, qui hunc ${ }^{27}$ [in $\left.{ }^{27}\right]$ mundum uenisti. Et cum hec dixisset, abiit et nocauit mariam sororem suam si[lentio] dicens, magister uenit ${ }^{28}$ et uocat te. At ${ }^{29}$ illa ... iudaei autem ${ }^{30}$ qui erant cum ea ${ }^{31}$ et consolabantur eam ut ${ }^{32}$ uid[erunt] mariam quod ${ }^{33}$ festinanter ${ }^{34}$ surrexisset ${ }^{35}$ et exisset ${ }^{36}$, subsequuti ${ }^{37}$ sunt ${ }^{38}$ dicentes, quoniam ${ }^{39}$ uadit ad mon[umen]tum ut ploret ibi. Maria au [tem $\left.{ }^{40} \mathrm{cum}\right]$ uenisset ubi erat ihesus, et ${ }^{41}$ uid[isset ${ }^{42}$ eum] procedit ${ }^{43}$ ad pedes eius ${ }^{44}$, domine [si fuis] $\operatorname{ses}^{45},{ }^{46}$ frater meus non fuis[set mor] tuus ${ }^{46}$. Ihesus autem ${ }^{47}$ cum $^{48}$ uidisset ${ }^{49}$ flentem, et iudeos qui uene[rant cum] ea flentes ${ }^{50}$,

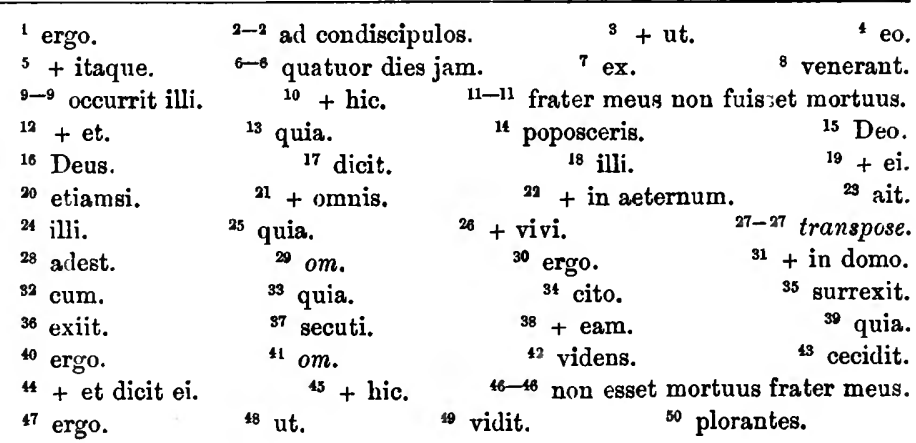


${ }^{1}$ turbatus est ${ }^{1}$ sp[iritu et] commotus ${ }^{2}$ dixit, Ubi posuisti[s eum]? Dicunt ${ }^{3}$, domine, ueni et uide. Et [lacri]matus est ihesus. Dixerunt autem ${ }^{4}$ [iudei] Ecce quomodo amabat illu $[\mathrm{m}]^{5} \ldots{ }^{6}$ nunt quidam ex eis ${ }^{6}$ non po[terat $]$..... [toll $]$ ite lapidem. Dixit ${ }^{7}$ ei martha ${ }^{8}$, domine iam pudet ${ }^{9},{ }^{10}$ qua[triduu]m enim habet ${ }^{10}$. Ait ${ }^{11}$ iliesus, Nonne [dixi tibi] quoniam ${ }^{12}$ sic ne di ${ }^{12} \ldots$ uidebitis $^{13}$ gloriam dei? Sustulerunt ${ }^{14}$ ergo la[pidem]. Ihesus autem ${ }^{15}$ eleuauit oculos sussum et ${ }^{15}$ dixit, pater gra[tias ag]o tibi quoniam audisti me. [Ego aut]em sciebam quoniam ${ }^{16}$ semper [me aud]is, sed propter turbam ${ }^{17}$ que $^{18}$ [circum] stat dixi, ut credant quoni[a]m ${ }^{19}$ me misisti. Et ${ }^{20}$ cum $^{21}$ hec ${ }^{21}$ di[xisset,] exclamauit ${ }^{22}$ noce magna ${ }^{23}$, [Lazar]e, prodi ${ }^{24}$ foras. Et confestim ${ }^{25}$ [prodiit] qui $^{26}$ mortuus erat ${ }^{27}$, ligatis ${ }^{28}$ pedibus $^{29}$ [et ma]nubus ${ }^{30}$ fasceis ${ }^{31}$ et facies eius ${ }^{32} \ldots$

A fragment of an office 'De Visitatione Infirmorum,' of the same date as the preceding fragment of an Officium Defunctorum, is now bound up in the same volume with it, No. I395. A facsimile of it is given in the (intended) Report on Rymer's Foedera ${ }^{33}$.

... iustitiae demonstra ei, et aperi ei portas iustitiae et repelle ab ea principes tenebrarum. Agnosce, domine, depositum fidele quod tuum est. Suscipe, domine, creaturam tuam non exdís alienis creatam, sed a te deo solo nero et uiuo; quia non est deus alius praeter te, domine, et non est saecundum opera tua. Laetifica, domine, animam serui(ae) tui(ae) .n.

\begin{tabular}{|c|c|c|c|}
\hline-1 infre & tur & eipsum et. & \\
\hline ergo. & 5 eum. & ${ }_{6-6}$ quidam auten & n ex ipsis dixe \\
\hline & ${ }^{8}+$ soror ejus & mortuus fuerat. & \\
\hline atridu & s est enim. & 11 dicit ei. & ${ }^{12-12} \mathrm{si}$ \\
\hline videbis. & 14 tulerunt. & ${ }^{15-15}$ elev & vatis surst \\
\hline quia. & ${ }^{17}$ populum. & 18 qui. & ${ }^{19}$ qui \\
\hline $\begin{array}{l}\text { om. } \\
\text { veni. }\end{array}$ & $\begin{array}{l}21 \text { transpose. } \\
25 \text { statim. }\end{array}$ & ${ }^{22}$ om. & $23+\operatorname{clam}_{27}$ \\
\hline
\end{tabular}

${ }^{32}$ illius. In twenty-nine of the above various readings the Text agrees with the unpublished MS. copy of the Vetus Itala preserved in Trinity College, Dublin, A. 4.15 .

${ }^{33}$ Appendix A, plates xxv-xxvii. 
Clarifica, domine, animam, serui(ae) tui(ae) .n. reuertentem ad te. Ne memineris pristinae iniquitatis et ebrietatis quam suscitauit feruor mali desiderii. Licet enim peccauit, patrem tamen et filium et spiritum sanctum non negauit, sed credidit et zelum Dei habuit, et deum fecisse omnia adorauit. Suscipe, domine, animam serui tui(ae) .n. reuertentem ad te; indue e(a)m uestem caelestem et laua eam in fontem uitae aeternae, ut inter sapientes sapiat, et inter gaudentes gaudeat, et inter martres possedeat, et inter profetas proficiat, et inter apostolos se custodiat, et inter angelos et archangelos claritatem dei inueniat, et inter rutulos lapides paradisi gaudium possedeat, et notitiam misterior ${ }^{1}$...

Three forms of benediction of water, or of salt and water, written on a single page, in a different and smaller handwriting than the foregoing collect, of about the same date, are bound up in the same volume, No. I395. A facsimile of this page is given in the (intended) Report on Rymer's Foedera ${ }^{2}$. The headings are written continuously with the text, but in a still smaller handwriting.

\section{Benedictio aquae et salis ad spergendum in dom[ibUs].}

Domine, sancte pater omnipotens, instaurator et conditor omnium el[emen]torum, qui per christum ihesum fi[lium tuum in] hanc creaturam spiritum creantem iussisti, té deprecamur, domine, ut hanc creaturam salis et aquae [benedicere et sanctificare digneris], ut ubicumque asparsa fuerint, omnis spiritus inmundus ab eo loco confusus et increpatus effugiat, $\mathrm{ne}$ [c] ulterius in eo loco habeat potestatem commorandi. Item presta, domine, per hanc creatam asparsionis sanitatem mentis, integritatem corporis, tutellam salutis, securitatem spei, cor-

1 The fragment breaks off abruptly at this point. The same prayer occurs in the Sacram. Gelas. p. 747, in a ninth-century French (Fleury) Ritual, printed by Martene (lib. iii. cap. I3, vol. fi. p. 38r), and in a twelfth-century Salzburg Pontifical (ib. p. $3^{87}$ ), where it opens thus, ' Omnipotens sempiterne Deus qui humano corpori animam,' \&c.

${ }^{2}$ Appendix A, plate xxii. 
roborationem fidei, híc et in aeterna saecula saeculorum. Amen ?.

\section{ITEM BENEDICTIO AQUAE SPARGENDUM IN DOMO.}

Deus, qui ad salutem humani generis maxima queque sacramenta in aquarum substantia condidisti, adesto inuocationibus nostris, et elemento huic omnimodis purificationibus preparato uirtutem tue benedíctionis infundes, ut creature mysteriiss túis seruens ad abigendos demones morbosque pellendos diuine gratie tue sumat effectus, ut quidquid in locis in domibus fidelium hẹc unda resparserit, careat inmunditia, liberet a noxia, non illic resedeat spiritus pestilens, non aura corumpens, abscedant omnes insidie latentes inimici, et si quid est quod incolmitati habitantium inuidet aut quieti, aspersione huius aquae effugiet, ut salubritas per inuocationem tui nominis expetita ab omni sit inpugnatione defensa, per dominum nostrum ihesum christum filium tuum, qui uenturus est iudicare uiuos et mortuos et seculum ${ }^{2}$.

\section{ITEM ALIA.}

Exorcizo te, creatura aquae, in nomine dei patris omnipotentis, et in nomiue ihesu christi filii eius, et spiritus sancti, omnis uirtus aduersárii, omnis incursus diabuli, et omue fantasma, omnes inimici potestates eridicare et effugare ab hac creatura aque.. Unde exorcizo te, creatura, per deum uerum, per deum uiuum, per deum sanctum, et per dominum nostrum ihesum christum, ut efficiaris aqua sancta, aqua benedicta, ut ubicunque effusa fueris uel sparsa, siue in domo siue in agro, effuges omnem fantasiam, omnem inimici potestatem, et spiritus sanctus habitet in domo hac, per dominum nostrum ihesum christum filium tuum, qui uenturus est indecare uiuos et mortuos et sęculum per ignem ${ }^{3}$.

1 This Benediction occurs, with some variation of text, in the Sacramentarium Gallicanum, Mab. edit. p. $3^{87}$.

2 Sacramen. Gelas. p. 738 ; Greg. p. 264; Rit. Rom. p. 288 ; Sacram. Gallican. Mab. edit. p. 387 ; Stowe Missal, pp. 207, 21 r.

${ }^{3}$ Stowe Missal, p. 213 ; Gerbert, Lit. Aleman. vol. ii. p. Io; Sacram. Gelas. p. 739 . 
§ 11.-Irish Fragaents. Basle MS. A. vii. 3 .

Among the MSS. in the Library at Basle, there is a ninthcentury Greek Psalter with an interlinear Latin version, No. A. vii. $3^{1}$. The first three leaves are occupied by some liturgical fragments, in a later Irish handwriting, consisting of tro Hymns, $(a)$ in honour of St. Mary the Virgin, $(b)$ of St. Bridget ${ }^{2}$; two prayers addressed $(a)$ to St. Mary, (b) to all Angels and Saints, and the following prayer for use before the altar :-

\section{De conscientiae reatu ante altare.}

(Fol. 2 b) Domine, deus omnipotens, ego humiliter te adoro. $\mathrm{Tu}$ es rex regum, et dominus dominantium. Tu es arbiter omnis saeculi. Tu es redemptor animarum. Tu es liberator credentium. Tu es spes laborantium. Tu es paraclitus dolentium. Tu es uia errantium. Tu es magister gentium. $\mathrm{Tu}$ es creator omnium. Tu es amator omnis boni. Tu es princeps omnium uirtutum. $\mathrm{Tu}$ es amator uirginum. $\mathrm{Tu}$ es fons sapientium. $\mathrm{Tu}$ es fides credentium. $\mathrm{Tu}$ es lux lucis. $\mathrm{Tu}$ es fons sanctitatis. Tu es gloria dei patris in excelso. Tu sedes ad dextram dei patris, in alto throno regnans in saecula. Ego te peto ut des mihi remissionem omnium peccatorum meorum, deus meus, ihesu christe. Tu es qui neminem uis perire, sed omnes uis saluos fieri, et ad agnitionem ueritatis uenire. Tu es qui ore tuo sancto et casto dixisti, In quacunque die conuersus fuerit peccator, uita uiuet et non morietur. Ego reuertor ad te, et in toto corde meo clamabo at te, domine deus meus. Delictum meum cognitum tibi facio, et iniustitiam meam non abscondo. Tibi bumiliter confiteor, domine deus meus, quia peccaui in cęlum et in terram coram te, et coram angelis tuis sanctis, et coram facie omnium sanctorum, tam per negligentiam mandatorum tuorum, et $\mathrm{q}[\mathrm{uam}]$ malefactorum meorum. Ego corde, ego

\footnotetext{
1 Haenel, F., Catal. Libr. MSS. p. 590; Keller, F., Bilder und Schriftzüge,p. 86.

${ }^{2}$ Mone, F., Lateinische Hymnen, Nos. $57^{2}, 85^{8}$.
} 
ore, ego opere, et omnibus uitiis coinquinatus sum. Peccaui per superbiam et inuidiam. Peccaui per detractionem et auaritiam. Peccaui per superbiam et malitiam. Peccaui per fornicationem et gulam. Peccaui per falsum testimonium et per odium hominum. Peccaui per furtum et rapinam. Peccaui per blasfemiam et carnis desiderium. Peccaui per ebrietatem, et per otiosas fabulas. Peccaui in dictis, in factis, in cogitationibus. Peccaui per contentiones et rixas. Peccaui per iuramentum et iracundiam. Peccaui per terrenam et transitoriam lętitiam. Peccaui per mentis mee suauitatem. Peccaui per dolorem et murmurationem. Peccaui in oculis ${ }^{1}$ et in auribus meis. Peccaui in lingua et in gutture. Peccaui in pectore et in collo. (f. 3 a) Peccaui in manibus et pedibus. Peccaui in medullis et in renibus. Peccaui in anima et in toto corpore meo. Si iniquitates obseruem, domine, domine quis sustinebit. Quanta in me ipsa fuerunt peccata mea, si multiplicaueris judicium tuum, quomodo sustineam, si nunc erit uindicta tua. Ideo confiteor tibi, domine, deus meus, qui solus sine peccato es. Et obsecro te, ihesu christe, deus misericordiarum, per passionem et per effusionem sanguinis tui, atque per signum ligni salutiferi crucis tuę, ut concedas mihi remissionem omnium peccatorum meorum, non secundúm meum meritum, sed secundúm magnam misericordiam tuam. Iudica me secundúm iudicium indulgentię tue. Ego homo te adiuro, omnipotens deus, ut non reddas mihi peccatorum poenam meorum, sed suscita timorem et amorem tuum perseuerantem in me, ac ueram penitentiam peccatorum meorum, et fletum praeteritorum propter nomen propter nomen sanctum tuum; et da mihi memoriam mandatorum tuorum, ut faciam. Adiuua me, domine deus meus, secundum multitudinem miscrationum tuarum dele iniquitatem meam usque semper; et ne auertas faciem tuam ab oratione mea; et ne proicias me á facie tua. Ne discesseris, et ne derelinquas me,

1 Another and more exhaustive enumeration of the parts of the body is contained in the Lorica of Gildas, Leabhar Breac, fol. 241; and in a collect in the Stowe Ordo Baptismi, p. 207. 
sed confirma me in tua uoluntate, et doce me facere uoluntatem tuam, et quae debeam loqui a [ut] tacere. Defende me, domine, ab omnibus inimicis meis, inuisilibibus et uisibilibus. Defende me, domine deus meus, contra iacula diaboli, et contra angelum tartari, de quo dixisti, uenit princeps mundi huius et in me non habet quicquam. Quapropter extingue mea peccata, et carnalia desideria in me. Redemptor animarum, ne me derelinquas unum miserum indignumque famulum tuum $N$. sed ut per te ambulem, et ad te perueniam, et in te requiescam, domine, deus meus, quia sive te nil possumus, qui uiuis et regnas cum deo patre, deus in unitate spiritus sancti, per omnia saecula saeculorum. Amen 1.

\section{§ 12.-Irish Fraguents. Antiphonary of Bangor.}

This relic of the ancient Church of Ireland ${ }^{2}$ contains chiefly hymns and other portions of the day and night Hours, but it includes the following passages, the liturgical use and connection of which are evident or probable.

\section{i. Yamum quando commonicarent sacerdotes.}

Sancti venite ${ }^{3}$, christi cor-

pus sumite; sanctum

bibentes quo re-

dempti sanguine.

1 This long prayer, though not found verbatim elsewhere, resembles in substance the private devotions for the priest frequently introduced into early Missals under the title of 'Apologia Sacerdotis' or 'Confessio Peccatoris.' Other examples, resembling the text in the enumeration of the parts of the human body by which sin has been committed, or in the multiplication of clauses commencing with the word 'Peccaui,' will be found in a 'Praeparatio ad Missam,' publi.hed by Gerbertus ex Cod. S. Blasian. saec. x (Lit. Aleman. i. 35I); in the 'Missa Flacii Illyrici,' published by Martene (ordo iv. pp. I 76-9); and in a tenth-century Tours Sacramentary (ordo vii. ib. p. 193).

${ }^{2}$ For its date, see List of Authorities. It has been printed nearly in extenso, and not very correctly, by Muratori in the fourth volume of his Anecdota Bibliothecae Ambrosianae, to the pages of which reference is made in the following foot-notes. The extracts have been grouped according to their subject-matter.

${ }^{3}$ Page I32. This hymn is printed in Daniel, H. A., Thes. Hymnol. i. 193 It is familiar to English readers from its translation in Hymns Ancient and Modern. The original arrangement of the quatrains has been retained here. 
Salvati christi corpore

et sanguine, a quo

refecti laudes di-

camus deo.

Hoc sacro mento corporis et sanguinis omnes ex-

uti ab inferni

faucibus.

Dator salutis, christus

filius dei, mundum

saluauit per cru-

cem et sanguinem.

Pro uniuersis im mo-

latus dominus ipse sa-

cerdos existit

et hostia.

Lege praeceptum immolari hosti-

as qua ad-

umbran-

tur diuina misteria.

Lucis indultor et

saluator omnium

praeclaram Sanctis

largitus est gratiam.

Accedunt omnes pu-

ra mente creduli,

sumant aeternam

salutis custodiam.

Sanctorum custos, rector

quoque dominus, uitae per-

ennis largitur cre-

dentibus.

Caelestem panem dat

esurientibus, 
de fonte

uiuo praebet sitientibus.

Alfa et $\omega$, ipse christus dominus

uenit,

uenturus iudicare homines.

ii. Ad pacem celebranday. See ch. ii. $\S 9$.

\section{iii. Incipit Symmolum.}

Credo in deum patrem omnipotentem inuisib[i]lem, omnium creaturarum uisibilium et inuisibilium conditorem.

Credo et in ihesum Christum, filium eius unicum dominum nostrum, deum omnipotentem, conceptum de spiritu sancto, natum de maria virgine, Passum sub pontio Pylato, qui crucifixus et sepultus descendit ad inferos, tertia die resurrexit a mortuis, ascendit in caelis, seditque ad dexteram dei patris omnipotentis, exinde uenturus iudicare uiuos ac mortuos.

Credo et in spiritum sanctum, deum omnipotentem, unam habentem substantiam cum patre et filio. sanctam esse aecclesiam catholicam, ab remisa peccatorum, sanctorum commonionem, carnis resurrectionem. credo uitam post mortem, et uitam aeternam in gloria Christi.

Haec omnia credo in Deum. Amen ${ }^{1}$.

Oratio diurna. Pater noster, \&c.

1 Page 145. This Creed differs in its wording from all other forms which are known to exist. Its liturgical position immediately before the Lord's Prayer is that of the Mozarabic rite, regulated by can. ii. of the Third Council of Toledo, A.D. 589: 'Sancta constituit synodus ut per omnes ecclesias Hispaniae vel Gallaeciae [= Gallia Narbonensis] secundum formam orientalium ecclesiarum, hoc est cl. episcoporum symbolum fidei recitetur, ut priusquam dominica dicatur oratio, voce clara a populo decantetur; quo et fides vera manifestum testimonium habeat, et ad Christi corpus et sanguinem praelibandum pectora populorum fide purificata accedant.' Mansi, Concil. tom. ix. p. 993. Other early forms of the Creed are preserved in the Book of Deer, p. 166, and in the Stowe Missal, p. 23 I. 


\section{iv. Benedictio PUERORUM ${ }^{1}$.}

Benedicite omnia opera domini, dominum; ymnum dicite, et superexaltate eum in saecula, \&c.

\section{Collectio post Benedictionem PUerorum.}

Exaudi praeces nostras, omnipotens deus, et praesta ut sicut indecantato Imno beata puerorum instituta sectamur, Ita pro tuo munere peccatorum laqueys absoluti aeterni ignis non ambiamur incendiis, saluator mundi, qui cum patre uiuis ${ }^{2}$.

\section{SUPER BENEDICTIONEM TRIUM PUERORUM.}

Sancte Domine, et gloriosae mirabilium uertutum effector, qui tribus pueris inter supplicia constitutis quartus adsistis, cui factum facilium est ignium temperare naturam, et uim quodammodo exusstantium coercere flammarum, ut inter incendia frigida ymnum tibi canentes cum magna uictoria exultarent, eandem nunc, domine, ad liberandos ac protegendos nos dona uirtutem, saluator mundi ${ }^{3}$.

\section{Post Benedictionem triuM PUERORUM.}

Deus, qui pueris fide feruentibus fornacis flammam frigidam facis, et tribus inuictis, morte diuicta, quartus adsistes, praecamur nobis aestibus carnis talem uirtutem praestes adustis per te, Ihesu Christe ${ }^{4}$.

\section{Post Benedi[ci]Te.}

Deus, qui tres pueros de fornace eripuisti, sic nos eripias de supplicis inferni, qui regnas in saecula ${ }^{5}$.

1 Page 131. See ch. ii. $\S$ I3. For the use of the Benedicite in both the Gallican and Mozarabic Liturgies between the Lections, see Mis. Mozar. pp. 25, 523; Germani Expos. Brev. Lit. Gall., sub tit. De Hymno; Mabillon, Mus. It. i. 283 ,

${ }^{2}$ Page 150.

3 Page I51.

- Page 152. Compare the collect 'Deus qui tribus pueris mitigasti,' which occurs in the present Roman Missal in the Gratiarum actio post Missam, and after the Canticle from Daniel on the four Ember Saturdays.

5 Page 153. 


\section{Post YMNUM TRIUM PUERORUM.}

Te enim, omnipotens deus, benedicimus iure, qui tres pueros liberasti ab igne nos quoque de supplicio mortis aeterne propter misericordiam tuam eripe, qui regnas ${ }^{1}$.

\section{Post Benedicite.}

Ut tres pueros in flamma saluasti discensu in fornacem caelestis nuntii, sic nos per angelum magni consilii liberare digneris ab igne inferni, qui regnas ${ }^{2}$.

\section{SUPER BENEDICTIONEM TRIUM PUERORUM.}

Tres ebrei uenerabiles numero, sacramento muniti, aetate teneri, sed fidei soliditate robusti, amore diuinae relegionis regis adorare imaginem contempserunt, utpute qui ipsum contempserant regem, qui ira sufflatus solito septies amplius caminum iusit incendi, ac pice et stuppa armatum citari in cendium aestuantibus globis. Erubescit quoque ipsum alienis ignibus coelum. Illo praecipitantur insontes, ibidemque te, propter quem praecipitantur inueniunt, Christe. Taliter nos ex tyranni intellectualis furore, et ab ingenito igni digneris liberare, saluator mundi, qui cum aeterno patre uivis ${ }^{3}$.

\section{INCIPIUNT ANTEFANI SUPER CANTENUS EI BENEDICITE.}

Tres pueri in camino missi sunt, et non timuerunt flammam ignis, dixerunt laudem domino nostro.

Tres pueri te orabant de medio ignis, ad te clamabant ex una uoce, ymnum dicebant.

Fornacis flammas pueri contempserunt, Christo iugiter immolauerunt, uiam iniquam diriliquerunt ${ }^{4}$.

\section{จ. Ad COMmonicare ${ }^{5}$.}

Corpus domini accipimus, et sanguine eius potati sumus, ab omni malo non timebimus, quia dominus nobiscum est.

\footnotetext{
1 Page I 53.

2 Page I 54.

3 Page 155.

4 Page 157

${ }^{5}$ Page ${ }_{5}$ 8. These seven Communion formulae are written consecutively.
} 


\section{ITEM ALIA.}

In labiis meis meditabor ymnum, alleluia; Cum docueris me ego iustitias respondebo, alleluia ${ }^{1}$.

\section{ITEM ALIA.}

Gustate et uidete, alleluia, quam suauis est dominus, alleluia $^{2}$.

\section{ITEM ALIA.}

Hoc sacrum corpus domini, et saluatoris sanguinem sumite uobis in uitam perennem ${ }^{3}$. alleluia.

\section{ITEM ALIA.}

Quam dulcia faucibus meis eloquia tua, Domine*.

\section{ITEM ALIA.}

Hic est panis uiuus qui de caelo descendit, alleluia. Qui manducat ex eo uiuet in aeternum, alleluia ${ }^{5}$.

\section{ITEM ALIA.}

Refecti christi corpore et sanguine tibi semper, Domine, dicamus, alleluia ${ }^{6}$.

\section{vi. Collectio post Euangelium.}

Exsultantes gaudio pro reddita nobis huius diei luce omnipotenti deo laudes gratiasque referamus, ipsius misericordiam obsecrantes, ut diem dominicae resurrectionis nobis sollempniter celebrantibus, pacem et tranquillitates, laetitiam praestare dignetur, ut a uigilia matutina usque ad noctem

1 Ps. cxviii. I7I. St. Gall. MS. I 394, p. I 78 ; Stowe Missal, p. 243.

2 Ps. xxxiii. 9. Stowe Missal, p. 243. See p. 267 , n. I 78.

s St. Gall. MS. 1394, p. 178; Stowe Missal, p. 243. The formula in the Drummond Missal (eleventh century) seems also to imply simultaneous communion in both kinds: 'Corpus et sanguis Domini nostri Jesu Christi maneat ad salutem et proficiat ad remedium in vitam eternam.'.

- Ps. crviii. 103.

5 St. John vi. 59. St. Gall. MS. I394, p. 177 ; Stowe Missal, p. 243.

- Book of Deer, p. 165 ; Book of Dimma, p. I71; Book of Mulling, p. 173; Stowe Missal, p. 225. 
clementiac suae fauore protecti exultantes laetitia perpetua gaudeamus, per dominum nostrum ihesum christum ${ }^{1}$.

\section{Post euningeliem.}

Dominicam nostrae resurrectionis initium ucnerantes trinitati deo nostro debitas laudes, et grates unito refferamus affectu obsecrantes misericordiam eius ut nobis domini et saluatoris nostri beatae resurrectionis participium tam in spiritu quam etiam in corpore concedat, qui cum patre uinit $^{2}$.

\section{Post euangelium.}

Resurgentem in hoc diluculo dominum dipraecamur ut et nos in uitam aeternam resurgamus per omnia saecula saeculorum ${ }^{3}$.

\section{Post euangelium.}

Canticis spiritalibus dilectati imnos, christe, consonantes canimus tibi, quibus tua maiestas possit placari, oblata laudis hostia spiritali, qui tecum uiuit ${ }^{4}$.

\section{ITEM POST EUANGELIUM.}

Deluculo lucis auctore resurgente exultemus in domino, devicta morte, quo peccata possimus semper obire, nitaeque ambulemus in nouitate, qui tecum uiuit ${ }^{5}$.

\section{Ad UeSPERUM ET AD Matutinam.}

Gloria in excelsis deo, et in terra pax hominibus bonae uoluntatis. Laudamus te, benedicimus te, adoramus te, glorificamus te, magnificamus te, gratias agimus tibi propter magnam misericordiam tuam, domine rex caelestis, deus pater omnipotens, domine filii unigenite iesu christe, sancte spiritus

1 Page I 50. No collect is found in any other than Irish Liturgies tbus entitled or placed. An example of its position and use survives in the Stowe Missal, p. 231; Book of Hymns, p. 196. The present short and invariable prayer used at the conclusion of the Gospel in the Roman rite, 'Per evangelica dicta deleantur nostra delicta,' may be the petrified survival of once varying collects.
2 Page 152.
Ib. 153 .
Ib. I53.
5 Ib. 154 . 
dei, et omnes dicimus, amen, domine, filii dei patris, agne dei qui tollis peccatum mundi, miserere nobis, suscipe orationem nostram qui sedes ad dexteram dei patris, misserere nobis, quoniam tu solus sanctus, tu solus dominus, tu solus gloriosus cum spiritu sancto in gloria dei patris. amen ${ }^{1}$.

\section{$\S 13$. Irish Fragients. Book of Hyans.}

The MS. known as the 'Liber Hymnorum,' or Book of Hymns, now in the Library of Trinity College, Dublin (E. 4. 2), is a collection of Hymns, Canticles, and Collects once used in the Irish Church. It has been assigned to the ninth or tenth century, but its heavy even angular writing and the mediaeval character of some of its contents point to a date two or three centuries later. Abont one-half of it (fol. I aI5 a) has been published by the Irish Archæological and Celtic Socicty, under the careful and competent editorship of Dr. J. H. Todd (vol. xvii). It is to be regretted that the work has never been completed. Among the devotions on the unpublished pages (ff. $20 \mathrm{~b}-34 \mathrm{~b}$ ) are a lengthy 'Lamentatio Ambrosii episcopi Mediolaniae' (f. 20a), to the recitation of which special virtue was attached, and a collection of ' ccclxii orationes quas beatus papa gregorius sparsim de toto psalterio, deo gubernante et adiuuante congregauit. $\mathrm{Si}$ deuota mente cantentur, uicem, ut fertur, omnium psalmorum, et sacrificii, et fidelis animarum commendationis continent.' But, although indulgenced with a sacrificial efficacy, neither these nor any of the devotions in the volume have a necessary eucharistic connection. It must therefore suffice here to exhibit a few sample forms of collects \&c. which, at the most, are not necessarily non-eucharistic in their association.

Prayer of St. Mugint, tutor of St. Finnian, in the earlier part of the sixth century :-

1 Page I 50. Other early Irish versions of this hymn occur in the Book of Hymus, p. 196, where see note, and in the Stowe Missal, p. 227. 
Fol. 4 a. 'Parce, Domine, parce populo tuo quem redemisti, Christe, sanguine tuo, et non in eternum irasceris nobis ${ }^{1}$ '

Fol. 4 b. 'Deprecamur te, domine, in omni misericordia tua ut auferatur furor tuus et ira tua a ciuitate ista et de domu sancta tua. Quoniam Peccauimus, Peccauimus tibi, domine, et tu jratus es nobis, et non est qui effugiat manum tuam. Sed supplicemus ut ueniat super nos misericordia tua, domine, qui in ninuen pepercisti inuocantes dominum. Exclamemus ut respicias populum tuum conculcatum et dolentem, et protegas templum sanctum tuum ne ab impiis contaminetur, et miserearis nimis afflicte ciuitati tuę. Exclamamus omnes ad dominum dicentes.

- Peccauimus tibi, Domine, peccauimus, patientiam habe in nobis, et erue nos a malis que quotidie crescunt super nos. Dimitte, domine, peccato populi tui secundum multitudinem misericordię tuę.

' Propitius fuisti patribus nostris, propitius esto nobis, et implebitur gloria tua in uniuersa tua ${ }^{2}$. Recordare, domine, dic angelo tuo percutienti populum tuum, Sufficit ${ }^{3}$, contene manum tuam, et cesset interfectio que grassatur in populo ut non perdas animam uiuentem.

'Exurge, domine, adiuua nos et redime nos propter n[omen] $\mathrm{t}[$ uum].'

To which is appended in a different handwriting :-

'Parce domine peccantibus, ignosce penitentibus, misere nobis te rogantibus, saluator omnium christe, respice in nos ihesu et miserere. Amen 4'

${ }^{1}$ Corpus Mis. p. 2 II ; Gerbert, Liturg. Aleman. ii. p. 34; Mart. i. pp. 321-323 ; Sarum Breviary, edit. 1879, p. 249.

2 For ' terra.'

32 Sam. xvi. 24.

4 These collects were evidently written for the use of some city or monastery (civitas) in the time of an epidemic or of a hostile invasion. Their language is inconsistent with the curious Irish legend of their origin as given in the Vernacular Preface, f. 4 a, translated in Lib. Hym. p. 97. Compare the wording of the collect in the Stowe Missal commencing 'Ante oculos tuos,' p. 230. 
Collect written at the end of the Hymnus S. Colmani Mic Ui Cluasaigh :-

Fol. 6 a. 'Orent pro nobis sancti illi in celis, quorum memoriam facimus in terris, ut deleantur delicta nostra per inuocationem sancti nominis tui, ihesu, et miserere qui regnas in secula seculorum.'

Prayers written at the end of the Hymnus S. Hilarii in laudem Christi :-

Fol. 8 a. 'Te decet ymnus, deus, in sion, et tibi reddetur uotum in hierusalem 1 .

'Canticis spiritualibus dilectati, ymnos, christe, consonantes canimus tibi quibus tua, domine, maiestas possit placari oblata deo laudis hostia spiritali, per te, christe ihesu, saluator ${ }^{2}$.

'Unitas in trinitate te deprecor, domine, ut me semper trahas totum tibi uotum uouere.'

Collects written after a copy of the Epistle of Christ to Abgarus King of Edessa:-

Fol. I5 a. 'Domine, domine, defende nos a malis, et custodi nos in bonis, ut simus filii tui, hic et in futuro: saluator omnium, christe, respice in nos, ihesu, et miserere nobis.

'Euangelium domini nostri ihesu christi, liberet nos, protegat nos, custodiat nos, defendat nos, ab omni malo, ab omni periculo, ab omni langore, ab omni dolore, ab omni plaga, ab omni inuidia, ab omnibus insidiis diabuli et malorum hominum hic et in futuro. amen ${ }^{3}$ '

\section{Gloria in Excelsis.}

Fol. 9 a. 'Gloria in excelsis. Angeli dei cecinerunt primum uersum huius ymni in nocte dominicae natiuitatis.

' Ic tur gabdur morro do ronsat.r. mile o hierusalem sair

1 Ps. Ixv. 2, 3. St. Gall MS. 1 395, p. I 80.

2 Antiphonary of Bangor, p. 193.

s Ib. n. I. 
do faillsigud morro connid macc de in ti ro genair ann do ronsat he. In ainisir octauin augusti do ronad.

'Ambrosius hautem fecit hunc ymnum a secundo uersu usque ad finem ymni ${ }^{1}$.'

'Gloria in excelsis deo et in terra pax hominibus bone uoluntatis.

'Laudamus te, benedicimus te, adoramus te, glorificamus te, magnificamus te.

' Gratias agimus tibi propter magnam miserecordiam tuam, domine, rex celestis, deus pater omnipotens.

' Domine, fili unigenite, ihesu christe, sancte spiritus dei, et omnes dicimus, amen.

'Domine, fili dei patris, agne dei, qui tollis peccata mundi, miserere nobis.

'Suscipe orationem nostram, qui sedes ad dexteram patris, miserere nobis, domine.

'Quoniam tu solus sanctus, tu solus dominus, tu solus gloriosus, cum spiritu sancto, in gloria dei patris. amen ${ }^{2}$ '

1 This Preface is translated, with notes, in the Liber Hymnorum, part ii. p. I77. It occurs also in F. p. clvii, with a translation by Mr. Whitley Stokes.

2 This Irish version of the Gloria in Excelsis, adapted from the Greek version (Bunsen, Analecta Ante-Nicaena, iii. 86), occurs again, in its liturgical position, in the Stowe Missal, p. 227. It is here followed by six antiphons from the Psalms, which indicate that it was used in the night Offices of the early Irish Church. The rubric preceding it in the Antiphon. Benchor. directs its use 'at vespers and matins;' p. 193. 


\section{$\S 14$. Irish Fragments. \\ THE STOWE MISSAL.}

Little is known about the history of the MS. which bears this name, and which is the earliest surviving Missal of the Irish Church $\mathbf{1}$.

The inscriptions on its cumhdach, a metal-work cover of eleventh-century workmanship, indicate that it originally belonged to some church in Munster, that church being possibly the monastery founded by St. Ruadhan at Lothra in the barony of Lower Ormond and County of Tipperary, where he died as its first abbot and patron ${ }^{2}$ A.D. $5^{84}$. The monastic character of the service book is also evidenced by the insertion of the words 'et abbate nostro' in the clause of the canon 'Te jgitur' \&c. (p. 234) and by the long lists of monastic Irish saints enumerated on pp. $23^{8}, 240$. Pos-

1 Transactions of the Royal Irish Academy, vol. xxiii. ad finem. See also O'Conor's Rerum Hibernicarum Scriptores, vol. ii. ad finem, and Bibliotheca MIS. Stowensis, vol. i. App. Dr. O'Conor's description is full of inaccuracies. The absence of any allusion to the mixed chalice is accounted for because that ceremony is only of human institution (p. 46). Natalis Calicis is translated 'Lent' (p. 47). The antiquity of the Creed is deduced from the absence of the article of 'The descent into hell' (p.45), as if that clause had ever formed part of the Nicene Creed. The contraction 'scōrum' for sanctorum is lengthened iuto 'Scotorum' (p. 48). The musical notes, of which he gives a long description (p. 43), are the creation of his own imagination, and do not exist in the original MS.

2 Hardly anything is known about St. Ruadhan. He is included in the list of Saints on p. $23^{8}$, but the name is written without any change in the size of letters, or exceptional ornamentation. His life is published by the Bollandists (Acta SS. Ap. 15, p. $3^{82}$ ), from a twelfth-century MS., a long tissue of such ludicrous and improbable miracles that the compilers confess in their Preface to having suppressed part of it, for fear of exciting ridicule. His abbey at Lothra was destroyed by the Danes A.D. 843 (Annal. IV. Magistr. sub anno), when this volume, if written before that date, must have been saved. 
sibly the presence of two collects, headed 'Oratio in sollemnitatibus Petri et Christi' (p. 227) and 'Oratio prima Petri' (p. 228), may point to the monastery having been dedicated to St. Peter. At an early date, probably in the twelfth century, it left Ireland, perhaps transferred to the Continent by some of those Irishmen who carried donations from Tordelbach O'Brian, king of Munster, to the monastery of Ratisbon A.D. II 3 . It was discovered abroad in the eighteenth century by John Grace, Esq., of Nenagh in Ireland, an officer in the German service, who died without leaving any memorandum respecting the monastery or library where it was found. From his hands it passed into those of the Duke of Buckingham, where it remained until the sale of the Stowe Library ( 1849 ), when it was bought by the Earl of Ashburnham, in whose library at Ashburnham Place it is now preserved.

The present contents of the volume are arranged as follows:-

Fol. I a-12 b. St. John's Gospel, written at a very early date by a scribe who at its conclusion appends his name in Ogham characters.

Fol. 1 $3^{a-37}$ a. Ordinary and Canon of the Mass, with the colophon 'moel caich scripsit.'

Fol. 37 a-40 b. Misa apostolorum, et martirum, et sanctorum, et sanctarum uirginum.

Fol. $40 \mathrm{~b}-43 \mathrm{~b}$. Misa pro penitentibus uiuis.

Fol. 43 b-45 a. Misa pro mortuis pluribus.

Fol. 45 b-64 a. Ordo babtismi.

Fol. 64 b-66 b. An old-Irish treatise on the Eucharist, followed by three old-Irish charms.

The Sacramental portion of the volume, with which alone we are here concerned, is in various handwritings, the oldest of which cannot, on liturgical grounds, be assigned to an earlier period than the ninth century, though several of the features enumerated on pp. 20I-203, taken singly, seem to point to a still earlier, and others to a still later date.

Palæographical evidence does not appear to be inconsistent 
with such a conclusion so far as it has been possible to compare the text of the Stowe Missal with such Irish .or Hiberno-Latin MSS. as have been found accessible either in the original, or in the facsimiles presented in the pages of the National MSS. of Ireland, and the publications of the Palæographical Society.

The following facts make it impossible to accept Dr. Todd's hasty assignation of the earlier portion of the Missal to the sixth century ${ }^{1}$, and in part suggest a date not earlier than the ninth century:-

(a) The use and position of the Nicene Creed; p. 236. n. 35 .

(6) The presence of the Agnus Dei ; p. 266. n. I $5^{6}$.

(c) The structural completeness of the Ordinarium Missae.

(d) The presence of the words 'diesque nostros in tua pace disponas, atque ab aeterna damnatione nos eripias, et in electorum tuorum jubeas grege numerari' (p. 236), which are known to have been added to the Canon by Gregory the Great (590-604) ${ }^{2}$, and which prove that we have not here a pure Gelasian text (p. 232).

(e) The date of several of the saints who are commemorated in the list commencing on $\mathrm{f} .3^{\mathrm{I}}$ a, including Laurence, Mellitus, and Justus, Archbishops of Canterbury, the latter of whom died in A.D. $627 ;$ p. 263 . n. II3. The list of saints on fol. 29 is written in the later hand on an interpolated leaf, and need not here be taken into account.

The following parts of the Missal are written in the older and larger handwriting, of which a sample is presented in the frontispiece:-f. 13 a, from the first Peccavimus; f. 13 b; f. I 4 a, from 'Rogo . . ad finem ;' f. I4 b, 'ascendat . . rex caelestis ;' f. 15 a, except the collect 'Deus qui diligentibus,' \&c.; f. I 5 b, except the collect 'Deus qui nos,' \&c.; ff. $16 a, b, 17 a$; f. I 7 b, to 'aceptos per dominum;' f. I9 a, b; f. $20 \mathrm{a}$, to 'emunda

1 Transactions of R. I. A., Appendix, p. 16. Dr. Todd saw the volume under disadvantageous limitations of time and action.

2 Bede, H. E., lib. ii. cap. I. 
per dominum;' f. $25 \mathrm{~b}$, from 'Et memoriam;' f. $26 \mathrm{a}, \mathrm{b}$; f. 27 a, except from 'in mei memoriam ;' f. 27 b, from 'unde et memores;' f. $28 \mathrm{ab}$; ff. $3^{1} \mathrm{ab}, 3^{2} \mathrm{ab}, 33 \mathrm{a}$; f. $33 \mathrm{~b}$, to 'peccatorum nostrorum;' ff. $3^{6 \mathrm{~b}-45} \mathrm{a}$; ff. $46 \mathrm{a}-64 \mathrm{a}$.

Of the above, f. $28 \mathrm{ab}, \mathrm{ff} .3 \mathrm{I}$ a-33 b, ff. 57 a-64 a are written in a darker ink and a more cursive and flourishing handwriting than the rest, which seems to denote a change of scribe but not any material change of date. A similar change of style is noticeable in other Celtic MSS., as in the Book of Kells (Palæogr. Soc. Publications, Plate 88, last line), the Codex S. Dunstani (Bodl. Lib. Auct. F. iv. 32, f. 46 b), and the diamond-shaped centre on f. 103 a in the Book of Armagh, and especially in the 'Argumentum pilagii in aepistulam ad Romanos' on f. Io7 b of that MS.

The excepted pages and portions of pages in the above list $^{1}$ are written in a smaller and later minuscule hand (that of Moel Caich, f. $3^{6}$ a), depending from single ruled lines, the older text having been in some places erased to make way for it. The headings of Missæ and Collects, all the Irish and Latin Rubrics, are in various and later handwritings, except the Rubrics in the Ordo Baptismi, which are coaeval with the text.

The collects 'Deus qui nos,' \&c. on f. I 5 b, and 'Quaesumus Domine' on $\mathrm{f}$. $18 \mathrm{~b}$, have been added at a still later period.

In spite of these variations of handwriting there seems little reason to doubt that the whole Ordo Missæ, as it now stands, was in use in some Church in Ireland in the tenth, and the older portion of it perhaps in the ninth century.

Though written in Ireland and by Irish scribes, it contains petitions 'pro piissimis imperatoribus et omni Romano exercitu' (p. 229), 'pro imperio Romano' (p. 235), and the

1 Viz., f. 14 a, Profeta-caelis per dominum; 14 b, deus pater-amen ; 15 a, Deus qui diligentibus-per dominum; $15 \mathrm{~b}$, Deus qui nos-nostrum; i $7 \mathrm{~b}$, from Ante oculos; $18 \mathrm{ab} ; 20 \mathrm{a}$, from Hostias; $20 \mathrm{~b} ; 21 \mathrm{ab} ; 22 \mathrm{ab} ; 23 \mathrm{ab}$; $24 \mathrm{a} \mathrm{b} ; 25 \mathrm{a} ; 25 \mathrm{~b}$, to discendit; $27 \mathrm{a}$, from in mei memoriam; $27 \mathrm{~b}$, to de caclis; $29 \mathrm{ab} ; 30 \mathrm{ab} ; 33 \mathrm{~b}$, from fiat; $34 \mathrm{ab} ; 35 \mathrm{ab} ; 36 \mathrm{a} ; 45 \mathrm{~b}$. 
heading 'Orationes et Preces Ecclesiae Romanae' (p. 228). The canon is headed, 'Canon dominicus papae Gilasi' (p. 234). Internal evidence of the truthfulness of this description is borne out by an examination of the text, and by the presence of such distinctly Gelasian peculiarities as the omission of the words 'Deum de Deo' from the Creed, and of the clauses 'Dominus vobiscum,' 'Et cum spiritu tuo' before the Sursum corda. The interest of the MS. partly lies in its containing one of the earliest known copies of the Gelasian text, partly in its being interspersed with fragments of an ancieut Celtic Liturgy which have either not been preserved elsewhere, or have been only recently discovered in the pages of other early Irish MSS. printed in this chapter.

Among its many liturgical peculiarities and indications of an early date, the following seem to deserve special and separate mention :-

I. The Litany at the commencement of the Ordo Missæ (p. 226).

2. The unique position of another ancient Missal Litany, entitled 'Deprecatio Sancti Martini,' between the Epistle and the Gospel (p. 229).

3. The presence of vernacular rubrics (pp. 210, 216, 230, $232,233,234,24 \mathrm{r}$ ).

4. The long lists of early saints, chiefly Irish, inserted in the text of the canon.

5. The absence of any special 'Proprium Sanctorum,' and the simple provision of a single Missa Commnis Sanctorum (p. 244) for all commemorations of saints, which, together with a single Mass for Penitents (p. 246) and another for the Dead (p. 247), make up the smallest known volume which ever passed under the title of a Missal.

6. The absence of the 'Filioque' from the Nicene Creed (p. 232. See frontispiece).

7. The fixed use of an unchanging Epistle and Gospel (pp. 228, 231).

8. The interpolation of various forms of private devotion 
for the priest in the shape of an Apologia or Confessio Sacerdotis (pp. 226, 227, 230, 239).

9. The enumeration of only three orders, Bishops, Priests, and Deacons, all notice of the minor orders being omitted (pp. 229, 233, 235).

10. The general paucity of rubrics, together with the absence of any allusion to the mixed chalice or to the use of incense, \&c.

II. The absence from the text of the canon of the tenthcentury additional clause, 'pro quibus tibi offerimus vel' (p. 234).

12. The paucity of crosses, only five being marked for use as against thirty-one in the present Roman Canon, and none occurring at the words of institution.

I3. The presence of early and rare liturgical terms, e.g. senior, augmentum, stella, kalendae, natalis calicis, quinquagensima, sacrificium spirituale, anathleticus gradus, liber vitae.

14. Singular usages, e.g. the position of the fraction of the Host before the Pater Noster (p. 244), the crossing of the child's hand and the washing of the feet in Baptism (pp. 217-8).

15. The petition that the founder of the church and all the people may be converted from idolatry (p. $23^{6}$ ).

There is a general resemblance in this Irish Mass to the niuth- or tenth-century Ordo Missae which was first published by M. Flacius Illyricus A.D. I 557 under the title of 'Missa Latina quae olim ante Romanam in usu fuit,' and which was afterwards printed by Martene ${ }^{1}$. Certain prayers and phrases (p. 249, notes $3,7,28,46$ ) are common to both, but there the resemblance ends. The text, especially in the 'Gloria in Excelsis' and the 'Nicene Creed,' is very dissimilar, and there is no ground for supposing that there

${ }^{1}$ Lib. i. c. 4 . art. 12 . ordo 4 , i. p. $\mathbf{1}_{7} 6$, where the name is misprinted as Flaccus. 
can be any original connection, or anything more than an accidental resemblance, between the two.

The Stowe Missal affords no certain proof, but throws some light on the question as to what was the earliest form of Liturgy in use in the Hiberno-Celtic Church. It proves that the Roman Canon was introduced into at least partial use in Ireland as early as the ninth century, while it retains certain portions of an earlier and a different Liturgy interwoven with it. The admixture of passages from the Ambrosian, Gallican, and Mozarabic rites with the Roman Canon is suggestive of a period when the diversity had not ceased to exist which is alluded to in Tirechan's sketch of the ancient Irish Church, when Irish saints ' diversas regulas et missas habebant, et diversam tonsuram ${ }^{1}$.'

The following 'Ordo Baptismi,' where it agrees with the Roman rite, follows the text of the Gelasian Sacramentary, but it does not altogether resemble the Gelasian or any other extant Ordo Baptismi, and is remarkable partly for its great length, partly for the differences which it exhibits both in text and ritual from every other known rite. It is important and interesting as presenting a hitherto unpublished MS. text of the earliest surviving Baptismal Office known to have been used in any part of the Church of these islands.

It consists of four clearly marked divisions :-

I. Ordo ad Catechumenum faciendum.

II. Consecratio Fontis.

III. Ordo Baptismi.

IV. Ordo Communionis nuper Baptizatorum.

I. The ordinary rites in use at the admission of catechumens, and which were repeated at the seven 'scrutinia catechumenorum' held during Lent, with however great local variety of usage ${ }^{2}$, were :-

Quoted in full on p. 8I.

Mart. lib. i. cap. I. art. vi. $x$. 
1. The sign of the cross upon the forehead.

2. The imposition of hands with prayer.

3. Exorcism.

4. Insufflation (Exsufflatio).

5. Touching the nose and ears with saliva.

6. Unction of the breast and shoulders.

Of these rites, 3, 4, and 6 are found in the Stowe Rite, while there is no mention of $\mathrm{I}, 2$, and $5^{\mathrm{I}}$.

In addition to these points, there is here the blessing of salt, and its imposition in the mouth of the catechumen, (as in the Gelasian Sacramentary ${ }^{2}$, and in the present Roman Ordines Baptismi, though with a different arrangement of words, p. 210), and a twofold application of the threefold questions of renunciation, separated by the threefold questions as to the candidate's faith (p. 209), an arrangement which does not appear to be found elsewhere.

II. The Benedictio or Consecratio Fontis opens with verses drawn from Psalms xli, xxviii, whereas the present Roman tract and verses sung during the procession to the font are drawn from the former Psalm only (xli. I, 2, 3). Then follows the lengthy Roman form of consecration substantially as found in the Gelasian Sacramentary, and as laid down for use in the present Roman Missal on Easter Eve. An older and shorter Benedictio aquae, consisting of two collects drawn, one from a Petrine, the other from an Ephesine source, are curiously placed, as if by way of appendix, at the conclusion of the Baptismal Office (Benedic Domine, \&c. fol. $5^{8} \mathrm{~b}$, Exorcizo te spiritus immunde, \&c. fol. 59 a).

III. The rite of baptism, differing both in language and ritual from any extant Ordo Baptismi, and especially remarkable for the presence of the 'Pedilavium' and the ceremonial crossing of the right hand of the candidate, and for the omission of the verbal formula of Baptism and of the presentation of the lighted taper (pp. 216, 217). 
IV. The Communion of the newly-baptized in both kinds conjointly, witl thanksgiving collect and antiphons (p. 218).

Then follow various short offices:-

I. Ad Visitandum Infirmum (p. 220).

2. De Sacramento Extremae Unctionis (p. 223).

3. Ad Communicandum Infirmum (Ib.)

It is hardly consistent with technical accuracy to print this 'Ordo Baptismi' under the heading of 'Reliquiae Liturgicae,' but a Eucharistic character is given to it by its retention of the custom, now obsolete in Western Christendom, of the immediate communion of the newly-baptized, and by there being appended to it offices for the Visitation, Unction, and Communion of the Sick, bearing a close resemblance, both verbal and substantial, to the similar Celtic offices surviving in the Books of Deer, Dimma, and Mulling. 


\section{INCIPIT ORDO BAPTISMI.}

Fol. 45 b. Deus, qui adam de limo terrae fecisti, et ille in paradiso pecauit, et illum peccatum mortis non reputasti, sed per per sanguinem unigeniti tui recuperare digneris et in sanctam hirusalem glorientem reducis. Ergo, maledicte, recognosce sententiam tuam, et da honorem domino et recede $a b$ hoc famulo dei quia hunc (hanc) deus et dominus noster ad suam sanctam gratiam atque missericordiam babtismi uocare dignatus est, per hoc signum crucis quod tu, diabule, nunquam adetis designare, per dominum nostrum.

Fol. 46 a.

\section{ORDO BABTISMI.}

Domine $^{1}$, sancte pater, omnipotens aeterne deus, expelle diabulum et gentilitatem ${ }^{2} a b$ homine isto, de capite, de cappillis, de uertice, de cerebro, de fronte, de oculis, de auribus, de naribus, de ore, de lingua, de sublingua, de gutore, de faucibus, de collo, de pectore, de corde, de corpore toto, intus, de foris, de manibus, de pedibus, de omnibus memris, de copaginibus memrorum eius, et de cogitationibus, de uerbis, de operibus, et omnibus conuersationibus híc et futuro per te, ihesu christe, qui reg[nas].

Fol. $46 \mathrm{~b}$. Deus ${ }^{3}$, qui ad salutem humani generis maxima queque sacramenta in aquarum substantia condidisti, adesto propitius inuocationibus nostris, et alimento huic multimodi purificationis tuae benedictiones infunde, ut creatum misterii

1 This collect is found among the 'Orationes contra Daemoniacum' in a tenthcentury codex in the library at Vienna, published by Gerbertus, Mon. Vet. Lit. Aleman. ii. p. I32. A still more exhaustive enumeration of the parts of the body is found in other collects of this date; Ib. pp. I31, 136; Leofric Missal, fol. $312 \mathrm{a}$.

2 This and similar expressions still found in the Roman Baptismal Offices point to a date when the candidate for Baptism was generally a convert from heathenism.

${ }^{3}$ Sacram. Gelas. p. $73^{8}$; Gregor. p. 264 ; Rit. Rom. p. 288 , Ordo ad faciendam aquam benedictam, with variations. This collect is repeated in extenso on p. 2 I I, and in St. Gall. MS. No. 1395, p. 184. 
seruiens ad abieciendos demones morbosque expellendos diuinae gratiae tuae sumat effectus, ut qui quid locu[m] in domibus fidelium bec un $[\mathrm{d}] \mathrm{a}$ resperserit, careat immunditia, liberetur a noxia, non illic residiat spiritus pestilens, non aura corrumpens, abscedant omnes insidiae latentis inimici, et si Fol. 47 a. quid est quod incolomitate habitantium inuidit aut quieti, aspersione aquae huius effugiat, ut salubritas per inuocationem nominis expetita ab omni sit impugnatione deffensa, per dominum nostrum.

\section{Consecratio salis incipit.}

Deus, qui ad salutem hominis medicinam per hunc salubrem salem, presta ut de errore gentilitatis anima illius conuertatur, et eripiatur, et trinum deum confiteatur, et diabulum repellat per abrenuntiationem, signumque crucis domini nostri ihesu christi, qui regnat cum patre et spiritu sancto in in saecula saeculorum.

\section{Item alia oratio ${ }^{1}$.}

Exorcizo té creatura salis, in nomine dei patris omnipotentis, et in caritate domini nostri ihesu christi, et in uirtute Fol. 47 b. spiritus sancti. Exorcizo te per deum uiuum, per deum uerum, qui te ad tutellam generis humani procreauit, et populo uenienti ad credulitatem per suos seruos consecreaisti precipit. Proinde rog(a)mus té, domine deus noster, ut hec creatura salis IN nomine trinitatis efficiatur salutare sacramentum ad effugandum inimicum, quod tu domine sanctificando sanctificis, benedicendo benedices, ut fiat omnibus accipientibus perfecta medicina permanens in uisceribus eorum, in nomine domini nostri ihesu christi, qui uenturus est iudicare uiuos et mortuos et saeculum per ignem ${ }^{2}$.

3 Rit. Rom. p. 24. Where this 'Benedictio salis' differs from that provided in the present R. Ordo Baptismi parvulorum, it follows the readings of the form given in the Gelasian Sacramentary, lib. i. No. xxxi. p. 534.

${ }^{2}$ Here follows in the Gelas. Sacram. the rubrical direction, substantially preserved in the present Rit. Rom., 'Et post hanc orationem pones sal in ore infuntis et dices. Accipe illi sal sapientiae propitiatus in vitam aeternam.' 
Fol. 48 a.

De abrenuntiatione.

Abrenuntias satanae? Res. Abrenuntio.

Et omnibus operibus eius? Res. Abrenuntio.

Et omnibus pompis eius? Res. Abrenuntio.

De confessione incipit.

Credis in deum patrem omnipotentem?

Respon. Credo.

Credis et in ihesum christum?

Respon. Credo.

Credis et in spiritum sanctum?

Respon. Credo.

Exsuflas et tanges eum. Deinde tanges pectus dorsum de oleo et crismate, dicens ${ }^{2}$.

Ungo té de oleo sanctificato, in nomine patris, et filii, et spiritus sancti.

Abrenuntias satanae?

Et omnibus operibus eius?

Et omnibus pompis eius?
Res. Abrenuntio.

Res. Abrenuntio.

Res. Abrenuntio.

Fol. 48b. Rogamus té, domine sancte pater, omnipotens aeterne deus, misserre famulo tuo .N. quem uocare ad rudimenta fidei dignatús es; caecitatem cordis omnem ab eo expellens disrumpe omnes laqueos satanae quibus fuerat colligatus; aperii ei ianuam ueritatis tuae, + ut signo sapientiae tuae indutus omnibus cupiditatem fetoribus careat, atque suaui odore preceptorum tuorum laetus tibi in aeclesia deseruiat, et proficiat de die in diem, ut idoneus efficiatur promisae gratiae tuae, in nomine patris, et filii, et spiritus sancti, in saecula saeculorum.

Fol. 49 a. Medellam ${ }^{3}$ tuam deprecor, domine sancte pater

1 These three questions occur in the Gelas. Sacram. in the Redditio Symboli (Catechumenorum) in Sabb. Sancto (Ordo xlii. p. 563), but they are not repeated twice as here, and the three questions 'Credis' \&c. are postponed till immediately before the act of baptism (Ib., Ordo xliv. p. 570). The renunciation in every Roman Office from the Gelas. Sacram. onwards is triple as here ; in the Milanese rite it was double, and in the Gallican single.

2 In the Gelas. Sacram. the rubric runs thus: 'Postea vero tangis ei pectus et inter scapulas de oleo exorcizato' (Ordo xlii. p. 563). See Introd. p. 66.

3 This collect, with very considerable variations, appears in the Baptismal Office in an ancient Limoges Ritual, published by Martene, de Ant. Ec. Rit. lib. i. c. I. art. xviii. ordo 18, and in a tenth-century German Ordo (Cod. Theol. 
ommipotens aeterne deus, qui subuenis in periculis, qui temperas flagillas, té, domine, supplices exoramus ut uisitatione tua sancta erigas famulum tuum .N. de hac ualitudine temtationem. Sicut in iob terminum pone, ne inimicus de anima ista sine redemtione babtismatis incipiat triumpare. Defer, domine, exitum mortis et spatium uitae distende. Reuela quem perducas ad babtismi sacramentum, nec redemptione tuae inferas damnum. Tolle occasionem diabulo triumphandi, Fol. 49 b. et reserua quem triumphis compares esse christi, ut sanus tibi in aeclesia tua gratia babtismatis renascatur, facturus cuncta quae petimus, per dominum.

Nec te lateat, satanas imminere tibi poenas, immine tibi gehinam, diem iudici, diem suplícii sempiterni, diem qui uenturus est uelud clibanus ignis ardens, in quo tibi adque angelis tuis sempiternus praeparatus est interitus; et ideo pro tua nequitia, dampnate atque damnande, da honorem deo Fol. 50 a. uiuo, da honorem ihesu christo, da honorem spiritu sancto paracleto, in cuius uirtute precipio tibi, quicumque es immundus spiritus, ut exeas et recedas ab his famulis dei, et eos deo suo reddas, quos dominus deus noster ihesus christus ad suam gratiam et benedictionem uocare dignatus est, ut fiat eius templum aquam regenerationis in remisionem omnium peccatorum, in nomine nostri domini ihesu christi, qui iudicaturus est iudicare uiuos et mortuos et saeculum per ignem ${ }^{1}$.

Isund doberar insalann imbelu indlelacti ${ }^{2}$.

Effeta, quod est apertio, effeta est hostia in honorem suanitatis, in nomine dei patris, et filii, et spiritus saucti ${ }^{3}$.

685 ; Bibl. Caes. Vind.) published by Gerbert, Liturg. Aleman. vol. ii. p. Io. col. I. In the Sacramentarium Augiense (Ib. Cod. Colbertin. No. I927; Mart. i. p. 7I), and in the Sacram. Gregor. p. 263 , it is entitled, as its contents indicate it to be, Oratio ad baptizandum infirmum.

1 R. Ordo Bapt. Adult., with verbal variations.

${ }^{2}$ Anglice, ' Here salt is put into the mouth of the child.'

3 In the present Roman Offices for Baptism, both of infants and adults, this formula, which is placed in the later and more strictly baptismal portion of the service, runs thus: 'Eppheta, quod est, Adaperire in odorem suavitatis. Tu autem effugare, diabole, appropinquabit enim judicium Dei.' It is used, not as here at the imposition of salt, but while the priest is touching the ears and 
Domine ${ }^{1}$ sancte, pater omnipotens, aeternae deus, qui es, et Fol. $50 \mathrm{~b}$. qui eras, et qui uenturns es, et permanens usque in finem, cuius origo nescitur, nec finis comprehendi potest; te, domine, supplicis inuocamus super hunc famulum tuum .N. quem liberasti de errore gentilium et conuersatione turpissima ; dignare exaudire eum qui tibi ceruices suas humiliat, perueniat ad babtismatis fontem, ut ut renouatus ex aqua et spiritu sancto, expoliatus ueterem hominem, induatur nouum qui sécundum té creatus est, accipiat uestem incorruptam et immaculatam tibi qui domino nostro seruire mereatur, in Fol. 51 a. nomine domini nostri ihesu christi, qui uenturus est iudicare uiuos et mortuos et saeeulum per ignem.

Deus $^{2}$, qui ad salutem humani generis maxima in aquarum substantia quecumque sacramenta in aquarum substantia condidisti, adesto propitius inuocationibus nostris, et elimento huic multimodo purificationis tuae effunde benedictionis, ut creatura misterii seruiens et abiecendos demones morbosque expellendos diuinae gratiae tuae sumat effectus, ut quicquid loqui ${ }^{3}$ in domibus fidelium hec unda resparserit, cariat immunditia, liberetur a noxia; non illic resideat spiritus pestilens, Fol. 51 b. non aura corrumpens, abscedant omnes insidiae latentes inimici; et si quid est quod incolimitate habitantium inuidit aut queti, asparsione aque huius effugiat, ut salubritas per inuocationem tui nominis expetita ab omni sit impugnatione deffensa. per.

Exandi ${ }^{4}$ nos, domine deus, pater omnipotens, aeternae deus,

nose of the candidate with saliva ; in the Gelas. Sacram. at the Catechismus Infantium in Sabbato Sancto (Ordo xlii. p. 563). The curious but intelligible reading of the text occurs in the Sacram. Gallican. (Mab. edit. p. 324): ' Effeta, effecta est hostia in odorem suavitatis.'

1 Rit. Rom. Ordo Bapt. Adult., with variations.

2 Rit. Rom. Ordo ad faciendam aquam benedictam; with variations. This collect has been previously given in extenso on p. 207 , q. v. for further references.

${ }^{3} \mathrm{c}$ and qu are sometimes interchanged by early Irish scribes. See Corpus Missal., Introd. p. 34. So 'scaloribus' is read infra, p. 215 ; 'corum' p. 24 I.

- This collect occurs in the 'Benedictio domorum facienda cum aspersione aquae benedictae' in the Rit. Rom. p. 300 ; Sacran. Gregor. p. 227 ; Gelas. p. 759 ; in the 'Benedictio Salis et Aquae' in the Sarum Brev. [Cambridge 
et mitire dignare angelum tuum sanctum de caelís, qui custodiat, subeat, protegat, uisitat, et defendat omnes inhabitantes in hoc habitaculo famuli tui illuc.

Huc usque catacominus. Incipit oleari oleo et crismate in pectus et item scabulas antequam babtizaretur ${ }^{1}$. Deinde letania cir. [ca] fontem canitur. Deinde benedictio fontis. Dcinde ii. psalmi; Sitiuit anima mea ${ }^{2}$ usque uiuum.

Quemadmodum uox domini super aquas multas ${ }^{3}$.

Adferte ${ }^{4}$.

Exorcizo $^{5}$ té, creatura aquae, per dominum niuum, per dominum sanctum qui te in principio uerbo separauit ab Fol. 52 a. arida, cuius spiritus super té ferebatur, qui té de paradiso emanere et in .iii. fluminibus totam terram rigari precipit, qui té de petra produxit, ${ }^{6}$ ut populum quem ex egypto liberauerat siti fatigatum rigaret, qui te amarissimam per lignum induleauit ${ }^{6}$.

Exorcyzo $^{7}$ té et per ihesum christum filium eius ${ }^{8}$, qui té in $\mathrm{c}(\mathrm{h})$ annan galiliae signo ammirabile sua potentia conuertit in uinum, qui pedibus superambulauit, et ab ionne in iordane in te babtizatus est, qui te una cum sanguine de latero suo produxit, et discipulís súis precipit dicens ; ite, docete, docete omnes gentes, babtitzantes eas in nomine patris, et filii, et spiritus sancti.

Fol. 52 b. Tibi ${ }^{9}$ igitur precipio omnis spiritus immunde, + omne fantasma, omne mendacium, eradicare, effugare ab hac creatura aquae ut discensurus in ea sit ei fons aquae sallientis

reprint, 1879, p. 354], and in the Office of Extreme Unction in the Rit. Rom. p. 130.

1 For the Unctions prescribed in this Office, see Introd. p. 66.

2 Ps. xli. 2.

3 Ps. xxviii. 3.

Ps. xxviii. 1. The R. Tract and vv. are from Ps. xli. I, 2, 3.

5 R. Benedico, from the Benedictio Fontis in Sabbato Sancto in Mis. Rom. p. 199 ; Sacram. Gel. p. 568 ; see Corpus Missal, fol. 201 a, with considerable variations. This and the following paragraph are transposed from their present R. position, where they come after 'consequantur' (on p. 214 .)
6-6 R. om.
${ }^{7}$ R. Benedico.
8 R. + unicum.

- This and the following paragraph are strangely placed here. The $R$. Benedictio Fontis proceeds with the clause 'Haec nobis praecepta,' \&c., \&8 on p. 215. 
in uitam aeternam. Efficae ergo, aqua sancta [a]qua benedicta, ad regenerandos filios deo patri omnipotenti, in nomine domini nostri ihesu christi, qui uenturus est in spiritu sancto iudicare seculum per ignem.

Exorcizo té, creatura aquac, in nomine dei patris omnipotentis, et in nomine domini nostri ihesu christi filii eius, et spiritus sancti, omnis uirtus aduersarii, omnis incursus diaFol. 53 a. buli, omne fantasma eradicare et effugare ab hac creatura aquae, ut sit fons sallientes in uitam aeternam, ut cum babtizatus fuerit fiat templum dei uiui in remisionem pecatorum, per dominum nostrum ihesum christum, qui uenturus est iudicare saeculum per ignem ${ }^{1}$.

Omnipotens sempiternae deus ${ }^{2}$, adesto magnae pietatis tuae misterís; adesto sacramentís, et ad creandos ${ }^{3}$ nouos populos Fol. 53 b. quos tibi fons babtismatis parturit ; spiritum adoptionis emitte ut quod humilitatis nostrae gerendum est ministerio tuae uirtutes compleatur effectu. per.

Deus $^{4}$, qui inuisibili potentia sacramentorum tuorum mirabiliter operaris effectu, et licet nos tantís misterís adsequandi sumus indigni, tú tamen gratiae tuae dona non deferens, etiam ad nostras preces aures tuae pietatis inclina, per. dominum nostrum deum.

Deus $^{5}$, cuius spiritus, super aquas inter ipsa mundi primordia fereabatur, ut etiam tunc virtutem sanctificationis aquarum natura conciperet.

Deus $^{6}$, qui innocentes mundi cremina per [a]quas abluens Fol. 54 a. regenerationis speciem in ipsa diluii effussione sig-

1 This form of 'Exorcismus aquae' occurs in a tenth-century German Ordo Baptismi, printed by Gerbert, Lit. Aleman. vol. ii. p. ro; and in part in St. Gall MS. No. $1395, \mathrm{p}$ 184. There is a collect resembling this one, but not identical with it, although opening with the same words, in the Ordo ad faciendam aquam benedictam Rit. Rom. p. 287 .

2 Mis. Rom. p. I9r, Benedictio fontis in Sabbato Sancto, with verbal variations; Corpus Missal, p. 199 ; Sacram. Gelas. p. 568 ; Gregor. p. 63.

From this point down to the unction immediately following the act of baptism the readings of the Gelasian Sacramentary are closely followed.

3 So Gel. ; recreandos Rit, Rom.

$\checkmark \mathrm{Ib}$,

1 Ib. Part of the Proper Preface.

I Ib. 
nasti, ut unius eiusdemque elementi ministerio, et finis esset uitís et origo nirtutibus, respice in faciem aeclesiae tuae, et multiplica in ea generationes tuas, qui gratiae affluentes impetu laetificas ciuitatem tuam, fontemque babtismatis aperis toto orbe terrarum gentibus innouandís, ut tuae maiestatis imperio sumat unigeniti tui gratiam de spiritu sancto, qui hanc aquam regenerandís hominibus preparatam arcana sui luminis ${ }^{1}$ ammixtione fecundet, ut, sanctificatione concepta, ab immaculato diuini foutes utero in nouam renouatam creaFol. 54b. turam progenies coelestis emergat; et quos aut sexus in corpore, aut aetas discernit in tempore, omnes in una pariat gratiam atque infantiam. Procul ergo hinc, iubente té. domine, omnis spiritus immundus abscedat. Procul tota nequitia diabuliticae fraudis absistat. Nihil hic loci habeat contrariae uirtutis ammixtio, non insidiando circumuolet, non latendo subripiat, non inficiendo corrumpat. Sit lec sancta et innocens creatura libera ab omni impugnationis incursu, et totius nequitiae purgata discessu. Sit fons uiuus, regenerans Fol. 55 a. aqua, unda purificans, ut omnes boc lauacro salutifero diluendi, operante in éis spiritu sancto, perfectae purificationis indulgentiam consequantur. per $^{2}$.

Unde benedico ${ }^{3}$ té, creaturae aquae, per deum uiuum, per deum sanctum, qui te in principio uerbo separauit $\mathrm{ab}$ arida ${ }^{4}$ et in quatuor fluminibus totam terram rigari precipit, qui té in deserto amaram suauitate indita fecit esse potabilem, et sitiFol. 55b. enti populo de petra produxit. Benedico te et per ihesum christum filium eius unicum, dominum nostrum; qui te in channan galileae signo ammirabili sua potentia conuertit in uinum; ${ }^{5}$ qui pedibus super té ambulauit, et $a b$

1 R. numinis.

${ }^{2}$ For the rubrics inserted here in the later Irish rite, see Corpus Missal, p. 200.

${ }^{3} \mathrm{Ib}$. This and the following paragraph have already occurred once on p. 212 , ' exorcizo ' being there substituted for 'benedico.'

- So Gel.; R. + cujus spiritus super te ferebatur qui te de paradisi fonte manare fecit.

${ }^{5-5}$ qui-sancti. A zigzag mark on the margin calls attention to the fact that this passage has already occurred in the form of 'Exorciamus aquae' on p. 212. 
iohanne in oirdane in té babtizatus est; qui té una cum sanguine de latera suo produxit, et discipulís suís iusit ut credentes baptizare(n)t in te, dicens, ite docete omnes gentes, baptizantes eos in nomine patris, et fili, et spiritus sancti ${ }^{5}$.

Haec nobis precepta seruantibus tú, deus omnipotens, clemens adesto, tú benignus aspira, tú has simplices aquas tuo ore benedicito, ut per te naturalem emundationem quam Fol. 56 a. lauandís possunt adhibere corporibus sint etiam purificandís mentibus efficaces, discendat in hanc plenitudinem fontis uirtus spiritus tui ${ }^{1}$, et totam huius aquae substantiam regenerandi fecundet effectu. Hic omnium pecatorum maculae deleantur. Híc natura ad imaginem tuam condita, ad honorem sui reformata principii, cunctís uetustatis scaloribus ${ }^{2}$ emundetur, ut omnis homo hoc sacramentum regenerationis ingressus in uerae innocentiae nouam infantiam renascatur, per dominum nostrum ihesum christum ${ }^{3}$.

Fol. 56 b. Deinde, benedictio completa, mittit sacerdos crisma in modum crucis in fontem, et quique uoluerit ${ }^{4}$ implet uasculum aqua benedictionis ad domos consecrandas, et populus pressens aspargilur aqua benedicta. Iterum roga a diacono si credat in patrem, et filium, et spiritum sanctum.

Credis in deum patrem omnipotentem ${ }^{5}$ ? $R$. Credo.

Credis et in ihesum christum filium eius unicum dominum nostrum natum et passum? $R$. Credo.

1 So Gel. ; R. + sancti, totamque.

${ }^{2}$ p. 2 II. n. 2 . 3 R. + qui venturus est, \&c.

4 There is a similar direction to the members of the congregation generally in the Corpus Missal, p. 202. The present R. rubric confines the right of taking away the consecrated water to 'unus ex ministris ecclesiae.' There too a triple use of oil is prescribed instead of the single application ordered here, viz. i. of the oil of the catechumens; ii. of the chrism; iii. of both oils combined. The Benediction of the font being now complete, the Baptismal Office proper is resumed. The Gelasian rubric runs thus, 'Inde benedicto fonte baptizas unumquemque in ordine suo sub his interrogationibus,' p. 570). In the later Roman Ordines Bapt. these three questions as to belief are immediately preceded by three questions as to the renunciation of Satan and his works. It is remarkable that while they are omitted here in accordance with Gelasian precedent, they should have occurred twice close together in the earlier portion of the service; p. 209.

5 So Gel. ; $\mathbf{R}+$ creatorem coeli et terrae. 
Credis et in spiritum sanctum, aeclesiam catholicam ${ }^{1}$, remisionem peccatorum, carnis resurrectionem ${ }^{2}$ ? Res. Credo.

${ }^{3}$ Discendit ${ }^{4}$ in fontem et tingitur ter uel aspargitur. ${ }^{5}$ Postquam babtizaretur oleatur cresmate in cerebrum in fronte ${ }^{5}, 3$ et dat uestem candidam diacunus super capute in frontae, et dicit prespiter $^{6}$;

Deus omnipotens, pater domini nostri ihesu christi, qui té regenerauit ex aqua et spiritu sancto, quique tibi dedit remisionem omnium peccatorum, ipse té lineat crismate salutis in christo.

Fol. 57 a. isund dognither intongath?.

Uigo ${ }^{8}$ té de oleo et de crismate salutis et sanctificationis, in nomine dei patris, et filii, et spiritus, nunc et per omnia in saecula saeculorum.

Operare $^{9}$, creatura olei, operare in nomine dei patris omnipotentis, et filii, et spiritus sancti, ut non lateat híc spiritus

1 Gel. sanctam.

${ }^{2}$ So Gel.; R. + et vitam aeternam. The text follows the Gelas. Sacram. in omitting the additional question now found in the Ordines Rom.:- 'Vis baptizari. B. Volo.'

${ }^{3-3}$ Gel. Sacram., Deinde per singulas vices mergis eum tertio in aqua. Postea, cum ascenderit a fonte infans signatur a Presbytero in cerebro de chrismate his verbis. (See Introd. p. 65.) The actual baptismal formula is omitted here as in the Gelas. Sacram. (Ordo xliv. p. 570; Gregor. Sacram. p. 65); in the description of baptism given in the Gallican work known under the title of St. Ambrose De Sacram. lib. ii. cap. 7 ; and in a ninth-century Sacramentary (Cod. Colbert, No. 1348) printed by Martene, Ordo v. vol. i. p. 66. The omission is strange. Perhaps, as in the case of the Eucharistic words of consecration, so often omitted, as on p. 246 , it was presumed that the priest would know them by heart.

* It is to be noticed that the direction to go down into the font implies that immersion was the general rule.

${ }^{3-5}$ Rit. Rom., 'Deinde intingit pollicem in sacro chrismate et ungit infantem in summitate capitis dicens.'

7 Anglice, 'Here the unction is made.'

- Rit. Rom. p. 3 .

- The only other place where a formula of unction occurs with the verb in the first person is in the Missal. Goth., 'Dum chrisma eum tangis dicis, Perungo te chrisma sanctitatis.' (Mab. ed. p. 248.)

9 This address to the oil occurs in the Ordo Baptismi in the Sacramentarium Gallicanum (Mart. i. p. 65 ; Mab. Lit. Gal. p. 324), but in connection with the rite of Unction before the act of Baptism; in an ancient but undated Ordo Vis. Infirm. in a Beauvais Pontif., Mart. i. p. $33^{2}$; in the Codex Vat. of the Greg. Sacram. editedby Rocca, Antv, 16I5, p. 224. 
immundus nec in membris, nec in medullis, compaginibus membrorum, sed operetur in té uirtus christi filii dei uiui altisimi, et spiritus sancti, per omnia saecula saeculorum. Amen.

Et dat nestem candidam diaconus super caput eius in frontae, et dum uestimento candido tegitur dicit prespiter ${ }^{2}$;

Accipe uestem candidam, sanctam, et immaculatam, quam Fol. 57 b. perferas ante tribunal domini nostri ihesu christi.

Res. Accipio et perferam ${ }^{2}$.

Et dicit prespiter,

Aperiatur manus pueri ${ }^{3}$.

Dicens,

Signum crucis christi + accipe in manum tuam dexteram, et conseruet te in uitam aeternam. $R$. Amen.

Tunc lauantur pedes eius, accepto linteo accepto 4 .

1 Rit. Rom. p. 30. The presentation of the white dress is followed in the R. Ordo Bapt. Parv. by the presentation, of a lighted taper, of which there is here no trace. Although not mentioned in the Gelas. and Gregor. Sacram., the latter ceremony is found in all mediaeval office books except those of Mayence.

${ }_{2}$ This response does not seem to occur elsewhere.

3 This ceremony is not found in the R. Ordo Bapt. nor in any of the Baptismal Offices printed by Martene, nor is any allusion made to it by him or by other writers on Baptism. But a similar rite is found in an eleventh century Jumieges Ritual, where it occurs at a much earlier point in the service, after the sign of the cross has been made on the infant's forehead: 'Tunc presbyter faciens crucem cum pollice intra palmam dextram infantis dicat. Trado signaculum Domini nostri Jesu Christi in manu tua dextera, ut te signes et te de adversa parte repellas, et in fide catholica permaneas, et habeas vitam aeternam, et vivas cum Domino semper in saecula saeculorum. Amen.' (Mart. Ordo xiii. vol. i. p. 73.)

4 This ceremonial washing of the feet, or 'pedilavium,' is not found in any Roman Office, but is common to the early Gallican 'Ordines Baptismi,' and was still in use in France in the eighth century, as we gather from a work, which usually passes under the name of St. Ambrose, and is bound up with his writings, but is now ascertained to be a Gallican production of about A.D. 800 , 'Ascendisti de fonte? Quid secutum est? Audisti lectionem. Succinctus summus sacerdos pedes tibi lavit... Non ignoramus quod Ecclesia Romana hanc consuetudinem non habeat.' (Ambros. De Sacram. lib. iii. cap. I, and Gallican Liturgies, ed. by G. H. Forbes, pp. 97, 189, 267.) Its presence in this ancient Irish Missal possibly supplies the clue to the meaning of one of the conditions of union offered, but without success, by St. Angustine to the British bishops, the precise interpretation of which has been hitherto left to 
Alleluia. Lucerna pedibus mieis uerbum tuum, domine ${ }^{1}$.

Alleluia. Adiuua me, domine, et saluus ero ${ }^{2}$.

Alleluia. Uisita nos, domine, in salutare tuo ${ }^{3}$.

Alleluia. Tu mandasti mandata tua custodire nimis ${ }^{4}$.

Mandasti missericordiam tuam, opus manuum tuarum ne despicias $^{5}$.

$\mathrm{Si}^{6}$ ego laui pedes nestras dominus et magister uester, et uos debetis alterutrius pedes lauare; exemplum enim dedi uobís ut quemadmodum feci uobis et uos faciteis ${ }^{7}$ aliis.

Dominus ${ }^{8}$ et saluator noster ihesus christus, pridie quam pateretur, accepto linteo splendido, sancto, et immaculato ${ }^{9}$, precinctís lumbís suís, misit aquam in piluem, lauit pedes discipulorum suorum. Hoc et tu facias exemplum domini nostri ihesu christi hospitibus et peregrinis tuis.

Fol. 58 a. Corpus ${ }^{10}$ et sanguinis domini nostri ihesu christi sit tibi in uitam aeternam. Amen.

conjecture:-'Ut ninisterium baptizandi, quo Deo renascimur, juxta morem sanctae Romanae et Apostolicae Ecclesiae compleatis.' (Bede, H. E. ii. 2 ; H. and S. i. 153.) This passage has by some been supposed to refer to confirma. tion. Dr. Lingard states, without giving any authority, that the Britons did not confirm after baptism. (A. S. Church, i. 295.) This rite of pedilavium obtained also at one time in Spain, but was abolished by Can. $4^{8}$ of the Council of Eliberis, A.D. 305. (Mansi, Concil. tom. ii. p. I4).

1 Ps. cxviii. 105.

4 Ps. cxviii. 4 .

2 Ib. II 7 . ${ }^{3}$ Ps. cr. 4. p. 225.

5 Ps. cxxxuii. 8.

6 Ioan. xiii. 14, 15. A sentence resembling this is ordered to be repeated at the Pedilavium in the three extant Gallican Ordines Bapt. Mis. Goth., Mab. ed. p. 249 ; Mis. Gallican., Mab. ed. p. $3^{64}$; Sacram. Gallican., Mab ed. p. $3^{25}$. The formula in the latter runs thus: 'Ego tibi lavo pedes, sicut Dominus noster,' \&c. ; n. 8.

7 For faciatis.

${ }^{8}$ Compare the following formula in the Sacram. Gallican. (Mab. ed. p. 325): - Dominus noster Jesus Christus de linteo, quo erat praecinctus tersit pedes discipulorum suorum, et ego facio tibi, tu facies peregrinis, hospitibus et pauperibus.'

9 Compare the three epithets applied to the chrisom, supra, 'Accipe vestem,' \&c.

10 [Communion of the newly-baptized.] The immediate approach to the altar of the newly-baptized, still clad in their white dress, 'familia candidata,' is described at length in the Gallican work usually printed as S. Ambros. de Sacram. lib. iii. $2 . \S 15 ;$ iv. 2 ; v. $3 . \S 14$. The confirmation or communion (generally both) of such persons is ordered in every mediaeval Ritual till the fourteenth century. The rubric in the Gelasian Ordo Bapt. (Murat. td. p. 571) simply prescribes, 'Deinde ab episcopo datur eis Spiritus septiformis.' In the 
Refecti ${ }^{1}$ spiritalibus escís, cibo coelesti, corpore et sanguine domini recreati, deo domino nostro ihesu christo debitas laudes et gratias referamus, orantes indefessam eius missericordiam, ut diuini muneris sacramentum ad inerementum fidei et profectum acternae salutis habeamus. per.

Oremus, fratres carisimi ${ }^{2}$, pro fratre nostro N. qui gratiam domiui consecutus est, ut babtismi quod accipit immaculatum atque integrum perferat ante tribunal domini nostri ihesu christi, qui.

Fol. 58 b. Deus ${ }^{3}$, tibi gratias agimus per quem misteria sancta celebrauimus, et a te sanctitatis do[num] deposcimus, per dominum.

Alleluia. Memento nostri, domine, in beneplacito populi tui, uísita nós in salutari tuo ${ }^{4}$.

Alleluia. Ó domine, saluum fac ${ }^{5}$.

$\delta$ domine, bene prosperare ${ }^{6}$.

ninth-century Gelasian Codices (Colbert. I 348, Reg. $3^{866}$ ) there is this order :- Postea si fuerit oblata, agenda est missa, et communicat. Sin autem, dabis, eis tantum sacramenta Corporis et Sanguinis Christi dicens, Corpus Domini nostri Jesu Christi sit tibi in vitam aeternam ;' followed by two short collects of thanksgiving for baptism. (Mart. i. p. 66.)

For this purpose altars were usually erected in baptisteries, a custom which can be traced back to the time of Pope Hilary (46I-7). (Mart. vol. i. pp. 5, 55.)

In a tenth-century Parisian Codex this rubric occurs : ' Et vestitur infans vestimentis suis. $\mathrm{Si}$ vero episcopus adest statim confirmari eum oportet chrismate et postea communicare; Et si episcopus deest, communicetur a presbytero dicente ita,' \&c. (Mart. Ordo x. vol. i. p. 7o.) Book of Deer, p. I64. n. 5 ; Book of Dimma, p. 170 ; Book of Mulling, p. 173.

1 For the Ephesine character of this and the following thanksgivings, see Book of Deer, p. 165. n. 1. Compare the post-reception collects in the Book of Dimma, p. 17 i ; Book of Mulling, p. 173.

${ }^{2}$ p. $167 \cdot n .3$. There are one or two post-baptismal collects of thanksgiving resembling this one in their tenor in all the Gallican Offices. Compare the following from the Sacram. Gallican. (Mab. edit. p. 325): 'Laudes et gratias Domino referamus, fratres dilectissimi, quod augere dignatus est ecclesiae suae congregationem per caros nostros qui modo baptizati sunt. Petamus ergo de Doınini misericordia ut baptismum sanctum quod acceperunt, inlibatum, inviolatum, et immaculatum perferant ante tribunal Christi.'

3 Book of Deer, p. 165. n. 7; Book of Dimma, p. 171 ; Book of Mulling, p. 173.

4. Ps. cv. 4. The latter half of this verse is repeated in the Ordo ad Com. Infirm. p. 225 .

5 Ps. exvii. 25.

- Ib. 
Alleluia. Ostende nobís, domine, usque nobís ${ }^{1}$.

Salua nos, ihesu, qui potes saluarae, qui dedit animam det et ${ }^{2}$ salutem, per dominum.

Benedíc $^{3}$, domine, hanc creaturam aquae, ut sit remedium Fol. 59 a. generi humano salutare, presta, per inuocationem nominis tui, per hanc creaturam aquae, corporis sanitatem, et animae tutellam, rerum defensionem. per.

Exorcizo 4 té, spiritus immunde, per deum patrem omnipotentem, qui fecit caelum et terram, mare, et omnia quae in eis sunt, ut omnis nitus aduersarii, omnis exercitus diabuli, omnis incursus, omne fantasma inimici eradicetur et effigetur ab hác creatura aquae, ut sit sancta et salutifera, et ignis ardens aduersus insidias inimici, per inuocationem nominis domini nostri ihesu christi, qui iudicaturus est saeculum per ignem in spiritu sancto. Amen.

\section{[ORDO AD VISITANDUM INFIRMUM.]}

Oremus $^{5}$, fratres, dominum deum nostrum pro fratre Fol. 59 b. nostro ad pressens malum langoris adulcerat, ut

\footnotetext{
1 Ps. lxxxiv. 8. Book of Dimma, p. 170; Stowe Mis. p. 232.

2 p. 221 , line 2.

3 Sacr. Gregor. p. 229. This and the following Exorcism are apparently
} misplaced here. They seem to be appended as forms once in use, but now rendered useless by the insertion of the larger Roman 'Benedictio Fontis' (p. 2 I 2 ) in its proper place.

4 This is a Gallican and Milanese Exorcism. It occurs in the Ordo Baptismi in the Sacramentarium Gallicanum (Mab. edit. p. 324), and in an Ambrosian Ritual quoted by Martene (Orlo xxi. vol. i. p. 80). In both cases it is an 'Exorcismus hominis,' not 'aquae.' We append the Gallican text : 'Exorcidio te, spiritus immunde, per Deum Patrem omnipotentem, qui fecit coelum et terram, mare et omnia quae in eis sunt, ut omnis virtus adversarii, omnes exercitus diaboli, omnes incursus, omne fantasma eradicetur ac fugetur ab hoc plasmate, ut fiat templum Dei sanctum in nomine Dei Patris omnipotentis, et Jesu Christi Filii ejus, qui judicaturus est saeculum per ignem in spiritu sancto in saecula saeculorum.' Its introductory rubric in the Milanese rite is this: ' Exsufflat in faciem ejus in similitudinem crucis dum dicit.' Compare the forms of 'Exorcismi' at the benediction of each of three oils on Maundy Thursday in the Roman Pontifical. That employed in the 'Benedictio chrismatis' most closely resembles the text.

${ }^{5}$ Here commences an Office for the 'Visitatio Infirmi.' It corresponds very closely with that preserved in the Book of Dimma, p. 167, to which the reader is referred for notes, and of which this forms the opening address. Gerbert, Lit. Al. ii. 33 . 
eum domini pietas coelestibus diguetur curare medicinis, qui dedit animam det et salutem. per.

Deum ${ }^{1}$ uium omnipotentem sua omnia opera restaurare, confirmare facillimum est, fratres carissimi ${ }^{2}$, pro fratre nostro infirmo .N. supliciter oremus, quo creatura manuum sentiat creatoris, ut aut in reparando aut in recipiendo in nomine suo pius pater opus suum recreare dignetur. per dominum nostrum ihesum christum.

Domine ${ }^{3}$, sancte pater, uniuersitatis auctor, omnipotens aeterne deus, cui cuncta uiuunt, qui uiuificas mortuos, et uocas Fol. 60 a. ea quae non sunt tanquam sunt, qui quod est tuum solitum opus, qui es magnus artifex pie exercere in hoc tuo plasmate $^{4}$, per christum.

Deus ${ }^{5}$, in cuins manu tam alitus uiuentes quam uita morientis, fratres delectissimi, deprecemur ut corporis huius infirmitatem sanet, et animae salutem prestet, ut quod per merita non meretur, missericordiae gratiae consequatur orantibus nobis prestet, per dominum nostrum ihesum christum.

Domine ${ }^{6}$, sancte pater, omnipotens aeterne deus, qui es uia, et veritas, et uita, exaudi et conserua famulum tuum Fol. 60 b. hunc N. quem uiuificasti et redemisti pretio magno sancti sanguinis filii tui, qui regnas.

1 Book of Dimma, p. 167.

2 For the Ephesine character of these addresses to 'fratres carissimi' or 'fratres dilectissimi,' see p. 167. n. 3. In the Mozarabic Lit. the 'Missa,' the 'Ad orationem dominicam,' the 'Alia oratio post missam,' the 'Post pridie' are frequently so addressed (pp. $257,830,879$, \&c.) In the Gallican Lit. the 'Praefatio,' the 'Collectio post nomina,' the 'Ante Orationem Dominicam,' the 'Post communio' assume the same form (Mis. Goth. pp. 37, 40, 46, 51). See Bouks of Dimma and Mulling; Corpus Missal, fol. roo a.

3 Book of Dimma, p. 167. This collect also occurs in an eleventh-century Narbonne Pontif., Mart. i. p. 318 ; in a twelfth-century Salzburg Pontif,, Ib. i. p. 325. The phrase 'uniuersitatis auctor' occurs again in a Postcom. on p. 271 .

4 For the use of this word 'plasma,' see p. I67. n. 7 .

5 Book of Dimma, p. 168.

- This collect occurs among the Prayers for the Sick in a tenth-century MS. published by Gerbert, Liturg. Aleman. ii. 3o. Also in an Ordo Extremae Unctionis, Ib. p. 33 ; in a twelfth-century Salzburg Pontif., published by Mart., Ordo xv. vol. i. p. 324 . 
Deus $^{1}$, qui non uís mortem ${ }^{2}$ sed ut conuertatur peccatoris ${ }^{2}$ et uiuat, huic ad té ex corde conuerso peccata dimite, et perennis uitae tribue gratiam, per dominum.

Deus $^{3}$, qui facturam tuam pio semper donaris affectu, iuclína aurem tuam suplicantibus nobís tibi ad famulum tuum .N. aduersitate uelitudinem corporis laborantem placidus respice, uissíta eum in salutari tuo et coelestis gratiae concede medicamentum. per.

Fol. 61 a. In ${ }^{4}$ illo tempore accesserunt saducei ad eum dicentes non esse resurrectionem, et interrogauerunt eum. Respondens ihesus illís ait; erratis nescientes scripturas neque uirtutem dei; in resurrectione enim neque nubent neque nubentur, sed erunt sicut angeli dei in caelo. De resurrectione autem mortuorum non legistis quomodo dictum est a domino dicente uobís, Ego sum deus abracham, deus issac, deus iacob; non est ergo deus mortuorum, sed deus uiuentium. Et audientes turbae mirabantur doctrina eius.

In ${ }^{5}$ illis diebus dixit ihesus; Statim hautem post Fol. 61 b. tribulationem dierum illorum sol obscurabitur, et luna non dabit lumen suum, et stellae cadent de caelo, et uirtutes caelorum commobebuntur, et tunc apparebit signum filii hominis in caelo, et tunc plangent sé omnes tribús terrae,

1 Book of Dimma, p. 168; Gerbert, Liturg. Aleman. ii. 30; also in a twelfth-century Salzburg Pontif., Mart., Ordo xv. vol. i. p. 324 ; in a Latin Ordo in use in Syria in the twelftl century ; Mart., Ordo xxiii. vol.i. p. 335 .

2 There has been an accidental transposition of words here.

3 Book of Dimma, p. I68; Gelas. Sacram., Murat. edit. p. 735; Greg. p. 21 I ; Corpus Missal, p. 207. Also in a tenth-century German Ordo (Cod. Th. v. 683) published by Gerbert, Lit. Aleman. ii. 29. Again in an eleventh-century Cod. Rhenaug., Ib. p. 37 ; in Codex Colbertin. No. 2585 (a French Ritual), copied by Mart. i. p. 31 I ; in a twelfth-century Salzburg Pontif., Mart. i. p. 323, Ordo xv; in a twelfth-century Remiremont Missal, Ib. Ordo xvii. p. 328; a ninth-century Fleury Codex, Ordo i, Ib. vol. ii. p. 377; a fourteenth-century Rouen Ritual, Ordo xii, Ib. p. 400.

4 Matt. xxii. 23-33. This forms the second of the two lections in the Book of Dimma, p. 168 , the readings in which differ in some particulars from those presented here.

s Matt. xxiv. 29-31. For this lection the Book of Dimma (p. 168) substitutes I Cor. xv. 19-22. None of these lections occur among those provided in the Ordo de Visitatione Infirm. in the Rit. Rom. 
et videbunt filium homines nenientem in nubibus caeli, cum uirtute multa et maistate, et mittet angelos suos cum tuba et uoce magna, et congregabunt electos suos a quatuor uéntis, a summis caelorum usque ad terminos eorum.

[ORDO MINISTRANDI SACRAMENTUM EXTREMAE UNCTIONIS] ${ }^{1}$.

Fol. 62 a. Ungo té de oleo sanctificato, ut salueris in nomine patris, et filii, et spiritus sancti, in saecula ${ }^{2}$.

Concede, domine, nobís famulís túis ut orantibus cum fiducia dicere meriamur ${ }^{3}$ :

Pater noster.

Libera nos, domine, ab omni malo, et custodi nós in omnilo ${ }^{4}$, ihesu christe, aucto[r] omnium bonorum, qui regnas in saecula saeculorum.

\section{[ORDO AD COMMUNICANDUM INFIRMUM $]^{5}$ :}

Oramus té, domine, pro fratré nostro .N. cui infirmitate sua officium commonionis, ut si qua eum saecularis macula inuassit, aut uitium mondialem ficit, dono tuae pietatis indulgeas et extergas. per.

1 The earliest extant Ordines Extremae Unctionis are found in certain ix-x cent. MSS. of the Gregor Sacram, Tilianus, Remensis, S. Eligii, Ratoldi, \&c. They are elaborate in their structure, and bear no resemblance to the simple rite in the Stowe Missal. A later and more expanded Irish Office, including the Unction of the various parts of the body, is given in the Corpus Missal, p. 208.

${ }^{2}$ This very nearly resembles the formula of Unction in the Book of Dimma, p. 169 ; Book of Mulling, p. I72.

3 This Preface and the following Enbolismus to the Pater Noster occur in the Book of Dimma, p. 169. Compare the Book of Deer, p. 164.n. 3 ; Book of Mulling, p. 172.

4 For omni bono.

${ }^{5}$ It appears from the order in which these services are arranged that Communion is intended to follow the rite of Unction, as in the case of the tenthcentury German Offices published by Gerbert, Lit. Aleman. ii. 33, and in accordance with the almost universal custom of the Western Church (Mart. i. p. 297). The whole 'Ordo' differs almost entirely from any extant Roman Office of Communion of the Sick. Its points of resemblance to other Celtic - Offices are pointed out in the following notes. 
Fol. 62 b. Domine ${ }^{1}$, sancte pater, te fideliter deprecemur ut accipiendi fratri nostro ${ }^{2}$ sacrosanctam hane æucharistiam corporis et sanguinis ${ }^{2}$ domini nostri ihesu christi, tam carnis quam animae sit salus. per dominum.

Exaudi nós, domine ihesu christe, deus noster, pro fratre nostro infirmo, té rogantes ut tua sancta euchoristia sit ei tutella per dominum.

Páx et caritás domini nostri ihesu christi et commonicatio sanctorum tuorum sit semper uobiscum ${ }^{3}$. 7 . Amen.

Corpus et sanguis domini nostri ihesu christi filii dei uiui altisimi. $\quad r l^{4}$.

Fol. 63 a. Accepto salutari diuini corporis cibo lalutari nostro, ihesu christo gratias agimus ${ }^{5}$, quod sui corporis et sanguinis sacramento nos á morte liberauit, et tam corporis quam auimae homano generi remedium donare dignatus est, qui regnat.

Agimus deo patri omnipotenti gratias, quod terrenae nos originis atque naturae sacramenti sui dono in coelestem uiuifieauerit denotationem, per dominum ${ }^{6}$.

Conuerte nós, deus salutum nostrarum, et infirmorum praesta salutem nostrorum ?

Fol. 63 b. Quia satiauit animam inanem, et animam essurientem satiauit ${ }^{8}$.

1 This collect occurs with various readings in Rit. Rom. p. I23, and in the Corpus Missal, p. 209.

2 R. sacrosanctum corpus.

3 Compare the formula in the Book of Dimma, p. I 70, where see note 3 as to this position of the Pax; Stowe Missal, p. 242. The Pax and Communion are curiously blended together in one clause in the tenth-century German Office, printed by Gerbert, Lit. Aleman. ii. 33: 'Pax et communicatio corporis et sanguinis Domini nostri Ihesu Christi conservet animam tuam in vitam eternam.'

* For the remainder of this formula of adninistration, see Buok of Deer, p. 164. n. 6; Book of Dimma, p. 170; and Book of Mulling, p. 173 .

5 This resembles in principle, but differs rerbally from, the collects of thanksgiving in the Books of Deer (p. 16 $6_{5}$ n. 1), Dimma (p. 170), and Mulling (p. I 73), and the Praefatio post Eucharistian in the Gallican Missa in Symboli Traditione (Mart. i. p. 35).

6 Book of Dimma, p. 170.

- Ps.cvi. 9. Book of Deer, p. 165 .

7 Ps. Ixxxiv. 5. Book of Dimma, p. 170. 
bis. Alleluia. Alleluia.

Uissita nos, deus, in salutari tuo ${ }^{1}$. Alleluia.

Fortitudo mea, usque salutem ${ }^{2}$. Alleluia.

Calicem salutaris accipiam usque inuocabo ${ }^{3}$. Alleluia.

Refecti christi corpore et sanguine tibi semper, domine, dicamus ${ }^{4}$. Alleluia.

Laudate dominum omnes gentes ${ }^{5}$, usque in finem.

Sacrificate sacrificium iustitiae, et sperate in domino ${ }^{6}$.

Fol. 64 a. Deus, tibi gratias agimuz per quem misteria sancta celebrauimus, et ad té sanctitatís dona deposcimus, qui regnas in saecula saeculorum ${ }^{7}$.

Benedicat tibi dominus et custodiat te, ostendatque dominus faciam suam tibi, et misseriatur tui, conuertat dominus uultum suum ad té, et det tibi pacem ${ }^{8}$.

et respondit. Amen.

Tunc signans eum dicito ${ }^{9}$,

Signaculo crucis christi signaris.

Páx tecum in uitam eternam.

et respondit. Amen.

Finit ordo commonis.

1 Ps. cr. 4. This verse is also used in the Communion of the newly-baptized, p. 218.

2 Ps. cxvii. 14. Book of Dimma, p. I70; Stowe Mis. p. 229.

${ }^{3}$ Ps. cxv. 13. Book of Deer, p. 165; Book of Dimma, p. I70; Book of Mulling, p. 173 .

4 Book of Deer, p. I65; Book of Dimma, p. I7I; Book of Mulling, p. I73; Antiphon. Benchor. p. 192.

5 Ps. cxvi. Book of Deer, p. I65; Book of Dimma, p. I 71 ; Book of Mulling, p. I73.

6 Ps. iv. 16. Book of Deer, p. 165; Book of Dimma, p. 171; Book of Mulling, p. 173 .

7 Book of Deer, p. 165; Book of Dimma, p. 170; Book of Mulling, p. 173 ; Mis. Goth. pp. 144, 150.

8 This Benediction occurs in an abbreviated form in the Book of Dimma, p. I II, and in its present form with various readings in the Book of Mulling, p. I72. Similar but not identical Benedictions occur near the end or at the conclusion of most mediaeval offices for the Visitation of the Sick.

- Compare the rubric in Book of Dimma, p. I 7 I. 


\section{[ORDINARIUM MISSÆ.]}

Fol. 13 a.

LETANIA ${ }^{1}$ APOSTOLORUM AC MARTIRUM SANCTORUM ET UIRGINUM INCIPIT (I).

Deus in adiutorium nostrum intende (2).

Peccauimus (3), domine, peccauimus, parce peccatis nostris, et salua nos, qui gubernasti noe super undas dilui exaudi nós, et ionam di abiso uerbo reuocasti libera nos, qui petro, mergenti manum porrexisti auxiliare nobis, christe.

Fol.13 b. Fili dei, ficisti mirabilia domini cum patribus nostris, et nostris propitiare temporibus. Emite manum tuum de alto.

Libera nos christe

Audi nos christe

cyrie elezion

sancta maria

sancte tathei

sancte petri

sancte pauli

sancte madiani $(4)$

sancte anrias

sancte marce

sancte iacobi

sancte bartholomei

sancte lucae

omnes sancti orate pro nobis. propitius esto, parcae nobis,

sancte tomae

sancte mathei domine; propitius esto, libera nos, domine;

sancte iacobe

ab omni malo libera nos, domine, per crucem tuam(5) libera nos, domine.

\section{Foth 29-30 ought to follow here.}

Fol. 14 a. Oratio Augustini(6).

Profeta omnes iustitae nostrae sicut pannus menstruate. Indigni sumus, domine christe, ut simus uiuentes, sed tú, deus,

1 In consequence of their necessary length the notes referred to by numbers between parentheses have been postponed to p. 249 . 
non uis mortem peccatoris; dá nobís ueniam in carne constitutís, ut per penitentiae labores uita aeterna perfruamur in caelis, per dominum.

Rogo (7) té, deus zabaoth altissime, pater sancte, uti me tonica caritatis digneris accingere, et meos lumbos ba(l)theo (8) tui amoris ambire, ac renes cordis mei tuae caritatis igne urire, ut pro peccatís méis possim intercedere, et adstantes populi peccatorum ueniam promeriri, ac pacificas singulorum hostias immolare, me quoque tibi audaciter accidentem non sinas perire (8), sed dignare lauare, ornare, et leniter suscipere, (8) per dominum nostrum.

Fol. $14 \mathrm{~b}$. Hec oratio in omni misa cantatur.

Ascendat oratio nostra usque ad tronum claritatis tuae, domine, et ne uacua reuertatur ad nos postulatio nostra, per.

\section{In SOllemitatibus Petri et ChRISTi(9).}

Deus, qui beato petro apostolo tuo, conlatis clauibus regni caelestis, animas ligandi autque soluendi(ro) pontificium tradidisti, suscipe propitius preces nostras, et intercessione eius, quesumus, domine, auxilium, ut a peccatorum nostrorum neximus liberemur, per dominum(II).

\section{IMNUS $\triangle N G E L I C U S(12)$.}

Gloria in excelsis deo, et in terra pax hominibus bonae uoluntatis. Laudamus té, benedicimus té, adoramus té, glorificamus té, ${ }^{1}$ magnificamus te ${ }^{1}$, gratias agimus tibi pro ${ }^{2}$ magnam misericordiam ${ }^{3}$ tuam, domine ${ }^{4}$, rex caelestis ${ }^{5}$, deus pater omnipotens, domine filii dei ${ }^{6}$ unigeniti ihesu christe, ${ }^{7}$ sancte spiritus dei, et omnes dicimus amen, domine, filii dei patris, agne dei, qui tollis peccatum mundi, misserere nobís, suscipe orationes nostras ${ }^{7}$, qui sedis ad dexteram dei $^{6}$ patris, misserere

\footnotetext{
${ }^{1-1}$ om. $\quad{ }^{2}$ propter. $\quad{ }^{3}$ gloriam. $\quad+$ Deus.

5 After this word the writing is continued in a later hand on a slip inserted between fol. $14 \mathrm{~b}$ and fol. I5 $\mathrm{a}$.

7-7 Domine Deus, Agnus Dei, Filius Patris, Qui tollis peccata mundi miserere nobis, Qui tollis peccata mundi suscipe deprecationem nostram.
} 
nobis ; quoniam tú solus sanctus, tú solus dominus, ${ }^{1}$ tú solus dominus ${ }^{1}$, tú solus ${ }^{2}$ gloriosus cum spiritu sancto ${ }^{2}$ in gloria dei patris. amen.

Fol. 15 a. Hec oratio pro uice dicitur qui culpa in cotidianís diebus...

Deus qui diligentibus té bona inuisibilia preparasti, effunde cordibus nóstrís tui amoris affectum, ut té in omnibus et super omnia diligentes promisiones tuas que omne desiderium superant consequamur, per dominum(rz).

\section{ÓRATIONÉS ET PRECÉS MISERICORDIAE AECLESIAE ROMANE (14).}

HEC ORATIO PRIMA PETRI.

Deus, (15) qui culpa offenderis, penitentia placaris, (15) adflictorum gemitus respice, et mala que iustae inrogas misericorditer auerte, per.

Hic augmentum(16).

LeCtio PaUli apostoli ad CORINTHEOS iNCiPit(it).

Fratres $^{3}$, quotiescumque ${ }^{4}$ manducabítis panem hunc, ${ }^{5}$ et Fol. $15 \mathrm{~b}$. bibetis calicem istum ${ }^{5}$, mortem domini adnunciabitis donec ueniat. Itaque quicumque manducauerit panem ${ }^{6}$, uel biberit calicem domini indigne, reus erit corporis et sanguinis domini. Probet hautem séipsum homo, et sic de pane illo edat et de calige bibat. Qui enim manducan ${ }^{7}$ et bibit $^{8}$ non discernens ${ }^{9}$ corpus domini. Propterea ${ }^{10}$ inter uos multi infirmi et egri11, et dormiunt multi. Quodsí nosmetipsos iudicaremus ${ }^{12}$, non utique iudicaremur. Dum

1-1 om.

${ }^{2-2}$ altissimus Jesu Christe.

[Differences from the Vulgate (Textus receptus) are noticed below, except in the case of merely orthographical discrepancies.]

3 V.om. $\quad$ V. + enim. $s_{-5} \mathrm{~V}$. et calicem bibetis.

${ }^{6} \mathrm{~V} .+$ hunc. ${ }^{7} \mathrm{~V}$. manducat. A later hand has written $t$ over this word.

${ }^{8} \mathrm{~V} .+$ indigne judicium sibi manducat et bibit-words which a later hand has also written over the line.

$1 \mathrm{~V}$, imbecilles.

- V. dijudicans.

$10 \mathrm{~V}$. Ideo.

12 V. dijudicaremus. 
hautem $^{1}$ iudicamur $^{2}$, a domino corripimur, ut non cum hoc mundo damnemur.

Deus, (18) qui nós regendo conseruás, parcendo iustificás, a temporali tribulatione nós eripe, et gaudia nobís eterna largire, per dominum nostrum. rl.

Omnipotens sempiterne deus, qui populum tuum unigeniti Fol. 16 a. tui sanguine redimisti, solue opera diabuli, rumpe uincula peccati, ut qui ad eternam uitam in confessione tui nominis sunt adepti nihil debeant mortis auctori. per.

Querite dominum et confirmamini, querite faciem eius semper( $18 \mathrm{a}$ ).

Confitemini, et inuocate nomen eius, usque, querentium dominum-querite ( $1 \& \mathrm{~b})$.

(19) Grata sint tibi, domine, munera quibus (19) misteria celebratur nostrae libertatis et uitae, per. alleluia.

Fortitudo mea et laudatio (2o) usque in salutem.

Sacrificiis presentibus, domine, quesumus, intende placatus, ut deuotionis nostrae proficiat ad salutem(21).

Fol. 16 b. DePRECATIO (22) SANCTI MARTINI PRO POPULO INCIPIT.

Amen. Deo gratias.

(a) Dicamus (23) omnes, domine, exaudi et missere, domine, misserre.

( $\beta$ ) Ex toto corde et ex tota mente quí respices super terram et facis eam tremere. oramus.

( $\gamma$ ) Pro altissima pace et trancillitate temporum nostrorum, pro sancta aeclesia catholicaque a finibus usque ad terminos orbis terrae. oramus.

( $\delta)$ Pro pastore .n. episcopo et omnibus episcopis, et praespeteris, et diaconis, et omni clero $(24)$. oramus.

( $\epsilon$ ) Pro hoc loco, et inhabitantibus in eo, pro pissimis imperatoribus $(25)$, et omni romano exercitu(25). oramus.

$(\zeta)$ Pro omnibus qui in sublimitate constituti sunt, pro uirginibus, uidúis, et orfánis. oramus. 
Fol. 17 a. ( $\eta$ ) Pro perigrinantibus, et iter agentibus, ac nauigantibus, et poenitentibus, et catacominis. oramus.

$(\theta)$ Pro his qui in sancta aeclesia fructus misserecordiae largiuntur, domine deus uirtutum, exaudi preces nostras. oramus.

( ا) Sanctorum apostolorum ac martirum memores símus, ut, orantibus éis pro nobís, ueniam meriamur. oramus.

( $\kappa$ ) Christianum et pacificum nolís finem concedi a domino deprecemur. Presta, domine, presta.

( $\lambda$ ) Et diuinum in nobís permanere uinculum caritatis sanctum dominum deprecemur. Presta.

$(\mu)$ Conseruare sanctitatem et catholicae fidei puritatem dominum deprecemur. Presta. Dicamus.

Fol. 17b. Sacrificium tibi domine celebrandum placatus intende, quod et nos a uitíis nostrae condicionis emundet, et tuo nomine retdat aceptos, per dominum(26).

Ante oculos tuos, domine, reus conscientiae testes adsisto; rogare pro alís non audio quod impetrare non meriar; tú enim scís, domine, omnia que aguntur in nobís; erubescimus confiteri id quod per nós noǹ timemus admitti; uerbís tibi tantum obsequimur, corde mentimur, et quod uelle nós dicimus Fol. 18 a. nostrís actibus adprobamus. Parce, domine confitentibus, ignosce peccantibus, misserere té rogantibus (27) sed quia in sacramentís tuís meus sensus infirmus est, presta, domine, ut qui ex nobís duro corde uerba non recipis per te nobís ueniam largiaris, per dominum (28).

Lethdírech sund (29).

Dirigatur domine usque nespertinum (30).

Ter canitur. Hic eleuatur lintiamen de calice(31).

Ueni, domine, sanctificator omnipotens, et benedic hóc sacrificium praeparatum tibi $\left(3^{2}\right)$.

Ter canitur. 
Fol. 18 b.

\section{INCIPIT LECTIO EUANGILII SECUNDUM}

$$
\text { I OH A N EM (33). }
$$

${ }^{1}$ Dominus nóster ihesus christus dixit' ${ }^{1}$; ego sum panis uiuus qui di coelo discendi. Sí quis manducauerit ex eo ${ }^{2}$ niuet in aeternum, et panis quem ego dabo ei caro mea est pro huius ${ }^{3}$ mundi uita. Litigabant ergo iudaei ad inuicem, dicentes, quomodo potest hic nobís dare ${ }^{4}$ carnem suam manducare $^{4}$ ? dixit ergo eís ihesus ; amen, amen, dico uobís, nisi manducaueritis carnem filii hominis sicut $^{5}$ panem $^{5}$, et biberitis $^{6}$ sanguinem huius ${ }^{7}$, non habebitis (34).

\section{Oratio gregoriana SUPER EUANGELIUM(34a).}

Quesumus, domine, omnipotens deus, ut uota nóstra tibi immulata clementer respicias; atque ad defentionem nóstram dextram tuae maestatis extendás, per dominum nóstrum .....rl :

Fol. 19 a. bitis uitam in uobís. Qui manducat meam carnem, et bibet meum sanguinem habet nitam aeternam, et ego resuscitabo eum in nouissimo diae. Caro enim mea uere est cibus, et sanguis meus uerus est potus; qui manducat meam carnem, et bibit meum sanguinem ipse in me manet, et ego in illo.

Credo(35) in unum deum patrem omnipotentem, factorem caeli et terrae, uissiuilium omnium et uisiuilium ${ }^{8}$, et in unum dominum nostrum ${ }^{9}$ ihesum christum, filium dei unigenitum ${ }^{10}$,

Variations from the Textus Receptus of the Vulgate.

1-1 V. om. $\quad 2$ V. hoc. $\quad 3$ V. om. suam dare ad manducandum. $\quad 3$ V. om. ${ }^{6} \mathrm{~V}$. + eius. ${ }^{7}$ V. om.

Variations from the Textus Receptus of the Creed.

This Creed agrees with the form given in the Ordo ad Catechum. faciendum in the Gelas. Sacram. in the following readings, 2, 4, 5, 14, 15-15, 17, 18 (Muratori, Lit. Rom. i. 540). Other early forms of the Creed are found in the Book of Deer, p. 166, and the Antiphon. Benchor. 189.

$8+$ omnium. The writer evidently intended this for visibilium et invisibilium.

' R. om. $20+$ et. 
${ }^{1}$ natum ex patre ${ }^{1}$ ante omnia saecula ${ }^{2}$, lumen de lumine, deum uerum de deo uero, natum ${ }^{3}$ non factum, consubstantialem patri, Fol. 19 b. per quem omnia facta sunt, qui propter nós homines et propter nostram salutem discendit de caelo ${ }^{4}$, et incarnatus est de spiritu sancto et ${ }^{5}$ maria uirgine, et homo natus ${ }^{6}$ est, crugifixus hautem ${ }^{7}$ pro nobís sub pontio pilato, passus et sepultus ${ }^{8}$; et resurrexit tertia die secundum scripturas, et ascendit in caelos ${ }^{9}$, et sedit a[d] dextram dei ${ }^{10}$ patris, et iterum uenturus ${ }^{11}$ cum gloria iudicare niuos et mortuos, cuius regni non erit finis. Et ${ }^{12}$ spiritum sanctum, dominum ${ }^{13}$ et viuificatorem ${ }^{14}$, ${ }^{15}$ ex patre procedentem, cum patre et filio coadorandum et conglorificandum ${ }^{15}$, qui loqutus est per profetas, et unam sanctam aeclesiam ${ }^{16}$ catholicam et apostolicam; confeteor nnum babFol. 20 a. tismum in remisionem pecatorum; spero ${ }^{17}$ resurrextionem mortuorum, et uitam futuri ${ }^{18}$ saeculi. Amen.

\section{landírech sund $\left({ }_{36} 6\right)$.}

Ostende nobís, domine, misericorer salutare tuum dabis (37).

$$
\text { ter canitur (38). }
$$

Oblata, domine, munera sanctifica, nosque a peccatorum nostro[rum] maculis emunda, per dominum(39).

Hostias, quesumus, domine, nostrae deuotionis benignus adsume, et per sacrificia gloriosa subditorum tibi corda purifica, per dominum (39a).

Hás oblationes(40) et sincera libamina immolamus tibi, Fol. 20 b. domine, ihesu christe, qui passus es pro nóbis, et

$1^{-1}$ ex patre natum.

$2+$ Deum de Deo. This clause was inserted at the Council of Nice (A.D. 325), omitted at Constantinople. It is usually found in Western forms of the Creed, with the exception of the Creed of the Gelasian Sacramentary.

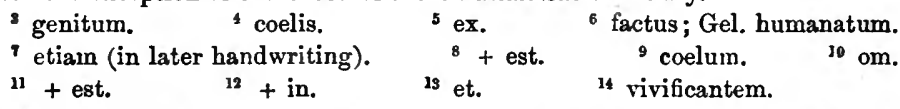

${ }^{15}{ }^{15}$ qui ex patre filioque procedit, qui cum patre et filio simul adoratur et conglorificatur. A later interlinear hand has written, 'qui ... filioque procedit . . simul' over the line, inserting a small 'qui' after procedentem, and a small 'tur' over the fourth syllable of co-adorandum, and over the fifth syllable of conglorificandum. The Gelasian Creed has 'ex (or et) Patre procedentem qui cum Patre et Filio simul adoratum et conglorificatum.'

16 Postpone to after apostolicam.

in et expecto.

18 venturi. 



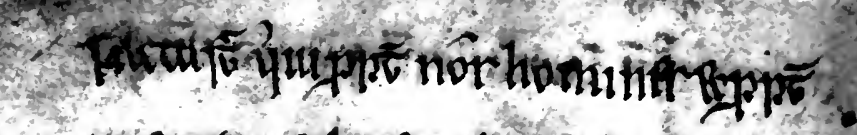

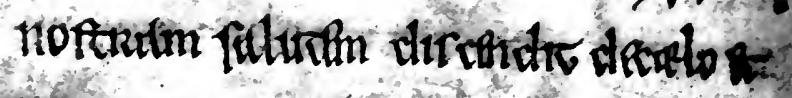

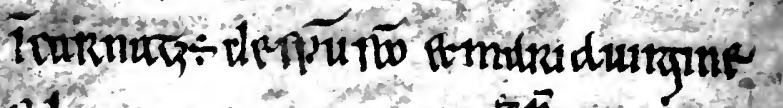

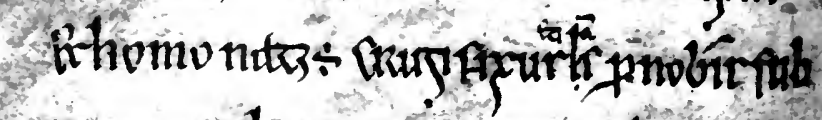

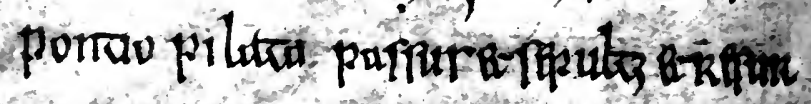

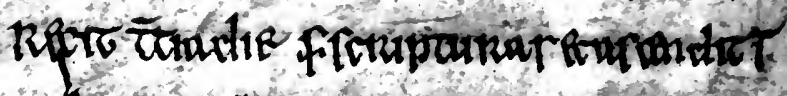

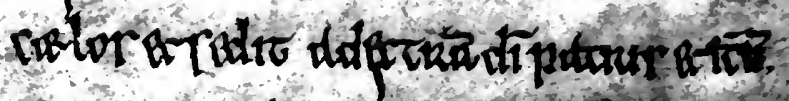

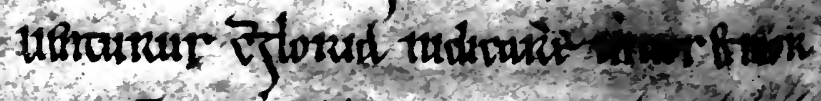

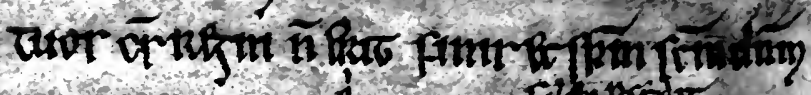

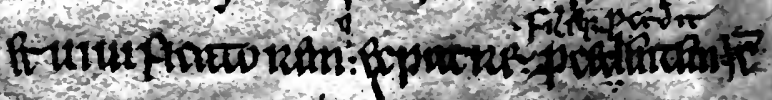

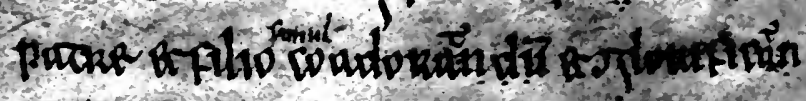

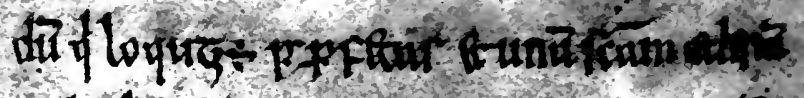

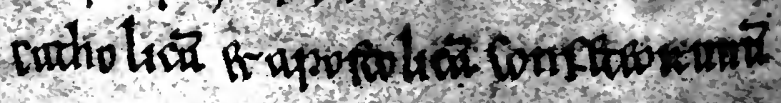


resurrexisti tertia die a mortuís, pro animamus carorum nostrorum .n. et cararum nostrarum quorum nomina recitamus, et quorumcumque non recitamus sed a té recitantur in libro uitae (41) aeternae, propter missericordiam tuam eripe, qui regnás in secula seculorum. Amen.

Secunda pars augmenti. hic super oblata $\left(4^{\mathrm{a}}\right)$.

Grata sit tibi bec oblatio plebis tuae quam tibi offerimus in Fol. 21 a. honorem domini nóstri ibesu christi, et in commemorationem beatorum apostolorum tuorum, ac martirum tuorum, et confessorum, quorum híc reliquias $\left(4^{2}{ }^{b}\right)$ spicialiter recolimus .n. et eorum quorum festiuitas hodie celebratur, et pro animamus omnium episcoporum nostrorum, et sacerdotum nóstrorum, et diaconorum nóstrorum, et carorum nóstrorum (43) et cararum nóstrarum, et puerorum nostrórum, et puellarum nostrarum, et paenitentium nóstrorum, cunctis proficiant ad salutem, per dominum.

Sursum corda (44). Habemus ad dominum.

Gratias agamus domino deo nóstro.

Dignum et iustum est.

Fol. 21 b. Uere (45) dignum et iustum est aequm et salutare est, nos tibi híc semper et ubique gratias agere, domine sancte, omnipotens aeterne deus, per christum dominum nostrum, qui cum unigenito tuo et spiritu sancto deus es unus et inmortalis, deus incorruptibilis et inmotabilis, deus inuisibilis et fidelis, deus mirabilis et laudabilis, deus honorabilis et fortis, deus altisimus et magnificus, deus uiuus et uerus, deus sapiens et potens, deus sanctus et spiciosus, deus magnus et bonus, deus terribilis et pacificus, deus pulcher et rectus, deus purus Fol. 22 a. et benignus, deus beatus et iustus, deus pius et sanctus, non unius singulariter personae sed unius trinitatis (46) substantiae, té credimus, té benedicimus, té adoramus, et laudamus nomen tuum in eternum et in saeculum seculi, per quem salus mundi, per quem uita hominum, per quem resurrectio mortuorum.

isund totét dignum intormaig ind maid per quem bes innadiudidi thall (47). 
Per quem maestatem tuam laudant angeli, adorant dominationes, $\operatorname{tr}[\mathrm{e}] \mathrm{ment}$ potestates, caeli caelorumque uirtutes ac Fol. 22 b. beata saraphim socia exsultatione concelebrant, cum quibus et nóstras uoces uti admitti iubeas deprecamur, supplici confessione dicentes; Sanctus.

isund totét dignum intórmig ind máid sanctus bess innadiudidi thall $(48)$.

Sanctus, sanctus, dominus dens sabaóth; pleni sunt caeli et uniuérsa terra gloria tua. Ossanna in excelsís, benedictus qui uenit in nomine domini. Ossanna in excelsis, benedictus qui uenit de celís ut conuersaretur in terrís, homo factus est ut dilicta carnis deleret, hostia factus est ut per passionem suam uitam aeternam credentibus daret, per dominum (49).

\section{Fol. 23 a. CANON DOMINICUS PAPAE GILASI.}

Té igitur, clementisime pater, per ihesum christum filium tuum dominum nostrum supplices té ${ }^{1}$ rogamus, et petimus, uti accepta habeas et benedicás haec dona, haec munera, haec sancta sacrificia inlibata, inprimís, que tibi offerimus pro tua sancta aeclesia catholica, quam pacificare, custodire, et ${ }^{1}$ unare $^{2}$, et regere digneris toto orbe terrarum, una cum beatissimo ${ }^{1}$ Fol. 23 b. famulo tuo .n. papa nóstro ${ }^{3}$, episcopo ${ }^{4}$ sedis apostolicae, et omnibus ortodoxís atque apostolice fidei cultoribus, et abbate nostro .n. episcopo ${ }^{4}(50)$.

Hic recitantur nomina uiuorum $\left({ }_{5} \mathrm{I}\right)$.

Memento etiam, domine, famulorum tuorum ${ }^{5}$.n..$^{5}$ famularumque tuarum, et omnium circum adstantium, quorum tibi fides cognita est et nota deuotio (52), qui tibi offerunt hoc sacrificium laudis pro se suisque omnibus, pro redemptione animarum suarum, ${ }^{6}$ pro stratu seniorum(6I) suorum, et ministrorum omnium puritate, pro intigritate uirginum, et continentia uiduarum, pro aeris temperie, et fructum fecunditate

Variations from the text of the Gelasian Canon of the Codex Vaticanus, as printed by Muratori (Lit. Rom. Vet. tom. i. p. 695), are here appended.

$1 \mathrm{om} . \quad 2$ adunare. $\quad 3+$ et antistite nostro ill.

5-5 om.

b- $\mathrm{om}$. 
Fol. 24 a. terrarum, pro pacis redetu et fine discriminum, pro incolimitate regum, et pace populorum, ac reditu captiuorum, pro uotís adstantium, pro memoria martirum, pro remisione pecatorum nóstrorum, et actuum emendatione eorum, ac requie defunctorum, et prosperitate iteneris nostri, pro domino papa episcopo, et omnibus episcopís, et prespeterís, et omni aeclesiastico ordine, pro imperio romano(25), et omnibus regibus christianís, pro fratribus et sororibus nostrís, pro fratribus Fol. 24 b. in uia directís (53), pro fratribus quos de caliginosís mundi huius tenebrís dominus arcisire dignatus est, uti eos in aeterna summae lucis quietae pietás diuina suscipiat, pro fratribus qui uarís dolorum generibus adfliguntur, uti eos diuina pietás curare dignetur ${ }^{6}$, pro spé salutís et incolimitatis suae, tibi reddunt uota sua eterno deo uiuo et uero commonicantes,

\section{In natale domini (54).}

${ }^{1}$ Et diem sacratisimam celebrantes in quo incontaminata uirginitas huic mundo edidit saluatorem :

$$
k l \text {. (54) }
$$

Fol. 25 a. Et diem sacratisimam celebrantes circumcisionis domini nóstri ihesu christi :

$$
\text { stellae (54). }
$$

Et diem sacratisimam celebrantes natalis calicis (54) domini nostri ihesu christi :

$$
\text { pasca. }
$$

Et noctem uel diem sacratisimam ressurrectionis domini nóstri ihesu christi :

$$
\text { in clausula pasca (54). }
$$

Et diem sacratisimam celebrantes clausulae pascae domini nóstri ihesu christi :

$$
\text { ascensio (54). }
$$

Fol. 25 b. Et diem sacratisimam celebrantes ascensionis domini nóstri ihesu christi ad caelum:

$$
\text { pentacostén (54). }
$$

Et diem sacratisimam celebrantes quinquagensimae (54)

$$
11 \mathrm{om}
$$


domini nostri ihesu christi, in qua spiritus sanctus super apostolos discendit'.

Et memoriam uenerantes, inprimís gloriosae semper uirginis mariae, genetricis (55) dei et domini nostri ihesu christi, (56) sed et beatorum apostolorum ac martirum tuorum, petri, pauli, Fol. 26 a. anriae, iacobi, iohannis, thomae, iacobi, pilippi, bartholomei, mathei, simonis et thathei, lini, ancliti ${ }^{2}$, clementis, xisti, córnili, cipriani, laurenti, crisogini, iohannis et pauli, cosme, et damiani, et omnium sanctorum tuorum, quorum meritis precibusque concedas ut in omnibus protectionis tuae muniamur auxilio. per ${ }^{3}$.

Hanc igitur oblationem seruitutis nostrae, sed et cunçtae familiae tuae, ${ }^{4}$ quam tibi offerimus in honorem domini nostri ihesu christi, et in conımemorationem beatorum martirum tuorum, in hac aeclesiae quam famulus tuus ad honorem nominis gloriae tuae aedificauit ${ }^{4},\left({ }_{5} 6\right)$, quesumus, domine, ut Fol. 26 b. placatus suscipias ${ }^{5},{ }^{6}$ eumque, adque omnem populum ab idulorum cultura eripias, et ad té deum uerum patrem omnipotentem conuertas ${ }^{6}(57)$, diesque $\left(5^{8}\right)$ nostros in tua pace disponas, atque ab aeterna damnatione nos eripias ${ }^{7}$, et in electorum tuorum iubeas grege numerari (58), per $^{8}$ dominum nostrum.

Quam oblationem té ${ }^{9}$, deus, in omnibus, quesumus, benedictam, + ascriptam, ratam, rationabilem, acceptabilemque facere dignareque ${ }^{10}$ nobís corpus et sanguis fiat dilectissimi fili tui domini ${ }^{11}$ nostri ihesu christi.

Qui pridie quam pateretur, accipit panem in sanctas ac Fol. 27 a. uenerabiles manus suas, eleuatis oculis suís ${ }^{12} \mathrm{ad}^{13}$ caelum ad té deum patrem suum omnipotentem, tibi gratias egit ${ }^{14}$, benedixit, fregit, dedit ${ }^{15}$ discipulís suís, diciens, accipite et manducate ex hoc omnes. Hoc est enim corpus meum. Simili modo posteaquam cenatum ${ }^{16}$, accipit ${ }^{17}$ et hunc pre-

\footnotetext{
2 Cleti. $\quad 3+$ Christum Dominum nostrum.

6-6 om.

1 eripi.

+ Christum.

il + dei.

12 om.

13 in.

14 agens.

4-4 om.

- tu.

5 accipias.

17 accipiens.

${ }^{15}+$ que. ${ }^{10}$ digneris ut.
} 
clarum calicem in sanctas ac uenerabiles manus suas, item tibi gratias agiens, benedixit, dedit discipulís suís, dicens, accipite et bibite ex hoc ${ }^{1}$ omnes. Hic est enim calix sancti ${ }^{2}$ sanguinis mei, noui et aeterni testamenti, misterium fidei, qui pro uobis et pro multis effundetur in remisionem peccatorum. Haec quotienscunque feceretis, in mei memoriam faciatis ${ }^{3},{ }^{4}$ passionem (59) meam predicabitis, resurrectionem meam adnuntiaFol. 27 b. bitis, aduentum meum sperabitis, donec iterum ueniam ad uós de caelís ${ }^{4}(59)$.

Unde et memores sumus, domine, nos tui serui, sed et plebs tua sancta, christi filii tui domini ${ }^{5}$ nostri tam beatae passionis, nec non et ab inferis resurrectionis, sed et in caelos gloriosae ascensionis, offerimus preclarae maiestati tuae de tuís donís ac datís, hostiam puram, hostiam sanctam, hostiam immaculatam, panem sanctum uitae aeternae, et calicem salutis perpetuae.

Supra quae propitio ac sereno uultu aspicire ${ }^{6}$ dignare $^{7}$, et accepta habere, sicuti accepta habere dignatús es munera Fol. 28 a. pueri tui insti abel, et sacrificium patriarchae nostri abrache, et quod tibi obtilit summus sacerdos tuus melchisedech, sanctum sacrificium, immaculatam hostiam.

Supplices té rogamus, et ${ }^{2}$ petimus, ${ }^{2}$ omnipotens deus, iube ${ }^{8}$ perferri $\mathrm{m}^{9}$ per manus sancti ${ }^{2}$ angeli tui in ${ }^{10}$ sublimi altari tuo ${ }^{10}$, in conspectu diuinae maistatis tuae, ut quotquot ex ${ }^{11}$ hoc altari sanctificationis" sacrosanctum filii tui corpus et sanguinem sumserimus, omni benedictione ${ }^{12}$ et gratia replemur ${ }^{13}$.

Fol. 28 b. ${ }^{14}$ Memento etiam, domine, et eorum nomina qui nos praecesserunt cum signo fidei, et dormiunt in somno pacis, cum omnibus in toto mundo offerentibus sacrificium spiritale (6o) deo patri, et filio, et spiritui sancto sanctis ac uenerabibus sacerdotibus offert senior noster .n. praespiter, pro sé,

\footnotetext{
1 eo. ${ }^{3}$ om. $\quad{ }^{3}$ facietis. $\quad{ }^{4}$ om. $\quad{ }^{5}+$ Dei. $\quad{ }^{6}$ respicere.

T digneris. $8+$ haec. Erroneous conmencement of manus.

10-10 sublime altare tuum. $11-11$ hac altaris participatione.

${ }^{12}+$ coelesti. $\quad{ }^{13}+$ per Christum Dominum nostrum. $\quad{ }^{14-14}$ om.
} 
et pro súis, et pro totius aeclesie cetu catholicae; et pro commemorando anathletico gradu (6oa) uenerabilium patriarcharum, profetarum, apostolorum, et martirum, et omnium quoque sanctorum, ut pro nobís dominum deum nostrum exorare dignentur(6r). Fot. 3la ought to follow here

Fol. 29 a.

sancte stefane, ora pro nobís (62).

sancte martini, ora pro nobís.

sancte hironime, ora pro nobís.

sancte augustine, ora pro nobís.

sancte grigorii, ora pro nobís.

sancte hilari, ora pro nobís.

sancte patricii $\left(6_{3}\right)$, ora pro nobís.

sancte ailbei (64), ora pro nobís.

sancte finnio $(65)$, ora pro nobís.

sancte finnio (66), ora pro nobís.

sancte ciarani (67), ora pro nobís.

sancte ciarani (68), ora pro nobís.

sancte brendini (69), ora pro nobís.

sancte columba(70), ora pro nobís.

sancte columba (7r), ora pro nobís.

Fol. 29 b.

sancte comgilli $\left(7_{2}\right)$, ora pro nobís. sancte cainnichi $(73)$, ora pro nobís. sancte findbarri (74), ora pro nobís. sancte nessani (75), ora pro nobís. sancte factni $(76)$, ora pro nobís. sancte lugidi (77), ora pro nobís. sancte lacteni (78), ora pro nobís. sancte ruadani (79), ora pro nobís. sancte carthegi (80), ora pro nobís. sancte coemgeni $\left(\mathrm{s}_{\mathrm{I}}\right)$, ora pro nobís. sancte mochonne $(82)$, ora pro nobís. sancte brigta $\left(8_{3}\right)$, ora pro nobís. sancte ita $\left(8_{4}\right)$, ora pro nobís. sancte scetha $\left(8_{5}\right)$, ora pro nobís. 
sancte sinecha (86), ora pro nobís.

sancte samdine $(87)$, ora pro nobís.

Fol. 30 a. omnes sancti, orate pro nobís.

Propitius esto. Parce nobís domine. Propitius esto.

Libera nós, domine, ab omni malo.

Libera nós, domine, per crucem tuam.

Libera nós, domine, peccatores.

Té rogamus audi nós.

Filii dei, té rogamus audi nós.

Ut pacem donés té rogamus.

Audi nós, agne dei.

Qui tollis peccata mundi, misserere nobís.

Christe, audii nós. Christe, audi nós. Christe, audi nós.

\section{ORATIO AMBROSI (88).}

Ante conspectum diuinae maestatis tuae, deus, adsisto, qui inuocare nomen sanctum tuum presumo, misserere mihi, doFol. $30 \mathrm{~b}$. mine, homini peccatori luto feccis inmunde inherenti, ignosce indigno sacerdoti per cuius manus haec oblatio uidetur offerri ; parce, domine, pulluto peccatori labe pre ceterís capitalium (creminum) et non intres in iudicio cum seruo tuo, quia non iustificabitur in conspectu tuo omnis uiuens, scilicet uitís ac uoluntatibus carnis grauati sumus, recordare, domine, quod caro sumus, et non est alius tibi comparandus; in tuo conspectu etiam caeli non sunt mundi, quanto magis nos homines terreni, quorum ut $\operatorname{dixit}(89):-$

Fol. 31 a.

\begin{tabular}{llll} 
ablis $(9 \circ)$ & dauid & nauum & iohannis \\
zeth & heliae & ambacuc & baptiste \\
enóc & helessiae & sophoniae & et uirginis \\
noe & essaiae & agiae & mariae \\
melch & heremiae & sachariae & petri \\
sedech & ezechelis & malachiae & pauli \\
abrache & danielis & tobiae & andriae \\
isac & hestre & ananiae & iacobi \\
\hline
\end{tabular}




$\begin{array}{llll}\text { iacob } & \text { osse } & \text { azariae } & \text { iohannis } \\ \text { ioseph } & \text { iohel } & \text { misahelis } & \text { pilipi } \\ \text { iob } & \text { amos } & \text { macha- } & \text { bartha } \\ \text { mosi } & \text { abdiae } & \text { beorum } & \text { lomae } \\ \text { essu } & \text { ionae } & \text { item in- } & \text { tomae } \\ \text { samuclis } & \text { michiae } & \text { fantum } & \text { mathei }\end{array}$

Fol. $31 \mathrm{~b}$.

\begin{tabular}{|c|c|c|c|}
\hline iacobi & et ceterorum & isernini $(97)$ & cuáni (III) \\
\hline simonis & patrum & cerbáni $\left(9^{8}\right)$ & $\operatorname{declach}\left(\begin{array}{ll}\text { I } & 2\end{array}\right)$ \\
\hline tathei & heremi & $\operatorname{erci}(99)$ & laurenti (II3) \\
\hline $\operatorname{madiani}(9 \mathrm{I})$ & $\operatorname{sciti}\left(9^{2}\right)$ & catheri (100) & melléti ( $\left.\mathrm{II}_{4}\right)$ \\
\hline madiani (9I) & item & ibori (101) & iusti (II5) \\
\hline arci & episcoporum & ailbi (102) & aedo (II6) \\
\hline cae & martini & conlai (103) & dagani (II $)$ \\
\hline efani & grigori & $\operatorname{maic}\left(\mathrm{IO}_{4}\right)$ & tigernich (118) \\
\hline rnili & maximi & $\operatorname{nissae}(10 \vdots)$ & muchti (rig) \\
\hline priani & felicis & moinenn (rc6) & ciannani (120) \\
\hline ceterorum & patrici (93) & senani (107) & buiti (12I) \\
\hline artirum & patrici (94) & finbarri (108) & eogeni (122) \\
\hline uli & secundini (95) & $n i($ I $\circ 9)$ & declani (123) \\
\hline toni & auxili (96) & colmani (Iro) & carthain (124) \\
\hline
\end{tabular}

Fol. 32 a.

\begin{tabular}{|c|c|c|}
\hline maile (125) & columbe (1 $\left.3^{6}\right)$ & et omnium \\
\hline ruen (126) & $\operatorname{colmani}\left({ }_{137}\right)$ & pausantium, (I $\left.4^{\circ}\right)$ \\
\hline item et & comgelli (1 38 ) & qui nós in domi- \\
\hline sacerdotum & coemgeni (139) & nica pace preces- \\
\hline ainniani $(127)$ & & erunt, abad- \\
\hline $\operatorname{arani}(128)$ & & am usque in ho- \\
\hline engusso (129) & & diernum diem, \\
\hline $\operatorname{ddi}(130)$ & & quorum deus non \\
\hline gilde (I3I) & & nominauit (140a) \\
\hline rendini $\left(\mathrm{r}^{2}{ }^{2}\right)$ & & et nouit, \\
\hline endini ( 133$)$ & & ipsis, et omnibus in \\
\hline innichi (134) & & christo quiescentibus, \\
\hline olumbe ( 135 ) & & locum refrigerii, \\
\hline
\end{tabular}


Fol. 32 b. lucis et pacis, ut indulgeas deprecamur.

Nobís quoque peccatoribus fanulís tuis de multitudine misserationum tuarum sperantibus partem aliquam, et societatem donare dignare ${ }^{1}$, cum tuís sanctis apostolís et martiribus, cum ${ }^{2}$ petro, paulo, patricio ${ }^{2}$, iohanne, stefano, mathia, barnaba, ignatio, alaxandro, marcellino, petro ${ }^{3}$, perpetua, agna, cicilia, felicitate, anatassia, agatha, lucia ${ }^{3}$, et cum omnibus sanctis tuís; intra corum ${ }^{4}$ nós consortia, Fol. 33 a. non estimatir meritis, sed ueniam, quesumus, largitor admitte. per ${ }^{5}$.

Per quem haec omnia, domine, semper bona creas, + sanctificas, + uiuificas, + benedicis, + et prestas nobís, per ipsum, et cum ipso, et in ipso, est tibi deo patri omnipotenti in unitate spiritus sancti, omnis honor et gloria per omnia saecula saeculorum ${ }^{6}$.

Ter canitur. isund conogabar indablu tuaír forsincailech fobdidithir leth nabairgine is in cailuch (14r).

Fiat domine misericordia tua super nos quemadmodum sperabimus in te $\left(\mathrm{I}_{4}{ }^{2}\right)$.

isund conbongar in bairgen (143).

Cognouerunt dominum. alleluia. in fractione panis(144). alleluia.

Fol. 33 b. Panis quem frangimus corpus est domini nostri ihesu christi(145). alleluia.

Calix quem benedicimus. (alleluia.) sanguis est domini nostri ihesu christi. (alleluia.) in remisionem peccatorum nostrorum ( 145$)$. (alleluia.)

Fiat domine missericordia tua super nós. alleluia. quemadmodum sperauimus in té. alleluia $\left({ }_{4} 46\right)$.

Cognouerunt dominum ( $r_{47}$ ): alleluia.

Credimus( $\left.{ }^{4} 48\right)$, domine, credimus in hác confractione ( ${ }^{4} 49$ ) corporis et effussione sanguinis nós esse redemptos, et confidimus,

1 digneris. $\quad{ }^{2}-{ }^{2}$ om. $\quad{ }^{3}-3$ after Petro + Felicitate, Perpetua, Agatha, Lucia, Agnem, Caecilia, Anastassia. $\quad$ quorum. $\quad$ + Christum Dominum nostrum. 'Amen. The variations from the Gelas. Text in the remainder of the Stowe Canon are too numerous for foot-notes. 
sacramenti huius adsumptione munitos, ut quod spé interim hic tenemus mansuri in celestibus uerís fructibus perfruamur, Fol. 34 a. per dominum :

Diuino magisterio edocti, et diuina institutione formati, audimus dicere $(150)$.

Pater noster, . . rl.

Libera ( 15 I) nós, domine, ab omni malo preterito, presenti, et futuro, et intercedentibus pro nobís beatís apostolís tuís petro et paulo, patricio, dá propitius pacem tuam in diebus nóstrís, ut ope missericordiae tuae adiuti et a peccato simus semper liberi, et ab omni perturbatione securi, per dominum.

Páx $\left(\mathrm{I}_{52}\right)$ et caritas domini nostri ihesu christi, et commoniFol. 34 b. catio sanctorum omnium, sit semper nobíscum.

Et cum spiritu tuo (153).

Pacem mandasti, pacem dedisti, pacem dirilinquisti. Pacem tuam, domine, dá nobís de celo, et pacificum hunc diem et ceteros dies uitae nóstrae in tua pace disponás (154), per dominum.

Commixtio corporis et sanguinis domini nostri ihesu christi sit nobís salús in uitam perpetuam ( $\left.{ }_{55}\right)$. amen.

Ecce agnus dei $(156)$.

Ecce. qui tollis peccata mundi.

Pacem meam do uobís (157). alleluia.

Fol. 35 a. Pacem relinquo uobís (157). alleluia.

$\operatorname{Pax}\left({ }_{15} 8\right)$ multa diligentibus legem tuam, domine. alleluia : et non est in illís scandalum (159). alleluia.

Regem caeli cum pace ( 160$)$. alleluia.

Plenum odorem uitae ( 161 ). alleluia.

Nouum carmen cantate (162). alleluia.

Omnes sancti uenite $\left(\mathrm{I} 6_{3}\right)$. alleluia.

Uenite, comedite panem meum. alleluia. et bibite uinum quod miscui uobis (164). alleluia.

Dominus reget me ( $16 \vdots)$.

Qui manducat corpus meum et bibit meum sanguinem( $\mathrm{I}(66)$. alleluia.

Ipse in me manet ego in illo $\left({ }_{1} \sigma_{7}\right)$. alleluia. 
Domini est terra (168).

Fol. 35 b. Hic est panis uiuus qui de celo discendit (169). alleluia.

Qui manducat ex eo uiuet in eternum ( 170$)$. alleluia.

Ad té, domine, leuaui animam meam (171).

Panem caeli dedit eís dominus. alleluia. panem angelorum manducauit homo $\left(\mathbf{I}^{2}\right)$. alleluia.

Iudica mé, domine (173).

Comedite amici mei. alleluia. et inebriamini carissimi ( $\left.{ }_{774}\right)$. alleluia.

Hoc sacrum corpus domini saluatoris sanguinem; alleluia. sumite uobís in uitam eternam (175). alleluia.

In labís meís meditabor ymnum, alleluia. cum docueris mé et ego iustias respondebo (I76). alleluia.

Fol. 36 a. Benedicam dominum in omni tempore. alleluia. semper laús eius in ore meo (177). alleluia.

Gustate et uidete. alleluia. quam suauis est dominus ( $\left.\mathrm{r}_{7} 8\right)$. alleluia.

Ubi ego fuero. alleluia. ibi erit et minister meus (179). alleluia.

Sinite paruulos uenire ad mé, alleluia. et nolite eos prohibere. alleluia. talium est enim regnum caelorum(r8o). alleluia.

Penitentiam agite. alleluia. adpropinquauit enim regnum celorum (r8r). alleluia.

Regnum celorum uim patitur, alleluia. et uiolenti rapiunt illud (r82). alleluia.

Uenite, benedicti patris mei, possidete regnum. alleluia. quod uobís paratum est ab origine mundi ( $\left.18_{3}\right)$. alleluia.

Gloria. Uenite. Sicut erat. Uenite ( $183 \mathrm{a})$.

móel caích (184) scripsit.

Fol. 36 b. Presta ut quos celesti, domine, dono satiasti, et a nostris enundemur occultis, et ab ostium liberemur insidis (185).

Gratias tibi agimus, domine, sancte pater, omnipotens aeterne deus, qui nos corporis et sanguinis christi filii tui commonione 
satiasti, tuamque missericordiam humiliter postulamus, ut hoc tuum, domine, sacramentum non sit nobís reatus ad penam, sed intercessio salutaris ad ueniam, sit ablutio scelerum, sit fortitudo fragilium, sit contra mundi periculo firmamentum, hec nos commonio purget a cremine, et caelestis gaudi tribuat esse participes (186). per.

misa acta est $(187)$.

in pace :-(188).

Fol. 37 a. Mísa apostolorum et martirum et sancTORUM ET SANCTARUM UIRGINUM (I89).

Deum patrem, deum filium, deum spiritum sanctum, unum et solum dominum dominantium, et regem regnantium, et gloriam futurorum per preuelegia clara patriarcharum, et gloriosa presagia profetarum, per sancta merita apostolorum, per marteria martirum, per fidem confessorum, per sanctitatem Fol. 37 b. uirginum, per teoricam uitam anchoritarum ( 190$)$, per silentium spiritale munachorum, per episcoporum ac abbatum catholicorum principatum, innixís ac continuis orationibus fideliter opsecremus spicialiter hoc per sancta sufragia sanctorum, uel sanctarum uirginum, quorum hodie sollemnítas á nobis celebratur, ut hec oblatio plebís tuae, quam sanctae trinitate in honorem eorum .n. offerimus, acceptabilis fiat deo, cunctis proficiat ad salutem. per.

Domine, deus noster, ihesu christe, splendor paternae Fol. 38 a. gloriae, et dies claritatis aeternae, gratias tibi agimus, quoniam accendere dignatus és .xii. apostolos tuos igne sancti spiritus tui, quique .xii. horas diei lumine solis inlustratas quibus dixisti, nos estis lux mundi, et iterum, nonne .xii. horae diei súnt, si quis ergo ambulauerit in lumine diei hic non offendit, orire nobís, domine, deus noster, ihesu christe, sol iustitiae, in cuius pennís est sanitas timentibus te, ut ambulemus in luce dum lucem habemus, ut simus filii lucis, qui inluminasti apostolos, quique luminaria huic mundo Fol. 38 b. et alios sanctos, quique tuos uel eorum nicarios gratia spiritu sancti ac doctrina preditos, discute a nobís 
tenebras ignorantiae, et iustitiae tuae per horum patrocinia .n. quorum festiuitas hodie colitur, ut in te, et per té, semper manemus. per.

Deus qui nos sanctorum tuorum beatisimorum spirituum, angelorum, archangelorumque, principum et potestatum, dominationum, uirtutum, ciruphín et saraphin, patriarcharum, profetarum, apostolorum, martirum, confessorumque, et uirginum, anchoritarum, coenouium, omniumque sanctorum conciuium supernorum et intercessionibus gloriosís circumdas Fol. 39 a. et protegis, presta, quesumus, eorum et emitatione proficere, et interpellatione tueri, et, intercedentibus sanctis, a cunctís nós defende periculis. per.

Domine, deus omnipotens, qui sanctos tuos cum mensura probas, et sine mensura glorificas, cuius precepta finem habent, et premia terminum non habent, exaudi preces nostras per marteria et merita illorum, et tribue eorum patrocinia adiuuent nos ad fidei profectum, ad bonorum operum fructum, ad prosperitatis bonum, ad salubritatis commodum, ad religionis Fol. 39 b. cultum, ad diuini timoris augmentum. Orent pro nobís sancti martires, et pro defunctís nostris, et pro pecoribus, et pro omnibus terrae nostrae fructibus, et pro omnibus in hoc loco commorantibus, et omnipotentem deum creaturarum caelestium et terrestrium innumerabilis multitudinis sanctorum tuorum et angelorum chori incessabili uoce proclamant dicentes;

Sanctus, Sanctus, Sanctus.

Dignum et iustum, aequm et iustum et gloriosum est, nos tibi semper gratias agere, omnibus diebus uitae Fol. 40 a. nostrae, domine deus omnipotens, sed in hac die gratias et habundantius debemus gratulari cum gaudio spiritus sancti solemnitatem apostolorum .n. siue sanctorum uel sanctarum .n. presta ergo nobís, omnipotens deus, fidem, spem, et caritatem, et catholicum finem ac pacificum, per merita ac commemoratione sanctorum tuorum .n. in quorum honorem bec oblatio hodie offertur, ut cunctís proficiat ad salutem, per dominum nostrum ihesum christum, cui omnes 
angeli et archangeli, profete et apostoli, martires et confessores, Fol. 40 b. uirgines et omnes sancti, immo perpetuo et indefessís laudibus, cum quatuor animalibus, uenti quatuor senioribus concindunt dicentes.

$\mathbf{S}$ [anctus].

Uere (I9I) sanctus, uere beuedictus, uere mirabilis in sanctis suis, deus noster ihesus christus ipse dabit uirtutem et fortitudine plebis suae; benedictus deus quem benedicimus in apostolis, et in omnibus sanctis suís, qui placuerunt ei ab initio sae[culi], per eundem dominum nostrum ihesum christum.

Qui pridie ( 192 ).

Sumpsimus, domine, sanctorum tuorum sollemnia celebrantes caelestia sacramenta; presta, quesumus, ut quod temporaliter gerimus aeternis gaudiis consequamur. $\operatorname{per}\left(19^{2} \mathrm{a}\right)$.

\section{INCIPIT MISA PRO PENITENTIBUS UIUís.}

Fol. $41 \mathrm{a.}$

Pro penitentibus uidis.

Exultatio diuina, paterna pietas, inmensa maestas, te supplices trementes depraecamur pro famulís tuís, ut des eís mentem puram, caritatem perfectam, in actibus sinceritatem, in corde puritatem, in opere uirtutem, in moribus disciplinam, et que iustiae tuae timore intigra mentes uel deuotione pro ipsis .n. tibi offerimus pietatis tuae obtinentia agnoscant. per.

Indulge, domine, penetentibus nobís famulís tuís poscentibus secura mente tibi, domine, deo nostro uictimam pro ipsís Fol. 41 b. .n. offerri ualeamus, et pie dictís suís ueniam obteniant, sanitatis, per té, pater sancte, munere consequti, ad salutem gratiae aeternae possint cum tuo adiutorio peruenire.

Iteramus, omnipotens deus, deprecationem (193) nostram ante conspectum maiestatis tuae, quam spicialiter pro famulis tuís .n. in honore sanctorum, mariae, petiri, pauli, iohannis, et omnium sanctorum tuorum, oblationem pro peccatís eorum offerimus, uota perficias, petitiones eorum ascendat ad aures 
Fol. 42 a. clementiae tuae, discendat super eos pia benedictio. ut sub umbra alarum tuarum in omnibus protegantur, et orationes nostrae, té propitiante, pro ipsís non refutentur a conspectu pietatis tuae, sed in omnibus auxiliare atque defendere digneris. per.

$\mathrm{U}$ [ere] $\mathrm{d}$ [ignum] per dominum nostrum ihesum christum, filium tuum, cuius potentia deprecanda est (194), missericordia adoranda, piatas amplectare. Quis enim aliís putare poterit omnis potentiae tuae miracula? nec aures hominis audire, nec in cór hominis ascendere, nec estimatio hominum poterit Fol. 42 b. inuenire quanta praeparas sanctis electis tuis (r95); sed in quantum possimus misseri terrenique de incontinentia sed de tua missericordia ueniam misserationis et refugium postulantes, atque in commemoratione sanctorum, per quorum suffragia sperantes ueniam, ut famulis tuis .n. remisionem tribuas peccatorum, opera eorum perficias, uota condones; dona eís denique séruis tuís, intercedentibus sanctis, remedium animarum suarum quod postulamus, ut uota desideriorum eorum Fol. 43 a. perfeciat, presta, omnipotens, suplicantibus nobís indulgentiam, postulantibus ueniam, poscentibus uota pingesce, protege eís nomen dei iacob, iube eis auxilium de sancto et de sion tueri .n. memor esto, missericors deus, sacrificium eorum, et holochaustum eorum ante conspectum sanctorum apinge fiat; tribue eís desideria sancta eorum, et omne consilium eorum confirmá in bonum, ut inletentur coram té corda desiderium eorum. per christum.

Deus ( $\left.{ }^{9} 6\right)$ qui confitentium tibi corda purificas, et accussantes sé conscientius et omnium iniquitate absoluis, dá Fol. 43 b. indulgentiam reís, et medicinam tribue uulneratis, ut, percepta remissionem omnem peccatorum, in sacramentis tuis sincera deinceps deditione permanent, et nullam redemptionis aeternae susteniant tetrimentum. per dominum nostrum.

Misa PRO MORTUís PLURIBUS.

Praesta, quesumus, omnipotens et missericors deus, ut 
animas famulorum tuorum .n. indulgentiam peccatorum et gaudia perpetua lucis inueniant.

Dá nobís missericordiam tuam, quesumus, domine, ut animas famulorum tuorum .n. ab omnibus uitiís expiatae, cum tua Fol 44 a. protectione securae diem futurae resurrectionis $\operatorname{expecta(n)t.~per~christum.~}$

Intende, domine, munera que altaribus tuís pro sanctorum tuorum .n. commemoratione deferimus, et pro nostris offentionibus imbulamus(r97).

$\mathrm{U}$ [ere] $\mathrm{d}$ [ignum] cuius promisionis plenus aeternorum bonorum in ipso expectamus manifestandus, in quo scimus eas absconditas domino nostro ihesu christo, qui nera est uita credentium, resurrectio famulorum tuorum .n. illorum pro quibus hoc sacrificium offerimus, obsæcrantes ut regeneraFol. 44 b. tionis fontae purgatos, et a temptationibus exceptos, beatorum numero digneris inserere, et quos adoptionis participes iubeas hereditatis tuae esse consortes. per.

Oremus, fratres carisimi (198), pro carís nastrís .n.(199) qui iam in dominice pace praecesserunt, quos finis debitus et ordo transmigrationis conclusit, ut deus omnipotens, pater domini nostri ihesu ehristi, iubeat carnem animamque et spiritum eorum suscipi in locum lucis, in partem refregéri, in sinibus Fol. 45 a. abrache, et isác, et iácob, dimittat quoque si quicquid incongrue per ignorantiam, atque subripiente inimico, peccanerunt, et spiritu oris sui eos refrigerare dignetur. per. (200) 


\section{NOTES.}

1. This title, together with the following Versicle, 'Letania-intende,' is written on the top margin of fol. I3 a. Compare the wording of the title on p. $2+4$.

2. This is the second Versicle at Matins, and the Introit for Dom.xii. Pentec. (S. R.).

3. The same Litany occurs in the St. Gall fragment, MS. No. I 395, p. I 79, and seems to be peculiarly Irish. A short Litany of this kind used always to precede Mass, intervening between it and the preceding office of Terce or Sext. Its use in the Cluniac constitutions was thus prescribed: 'Majorem missam in privatis diebus solet iterum letania praevenire, quae tamen non est multum prolixa, tribus tantum Sanctis de singulis ordinibus nominandis.' Udalricus, Antiq. Consuet. Cluniacens. lib. i. c. 6.

The opening rubric of the Mass edited by Mat. Flac. Illyricus (Mart. i. p. 176) runs thus: 'In primis quomodo sacerdos Apologetica celebrare debeat, antequam ad missarum celebrationem accedat. Mox antequam sacerdotalibus induatur restibus, si locus acciderit, vel tempus permiserit, flexis genibus coram altare cantet vii. Psalmos poenitentiales cum litania, qua finita dicat "Pater Noster," Credo in Deum Patrem omnipotentem. Post has preces.' Among these preces the following bear resemblance, partly verbal, partly substantial, to the opening devotions of the Stowe Missal :-

'Peccavimus cum patribus nostris, injuste egimus, iniquitatem fecimus Domine.'

'Adjuva nos, Deus salutaris noster, et propter gloriam nominis tui, Domine, libera nos, et propitius esto peccatis nostris propter nomen tuum.'

'Extende, Domine, brachium tuum ; et libera animas nostras ne pereamus.'

'Domine exaudi orationem meam.'

The triple Kyrie eleison is the sole surviving relic in the present Roman Ordinary of the Mass of an older Litany ; De Vert, Cérémonies de l'Eglise, i. 67.

4. St. Madianus occupies the same position in the list of saints within the Canon (p. 240), and in the Litany in the St. Gall fragment, No. 1395, p. 180. See note 91 .

5. The preparatory absolution in a Tours Missal, A.D. I 533, is given: '... per auxilium et signum sanctae crucis . . . et per intercessionem . . . et omnium Sanctorum et Sanctarum' (Mart. i. p. I 30 ).

6. The words which follow are the usual conclusion of the prayer of St. Foll.29 Ambrose; see p. 239. n. (89). Possibly the scribe intended to insert the 'Prayer

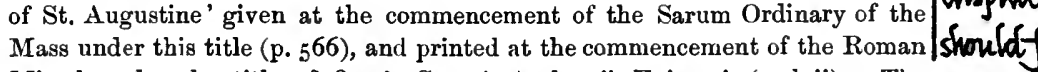
Missal under the title of Oratio Sancti Ambrosii Episcopi (p. lxii). The Roman rubric directs it to be said 'Pro opportunitate sacerdotis ante celebra- fol. 13. tionem et communionem.' The rubric in a Sarum Missal given by a Lord Prior of Worcester to the church of Bromsgrove, A.D. I51 I, runs thus: 'Oratio Sancti Augustini dicenda a sacerdote in Missa dum canitur Officium et Kyrie 
et Gloria in Excelsis et Credo in unum; vel tota dicitur ante missam quod melius est.'

7. This prayer occurs in a ninth-century Troyes Pontifical, at vesting, ' ad tunicam ' (Mart. ordo vi. p. I9I); in a ninth-century Tours Missal among the apologiae after vesting (ib. ordo vii. p. I93); in a Rheims Pontifical, undated (ib. ordo ix. p. 195); in a tenth-century Corbie Sacramentary, 'ad baltheum' (ib. ordo xi.p. 203); in the Missa 'Flacii Illyrici postquam sacerdos infulatus fuerit' (ib. ordo iv. p. I 77); in the Codex Chisii in the Preparatio sacerdotis ad Missam, after vesting (ib. ordo xii. p. 205); in the Ambrosian rite, as the 'Oratio secreta antequam sacerdos accedat altare' (Pamel. Liturg. i. 293). The presence and position of this and similar prayers for the personal use of the priest are in themselves a proof of the antiquity of any Missal.

8. A later hand had added ' 1 ' over 'batheo ;' 'neque permittas' over 'perire ;' 'praesta' before 'per dominum ;' and seems to suggest the abbreviation of the collect by the omission of the words from ' ut-pacificas.'

9. The scribe must have been an ardent devotee of St. Peter to write down Petri et Christi instead of Christi et Petri ; or is Christi a clerical error for Pauli ?

10. Compare the language of the Absolution in the Reconciliatio poenitentiam on Maundy Thursday: 'Absolvimus vos vice beati Petri, apostolorum principis cui collata est a Domino potestas ligandi atque solvendi,'\&c. Sar. Mis. p. 300 ; Corpus Mis. p. 2 Io. The words 'Deus-tradidisti' are the opening words of the collect 'in Com. S. Petri Ap.' on June 30 in the Rom. Mis. p. 438, Sar. Mis. p. 790. In a Syrian collect of Absolution quoted by Mart., ordo xxiii. vol. i. p. 335, the words 'ceterisque discipulis suis' have been significantly added after 'beato Petri;' also in a fourteenth-century Rouen Rit., ordo xii. Mart. vol. ii. p. 402.

11. This is the Roman collect, with verbal variations, in Cathedra S. Petri, Jan. 18, 25, Feb. 22, and the memorial collect of St. Peter on June 30. Its earliest occurrence is in the Gelas. Sacram. lib. ii. ordo xxx. It also occurs in the Missale Vesontionense under the heading of 'Missa Romensis Cottidiana,' p. 206.

12. The 'Gloria in Excelsis' was introduced into the Roman Liturgy by Pope Symmachus, 498-5I4 (Wal. Strabo, De Rebus Eccles. c. 22). Several variations from the received Western text will be observed here. Compare the text in the Ant. Bench. p. 193 ; Book of Hymns, p. 197. It forms no part of the Eastern nor of the ancient Gallican Liturgy, judging from the omission of any reference to it in Germanus's Expos. Brev. Antiq. Lit. Gallican. (Mart. i. p. I67). It is noteworthy however that in the Sacramentarium Gallicanum it occurs as in the Anglican Liturgy, in the position of a thanksgiving after the Communion (Mabillon, Mus. It. i. p. 28I).

13. This collect is assigned to Dom. v. Pentec. (R.), Dom. vi. post Trin. (S.), Gelas. Sacr. iii. coll. i; Greg. Sacr. Hebd. vi. post Pentec.

14. There are frequent allusions in later Missals to the 'Romanus Ordo' or 'Ecclesia Romana' (York Missal, i. pp. I68, I69), as differing from the local or national use ; or to the latter as differing from the former (Sarum Missal, pp. 6, I5). In the case of the York Missal such expressions have been taken to date from the time of Charlemague, when the Ordo Romanus was introduced into France by royal authority, and probally into York by Alcuin or his pupil Archbishop Eanbald II. In the present text a contrast seems to be implied between the devotions of the foreign Church of Rome and those of the ancient national Church of Ireland. 
15-15. Deus-placaris. These are the opening words in the Greg. Sacr. for the Feria v. in Quinquagesima, but the rest of the collect is different. The present collect occurs nearly in this position in the Sacramentarium Gallicanum (Mabillon, Mus. It. i. p. 279).

16. This is a rare word of sacrificial signification used by Arnobius, Adv. Gentes, lib. vii.c. 24, and defined by Varro as 'quod ex immolata hostia dejectum in jecore in porriciendo augendi causa ;' De Iingua Lat. lib. v. § I I 2. p. 44, edit. 1833. I have not met with its use elsewhere as a term of Christian ritual. It may refer to some unwritten addition made at this point of the service, or can it refer merely to the concluding unwritten words of the collect 'Jesum Christum,' \&c.? Compare the rubric on p. 233. The word ' augmentum' occurs in cap. 7 of the Regula S. Columbani quoted on p. 97 .

17. I Cor. xi. 26-32. This is a portion of the Epistle assigned to Coena Domini in the Roman and Sarum Missals ( 1 Cor. xi. 20-32), in the Sacram. Gallican. (I Cor. xi, 20-26). The presence here of single fixed lessons is remarkable, and an evidence of great antiquity. The only other case where the same Epistle and Gospel are conjectured to have been always used is that of the Liturgy of the Church of Malabar; Le Brun, Explication de la Messe, tom. vi. p. 487. The suitableness of the passages of Scripture selected here for constant use, both of them bearing on the institution of the Eucharist, is obvious.

18. This collect is written on the lower margin of fol. $15 \mathrm{~b}$, in the later hand. 18 a. Ps. civ. 4 .

18 b. I Par. xvi. 8-Io.

19. These are the opening words (Grata-quibus) of a Secret in the Corpus Missal, p. Igo, and in the Gelasian Sacram. p. 682.

20. Ps. cxvii. 14. V. Laus, Bk. of Dimma, p. I 7o, Stowe Missal, p. 25.

21. This only differs slightly from the Roman Secret for Dom. iv. Adv.: 'Sacrificiis praesentibus quaesumus, Domine, placatus intende : ut et devotioni nostrae proficiant et saluti.' Sacr. Leon. p. 482 ; Gelas. p. 682 ; Greg. pp. 29, $43,105,108,124,138$.

22. It is curious to find this word lingering as the title of mediaeval devotions of the same character. The York Bidding Prayers, A.D. I 405, commence thus: 'Deprecemur Deum Patrem Omnipotentem pro pace et stabilitate sanctae nuatris Ecclesiae' (Early Eng. Text Soc. vol. 71. p. 64). Another form of Bidding Prayers (A.D. 1440-50) is headed 'Deprecacio pro pace Ecclesiae et regni in diebus dominicis' (ib. p. 68). For another use of the word 'deprecatio,' see p. 106. The association of these prayers with the name of St. Martin, Bishop of Tours $(371-401)$, indicates that, though of Eastern origin, they reached Ireland through a Gallican channel.

That such a Litany existed in the ancient Gallican rite is proved by the allusions of various writers. Caesarius of Arles speaks of the 'Oratio (quae) Diacono clamante indicitur' (Serm. cclxxxvi. in App. ad Opp. S. Aug., Migne, Bib. Pat. Lat. xxxix. 2285). Germanus Parisiensis devotes a paragraph to its description under the name of 'Prex,' and indicates its position after the homily and before the expulsion of the catechumens (Mart.i. p. I67). No traces of the wording of this 'Prex' exist in auy extant Gallican Missal, except that the Mozarabic Litany for Passion Sunday occurs in the Sacramentarium Gallicanum for Easter Eve (Mus. Ital. i. 317; Mis. Moz. p. 372); and the expression 'Collectio post precem,' which is the title of a prayer in the Missale Gothicum on Christmas Day and Easter Day, possibly refers to a preceding Litany, although Mabillon gives a different interpretation of it (Lit. Gallic. p. I90). 
It is noteworthy that the character of these intercessions corresponds to those enumerated, in a somewhat different order, in a passage in the Regula $S$. Columbani : ' Cum versiculorum augmento intervenientium pro peccatis primum nostris, deinde pro omni populo Christiann, deinde pro sacerdotibus, et reliquis Deo consecratis sacrae plebis gradibus, postremo pro eleemosynas facientibus, postea pro pace regum, norissime pro inimicis, ne illis Deus statuat in peccatum quod persequuntur nos, et detrahunt nobis, quia nesciunt quod faciunt.'

23. Similar passages are found in the Rogation Litany printed from a tenth-century Pontifical of the diocese of Münster in Westphalia (Mart. lib. iv. c. 27. p. 185 ). Compare the 'Orationes Sollemnes' after the Gospel on Good Friday and the Litany before Mass on Easter Eve in the present Roman Missal; the petitions after the Ingressa on four Sundays in Lent in the Milanese rite; after the Psallendo and before the Epistle on the first five Sundays in Lent in the Mozarabic rite; in the Liturgies of St. Chrysostom and St. Basil before the Introit; in the Liturgies of Armenia and Malabar before the first lection. The present position between the Epistle and the Gospel appears to be unique. There is also a strong resemblance to the 'Bidding Prayers,' or Preces Dominicales, which immediately preceded the sermon in the mediæval English Church, and were said in the Procession before Mass in cathedral and collegiate churches, but after the Gospel and Offertory in parish churches. Compare the tenth-century form in use at York, printed in Early English Text Society, vol. 71.p. 62, with Mr. Simmons' exhaustive note, ib. p. $3^{15}$. Similar prayers in the vernacular were drawn up for the use of lay people during the recitation of the Canon by the officiating priest; ib. pp. $3^{2-36}$, Text B. They are a survival from an Eastern source. A near approach to this whole passage, both in form and substance, is to be found in the following Missal Litany, transcribed by Wicelius from an ancient MS. in the Library of Fulda, and printed by Bona, Rer. Litur. lib. ii. cap. iv. § 3 :-

'In Codice Fuldensi Litania Missalis.

(a) Dicamus omnes ex toto corde totaque mente: Domine miserere.

( $\beta$ ) Qui respicis terram et facis eam tremere. Oramus te, Domine, exaudi et miserere.

( $\gamma$ ) Pro altissima pace et tranquillitate temporum nostrorum. Oramus, \&c.

Pro sancta ecclesia catholica, quae est a finibus usque ad terminos orbis terrarum. Oramus, \&c.

( $\delta$ ) Pro patre nostro episcopo, pro omnibus episcopis, ac presbyteris, et diaconis, omnique clero. Oramus, \&c.

(є) Pro hoc loco et habitantibus in eo. Oramus, \&c.

Pro piissimo iupperatore et toto Romano exercitu. Oramus, \&c.

Pro omnibus qui in sublimitate constituti sunt, pro virginibus, viduis, et orphanis. Oramus, \&c.

( $)$ Pro poenitentibus et catechumenis. Oramus, \&c.

$(\theta)$ Pro his qui in sancta ecclesia fructus misericordiae largiuntur. Domine Deus virtutum exaudi preces nostras. Oramus, \&c.

( () Sanctorum apostolorum ac martyrum memores sumus, ut, orantibus eis pro nobis, veniam mereamur. Oramus, \&c.

( $\kappa$ ) Cloristianum ac pacificum nobis finem concedi a Domino oomprecemur. Praesta, Domine, praesta.

(A) Et divinum in nobis permanere vinculum charitatis, Dominum comprecemur. Praesta, Domine, praesta. 
( $\mu$ ) Conservare sanctitatem ac puritatem catholicae fidei sanctum Deum comprecemur. Praesta, Domine, praesta.

Dicamus onnes, Domine exaudi et miserere.'

We subjoin another form of Missal Litany, Gallican in its wording and character, written in a ninth-century hand on fol. 1 3 a, b of the Leofric Missal. It is not part of the Leofric Sacramentary, properly so called, but occurs on one of the miscellaneous leaves which have been bound up together at the commencement of the MS. volume which bears that name :-

'Oremus, fratres karissimi, domini misericordiam pro fratribus ac sororibus nostris ab oriente usque ad occidentem, ut et illi orent pro nobis unusquisque in diversis locis per christum dominum nostrum.

' Oremus etiam pro unitate aecclesiarum, pro infirmis, pro debilibus, pro captiuis, pro poenitentibus, pro laborantibus, pro nauigantibus, pro iter agentibus, pro elemosinas facientibus, pro defunctorum spiritibus, et pro his qui non communicant, ut det illis dominus dignam agere poenitentiam, per christum dominum nostrum.

- Oremus etiam domini misericordiam pro spiritibus carorum nostrorum pausantium .ill. ut eis dominus placidum refrigerium tribuere dignetur, et in locum quietis ac refrigerii sanctorum suorum intercessione eos transferat, per ihesum christum dominum nostrum.

- Offerimus tibi, domine ihesu christe, hanc orationem ab ortu solis usque ad occidentem, a dextera usque ad sinistram, in honorem et gloriam diuinitatis christi et humanitatis, in honorem et gloriam onnium graduum coelestium, michahelem, gabrihelem archangelum; in honorem et gloriam patriarcharum, prophetarum, apostolorum, ac martyrum ; pro omnibus uirginibus, fidelibus poenitentibus, pro omnibus matrimoniis, pro bonis non ualde, pro malis non ualde, pro omnibus merentibus orationem et deprecationem [note 22] nostram, per eundem.'

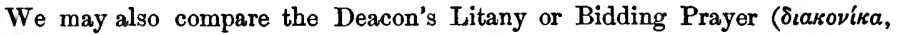

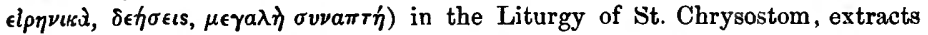
from which are here appended in Goar's Latin translation (Eucholog. pp. 64-65):-

(a) 'In pace Dominum precemur. Domine miserere.

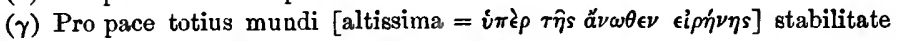
sanctarum Dei ecclesiarum, et pro omnium concordia, Dominum precemur.

( $\delta$ ) Pro Archiepiscopo nostro N. Venerandis presbyteris, in Christo Diaconis, universo clero Dominum precemur.

(є) Pro hac sancta domo, et iis qui cum fide, religione, et Dei timore ipsam ingrediuntur, Dominum precemur.

Pro piissimis et a Deo custoditis regibus nostris, toto palatio et exercitu ipsorum Dominum precemur.

Pro sancta hac mansione, omni urbe, et regione, et cun fide habitantibus in ipsis Dominum precemur.

( $\eta$ ) Pro nauigantibus, iter agentibus, aegrotis, laborantibus, captivis, et salute ipsorum, Dominum precemur.

$(\gamma)$ There is a corresponding prayer in the Clementine liturgy: ' $\Upsilon \pi \dot{\epsilon} \rho \tau \hat{\eta}$ s

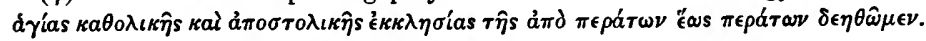

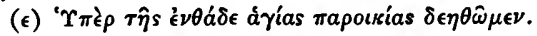

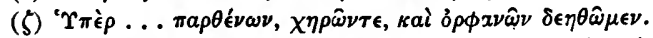

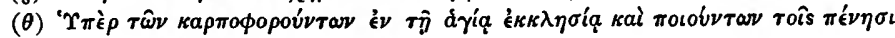

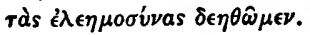




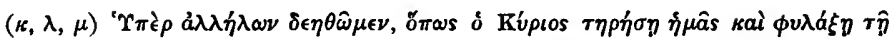

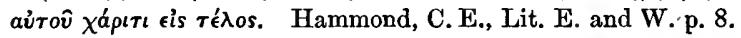

The presence of these devotions in the Stowe Missal goes to support Goar's assertion that similar petitions were found in Western Liturgies before the ninth century (Euchol. p. I23. n. 62). We append the following specimen from the Ambrosian Missal, which also bears a close resemblance to the Stowe text (Pamel. Liturgicon, i. 328) :-

\section{'Dom. Quadrag. dicta De Samaitana.}

Finita ingressa, preces per Diaconum pronunciatae, respondente choro (after each petition) :-

(a) Domine miserere.

( $\beta)$ Divinae pacis et indulgentiae munere supplicantes ex toto corde et ex tota mente precanur te.

$(\gamma)$ Pro ecclesia tua sancta catholica, quae hic et per universum orbem diffusa est precamur te.

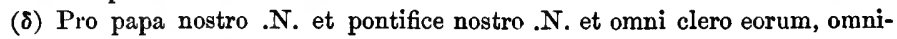
busque sacerdotibus ac ministris precamur te.

( $\epsilon$ ) Pro famulo tuo .N. imperatore, et famula tua .N. imperatrice, et omni exercitu eorum, precamur te.

Pro famulo tuo .N. rege, et duce nostro, et omni exercitu ejus, precamur te.

Pro pace ecclesiarum, vocatione gentium, et quiete populorum, precamur te.

Pro civitate bac et conversatione ejus, omnibusque habitantibus in ea, precamur te.

Pro aeris temperie, ac fructuum, et foecunditate terrarum, precamur te.

(ङ) Pro virginibus, viduis, orphanis, captivis, ac poenitentibus, precamur te.

Pro navigantibus, iter agentibus, in carceribus, in vinculis, in metallis, in exiliis constitutis, precamur te.

Pro his qui diversis infirmitatibus detinentur, quique spiritibus vexantur immundis, precamur te.

( $\theta)$ Pro his qui in sancta tua ecclesia fructus misericordiae largiuntur, precamur te.

(a) Exaudi nos, Deus, in omni oratione atque deprecatione nostra, precamur te.'

24. Notice the absence of any mention of the Pope or of the minor orders.

25. 'These words, 'piissimi imperatores,' are a direct translation of the $\epsilon \dot{v} \sigma \epsilon-$ $\beta$ '́⿴囗⿱一一) of those various periods in the fourth century between the death of Constantine, A.D. 337, and the division of the Empire into East and West, A.D. 395, when several persons were associated on the imperial throne. It is as fruitless to enquire what possible meaning the Latin words can have borne in Ireland, as it. was for Goar to ask to whom the Greek words referred, when he heard them used at Constantinople in the beginning of the seventeenth century (Euchol. p. 46. n. 2); or as it would be to ask who is meant in the petition, 'Oremus et pro christianissimo imperatore nostro,' which occurs in the present Roman Missal on Good Friday. The phrase has been imported verbatim from the continent into the Irish Liturgy, without consideration that it thereby became unmeaning. It is noteworthy that the above-quoted Fulda Litany reads 'piissimo imperatore' in the singular, and that in the mucl later Corpus Irish Missal the 'rex' and 'exercitus Hiberniensium' are prayed for instead of the Roman emperor and army. See Introd. to Corpus Missal, p. 47.

Curious instances of a similar confusion may be found in foreign liturgical co- 
dices. In the Gregorian Sacramentary (Codex Ratoldi) the King of the Franks is elected to the ' regnum totius Albionis' (Migne, Pat. Lat. Ixxviii. 257). The following passage occurs in the offce for the Comation of a King (Benedictio Regis) in a ninth-century Rheims Pontifical (Col. Agrip. Bib. Eccles. Metrop. no. 14I; Hartzeim, Catalogus MSS. p. I I I), in another Pontifical of the same date in the monastery 'Sancti Germani a Pratis' (Migne, Bib. Pat. Lat. Ixxriii. 572), and in the service used at the coronation of Charles $\nabla$ of France (Cott. Tib. B. viii; Maskell, W., Mon. Rit. iii. I4):-

' Ut regale solium, videlicet Saxonum, Merciorum, Nordan-Humbrorumque sceptra non deserat, sed ad pristinae fidei pacisque concordiam enrum animos, te opitulante, reformet, ut utrorumque horum populorum debita sibi subjectione fultus, cum digno amore per longum vitae spatium paternae apicem gloriae tua miseratione unatim stabilire et gubernare mereatur.'

The real explanation of the above passages is this. When Charles the Great abolished the national Liturgy in France, there was a sudden and great denand for new liturgical codices. Under Alcuin's directions, Anglo-Saxon Office Books were imported into France for the purpose of being copied, and French scribes wrote them out, word for word, forgetting the geographical and dynastic differences of the two countries.

Menard's remarks on the above extracts illustrate the danger of basing historical conclusions on liturgical expressions: 'Quae quidem verba satis manifestant aliquem Francorum regem id temporis in Anglorum regem unctum fuisse; quod tamen est difficile scitu, cum nihil tale in historicis antiquis, cum Francorum, tum Anglorum, repereris, per quos huic difficultati lucem afferre quis possit.' Migne, Bib. Pat. Lat. Ixxviii. $57 \mathrm{I}$, note 1090.

26. S. secret for Domin. prox. ante Adv.; Sacr. Leon. p. 364 ; Gelas. p. 68r.

27. Compare collect in Book of Hymns, p. 195.

28. This prayer is found in a similar position in the Mass published by M. Flacius Illyricus, its rubric directing ' inter lectionem et evangelium, id est tempore Gradualis, Alleluia, ac Sequentiae, episcopus dicat has orationes ;' Martene, De Ant. Eccles. Rit. I. iv. art. xi. ordo 4. p. I82 : also in a French Missal, c. A.D. 800 ; ib. ordo v. p. 187 ; in a ninth-century Troyes Pontifical after the Gospel; ib. ordo vi. p. I9I ; ib. viii. p. I94; ib. xiii. p. 207 ; ib. xvi. p. 215 : after vesting; ib. xv. p. 2 10. Similar prayers under the title of 'Apologia' or Confessio Sacerdotis' are found in the Missale Gothicum, No. xxxvii ; Mis. Moz., Leslie, tom. i. p. 224. Fifteen such forms exist in the Gregor. Sacram. as edited by Menard, pp. $228,526, n$. 78 b. A trace of it may exist in the solitary 'Oremus,' not followed by any prayer, in the present Roman Missal before the Offertory.

29. Anglice, 'A half uncovering here.' Some light is thrown on the meaning of this rubric, together with the corresponding Irish rubric on p. 232, by the following extract from a tract on the Eucharist preserved in the Leabhar Breac:-

'The two uncoverings, including the half of the chalice of the Offertory and of the Oblation, and what is chaunted with them, both in the Gospel and Alleoir ( = Alleluia ?), figure the written law in which Christ was manifestly foretold but was not seen until his birth. The elevation of the chalice of the Offertory and the paten, after the full uncovering at which is sung the verse "Immola Deo sacrificium laudis." Fol. 25 I. col. 1. Compare Stowe Mis. f. 64 b. 30. Ps. cxl. 2. It occurs as the Grad. and Vers., Fer. iii. post Invocavit; Dom. xix. post Trin.; Sabb. iv. Temp. Sept. (S. R.) It is also used in the Roman Ordinarium Missae, at the point where the priest incenses the altar. 
31. This seems to have been the ancient Gallican position of the Preparation of the Chalice. It survived in the mediaeval French Uses of Amiens, Soissons, Chalons-sur-Saone, and in the English Use of Sarum (Mis. p. 587). The mixture of water with wine took place here also at Salisbury (ib.), and in other places (Mart. iv. 57) ; but there are no traces of such a rite here.

32. This prayer is said, with slight variation of reading, after the presentation of the elements in the present Roman rite. It is ordered in this form in the VI. Ordo Rom. $\S$ Io. Micrologus asserts that it was introduced into the Roman from the Gallican Use : ' Dicit sacerdos hanc orationem juxta Gallicanum Ordinem' (De Eccles. Observ. c. xi). In a ninth-century Rheims Missal it is said 'dum elevatur Sanctum a sacerdote' (Mart. i. p. 197).

33. St. Johu vi. $5 \mathbf{I}-57$. Various portions of this passage of St. John's Gospel nccur among the Gospels in the 'Missae Defunctorum,' and in Festo Corporis Christi (R.S.).

34. Here follows a mutilated leaf two-thirds of which have been cut away. On the recto are written the words from Oratio Gregoriana-rl. The verso is blank.

34 a. Other collects 'post Evang.' are provided in the Antiphon. Benchor. p. I93; Book of Hymns, p. 196. This collect occurs twice in Sacr. Greg. pp. 34, 39.

35. This Creed was first introduced into the Liturgy of Constantinople by the Patriarch Timotheus, A.D. 511; into the Church of Spain and France (Gallia Narbonensis) by the second canon of the third Council of Toledo, A.D. 589 ; into the Roman Liturgy, probably in the reign of Henry II, A.D. IOO21024, but possibly in that of Charlemagne (ninth century). There are no traces of its present liturgical use in the Gelasian and Gregorian Sacramentaries, or in the earliest Ordo Romanus. Mart. i. p. 138. Its position here may be accepted as probibitive of the assignation of an earlier date than the ninth century to the Stowe Missal.

36. Anglice, 'A full uncovering here.' Sce note 29.

37. Ps. lxxxiv. 8. Book of Dimma, p. I 70; Stowe Mis. p. 220.

38. This rubric has been added by a later hand.

39. R. S. Sec. in Nativ. Dmi. ad iii. Missam; Sacr. Gregor. pp. 1o, 159. The wording of these collects seems to imply the joint presentation of both paten and chalice, in accordance with the later custom of Hereford (Mis. p. II7), Sarum (Mis. p. 593), and the following French churches-Moysac (Mart. i. p. 194), St. Thierry by Rheims (ib. p. 197), Soissons (ib. p. 220), Fécamp (ib. p. 2 29), Lehon (ib. p. 238), Le Bec (ib. p. 242). On the other hand, the Roman and York Missals (i. p. I7 I) direct. that the elements shall be offered separately and consecutively, providing a separate collect of oblation for each.

It seems hardly fair to infer with Dr. O'Conor (Stowe Catalog. i. App. p. 47), from the absence bere of any allusion to wine and water, that the mixed chalice was omitted 'as merely of human institution.'

39 a. Sacr. Leon. p. $35^{2}$.

40. The allusion to the diptychs in this and the following collect, and the position of these intercessions for the departed before the Canon, is distinctly Ephesine, and has never been found in any Petrine Liturgy. They are specimens of the 'Collectio post nonina' of the Gallican and the 'Oratio post nomina' of the Mozarabic rite. A similar allusion to diptychs is contained in a passage in the Rede Boke of Darbye (an Anglo-Saxon MS. c. Io6I, C. C. C. C. 422); but it has been shifted from its Gallican position before the Preface to 
its Roman position within the Canon, where it forms part of the present Commemoratio pro vivis: 'Memento, Domine, famulorum famularumque tuarum, omnis congregationis beatae Dei genitricis semperque virginis Mariae, omniumque propinquorum nostrorum, et quorum eleeınosynas suscepimus, seu quorum nomina super sanctum altare tuum scripta habentur,' \&c. This reading occurs nearly verbatim and in the same position in a tenth-century Sacramentary belonging to the monastery of Corbie, and quoted by Martene, vol. i. p. 146; and a similar allusion to diptychs placed on the altar is found in the marginal reading of an early Cologne Codex of the Gregorian Canon, printed by Pamelius (Liturgicon, vol. ii. p. I80).

There are references to both the 'reliquiae' and 'nomina sanctorum' in one of the many 'Secrets' supplied in the Missa Flacii Illyrici, introduced with this rubric:-

- Istae orationes cum oblationes offer'untur ad altare dicendae sunt, et haec est prima quotidiana et generalis.

'Suscipe, sancta Trinitas, hanc oblationem, quan tibi offero in memoriam incarnationis, nativitatis, passionis, resurrectionis, ascensionis Domini nostri Jesu Christi, et in honorem sanctorum tuorum qui tibi placuerunt ab initio mundi, et eorum quorum hodie festivitas celebratur, et quorum hic nomina et reliquiae habentur, ut proficiat ad honorem,' \&c. The collect of oblation now in the Roman Liturgy, p. 213 , was introduced into it from a foreign source in the twelfth century (Le Brun, Explic. de la Messe, i. 354; Microl. § xi).

The above collect and similar phrases occur in the eighth-century Gallican Missal published by Martene, ordo v. p. 189, which consists of the Roman Canon as introduced into Gaul under Charlemagne, interspersed with relics of the national but superseded Liturgy, and in a ninth-century Troye Pontifical (ib. ordo vi. p. I92), of Reims (ix. p. 196; x. p. 197; xv. p. 213 ; xvi. p. $21_{5}$; xvii. p. 216; xxvii. p. 230). The Ordo Missae Flacii Illyrici (Mart. i. p. 185) contains a reference, under the title 'liber vitae,' to the diptychs with the names of the departed inscribed on them, in the later passage withiu the Canon, entitled in the present Roman Missal Commemoratio pro defunctis, but there

'Item pro salute vicorum et mortuorum.

'Memento etiam .... et animabus famulorum famularumque tuarum, videlicet omnium orthodoxorum, quorum commemorationem agimus, et quorum corpora hic et ubique requiescunt, vel quorum nomina hic in libro vitae scripta esse videntur, indulgentiam et remissionem omnium tribuas peccatorum, et in consortio electorum tuorum habere digneris.

'Hic recites nomina quorum velis.

'Istis et omnibus fide catholica quiescentibus locum pacis, refrigerii et quietis indulgeas deprecaurur.'

The expression ' the Book of Life' for the 'Diptychs' was perhaps derived from the East. Renaudot quotes a Nestorian writer as aaying with reference to two Metropolitans, 'eorum nomina libro vitae inscripta non fuisse, eo quod contra leges ecclesiasticas dignitatem usurpaverant' (Liturg. Or. Coll. 1234).

41. There are frequent references to the Book of Life in the Gallican Orationes post nomina. 'Litteris mereantur conscribi coelestibus;' Miss. Goth. ordo iii: ' in aeterno vitae libro conscribi;' Sacram. Gall., Mab. ed. p. 359 : ' in coelesti pagina conscribi praecipias ;' Miss. Goth. xxii : 'coelesti chirographo in libro vitae jubeas ascribi ;' ib. xxiii, xxiv: 'in libro vitae censeas deputari ;' ib. lv: 'in coelesti pagina jubeas intimari ;' ib. lviii : 'in coelestibus paginis conscribantur ;' ib. lxv: 'aeternalibus indita paginis ;' ib. xl : ‘nomina jubeas scribi in acternitate ;' ib. 
iv : 'nomina faciat in beatitudinem aeterni gaudii recenseri ;' ib. liii : 'nomina aeternitatis titulo jubeas praesignari ;' ib. xxvi: 'nomina figere in scriptione sempiterna digneris ;' ib. xxv: 'in aeterno vitae libro nomina conscribe;' Sacram. Gall., Mab. edit. p. 359 : 'in libro vitae jubeas paginam intimare ;' ib. $\mathbf{3 8}^{8}$. also in some Gallican prayers, surviving in an unpublished tenth-century French Greg. Sacr. (Bodl. Auct. D. i. 20, fol. 4o b). Similar phrases occur occasionally in the Mozarabic Liturgy (pp. 226, 286, 346, 41 5, 483, \&c.), always including a reference both to the living and the dead. There is only one instance of such a phrase in the Roman books, and there the reference is to the living only (Sacram. Leon., Murat. edit. p. 318). For further information as to Celtic usage on this point, see p. 105 . There is reference to a 'beatae predestinationis liber,' in which are written 'nomina ficlelium eorum quos in oratione commendatos suscepimus,' in a ninth-century French Codex (Mart. ordo x. p. 201). This collect reappears in the Anglo-Saxon Leofric Missal, fol. 237 b.

42 a. See p. 227, n. (16).

42 b. Oct. I was the Feast of the Holy Relics; F. cciv.

43. These tender expressions are peculiarly characteristic of the Gallican Liturgies. See Missale Richenovens. missa ii ; Mis. Goth. ordo iii, xviii, xxxiii, xxxvii, liii, lviii ; also Milanese fragment quoted in Peyron, Cic. Frag. Orat. p. 226 .

44. The absence of the formulae of mutual salutation, 'Dominus vobiscum, Et cum spiritu tuo,' is worthy of notice. It formed part of the Gregorian, but not of the Gelasian Canon.

45. This Preface does not occur elsewhere, but there was a great wealth and beauty of Prefaces in early Western Liturgies. A variety of festivals is recognised in the paragraph 'Communicantes,' \&c. within the Canon, p. 235, and other Prefaces occur on pp. 245-7-8.

46. Some of the expressions in this Preface, 'sanctus, fortis, immortalis,' occur in the Reproaches on Good Friday. Others, 'non unius singulariter personae sed unius trinitatis substantiae,' occur in the Roman Preface for the Feast of Trinity.

47. Anglice, "Here the "Dignum" receives the addition if "per quem" follows in the text.' The Irish words run continuously together in the original text, both here and in the next rubric.

48. Anglice, "Here the "Dignum" receives the addition if "sanctus" follows in the text.' 'The addition' referred to in both these Irish rubrics seems to be the 'Proper Preface' appointed for the festival.

49. This resembles the Mozarabic Post-Sanctus for Christmas Day (Migne Edit. p. 189), and that in the Missale Gothicum in Vigil. Natal. Domini. It is a survival of the varying Ephesine Canon, where it immediately precedes the 'Qui pridie.'

50. These words, sedis-episcopo, are omitted in the Gelasian and many Sacramentaries earlier than the tenth century, and do not form part of the text of the Canon as given by Micrologus, cap. 25. They are found, except the last four words, in the Codex Othobonianus, but not in the Codex Vaticanus of the Gregor. Sacram. Martene supplies two other instances of Missals (de Prez and Monte Casino) containing here a petition 'pro abbate nostro' (i. p. I45).

51. There is no rubric here in the later Irish Missals. The recitation of names is not ordered in any of the varying forms of this short rubric in the Roman Canon, or in the English Uses of Sarum, Hereford, and York ; but in some mediaeval Gallican forms of the Canon this 'Memento' includes a petition 
for those 'quorum nomina super sanctum altare tuum scripta habentur' (in a Reims Pontifical, Mart. ordo ix. p. 197). See note 40.

52. Note the absence of the tenth-century additional clause 'pro quibus tibi offerimus vel.' Comp. Corpus Missal, p. 3, where the omission still survives in a twelfth-century text.

53. Cap. lxvii. of the Rule of St. Benedict is entitled 'De fratribus in viam directis.' Comp. the language in a Contestatio Paschalis in the Sacram. Gallicanum, 'dum justos per viam rectam gradientes coelestem ducit ad patriam' (Mabillon, Mus. Ital. i. 332).

54. The festivals here commemorated are-

(I) 'Natale Domini' = Christmas Day.

(2) 'Kl:' (= Kalendis Januariis), Feast of the Circumcision.

(3) 'Stella' = Feast of the Epiphany.

(4) 'Natalis Calicis' = Maundy Thursday. So in the Kalendar of Polemius Silvius for March 24, 403; Migne, Bib. Pat. Lat. xiii. 678. Both Dr. O'Conor and Dr. Todd unaccountably refer this phrase to 'Ash Wednesday.' Neither interpretation suits the preceding heading 'Stellae.'

(5) 'Pasca' = Easter Day.

(6) 'Clausula Pasca' = Low Sunday, or Clausum Paschae. Mis. Goth. No. xliv. p. 108.

(7) 'Ascensio' = Holy Thursday.

(8) 'Dies Quinquagensimae,' or 'Pentacosten ' = Whitsun Day.

The occasions on which a variation occurs in the clause 'Communicantes,' \&c. in the present Roman Canon are Christmas, Epiphany, Maundy Thursday, Eastertide, Holy Thursday, Whitsuntide. We have independent testimony that some such variation formed part of the original Gelasian text in a letter written by Pope Vigilius to Profuturus Bishop of Braga in Spain, A.D. 538, in which he said: 'Ordinem quoque precuin in celebritate missarum nullo nos tempore, nulla festivitate, significamus habere divisum, sed semper eodem tenore oblata Deo munera consecrare. Quoties vero Paschalis, aut Ascensionis Domini, vel Pentecostes, et Epiphaniae, Sanctorumque Dei fuerit agenda festivitas singula, capitula diebus apta subjungimus, quibus commemorationem sanctae solemnitatis, aut eorum faciamus quorum natalitia celebramus, caetera vero ordine consueto persequimur.' Migne, Bib. Pat. Lat. lxix. p. 18.

55-55. The presence here of these seven words is not inconsistent with Mr. Simmons' suggestion that they may have been introduced into the Canon by Eugenius I, $655^{-8}$. The Gelasian title of this Canon must not be pressed to confirm his other supposition that they may have formed part of the Canon before the time of St. Gregory. (Early Eng. Text Soc. vol. 71. p. 356.)

56. An allusion to a special Church is contained in the Deacon's Litany or

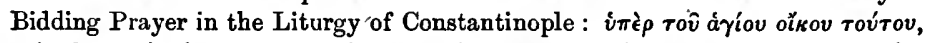

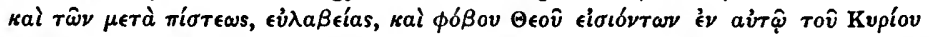
$\delta \epsilon \eta \theta \hat{\omega} \mu \epsilon \nu$. (Hammond, C. E., edit. p. 9I.) Another instance is found in the earliest extant form of those bidding prayers which, derived from the East through the ancient Gallican Church, form one of the distinguishing characteristics of the Anglican Liturgy: 'Wutan we gebiddan for ealles thæs folces gebed be pas balgan stowe mid ælmesan seceth,' \&c. = Let us pray for all those people's prayer who seek this holy place with alms, \&c. (From a York MS. aec. x, printed by Early Eng. Text Soc. vol. 71. p. 62.)

57. This passage suggests the possibility of the Stowe Canon being part of a Missa Dedicationis. A special 'Hanc igitur' is very common in the Gelasian, 
rare in the Gregorian Sacramentary, and only occurs thrice in the present Roman Missal. There is a 'Hanc igitur' similar in intent but with little verbal identity in an 'Ordo ad dedicandam basilicam,' ex MS. Missal. Gellonens. (eighth oentury), published by Martene, tom. ii. p. 246. The present passage refers to a particular church, the founder or builder of which was still living; and the prayer that he and all the people may be converted from idolatry may imply that the founder was himself a pagan, and proves that when the words were written paganism was not extinct in Ireland. This is important as bearing upon the date of the Stowe Missal. It affords an instance of literal compliance with can. I9 of the Council of Emerita, A.D. 666: 'Salubri deliberatione censemus, ut pro singulis quibusque ecclesiis, in quibus presbyter jussus fuerit per sui episcopi ordinationem praeesse, pro singulis diebus Dominicis sacrificium Deo procuret offerre, et eorum nomina a quibus eas ecclesias constat esse constructas, vel qui aliquid his sanctis ecclesiis videntur aut visi sunt contulisse si viventes in corpore sunt ante altare recitentur tempore missae; quod si ab hac discesserunt vel discesserint luce, nomina eorum cum defunctis fidelibus recitentur suo ordine.' (Labbe, tom. vi. col. 5०7.)

58-58. These words (diesque-numerari) are said by Bede (Hist. Ec. lib. ii. cap. i) to have been added to the Canon by Gregory the Great, but they are found in the Codex Vaticanus of the Gelasian Canon published by Muratori (p. 696).

59-59. This passage (passionem-coelis) occurs at the close of the 'Qui pridie ' in the Ambrosian Liturgy. (Pamel. Liturg. i.p. 302.) A similar passage occurs in the Greek Liturgies of St. James, St. Basil, St. Chrysostom, St. Mark, in the Coptic St. Cyril and St. Basil, and in the Ethiopic. (Hammond, C. E., Lit. pp. 70, 111, I12, I87, 211, 220, 258; compare also the closing words of the Prayer of Consecration in the Mozarabic Liturgy, p. I I 7.)

60. This expression (sacrificium spirituale) occurs in the Post-com. for St. Patrick's Day in the Drummond, Corpus, and Rosslyn Irish Missals, p. 27r. It is uncommon in Western liturgical phraseology, although 'spiritualis' as an epithet of 'cibus' or 'poculum ' is frequently met with. Compare the following passage in the Mozarabic Preface for ii. Domin. post Oct. Epiphan. : 'Nam licet verum corpus edatur, et sanguis manifestissimus hauriatur, nullus tamen horror incutitur, cum salus animarum in spirituali cibo et poculo ministratur ;' p. 249. The equivalent $\dot{\eta} \pi \nu \epsilon \nu \mu a \tau \iota \kappa\rangle) ~ \theta v \sigma i a$ is used by St. Cyril of Jerusalem, Catech. Myst. v. § vi, ed. A.D. $16_{3} 1$, p. 241 .

60 a. The expression 'Electus dei anthleta' occurs in Lib. Hymn. f. $3^{\mathbf{I}}$ b. For the superfluous ' $n$ ' see Corpus Missal, p. 35 .

61. There is a passage similar to this in the Commemoratio pro vivis in the Mozarabic Liturgy, § 225: 'Offerunt Deo Domino oblationem sacerdotes nostri, Papa Romensis et reliqui pro se et pro omni clero ac plebibus ecclesiae sibimet consignatis, vel pro universa fraternitate. Item offerunt universi presbyteri, diaconi, clerici, ac populi circunstantes, in honorem sanctorum pro se et suis.' Compare also the following Collectio post nomina for Easter Eve in the Missale Gothicum ; 'Oremus pro his qui offerunt munera Domino Deo nostro sacrosancta spiritalia, pro se, et pro caris suis, et pro spiritibus carorum suorum, in commemoratione sanctorum martyrum; ut Dominus Deus noster preces illorum clementer exaudire dignetur. Per Resurgentem.' Mis. Goth. p. $9^{\circ}$.

The order of intercessions as arranged in St. Coluinbanus' Rule has been already referred to, p. 25I, n. 22. The word 'senior' has occurred on fol. 23 b. It also occurs in the Regula Columbani, c. 7 ; Poenitentiale, c. 28 ; in the Missale 
Gallicanum, p. I59; Tertullian, A polog. 39. It is explained by Alcuin, Lil. de Div. Off. p. 6r, edit. Hittorp. In the Irisl Rule of St. Columba the head of a community is entitled 'senora.' (H. and S. ii. p. II9.) In the Misa Flacii Illyrici there is a collect commencing 'Suscipe Sancta Trinitas hanc oblationem quam (offero tibi) pro seniore nostro, et cuncta congregatione sancti Petri,' \&c. (Mart. i. p. 184.) The presence of this passage here is one of various slight indications that this Ordo Missae, which was written c. A.D. 900 , and for which such various origins have been clained (ib. p. I76), may have been of Irish origin. The word 'seniores' occurs repeatedly in consecutive clauses in a charter of confederation of German monasteries in an eleventh-twelfth century Cod. Vindobonensis printed by Gerbert, ii. 140. The Latin 'senior' and Celtic 'senora' became 'aldor' or 'aldermann' in Anglo-Saxon times. In the ecclesiastical laws of Wihtred King of Kent, promulgated at Bersted in 696, it was enacted, 'Mynstres aldor hine cænne in preostes canne' $=$ Let the senior of a minster clear hinself with a priest's clearance (No. xvii. H. and S. iii. 236). In the Ormulum (thirteenth century, line 6304) the word 'alderrmann' occurs in the same sense; for several other instances of this use of the word in the same work, see R. M. White's edit., Oxford, 1852, vol. ii. p. 442.

62. Many of the names of saints in the following lists are in the genitive case -a common occurrence in ancient martyrologies-the word festum being understood. The writer appears to have copied out the names forgetting always to change the genitive into a vocative case. The frequent repetitions are caused by the existence of nore than one saint bearing the same name. I can detect no paleographical evidence for the stateurent endorsed by Mr. Scudamore (Notit. Euch. p. 425, second edit.) that the 'ora pro nobis' has been added throughout by the later hand of a scribe who was ignorant of the real purport of the list, but the whole of fol. $29 \mathrm{ab}$ is written in a later handwriting on an interpolated leaf. Fol. $30 \mathrm{ab}$ is also an addition to the original text, which passed on at once to the long list of departed saints commencing on fol. 3 I a. For similar Litanies to the Saints, see Gerbert, Lit. Al. ii. 34. Brit. Mus. Add. MSS. 28 , 188.

63. March I7. A postle of Ireland, ob. 493.

64. Sept. 12. First Bp. of Emly, patron of Munster, ob. 534. [B. F. p. cexii.]

\begin{tabular}{l} 
65. March 2. Bp. of Cluain-Iraird, now Clonard, ob. 549. [B. Book of \\
\hline
\end{tabular} Obits, p. lxxxvi.]

66. March 16. Abb., ob. 615. [B. F. p. celxii = Finan.]

67. March 5. Of Saighir, = Cornish Piran, older than St. Patrick. [B. F. p. cexxxii.]

68. Sept. 9. Kieran, or Queranus, first Abb. of Clonmacnoise, ob. 549. [B. D.]

69. May 16. The elder Abb. of Clonfert, ob. 576. [B. D.] There are
[B. ten saints bearing this name in D. = Brenann of Cluain-ferta, F. p. ccxxvi.

70. Dec. I3. Abb. of Tyrdaglas, one of the twelve apostles of Ireland. [B. D. F. p. ccxxxvii.] The names of the twelve Irish apostles are given in F. p. exviii.

71. June 9. Abb. of Iona, ob. 597. Two other Columbs are commemorated in F., June 7, Sept. 6.

72. May ro. Comgallus, Abb. and Conf. of Bangor in the sixth century. [Book of Obits, p. lxi; F. p. ccxxxvii.] There are seven saints of this name commemorated in $\mathbf{D}$.

73. Oct. 11. Cannicha, or Canice, Abb. and Conf., founder of Achad-bho, now Aghaboe, ob. 598. [B. D.] = Caindech, F. p. cexxviii. 
74. Sept 25. Barrus, Bp. of Cork. [B. D.] Or July 4, Findbarr of Magh Bile, F. p. cclxii.

75. Dec. 6. Nessan, $w^{\cdot}$ Neassan, Bp. [B. D. F. p. ccxlix.]

76. Jan. 19. Factnae, Bp. of Nuachonghbail. [D. F. p. cclix.]

77. Aug. 4. Luan, or Molua, or Lugeus, or Lugidus, Abb. of Cluain-fertamolua, ob. 622. [B. D.] Or Abb. of Lismore in the Hebrides; [Book of Obits, p. $\operatorname{lxv}$.]

78. March 18. Lactenus, or Lactinus, Abb. of Achadh-Ur, and Bp., ob. 622. [B. D. Colgan, Acta SS. p. 655.]

79. April 15. Abb. of Lothra, ob. 584. [B. D. F. p. cccix.]

80. March 5. Carthach, Abb. and Bp., succeeded St. Kieran the elder. [B. D. F. p. ccxxx.]

81. June 3. Coemgen, or Kevin, Abb. of Gleann.da loch $=$ Glendalough, ob. 615. [B. D. Book of Obits, p. xlvii, F. p. cexxxvi.]

82. March 8. There are eleven saints of this name commemorated in D. The person represented by this name may be S. Mochonna, ob. 704; F. cexciii.

83. Feb. 1. Virgin, Abbess of Kildare, ob. 523. [B. D. F. p. ccxxvii.]

84. Jan. 15. Ite, or $\mathbf{Y}$ the, or Mida, Virgin of Cluain-creadhail and Abbess, ob. 569. [B. D. F. p. cclxxix.]

85. Jan. I. Or Sceath, Virgin, of Feart-Scethe. [D. T.] Perhaps she may be identified with Scite or Scithe, commemorated on May 13 in the Lib. S. Trinitatis [Book of Obits, pp. lxi, 115 ], or with Sciath, Sept. 6 ; F. cccxi.

86. Nov. 9. Sincha, or Sinech, of Cluain-Leith-teangadh, Virgin. There are three other saints of this name commemorated in D. [Book of Obits, p. lxxix; F. cccxv.]

87. Dec. 19. Perhaps Samhthann, Virgin, of Cluain-Bronaigh, ob. 734 . [D.] Samthann, Samdann, F. p. cccxi.

88. This prayer of St. Ambrose is found in a 'Libellus sacrarum precum' written at Fleury c. A.D. 900, and printed by Marteno (De Ant. Eccl. Rit. lib. iv. c. 34 , tom. iii. p. 245). Its liturgical use is found in many a French Missal written c. A.D. 800-900. (Ib. lib. i. cap. iv. art. xii. ordd. v, vi, vii, |ix, xiii, xir, xv, xvi.) There are many variations in the text. Its usual position is at a much earlier point in the service, either among the 'Orationes ante Missam,' or immediately before the 'Secreta.'

89. For these unintelligible words (quorum ut dixit) most forms of the prayer substitute 'immundi sicut pannus menstruatae. Indigni sumus, Jesu Christe ut simus viventes sed tu qui non vis mortem peccatoris da nobis veniam in carne constitutis, ut per poenitentine labores vita aeterna perfruamur in coelis, per te, Jesu Christe, qui,' \&c.

90. = Abel. These 'Nomina justorum ac prophetarum' occur at the commencement of a long Litany in an eleventh-century Psalter at Florence (Bibl. Laur. Plut. xvii. cod. iii. fol. I 44 a), where Seth, Melchisedech, Joseph, Job, Joshua, Tobit, the tres pueri, and the Machabeorum infantes are omitted, and Aaron, Elijah, and Elisha are added. Patriarchs and prophets are also commemorated in the Fellire of Oengus, in the Kalendar of the Drummond Missal, and in the Book of Obits of Christ Church, Dublin. See S. Hieron. Martyrologium, Migne, Pat. Lat. Ours. xi. 437. In the York Bidding prayer, tenth century, people are invited to pray for the souls of all that have believed in Christ, 'fram Adames dæge to pisum dæge.' Early Eng. Text. Soc. vol. 7I. p. 62. The same wide range is included in the language of early Eastern Liturgies, as in the Oratio generalis of the Syro-Jacubite Ordo: 'Memoriam 
agimus ... eorum etiam qui nobiscum adstant et orant, cum omnibus qui a saeculo tibi placuerunt ab Adamo ad hanc usque diem.' Renaudot, Liturg. Orient. Coll. ii. I6.

91. Dots placed over the lower Madiani imply that the word has been repeated by error. Matthias and Barnabas usually occupy the place here assigned to Madianus [D. Jan. 24]. Forbes, A. P., Kalendar of Scot. Ch. p. 382. But this name occupies the same anomalous position elsewhere; pp. I 80, 226. Madianus is the mediaeval Hiberno-Latin form of Matthias, who is commemorated under the name of Madian in the Félire of Oengus; Leabhar Breac, fol. $82 \mathrm{~b}$; in a list of the Apostles, ib. p. 9I ; Hymnus Cuminei, Lib. Hymn. p. 77 ; on the last page of the Appendix to the Glamis copy of the Aberdeen Breviary, printed in facsimile by D. Laing at the end of his Pref. to the Brev. Aberdon.

92. Did the scribe mean to write 'tarum'? - $\sum k \hat{\eta} T \eta-y / H T$.

93. March 17. Apostle of Ireland, ob. 493.

94. Aug. 24. Abb. and Bp., nephew of the former, Or is one of these two Patricks to be identified with Palladius?

95. Nov. 27. Or Sechnall, British, by birth, coadjutor of St. Patrick, ob. 448. [Book of Obits, p. lxxxv. F. p. ccexii.]

96. Sept. 16. British by birth, coadjutor of St. Patrick, ob. 454. [Book of Obits, p. Ixxvii.]

97. Dec. 2. British by birth, coadjutor of St. Patrick.

98. A disciple of St. Kieran, ob. 499. [Colgan, Acta SS. 473.]

99. April 16. First Bp. of Slane, ob. 5 14. [B.] Nov. 2, F. clxii.

100. Not identified. The name Cathar occurs in F. Ixiv, lxxii.

101. April 23. Iobhar, Bp., coadjutor of St. Patrick, ob. 500. [B. D. F. p. cclxxiv.]

102. See note 64 .

103. Feb. 2, or May 3. Conlaedh, Bp. of Kildare, ob. 519.

104. Aug. I. Is this Mica of Ermudhe? [D.]

105. Is this Mac Nisse, founder and first bishop of the See of Connor, ob.

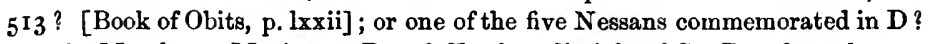

106. March I. Maoinenn, Bp. of Clonfert, disciple of St. Brendan, ob. A.D. 572. [Four Masters, D.]

107. March I and 8. Senan, Bp. of Inis-Cathaigh, ob. 544. [F. ccexiii.]

108. See note 74 .

109. A portion of this word is erased in the MS.

110. Is this Colman, Bp. of Glendalough, ob. Dec. 13, 659? There are ninety-seven persons of this name commemorated in D. I7, in F. p. ccxxxvi.

111. April 2. Alias Mochua, Abb. [B.] Twelve persons named Cuanus are commemorated in Colgan's Acta SS. St. Cuana of Kill-chuana, alias Killskanny, Co. Clare, ob. 650 .

112. Nov. 17. Is this Dulech, or Duileach, or Doulough, Bp. and Conf. ? [D. Book of Obits, pp. xlvi, lxxx.]

113, 114, 115. Second, third, and fourth Archbps. of Canterbury. The presence of these names proves the existence of intercourse between the AngloSaxon and Irish Churches. The absence of St. Augustine's name is remarkable, but may be accounted for by the feeling of hostility which existed between him and the Celtic clergy. Laurence is known to have written a letter to the Irish bishops, urging them in vain to come to terms of union with the Anglo-Saxon Church. Bede H. E. ii. 4. St. Augustine is commemorated in F., May 24. 
116. Nov. 10. Aedh, Bp. of Ciltair, ob. 588. There are twenty-six saints of this name commemorated in D. See F. p. ccxi.

117. Sept. I3. Bp. of Inver-Daoile; see also March 1 2. [D. F. p. ccxliv.] 118. April 4 or 5. Bp. of Clogher, founder of Clones (Cluaineois), ob. 548 . [B. D. F. p. ccexxiii.]

119. Aug. 22. Mocbteus, first Bp. of Louth, ob. $535=$ Mochta. D. Or Aug. I9, or March 24, as in Colgan's Acta SS.

120. Nov. 24. Bp. of Daimhliag, ob. 488 . [D.] The other saints of this name are found under Feb. 25 , Nov. 29, Nov. 24. F. p. cexxxii.

121. Dec. 7. Buite, or Boetins, or Beo, now St. Baoithin, Bp., ob. 520. The festival of his elevation is on Dec. II. [D. Book of Obits, p. xlix. F. p. ccxxxviii.]

122. Aug. 23. Eoghan, or Eugesius, Bp. of Ard-sratha (Ardstraw, Tyrone), ob. 570 or 618 . There are nine other saints of this name commemorated. [D. F. p. cclvi.]

123. July 24. Declan, Decclan, or Deglan, Bp. of Ard-mor, fifth century. [B. D. F. p. ccxlv.]

124. March 5. Is this Cartbach, Bp. and Abb. of Druim-fertain ? [B. D. F.] Two other saints of this name are commemorated on March 26, May I4. A Carthagius is named in Colgan's Acta SS. p. 473.

125. Feb. 6. Perhaps = Mel, Bp. of Ard-achadh, nephew and disciple of St. Patrick, ob. $4^{8} 7$. [B. D.]

126. Sept. 25. Ruine. [T.]

127. Dec. 1. Uinnian, or Finnian, or Finnen, Bp. and Conf., of Magbbile, ob. 578. [Lib. Hyiun p. 100.]

128. See note 67 .

129. Nov. 17. Of Cill-mor. Six saints of this name (Oenghus) are commemorated in D. F. ccci.

130. March 21. Enda, Abb. of Isle of Aran. [B. D.] See Dec. 3 I, F. cclvi.

131. Nov. 4. Gildas the elder, ob. 512 ; the younger, ob. 570. Jan. 29. [B.]

132. See note 69 .

133. Nov. 29 or 30 , the younger. Abbot of Birra, ob. 577. [B. D.]

134. See note 73 .

135. See note 70 .

136. See note 71 .

137. There are 230 Irish saints bearing this name. [B. D.]

138. See note 72 .

139. See note 81 .

140. This word occurs in the Collectio post nomina in Mis. Goth. ordd. xvii, xl. In ordo xxxiii. there is an Oratio pro spiritibus pausantium; so in the Sacram. Gallican., Mab. edit. p. $3^{21}$; in the Commemoratio pro defunctis in the Mozarabic Liturgy, $\S \S 226,252$, pp. 114, 168,603, 730; in the Poenitentiale of Cuminius, p. 23. n. I. Adamnan speaks of St. Columba's grave as 'locus in quo ipsius sancta pausant ossa' (lib. iii. cap. 23). 'Pausantes' for 'mortui,' ' pausatorium' for 'sepulchrum,' are words of rare use in late Latin; vid. Du Cange, sub voc. 'Pausare' is the word generally employed in the Annals of Ulster (saec. xiv-xv. Rawl. MSS. B. 489 , fol. 9 b, \&c.) in recording the deaths of bishops and abbots, whereas 'quievit, mortuus est,' \&c. are used in the case of kings and other lay persons. Pausare is used in the same sense in early mortuary inscriptions in the Roman Catacombs (De Rossi, Inscriptiones Christianae, sub an. 353), and in early Christian inscriptions in Gaul 
(Le Blant's edit. nos. 230, $5 \mathrm{II}, 534$ ). It occurs also in a collect in the Coemiterii Benedictio in the Roman Pontifical, 'Deus sancte, Pater O,' \&c. 'Avámavoıs

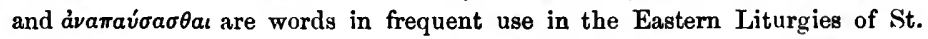
Clement, St. James, St. Basil, St. Chrysostom (Hammond's, C. E., edit. pp. 2o, $3^{6}, 3^{8}, 1_{15}, 118$, \&c.). Compare the Oratio post Diptycha in the Coptic Lit. (Anaphora of St. Cyril, Hammond's edit. p. 210 ) on behalf of 'omniun quorum nowina recitamus et quorum non recitamus, quos unusquisque nostrum in mente habet, et eorum quorum memoria non occurrit nobis qui dormierunt et quieverunt in fide Christi,' \&c. The whole of the paragraph 'Memento etiam Domine farmulorum' in the Roman Canon is preceded in some ancient MSS. by the title 'Super Diptycha.' In a tenth-century Tours Sacramentary that title is followed by the rubric, ' $S i$ fuerint nomina defunctorum recitentur. Dicat sacerdos : Memento etiam, \&c. . . . in somno pacis. Deinde postquam recitati fuerint, dicat sacerdos : Ipsis et omnibus,' etc. It is not easy to assign the exact date at which the custom fell into desuetude. Martene (i. p. 150) quotes at length the diptychs as read at Amiens early in the twelfth century, but the custom had become generally obsolete a century or two before that date. The diptychs in this Irish Missal, consisting of forty-seven names from Abel to Coenigeni, are of unusual length. One would at least equally have expected to find them connected with the two collects preceding the Sursum Corda (q. v. p. 233).

140 a. Compgre the following ancient and anonymous inscription in the church of St. Allyre in Gaul: 'Hic requiescunt corpora sanctorum quorum nomina Deus scit.' Le Blant, Inscript. Chrét. de la Gaule, No. 563, where further instances of the early use of the phrase are supplied in the notes.

141. Anglice, 'Here the oblation is lifted over the chalice, and half of the bread is dipped into the chalice.'

142. Ps. xxxii. 22. See below, n. 146 .

143. Anglice, 'Here the bread (lit. cake or wafer) is broken.' The fraction of the Host in the present Roman rite takes place during the Embolismus after the Pater Noster.

144. Luc. xxiv. 35. See below, n. 147 .

145. Adapted from I Cor. x. 16.

146. Ps. xxxii. 22. See above, n. 142.

147. Luc. xxiv. 35. See above, n. 144 .

148. Similar confessions of faith are found in various Eastern Liturgies; the Syriac Lit. of St. James, Hammond's edit. p. 77 ; the Ethiopic Lit., ib. p. 26r. They are also found in the Mozarabic Liturgy, pp. I16, 118 , 1009.

149. Confractio. The word confringo is found in the Gallicall and Ambrosian words of Institution, and we may infer from this passage that it was employed in the ancient Celtic Prayer of Consecration. Compare the Gallican Post Secreta for Christmas Day: 'Credimus, Domine, adventum tuum, recolimus passionem tuum. Corpus tuum in peccatorum nostrorum remissionem confractum. Sanguis sanctus tuus in pretium nostrae redemptionis effusus est, qui cum Patre,' etc. (Missale Gothicum, Mab. edit. p. 192).

150. 'Praeceptis salutaribus moniti' Miss. Rom. This difference from the unvarying Roman formula of introduction to the Pater Noster is noteworthy. See St. Gall MS. No. 1394, p. 177 ; Book of Dimma, p. 169.

151. 'Libera nos, quaesumus, Domine ab omnibus malis praeteritis, praesentibus, et futuris, et intercedente pro nobis beata et gloriosa semper Virgine Dei Genitrice Maria, cum beatis Apostolis tuis Petro, et Paulo, atque Andrea' 
Miss. Rom. The name of Patrick is substituted for Andrew in the text, in accordance with the very early custom of the priest inserting here at his option the names of patron or local saints. St. Andrew is also omitted in a ninth-century Gallican Missal quoted by Martene (i. p. 152). St. Ambrose is added in a Milanese Missal, A.D. 1560; Dionysius, Eletherius and Rusticus, in a eighth and ninth century Gallican Missal (Mart. i. ordo v. p. 190 ; see ordo ix. p. 197).

152. The Roman formula is 'Pax Domini sit semper vobiscum.' This is the Roman position of the Pax. In the Gallican and Mozarabic Liturgies it preceded the Sursum corda. The wording of the text resembles somewhat the Mozarabic formula, 'Gratia Dei Patris omnipotentis, pax ac dilectio Domini nostri Jesu Christi, et communicatio Spiritus Sancti sit semper cum omnibus nobis' (p. 115). It occurs again with a verbal alteration on p. 224; Book of Dimma, p. 170 .

153. Here follow in the Gelas. Canon. twelve Postcommuniones and fifteen Benedictiones super populum. Muratori edit. p. 698.

154. Similar words accompany the bestowal of the Pax in the Mozarabic Liturgy, § 226 , p. 115 .

155. The Commixture here precedes the Agnus Dei, according to the Roman Use, differing from that of Sarum, Hereford and York, and from mediaeval French Liturgies. Mart. i. ordo v. p. 190 ; vi. p. 192 ; vii.p. 193 ; viii. p. 194.

156. The Agnus Dei was appointed to be sung here by Sergius, i. 687-70 t. It was always sung once or thrice. Here apparently it is to be used twice (so John of Avranches, de Eccles. Offic. c. xlviii). There was some variation in the wording of the third clause, which does not however appear to have been elsewhere entirely omitted (Gerbert, Disquis. iv. vol. i. p. 381). The Agnus Dei is omitted altogether from other editions of the Gelas. Sacram.; Muratori, Lit. Rom. i. 698 ; Scudamore, W. E., Notit. Euchar. 2nd edit. p. 6 ;9.

157. Ioan. xiv. 27. St. Gall MS. I 394, p. 177 .

158. For the whole of this passage compare the Irish fragment of St. Gall MS. No. I394, p. I77; the extracts from the Antiphonarium Benchorense (p. 192), and from the Books of Deer (p. I65), Dimma (p. 170), and Mulling (p. I 73 ). This is very nearly the anthem sung in the Mozarabic Liturgy by the choir at the Kiss of Yeace, $\$ 226$, p. 546. I have not found any passage resembling it in any printed or MS. edition of the Gelasian or Gregorian Sacramentaries.

159. Ps. cxviii. $16_{5}$.

160. Not identified.

161. Not identified.

162. Perhaps Ps. xcv. I.

163. Perhaps the communion hymn in the Antiphon. Benchor. p. 187.

164. Prov. ix. 5. St. Gall MS. I 394 , p. 178 .

165. Ps. xxii. 1. St. Gall MS. 1394, p. 177 .

166. Ioan. vi. 57 .

167. V. om. ipse. Ib. St. Gall MS. I 394, p. I77. This is the Mozarabic 'Ant. ad Accedentes' for the Friday after the first Sunday in Lent, p. $3^{\text {I } 6 . ~}$

168. Ps. $x \times$ iii. 1 .

169. Ioan. vi. 59. V. om. vivus. St. Gall MS. 1394, p. 177; Antiphon. Benchor. p. 192. This passage occurs as part of the Communio in the Ethiopic Liturgy, Hammond's edit. p. 262. It is also part of the Mozarabic Ad Acce. dendum for the third Sunday in Lent, p. 343 . 
170. Ib. For 'ex eo' V. reads ' hunc panem.' Ib. comp. the 'Ad Accedentes' for the fifth Sunday in Lent; Mis. Mozar. p. 377.

171. Ps. xxiv. I. St. Gall MS. 1394, p. 178.

172. Ps. Ixxvii. 24, 25.

173. Ps. vii. 9. St. Gall MS. 1394, p. 178.

174. Cant. v. I. St. Gall MS. I394, p. 178.

175. This formula of administration is found in the St. Gall. MS. No. 1 394, p. 178 ; Antiphon. Benchor. p. 192. It appears, like the formula in the Book of Deer, \&c. (p. 164), to involve Communion in both kinds at once.

176. Ps. cxviii. I7 r. V. 'Eructabunt labia mea hymnum, cum docueris me iustificationes tuas.' St. Gall MS. I394, p. I78 ; Antiphon. Benchor. p. 192.

177. Ps. xxxiii. 2. Mozar. Lit. \$232. p. 565 .

178. Ps. xxxiii. 9; Antiphon. Benchor. p. $19^{2}$. This is sung during the fraction in the Greek Lit. of St. James (Hammond, C. E., edit. p. 5I). The whole of this psalm was ordered to be sung during the Communion of the people, in the Apostolic Constitutions (lib. viii. c. I3, al. 20). St. Cyril speaks of this verse being sung in his time (348-86) at Jerusalem : Meтd тav̂ra ákoú-

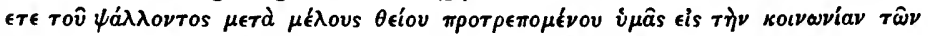

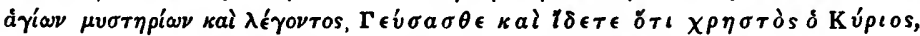
$\kappa . \tau . \lambda$. St. Ambrose alludes to it as sung at Milan in the same century: - Unde et ecclesia videns tantam gratiam hortatur filios suos GUSTATE ET vIDETE QUONIAM SUAVIS EST DOMINUS,' \&c. It is the ordinary Antiphona ad accedentes in the Mozarabic Liturgy, except from the first Sunday in Lent to the vigil of Pentecost (Hammond, C. E., edit. p. 349). It does not form part now, though it did form part of the Roman Liturgy in St. Jerome's days, who said, 'Quotidie coelesti pane saturati dicimus, Gustate et videte quam suavis est Dominus' (Comment. in Es. ii. c. v. 20; Migne, Bib. Pat. Lat. xxiv. 88).

179. Ioan. xii. 26. V. ' Ubi sum ego, illic et minister meus erit.' St. Gall MS. I394, p. I 78 .

180. Mat. xix. I4. V. 'Sinite parvulos et nolite eos prohibere ad me venire,' \&c. The employment of this verse as a Communion anthem points to the custom of infant communion. There is a rubric in the twelfth-century Irish Ordo Baptismi in the Corpus Missal, ordering the confirmation of infants, which was probably a prelude to their communion (fol. 203 a); St. Gall MS. 1394, p. I 78, commencing with ' Nolite.'

181. Mat. iii. 2. St. Gall MS. I394, p. I 78.

182. Mat. xi. 12. St. Gall MS. I 394, p. 178.

183. Mat. xxv. 34. V. 'possidete paratum vobis regnum a constitutione mundi.' St. Gall MS. 1394, p. 178. 'This is the Mozarabic 'Sacrifioium' in festo SS. Servandi et Germani, p. 884 .

183 a. See p. $16_{5}$, n. 1.

184. This is an early Irish name belonging to a period when Pagan names were still retained, but the bearer of it has not yet been identified. Used as a prefix, Maol, Mael, or Moel, means the servant or devotee of the person whose name follows, as Maol Colaim, Maol Seacnaill; so here Moel Caich. It is the old Irish word for 'tonsus.'

185. St. Gall MS. No. I 394, p. I79, where see note 2.

186. This prayer is the 'Consummatio Missae' in the Sacramentarium Gallicanum, p. 209. It occurs in the ninth-century Irish fragment at St. Gall, No. I 394 (p I 79). The first part, 'Gratias ueniam,' occurs in the Leon. Sacr., mense Jul. No. xxiv, the remainder in mense Sept. No. iii, with verbal 
variations. Comp. the thanksgiving collect in the Sarum Canon, "Gratias tibi ago, \&c., p. 626. For the generally Ephesine character of these forms of thanksgiving, see Book of Deer, p. $16_{5}$, n. 7 .

187. This is the Mozarabic formula for conclusion 'in feriali officio.'

188. The omission of any allusion to the ablutions and to the final Gospel 'In principio' is common to all Missals written before the twelfth-thirteenth century. The earliest date of any allusion to those customs in the Church of these islands is given in the Early Eng. Text Soc. vol. 71. pp. 30r, 383 .

189. This Missa bears a general resemblance in its length of collects, possession of a Proper Preface, width of application, exhaustive enumeration of orders of saints, to a Missa generalis printed by Martene from a ninthcentury codex belonging to a monastery at Rheims (De Eccles. Antiq. Rit. i. p. 197). Compare the title on p. 226.

190. Compare the language in the Faeth Fiada, the ancient Irish Hymn of St. Patrick: 'I bind to myself to-day the power of the love of seraphim, in the obedience of angels, in the hope of Resurrection unto rewards, in prayers of patriarchs, in predictions of prophets, in the precepts of apostles, in the faith of confessors, in the purity of holy virgins, in works of just men. (Kilkenny Archaeol Soc. I868, p. 295 ; Todd, J. H., Life of St. Patrick, p. 427.)

191. In these words we have at least one form of the opening words of the Prayer of Consecration in the Celtic Church. As in the case of the Gallican Liturgy the opening words of the Canon down to 'Qui pridie' varied with each festival. The Gallican Canon for Christmas Eve opened with the words of the Canon in this Irish Missa, 'Vere sanctus, vere benedictus,' \&c. Daniel, Cod. Lit. i. p. 83 ; Mabillon, Lit. Gall. p. 188. See p. I09.

192. The words of consecration in full are not found in any extant Gallican Missal, but their presence is sometimes indicated as here by the opening words 'Qui pridie.' So in an eighth-century Gallican fragment found by the Rev. H. B. Swete, A.D. 1867 , attached to one of the covers of MS. 153 in Gonville and Caius College, Cambridge. Miss. Richenov. ii. p. 4 ; Miss. Goth. No. lxxv. p. 142. See Post Sanctus in Miss. Moz. pr. 181, 198, \&c. The remainder may be supplied in the case of the Gallican Liturgy, and therefore by implication in the case of the Celtic Liturgy, from S. Ambros. de Sacram. lib. iv. cap. 5. See pp. 109-10.

192 a. Sac. Leon. p. 305 ; Gregor. pp. 100, 182.

193. We have here an example of the 'Deprecatio' of the Celtic Liturgy, in its proper position before the Preface, offered here pro vivis instead of pro defunctis. See p. 106.

194. See note 193. The same word (deprecari) occurs in Prefaces peculiar to the Drummond Missal. 'Et tuam immensam dementiam humiliter deprecari, ut mentibus nostris in beati apostoli,' \&c. (fol. $6_{5}$ b). 'Deprecantes niajestatem tuam ut venturam beati .N. confessoris tui festivitatem,' \&c. (fol. 83 a).

195. I Cor. ii. 9 These words occur in the Great Oblation in the Greek Liturgy of St. James, and in the Preface of that of St. Mark.

196. This collect occurs at the conclusion of an office for the Unction and Communion of the sick in a French thirteenth-century codex in the Library of St. Victor de Paris ; Mart. vol. i. ordo xxii. p. 335 ; Sac. Gelas. p. 553.

197. A similar framework of a collect occurs in Sac. Leon. p. $46 \mathrm{r}$.

198. See p. 167. n. 3 .

199. See note 43 .

200. The rest of fol. 45 a is blank. 


\section{§ 15.-Irish Fragments. Later Irish Missals.}

Three Irish MS. Missals are extant of considerably later date than the Stowe Missal; viz. the Drummond Missal (eleventh century), the property of Lady Willoughby d'Eresby, found at Drummond Castle in Perthshire A.D. 1787; the Corpus Missal (twelfth century), in the Library of Corpus Christi College, Oxford, published by Messrs. Pickering, London, I879 (several coloured photozincograph facsimiles of pages in this Missal are exhibited in the Second Part of the National Manuscripts of Ireland, Dublin, 1878); the Rosslyn Missal (thirteenth or fourteenth century), which once belonged to the Sinclairs of Rosslyn, and is now in the Advocates' Library at Edinburgh.

All these Missals are mainly Roman or Sarum in their structure and contents, and throw no light on the liturgical use of the early Celtic Church, except in the exhibition of various modifications of ritual, the retention of certain Irish and other names of saints ${ }^{1}$, and the use of certain collects, postcommons, \&c. which are not found in other Missals, and the allusions in which are evidently drawn from some purely local source. It would be impossible here to present all these variations in a tabular form ${ }^{2}$. Attention has been drawn to a few of the more important of them, in illustration of points touched upon in the foregoing pages. As a sample of such collects, \&c. we append the Missae for the festivals of St. Bridget and St. Patrick as contained in the Corpus and Rosslyn Missals, calling attention to the evident antiquity of the language. The Roman Missal contains no proper

1 e.g. In the Canon of the Drummond Missal the names of 'Eugenia' and 'Brigita' follow Anastasia. The name of S. Eugenia also appears twice in the Sacramentarium Gallicanum, following that of Lucia within the Canon (Mab. Mus. It. i. 28r), and occurring in the 'Collectio ad Pacem' for Christmas Eve (Ib. p. 289). This service book of the Ephesine family was discovered in the Irish monastery of Bobbio, and thus we may have a slight indication of an original Gallican influence on the Irish Liturgy. See p. 6r.

${ }_{2}$ The collects, \&c. of the Drummond Missal are indexed at the end of G. H. Forbes' edit, of the Sarum Missal. 
Missa for St. Bridget, only a special collect for St. Patrick. The Sarum Missal contains proper Missae both for St. Bridget and St. Patrick, but in neither Missal do any of the following collects occur. There is nothing, however, technically Celtic about them. They are either native compositions on the Roman model, or consist of Gelasian or Gregorian frames with the names of Celtic saints patchworked into them.

\section{Missa Sancte Brigide Uirginis. Kal. Feb. ${ }^{1}$ \\ Oratio.}

Celorum atque terrarum conditor et gubernator, omnipotens deus, precanti populo succurre tua pietate, et presta ut qui in honore sancte brigide presentem dei huius gerimus sollennitatem per ipsius suffragia perhenni misericordia tua potiamur. per.

\section{Secreta.}

Eclesię tuẹ quesumus domine preces et hostias beate brig ide commendet oratio, ut qui pro illius meritis maiestatem tuam indefessa [m] atque exorabilem humiliter imploramus. Cuius precibus adiuti misericordiam tuam sentiamus. per.

\section{Postcommunio.}

Adiuuent nos, quesumus, domine, hec misteria sancta que sumpsimus, et beate uirginis tuae brigitae intercessio ueneranda, per dominum nostrum.

\section{Missa Sancti Patricir Episcopi. xvi. Kal. Ap. ${ }^{2}$ Oratio.}

Deus, qui sanctum patricium scotorum apostolum tua prouidentia elegisti, ut hibernenses gentes in tenebris et in errore gentilitatis errantes ad uerum dei lumen scientie reduceret, et per lauacrum regenerationis filios excelsi dei efficeret, tribue nobis, quesumus, eius piis intercessionibus ut ad ea que recta quantocius festinemus ${ }^{3}$. per.

1 Corpus Missal, fol. I 30 a ; Rosslyn Missal, fol. 80 a.

${ }^{2}$ Corpus Missal, fol. 135 a ; Rosslyn Missal, fol. 87 b.

3 Indications of an eariy date of composition are furnished ( $I$ ) by the equiva- 


\section{Secreta.}

Hostias tibi quas in honore sancti patricii offerimus deuotus accipias, ut nos a timore iudicii liberemur. per.

\section{Postcommunio.}

Omnipotentem deum uniuersitatis auctorem ${ }^{1}$ suppliciter exoramus, ut qui spirituale sacrificium in honorem sancti patricii offerimus fiat nobis remedium sempiternum. per.

\section{§ 16.-Irish Fragments. Paris MS. 2333 A. Colbert.}

The following Missa is written at the close of a life of St. Brendan in a fourteenth-century MS. 2333 A. Colbert. Nat. Libr. Paris. Fol. 147 b. Printed Catalogue, iv. 504.

\section{[Missa in festo Sancti Brendani.]}

\section{Oratio.}

Deus, qui hodiernam diem sacratissimam nobis, beati brendani confessoris tui atque abbatis solempnitate tribuisti, adesto piis ecclesie tue precibus, ut cuius gloriatur meritis muniatur suffragiis. per.

\section{Secreta.}

Sacris altaribus, domine, hostias superpositas beatus brendanus abbas in salutem nobis peruenire deposca[t] dominum nostrum.

lent use of the words 'Scoti' and 'Hibernenses,' which ceased to be convertible terms in the tenth century; (2) the reference to the previous heathenism of Ireland; (3) the oblique mode of the Invocation of Saints which marks the above collects; (4) the description of the Eucharistic offering as 'spirituale sacrificium,' Stowe Missal, p. 237 ; (5) the allusion in the secreta to the ancient tradition found both in the Gaelic hymn of St. Fiacc and the Latin hymn of St. Sechnall, that on the day of judgment the men of Erin will st:und round St. Patrick before the judgment-seat of God (Lib. Hymn., part ii. p. 297 ; part i. p. 22. n. 92). The memoirs of St. Patrick in the Book of Armagh speak of his 'conductio omnium sanctorum Hiberniae in die judicii' (fol. I5, 16). An old Gaelic Life of St. Patrick preserved in the Leabhar Breac asserts that 'though great is St. Patrick's honour still among men, it will be still greater at the meeting of Doom, where he will be like every chief apostle, passing judgment on the men of Ireland unto whom he preached ' (fol. 29 b). It was one of the three requests granted to St. Patrick before his death ' ut Hybernenses omnes in die judicii a te judicentur' (Vit. S. Patric. ii. p. 333, inter Bedae Op., Basil. I563).

1 p. 167. n. 6. 


\section{Postcommunio.}

Protegat nos, domine, cum tui perceptione sacramenti beatus brendanus abbas pro nobis intercedendo, ut conuersacionis eius experiamur insignia, et intercessionis eius experiamur suffragia. per.

\section{§ 17.-Missale Vesontionense.}

This Sacramentary, which is described by Dr. O'Conor at some length as 'Missale Hibernicum Bobiense 1'; and by Dr. Lanigan as 'Cursus Scotorum 2', is a Gallican, not an Irish Missal, and has been printed as such by Mabillon under the title of 'Sacramentarium Gallicanum ${ }^{3}$,' by Muratori ${ }^{4}$, and by G. H. Forbes, with a complete apparatus criticus, under the title of Missale Vesontionense ${ }^{5}$ (=of Besançon). It is a seventhcentury MS. found by Mabillon in the monastery of Bobbio, and believed to have been carried thither by St. Columbanus from Luxeuil. It is now in the National Library at Paris, No. 13246 .

As frequent and confusing allusions have been made to this supposed Irish Missal in the pages of various writers, in recent times ${ }^{6}$, it may be useful to summarise the reasons against an Irish and in favour of its Gallican origin.

(a) The non-Irish character of its handwriting. This can be proved by an inspection of the facsimiles presented by Mabillon ${ }^{7}$ and $\mathrm{O}^{\prime}$ Conor ${ }^{8}$.

I Rerum Hibern. Script. i. cxxx-cxliii.

2 Eccles. Hist. of Ireland, iv. 37 I Dublin, 1829.

Mus. It. i. 273-392.

Lit. Rom. Vet. ii. 766 .

5 Gallican Liturgies, p. 205. See also Dr. Todd's remarks in Transactions of R. I. A. vol. xxiii. p. 26 , ad finem.

6 e.g. Ozanam, Civilization Chretienne, A.D. 1849, p. 100; Bishop Greith, Altirischen Kirche, A.D. 1867, p. 437 ; Dr. Moran, Essay on Early Irish Church, Dublin, 1864, pp. 276-296; Allnatt, C. F. B., Cathedra Petri, Lond. 1879, p. 47 ; Malone, S., Ch. Hist. of Ireland, Dublin, I880, vol. i. ch. 10. These writers appear to have been misled in the first instance by Dr. O'Conor, of whose competence to argue on a liturgical or palaeographical point some specimens have been given, p. 198. n. I.

7 Mus. It. i. 276.

${ }^{8}$ Rer. Hibern. Script. i. p. xxхi. 
(b) The absence throughout of the names of any Irish saints.

(c) The presence of the names of various Gallican saints ; e.g. of St. Hilary and St. Martin in the clause 'Communicantes,' \&c. within the Canon'. There are proper Missae for St. Martin of Tours, 'In depositione Sancti Martini Episcopi ${ }^{2}$;' and for St. Sigismund, King of the Burgundians, 'Missa Sancti Sigismundi Regis ${ }^{3}$.' Sigismund was defeated and murdered by Chlodomir A.D. 523. The commemoration of this king suggested the title of 'Missale Vesontionense' for this Sacramentary.

(d) The use throughout of Gallican terms; e.g. Collectio post nomina, Collectio ad pacem, Contestatio, Benedictio turris ${ }^{4}$.

(e) Certain well-known Gallican features of arrangement; e.g. the Rogation Days are marked for observance before Ascension Day by the provision of Legenda and a Missa in Letaniis. The 'Missa in Adsumptione Sanctae Mariae' is assigned to Jan. 18 (instead of Aug. 15), immediately preceded by the 'Missa in Cathedra Sancti Petri ${ }^{5}$.'

Further forms of devotion not of a technically liturgical character, and in their present shape only very remotely connected with the Celtic Church, survive in a tenth-century Breton Litany, first published by Mabillon ${ }^{6}$ from a Rheims MS., and printed in H. and S., Councils, ii. i. 8I ; and in the sixteenth-century Scottish Litany (Antiquae Litaniae) referred to on p. 166 .

1 Mabillon, Mus. Ital. i. p. 207.

2 Ib. p. 303 .

3 Ib. p. 297.

4 Ib. p. 362 .

${ }^{5}$ It is fair to add that the same arrangement accurs in the Felire of Oengus, Leabhar Breac, p. 8o. In the same 'Félire' St. John and St. James are simultareously commemorated on Dec. 27 (ib. p. 102), a curious association which is also found in the Sacramentarium Gallicanum, p. 226, and the

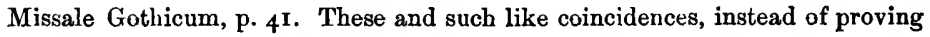
the Irish origin of the Missale Vesontionense, prove how far certain early Irish ecclesiastical documents were affected by Gallican influence.

6 Analect. tom. ii. p. 669 , edit. 1676 . 



\section{N D E X}

\section{Of Collects and other Liturgical Formulae.}

An asterisk (*) prefixed to a Collect, \&c. indicates that it occurs in Roman Office-Books, but with frequent and important variations of text.
æ. $=$ aeternus.
b. $=$ beatus.
D. $=$ Deus.
Dns. $=$ Dominus.
I. $=$ Jesus.
n. $=$ noster.
o. $=$ omnipotens.
p. = pater.
q. = quaesumus.
s. $=$ sanctus.
Xtus, $=$ Christus

Ablis, Zeth, Encc, \&c. [nomina pausantium], 239.

Accepto salutari diuini corporis cibo, 224.

Accipe illud volumen evangelii, 73 .

Accipe, puella, pallium candidum, 23.

*Accipe uestem candidam, sanctam, et, 217.

Ad te, Dne., leuaui animam, I78, 243.

Adferte [Dno. filii Dei, adferte Dno.], 212.

Adiuua me, Dne., et saluus ero, 2 I8.

Adiuuent nos q. Dne. hec misteria, 270.

* Eterne D. qui tuae mensae participes, 176 .

Agimus D. p. o. gratias quod terrene, r70, 224.

Agnosce, Dne., uerba quae precepisti, I 69.

Ante conspectum diuinae maiestatis tue, 239.

Ante oculos tuos, Dne., reus conscientiae, 230.

Ascendat oratio nostra usque ad tronum, 227.

Babtizatus est Dns. aperti sunt coeli et, I 78 .

Beati Theilai confessoris tui atque pontificis, $16_{3}$.

Benedic, Dne., et sanctifica has manus sacerdotis, 70.

Benedic, Dne., hanc creaturam aquae, 220.

Benedicam Dnm. in omni tempore, 243.

Benedicat tibi, Dns. et custodiat te, I 7 I, I 72, 225 .

Benedicite omnia opera Dni. Dnm. hymnum, I 90.

Calicem salutaris accipiam et nomen, $165,170,173,225$.

Calix quem benedicimus sanguis est Dni., $24 \mathrm{I}$.

Canticis spiritualibus delectati hymnos, $193,196$.

${ }^{*}$ Celesti lumine q. Dne. semper et ubique nos, I76.

Celorum atque terrarum conditor et, 270.

Cognouerunt Dnm. in fractione panis, 241. 
Comedite amici mei et inebriamini, $178,243$.

Commixtio corporis et sanguinis Dni. n., 242.

Concede (Dne) nobis famulis tuis ut orantes, $169,223$.

Concede nobis o. et misericors D. ut haec, $\mathbf{1} 60$.

${ }^{*}$ Concede nobis o. D. et misericors ut salutare, 176 .

Confitemini et invocate nomen, 229.

Consecrentur manus istae q. Dne. et sanctificentur, $70,7 \mathrm{I}$.

Conserva, Dne., istius devotae pudorem castitatis, 23.

Conuerte nos D. Ealutum n. et, 170, 224.

Corpus cum sangine Dni. n. I. Xti. sanitas, 164, 173.

Corpus Dui. accepimus et sanguine eius, 191 .

Corpus et sanguis Dni. n. I. Xti. filii D., I 70, 224.

Corpus et sanguinis Dni n. I. Xti. sit sibi, 218.

Creator naturarum omnium D. et parens, I6 4 , 172.

Credimus, Dne,, credimus in hac confractione, $24 \mathrm{I}$.

Credo iu Deum patrem, I 72.

Credo in Deum patrem omnipotentem, 166, 169, 189.

${ }^{*}$ Credo in unum D. p. o. factorem, $23 \mathrm{I}$.

Custodi intra nos, Dne., gloriae tuae munus, 173 .

Da nobis missericordiam tuam q. Dne., 248.

Deprecamur te, Dne., in omni misericordia, 195.

Deum patrem, D. filium D. spiritum S., 244.

Deum uiuum o. cui sua omuia opera, $167,221$.

*Deus in adiutorum nostrum intende, 226.

Deus $[\mathrm{m}]$ in cuius manu tam alitus uiuentis, $\mathbf{6} 68,226$.

Deus, inmensae clementiae atque, 174 .

*Deus o. p. Dni. n. I. Xti. qui te regenerauit, 216.

Deus qui ad salutem hominis medicinam, 208.

*Deus qui ad salutem humani generis, 184, 207, 2 r 1.

Deus qui Adam de limo terrae fecisti, 207.

Deus qui b. confessorem tuum David, r6r.

*Deus, qui b. Petro apostolo tuo conlatis, 227.

*Deus qui confitentium tibi corda purificas, 247.

Deus qui culpa offenderis, penitentia, 228.

*Deus qui diligentibus te bona, 228.

*Deus qui facturam tuam pio semper donaris, I68, 222.

Deus, qui famulantibus tibi mentis, 159.

Deus qui hodiernam diem sacratissimam, $27 \mathbf{I}$.

Deus qui non uis morten peccatoris, 168, 22.

Deus qui nos regendo conseruas, 229.

Deus qui nos s. tuorum beatisimorum, 245 . 
Deus, qui pueris fide ferventibus fornacis, 190.

Deus, qui s. Patricium Scotorum apostolum, 270.

Deus, qui tres pueros de fornace eripuisti, 190.

*Deus qui unigenito tuo notam creaturam, 175 .

Deus, tibi gratias agimus per quem, 165, x71, 173, 219,225 .

Dicamus omnes, Dne., exaudi et, 228 .

Diluculo lucis auctore resurgente exultemus, 193.

*Dirigatur, Dne, [oratio mea], 230.

Dispersit dedit pauperibus, iustitia eius, $\mathbf{1} 3 \mathbf{I}$.

Diuino magisterio edocti et diuina, 169, 177, 242.

Domine D. n. I. Xte. splendor paternae, 244.

Domine, D. o. ego humiliter te, 185 .

Domine D. o. qui s. tuos cum mensura, 245.

Domine, Dne., defende nos a malis et, 196.

Domine sancte p. o. ae. D. expelle diabulum, 207.

*Domine s. p. o. ae. D. qui es et qui eras, 2 Ir.

Domine s. p. o. ae. D. qui es uia et ueritas, 221.

Domine s. p. o. instaurator et conditor, 183 .

*Domine s. p. te fideliter deprecemur, ut, 224.

Domine, s. p., uniuersitatis auctor, 167,221 .

Domini est terra, 243.

Dominicam nostrae resurrectionis initium, 193.

Dominus et saluator noster I. Xtus., pridie, 218.

Dorninus n. I. Xtus. dixit. Ego, 23 I.

Dominus reget me, II 7, 242.

Ecce agnus Dei, 242.

Ecce qui tollis peccata mundi, 242.

Eclesie tue q. Dne. preces et hostias, 270.

Effeta, quod est apertio, effeta est lıostia, 2 ro.

Effundam de spiritu meo super omnem, 179.

Eleemosynas facientibus in hoc mundo, $\mathbf{3} \mathbf{3}$.

Et sacrificent sacrificium laudis et, 165,173 .

Euangelium Dni. n. I. Xti. liberet nos, 196.

*Exaudi, Dne., preces nostras et confitentium, $\mathbf{r}_{52}$.

*Exaudi nos Dne. D. p. o. ae. d. et mittere, 21 I.

Exaudi nos, Dne. I. Xte. d. n. pro fratre, 224.

Exaudi preces nostras, o. D. et presta ut sicut, 190.

*Exorcizo te, creatura aquae, in nomine D., I84, 213.

*Exorcizo te, creatura aquae, per Dnm. uiuum, 2 I 2.

*Exorcizo te, creatura salis, in nomine, 208.

Exorcizo te, spiritus immunde per D. patrem, 220. 
Exultantes gaudio pro reddita nobis, 192.

Exultatio diuina, paterna pietas, immensa, 246.

Exurge, Dne., adiuua nos et redime nos, 195.

Fiat, Dne., misericordia tua super nos, 241 .

Fili D. fecisti mirabilia Dni. cum, 226.

Fornacis flammas pueri contempserunt, 191 .

Fortitudo mea et laus mea Dns., I70, 225, 229.

Fratres, quotiescunque manducabitis, 228.

-*Gloria in excelsis D., et in terra, 193, 196, 227.

Grata sint tibi, Dne., munera quibus, 22.

Grata sit tibi hec oblatio plebis tue, 233.

Gratias tibi agimus Dne. s. p. o. ae. D., I79, 243.

Gustate et uidete quam suauis est, 191, 243 .

Has oblationes et sincera libamina, $23^{2}$.

Hic est panis uiuus qui de coelo, $177,192,243$.

Hoc sacrum corpus Dni. saluatoris sanguinem, $178,192,243$.

Hostias laudis et preces deuotionis quas, $\mathbf{r} 6 \mathbf{r}$.

*Hostias q. Dne., n. deuotionis benignus adsume, $23^{2}$.

Hostias tibi quas in honore S. Patricii, $27 \mathrm{x}$.

Immola Deo sacrificium laudis, 255.

In illis diebus dixit I. Statim hautem, 222.

In illis diebus, dixit I. ad discipulos, 180 .

In illo tempore [die] accesserunt Saducei, I69, 222.

In labis meis meditabor ymnum, $178,192,243$.

In nomine sanctae Trinitatis et unicae, 72.

In tuis tibi Dne. gratias, 175 .

Indulge Dne. penetentibus nobis, 246.

Iniuste egimus, redemisti nos, Dne., 102.

Intende Dne. munera que altaribus tuis, 248.

Iteramus o. D. deprecationem nostram ante, 246.

Iudica me, Dne., quoniam ego, $178,243$.

Laudate, Dnm., omnes gentes, laudate, $\mathbf{6} 65,17$ I, I73, 225.

Libera nos a malo, Dne., Xte. I., et custodies, I 72.

Libera nos, Dne, a malo Dne. Xte. I. custodi, I64.

Libera nos, Dne., ab omni malo, et custodi, r 70, 223.

Libera nos, Dne., ab omni malo preterito, I77, 242.

Lucerna pedibus meis verbum tuum, 218.

Mandasti misericordiam tuam, opus, 218.

*Medellam tuam deprecor, Dne., sancte p. o. ae. D., 209.

Memento . . . cum omnibus in . toto mundo offerentibus, 236 .

Iemento nostri, Dne., in beneplacito, 219. 


\section{Index of Collects Ec.}

Memento ... pro stratu seruorum suorum et, 234.

Mittet Pater, indulgeat Filius, misereatur, $\mathbf{I}_{3} \mathbf{r}$.

Mnndemus conscientias n. ab omni labe uitiorum, 176 .

*Nec te lateat Satanas imminere tibi, 2 ro.

Nos oportet celebrare magni regis in, 178.

Nouum carmen cantate, 242.

O Dne. saluum fac, 2 I 9.

*Oblata Dne. munera sanctifica, nosque, $23^{2}$.

Omnes sancti uenite, 242.

*Omnipotens s. D. adesto magnae, 2 I3.

* Omnipotens s. D. qui de b. corpore s. Thelyai, 162 .

*[Omnipotens s. D. qui humano corpori animam], 183 .

Omnipotens s. D. qui populum tuum, 229.

Omnipotens s. D. virtutum omnium fons et, 162 .

Omnipotentem D. universitatis auctorem, $27 \mathrm{I}$.

Operare, creatura olei, operare in, 216.

Oramus te, Dne., pro fratre n. N. cui, 223.

Oremus et postulemus de Dni. missericordia, 172.

Oremus, fratres carissimi, misericordiam ut euntum, 23.

Oremus, fratres carissimi, pro caris n. N. qui, 248.

Oremus, fratres carissimi, pro fratre n., I 7 I, 2 I 9.

Oremus, fratres carissimi, pro spiritu cari n. N., I 7 I.

Oremus, fratres Dnm. D. n. pro fratre n., $167,220$.

Orent pro nobis sancti illi in coelis, 196.

Ostende nobis, Dne., misericordiam, I 70, 220, $23^{2}$.

Pacem mandasti, pacem dedisti, pacem, 242.

Pacem meam do uobis, pacem relinquo, I77, 242.

Panem coeli dedit eis Dns., panem, 243.

Panis quem frangimus corpus est Dni., 24 I.

Parce, Dne., parce populo tuo quem redemisti, 195.

Parce, Dne., peccantibus ignosce penitentibus, 195.

Pax et caritas Dni. et communicatio, 177.

Pax et caritas Dni. n. I. Xti. et commonicatio, $224,242$.

Pax et caritas Dni. n. I. Xti. sit semper, I 70.

Pax et communicatio sanctorum tuorum Xte. I., I 70.

Pax multa diligentibus legem tuam, Dne., 242.

Pax multa diligentibus pax tua, Dne., 102.

Pax tecum in uitam aeternam, 225.

Peccauimus, Dne., peccauimus, parce, r79, 226.

Peccauimus tibi, Dne., peccauimus, patientiam, 195.

Penitentiam agite, appropinquauit enim, I 78, 242. 
Permaneat ad prudentibus qui virginibus, 23.

Peto te, Pater, deprecor te, filii, 13 I.

Plenum odorem vitae, $24^{2}$.

*Presta q. Dne. dignum poenitentiae fractum, $15^{2}$.

Presta q. o. et misericors D. ut animas, 247.

*Presta ut quos celesti dono satiasti, I79, 243.

*Preueniat hunc famulum tuum ill., I 52 .

Profeta omnes iustitiae nostrae sicut, 226.

Propitiare Dne. D. omni populo Xtiano ex, I59.

Propitius fuisti patribus nostris propitius, 195.

Protegat nos Dne. cum tui perceptione, 272.

Quaerite Dnm. et confirmamini, 229.

Quaeso te, Pater, deprecor te, filii, I3r.

Quam dulcia faucibus meis eloquia, 192.

Quemadmodum uox Dni. insuper aquas, 212.

Quesumus, Due, o. D. ut uota nostra tibi, 23 I.

Quesumus o. D. ut meritis reparati sanctissimi, I63.

Qui manducat corpus meum et bibit, I77, 242.

Qui manducat ex eo uiuet in, $177,243$.

Quia satiauit animam inanem, et, $165,224$.

${ }^{*}$ Quos celesti, Dne., dono satiasti, I79.

Refecti spiritalibus escis, cibo coelesti, 2 r9.

Reffecti Xti corpore et sanguine tibi, I65, I71, I73, 192, 225 .

Regem coeli cum pace, 242.

Regnum coelorum uim patitur et uiolenti, $1_{7} 8,243$.

Remittat Pater, indulgeat Filius, misereatur, $\mathbf{1}_{3} \mathbf{I}$.

Repleti, Dne., participatione sacramenti q. ut, 162.

Resurgentem in hoc diluculo Dnm., 193.

Rogamus te, Dne., sancte p. o. ae. D. miserere, 209.

Rogo te, D., Zabaoth altissime, p. S., uti, 227.

Sacrificate sacrificium iustitiae et sperate, 165, 171, 173, 225 .

* Sacrificiis presentibus Dne. q. intende, 229.

*Sacrificium tibi, Dne., celebrandum, 230.

Sacris altaribus, Dne., hostias superpositas, 271.

Salua nos, Thesu, qui potes saluare, 220.

Sancte Dne. et gloriose mirabilium uirtutum, 190.

Sancti uenite, Christi corpus sumite, 187 .

Sanctus... benedictus qui uenit de coelis ut, 233 .

Seculi saluator Dns. hodie resurrexit, 179.

$\mathrm{Si}$ ego laui pedes uestras, Dus. et magister, 218.

Signaculo crucis Xti. signaris, 225. 
Signum crucis Xti. accipe in manum, 217.

$\mathrm{Si}$ in hac uita tantum in Xto. sperantes, 168.

Simulque precantes oramus etiam, Dne., 106.

Sinite paruulos uenire ad me, et nolite, $\mathbf{1}_{7} 8,243$.

*Sitiuit anima mea [ad D. fortem] uiuum, 2 I 2.

Stola iustitiae circumdet Dns, cervicem, 74.

*Sumpsimus, Dne., s. tuorum sollemnia, 246.

Sumptis Dne. sacramentis in honore s. confessoris, $\mathbf{1} 6 \mathbf{r}$.

*Sursum corda, \&c., 233.

Te decet, Dne., [hymnus] D. in Sion et tibi, 180, 196.

Te enim, o. D., benedicimus iure qui tres, $19 \mathbf{r}$.

*Te igitur, Gelasian Canon, 234.

Tibi igitur precipio, omnis spiritus immunde, $2 \mathbf{2} 2$.

Tres Hebraei uenerabiles numero, sacramento, 191.

Tres pueri in camino missi sunt ut, $\mathbf{1 9 1 .}$

Tres pueri te orabant de medio, $19 \mathrm{I}$.

Tu mandasti mandata tua custodire, 218.

Ubi ego fuero ibi erit et minister, $178,243$.

U. D. cuius promissionis plenus aeternorum, 248 .

[U.] D. et iustum, aequm et iustum et gloriosum est, nos tibi semper gratias agere, 245 .

U. D. et iustum est. Qui ut nos a seruitute, 175 .

U. D. eterne $D$. et te laudare mirabilem, 160 .

U. D. per Dnm. n. I. Xtum. filium tuum cuius, 247.

U. D. per ... qui cum unigenito tuo et Spiritu s., 233.

*Ueni Dne. sanctificator et benedic, $23^{\circ}$.

Uenite benedicti patris mei et, $178,243$.

Uenite comedite panem meum et bibite, 178, 242.

Uere sanctus, uere benedictus, Celtic Canon, 109, 246.

Uisita nos D. in salutari tuo, 218,225 .

Ungo te de oleo sanctificationis in nomine Dei, $\mathbf{I}_{72}$.

Ungo te de oleo sanctificato, in nomine Patris, 209.

Ungo te de oleo sanctificato, ut salueris, 223.

Ungo te oleo et de crismate salutis, 2 I 6.

Ungo te oleo sanctificato in nomine Trinitatis, 169.

Unguatur et consecretur caput tuum, 70 .

Unitas in Trinitate, te, deprecor, 196.

Ut tres pueros in flamma saluasti, r9r. 


\section{N D E X}

\section{OF PASSAGES OF SCRIPTURE.}

\section{PAGE \\ Num.}

vi. $24-26 \ldots \ldots \ldots \ldots \ldots \ldots$ I 7 I, I 72, 225

II REG.

xvi. 24 195

I Par.

xvi. 8-10

229

\section{Psalm.}

vi. 16

$165,171,173,225$

vii. $9 \ldots \ldots \ldots \ldots \ldots \ldots \ldots \ldots \ldots$ I 78,243

xxii. I..................... I 7 7,242

xxiii. I .............................. 243

xxiv. I ..................... I 78,243

xxviii. I, 3 ...................... 212

xxxii, 22 ......................... $24^{I}$

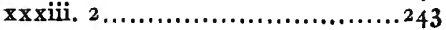

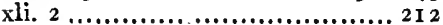

lxv. $2,3 \ldots \ldots \ldots \ldots \ldots \ldots \ldots \ldots \ldots$

Ixxvii. 24, $25 \ldots \ldots \ldots \ldots \ldots \ldots \ldots . . \ldots 243$

Ixxxiv. $5 \ldots \ldots \ldots \ldots \ldots \ldots \ldots$ I 70,220

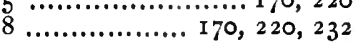

xcv. I..............................242

civ. 4 .............................2 29

cv. $4 \ldots \ldots \ldots \ldots \ldots \ldots \ldots \ldots \ldots \ldots \ldots \ldots \ldots \ldots, 218,25$

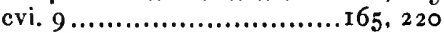

$22 \ldots \ldots \ldots \ldots \ldots \ldots \ldots \ldots$ I65, I 73

cxv. I $3 \ldots \ldots \ldots \ldots \ldots$ I $65,170,173,225$ cxvi................. 165, 17 1, 173, 225

cxvii. 14............. I $71,214,225,229$

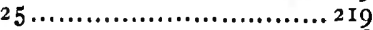

cxviii. 4 ............................ 2 I8

$103 \ldots \ldots \ldots \ldots \ldots \ldots \ldots \ldots 192$

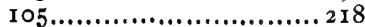

II $7 \ldots \ldots \ldots \ldots \ldots \ldots \ldots \ldots \ldots \ldots \ldots \ldots$

$165 \ldots \ldots \ldots \ldots \ldots \ldots \ldots \ldots \ldots 24^{2}$
PAGE

cxviii. I 7 I ................. 178, 192, 243

cxxxvii. $8 \ldots \ldots \ldots \ldots \ldots \ldots \ldots \ldots \ldots . \ldots . \ldots . \ldots 218$

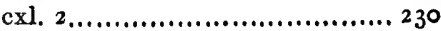

Prov.

ix. 5 178,242

Cant.

v. I ....................... I 78,243

\section{MaTT.}

iii. 2 178,243

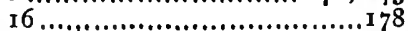
xi. I $2 \ldots \ldots \ldots \ldots \ldots \ldots \ldots \ldots \ldots \ldots$.................. 78,243 xxii. $23-33 \ldots \ldots \ldots \ldots \ldots \ldots$ I69, 222 xxiv. $29-31$...................... 222 xxv. $34 \ldots \ldots \ldots \ldots \ldots \ldots \ldots \ldots$ I 78,243

Luo.

xxiv. $35 \ldots \ldots \ldots \ldots \ldots \ldots \ldots \ldots \ldots . . . \ldots 24$ I

IOAN.

vi. $15 \ldots \ldots \ldots \ldots \ldots \ldots \ldots \ldots 177,192$ $5 \mathrm{I}-57 \ldots \ldots \ldots \ldots \ldots \ldots \ldots \ldots . . . \ldots 23 \mathrm{I}$ $57 \ldots \ldots \ldots \ldots \ldots \ldots \ldots \ldots \ldots \ldots \ldots \ldots \ldots \ldots \ldots, 242$ $59 \ldots \ldots \ldots \ldots \ldots \ldots \ldots$ I7 $, 192,243$

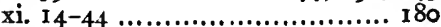
xii. $26 \ldots \ldots \ldots \ldots \ldots \ldots \ldots \ldots \ldots$ 1 78,243 xiii. $14,15 \ldots \ldots \ldots \ldots \ldots \ldots \ldots \ldots . \ldots . \ldots . \ldots 18$ xiv. $27 \ldots \ldots \ldots \ldots \ldots \ldots \ldots \ldots$ I 77,242 AcTa.

ii. $17,18 \ldots \ldots \ldots \ldots \ldots \ldots \ldots \ldots \ldots . \ldots \ldots$ I CoR.

ii. $9 \ldots \ldots \ldots \ldots \ldots \ldots \ldots \ldots \ldots \ldots \ldots \ldots{ }^{2} 47$

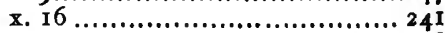
xi. $26-32 \ldots \ldots \ldots \ldots \ldots \ldots \ldots \ldots \ldots \ldots . \ldots . \ldots . \ldots 28$ $x \nabla .19-23 \ldots \ldots \ldots \ldots \ldots \ldots \ldots \ldots \ldots \ldots$ 


\section{GENERAL INDEX.}

A.

Aaron, p. ${ }_{5} 6$.

Aberdeen Breviary, 35, 81, 82, I 16.

Abgarus, 196 .

A blutions, 268.

Adamnan, xiii, 5, 6, 9, 20, 36,60, I $_{4} 8$.

Adamnanus, 150.

Aedh, St., 37, 240.

Aengus $=$ Oengus.

Aghaboe, ${ }^{5}$, $139,45$.

Agilbert, 22.

Agnus Dei, 242, 266.

Agrestius, 96 .

Aidan, bishop, I 7, 24, 26, 1 I 5, 146 .

Aidan, king, 148.

Ailbe, St., 238, 240.

Aileran, 36 , 127.

Ailred, 32, 36 .

Alb, I I 4 .

Albau, St., $122,156$.

Aldermann, 26r.

Aldfrith, 5, 22.

Aldhelm, St., 4, 33, 36, 43 .

Altars, 91 ; of wood, 91 ; of stone, $9^{2}$; in baptisteries, 219.

Amboise, 15 .

Ambrosian Liturgy, see Milanese.

Ambrosii oratio, 239, 249, 262.

Amphibalus, 122.

Anathleticus gradus, $203,238$.

Anegray, 15 .

Anmcara, 146, $147,149$.

Anthems sung during Communion, 110 , $187,191,24^{2}$.

Anthleta, 260.

Antiphonary of Bangor, xiii, 131, 187.

A pologia Sacerdotis, forms of, 185,226 , $227,230,239,250$.

Aran, 15.

Arbedoc, 20.

Arbuthnott Missal, 166.

Archimandrita, 55, 159 .

Architecture, Celtic, 48, 85.

Arculfus, 60 .

Ardbraccan, xix.

Ardoilan, 92.

A riminum, Council of, 27.

Arles, Council of, 29.
Armagb, 10 ; Book of, xiii, 37,173 .

Arnulf, bishop, 20.

Arran, 24.

Asaph, St., 14.

Ascensio, 235 .

Asic, St., 1 I 5 .

Assumption of B.V.M., 273 .

Athanasius, St., 28.

Athelstan, king, 4.

Attala, xvi.

Augmentum, 203, 228, 233, 251, 252.

Augustine, St., of Canterbury, 26, 34, $40,61,62,63,64,26_{3}$.

Augustine's Oak, 29.

Augustini Oratio, 226, 249.

Auxilius, St., 240.

\section{B.}

Bachalmore, the, 117 .

Baithene, St., 18, 19, 141, 142.

Bangor, $15,17$.

Bangor, Antiphonary of, see Antiphonary.

Bangor, Rule of, 18.

Bangor-Deiniol, 14.

Bangor-Garmon, 14.

Bangor-Iscoed, I4, I 7 .

Baoithin, St., 264 .

Baptism, Celtic Ritual of, 64. 204 ; Office of, 207 ; nnction at, 66 ; by a parent, 67 ; in milk, 67 ; validity of, doubted by Archbishop Theodore, 42.

Baresy, 15.

Barrus, St., 262.

Basle, Irish fragments at, 185 .

Beatus, bishop, 59.

Beaulieu, 15.

Bede, anti-Celtic bias of, 33 ; pro-papal bias of, 34 .

Bega, St., 25.

Bells, 92,

Benedicite, the, III, 190.

Benedict XIV, 96 .

Benedict Biscop, 87, 90 .

Benedict, St., Rule of, $12,1_{7}, 1_{4} 6$.

Benedictio aquae, 184, 207, $211,214$.

Benedictio aquae et salis, 183 .

Benedictio Fontis, 205, 2 I 2. 
Benedictio salis, 208.

Benediction, modes of giving, I00; position of, 101 ; forms of, 171,172 , 225.

Beo, St., 264.

Bernard, St., vii, I0, I5, I6, I50.

Besançon, I 5 .

Beuno, St., 75.

Bezieres, 15.

Bible, Celtic version of, $61,180,279$.

Birinus, St., 22.

Birr, 15.

Blaan, St., 24.

Bobbio, 16, 26.

Bodmin, 4.

Boniface IV, 38 .

Boniface, St., II , 45.

Book of Hymns, 194.

Bracelets, I I 7 .

Breac Moedog, I 44 .

Bregenz, 16.

Brendan, St., of Seil, 24 ; of Clonfert, $121,123,141,142,157,238,240$, 271.

Brezille, 15.

Bridget, St., $x, 7,116,135,136,142$, $238,269,270$; church of, 89 ; altar of, 91 .

Brieuc, St., I 5 .

Britona, See of (Bretona), 63, 162 .

Brittany, I I, 47 ; Celtic monasteries in, 15 .

Brooches, I 20.

Buite, St., 240.

Burgh Castle, I4, 25.

Burton-on-Trent, 25.

Bute, 24.

\section{C.}

Cadoc, St., 24.

Cælestine, pope, 30, 32 .

Cælestius, 35 .

Caergybi, 14.

Caerleon, I4, 155 .

Caerworgern, 14.

Cainnech, St., $23^{8}, 24^{\circ}$.

Calceamentum, 122.

Calceus, I 22.

Caldey, I03.

Cambo, II 5.

Cambutta, I 15 .

Campanarius, 93 .

Canice, St., $26 \mathrm{I}$.

Canon, see Celtic, Gelasian, Gregorian, Roman.

Canons, Celtic, xiv, xix.

Canterbury, archbishops of, 200, 240, 263.

Caracalla, 122.

Caraxare, 20.

Carloman, 45.

Carthain, St., 240.
Carthegus, St., 238.

Cashel, ${ }_{4} 8$; Synod of, 1 I.

Cataldus, 26.

Catan, St., 24.

Cathach, 156.

Cathbhuaidh, I 6 .

Catherus, St., 240.

Catuoconus, 103.

Celchyth, Council of, 44 .

Celtic Canon, 108, 109, 246, 268.

Celtic Churcl, extent and duration of, 3 ; monastic character of, 12 ; mis. sionary character of, 24 ; orthodoxy of, 26 ; non-Roman origin of, 35,36 , 37 ; Anglo-Saxon and Roman hostility to, $4 \mathrm{I}-46$; hostility of, to AngloSaxon Church, 43 ; hostility of Continental Church to, 45 ; Eastern origin of, 46 ; Gallican connection, 57 ; Spanish connection of, 62 ; its points of difference from Rome, $6_{3}$; Early Latin or Celtic character of, $155^{-1} 5^{8}$.

Celtic language, Liturgical use of, 157 . See Vernacular.

Celtic Liturgy, documents concerning, 75-81 ; survival of, in England, 3, 77; in Scotland, 9, 81, 82 ; in Ireland, 10.

Celts and Anglo-Saxons, hostility between, 34 .

Central England, Church in, 3.

Ceolfrid, 6s.

Ceollach, 25.

Ceolnoth, arcbbishop, 4 .

Ceracula, 20.

Cerbanus, St., 240.

Chad, St., 22, 29, 43 .

Chalice, Latin and Irish names for, 143 ; of bronze, 133, 143; of glass, 143 ; of silver, I43; of gold, 143 ; of wood, I 43 ; administered by a deacon, I 36 ; uncovering of, $230,232,255$; preparation of, 256 ; mixed, 131,133 , 256.

Chasuble, I I 2.

Charaxare, 20.

Chillenus, 25.

Choral Service, I 25, I 26.

Chrism, see Unction.

Chrismal, 138.

Chrisom, the, in Baptism, 65, 66, 217 .

Christianity, first introduction of into Britain, 57,156 ; Ireland, 30, 35; Scotland, 3 I.

Christianus, bishop, II.

Chrysostom, St., 28.

Churches, of earth, 85 ; of wood, $85-88$; of stone, 86-88; number of, 91 size of, 48, 89; arrangement of, 9 r.

Churchyards, 94 .

Cianan = Kienan. 
Ciannanus, St.. 240.

Ciaran, St., 25, 85, $238,240$.

Circumcision, Festival of, $175,235,259$.

Clausula Paschae, 235.

Clement, 45.

Clonard, 14.

Clonfert, 15.

Clonmacnois, 14.

Clynnog-Fawr, 14.

Coemgen, St., 48, 86, 238, 240.

Cogitosus, xiv, 89 .

Coldingham, I4.

Collectio post nomina, $107,232,233$, 256 ; post Evangelium, 192, 193 , $196,231,256$.

Collects, number of, 96 .

Colman, deacon, 25.

Colman, bishop, 4, 25,56 .

Colman, St., 196, 240.

Cologne, 16.

Colours, use of, 122.

Columba, St., I5, 19, 20, 22, 24, 26, 36,68 , I 16, I 26, I 29, I30, I 33, I40, $I_{4} I, I_{42}, 1_{4} 8,1_{49}$, I $51,1_{56}, 238$, 240 ; Gospels of, 103 ; Rule of, xviii, I 2,17 .

Columbanus, St., 25. 26, 28, 36, 4I, $87,133,135,138,142,143$; quotations from writings of, $28,37,56$; Rule of, xviii, 12, 13, I7, I39.

Columbanus, bishop of Leinster, 106.

Comb, ritual use of, I I 9 .

Comgall, St., I 7, $238,240$.

Commixture, I 77, 242, 266.

Communion, in both kinds, 134,164 , $177,192,267$; of newly-baptized, 206,218 ; of infants, $136,178,243$, 267 ; of the sick, $164,167,171,223$.

Conan, bishop, 4.

Confession, 147 ; its disuse in Ireland, $149,150$.

Confirmation, I 50, 218.

Confractio, 241, 265.

Conlaeth, bishop, 89, 90, 1 I 2, 240, 263.

Consecration, Prayer of, said by several priests jointly, I 28 ; 8ee Celtic Canon, Gelasian Canon.

Consecration by a single bishop, 40, 68,69 .

Consecration of churches, 74 .

Constance, 16.

Constantius of Lyone, 32 .

Continent, Celtic Church on the, II, I $5,16,45$.

Corentin, St., 15.

Cornwall, Church of, $4,43,47,4^{8}$; independence of, 35,36 ; liturgical remains of, 159.

Corpus Missal, 269.

Crassare, craxare, 20.

Crediton, 36.
Creed, forms of, $166,169,172,189,231$.

Cronan, bishop, roI.

Cross, sign of the, 145, 171, 177, 203, $217,225$.

Crowns, I 19 ; suspended over altars, I 20.

Cuanus, St., 240.

Cuculla, 122.

Culdees, 8, 104, 14I, I46, $1_{4}^{8}$; Rule of, xviii.

Cuminius, abbot, $x \nabla, 36,1_{37}, 1_{4} 1,1_{49}$.

Cummian, abbot, 9 .

Cusance, I $5,{ }_{4}$.

Cuthbert, St., 5, 22, 25, 43.

Cyric, St., 1 I 7 .

D.

Dagaeus, St., I9, $21, I_{5}$.

Daganus, bishop, 41, 240.

Damnonia, 43 .

David, St., 24, I17 ; Mass of, I6r.

Declach, St., $2+0$.

Declan, St., $48,240$.

Deer, Book of, 163 .

Dega, St., = Dagaeus.

Deprecatio, 106, 246, 251, 253, 268.

Derbbfraich, St., 85 .

Devon, Church in, 4,43 .

Dicuilus, 26.

Dimma, Book of, 167 .

Diptychs, 105, 256, $257,265$.

Disciplina arcani, 110.

Discus, 143.

Diuma, 25.

Docwinni, 14.

Dogmael, St., 75 .

Dol, 1 I9.

Dominicale, 137 .

Donatus, 26.

Donnan, St., 24, 148.

Dromore, 15.

Drummond Missal, 269.

Dunchad, abbot, 6.

Dunkeld, I 5 .

Dunstan, archbishop, 14.

Duplicating, 143 .

Durrow, 9, 14 ; Book of, 103.

E.

Eadulf, bishop, 35 .

Easter Day, 7. See Pascha, Pascha] Controversy.

Eastern authority claimed for Celtic practices, 56 .

Eastern Influence on Celtic Church, 46 ; architectural evidence for, $4^{8}$; palaeographical evidence, 50 ; liturgical evidence, 54; historical evidence, 55 .

Eastern Liturgies and Ritual, traces of, $100,1_{20}, 137,139,144,145,165$, 
$197,251,252,253,259,260,262$, $263,265,266,267,268$.

Ecclesia primitiva, notices of, in Ireland, 35 ; in Scotland, $8 \mathrm{r}$.

Ecgbert, priest, 6.

Eddius, $34,4^{1}$; his anti-Celtic bias, $4^{2}$.

Edwin, king, 88.

Egbert, 22.

Eig, 24, 148.

Eleutherus, pope, 30, 32 .

Elider, St., 75 .

Eliphius, 35 .

Embolismus, forms of, 99, 164, 169, $172,177,223,242,265$.

Enda, St., $15,240$.

England, first introduction of Christianity into, $3 \circ$; Celtic monasteries in, 14 ; Church in, 3,155 .

Enlli, 14.

Eoghan, St., 240.

Ephesine features of Celtic Liturgy, see Eastern, Gallican, Mozarabic.

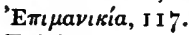

Epiphany, 178. See Stella.

Ercus, St., 240.

Erfurt, 16.

Ermenfried, 140.

Etchain, bishop, 68.

Ettenheimmiunster, 16.

Eucharist, frequency of, I40 ; on Sundays and Saints' Days, 141 ; hours of celebrating, 142. See Thanksgirings.

Eucharius, 35 .

Eugenia, St., 6r, 269.

Eugesius, bishop, 264 .

Eulogiae, I 39.

Eustasius (Eustace), xri, 96.

Evin, St., Xv.

Exedra or Exedriola, 92.

Exorcism, forms of, 207, 208, 210,211 , $212,213,220$.

Extended hands, I 12.

\section{F.}

Factnae, St., 238.

Faenza, 16.

Fan, I 44 .

Faremoutier, 15 .

Faroe Islands, I 1, 26.

Fastidius, bishop, xv.

Fasting, $1_{4} 6$; before the consecration of churches, 75 ; on Wednesday and Friday, 55, 146.

Feachnans, $\mathbf{I}_{4} 8$.

Fechin, St., 92.

Félire of Oengus, $x \mathbf{~}$

Ferdomnach, 173.

Ferghal, aobot, 45 .

Fiacc, St., $x v, 36,37$.

Fiacrius, 25.
Fico, 122.

Fiesole, 16, 26 .

Filioque, omission of, 202, 232.

Fillan, St:, 93.

Finan, bishop, 4, 25, 87 .

Findbar, St., 238, 240.

Finden, St., 133 .

Finnian, St., 17, 141, 194, 238, 26 r. See Vinnian.

Flabellum $=$ fan .

Flacius (M.) Illyricus, see Missa.

Foillanus, 25.

Fontaines, 15.

Fontenelles, I 5 .

Fonts, size of, 64 .

Fortunatus, 28.

Fraction, 109, 203, 265.

France, Celtic monasteries in, 15 .

Freyburg, 16.

Fridolin, St., 25.

Frugdual, St., I 5 .

Furseus, St., 22, 25.

G.

Gall, St., I6, 22, 25, 26, 95, I 42, 143.

Gallican Church, Oriental origin and character of, 58 ; intercourse with British, 58-62.

Gallican Liturgy and Ritnal, traces of, 61, 97, 101, 106, 109, I I I, 117,123 , $125,137,143,144,145,147,159$, $163,164,165,167,168,169,170$, $171,173,177,184,190,211,216$, $217,218,219,220,221,224,251$, $255,256,257,258,259,260,264$, $265,266,267,268,269,272,273$.

Gallican Psalter, 60.

Gallicia, 1 I, 24.

Gallicum opus, 88 .

Gaul, commercial intercourse of, with Britain, 59.

Gelasian Canon, 202, 234.

Geraint $=$ Geruntius .

Germanus, St., 27, 32, 60, 127,157 , 160.

Germany, Celtic monasteries in, 16 .

Geruntius, 43.

Gildas, St., Xv, I3, I 5, 24, 36, I I I, I $12, I_{23}, I_{25}, I_{3} 1, I_{47}, 1_{57}, 240$.

Gillebert, bishop, Io.

Giraldus Cambrensis, 35, 117 .

Glaisnaoidhen, 15 .

Glasgow, 9.

Glastonbury, 14, 87 .

Glendalough, 48 .

Gloria in Excelsis, 193, 196, 227, 250.

Gloria Patri, I65, I 73 .

Gobban, St., 86.

Gospel, at end of Mass, 268 ; collects after, 192, 193, 196, 231, 256. 
Graphium, 20.

Great St. Martin's, I6.

Greek cross, $47,48,50$.

Greek language, liturgical use of, 157 .

Gregorian Canon, I 74, 260.

Gregory, St., of Tours, 6o, II 5 .

Gregory I, pope, 26, 27, 40, 6r, 62, 160.

Gregory III, pope, 45 .

Gueldres, I6.

Gundleius, St., 87.

Guorthernus $=$ Vortigern .

Gwnnws, 102.

Gwynllyw, St. $=$ Gundleius.

\section{H.}

Hautmont, 16.

Hautvillers, I5.

Hentland-on-the-Wye, I4.

Herbert, bishop, 9.

Hii = Iona, q, v.

Hilary, St., 27, 59, 60, 273.

Hohenaug, I6.

Honorius, pope, 9.

Hymns sung during Communion, 1 ro, 187.

\section{I.}

Ibar, St., 240, 263.

Iceland, I I, 26.

Immersion, 216 ; single, 64 .

Imperatores, 254 .

Incense, 127.

Incest, I 5 I.

Inchcolm, I5.

Infants, Communion of, see Communion.

Inismacsaint, 15 .

Inismurray, 92.

Innocent II, IO.

Intinction, 164, I 70, 173, 192, 224.

Introductions to Pater Noster, 164,169 , $172,177,223,242$.

Inverdaoile, 41 .

Invocation, triple, in Baptism, 66 .

Iona, $5,6,15,24,103,122,128,1_{34}$, $140,143,145,146$.

Ireland, first introduction of Christianity into, 30, 35 ; monasteries in, 14.

Ireland, North, Church of, 9 .

Ireland, South, Church of, 9 .

Irish churches, smallness of, 48,49 ; number of, 48 .

Irish Missals lost, 175 ; later Missals, 269.

Iserninus, St., 240.

Islay, 24 .

Ita, St., $23^{8}$.

Italy, Celtic monasteries in, 16.
J.

Jerome, St., 28.

Jerusalem, $3^{6}, 3^{8}$.

John and James, SS., Festival of, 273.

Jonas, xvi.

Jonaire, I 5 .

Julius, 156.

Jumièges, 15 .

Justus, 240.

K.

Kalendae, 203, 235, 259.

Keby, St., 60 .

Kells, I5 ; Synod of, ro.

Kenen = Kienan.

Kenneth, St., I 39.

Kenstec, bishop, 4 .

Kentigern, St., 68, $87,1 \times 5$.

Kenulf, 44.

Kevin, St. = Coemgen.

Kienan, St., 88.

Kieran, St, 59, 144, 261 .

Kildare, 14, I35, I42.

Kilian, St., 25, 26.

Kirkmaiden, 88.

Kirriemuir, I13.

Kiss of Peace, see Pax.

Knife, $1_{44}$.

Kremsmünster, I 3 .

L.

Labarum, the, 48 .

Lactenus, St., 238.

Lagny, $15,25$.

Lastingham, I4.

Latin character of first Church in Britain, 155 .

Latin Liturgy, early use of, 156.

Laurentius, archbishop, 40, 4I, 158 , $240,263$.

Lavabo, the, I33.

Leabhar Breac, xvi.

Lections, 98.

Lent, 7,146 .

Leo I, pope, 30 .

Leofric Missal, 35, 164, 168, 207, 253 , 258.

Lewis, 24.

Liber Hymnornm, see Book of Hymns.

Liber vitae, 203, 233, 257.

Liege, 16.

Limerick, 10.

Lindisfarne, I 2, 14.

Lismore, I I, 24 .

Litany (Missal), I 79, 229, 249, 252.

Liudhard, bishop, 6r.

Llanaledh, I60.

Llancarvan, 14.

Llandabarn-fawr, 14, 116.

Llanelwy, $\mathbf{I}_{4}$. 
Llanfair, I 28.

Llangwynodd, 93.

Llan-Iltut, I 4 .

London, I 55 .

Lord's Prayer the, see Pater Noster.

Lothra, 198.

Louis le Débonnaire, I 2.

Luan, St., I 5, 262.

Lucca, 16.

Lucius, 3o, $3^{2}$.

Luglimagh, 18.

Lugidus, St., $23^{8}$.

Lupiae, 26.

Lupus, St., 27, 32, 6o, 127.

Lure, I 5.

Luxeuil, I 5, 25, 96.

M.

Maccaldus, 24.

Mac Regol, Book of, Io3.

Madianus, $180,226,240,249,263$.

Madoc, 24.

Mael = Moel.

Maelbrighte, 16 .

Maelruain, St., xviii.

Maelrubha, St., 24.

Magloire, St., I5.

Magnoaldus, 95 .

Maic, St., 240.

Mail, St., 240.

Mailduf, 25.

Mailoc, bishop, 62 .

Mailros, I 4.

Malachy, st., Io, 86, I 5 O.

Malcolm III, king, $7,8,9$.

Malmesbury, I 4, 25.

Malo, St., I 5 .

Man, 24.

Manacus, St., 75 .

Mauchan, St., 117.

Maniple, I I 4 .

Mansuetus, bisbop of Toul, 35, 59 .

Mansuetus, a Breton bishop, 59.

Maoinenn, St., 240.

Margaret, queen, $6,7,8,9$, I 55 .

Marianus Scotus, I6.

Marriage, I 50.

Married clergy, notices of, I 3 .

Martin, St., 59, 60, 107, $240,273$.

Martini deprecatio, 229.

Martyrologies, Irish, xvi.

Matthew, St., collect for, I 74 .

Maucteus, 37 .

Maur-les-Fosses, St., I 5 .

Mawnanus, St., 75 .

Mawr, 14.

Meaux, 25.

Medan, St., 88.

Meildulfus, 25.

$\mathrm{M}$ el $=$ Moel.
Mellitus, 4I, 240.

Melrose, I4.

Memmingen, I6.

Mentz, I6, 45 .

Meran, St., 75 .

Methodius, 56 .

Aetopius, bishop, $6_{3}$.

Mida, St., 263.

Milanese Liturgy, traces of, 220,252 , $254,258,265,267,260$.

Missa, Missal, meaning of, I43.

Missa a M. Flacio Illyrico elita, 113 , I $87,203,249,250,255,256,257$.

Missa A postolorum, etc., 244 .

Missa de Infirmis, $164,167,171,223$.

Missa Dedicationis, 259 .

Missa pro mortuis, 247.

Missa pro poenitentibus, 246.

Missale Vesontionense, 272.

Mitre, I 20.

Mixed Chalice, I 3 I, I 33, 256.

Mochaoi, St., 86.

Mochonna, St., $23^{8 .}$

Mochta, St., I 8, $24^{\circ}$.

Modwenna, St., 25.

Moel Caich, 199, 243, 267.

Moel, St., 92 .

Mogue, St., 93.

Molaise, St., 24, 92, 116.

Mollagga, St., 48 .

Moloch, St. (Molocus), 94, I 17.

Molua, St., 48, 262.

Moluoc, St., 24 .

Monasteries, list of Celtic, I4 ; size of, I 6 ; structure of, $\mathrm{I} 7$.

Monastic character of Celtic Church, I 2 ; Rule, I 8,54 ; its severity, 55 ; see Columba, Columbanus, Culdees.

Monenna, St., 85 .

Monks, occupation of, 18.

Mont St. Victor, 16.

Moutier-en-Der, I5.

Moutier-la-Celle, I5.

Moville, $\mathbf{I}_{5}$.

Mozarabic Liturgy and Ritual, traces of, 53,97 , IOI, $111,16_{3}, 16_{4}, 16_{5}$, I $68,169,189,190,218,22 \mathrm{I}, 25 \mathrm{I}$, $252,255,256,258,260,264,265$, $266,267,268$.

Mugint, St., I94.

Muirchu Maccumactheni, 37.

Mull, 24.

Mulling, St., 86, I23, I7 1.

Mullucc, 25.

N.

Namur, 16.

Natale Domini, I 78, 235.

Natalis Calicis, 198, 203, 235, 259.

Nectan, 6, 68, 87. 
Nessan, St., 238.

Netherlands, the, Celtic monasteries in, I6.

Nice, Council of, 29.

Nicene Creed, 231, 256.

Ninian, St., 31, 32, 36, 60, 86.

Nisse, St., 240.

Nonnus, 55 .

North Wales, Church of, 4 .

Northumberland, Church of, 4,5 .

Nüremburg, 16 .

\section{O.}

Oblations, I 30 ; ritual usage of, 131 .

Oengus, St., 240.

Offertory, I $3 \circ$.

Officium defunctorum, 180, 247.

Oghams, 19, 104.

Oratio, see Collectio.

Ordinal, the Celtic, 68 ; lections in, 69.

Ordination (Celtic), validity of, doubted by Theodore, 68 .

Organs, I 26.

Oriental, see Eastern.

Oronsay, 24.

Osmund, bishop, 9 .

Oswald, king, 4.

Oswy, king, $4^{2}$.

P.

Padarn, St., I 6 .

Palaeography, Celtic style of, 50, $5 \mathrm{r}$.

Palla, I 23.

Palladius, 30, 31, 32, 81.

Pallium, I 22.

Panis benedictns, I39.

Paparo, Johannes, I I.

Paracaraximus, 55.

Pascha, I 79, 235.

Paschal controversy, the, $4,5,6,56$, $60,63,64$.

Pastoral staff, I 5 .

Paten, 143, 256.

Pater Noster, 98, 164, 169, 172,177 , $189,223,242$.

Patriarchs, names of, 239, 262.

Patrick, St., xvii, 7, I 3, I 7, $18,36,37$, 60,92 , I $30,134,143,161,162$, $238,240,265,266,269,270,27 \mathrm{I}$.

Pausare, 240, 264.

Pax, the, I02, 170, I77, $224,242,266$.

Paximacium, 55 .

Pectoral cross, II 5 .

Pedilavium, 66, 203, 2 I 7.

Pelagius, 27.

Penkivel, 92.

Pentecost, I 79, 235.

Peristethion, II 4 .

Peronne, 15, 25.
Perranzabuloe, 92.

Phoenicians, 47 .

Pilgrimages, of Celtic saints, $36,5^{6}$.

Piran, St., 25, 92.

Plasma, I68, 22 I.

Poenitentiae Ordo, I5I.

Poenitentialia Celtica, xrii.

Poitiers, 25.

Polaires, 54, 1 I 5 .

Position of the priest at the altar, III.

Pothinua, bishop, $5^{8}$.

Prayer for the departed, IO2; in inscriptions, 103 ; in MSS., IO3; in the Liturgy, I05, I80, 237,239 , 247-248.

Prayer to the departed, IOS, I80, 226. 238.

Prefaces, 99, $167,175,233,245,247$, 248, 257.

Probus, 37.

Prosper of Aquitaine, 30; pro-papal bias of, 32,33 .

Pugillaria, 20.

Purple, nse of, 123.

Q.

Quartodecimani, 42.

Queranus, St., 26 r.

Quinquagensima, 203, 235, 259

R.

Raasay, 24.

Rationale, II 3 .

Rebais, I5.

Rede Boke of Darbye, $25^{6}$.

Regensburg, I6.

Reichenan, I6.

Relics, 233, 257.

Remiremont, 15 .

Renunciation, baptismal, 209.

Reservation, 138.

Reuil, 15 .

Rheinau, 16.

Ring, 114 .

Ripon, 14.

Rogation Days, I46, 273.

Romain-Moutier, 15.

Roman Canon, $174,204,234$; date of introduction into Ireland, 10, 204; see Gelasian, Gregorian.

Roman inflnence, spread of, in Ireland, I58.

Roman Liturgy, date of introduction into Ireland, I 58.

Romanense opus, 88.

Romanus Ordo, Ecclesia, \&c., 159, 202, 250.

Rosslyn Missal, 269.

Ronnd Towers, 93 . 
Ruadhan, St., 198, $23^{8}$.

Ruen, St., 240.

Rules, monastic, xviii.

\section{S.}

Sacorfaicc $=$ Sacrificium .

Sacramentarium Gallicanum, see Missale Vesontionense.

Sacrificium, 95, I3I, I64; spirituale, $203,237,260,271$.

St. Bees, $14,25$.

St. Gall, I6 ; Irish fragments at, I 51 , I 74, I 79, I80, 182, 183 .

St. Germans, I 60 .

St. Maur-les-Fosses, I 5 .

St. Saens, 15 .

St. Salaberga, 15.

St. Ursanne, 15.

St. Vigeans, 122.

Sambuca, II5.

Samdina, St., 239.

Sampson, St., I 5, I 19.

Sandals, 122.

Sardica, Council of, 29.

Sarum Use, 7, I01, 1 25, 266, 267 ; introduced into Scotland, 9; into Ireland, I I.

Scetha, St., 238.

Schuttern, 16.

Scilly islands, 62 .

Scoticum opus, 85 .

Scotland, first introduction of Christianity into, 31 ; Church in, $5,47,81$; monasteries, 15 ; Liturgy of, 163 .

Screens, 9I.

Scribe, office of, I8.

Sechnall, St., 36, 37, 240, 263; Hymn of, xviii.

Seckingen, I6, 25.

Secundinus $=$ Sechnall.

Sedulius (I), bishop, 5 .

Sedulius (2), viii, 35 .

Segine, abbot, 9 .

Seil, 24.

Senan, St., 240.

Senchus Mor, xviii.

Senior, 203, 234, 237, 260, 261 .

Senora, 261.

Serf, St., 81, 82, I 16.

Sermons, 99, 157 .

Serpent, the, in illumination and carving, 52 ; ritual use of, 53 .

Severus, bishop, 27.

Sidonius, 45 .

Sigismund, St., 273.

Sign of the cross, see Cross.

Sinecha, St., 239.

Siricius, pope, 32 .

Skye, 24 .

Soignes, 46.

Soiscel Molaise, I 14, 116.
Somerset, Church in, 4.

Song of the Three Children, see Benedicite.

Sonum, I3I.

Soroby, I5.

South Wales, Church of, 4 .

Spain, 11, 24, 62.

Spoons, use of, 66, I33-134.

Stella, 203, 235, 259.

Stimulus, 20.

Stole, presentation of, at ordination, 72 .

Stowe Missal, 198.

Strasbourg, I5, 25.

Strathclyde, Church in, 5 .

Suibhne, abbot, 6 .

Switzerland, Celtic monasteries in, I6.

\section{T.}

Tabulae, 20.

Tallaght, xvii, xviii.

Tara, Synod of, 9 .

Taranto, I6, 26.

Teilo, St., I5; Mass of, 162.

Temple Molaga, $9^{2}$.

Ternan, St., 94 .

Thanksgivings, Eucharistic, I 65, I 70 , I $73,179,2$ 19, 224, 225, 243.

Theliau $=$ Teilo .

Theodore, archbishop, 29, 42, 43, 68 .

Tigernich, 240.

Tirechan, 37 .

Tiree, 24 .

Tirrdaglas, 15.

Titles of the Liturgy, 94 .

Toledo IV, Council of, I I.

Tonsure (Celtic), $4,6,63$; various forms of, 67 ; controversy about, 68 .

Totman, 25.

Toul, 15.

Transitorium, III.

Trecanum, III.

Tunica, 122.

Tygwyn-ar-Daf, $\mathbf{I}_{4}$.

U.

Uinnian, St. (=Finnian, q.v.), xiii, 240.

Ultan, bishop, xix.

Ultanus, 25.

Unction, $212,216,223$; forms of, 145 , 169,172 ; of hands at ordination, 70 ; omission of and use of in Ireland, 65,66 .

Universitatis Auctor, 22 I.

Unleavened bread, use of, 131 ; traces of, 132 .

V.

Vernacular Liturgy, no proof of a, 155 ; traces of, 7,8 .

Vestments, II 2 . 


\section{General Index.}

Vestry, 92.

Viaticum, 95, 135.

Victricius, bishop, 27, 59 .

Vigilius, pope, 38 .

Vinnian, St. = Uinnian, q. $\nabla$.

Virgilius, 26,45 .

Visitatio Informorum, I82, 220.

Vitalian, pope, 42.

Vortigern, 160.

W.

Wafers, see Unleavened bread.

Wales, Celtic monasteries in, I4.

Wales, Church in, 4, I4.

Wales and Brittany, connection between, 59 .

Water, Eucharistic use of, I 3 I, I 33 .

Wednesday and Friday, 55, 146.

Welsh Fragments, 161-3.

Whitby, $\mathrm{I}_{4}$; Synod of, 4, 25, 29, 56.

White, use of, 124.

Wilfrid, St., 28, 4I, $5^{6}$; his dislike of the Celtic Church, 4I-42.
Willibrord, 22.

Winfrid $=$ Boniface.

Wini, bishop, 29, 42, 43, 68 .

Women ordered to receive under a veil, 136 ; not to approach the altar or touch the chalice, 137 .

Writing, origin of, 19; mode of, 20.

Wulfhelm, archbishop, 4 .

Wulfred, archbishop, 44 .

Würtzburg, 16.

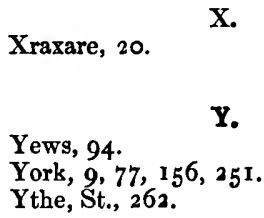

$\mathbf{X}$.

Xraxare, 20.

$\mathbf{Y}$

Yews, 94.

York, 9, 77, 156, 251 .

Ythe, St., 262.

Z.

Zachary, pope, 45 .

E R R A T A.

Page 158, note 4, for 239 read 240

Page 168, note $\mathrm{I}$, line 5, for $220 \mathrm{read} 22 \mathrm{I}$

Page 199, lines 28, 29, omit old- 

March, i887.

\section{Clarenoon 羽ress, (Bxford}

A SELECTION OF

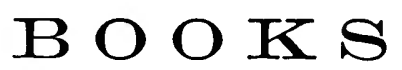

PUBLISHED FOR THE UNIVERSITY BY

HENRY FROWDE,

AT THE OXFORD UNIVERSITY PRESS WAREHOUSE,

AMEN CORNER, LONDON.

ALSO TO BE HAD AT THE

CLARENDON PRESS DEPOSITORY, OXFORD.

[Every book is bound in cloth, unless otherwise described.]

LEXICONS, GRAMMARS, ORIENTAL WORKS, \&c.

Anglo-Saxon.-An Anglo-Saxon Dictionary, based on the MS. Collections of the late Joseph Bosworth, D.D., Professor of Anglo-Saxon, Oxford. Edited and enlarged by Prof. T. N. Toller, M.A. (To be completed in four parts.) Parts I and II. A-HWISTLIAN. 4to. I 5 s. each.

Chinese. $-A$ Handbook of the Chinese Language: By James Summers. $186_{3}$. $8 \mathrm{vo}$. half bound, $\mathrm{r} l .8 s$.

A Record of Buddhistic Kingdoms, by the Chinese Monk FÂ-HIEN. Translated and annotated by James Legge, M.A., LL.D. Crown 4to. cloth back, ros. $6 d$.

English.-A New English Dictionary, on Historical Principles: founded mainly on the materials collected by the Philological Society. Edited by James A. H. Murray, LL.D., with the assistance of many Scholars and men of Science. Part I. A-ANT. Part II. ANT-BATTEN. Imperial 4to. I 2s. $6 d$. each.

An Etymological Dictionar"y of the English Language. By W. W. Skeat, M.A. Second Editim. 1884. 4to. 2l. 4 s.

Supplement to the First Edition of the above. 4to. 2s. $6 d$.

A Concise Etymological Dictionary of the English Lan3uage. By W. W. Skeat, M.A. Second Edition. I885. Crown 8vo. 5s. 6d. [9] 
GREEK.-A Greek-English Lexicon, by Henry George Liddell, D.D., and Robert Scott, D.D. Seventh Edition, Revised and Augmented throughont. 1883. 4to. 1 $l$. $16 s$.

A Greek-English Lexicon, abridged from Liddell and Scott's 4 to. edition, chiefly for the use of Schools. Twenty-first Edition. 1884. Square $12 \mathrm{mo}$. 7s. $6 \mathrm{~d}$.

- A copious Greek-English Vocabulary, compiled from the best authorities. I $\$$, o. 24mo. $3^{s}$.

- A Practical Introduction to Greek Accentuation, by $\mathrm{H}$. W. Chandler, M.A. Second Edition. I 881. Svo. Ios. $6 d$.

HEBREW.-The Book of Hebrere Roots, by Abu 'l-Walîd Marwân ibn Janâh, otherwise called Rabbî Yônâh. Now first edited, with an Appendix, by Ad. Neubauer. I875. 4 to. $2 l .7 s .6 d$.

A Treatise on the use of the Tenses in Hebrez. By S. R. Driver, D.D. Second Edition. I881. Extra fcap. 8vo. 7s. $6 d$.

Hebrew Accentuation of Psalms, Proverbs, and $\mathcal{F} o b$. By William Wickes, D.D. I881. Demy 8vo. stiff covers, $5^{s}$.

ICELANDIC.-An Icelandic-English Dictionary, based on the MS. collections of the late Richard Cleasby.. Enlarged and completed by G. Vigfússon, M.A. With an Introduction, and Life of Richard Cleasby, by G. Webbe Dasent, D.C.L. 1874. 4to. $3 l .7 s$.

- A List of English Words the Etymology of which is illustrated by comparison with Icelandic. Prepared in the form of an APPENDIX to the above. By W. W. Skeat, M.A. 1876. stitched, $2 s$.

- An Icelandic Primer, with Grammar, Notes, and Glossary. By Henry Sweet, M.A. Extra fcap. 8vo. 3s. 6d.

An Icelandic Prose Reader, with Notes, Grammar and Glossary, by Dr. Gudbrand Vigfússon and F. York Powell, M.A. 1879 . Extra fcap. 8vo. 1 os. $6 d$.

Latin.-A Latin Dictionary, founded on Andrews' edition of Freund's Latin Dictionary, revised, enlarged, and in great part rewritten by Charlton T. Lewis, Ph.D., and Charles Short, LL.D. 1879. $4^{\text {to. }} 1$ l. $5^{s}$.

MELANESIAN.-The Melanesian Languages. By R. H. Codrington, D.D., of the Melanesian Mission. 8vo. I 8 s.

SANSKRIT.-A Practical Grammar of the Sanskrit Language, arranged with reference to the Classical Languages of Europe, for the use of English Students, by Sir M. Monier-Williams, M.A. Fourth Edition. 8vo. $15 s$.

- A Sanskrit-English Dictionary, Etymologically and Philologically arranged, with special reference to Greek, Iatin, German, AngloSaxon, English, and other cognate Indo-European Languages. By Sir M. Monier-Williams, M.A. 1872. $4^{\text {to. }} 4 l .14 s .6 d$. 
SANSKRIT.-Nalopákhyánam. Story of Nala, an Episode of the Mahá-Bhárata: the Sanskrit text, with a copious Vocabulary, and an improved version of Dean Milman's Translation, by Sir M. Monier-Williams, M.A. Second Edition, Revised and Improved. 1879. 8vo. I5s.

Sakuntalā. A Sanskrit Drama, in Seven Acts. Edited by Sir M. Monier-Williams, M.A. Second Edition, 1876. 8vo. 21 s.

SYRIAC.-Thesaurus Syriacus : collegerunt Quatremère, Bernstein, Lorsbach, Arnoldi, Agrell, Field, Roediger: edidit R. Payne Smith, S.T.P. Fasc. I-VI. 1 868-83. sm. fol. each, rl. rs. Fasc. VII. rl. 11s. $6 d$.

Vol. I, containing Fasc. I-V, sm. fol. 5 l. $5^{\text {s. }}$

- The Book of Kalizlah and Dimnah. Translated from Arabic into Syriac. Edited by W. Wright, LL.D. I884. 8vo. 2 Is.

\section{GREEK CLASSICS, \&c.}

Aristophanes: A Complete Concordance to the Comedies and Fragments. By Henry Dunbar, M.D. 4to. Il. Is.

Aristotle: The Politics, with Introduction, Notes, etc., by W. L. Newman, M.A., Fellow of Balliol College, Oxford. Vols. I. and II. Nearly ready.

Aristotle: The Politics, translated into English, with Introdnction, Marginal Analysis, Notes, and Indices, by B. Jowett, M.A. Medium 8 vo. 2 vols. 21 s.

Catalogus Codicum Graecorum Sinaiticorum. Scripsit V. Gardthausen Lipsiensis. With six pages of Facsimiles. 8vo. linen, 25 s.

Heracliti Ephesii Reliquiae. Recensuit I. Bywater, M.A. Appendicis loco additae sunt Diogenis Laertii Vita Heracliti, Particulae Hippocratei De Diaeta Libri Primi, Epistolae Heracliteae. 1877. 8vo.6s.

Herculanensium Voluminum Partes II. 1824. 8vo. Ios.

Fragmenta Herculanensia. A Descriptive Catalogue of the Oxford copies of the Herculanean Rolls, together with the texts of several papyri, accompanied by facsimiles. Edited by Walter Scott, M.A., Fellow of Merton College, Oxford. Royal 8vo. cloth, 2Is.

Homer: A Complete Concordance to the Odyssey and Hymns of Homer; to which is added a Concordance to the Parallel Passages in the Iliad, Odyssey, and Hymns. By Henry Dunbar, M.D. 1880. 4to. Il. Is.

Scholia Graeca in Iliadem. Edited by Professor W. Dindorf, after a new collation of the Venetian MSS. by D. B. Monro, M.A., Provost of Oriel College. 4 vols. 8vo. 2l. ros. Vols. V and VI. In the Press.

- Scholia Graeca in Odysseam. Edidit Guil. Dindorfius. Tomi II. 1855. 8 vo. I 5 s. 6 d. 
Plato: Apology, with a revised Text and English Notes, and a Digest of Platonic Idioms, by James Riddell, M.A. 1878. 8vo. 8s. $6 d$.

Philebus, with a revised Text and English Notes, by Edward Poste, M.A. 1860. 8vo. 7s. 6d.

Sophistes and Politicus, with a revised Text and English Notes, by L. Campbell, M.A. I867. 8vo. $18 s$.

- Theaetetus, with a revised Text and English Notes. by L. Campbell, M.A. Second Edition. 8vo. Ios. $6 d$.

The Dialogues, translated into English, with Analyses and Introductions, by B. Jowett, M.A. A new Edition in 5 volumes, medium 8vo. 1875 . 3l. Ios.

The Republic, translated into English, with an Analysis and Introduction, by B. Jowett, M.A. Medium 8vo. I2s. $6 d$.

Thucydides: Translated into English, with Introduction, Marginal Analysis, Notes, and Indices. By B. Jowett, M.A. 2 vols. 1881. Medium 8vo. Il. I2s.

\section{THE HOLY SCRIPTURES, \&c.}

Studia Brblica.-Essays in Biblical Archæology and Criticism, and kindred snbjects. By Members of the University of Oxford. 8vo. เos. $6 d$.

ENGLISH.-The Holy Bible in the earliest English Versions, made from the Latin Vulgate by John $W$ ycliffe and his followers: edited by the Rev.J. Forshall and Sir F. Madden. 4 vols. 1850 . Royal 4 to. $3 l \cdot 3 s$.

[Also reprinted from the above, with Introduction and Glossary

by W. W. Skeat, M.A.

- The Books of Fob, Psalms, Proverbs, Ecclesiastes, and the Song of Solomon: according to the Wycliffite Version made by Nicholas de Hereford, abont A.D. I3SI, and Revised by John Pnrvey, abont A.D. I388. Extra fcap. 8vo. $3 s .6 d$.

The New Testament in English, according to the Version by John Wycliffe, about A.D. I380, and Revised by John Parrey, about A.D. 1388. Extra fcap. 8vo $6 s$.] 
ENGLISH.-The Holy Bible: an exact reprint, page for page, of the Authorised Version published in the year 16I1. Demy 4 to. half bound, Il. Is.

The Psalter, or Psalms of David, and certain Canticles, with a Translation and Exposition in English, by Richard Rolle of Hampole. Edited by H. R. Bramley, M.A., Fellow of S. M. Magdalen College, Oxford. With an Introduction and Glossary. Demy 8vo. 1 l. Is.

Lectures on Ecclesiastes. Delivered in Westminster Abbey by the Very Rev. George Granville Bradley, D.D., Dean of Westminster. Crown 8vo. $4 s .6 d$.

GotHIC.-The Gospel of St. Mark in Gothic, according to the translation made by Wnlfila in the Fourth Century. Edited with a Grammatical Introduction and Glossarial Index by W. W. Skeat, M.A. Extra fcap. 8vo. $4 s$.

GREEK.-Vetus Testamentum ex Versione Septuaginta Interpretum secundum exemplar Vaticanum Romae editum. Accedit potior varietas Codicis Alexandrini. Tomi III. Editio Altera. I8mo. I8s.

Origenis Hexaplorum quae supersunt; sive, Veterum Interpretum Graecorum in totum Vetus Testamentum Fragmenta. Edidit Fridericus Field, A.M. 2 vols. $1875 \cdot 4^{\text {to. }} 5^{l \cdot} \cdot 5^{s}$.

The Book of Wisdom: the Greek Text, the Latin Vulgate, and the Authorised English Version; with an Introduction, Critical Apparatus, and a Commentary. By William J. Deane, M.A. Small 4to. I $2 s .6 d$.

Novum Testamentum Graece. Antiquissimorum Codicum Textus in ordine parallelo dispositi. Accedit collatio Codicis Sinaitici. Edidit E. H. Hansell, S.T. B. Tomi 1II. 1864. 8vo. half morocco. Price reduced to $24 s$.

Novum Testamentum Graece. Accedunt parallela S. Scripturae loca, etc. Edidit Carolus Lloyd, S.T.P.R. 18 mo. $3^{s .}$

On writing paper, with wide margin, Ios.

Novum Testamentum Graece juxta Exemplar Millianum. 18mo. 2s. $6 d$. On writing paper, with wide margin, $9 s$.

Evangelia Sacra Graece. Fcap. 8vo. limp, is.6d.

The Greek Testament, with the Readings adopted by the Revisers of the Authorised Version:-

(1) Pica type, with Marginal References. Demy 8vo. ros. $6 d$.

(2) Long Primer type. Fcap. 8vo. $4^{\text {s. }} 6 d$.

(3) The same, on writing paper, with wide margin, ${ }^{5}$ s.

- The Parallel New Testament, Greek and English; being the Authorised Version, 1611 ; the Revised Version, 1881; and the Greek Text followed in the Revised Version. 8vo. 12s. $6 d$.

The Revised Version is the joint property of the Universities of Oxford and Cambridge. 
GREEK.-Canon Muratorianus: the earliest Catalogue of the Books of the New Testament. Edited with Notes and a Facsimile of the MS. in the Ambrosian Library at Milan, by S. P. Tregelles, LL.D. 1867. 4to. Ios. $6 d$.

Outlines of Textual Criticism applied to the New Testament. By C. E. Hammond, M.A. Fourth Edition. Extra fcap. 8vo. 3s.6d.

HeBREw, etc.-The Psalms in Hebrew without points. 1879. Crown 8vo. 3s. $6 d$.

A Commentary on the Book of Proverbs. Attributed to Abraham Ibn Ezra. Edited from a MS. in the Bodleian Library by S. R. Driver, M.A. Crown 8vo. paper covers, 3 s. $6 d$.

The Book of Tobit. A Chaldee Text, from a unique MS. in the Bodleian Library; with other Rabbinical Texts, English Translations, and the Itala. Edited by Ad. Neubauer, M.A. 1878. Crown 8vo. 6s.

- Horae Hebraicae et Talmudicae, a J. Lightfoot. A new Edition, by R. Gandell, M.A. 4 vols. 1859 . 8vo. Il. Is.

Latin.-Libri Psalmorum Versio antiqua Latina, cum Paraphrasi Anglo-Saxonica. Edidit B. Thorpe, F.A.S. 1835. 8vo. ros. 6d.

Old-Latin Biblical Texts: No. I. The Gospel according to St. Matthew from the St. Germain MS. $\left(g_{1}\right)$. Edited with Introduction and Appendices by John Wordsworth, D.D. Small 4 to., stiff covers, $6 s$.

Old-Latin Biblical Texts: No.II. Portions of the Gospels according to St. Mark and St. Matthew, from the Bobbio MS. (k), \&c. Edited by John Wordsworth, D.D., W. Sanday, M.A., D.D., and H. J. White, M.A. Small 4to., stiff covers, $21 s$.

OLd-French.-Libri Psalmorum Versio antiqua Gallica e Cod. MS. in Bibl. Bodleiana adservato, una cum Versione Metrica aiiisque Monumentis pervetustis. Nunc primum descripsit et edidit Franciscus Michel, Phil. Doc. 1860. 8vo. 10s. $6 d$.

\section{FATHERS OF THE CHURCH, \&c.}

St. Athanasius: Historical Writings, according to the Benedictine Text. With an Introduction by William Bright, D.D. 188I. Crown 8 vo. IOs. $6 d$.

Orations against the Arians. With an Account of his Life by William Bright, D.D. 1873. Crown 8vo. 9 s.

St.Augustine: Select Anti-Pelagian Treatises, and the Acts of the Second Council of Orange. With an Introduction by William Bright, D.D. Crown 8vo. 9 s. 
Canons of the First Four General Councils of Nicaea, Constantinople, Ephesus, and Chalcedon. 1877. Crown 8vo. 2s. $6 d$.

Notes on the Canons of the First Four General Councils. By William Bright, D.D. I882. Crown 8vo. 5 s. $6 d$.

Cyrilli Archiepiscopi Alexandrini in XII Prophetas. Edidit P. E. Pusey, A.M. Tomi II. I868. 8vo. cloth, 2l. $2 s$.

in D. Foannis Evangelium. Accedunt Fragmenta varia necnon Tractatus ad Tiberium Diaconum duo. Edidit post Aubertum P. E. Pusey, A.M. Tomi III. 1872. 8vo. 2l. 5s.

Commentarii in Lucae Evangelinm quae supersunt Syriace. E MSS. apud Mus. Britan. edidit R. Payne Smith, A.M. $185^{8}$. 4to. 1l. 2s.

— Translated by R. Payne Smith, M.A. 2 vols. 1859. 8vo. I4s.

Ephraemi Syri, Rabulae Episcopi Edesseni, Balaei, aliorumque Opera Selecta. E Codd. Syriacis MSS. in Museo Britannico et Bibliotheca Bodleiana asservatis primus edidit J. J. Overbeck. I865. 8vo. Il. Is.

Eusebius' Ecclesiastical History, according to the text of Burton, with an Introduction by William Bright, D.D. I881. Crown 8 vo. $8 s .6 d$.

Irenaeus: The Third Book of St.Irenaeus, Bishop of Lyons, against Heresies. With short Notes and a Glossary by H. Deane, B.D. 1874. Crown 8vo. 5s. $6 d$.

Patrum Apostolicorım, S. Clementis Romani, S. Ignatii, S. Polycarpi, quae supersunt. Edidit Guil. Jacobson, S.T.P.R. Tomi II. Fourth Edition, 1863. 8vo. 1l. 1s.

Socrates' Ecclesiastical History, according to the Text of Hussey, with an Introduction by William Bright, D.D. I878. Crown 8vo. $7 s .6 d$.

\section{ECCLESIASTICAL HISTORY, BIOGRAPHY, \&c.}

Ancient Liturgy of the Church of England, according to the nses of Sarum, York, Hereford, and Bangor, and the Roman Liturgy arranged in parallel columns, with preface and notes. By William Maskell, M.A Third Edition. 1882. 8vo. $15 s$.

Baedae Historia Ecclesiastica. Edited, with English Notes, by G. H. Moberly, M.A. 1881. Crown 8vo. Ios. $6 d$. 
Bright (W.). Chapters of Early English Church History. I 878 . 8vo. I $2 s$.

Burnet's History of the Reformation of the Church of England. A new Edition. Carefully revised, and the Records collated with the originals, by N. Yocock, M.A. 7 vols. 1865. 8vo. Price reduced to 1 l. $10 s$.

Councils and Ecclesiastical Documents relating to Great Britain and Ireland. Edited, after Spelman and Wilkins, by A. W. Haddan, B.D, and W. Stubbs, M.A. Vols. I. and III. 1869-7I. Medium 8vo. each Il. Is.

Vol. II. Part I. 1873. Medium 8vo. 10s. $6 d$.

Vol. II. Part II. 18 78 . Church of Ireland; Memorials of St. Patrick. Stiff covers, $3 s .6 d^{2}$.

Hamilton (Fohn, Archbishop of St. Andrews), The Catechism of. Edited, with Introduction and Glossary, by Thomas Graves Law. With a Preface by the Right Hon. W. E. Gladstone. 8 vo. i $2 s .6 d$.

Hammond (C. E.). Liturgies, Eastern and Western. Edited, with Introduction, Notes, and Liturgical Glossary. 1878. Crown 8vo. $10 s .6 d$.

An Appendix to the above. I879. Crown 8vo. paper covers, is. $6 d$.

Fohn, Bishop of Ephesus. The Third Part of his Ecclesiastical History. [In Syriac.] Now first edited by William Cureton, M.A. 1853. 4to. 1 l. 125 .

Translated by R. Payne Smith, M.A. I 860. 8vo. 10 s.

Leofric Missal, The, as used in the Cathedral of Exeter dnring the Episcopate of its first Bishop, A.D. 1050-1072 ; together with some Account of the Red Book of Derby, the Missal of Robert of Jumièges, and a few other early MS. Service Books of the English Church. Edited, with Introduction and Notes, by F. E. Warren, B.D. 4 to. half morocco, $35^{s}$.

Monumenta Ritualia Ecclesiae Anglicanae. The occasional Offices of the Church of England according to the old use of Salisbury, the Prymer in English, and other prayers and forms, with dissertations and notes. By William Maskell, M.A. Second Edition. 1882. 3 vols. 8 vo. 2l. Ios.

Records of the Reformation. The Divorce, 1527-1 533. Mostly now for the first time printed from MSS. in the British Museum and other libraries. Collected and arranged by N. Pocock, M.A. 1870. 2 vols. 8 vo. 1l. $16 s$.

Shirley $(W . W$.$) . Some Account of the Church in the Apostolic$ Age. Second Edition, 1874 . Fcap. 8vo. 3s. 6d.

Stubbs $(W$.$) . Registrum Sacrum Anglicanum. An attempt$ to exhibit the course of Episcopal Succession in England. 1858 . Small 4 to. 8s. $6 d$.

Warren (F. E.). Liturgy and Ritual of the Celtic Church. I881. 8vo. 14s. 


\section{ENGIISH THEOIOGY.}

Bampton Lectures, 1886. The Christian Platonists of Alexandria. By Charles Bigg, D.D. 8vo. Ios. $6 d$.

Butler's Works, with an Index to the Analogy. 2 vols. 1874. 8 vo. IIs.

Also separately,

Sermons, 5s.6d. Analogy of Religion, 5s.6d

Greswell's Harmonia Evangelica. Fifth Edition. 8vo. I 855. 9s. $6 d$.

Heurtley's Harmonia Symbolica: Creeds of the Western Church. 1858. 8vo. 6s. $6 d$.

Homilies appointed to be read in Churches. Edited by J. Griffiths, M.A. 1859. 8vo. 7s. $6 d$.

Hooker's Works, with his life by Walton, arranged by John Keble, M.A. Sixth Edition, 1874. 3 vols. 8vo. Il. IIs. $6 d$.

the text as arranged by John Keble, M.A. 2 vols. 1875. 8vo. IIs.

Fervel's Works. Edited by R. W. Jelf, D.D. 8 vols. 1848 . 8 vo. Il. Ios.

Pearson's Exposition of the Creed. Revised and corrected by E. Burton, D.D. Sixth Edition, 1877. 8vo. Ios. $6 d$.

Waterland's Revieze of the Doctrine of the Eucharist, with a Preface by the late Bishop of London. Crown 8vo. 6s. 6d.

Works, with Life, by Bp. Van Mildert. A new Edition, with copious Indexes. 6 vols. 1856 . 8vo. 2l. I Is.

Wheatly's Illustration of the Book of Common Prayer. A new Edition, 1846. 8vo. $5 s$.

Wyclif. A Catalogue of the Original Works of Fohn Wyclif, by W. W. Shirley, D.D. 1865. 8vo. 3s. $6 d$.

Select English Works. By T. Arnold, M.A. 3 vols. 1869-1871. 8vo. Il. xs.

Trialogus. With the Supplement now first edited. By Gotthard Lechler. 1869. 8vo. $7 s$. 


\section{HISTORICAL AND DOCUMENTARY WORKS.}

British Barrows, a Record of the Examination of Sepulchral

Mounds in various parts of England. By William Greenwell, M.A., F.S.A. Together with Description of Figures of Skulls, General Remarks on Prehistoric Crania, and an Appendix by George Rolleston, M.D., F.R.S. 1877. Medium 8vo. 25 s.

Britton. A Treatise upon the Common Law of England, composed by order of King Edward I. The French Text carefully revised, with an English Translation, Introduction, and Notes, by F. M. Nichols, M.A. 2 vols. 1865 . Royal 8 vo. I $l$. 16s.

Clarendon's History of the Rebellion and Civil Wars in England. 7 vols. 1839 . $18 \mathrm{mo}$. Il. Is.

Clarendon's History of the Rebellion and Civil Wars in England. Also his Life, written by himself, in which is included a Continuation of his History of the Grand Rebellion. With copious Indexes. In one volume, royal 8 vo. 1842 . I $l$. $2 s$.

Clinton's Epatome of the Fasti Hellenici. 1851. 8vo. 6s.6d. Epitome of the Fasti Romani. I 854. 8vo. 7 s.

Corpus Poeticum Boreale. The Poetry of the Old Northern Tongue, from the Earliest Times to the Thirteenth Century. Edited, classified, and translated, with Introduction, Excursus, and Notes, by Gudbrand Vigfússon, M.A., and F. York Powell, M.A. 2 vols. 1883.8 vo. $42 s$.

Freeman (E.A.). History of the Norman Conquest of England; its Causes and Results. In Six Volumes. 8vo. 5 l. 9 s. $6 d$.

The Reign of William Rufus and the Accession of Henry the First. 2 vols. 8vo. Il. I6s.

Gascoigne's Theological Dictionary ("Liber Veritatum"): Selected Passages, illustrating the condition of Church and State, 1403-1458. With an Introduction by James E. Thorold Rogers, M.A. Small $4^{\text {to. }}$ Ios. $6 d$.

Magna Carta, a careful Reprint. Edited by W. Stubbs, D.D. 1879. 4 to. stitched, is.

Passio et Miracula Beati Olaui. Edited from a TwelfthCentury MS. in the Library of Corpus Christi College, Oxford, with an Introduction and Notes, by Frederick Metcalfe, M.A. Small 4to. stiff covers, $6 s$. 
Protests of the Lords, including those which have been expunged, from I 624 to 1874 ; with Historical Introductions. Edited by James E. Thorold Rogers, M.A. $1875 \cdot 3$ vols. 8 vo. $2 l .2 s$.

Rogers (F. E. T.). History of Agriculture and Prices in England, A.D. $1259^{-1} 793$.

Vols. I and II (1 259-1400). I 866, 8vo. 2l. 2s.

Vols. III and IV (I4OI-1 582). 1882. 8vo. 2l. IOs.

Saxon Chronicles (Two of the) parallel, with Supplementary Extracts from the Others. Edited, with Introduction, Notes, and a Glossarial Index, by J. Earle, M.A. I865. 8vo. I $6 s$.

Stubbs (W., D.D.). Seventeen Lectures on the Study of Medieval and Modern History, \&c., delivered at Oxford $1867-188_{4}$. Demy 8 vo. half-bound, Ios. $6 d$.

Sturlunga Saga, including the Islendinga Saga of Lawman Sturla Thordsson and other works. Edited by Dr. Gudbrand Vigfússon. In 2 vols. 1878 . 8 vo. $2 l .2 s$.

York Plays. The Plays performed by the Crafts or Mysteries of York on the day of Corpus Christi in the $14^{\text {th, }} 15^{\text {th }}$, and 16 th centuries. Now first printed from the unique MS. in the Library of Lord Ashburnham. Edited with Introduction and Glossary by Lucy Toulmin Smith. 8vo. 2 Is.

Statutes made for the University of Oxford, and for the Colleges and Halls therein, by the University of Oxford Commissioners. 1882. 8vo. I2s. $6 d$.

Statuta Universitatis Oxoniensis. I886. 8 vo. $5^{s}$.

The Examination Statutes for the Degrees of B.A., B. Mus., B.C.L., and B.M. Revised to Hilary Term, I887. 8vo. sewed, Is.

The Student's Handbook to the University and Colleges of Oxford. Extra fcap. 8vo. 2s. 6 d.

The Oxford University Calendar for the year 1887 . Crown 8 vo. $4^{\text {s. }} 6 d$.

The present Edition includes all Class Lists and other University distinctions for the seven years ending with 1886 .

Also, supplementary to the above, price 5s. (pp. 608),

The Honours Register of the University of Oxford. A complete Record of University Honours, Officers, Distinctions, and Class Lists; of the Heads of Colleges, \&c., \&c., from the Thirteenth Century to 1883 . 
MATHEMATICS, PHYSICAL SCIENCE, \&C.

Acland (H. W., M.D., F.R.S.). Synopsis of the Pathological Series in the Oxford Museum. 1867. 8vo. 2s.6d.

De Bary (Dr. A.). Comparative Anatomy of the Vegetative Organs of the Phanerogams and Ferns. Translated and Annotated by F.O. Bower, M.A., F.L.S., and D. H. Scott, M.A., Ph.D., F.L.S. With 241 woodcuts and an Index. Royal 8vo., half morocco, Il. 2s. $6 d$.

Goebel (Dr. K.). Outlines of Classification and Special Morphology of Plants. A New Edition of Sachs' Text Book of Botany, Book II. English Translation by H. E. F. Garnsey, M.A. Revised by I. Bayley Balfour, M.A., M.D., F.R.S. With 407 Woodcuts. Royal 8vo. half Morocco, $21 s$.

Lcctures on the Physiology of Plants. By Julius Sachs. Translated by H. Marshall Ward, M.A. With 445 Woodcuts. Royal 8vo. Just ready.

Miuller (F.). On certain Variations in the Vocal Organs of the Passeres that have hitherto escaped notice. Translated by F. J. Bell, B.A., and edited, with an Appendix, by A. H. Garrod. M.A., F.R.S. With Plates. 1878. 4to. paper covers, $75.6 \mathrm{~d}$.

Price (Bartholomew, M.A., F.R.S.). Treatise on Infinitesimal Calculus.

Vol. I. Differential Calculus. Second Edition. 8vo. I4s. $6 d$.

Vol. II. Integral Calculus, Calculus of Variations, and Differential Equations. Second Edition, 1865. 8vo. $18 s$.

Vol.III. Statics, including Attractions; Dynamics of a Material Particle. Second Edition, 1868. 8vo. I6s.

Vol.IV. Dynamics of Material Systems; together with a chapter on Theoretical Dynamics, by W. F. Donkin, M.A., F.R.S. 1862. Svo. I6s.

Pritchard (C., D.D., F.R.S.). Uranometria Nova Oxoniensis. A Photometric determination of the magnitudes of all Stars visible to the naked eye, trom the Pole to ten degrees south of the Equator. I885. Royal 8vo. 8s.6d.

- Astronomical Observations made at the University Observatory, Oxford, under the direction of C. Pritchard, D.D. No. I. 1878. Royal 8vo. paper covers. $3 s .6 d$.

Rigand's Correspondence of Scientific Men of the I 7th Century, with Table of Contents by A. de Morgan, and Index by the Rev. J. Rigaud, M.A. 2 vols. $184^{1-1} 862$. 8vo. 18s. $6 d$.

Rolleston (George, M.D., F.R.S.). Scientific Papers and Addresses. Arranged and Edited by William Tumer, M.B., F.R.S. With a Biographical Sketch by Edward Tylor, F.R.S. With Portrait. Plates, and Woodcuts. 2 vols. 8 ro. Il. 4 s.

Westwood (F. O., M.A., F.R.S.). Thesaurus Entomologicus Hopeianzus, or a Description of the rarest Insects in the Collection given to the University by the Rev. William Hope. With 40 Plates. 1874 . Small folio, half morocco, 7 l. 10 s. 


\section{The Sacred 3Books of the East.}

Translated by various Oriental Scholars, and edited by F. MAX MÜLLER.

[Demy 8vo. cloth.]

Vol. I. The Upanishads. Translated by F. Max Müller. Part I. The Khândogya-upanishad, The Talavakâra-upanishad, The Aitareyaâranyaka, The Kaushîtaki-brâhmana-upanishad, and The Vâgasaneyi-samhitâupanishad. ros. $6 d$.

Vol. II. The Sacred Laws of the Âryas, as taught in the Schools of Âpastamba, Gautama, Vâsishtha, and Baudhâyana. Translated by Prof. Georg Bühler. Part I. Â pastamba and Gautama. Ios. $6 d$.

Vol. III. The Sacred Books of China. The Texts of Confucianism. Translated by James Legge. Part I. The Shû King, The Religious portions of the Shih King, and The Hsiâo King. I $2 s .6 d$.

Vol. IV. The Zend-Avesta. Translated by James Darmesteter. Part I. The Vendîdâd. ros. $6 d$.

Vol. V. The Pahlavi Texts. Translated by E. W. West. Part I. The Bundahis, Bahman Yast, and Shâyast lâ-shâyast. 1 2s. $6 d$.

Vols. VI and IX. The Qur'ân. Parts I and II. Translated by E. H. Palmer. $21 s$.

Vol. VII. The Institutes of Vishnu. Translated by Julius Jolly. Ios. $6 d$.

Vol. VIII. The Bhagavadgîtâ, with The Sanatsugâtîya, and The Anugîtâ. Translated by Kâshinâth Trimbak Telang. Ios. $6 d$.

Vol. X. The Dhammapada, translated from Pâli by F. Max Muiller; and The Sutta-Nipâta, translated from Pâli by V. Fausböll; being Canonical Books of the Buddhists. Ios. $6 d$.

Vol. XI. Buddhist Suttas. Translated from Pâli by T. W. Rhys Davids. 1. The Mahâparinibbâna Suttanta ; 2. The Dhamma-kakkappavattana Sutta; 3. The Tevigga Suttanta; 4. The Akankheyya Sutta; 5. The Ketokhila Sutta; 6. The Mahâ-sudassana Suttanta ; 7. The Sabbâsava Sutta. IOs. 6 d. 
Vol. XII. The Satapatha-Brâhmana, according to the Text of the Mâdhyandina School. Translated by Julius Eggeling. Part I. Books I and II. I $2 s .6 d$.

Vol. XIII. Vinaya Texts. Translated from the Pâli by T. W. Rhys Davids and Hermaun Oldenberg. Part I. The Pâtimokkha. The Mahâvagga, I-IV. IOs. $6 d$.

Vol. XIV. The Sacred Laws of the Âryas, as taught in the Schools of Apastamba, Gautama, Vâsishtha and Baudhâyana. Translated by Georg Bühler. Part II. Vâsishtha and Baudhâyana. Ios. $6 d$.

Vol. XV. The Upanishads. Translated by F. Max Müller. Part II. The Katha-upanishad, The Mundaka-upanishad, The Taittiriyakaupanishad, The Brihadâranyaka-upanishad, The Svetasvatara-upanishad, The Prasña-upanishad, and The Maitrâyana-Brâhmana-upanishad. Ios. $6 d$.

Vol. XVI. The Sacred Books of China. The Texts of Confucianism. Translated by James Legge. Part II. The Yî King. Ios. $6 d$.

Vol. XVII. Vinaya Texts. Translated from the Pâli by T. W. Rhys Davids and Hermann Oldenberg. Part II. The Mahâvagga, V-X. The Kullavagga, I-III. Ios. $6 d$.

Vol. XVIII. Pahlavi Texts. Translated by E. W. West. Part II. The Dâdistân-î Dînîk and The Epistles of Mânûskîhar. I 2s. 6d.

Vol. XIX. The Fo-sho-hing-tsan-king. A Life of Buddha by Asvaghosha Bodhisattva, translated from Sanskrit into Chinese by Dharmaraksha, A.D. 420, and from Chinese into English by Samuel Beal. Ios. $6 d$.

Vol. XX. Vinaya Texts. Translated from the Pâli by T. W. Rhys Davids and Hermann Oldenberg. Part III. The Kullavagga, IV-XII. IOS. $6 d$.

Vol. XXI. The Saddharma-pundarîka; or, the Lotus of the True Law. Translated by H. Kern. I $2 s .6 d$.

Vol. XXII. Gaina-Sûtras. Translated from Prâkrit by Hermann Jacobi. Part I. The Âkârânga-Sûtra. The Kalpa-Sûtra. Ios. $6 d$.

Vol. XXIII. The Zend-Avesta. Translated by James Darmesteter. Part II. The Sîrôzahs, Yasts, and Nyâyis. ros. 6d.

Vol. XXIV. Pahlavi Texts. Translated by E. W. West. Part III. Dînâ-î Maînôg-î Khirad, Sikand-gûmânîk, and Sad-Dar. Ios. 6d. 


\section{Second Series.}

Vol. XXV. Manu. Translated by Georg Bühler. 21s.

Vol. XXVI. The Satapatha-Brâhmana. Translated by Julius Eggeling. Part II. 12s. 6 d.

\section{Vols. XXVII and XXVIII. The Sacred Books of China.} The Texts of Confucianism. Translated by James Legge. Parts III and IV. The Lî $K \hat{1}$, or Collection of Treatises on the Rules of Propriety, or Ceremonial Usages. $25^{s}$.

Vols. XXIX and XXX. The Grihya-Sûtras, Rules of Vedic Domestic Ceremonies. Translated by Hermann Oldenberg.

Part I (Vol, XXIX), i 2s. 6d. Just Published.

Part II (Vol. XXX). In the Press.

The following Volumes are in the Press:-

Vol. XXXI. The Zend-Avesta. Part III. The Yasna, Visparad, Âfrînagân, and Gâhs. Translated by the Rev. L. H. Mills. Just ready.

Vol. XXXII. Vedic Hymns. Translated by F. Max Müller. Part I.

Vol. XXXIII. Nârada, and some Minor Law-books. Translated by Julius Jolly. [Preparing.]

Vol. XXXIV. The Vedânta-Sûtras, with Sankara's Commentary. Translated by G. Thibaut. [Preparing.]

** The Second Series will consist of Twenty-Four Volumes. 


\section{CTarenoon gavess Series}

I. ENGLISH, \&c.

A First Reading Book. By Marie Eichens of Berlin; and edited by Anne J. Clough. Extra fcap. 8vo. stiff covers, $4 d$.

Oxford Reading Book, Part I. For Little Children. Extra fcap. 8 vo. stiff covers, $6 d$.

Oxford Reading Book, Part II. For Junior Classes. Extra fcap. 8vo. stiff covers, $6 d$.

An Elementary English Grammar and Exercise Book. By O. W. Tancock, M.A. Second Edition. Extra fcap. 8vo. Is. 6d.

An English Grammar and Reading Book, for Lower Forms in Classical Schools. By O. W. Tancock, M.A. Fourth Edition. Extra fap. 8 vo. $3 s .6 d$.

Typical Selections from the best English Writers, with Introductory Notices. Second Edition. In 2 vols. Extra fcap. 8vo. 3s. 6d. each.

Vol. I. Latimer to Berkeley.

Vol. II. Pope to Macallay.

Shairp (F.C., LL.D.). Aspects of Poetry; being Lectures delivered at Oxford. Crown 8vo. Ios. 6 d.

A Book for the Beginner in Anglo-Saxon. By John Earle, M.A. Third Edition. Extra fcap. 8vo. 2s. $6 d$.

An Anglo-Saxon Reader. In Prose and Verse. With Grammatical Introduction, Notes, and Glossary. By Henry Sweet, M.A. Fourth Edition, Revised and Enlarged. Extra fcap. Svo. 8s. $6 d$.

A Second Anglo-Saxon Reader. By the same Author. Extra fcap. Svo. Nearly ready.

An Anglo-Saxon Primer, with Grammar, Notes, and Glossary. By the same Author. Second Edition. Extra fcap. 8vo. 2s. 6d.

Old English Reading Primers; edited by Henry Sweet, M.A.

I. Selected Homilies of Elfric. Extra fcap. Sro., stiff covers, is. $6 d$.

II. Extracts from Alfred's Orosins. Extra fcap. 8vo., stiff covers, is. $6 d$.

First Middle English Primer, with Grammar and Glossary. By the same Author. Extra fcap. 8vo. $2 s$.

Second Middle English Primer. Extracts from Chaucer, with Grammar and Glossary. By the same Author. Extra fcap. 8ro. 2s. Principles of English Etymology. First Series. By W. W. Skeat, Litt.D. Crown 8ro. Nearly ready. 
The Philology of the English Tongue. By J. Earle, M.A. Third Edition. Extra fcap. 8vo. 7s. $6 d$.

An Icelandic Primer, with Grammar, Notes, and Glossary. By the same Author. Extra fcap. 8vo. 3s. 6d.

An Icelandic Prose Reader, with Notes, Grammar, and Glossary. By G. Vigfússon, M.A., and F. York Powell, M.A. Ext. fcap. 8vo. Ios. 6d.

A Handbook of Phonetics, including a Popular Exposition of the Principles of Spelling Reform. By H. Sweet, M.A. Extra fcap. 8vo. 4s. fd. Elementarbuch des Gesprochenein Englisch. Grammatik,

Texte and Glossar. Von Henry Sweet. Extra fcap. 8vo., stiff covers, 2s. 6d. The Ormulum; with the Notes and Glossary of Dr. R. M.

White. Edited by R. Holt, M.A. 1878. 2 vols. Extra fcap. 8vo. 2 Is. Specimens of Early English. A New and Revised Edition. With Introduction, Notes, and Glossarial Index. By R. Morris, LL D.. and W. W. Skeat, M.A.

Part I. From Old English Homilies to King Horn (A.D. I I 50 to A.D. I300). Second Edition. Extra fcap. 8vo. 9s.

Part II. From Robert of Gloucester to Gower (A.D. I 298 to A.D. I 393). Second Edition. Extra fcap. 8vo. 7s. $6 d$.

Specimens of English Literature, from the 'Ploughmans Crede' to the 'Shepheardes Calender' (A.D. 1394 to A.D. 1579). With Introduction, Notes, and Glossarial Index. By W. W. Skeat, M.A. Extra fcap. 8vo. 75. $6 d$.

The Vision of William concerning Piers the Plowman, in three Parallel Texts; together with Richard the Redeless. By William Langland (abont I 362-1399 A.D.). Edited from numerous Manuscripts, with Preface, Notes, and a Glossary, by W. W. Skeat, Litt.D. 2 vols. 8vo. 31s. $6 \mathrm{~d}$.

The Vision of William concerning Piers the Ploweman, by William Langland. Edited, with Notes, by W. W. Skeat, M.A. Third Edition. Extra fcap. 8vo. $4^{\text {s. } 6 d .}$

Chaucer. I. The Prologue to the Canterbury Tales; the Knightes Tale; The Nonne Prestes Tale. Edited by R. Morris, Editor of Specimens of Early English, \&c., \&c. Extra fcap. 8vo. 2s. $6 d$.

II. The Prioresses Tale; Sir Thopas; The Monkes Tale; The Clerkes Tale; The Squieres Tale, \&c. Edited by W. W. Skeat, M.A. Second Edition. Extra fcap. 8vo. 4s. $6 d$.

III. The Tale of the Man of Lazve; The Pardoneres Tale; The Second Nonnes Tale; The Chanouns Yemannes Tale. By the same Editor. Second Edition. Extra fcap. 8vo. 4s. $6 d$.

Gamelyn, The Tale of. Edited with Notes, Glossary, \&c., by W. W. Skeat, M.A. Extra fcap. 8vo. Stiff covers, is. $6 d$. Minot (Laurence). Poems. Edited, with Introduction and Notes, by Joseph Hall, M.A. Extra fcap. 8ro. Nearly ready. 
Spenser's Faery Queene. Books I and II. Designed chiefly for the use of Schools. With Introduction, Notes, and Glossary. By G. W. Kitchin, D.D. Extra fcap. 8vo. 2s. 6d. each.

Hooker. Ecclesiastical Polity, Book I. Edited by R. W. Church, M.A. Second Edition. Extra fcap. 8vo. $2 s$.

$$
\text { OLD ENGLISH DRAMA. }
$$

The Pilgrimage to Parnassus with The Two Parts of the Return from Parnassus. 'Three Comedies performed in St. John's College, Cainbridge, A.D. MDXCViI-MDCI. Edited from MSS. by the Rev. W. D. Macray, M.A., F.S.A. Medium Svo. Bevelled Boards, Gilt top, 8s. 6d.

Marlowe and Greene. Marlowe's Tragical History of Dr. Faustus, and Greene's Honourable History of Friar Bacon and Friar Bungay. Edited by A. W. Ward, M.A. New and Enlarged Edition. Extra fcap. Svo. 6s.

Marlowe. Edward II. With Introduction, Notes, \&c. By O. W. Tancock, M.A. Extra fcap. 8vo. 3s.

\section{SHAKESPEARE.}

Shakespeare. Select Plays. Edited by W. G. Clark, M.A., and W. Aldis Wright, M.A. Extra fcap. 8vo. stiff covers.

The Merchant of Venice. Is. Macbeth. Is. $6 d$.

Richard the Second. Is. 6d. Hamlet. 2s. Edited by W. Aldis Wright, M.A.

The Tempest. Is. $6 d$.

As You Like It. Is. $6 d$.

Julius Cæesar. $2 s$.

Richard the Third. 2s. 6 d.

King Lear. is. $6 d$.
Midsummer Night's Dream. Is. $6 d$. Coriolanus. 2s. $6 d$.

Henry the Fifth. $2 s$.

Twelfth Night. Is. $6 d$.

King John. Is. $6 d$.

Shakespeare as a Dramatic Artist; a popular Illustration of the Principles of Scientific Criticism. By R. G. Moulton, M.A. Crown 8vo. $5^{\text {s. }}$

Bacon. I. Advancement of Learning. Edited by W. Aldis Wright, M.A. Second Edition. Extra fcap. 8vo. 4s. $6 d$.

II. The Essays. With Introduction and Notes. By S. H. Reynolds, M.A., late Fellow of Brasenose College. In Preparation.

Milton. I. Areopagitica. With Introduction and Notes. By John W. Hales, M.A. Third Edition. Extra fcap. 8vo. $3^{s}$.

II. Poems. Edited by R. C. Browne, M.A. 2 vols. Fifth Edition. Extra fcap. 8vo. 6s. 6d. Sold separately, Vol. I. 4s.; Vol. II. 3 s.

In paper covers :-

Lycidas, $3 d$. L'Allegro, $3 d$. Il Penseroso, $4 d$. Comus, $6 d$. Samson Agonistes, $6 d$.

III. Samson Agonistes. Edited with Introduction and Notes by John Churton Collins. Extra fcap. 8 vo. stiff covers, is. 
Bunyan. I. The Pilgrim's Progress, Grace Abounding, Relation of the Imprisonment of Mr. John Bunyan. Edited, with Biographical Introduction and Notes, by E. Venables, M.A. 1879. Extra fcap.8vo. 5s. In ornamental Parchment, $6 s$.

II. Holy War, Eoc. Edited by E. Venables, M.A. In the Press.

Clarendon. History of the Rebellion. Book VI. Edited by T. Arnold, M.A. Extra fcap. 8vo. 4 s. $6 d$.

Dryden. Select Poems. Stanzas on the Death of Oliver Cromwell; Astræa Redux; Annus Mirabilis; Absalom and Achitophel; Religio Laici; The Hind and the Panther. Edited by W. D. Christie, M.A. Second Edition. Extra fcap. 8vo. $3^{s .6 d}$.

Locke's. Conduct of the Understanding. Edited, with Introduction, Notes, \&c., by T. Fowler, M.A. Second Edition. Extra fcap. 8vo. 2s. Addison. Selections from Papers in the Spectator. With Notes. By T. Arnold, M.A. Extra fcap. 8vo. 4s. $6 d$. In ornamental Parchment, $6 s$. Steele. Selections from the Tatler, Spectator, and Guardian. Edited by Austin Dobson. Extra fcap. 8vo. $4 s$. $6 d$. In white Parchment, $7 s .6 d$. Pope. With Introduction and Notes. By Mark Pattison, B.D. I. Essay on Man. Extra fcap. 8vo. Is. $6 d$. II. Satires and Epistles: Extra fcap. 8vo. $2 s$.

Parnell. The Hermit. Paper covers, $2 d$.

Gray. Selected Poems. Edited by Edmund Gosse. Extra fcap. 8vo. Stiff covers, Is. $6 d$. In white Parchment, 3 s. - Elegy and Ode on Eton College. Paper covers, $2 d$. Goldsmith. The Deserted Village. Paper covers, $2 d$. Fohnson. I. Rasselas; Lives of Dryden and Pope. Edited by Alfred Milnes, M.A. (London). Extra fcap. 8vo. 4s. 6d., or Lives of Dryden and Pope only, stiff covers, $2 s .6 d$.

II. Vanity of Human Wishes. With Notes, by E. J. Payne, M.A. Paper covers, $4 d$.

Boswell's Life of Fohnson. With the Fournal of a Tour to the Hebrides. Edited, with copious Notes, Appendices, and Index, by G. Birkbeck Hill, D.C.L., Pembroke College. With Portraits and Facsimiles. 6 vols. Medinm 8vo. Nearly ready.

Cowper. Edited, with Life, Introductions, and Notes, by H. T. Griffith, B.A.

I. The Didactic Poems of 1782 , with Selections from the Minor Pieces, A.D. $1779^{-1} 783$. Extra fcap. 8vo. $3^{\text {s. }}$

II. The Task, with Tirocinium, and Selections from the Minor Poems, A.D. 1784-1 799. Second Edition. Extra fcap. 8vo. $3^{\text {s. }}$ 
Burke. Select Works. Edited, with Introduction and Notes, by E. J. Payne, M.A.

- I. Thoughts on the Present Discontents; the two Speeches on America. Second Edition. Extra fcap. 8ro. 4 s. 6d.

II. Reflections on the French Revolution. Second Edition. Extra fcap. 8vo. 5 s.

III. Four Letters on the Proposals for Peace with the Regicide Directory of France. Second Edition. Extra fcap. 8vo. 5s.

Keats. Hyperion, Book I. With Notes by W. T. Arnold, B.A. Paper covers, $4 d$.

Byron. Childe Harold. Edited, with Introduction and Notes, by H. F. Tozer, M.A. Extra fcap. 8vo. 3s. 6d. In white Parchment, 5 s.

Scott. Lay of the Last Minstrel. Edited with Preface and Notes by W. Minto, M.A. With Map. Extra fcap. 8ro. Stiff covers, 2s. Ornamental Parchment, 3 s. $6 d$.

- - Lay of the Last Minstrel. Introduction and Canto I., with Preface and Notes, by the same Editor. $6 d$.

\section{LATIN.}

Rudimenta Latina. Comprising Accidence, and Exercises of a very Elementary Character, for the use of Beginners. By John Barrow Allen, M.A. Extra fcap. Sro. $2 s$.

An Elementary Latin Grammar. By the same Author. Forty-second Thousand. Extra fcap. 8vo. 2s.6d.

A First Latin Exercise Book. By the same Author. Fourth Edition. Extra fcap. 8vo. 2s. $6 d$.

A Second Latin Exercise Book. By the same Author. Extra fcap. 8vo. 3s. $6 d$.

Reddenda Minora, or Easy Passages, Latin and Greek, for Unseen Translation. For the use of Lower Forms. Composed and selected by C. S. Jerram, M.A. Extra fcap. 8ro. 1s. $6 d$.

Anglice Reddenda, or Easy Extracts, Latin and Greek, for Unseen Translation. By C. S. Jerram, M.A. Third Edition, Revised and Enlarged. Extra fcap. 8vo. 2s. $6 d$.

Anglice Reddenda. Second Series. By the same Author. Extra fcap. 8vo. 3r. Just Published.

Passages for Translation into Latin. For the use of Passmen and others. Selected by J.Y. Sargent, M.A. Fifth Edition. Extra fcap. 8 vo. $2 s, 6 d$. 
Exerciscs in Latin Prose Composition; with Introduction, Notes and Passages of Graduated Difficulty for Translation into Latin. By G. G. Ramsay, M.A., LL.D. Second Edition. Extra fcap. 8vo. 4 s. $6 d$.

Hints and Helps for Latin Elegiacs. By H. Lee-Warner,M.A. Extra fiap. 8vo. 3 s. $6 d$.

First Latin Reader. By T. J. Nunns, M.A. Third Edition. Extra fcap. 8vo. 2s.

Caesar. The Commentaries (for Schools). With Notes and Maps. By Charles E. Moberly, M.A.

Part I. The Gallic War. Second Edition. Extra fcap. 8vo. 4s. 6d.

Part II. The Civil War. Extra fcap. 8vo. 3s. 6d.

The Civil War. Book I. Second Edition. Extra fcap. 8vo. 2s.

Cicero. Speeches against Catilina. By E. A. Upcott, M.A., Assistant Master in Wellingion College. In the Press.

Cicero. Selection of interesting and descriptive passages. With Notes. By Henry Walford, M.A. In three Parts. Extra fcap. 8vo. 4s.6d. Each Part separately, limp, is. $6 d$.

Part I. Anecdotes from Grecian and Roman History. Third Edition.

Part II. Omens and Dreams: Beauties of Nature. Third Edition.

Part III. Rome's Rule of her Provinces. Third Edition.

Cicero. De Senectute. Edited, with Introduction and Notes, by L. Huxley, M.A. Extra fcap. 8vo. $2 s$.

Or separately, Text and Introdnction, is. Notes is.

Cicero. Selected Letters (for Schools). With Notes. By the late C. E. Prichard, M.A., and E. R. Bernard, M.A. Second Edition. Extra fcap. 8vo. 3 s.

Cicero. Select Orations (for Schools). In Verrem I. De Imperio Gn. Pompeii. Pro Archia. Philippica IX. With Introduction and Notes by J. R. King, M.A. Second Edition. Extra fcap. 8vo. 2s. $6 d$.

Cornelius Nepos. With Notes. By Oscar Browning, M.A. Second Edition. Extra fcap. 8vo. 2s. $6 \mathrm{~d}$.

Horace. Selected Odes. With Notes for the use of a Fifth

Form. By E. C. Wickham, M.A. In two Parts. Extra fcap. 8vo. cloth, 2s. Or separately, Part I. Text, Is. Part II. Notes, is.

Livy. Selections (for Schools). With Notes and Maps. By H. Lee-Warner, M.A. Extra fcap. 8vo. In Parts, limp, each is. $6 d$.

Part I. The Caudine Disaster. Part II. Hannibal's Campaign in Italy. Part III. The Macedonian War.

Livy. Books V-VII. With Introduction and Notes. By A. R. Cluer, B.A. Second Edition. Revised by P. E. Matheson, M.A. Extra fcap. 8vo. (In one or two vols.) 5 s.

Livy. Books XXI, XXII, and XXIII. With Introduction and Notes. By M. T. Tatham, M.A. Extra fcap. 8 vo. $4 s .6 d$. 
Ovid. Selections for the use of Schools. With Introductions and Notes, and an Appendix on the Roman Calendar. By W. Ramsay, M.A. Edited by G. G. Ramsay, M.A. Third Edition. Extra fcap. 8vo. 5s. 6d.

Ovid. Tristia. Book I. The Text revised, with an Introduction and Notes. By S. G. Owen, B.A. Extra fcap. 8vo. 3s. $6 d$.

Plautus. Captivi. Edited by W. M. Lindsay, M.A. Extra fcap. 8vo. In the Press.

Plautus. The Trinummius. With Notes and Introductions. Intended for the Higher Forms of Public Schools. By C. E. Freeman, M.A., and A. Sloman, M.A. Extra fcap. 8vo. 3s.

Pliny. Selected Letters (for Schools). With Notes. By the late C. E. Prichard, M.A., and E. R. Bernard, M.A. Extra fcap. 8vo. 3 s.

Sallust. With Introduction and Notes. By W. W. Capes, M.A. Extra fcap. 8vo. $4 s .6 d$.

Tacitus. The Annals. Books I-IV. Edited, with Introduction and Notes for the use of Schools and Junior Students, by H. Furneaux. M.A. Extra fcap. Svo. 5 s.

Terence. Andria. With Notes and Introductions. By C. E. Freeman, M.A., and A. Sloman, M.A. Extra fcap. 8ro. $3^{\text {s. }}$

- Adelphi. With Notes and Introductions. Intended for the Higher Forms of Public Schools. By A. Sloman, M.A. Extra fcap. 8vo. 3 s.

Tibullus and Propertius. Selections. Edited by G. G. Ramsay, M.A. Extra fcap. 8vo. (In one or two vols.) 6s. Tust Published.

Virgil. With Introduction and Notes. By T. L. Papillon, M.A. Two vols. Crown 8vo. Ios. $6 d$. The Text separately, $4 s .6 d$.

Virgil. The Eclogues. Edited by C. S. Jerram, M.A. In two Parts. Crown 8vo. Nearly ready.

Catulli Veronensis Liber. Iterum recognovit, apparatum criticnm prolegomena appendices addidit, Robinson Ellis, A.M. 1878. Demy 8vo. I6s.

-..A Commentary on Catullus. By Robinson Ellis, M.A. 1876. Demy 8vo. I6s.

Catulli Veronensis Carmina Selecta, secundum recognitionem Robinson Ellis, A.M. Extra fcap. 8vo. 3s. $6 d$.

Cicero de Oratore. With Introduction and Notes. By A. S. Wilkins, M.A.

Book I. 1879. 8vo. 6s. Book II. I881. 8vo. 5s.

Philippic Orations. With Notes. By J. R. King, M.A. Second F.dition. 1879. 8vo. Ios. $6 d$. 
Cicero. Select Letters. With English Introductions, Notes, and Appendices. By Albert Watson, M.A. Third Edition. Demy 8vo. 18s.

Select Letters. Text. By the same Editor. Second Edition. Extra fcap. 8vo. $4^{s}$.

- pro Cluentio. With Introduction and Notes. By W. Ramsay, M.A. Edited by G. G. Ramsay, M.A. 2nd Ed. Ext. fcap. 8vo.3s. 6d. Horace. With a Commentary. Volume I. The Odes, Carmen Seculare, and Epodes. By Edward C. Wickham, M.A. Second Edition. I877. Demy 8vo. I $2 s$.

A reprint of the above, in a size suitable for the use of Schools. Extra fap. 8vo. 6s. (May also be had in two parts.)

Livy, Book I. With Introduction, Historical Examination, and Notes. By J. R. Seeley, M.A. Second Edition. I881. Svo. 6s.

Ovid. P. Ovidii Nasonis Ibis. Ex Novis Codicibus edidit, Scholia Vetera Commentarium cum Prolegomenis Appendice Indice addidit, R. Ellis, A.M. 8vo. Ios. $6 d$.

Persius. The Satires. With a Translation and Commentary. By John Conington, M.A. Edited by Henry Nettleship, M.A. Second Edition. 1874. 8vo. 7s. $6 d$.

Fuvenal. XIII Satires. Edited, with Introduction and Notes, by C. H. Pearson, M.A., and Herbert A. Strong, M.A., LL.D., Professor of Latin in Liverpool University College, Victoria University. In two Parts. Crown 8vo. Complete, 6s. Just Published.

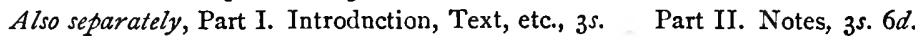
Tacitus. The Annals. Books I-VI. Edited, with Introduction and Notes, by H. Furneaux, M.A. 8vo. I8s.

Nettleship (H., M.A.). Lectures and Essays on Subjects connected with Latin Scholarship and Literatnre. Crown 8vo. $7 s .6 d$.

The Roman Satura: its original form in connection with its literary development. 8vo. sewed, is.

- Ancient Lives of Vergil. With an Essay on the Poems of Vergil, in connection with his Life and Times. 8vo. sewed, 2s.

Papillon (T. L., M.A.). A Manual of Comparative Philology. Third Edition, Revised and Corrected. 1882. Crown 8vo. 6s.

Pinder (North, M.A.). Selections from the less known Latin Poets. 1869. 8vo. I 5 s.

Sellar (W. Y., M.A.). Roman Poets of the Augustan Age. - Virgil. New Edition. 1883. Crown 8vo. 9s.

Roman Poets of the Republic. New Edition, Revised and Enlarged. I881. 8vo. 14s.

Wordsworth (F., M.A.). Fragments and Specimens of Early

Latin. With Introductions and Notes. 1874. 8vo. 18s. 


\section{GREEK.}

A Greek Primer, for the use of beginners in that Language. By the Right Rev. Charles Wordsworth, D.C.L. Seventh Edition. Extra fcap. 8 vo. Is. $6 d$.

Easy Greek Reader. By Evelyn Abbott, M.A. In two Parts. Extra fcap. 8vo. 3 s.

The Text and Notes may be had separately, is. $6 d$. each.

Graecae Grammaticae Rudimenta in usum Scholarum. Auctore Carolo Wordsworth, D.C.L. Nineteenth Edition, 1882. 12mo. 4s.

A Greek-English Lexicon, abridged from Liddell and Scott's 4to. edition, chiefly for the use of Schools. Twenty-first Edition. 1884. Square I $2 \mathrm{mo} .7 \mathrm{~s} .6 \mathrm{~d}$.

Greek Verbs, Irregular and Defective; their forms, meaning, and quantity; embracing all the Tenses used by Greek writers, with references to the passages in which they are found. By W. Veitch. Fourth Edition. Crown 8vo. ros. $6 d$.

The Elements of Greek Accentuation (for Schools): abridged from his larger work by H. W. Chandler, M.A. Extra fcap. 8vo. 2s.6d.

A Series of Graduated Greek Readers:-

First Greek Reader. By W. G. Rushbrooke, M.L. Second Edition. Extra fcap. 8vo. 2s. $6 d$.

Second Greek Reader. By A. M. Bell, M.A. Extra fcap. 8vo. 3s. $6 d$.

Fourth Greek Reader; being Specimens of Greek Dialects. With Introductions, etc. By W. W. Merry, M.A. Extra fcap. 8vo. $4 s .6 d$.

Fifth Greek Reader. Selections from Greek Epic and Dramatic Poetry, with Introductions and Notes. By Evelyn Abbott, M.A. Extra fcap. 8vo. 4 s. $6 d$.

The Golden Treasury of Ancient Greek Poetry: being a Collection of the finest passages in the Greek Classic Poets, with Introductory Notices and Notes. By R.S. Wright. M.A. Extra fcap. 8vo. 8s. $6 d$.

A Golden Treasury of Greek Prose, being a Collection of the finest passages in the principal Greek Prose Writers, with Introductory Notices and Notes. By R. S. Wright, M.A., and J. E.L. Shadwell, M.A. Extra fcap. 8 vo. 4 s. $6 d$.

Aeschylus. Prometheus Bound (for Schools). With Introduction and Notes, by A. O. Prickard, M.A. Second Edition. Extra fcap. 8vo. $2 s$.

- - Agamemnon. With Introduction and Notes, by Arthur Sidgivick, M.A. Second Edition. Extra fcap. 8vo. $3^{\text {s. }}$

Choephoroi. With Introduction and Notes by the same Editor. Extra fcap. 8vo. 3s. 
Aristophanes. In Single Plays. Edited, with English Notes, Introductions, \&cc., by W. W. Merry, M.A. Extra fcap. $\delta$ vo.

I. The Clouds, Second Edition, $2 s$.

II. The Acharnians, 2s. III. The Frogs, $2 s$.

Cebes. Tabula. With Introduction and Notes. By C. S. Jerram, M.A. Extra fcap. 8vo. $2 s .6$.

Demosthenes. Olynthiacs and Philippics. Edited by Evelyn Abbott, M.A. Extra fcap. 8vo. In two Parts. In the Press.

Euripides. Alcestis (for Schools). By C. S. Jerram, M.A. Extra fcap. 8vo. 2s. 6d.

- Helena. Edited, with Introduction, Notes, etc., for Upper and Middle Forms. By C.S. Jerram, M.A. Extra fcap. 8vo. $3 s$.

- Iphigenia in Tauris. Edited, with Introduction, Notes, etc., for Upper and Middle Forms. By C.S. Jerram, M.A. Extra fcap. 8vo. cloth, $3^{s}$.

Medea. By C. B. Heberden, M.A. In two Parts. Extra fcap. 8vo. 2s.

Or separately, Part I. Introduction and Text, is.

Part II. Notes and Appendices, is.

Herodotus, Selections from. Edited, with Introduction, Notes, and a Map, by W. W. Merry, M.A. Extra fcap. 8vo. 2s. $6 d$.

Homer. Odyssey, Books I-XII (for Schools). By W. W. Merry, M.A. Twenty-seventh Thousand. Extra fcap. 8vo. 4s. $6 d$.

Book II, separately, is. 6 d.

- Odyssey, Books XIII-XXIV (for Schools). By the same Editor. Second Edition. Extra fcap. 8vo. 5 s.

Iliad, Book I (for Schools). By D. B. Monro, M.A. Second Edition. Extra fcap. 8vo. 2s.

Iliad, Books I-XII (for Schools). With an Introduction, a brief Homeric Grammar, and Notes. By D. B. Monro, M.A. Second Edition. Extra fcap. 8vo. 6s.

Iliad, Books VI and XXI. With Introduction and Notes. By Herbert Hailstone, M.A. Extra fcap. 8vo. rs. $6 d$. each.

Lucian. Vera Historia (for Schools). By C. S. Jerram, M.A. Second Edition. Extra fcap. 8vo. 1s. 6d.

Plato. Selections from the Dialogues [including the whole of the Apology and Crito]. With Introduction and Notes by John Purves, M.A., and a Preface by the Rev. B. Jowett, M.A. Extra fcap. 8vo. 6s. $6 d$. 
Sophocles. For the use of Schools. Edited with Introductions and English Notes By Lewis Campbell, M.A., and Evelyn Abbott,

M.A. New and Revised Edition. 2 Vols. Extra fcap. 8vo. 1os. 6d.

Sold separately, Vol. I, Text, 4s. 6d.; Vol. II, Explanatory Notes, $6 s$.

Sofhocles. In Single Plays, with English Notes, \&c. By

Lewis Campbell, M.A., and Evelyn Abbott, M.A. Extra fcap. 8vo.limp.

Oedipus Tyrannus, Philoctetes. New and Revised Edition, 2s. each.

Oedipus Coloneus, Antigone, Is. $9 d$. each.

Ajax, Electra, - Trachiniae, 2s. each.

Oedipus Rex: Dindorfs Text, with Notes by the present Bishop of St. David's. Extra fcap. 8vo. limp, Is. 6d.

Thcocritus (for Schools). With Notes. By H. Kynaston, D.D. (late Snow). Third Edition. Extra fcap. 8vo. 4s. $6 \mathrm{~d}$.

Xonophon. Easy Selections (for Junior Classes). With a Vocabulary, Notes, and Map. By J. S. Phillpotts, B.C.L., and C. S. Jerram, M.A. Third Edition. Extra fcap. 8vo. 3s. $6 d$.

- Selcctions (for Schools). With Notes and Maps. By J. S. Phillpotts. B.C.L. Fourth Edition. Extra fcap. 8 vo. 3 s. 6 d.

- Anabasis, Book I. Edited for the use of Junior Classes and Private Students. With Introduction, Notes, etc. By J. Marshall, M.A., Rector of the Royal High School, Edinburgh. Extra fcap. 8vo. 2s. 6d.

- Anabasis, Book II. With Notes and Map. By C. S. Jerram, M.A. Extra fcap. 8 ro. $2 s$.

Cyropacdia, Books IV and V. With Introduction and Notes by C. Bigg, D.D. Extra fcap. 8vo. 2s. 6d.

Aristotle's Politics. By W. L. Newman, M.A. [In the Press.] Aristotelian Studies. I. On the Structure of the Seventh Book of the Nicomachean Ethics. By J.C. Wilson, M.A. 8ro. stiff, 5 s.

Aristotelis Ethica Nicomachea, ex recensione Immanuelis Bekkeri. Crown 8vo. 5s.

Demosthenes and Aeschines. The Orations of Demosthenes and Aischines on the Crown. With Introductory Essays and Notes. By G. A. Simcox, M.A., and W. H. Simcox, M.A. 1872 . 8 ro. I2s.

Head (Barclay V.). Historia Numorum: A Manual of Gresk Numismatics. Royal 8vo. half-bound. 2l. 2s. Just Fublished.

Hicks (E. L., M.A.). A Manual of Greek Historical Inscriptions. Demy 8vo. 1os. $6 d$. 
Homer. Odyssey, Books I-XII. Edited with English Notes, Appendices, etc. By W. W. Merry, M.A., and the late James Riddell, M.A. 1886. Second Edition. Demy 8vo. I6s.

Homer. A Grammar of the Homeric Dialect. By D. B. Monro, M.A. Demy 8vo. ios. $6 d$.

Sophocles. The Plays and Fragments. With English Notes and Introductions, by Lewis Campbell, M.A. 2 vols.

Vol. I. Oedipus Tyrannus. Oedipns Coloneus. Antigone. 8vo. 16s.

Vol. II. Ajax. Electra. Trachiniae. Philoctetes. Fragments. 8vo. i6s.

\section{FRENCH AND ITALIAN.}

Brachet's Etymological Dictionary of the French Language, with a Preface on the Principles of French Etymology. Translated into English by G. W. Kitchin, D.D. Third Edition. Crown 8vo. 7s. 6d.

- Historical Grammar of the French Language. Translated into English by G. W. Kitchin, D.D. Fourth Edition. Extra fcap. 8vo. 3 s. $6 d$.

Works by GEORGE SAINTSBURY, M.A.

Primer of French Literature. Extra fcap. 8vo. $2 s$. Short History of French Literature. Crown 8vo. Ios. $6 d$. Specimens of French Litcrature, from Villon to Hugo. Crown 8 vo. 9 s.

\section{MASTERPIECES OF THE FRENCH DRAMA.}

Corncille's Horace. Edited, with Introduction and Notes, by George Saintsbury, M.A. Extra fcap. 8vo, 2s. $6 d$.

Molière's Les Précieuses Ridicules. Edited, with Introduction and Notes, by Andrew Lang, M.A. Extra fcap. 8vo. Is. $6 d$.

Racine's Esther. Edited, with Introduction and Notes, by George Saintsbury, M.A. Extra fcap. 8vo. 2s.

Beaumarchais' Le Barbier de Séville. Edited, with Introduction and Notes, by Austin Dobson. Extra fcap. 8vo. 2s. $6 d$.

Voltaire's Mérope. Edited, with Introduction and Notes, by George Saintsbury. Extra fcap. 8vo. cloth, 2s.

Musset's On ne badine pas avec l'Amour, and Fantasio. Edited, with Prolegomena, Notes, etc., by Walter Herries Pollock. Extra fcap. 8 vo. $2 s$.

The above six Plays may be had in ornamental case, and bound in Imitation Parchment, price I 2s. $6 d$. 
Sainte-Beuve. Selections from the Causeries du Lundi. Edited by George Saintsbury. Extra fcap. 8vo. 2s.

Quinet's Lettres à sa Mère. Selected and edited by George Saintsbury. Extra fcap. Sro. $2 s$.

Gautier, Théophile. Scenes of Travel. Selected and Edited by George Saintsbury. Extra fcap. 8 vo. $2 s$.

L'Eloquence de la Chaire et de la Tribune Françaises. Edited by Paul Blouët, B.A. (Univ. Gallic.). Vol. I. French Sacred Oratory. Extra fcap. 8vo. 2s. $6 d$.

\section{Edited by GUSTAVE MASSON, B.A.}

Corncille's Cinna. With Notes, Glossary, etc. Extra fcap. 8 vo. cloth, 2s. Stiff covers, Is. $6 d$.

Louis XIV and his Contemporaries; as described in Extracts from the best Memoirs of the Seventeenth Century. With English Notes, Genealogical Tables, \&c. Extra fcap. 8vo. 2s. $6 d$.

IIaistre, Xavier de. Voyage autour de ma Chambre. Ourika, by Madame de Duras; Le Vieux Tailleur, by MM. Erckmann-Chatrian; La Veillée de Vincennes, by Alfred le Vigny; Les Jumeaux de l'Hôtel Coineille, by Edmond About; Mésaventures d'un Écolier, by Rodolphe Topffer. Third Edition, Revised and Corrected. Extra fcap. 8vo. 2s. $6 d$.

Moliere's Les Fourberies de Scapin, and Racine's Athalie. With Voltaire's Life of Molière. Extra fcap. 8vo. 2s. $6 d$.

Miolicre's Lies Fourberies de Scapin. With Voltaire's Life of Molière. Extra fcap. 8vo. stiff covers, is. 6 d.

Moliere's Les Femmos Savantes. With Notes, Glossary, etc. Extra fcap. 8vo. cloth, 2s. Stiff covers, is. $6 d$.

Racine's Andromaque, and Corneille's Le Menteur. With Louis Racine's Life of his Father. Extra fcap. 8vo. 2s. $6 d$.

Rcgnard's Le Foueur, and Brueys and Palaprat's Le Grondeur. Extra fcap. 8vo. 2s. $6 d$.

Sévigne, Madame de, and her chief Contemporaries, Selections from the Correspondence of. Intended more especially for Girls' Schools. Extra fcap. 8 vo. $3^{s}$.

Dante. Selections from the Inferno. With Introduction and Notes. By H. B. Cotterill, B.A. Extra fcap. 8vo. 4s.6d.

Tasso. La Gerusalemme Liberata. Cantos i, ii. With Introduction and Notes. By the same Editor. Extra fcap. 8vo. 25. $6 d$. 


\section{GERMAN.}

Scherer $(W$.$) . A History of German Literature. Translated$ from the Third German Edition by Mrs. F. Conybeare. Edited by $F$. Max Müller. 2 vols. 8 vo. 2 Is.

Max Mïller. The German Classics, from the Fourth to the

Nineteenth Century. With Biographical Notices, Translations into Modern German, and Notes. By F. Max Müller, M.A. A New Edition, Revised, Enlarged, and Adapted to Wilhelm Scherer's 'History of German Literature,' by F. Lichtenstein. 2 vols. crown 8 vo. 2 Is.

\section{GERMAN COURSE. By HERMANN LANGE.}

The Germans at Home; a Practical Introduction to German Conversation, with an Appendix containing the Essentials of German Grammar. Second Edition. 8vo. 2s. $6 d$.

The German Manual; a German Grammar, Reading Book, and a Handbook of German Conversation. 8vo. $7 s .6 d$

Grammar of the German Language. $8 \mathrm{vo} .3^{s .6 d .}$

German Composition; A Theoretical and Practical Guide to the Art of Translating English Prose into Gernan. 8vo. $4 s .6 d$.

Lessing's Laokoon. With Introduction, English Notes, etc. By A Hamann, Phil. Doc., M.A. Extra fcap. 8vo. 4 s. $6 \mathrm{~d}$.

Schiller's Wilhelm Tell. Translated into English Verse by E. Massie, M.A. Extra fcap. 8 vo. $5^{s}$.

Also, Edited by C. A. BUCHнFIM, Phil. Doc.

Becker's Friedrich der Grosse. Extra fcap. 8vo. In the Press. Goethe's Egmont. With a Life of Goethe, \&c. Third Edition. Extra fcap. 8vo. 3 s.

- Iphigenie auf Tauris. A Drama. With a Critical Introduction and Notes. Second Edition. Extra fcap. 8vo. 3 s.

Heine's Prosa, being Selections from his Prose Works. With English Notes, etc. Extra fcap. 8vo. $4 s .6 d$.

Heine's Harzreise. With Life of Heine, Descriptive Sketch of the Harz, and Index. Extra fcap. 8vo. paper covers, Is. 6d.; cloth, 2s. $6 d$. Lessing's Minna von Barnhelm. A Comedy. With a Life of Lessing, Critical Analysis, etc. Extra fcap. 8vo. 3s. $6 d$.

Nathan der Weise. With Introduction, Notes, etc. Extra fcap. 8vo. $4^{s .6 d}$. 
Schiller's Historische Skizzen; Egmont's Leben und Tod, and Belagerung von Antwerpen. With a Map. Extra fcap. 8vo. 2s. 6d.

- Wilhelm Tell. With a Life of Schiller; an historical and critical Introduction, Arguments, and a complete Commentary, and Map. Sixth Edition. Extra fcap. 8vo. 3s. $6 d$.

- Wilhelm Tell. School Edition. With Map. 2s.

Modern German Reader. A Graduated Collection of Extracts in Prose and Poetry from Modern German writers :-

Part I. With English Notes, a Grammatical Appendix, and a complete Vocabulary. Fourth Edition. Extra fcap. 8vo. 2s. $6 d$.

Part II. With English Notes and an Index. Extra fcap. 8vo. 2s. 6d.

Niebuhr's Griechische Heroen-Geschichten. Tales of Greek Heroes. Edited with English Notes and a Vocabulary, by Emma S. Buchheim.

School Edition. Extra fcap. 8vo., cloth, 2s. Sliff covers, Is. 6d.

\section{MATHEMATICS, PHYSICAL SCIENCE, \&c.}

\section{By LEWIS HENSLEY, M.A.}

Figures made Easy: a first Arithmetic Book. Crown 8vo. 6d. Answers to the Examples in Figures made Easy, together

with two thousand additional Examples, with Answers. Crown 8vo. Is. The Scholar's Arithmetic: with Answers. Crown 8vo. 4s.6d. The Scholar's Algebra. Crown 8vo. 4s.6d.

Aldis (W. S., M.A.). A Text-Book of Algebra. Crown 8vo. Nearly ready.

Baynes (R. E., M.A.). Lessons on Thermodynamics. 1878. Crown 8vo. 7s. $6 d$.

Cliambers (G. F., F.R.A.S.). A Handbook of Descriptive Astronomy. Third Edition. 1877. Demy 8vo. 28s.

Clarke (Col.A.R., C.B., R.E.). Geodesy. I 88o. 8vo. I2s. 6 d. Cremona (Luigi). Elements of Projective Geometry. Translated by C. Lendesdorf, M.A. 8vo. I 2s. $6 d$.

Donkin. Acoustics. Second Edition. Crown 8vo. 7s. 6d. Euclid Revised. Containing the Essentials of the Elements of Plane Geometry as given by Euclid in his first Six Books. Edited by R. C. J. Nixon, M.A. Crown 8vo. $7 s .6 d$.

Sold separately as follows,

Books I-IV. $3 s .6 d$. Books I, II. Is. $6 d$.

Book I. Is. 
Galton (Douglas, C.B., F.R.S.). The Construction of Healthy Dwellings. Demy 8vo. Ios. $6 d$.

Hamilton (Sir R. G. C.), and F. Ball. Book-keeping. New and enlarged Edition. Extra fcap. 8vo. limp cloth, 2s.

Ruled Exercise books adapted to the above may be had, price $2 s$.

Harcourt (A. G. Vernon, M.A.), and H. G. Madan, M.A. Exercises in Practical Chemistry. Vol. I. Elementary Exercises. Third Edition. Crown 8vo. 9s.

Maclaren (Archibald). A System of Physical Education: Theoretical and Practical. Extra fcap. 8vo. 7 s. $6 d$.

Madan (H. G., M.A.). Tables of Qualitative Analysis. Large 4 to. paper, $4 s, 6 d$.

Maxzell (F. Clerk, M.A., F.R.S.). A Treatise on Electricity and Magnetism. Second Edition. 2 vols. Demy 8vo. I $l$. IIs. $6 d$.

An Elementary Treatise on Electricity. Edited by William Garnett, M.A. Demy 8vo. $7 s .6 d$.

Minchin (G. M., M.A.). A Treatise on Statics with Applications to Physics. Third Edition, Corrected and Enlarged. Vol. I. Equilibrium of Coplanar Forces. 8vo. 9s. Vol. II. Statics. 8vo. I6s.

Uniplanar Kinematics of Solids and Fluids. Crown 8vo. $7 s, 6 d$.

Phillips (Foln, M.A., F.R.S.). Geology of Oxford and the Valley of the Thames. I871. 8vo. 21 s.

- Vesuvius. 1869. Crown 8vo. ros. 6d.

Prestwich(Foseph, M.A., F.R.S.). Geology, Chemical, Physical, and Stratigraphical. Vol. I. Chemical and Physical. Royal 8vo. 25 s.

Roach (T., M.A.). Elementary Trigonometry. Crown 8vo. Nearly ready.

Rolleston's Forms of Animal Life. Illustrated by Descriptions and Drawings of Dissections. New Edition. (Nearly ready.)

Smyth. A Cycle of Celestial Objects. Observed, Reduced, and Discussed by Admiral W. H. Smyth, R.N. Revised, condensed, and greatly enlarged by G. F. Chambers, F.R.A.S. 188I. Svo. Price reduced to I $2 s$.

Stewart (Balfour, LL.D., F.R.S.). A Treatise on Heat, with numerous Woodcuts and Diagrams. Fourth Edition. Extra fcap. 8vo. 7s. $6 d$. 
Vernon-Harcourt (L.F., M.A.). A Treatise on Rivers and Canals, relating to the Control and Improvement of Rivers, and the Design, Construction, and Development of Canals. 2 vols. (Vol. I, Text. Vol. II, Plates.) 8vo. 21s.

Harbours and Docks; their Physical Features, History, Construction, Equipment, and Maintenance; with Statistics as to their Commercial Development. 2 vols. 8 vo. 25 s.

Watson (H. W., M.A.). A Treatise on the Kinetic Theory of Gases. 1876. 8vo. 3s. $6 d$.

Watson (H. W., D. Sc., F.R.S.), and S. H. Burbury, M.A.

I. A Treatise on the Application of Generalised Coordinates to the Kinetics of a Material System. 1879. 8vo. 6s.

II. The Mathematical Theory of Electricity and Magnetism. Vol. I. Electrostatics. 8 vo. 10 s. $6 d$.

Williamson (A. W., Phil. Doc., F.R.S.). Chemistry for Students. A new Edition, with Solutions. 1873. Extra fcap. 8vo. 8s. 6d.

\section{HISTORY.}

Bluntschli $(\mathcal{F} . K$.$) . The Theory of the State. By J. K.$ Bluntschli, late Professor of Political Sciences in the University of Heidelberg. Authorised English Translation from the Sixth German Edition. Demy 8ro. half bound, i $2 s .6 d$.

Finlay (George, LL.D.). A History of Greece from its Conquest by the Romans to the present time, B.C. 146 to A.D. 1864 . A new Edition, revised throughout, and in part re-written, with considerable additions, by the Author, and edited by H. F. Tozer, M.A. 7 vols. 8vo. $3^{l}$. 1os.

Fortescue (Sir Fohn, Kt.). The Governance of England: otherwise called The Difference between an Absolute and a Limited Monarchy. A Revised Text. Edited, with Introduction, Notes, and Appendices, by Charles Plummer, M.A. 8 ro. half bound, 12s. $6 d$.

Freeman (E.A., D.C.L.). A Short History of the Norman Conquest of England. Second Edition. Extra fcap. Svo. 2s. $6 d$.

George (H.B., M.A.). Genealogical Tables illustrative of Modern History. Third Edition, Revised and Enlarged. Small 4 to. I2s.

Hodgkin (T.). Italy and her Invaders. Illustrated with Plates and Maps. Vols. I-IV., A.D. 376-553. 8vo. 3 l. 8s.

Kitchin (G. W., D.D.). A History of France. With numerous Maps, Plans, and Tables. In Three Volumes. Second Edition. Crown 8 vo. each 10s. $6 d$.

Vol. I. Down to the Year 1453 .

Vol. 2. From I453-1624. Vol. 3. From 1624-1 793. 
Payne (E. F., M.A.). A History of the United States of America. In the Press.

Ranke (L. von). A History of England, principally in the Seventeenth Century. Translated by Resident Members of the University of Oxford, under the superintendence of G. W. Kitchin, D.D., and C. W. Boase, M.A. 1875.6 vols. 8 vo. $3^{l .} 3 s$.

Rawlinson (Gtorge, M.A.). A Manual of Ancient History. Second Edition. Demy 8vo. 14 s.

Rogers (F. E. Thorold, M.A.). The First Nine Ycars of the Bank of England. 8vo. clotb. Just ready.

Select Charters and other Illustrations of English Constitutional History, from the Earliest Times to the Reign of Edward I. Arranged and edited by W. Stubbs, D.D. Fifth Edition. I883. Crown 8vo. 8s. $6 d$.

Stubbs (W., D.D.). The Constitutional History of England, in its Origin and Development. Library Edition. 3 vols. demy 8vo. 2l. $8 \mathrm{~s}$.

Also in 3 vols. crown 8vo. price i $2 s$. each.

Seventeen Lectures on the Study of Medieval and Modern History, \&c., delivered at Oxford 1867-1884. Demy 8vo. half-bound, Ios. 6 d.

Wellesley. A Selection from the Despatches, Treaties, and other Papers of the Marquess Wellesley, K.G., during his Government of India. Edited by S. J. Owen, M.A. 1877. 8vo. $11.4^{s .}$

Wellington. A Selection from the Despatches, Treaties, and other Papers relating to India of Field-Marshal the Duke of Wellington, K.G. Edited by S. J. Owen, M.A. 1880 . 8vo. 24s.

A History of British India. By S. J. Owen, M.A., Reader in Indian History in the University of Oxford. In preparation.

\section{LAW.}

Alberici Gentilis, I.C.D., I.C., De Iure Belli Libri Tres. Edidit T. E. Holland, I.C.D. 1877. Small 4 to. half morocco, 21 s.

Anson (Sir William R., Bart., D.C.L.). Principles of the English Lazu of Contract, and of Agency in its Relation to Contract. Fourth Edition. Demy 8vo. 1os. $6 d$.

- Law and Custom of the Constitution. Part I. Parliament. Demy 8vo. 1os. $6 d$.

Bentham (Feremy). An Introduction to the Principles of Morals and Legislation. Crown 8vo. 6s. 6d.

Digby (Kenelm E., M.A.). An Introduction to the History of the Lazu of Real Property. Third Edition. Demy 8vo. 1os. 6d.

Gaii Institutionum Furis Civilis Commentarii Quattuor; or, Elements of Roman Law by Gaius. With a Translation and Commentary by Edward Poste, M.A. Second Edition. 1875. 8vo. 18s. 
Hall (W.E., M.A.). International Law. Second Ed.8vo.21s. Holland (T. E., D.C.L.). The Elements of Furisprudence. Third Edition. Demy 8vo. Ios. $6 d$.

The European Concert in the Eastern Question, a Collection of Treaties and other Public Acts. Edited, with Introductions and Notes, by Thomas Erskine Holland, D.C.L. 8vo. I 2s. $6 d$.

Imperatoris Iustiniani Institutionum Libri Quattuor; with Introductions, Commentary, Excursus and Translation. By J. B. Moyle, B.C.L.. M.A. 2 vols. Demy 8vo. $21 s$.

Fustinian, The Institutes of, edited as a recension of the Institutes of Gaius, by Thomas Erskine Holland, D.C.L. Second Edition, 1881. Extra fcap. 8vo. $5^{s}$.

Fustinian, Select Titles from the Digest of. By T. E. Holland, D.C.L., and C. L. Shadwell, B.C.L. 8ro. 14s. Also sold in Parts, in paper covers, as follows :-

Part I. Introductory Titles. 2s. 6d. Part II. Family Law. Is. Part III. Property Law. 2s. 6d. Part IV. Law of Obligations (No. I). 3s. $6 d$. Part IV. Law of Obligations (No. 2). 4s. 6d.

Lex Aquilia. The Roman Law of Damage to Property: being a Commentary on the Title of the Digest 'Ad Legem Aquiliam ' (ix. 2). With an Introduction to the Study of the Corpus Iuris Civilis. By Erwin Grueber, Dr. Jur., M.A. Demy 8vo. Ios. $6 d$.

Markby (W., D.C.L.). Elements of Laze considered with reference to Principles of General Jurisprudence. Third Edition. Demy 8vo. I 2s.6d.

Truiss (Sir Travers, D.C.L.). The Law of Nations considered as Independent Political Communities.

Part I. On the Rights and Duties of Nations in time of Peace. A new Edition, Revised and Enlarged. I 884 . Demy 8vo. I 5 s.

Part II. On the Rights and Duties of Nations in Time of War. Second Edition Revised. I875. Demy 8ro. $21 s$.

\section{MENTAI AND MORAL PHILOSOPHY, \&c:}

Bacon's Novum Organum. Edited, with English Notes, by G. W. Kitchin, D.D. 1855 . 8vo. 9 s. $6 d$.

Translated by G. W. Kitchin, D.D. I 855. 8vo. 9s. $6 d$.

Borkcley. The Works of George Berkeley, D.D., formerly Bishop of Cloyne; including many of his writings hitherto unpublished. With Prefaces, Annotations, and an Account of his Life and Philosophy, by Alexander Campbell Fraser, M.A. 4 vols. 187 I. 8 vo. 2l. I8s. The Life, Letters, \&c. I vol. $16 s$.

Selections from. With an Introduction and Notes. For the use of Students in the Universities. By Alexander Campbell Fraser, LL.D. Second Edition. Crown 8ro. 7s.6d. 
Fowler (T.,D.D.). The Elements of Deductive Logic, designed mainly for the use of Junior Students in the Universities. Eighth Edition, with a Collection of Examples. Extra fcap. 8vo. 3s. $6 d$.

- The Elements of Inductive Logic, designed mainly for the use of Students in the Universities. Fourth Edition. Extra fcap. 8vo. 6s. and Wilson (F. M., B.D.). The Principles of Morals (Introductory Chapters). 8vo. boards, 3s. $6 d$.

- The Principles of Morals. Part II. (Being the Body of the Work.) 8vo. Ios. 6d. Just Published.

Edited by T. FOWLER, D.D.

Bacon. Novum Organum. With Introduction, Notes, \&c. I878. $8 \mathrm{vo}$. 14 s.

Locke's Conduct of the Understanding. Second Edition. Extra fcap. 8vo. 2s.

Danson (F. T.). The Wealth of Households. Crown 8vo. 5 s. Green (T. H., M.A.). Prolegomena to Ethics. Edited by A. C. Bradley, M.A. Demy 8vo. i 2s. $6 d$.

Hegel. The Logic of Hegel; translated from the Encyclopaedia of the Philosophical Sciences. With Prolegomena by William

Wallace, M.A. $1874.8 \mathrm{vo}$. $14 \mathrm{~s}$.

Lotze's Logic, in Three Books; of Thought, of Investigation, and of Knowledge. English Translation; Edited by B. Bosanquet, M.A., Fellow of University College, Oxford, 8vo, cloth, $12 s .6 d$.

- Metaphysic, in Three Books; Ontology, Cosmology, and Psychology. English Translation; Edited by B. Bosanquet, M.A. 8 vo. cloth, $12 s .6 d$.

Martineau (Fames, D.D.). Types of Ethical Theory. Second Edition. 2 vols. Crown 8vo. I5s.

Rogers (F.E.Thorold, M.A.). A Manual of Political Economy, for the use of Schools. Third Edition. Extra fcap. 8vo. 4s.6d.

Smith's Wealth of Nations. A new Edition, with Notes, by J. E. Thorold Rogers, M.A. 2 vols. 8vo. 1880. 21s.

X. ART, \&c.

Head (Barclay V.). Historia Numorum. A Manual of Greek Numismatics. Royal $8 \mathrm{vo}$. half morocco, $42 \mathrm{~s}$.

Hullah (Fohn). The Cultivation of the Speaking Voice. Second Edition. Extra fcap. 8vo. 2s. $6 d$.

Ouseley (Sir F. A. Gore, Bart.). A Treatise on Harmony. Third Edition. 4to. Ios.

- A Treatise on Counterpoint, Canon, and Fugue, based upon that of Cherubini. Second Edition. 4to. $16 s$.

A Treatise on Musical Form and General Composition. Second Edition. 4to. ros. 
Robinson (F.C., F.S.A.). A Critical Account of the Drawings by Wichel Angelo and Raffallo in the University Galleries, Oxford. Is 70 . Crown Svo. 4 s.

Ruskin (Folm, M.A.). A Course of Lectures on Art, delivered before the University of Oxford in Hilary Term, is 8 o. 8ro. 65.

Troutbeck (F., M.A.) and R. F. Dale, M.A. A Music Primer (for Schools). Second Edition. Crown Sro. Is.6d.

Tyrahitt (R. St. F., M.A.). A Handbook of Pictorial Art. With coloured Illustrations, Photographs, and a chapter on Perspectire by A. Macdonald. Second Edition. 18:s. 8ro. half morocco, 18 s.

Upeott (L. E., M.A.). An Introduction to Greek Sculpture. Crown Sro. 4. 6.t.

Vaux (W.S.W., M.A.). Catalogue of the Castellani Collection of Antiguities in the University Galleries, Oxford. Crown Sro. is.

The Oxford Bible for Teachers, containing supplementary HeLPS TO THE STUDY OF THE BIBLE, including Summaries of the several Books, with copious Explanatory Notes and Tables illustrative of Scripture History and the characteristics of Bible Lands; with a complete Index of Subjects, a Concordance, a Dictionary of Proper Names, and a series of Maps. Prices in various sizes and bindings from 35 . to $2 l .55$.

Helps to the Study of the Bible, taken from the OXFORD BIBLE FOR TEACHERS, comprising Summaries of the several Books, with copious Explanatory Notes and Tables illustrative of Scripture History and the Characteristics of Bible Lands; with a complete Index of Subjects, a Concordance, a Dictionary of Proper Names, and a series of Maps. Crown 8vo. cloth, 3s. 6d.; $16 \mathrm{mo} . \mathrm{cloth}, \mathrm{Is}$.

\section{$+$ \\ LONDON: HENRY FROWDE, \\ Oxford Untrerstty Press Warehotse, Ames Corner, OXFORD: CLARENDON PRESS DEPOSITORY, II6 High STREet.}

\footnotetext{
The Delegates of THe Press ixvite suggestions and advice from all persons interested in education; and will be thankful for hints, so. addressed to the Secretari to the Delegates, Clarendon Press, Oxford.
} 




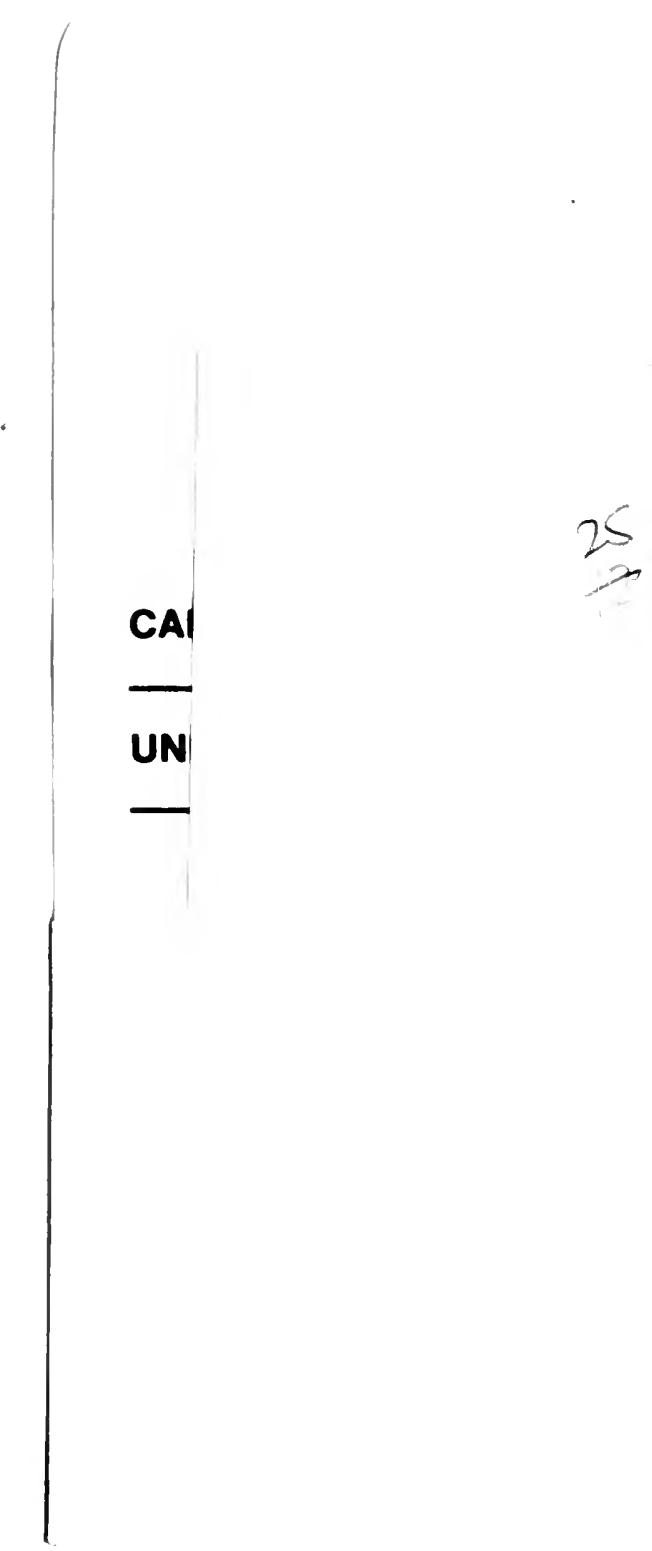


